Doktori $(\mathrm{PhD})$ értekezés

\title{
AZ ALANY ÉS A VIRÁGRITKÍTÁS HATÁSA CSERESZNYEFAJTÁK GYÜMÖLCSMINŐSÉGÉRE
}

\author{
Hajagos Anikó \\ Témavezető: Dr. Végvári György, CSc \\ egyetemi tanár
}

Budapesti Corvinus Egyetem

Kertészettudományi Kar

Talajtan és Vízgazdálkodás Tanszék

Budapest

2015 
A doktori iskola

megnevezése: $\quad$ Kertészettudományi Doktori Iskola

tudományága: Növénytermesztési és Kertészeti Tudományok

vezetője: $\quad$ Dr. Tóth Magdolna

egyetemi tanár, DSc

Budapesti Corvinus Egyetem, Kertészettudományi Kar, Gyümölcstermő Növények Tanszék

Témavezető: $\quad$ Dr. Végvári György

egyetemi tanár, CSc

Budapesti Corvinus Egyetem, Kertészettudományi Kar, Talajtan és Vízgazdálkodás Tanszék

A jelölt a Budapesti Corvinus Egyetem Doktori Szabályzatában előírt valamennyi feltételnek eleget tett, az értekezés mühelyvitájában elhangzott észrevételeket és javaslatokat az értekezés átdolgozásakor figyelembe vette, azért az értekezés védési eljárásra bocsátható. 
A Budapesti Corvinus Egyetem Élettudományi Területi Doktori Tanácsának 2015. október 13-i határozatában a nyilvános vita lefolytatására az alábbi bíráló Bizottságot jelölte ki:

\title{
BÍRÁLÓ BIZOTTSÁG:
}

\section{Elnöke}

Porpáczy Aladár, DSc

\author{
Tagjai \\ Höhn Mária, CSc \\ Horváthné Baracsi Éva, PhD \\ Stefanovitsné Bányai Éva, DSc \\ Kállay Tamásné, CSc
}

\section{Opponensek}

Kovácsné Békefi Zsuzsanna, PhD

Gonda István, CSc

Titkár

Kotroczó Zsolt, PhD 


\section{TARTALOMJEGYZÉK}

1. BEVEZETÉS 1

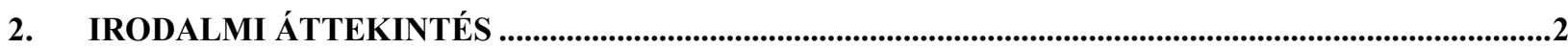

2.1. A CSERESZNYE RENDSZERTANA, NEVEZÉKTANA, ELTERJEDÉSE, BOTANIKÁJA, ALAKKÖREI.......................2

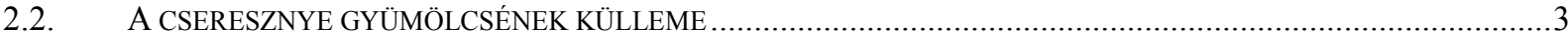

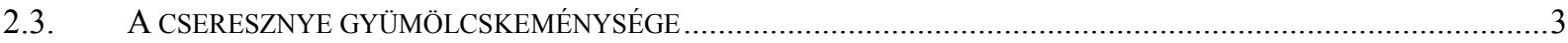

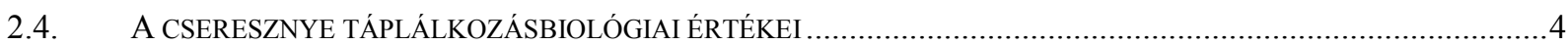

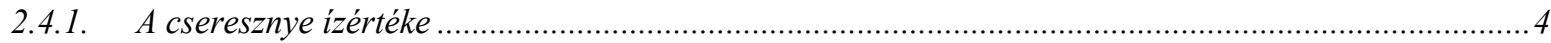

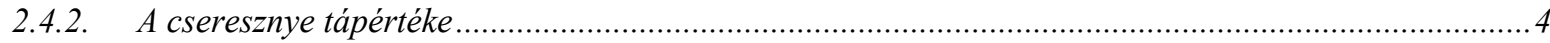

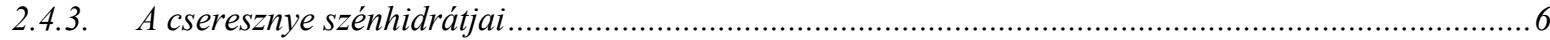

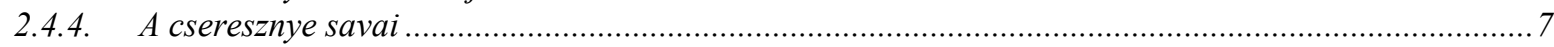

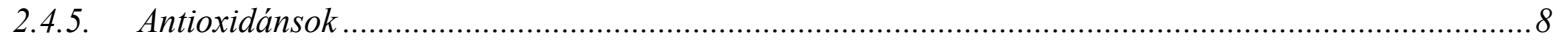

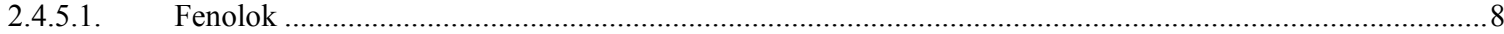

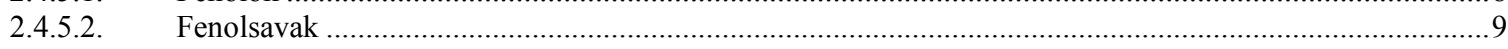

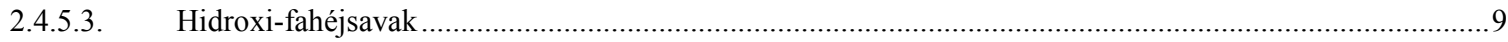

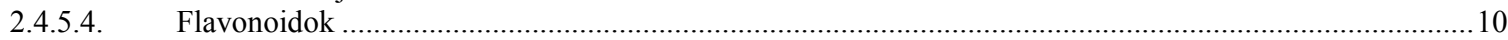

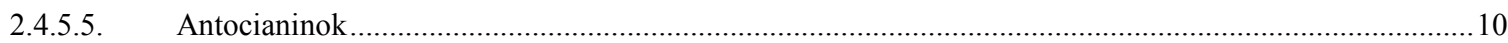

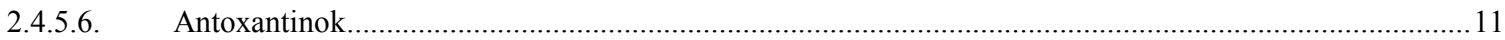

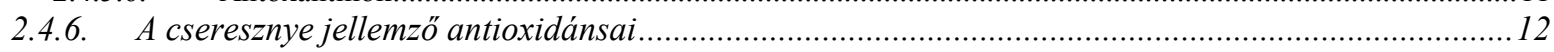

2.5. A CSERESZNYE EGÉSZSÉGVÉDŐ ÉRTÉKEINEK TUDOMÁNYOS BIZONYÍTÉKAI .........................................13

2.5.1. A cseresznye alkalmazása in vivo humán gyógyászati kísérletekben...........................................14

2.6. AZ ALANY ÉS A VIRÁGRITKÍTÁS HATÁSA A CSERESZNYEGYÜMÖLCSÖK MINŐSÉGÉRE, EGÉSZSÉGVÉDŐ

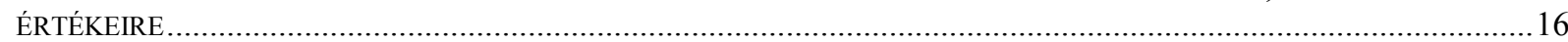

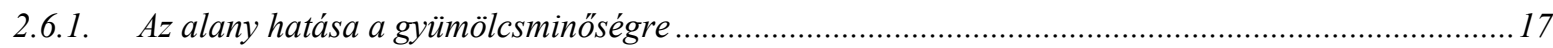

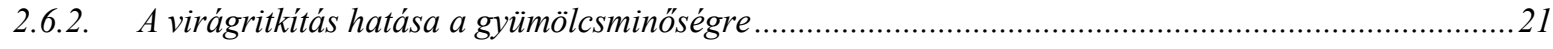

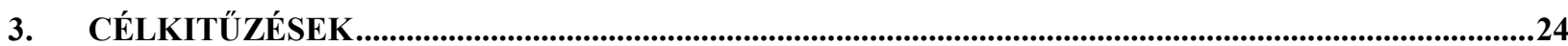

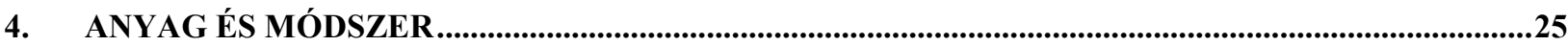

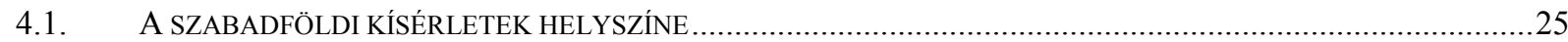

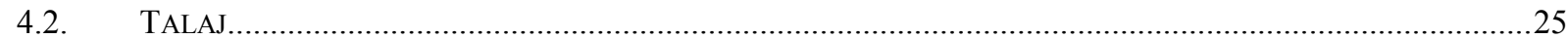

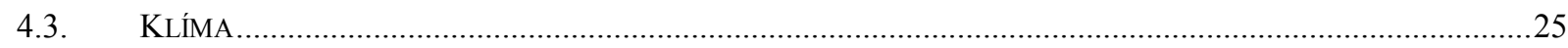

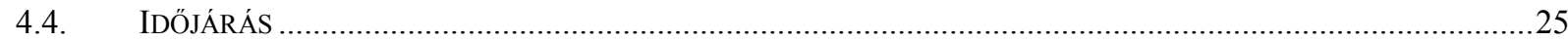

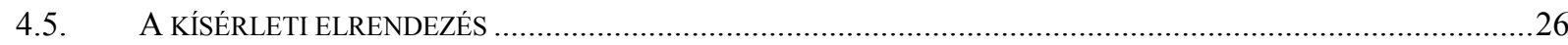

4.5.1. Q10 ültetvény (alanyhatás vizsgálatának helyszine) ...............................................................26

4.5.2. Q26 ültetvény (virágritkitás hatásának vizsgálati helyszíne) .....................................................27

4.6. A VIZSGÁLATOKBAN RÉSZTVEVÖ NEMESFAJTÁK JELLEMZÉSE ....................................................27

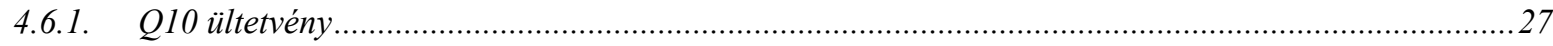

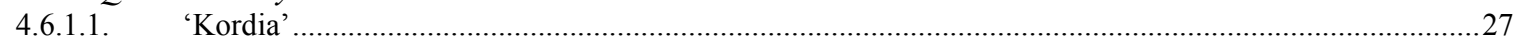

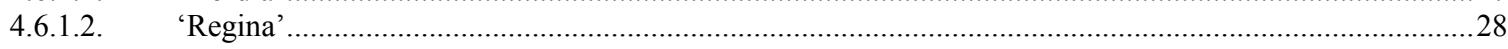

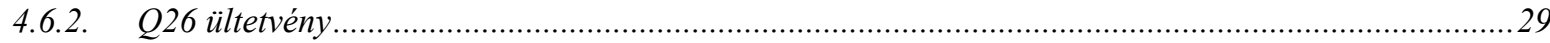

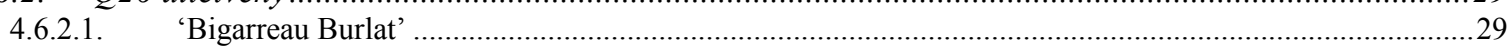

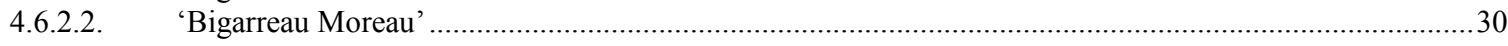

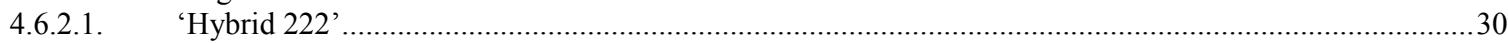

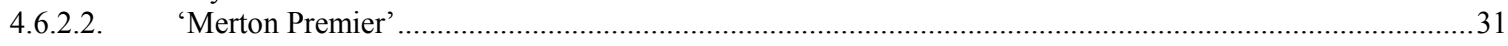

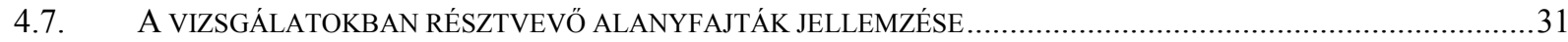

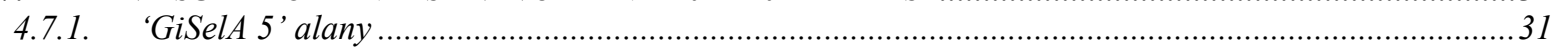

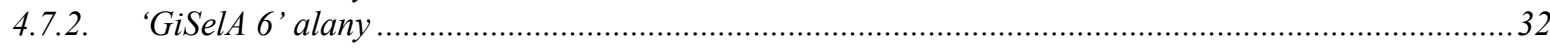

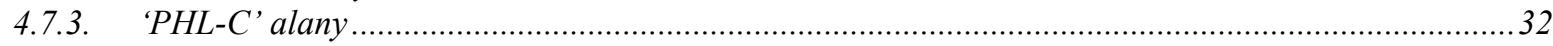

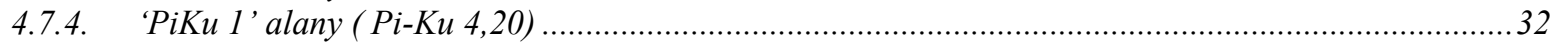

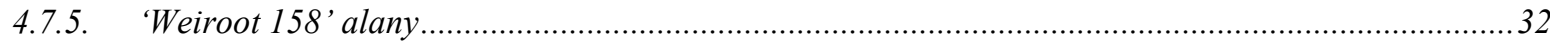

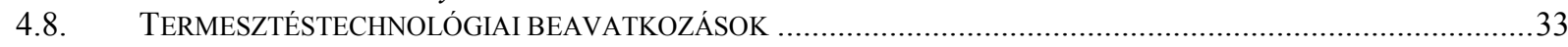

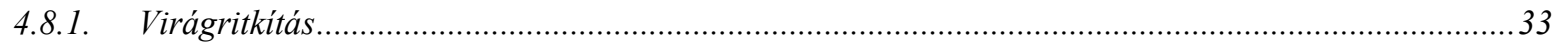

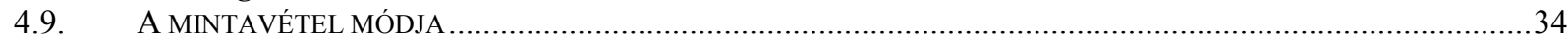

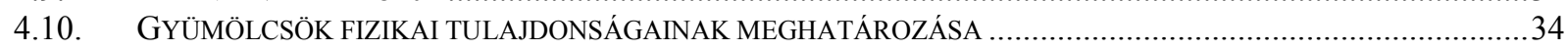

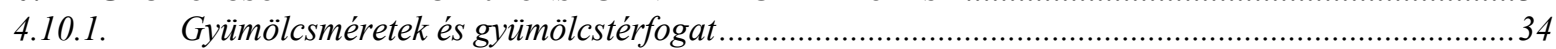

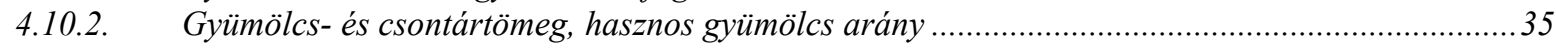

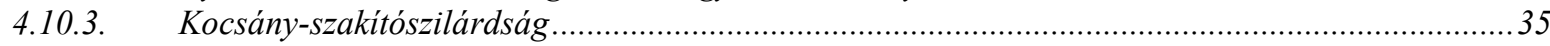

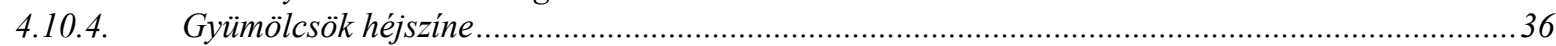

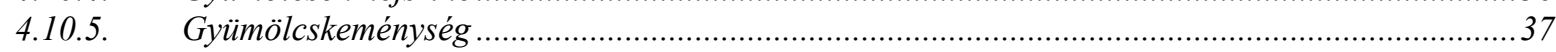


4.11. ÁLTALÁNOS FIZIKOKÉMIAI PARAMÉTEREK MEGHATÁROZÁSA ……………………....................................37

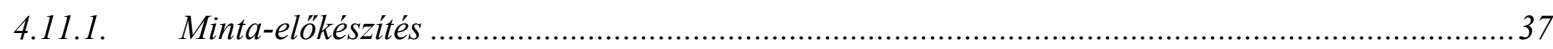

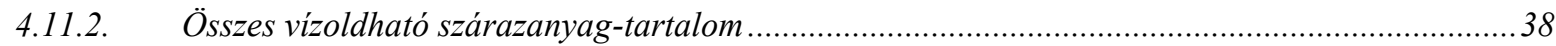

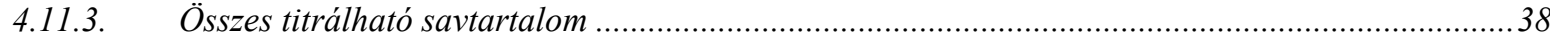

4.12. EGYEDI KOMPONENSEK ÉS KOMPONENSCSOPORTOK MEGHATÁROZÁSA …...............................................38

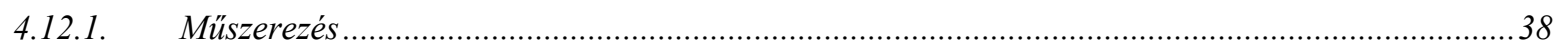

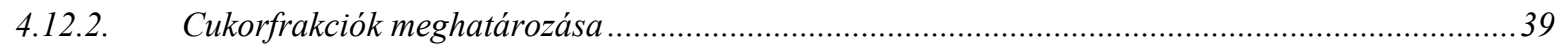

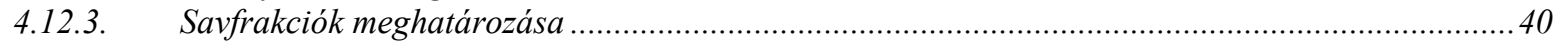

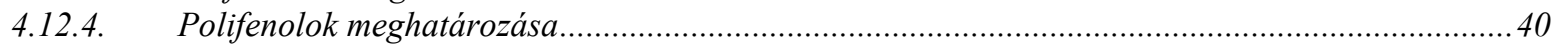

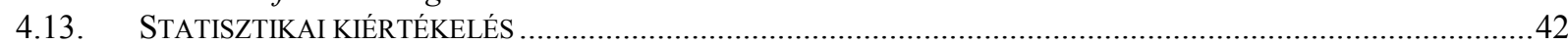

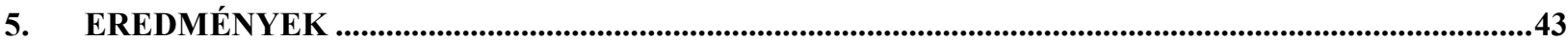

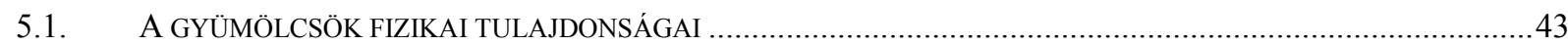

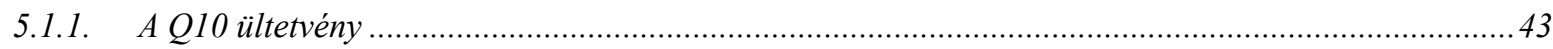

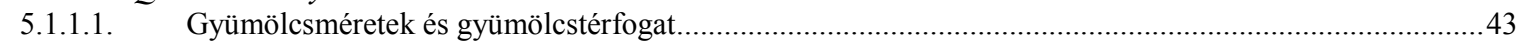

5.1.1.2. Gyümölcs- és csontártömeg, hasznos gyümölcs arány …………………………………………………... 44

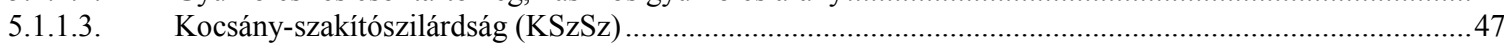

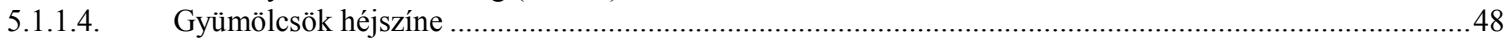

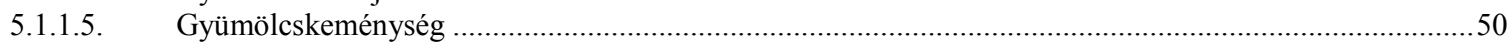

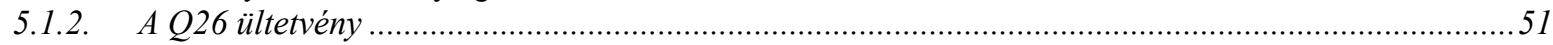

5.1.2.1. Gyümölcsméretek és gyümölcstérfogat......................................................................................

5.1.2.2. Gyümölcs- és csontártömeg, hasznos gyümölcs arány ...........................................................................52

5.1.2.3. Kocsány-szakítószilárdság (KSzSz) ……………………………………………………………....5

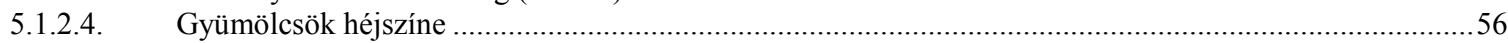

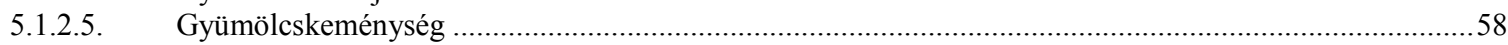

5.2. A GYÜMÖLCSÖK ÁLTALÁNOS FIZIKOKÉMIAI PARAMÉTEREI ……......................................................60

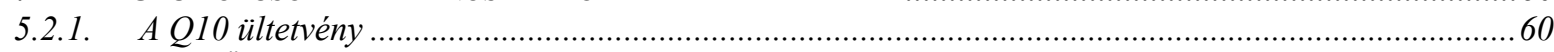

5.2.1.1. Összes vízoldható szárazanyag-tartalom (TSS)_.......................................................................................6

5.2.1.2. Összes titrálható savtartalom (TA) …………………………………………………………………....61

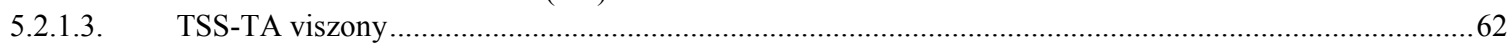

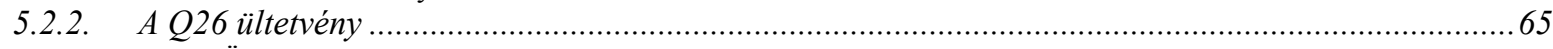

5.2.2.1. Összes vízoldható szárazanyag-tartalom ........................................................................................65

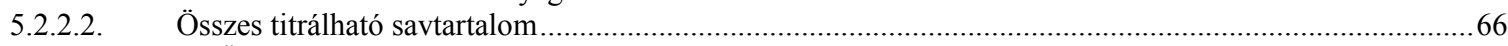

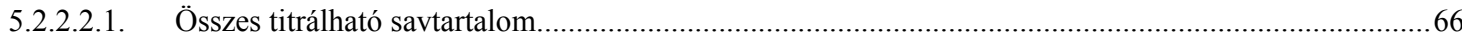

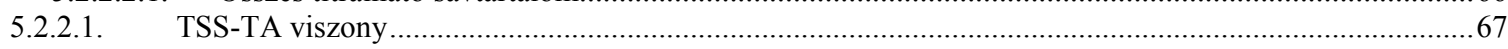

5.3. A GYÜMÖLCSÖK EGYEDI KOMPONENSEI ÉS KOMPONENSCSOPORTJAI......................................................68

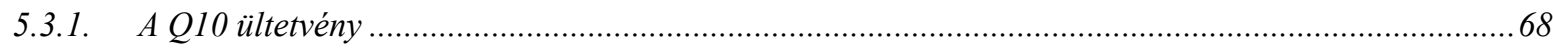

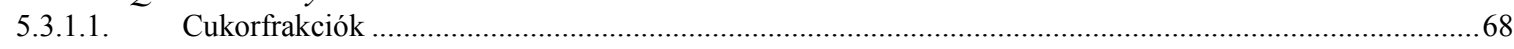

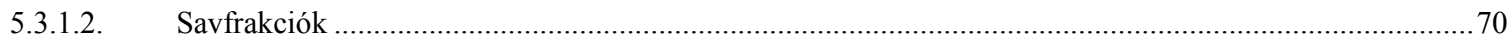

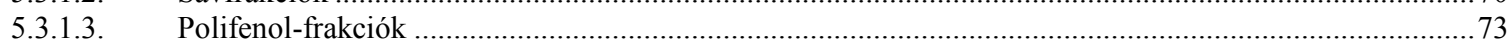

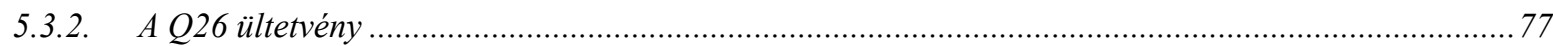

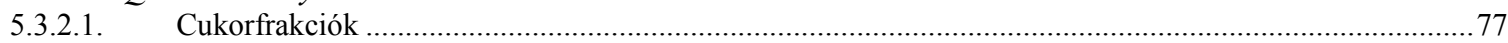

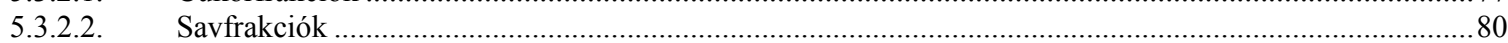

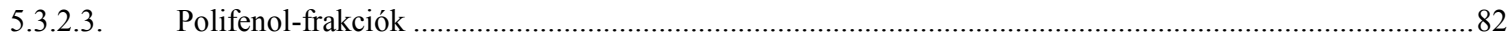

6. EREDMÉNYEK ÉRTÉKELÉSE, KÖVETKEZTETÉSEK ….............................................................86

6.1. GYÜMÖLCSÖK FIZIKAI TULAJDONSÁGAINAK ÖSSZEHASONLÍTÓ ÉRTÉKELÉSE ……................................87

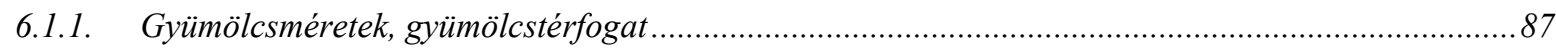

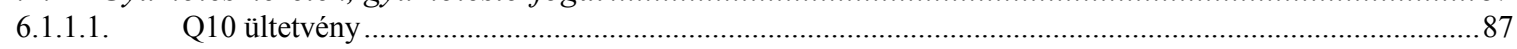

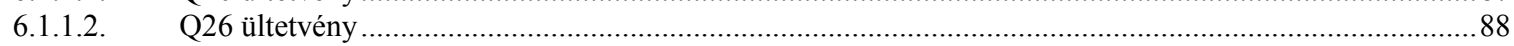

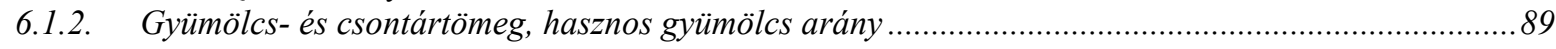

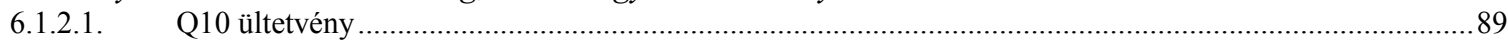

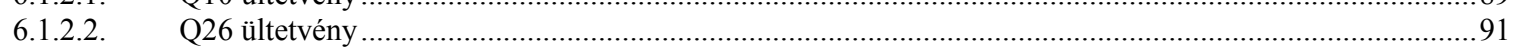

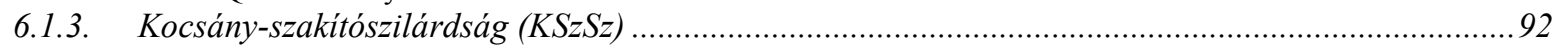

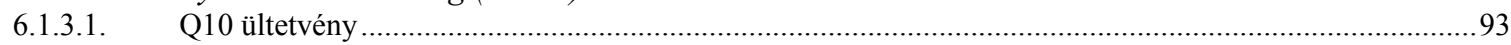

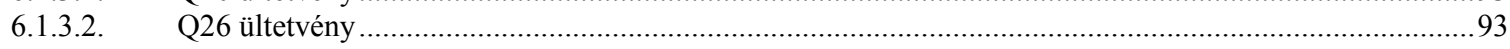

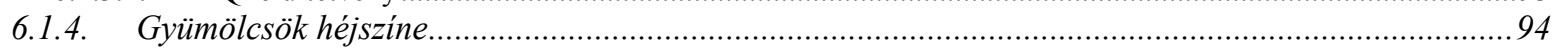

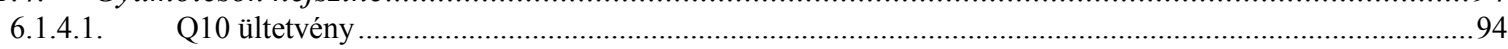

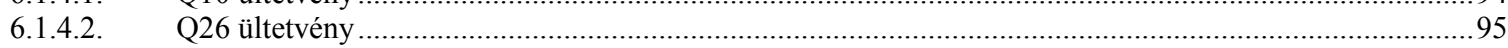

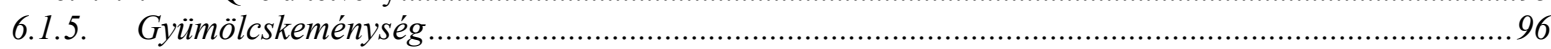

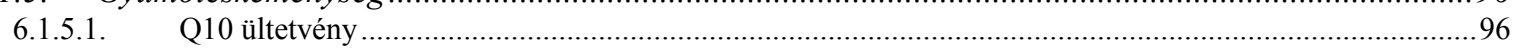

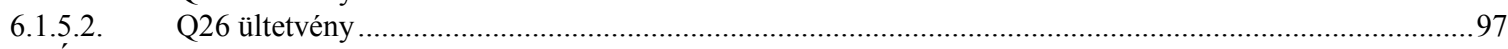

6.2. ÁLTALÁNOS FIZIKOKÉMIAI PARAMÉTEREK ÖSSZEHASONLÍTÓ ÉRTÉKELÉSE ……………………………...98

6.2.1. Vizoldható szárazanyag-tartalom (TSS), titrálható savtartalom (TA), TSS-TA viszony ……..............98

6.2.1.1. Q10 ültetvény .................................................................................................................99

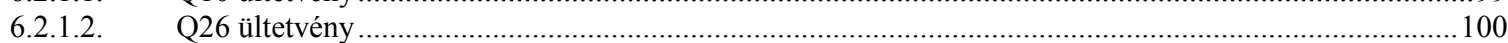


6.3. EGYEDI KOMPONENSEK ÉS KOMPONENSCSOPORTOK ÖSSZEHASONLÍTÓ ÉRTÉKELÉSE ……......................101

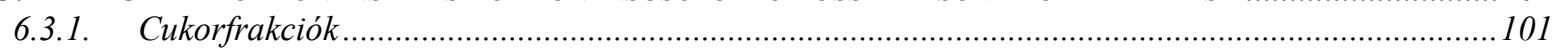

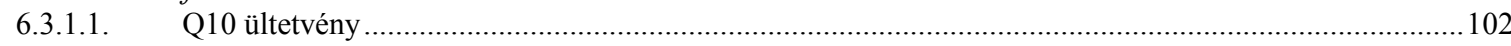

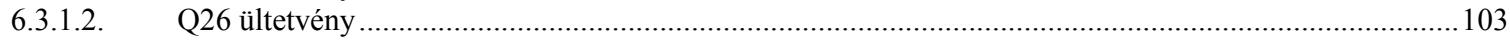

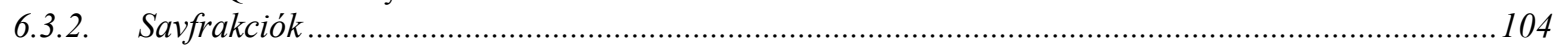

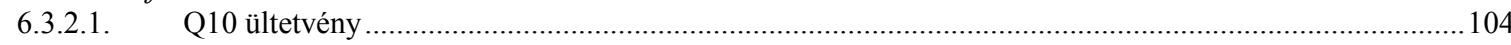

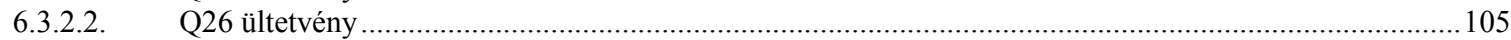

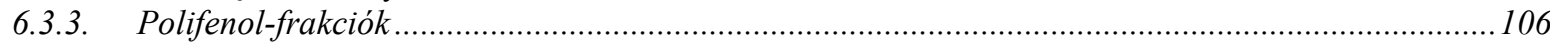

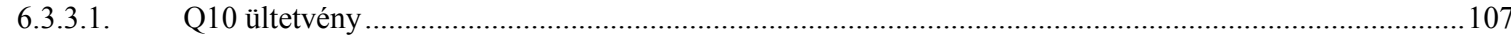

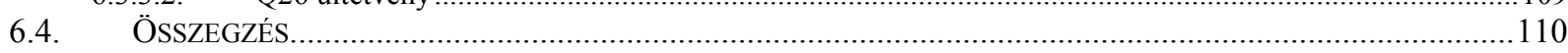

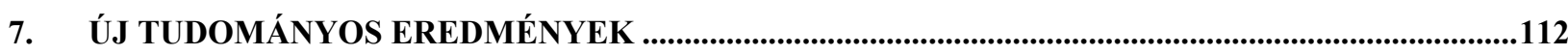

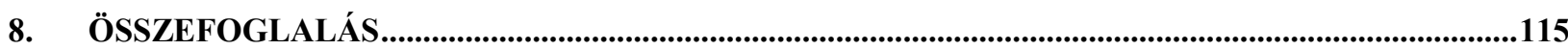

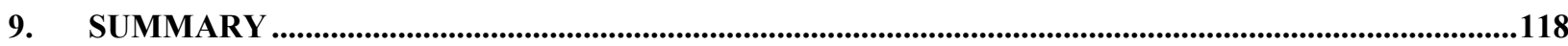

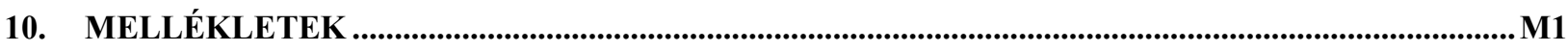

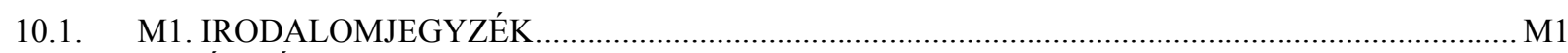

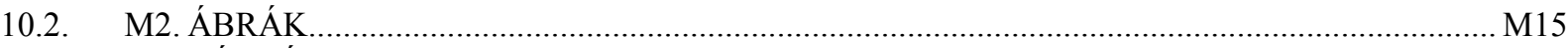

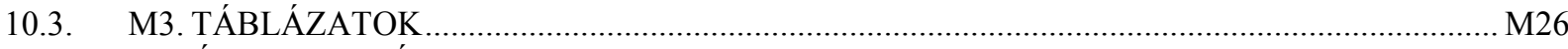

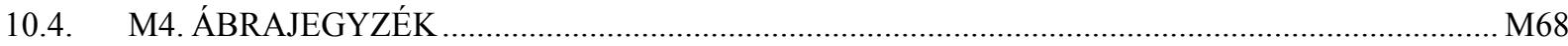

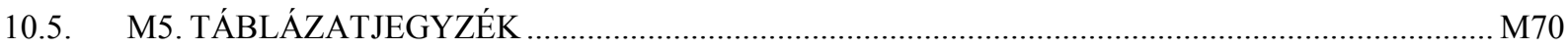

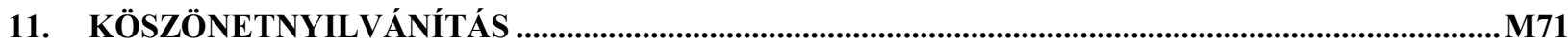




\section{BEVEZETÉS}

A cseresznye (Prunus avium (L.) L.) korai érésének, tetszetős külső megjelenésének és kedvező beltartalmi értékeinek köszönhetően egyike a legkedveltebb nyári gyümölcsöknek mind Európában, mind a világ számos más piacán. A világon megtermelt cseresznye mennyisége kb. 2000-2200 tonna/év, melyből Európa 30-40\%-kal részesedik (FAOSTAT 2015). Kultúrájának története során számos cseresznyefajta került nemesítésre és termesztésbe vonásra.

A ma fellelhetö fajták köztudottan eltérö fizikai tulajdonságokkal (gyümölcsök mérete, héjszíne, keménysége stb.), különböző beltartalmi összetevőkkel (cukortartalom, savtartalom, vitaminok, polifenolok stb.) rendelkeznek. Azonban ma már egyre több vizsgálat bizonyítja, hogy ezek a tulajdonságok nem csak a nemes fajtától függnek, az alany is befolyással van a fák gyümölcsének bizonyos minőségi jegyeire, bár a hatás jellege még nem teljesen tisztázott (AĞLAR és Yildiz 2014, CANTín et al. 2010, GonçALVES et al. 2005, GRATACós et al. 2008, JimÉnEZ et al. 2004, LANAUSKAS et al. 2012, SiMON et al. 2004, SiTAREK és BARTOSIEWICZ 2012, SPINARDI et al. 2005, Szot és MELAnd 2001, TAREen és TAREen 2006, UseniK et al. 2010).

Az utóbbi évtizedben egyes publikációkban arról is olvashattunk, hogy a virágritkításnak is hatása lehet a cseresznye gyümölcsök minőségi paramétereire (AYALA és ANDRADE 2009, CitTAdini et al. 2013, Schoedl et al. 2009, Whiting és LANG 2004). Az alacsony számú publikáció eltérő eredményeiből azonban nem vonhatók le egyértelmü következtetések, továbbra is nyitott a kérdés, hogy ezek a hatások léteznek-e, és ha igen, akkor milyen irányba és milyen mértékben befolyásolják a gyümölcs minőségét.

Gyümölcsmintákon végzett vizsgálatok igazolták, hogy egyes beltartalmi jellemzőkben (pl. oldható szárazanyag-tartalom, titrálható savtartalom stb.) jelentős eltérések tapasztalhatók az érési idő függvényében is, így élelmiszeripari szempontból különösen fontos az összetevők érés alatti nyomon követése (SANG et al. 2003, STÉGERNÉ et al. 2003). Egyrészt bizonyos alkotórészek mennyisége meghatározza a termék jellegét (pl. cukor- és savtartalom), másrészt fontos tényező a késztermékek minőségének alakulása szempontjából is (pl. vitaminok, ásványi anyagok, rostok) (DiPLOCK et al. 1999, FICZEK 2012, HiMELRICK 2002, VERES et al. 2005).

Korunkban egyre nagyobb figyelmet kap a helyes táplálkozás, és annak egészségvédő, betegségmegelőző hatása. Ehhez nélkülözhetetlen a kedvező beltartalmi értékekkel rendelkező friss gyümölcsök és zöldségek, illetve az azokból előállított - szintén magas beltartalmi értékű produktumok fogyasztása. Éppen ezért a cseresznyetermesztők is érdekeltek abban, hogy minél jobb beltartalommal és egészségvédő hatással rendelkező gyümölcsöt produkáló cseresznyeoltványokat használjanak, hogy a fogyasztói igényeket ki tudják elégíteni. Kutatásainkkal többek között arra keressük a választ, hogy melyik alany-nemes kombináció lehet a legmegfelelőbb ezekre a célokra, valamint, hogy milyen pozitív hatásai lehetnek a virágritkításnak az említett tulajdonságokra. 


\section{IRODALMI ÁTTEKINTÉS}

\subsection{A cseresznye rendszertana, nevezéktana, elterjedése, botanikája, alakkörei}

A cseresznye - Prunus avium (L.) L. - növényrendszertani besorolása az aktuális kladisztikus rendszerben - APG III (ANGIOSPERM PHYLOGENY GROUP 2009, STEVENS 2013) - a következö:

Zárvatermők (Angiospermae)

Valódi kétsziküek (Eudicot csoport)

Központi kétsziküek (Rosid klád)

Rózsavirágúak rendje (Rosales)

Rózsafélék családja (Rosaceae)

Csonthéjasok alcsaládja (Amygdaloideae)

Prunus nemzetség

Cerasus alnemzetség

A faj tudományos nevezéktana máig sem rendezett teljes mértékben. Mind a két alábbi szinoním nevét elfogadott névként tartja nyilván a tudományos növénynevek adatbázisa (THE PLANT LisT 2015):

Prunus avium (L.) L. Fl. Suec., ed. 2 (Linnaeus) 165. 1755

Cerasus avium (L.) Moench Methodus (Moench) 672. 1794 [4 May 1794]

Mindkét név a Prunus cerasus L. var. avium L. Sp. Pl. 1: 474. 1753 [1 May 1753] eredeti név faji szintre emeléséből keletkezett (THE InTERnAtional Plant NAMES INDEX 2015). A prioritás elve alapján a korábbi, Prunus avium (L.) L. név a botanikai szempontból helyesebb, de a kertészeti praktikumban gyakran még ma is a Cerasus nemzetségnevet használják. Dolgozatomban a növénytanilag helyes Prunus nemzetségnevet fogom használni a továbbiakban a cseresznyére és rokon fajaira.

A cseresznye faj természetes elterjedési területe Európa és Nyugat-Ázsia a Kaukázusig, de megtalálható Észak-Afrika mediterrán partvidékén is (Melléklet 46. ábra) (EUFORGEN 2009). Vad alakja az üde lombos erdők elegyfaja, Közép-Európában jellemzően a gyertyános-tölgyesek karakterfája.

Nagytermetü fa, hajtásrendszere felfelé törő, ezüstösbarna színű. A levéllemez alakja hosszúkás visszás tojásdad, levélcsúcsa hosszan kihegyezett, felülete sima, a fonákon finom szőrökkel. A lemez hossza legfeljebb $18 \mathrm{~cm}$, szélessége 8-9 cm, a levélszél fogai nagyok, elállók. A levélnyél hossza harmada-negyede a lemez hosszának, rajta 2-3 mézfejtő található. A virágok bogernyőbe rendezettek, fehérek, a csészecimpák épek (SURÁNYI 2003).

A cseresznye termése csonthéjas, monokarp termőből fejlődik. Az exocarpium sima, fényes, viaszos felületü, rajta jól megfigyelhető a termő záródásának varrata; a mezocarpium (terméshús) többrétegü, parenchimasejtekből épül fel, többnyire leves, édes, savanykás vagy kesernyés ízü; az 
endocarpium a kősejtekből álló csonthéj; a csonthéjon belül rendszerint egy mag fejlődik (SURÁNYI 2003).

A cseresznye, mint régi kultúrnövény, igen gazdag alakkörrel rendelkezik. Általában három rasszát (convarietas) szokták megkülönböztetni (SURÁNYI et al. 2003, SPORNBERGER és MODL 2009):

- convar. sylvestris - madárcseresznye (pl. 'CT. 2493', 'F 12/1', 'Májusi korai’): apró termésü, vörös vagy feketés húsú, hajlamos fán aszalódásra; aszalványnak illetve alanynak jó

- convar. juliana - szívcseresznye (pl. 'Valeska', 'Primavera', 'Ökörszív', 'Pongrádi'): gyümölcse fekete vagy sárga húsú, puha állományú, leveses, néha festő, középnagy

- convar. duracina - ropogós cseresznye (pl. 'Bigarreau Burlat', 'Bigarreau Moreau', 'Merton Premier', 'Germersdorfi', 'Kordia', 'Regina'): gyümölcse piros vagy sárga húsú, kemény állományú, ropogós, nagyméretü

\subsection{A cseresznye gyümölcsének külleme}

A gyümölcsök - így a cseresznye - piacon való sikeres jelenléte illetve eladhatósága főként a külső megjelenéstől függ. A frisspiaci igények igen nagymértékben megváltoztak az elmúlt két évtizedben, és a gyümölcsméret egy fontos tényező lett a fogyasztóknál. Jó áron a kifejezetten nagyméretü (28-30 mm átmérőjü) gyümölcsöket lehet értékesíteni (THURZÓ et al. 2008). A nagyobb gyümölcsméret vonzóbb a szemnek, és ezért általában könnyebben és magasabb áron adható el.

A méret mellett egy másik kiemelt tényező a gyümölcsök színe. CRISOSTO et al. (2003) szerint friss fogyasztásra - a fogyasztók korára, nemére, származására tekintet nélkül - a sötétebb, bordópiros változatok a közkedveltek, míg SANSAVINI és LUIGI (2005) szerint ez a megállapítás inkább az európai tipusú társadalmakra igaz, az ázsiaiak jobban kedvelik a világosabb színü, pl. rózsaszín, narancssárga, sárga színủ cseresznyéket. A sárga alapszínüek, mint például a 'Rainier' fajta, tipikus befött-készítésre alkalmas célfajták. Bár hazánkban egyelőre csak a bordópiros cseresznyékből készítenek befőttet, Nyugat-Európában és az USA-ban a sárga cseresznyéből készült befött is közkedvelt.

\subsection{A cseresznye gyümölcskeménysége}

A következö kulcsfontosságú tulajdonság a gyümölcskeménység. A könnyebb kezelhetőség és szállíthatóság miatt mind a termelők, mind a kereskedők, mind az exportőrök előnyben részesítik a keményebb gyümölcsöket, melyek ráadásul még hosszabb ideig is tárolhatók. Mindez persze nem azt jelenti, hogy nincs lehetőség a piacon a puhább gyümölcsű fajták számára, de azokat rosszabb szállíthatóságuk miatt csak a helyi, vagy a közelben lévő piacokon lehet eredményesen értékesíteni (REVELL 2008). Az sem mellékes azonban, hogy a fogyasztók körében is kedveltebb a keményebb, ropogós húsállományú cseresznye. 


\subsection{A cseresznye táplálkozásbiológiai értékei}

A gyümölcsök attraktív megjelenése nem elegendő, tartós sikerre csak azok a fajták számíthatnak, amelyeknek beltartalmi értékei is megfelelőek. A fogyasztók végső döntésében a gyümölcs íze és zamata is kiemelt szerepet játszik, a tudatos vásárló pedig figyelembe veszi a kedvező élettani hatásokat is. A cseresznye mindezen erényeit számos kémiai összetevő együttese hozza létre.

\subsubsection{A cseresznye izértéke}

A fogyasztói elfogadottság szempontjából a cseresznye íze kiemelt fontosságú jellemző (TURNER et al. 2008, GARCIA-MonTIEL et al. 2010, DEVER et al. 1996). A gyümölcs íze elsősorban annak cukor- és savtartalmától függ, pontosabban azoknak a harmonikus, kiegyensúlyozott kombinációjától (DRKENDA et al. 2014, EsQuiVEL et al. 2012, KEMP 2010, PoLL 1981, REVELL 2008, StintZing et al. 2003, UlRICH et al. 2007, WosiaCKI et al. 2009). REVELL (2008) szerint a cseresznye esetében a legjobb ízkombináció akkor jön létre, ha a gyümölcsben magas a cukortartalom és közepesen magas a savtartalom. Ezt az összefüggést szemlélteti az 1. táblázat.

\section{1. táblázat: A cseresznye cukor-sav arányának összefüggése az ízértékkel (REVELL 2008)}

\begin{tabular}{|c|c|c|c|}
\hline \multicolumn{2}{|c|}{} & \multicolumn{2}{c|}{ CUKROK } \\
\cline { 3 - 4 } \multicolumn{2}{|c|}{} & magas & alacsony \\
\hline \multirow{2}{*}{ SAVAK } & közepesen magas & legjobb ízkombináció & savanyú, fanyar, keserü \\
\cline { 2 - 4 } & alacsony & édes & ízetlen \\
\hline
\end{tabular}

A cukormennyiség mérőszámának az összes vízoldható szárazanyag-tartalom (TSS) értéket szokás tekinteni, az ízek alakulásáért felelős különféle savak együttes mennyiségét pedig az összes titrálható savtartalom (TA) jellemzi (CANLI et al. 2015, CANTíN et al. 2010, GIRARD és KoPP 1998, Gonçalves et al. 2005, Gratacós et al. 2008, Simon et al. 2004, Szot és Meland 2001, TURNER et al. 2008, VURSAVUŞ et al. 2006). Ezekröl a mennyiségekröl a későbbiekben még szót ejtünk.

\subsubsection{A cseresznye tápértéke}

A cseresznyegyümölcs 100 grammjának az energiatartalma 264 kJoule (63 kcal). 82,6\%-ban tartalmaz vizet, mindemellett alacsony a zsír- és fehérjetartalma, viszont sok szénhidrát és növényi rost található benne (SOUCI et al. 2008, WILLS et al. 1983). A cseresznye föbb összetevői és azok mennyisége a 2. táblázatban láthatók.

2. táblázat: A cseresznye fő összetevői (SoUCI et al. 2008)

\begin{tabular}{|c|c|}
\hline Alkotóelemek & átlag $(\mathrm{g} / 100 \mathrm{~g})$ \\
\hline víz & 82,8 \\
\hline nitrogén & 0,14 \\
\hline fehérje & 0,9 \\
\hline zsír & 0,31 \\
\hline
\end{tabular}

\begin{tabular}{|c|c|}
\hline Alkotóelemek & átlag $(\mathrm{g} / 100 \mathrm{~g})$ \\
\hline szénhidrát & 13,3 \\
\hline élelmi rost & 1,31 \\
\hline szerves sav & 0,95 \\
\hline ásványok & 0,49 \\
\hline
\end{tabular}


A cseresznye gyümölcse rengeteg vitamint tartalmaz, melyek az emberi szervezet egészséges müködéséhez elengedhetetlenek. A cseresznyében fellelhető fontosabb vitaminokat és azok mennyiségét a 3. táblázat mutatja be (FERRETI et al. 2010, SOUCI et al. 2008 és 2015, SOUZA et al. 2014).

3. táblázat: A cseresznyében fellelhetó vitaminok (SOUCI et al. 2008)

\begin{tabular}{|c|c|}
\hline Vitaminok & átlag $(\mu \mathrm{g} / 100 \mathrm{~g})$ \\
\hline$\beta$-karotin & 35 \\
\hline E-vitamin & 130 \\
\hline$\alpha$-tokoferol & 130 \\
\hline K-vitamin & 1,5 \\
\hline B1-vitamin & 39 \\
\hline B2-vitamin & 42 \\
\hline
\end{tabular}

\begin{tabular}{|c|c|}
\hline Vitaminok & átlag $(\mu \mathrm{g} / 100 \mathrm{~g})$ \\
\hline B3-vitamin & 270 \\
\hline pantoténsav & 190 \\
\hline B6-vitamin & 45 \\
\hline biotin & 400 \\
\hline folsav & 52 \\
\hline C-vitamin & 15 \\
\hline
\end{tabular}

Sok ásványi anyagot és nyomelemet vehetünk magunkhoz a cseresznye gyümölcsének fogyasztásával (KALYONCU et al. 2009, MAHMOOD et al. 2012b, NEILSEN et al. 2009, SouCI et al. 2008 és 2015). A 4. táblázat foglalja össze a cseresznyében található különböző ásványi anyagok és nyomelemek mennyiségét. Az ásványi anyagok nélkülözhetetlenek a szellemi frissesség és a testi erő megőrzése érdekében, részt vesznek az energiaszolgáltató folyamatokban, szabadgyökök elleni védelemben, a hemoglobin szintézisben, a csontállomány kialakításában, az immunrendszer müködésében, az ideg- és izommüködésben, az ingerület átadásban, valamint segítik az emésztést és a tápanyagok hasznosulását (BLÁZOVICS et al. 2003 és 2004, RODLER 2005).

4. táblázat: A cseresznyében előforduló ásványi anyagok és nyomelemek (SoUCI et al. 2008 és 2015)

\begin{tabular}{|c|c|c|}
\hline Alkotóelemek & dimenzió & átlag \\
\hline nátrium & $\mathrm{mg} / 100 \mathrm{~g}$ & 2,7 \\
\hline kálium & $\mathrm{mg} / 100 \mathrm{~g}$ & 235 \\
\hline magnézium & $\mathrm{mg} / 100 \mathrm{~g}$ & 13 \\
\hline kálcium & $\mathrm{mg} / 100 \mathrm{~g}$ & 17 \\
\hline mangán & $\mu \mathrm{g} / 100 \mathrm{~g}$ & 86 \\
\hline vas & $\mu \mathrm{g} / 100 \mathrm{~g}$ & 350 \\
\hline réz & $\mu \mathrm{g} / 100 \mathrm{~g}$ & 100 \\
\hline cink & $\mu \mathrm{g} / 100 \mathrm{~g}$ & 85 \\
\hline
\end{tabular}

\begin{tabular}{|c|c|c|}
\hline Alkotóelemek & dimenzió & átlag \\
\hline króm & $\mu \mathrm{g} / 100 \mathrm{~g}$ & 3 \\
\hline nikkel & $\mu \mathrm{g} / 100 \mathrm{~g}$ & 5 \\
\hline foszfor & $\mu \mathrm{g} / 100 \mathrm{~g}$ & 24 \\
\hline fluor & $\mu \mathrm{g} / 100 \mathrm{~g}$ & 18 \\
\hline jód & $\mu \mathrm{g} / 100 \mathrm{~g}$ & 1,2 \\
\hline bór & $\mu \mathrm{g} / 100 \mathrm{~g}$ & 340 \\
\hline szelén & $\mu \mathrm{g} / 100 \mathrm{~g}$ & 1,2 \\
\hline
\end{tabular}

A cseresznye tartalmazza mind a kilenc, az emberi szervezet számára esszenciális aminosavat (MARTYN 2011, NAMES 2012, PACIFICO et al. 2014). A SouCI et al. (2008 és 2015) által elkészített jegyzékek alapján az 5. táblázat mutatja a cseresznyében előforduló aminosavakat és jellemző mennyiségeiket.

5. táblázat: A cseresznyében megtalálható aminosavak (SOUCI et al. 2008 és 2015)

\begin{tabular}{|c|c|}
\hline Aminosavak & átlag $(\mathrm{mg} / 100 \mathrm{~g})$ \\
\hline alanin & 24 \\
\hline arginin & 14 \\
\hline aszparaginsav & 483 \\
\hline cisztin & 3 \\
\hline glutaminsav & 31 \\
\hline glicin & 19 \\
\hline
\end{tabular}

\begin{tabular}{|c|c|}
\hline Aminosavak & átlag $(\mathrm{mg} / 100 \mathrm{~g})$ \\
\hline hisztidin & 11 \\
\hline izoleucin & 16 \\
\hline leucin & 23 \\
\hline lizin & 31 \\
\hline metionin & 4 \\
\hline fenilalanin & 16 \\
\hline
\end{tabular}

\begin{tabular}{|c|c|}
\hline Aminosavak & átlag $(\mathrm{mg} / 100 \mathrm{~g})$ \\
\hline prolin & 26 \\
\hline serin & 26 \\
\hline treonin & 18 \\
\hline triptofán & 8 \\
\hline tirozin & 10 \\
\hline valin & 22 \\
\hline
\end{tabular}




\subsubsection{A cseresznye szénhidrátjai}

A cseresznye gyümölcsének szénhidrát-tartalma széleskörü érdeklődésre tart számot. Hagyományosan elfogadott - és egy OECD útmutatás által is támogatott - módszer a gyümölcsök összes cukortartalmát az összes oldható szárazanyag-tartalommal (Total Soluble Solids, TSS) azonosítani, amelyet törésmutató-méréssel határoznak meg (OECD, Guidance on Objective Tests To Determine Quality of Fruits and vegetables and dry and dried produce), jóllehet a törésmutatót nem csak a cukrok, hanem minden egyéb oldott anyag is befolyásolja. Ám a korreláció elég jó ahhoz, hogy a TSS alapján az édes karaktert becsülni lehessen (BLAŽKOVÁ et al. 2002, CANTíN et al. 2010, GONÇALVES et al. 2005, GrATACÓs et al. 2008, KurLus 2004, JiMÉNEZ et al. 2004, Sitarek és Grzyb 2010, Szot és Meland 2001, TAReEn és TAReEn 2006, UseniK et al. 2010).

Mélyrehatóbb kutatások a gyümölcs egyedi szénhidrátkomponenseit vizsgálják (DOLENC és ŠTAMPAR 1998, GiRARD és KopP 1998, JimÉNEZ et al. 2004, KELEBEK és SELLi 2011, MAHMOOD et al. 2012a, SERRADILLA et al. 2011, SPINARDI et. al. 2005, USENIK et al. 2008, VoĆA et al. 2009). A fenti szakirodalmak alapján a 6 . táblázat mutatja a cseresznyében leggyakrabban talált szénhidrátokat azok jellemző koncentráció-tartományával együtt.

\section{6. táblázat: A legfontosabb szénhidrátok koncentrációja az érett cseresznyében}

\begin{tabular}{|c|c|}
\hline Szénhidrát neve & koncentráció $(\mathrm{g} / \mathrm{kg})$ \\
\hline glükóz & $33,9-164$ \\
\hline fruktóz & $23,5-121$ \\
\hline szorbitol & $4,4-26,7$ \\
\hline szacharóz & $0 *-12,5$ \\
\hline mannitol & $0,05-0,42$ \\
\hline
\end{tabular}

(*nem kimutatható)

A táblázatból jól látható, hogy az eredmények nagyon széles tartományt ölelnek fel, ami nem meglepő, ha figyelembe vesszük, hogy a cukortartalom nagymértékben függ többek között a fajtától és a klimatikus viszonyoktól (a hivatkozott eredmények között pl. kanadai, spanyol és pakisztáni is van). Abban azonban gyakorlatilag minden szerző egyetért, hogy a legmeghatározóbb szénhidrátok a cseresznye gyümölcsében két monoszacharid: a glükóz és a fruktóz, illetőleg egy cukoralkohol: a szorbitol. Ritkábban említik az ezeknél kisebb, de még viszonylag jelentős mennyiségben megtalálható szacharózt, és egy másik cukoralkoholt, a mannitolt. Az 1. ábra szemlélteti a cseresznyében legnagyobb mennyiségben előforduló szénhidrátokat. 


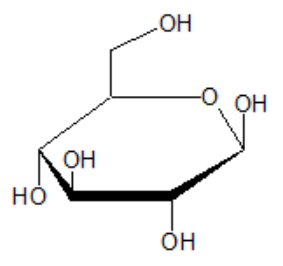

ß-D-Glūkóz

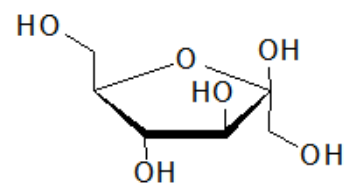

B-D-Fruktóz

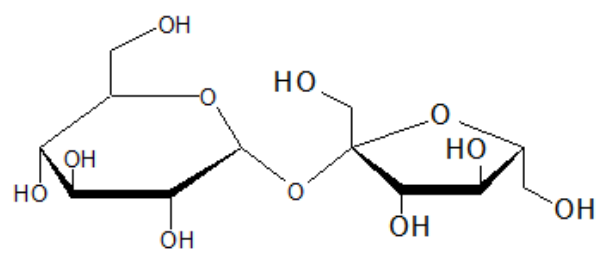

Szacharóz<smiles>OC[C@@H](O)[C@@H](O)[C@H](O)[C@H](O)CO</smiles>

Szorbitol<smiles>CC[C@H](O)[C@@H](O)[C@H](O)[C@H](O)CO</smiles>

Mannitol

1. ábra: A cseresznyében legnagyobb mennyiségben található szénhidrátok szerkezeti képlete

\subsubsection{A cseresznye savai}

A savak esete a cukrokéhoz igen hasonló. A TSS-sel analóg módon a gyümölcs összes savtartalmát titrálással határozzák meg (Titratable Acidity, TA), és ez az érték megfelelő alapot ad az ízérték becsléséhez (CANTín et al. 2010, GonÇALVES et al. 2005, GrATACós et al. 2008, SimON et al. 2004, Szot és MELAND 2001).

A mélyrehatóbb kutatások a cseresznye egyszerü savkomponenseinek egyedi meghatározására törekednek, melyet leggyakrabban kromatográfiás módszerekkel érnek el. A cukrokhoz hasonlóan itt is nagy az egyetértés a kutatók között, legalábbis ami az egyedi savkomponensek azonosítását illeti (GIRARD és KOPP 1998, KELEBEK és SELLI 2011, MAHMOOD et al. 2012a, SERrADILla et al. 2011, SPINARDi et al. 2005, UsENIK et al. 2008). A leggyakoribb savkomponenseket és azok jellemző mennyiségét a 7. táblázat tartalmazza.

\section{7. táblázat: A legfontosabb savak koncentrációja az érett cseresznyében}

\begin{tabular}{|c|c|}
\hline Karbonsav neve & koncentráció $(\mathrm{mg} / \mathrm{kg})$ \\
\hline almasav & $3530-29940$ \\
\hline aszkorbinsav & $84-176$ \\
\hline citromsav & $20-6260$ \\
\hline borostyánkősav (szukcinsav) & $224-10660$ \\
\hline fumársav & $0,82-7,56$ \\
\hline borkősav & $5407-10061$ \\
\hline
\end{tabular}

Az irodalmi adatok azt mutatják, hogy az érett cseresznye savkomponenseinek mennyiségében a kutatók nagyságrendi különbségeket mértek. Legszembetünőbb a citromsav, amelyet a '13S-20-30' fajta esetében GIRARD és KOPP (1998) 20 mg/kg-ban határozott meg, SERRADILLA et al. (2011) pedig közel 300-szor akkora értéket, $6260 \mathrm{mg} / \mathrm{kg}$-ot mértek az 'Ambrunés' fajta gyümölcseiben. Bár az éghajlati- és fajta-paraméterek nyilván nagymértékben befolyásolják a savtartalmat, ekkora különbség már felveti a mérési hiba gyanúját. A 2. ábra mutatja a cseresznye legfontosabb szerves savainak szerkezeti képletét. 
<smiles>O=C(O)[C@H](O)[C@@H](O)C(=O)O</smiles>

borkősav<smiles>O=C(O)CCC(=O)O</smiles>

borostyánkősav<smiles>O=C(O)C[C@@H](O)C(=O)O</smiles>

L-almasav<smiles>O=C(O)C=CC(=O)O</smiles>
fumársav<smiles>O=C(O)CC(O)(CC(=O)O)C(=O)O</smiles>

ciromsav<smiles>O=C1O[C@H]([C@@H](O)CO)C(O)=C1O</smiles>

L-aszkorbinsav

2. ábra: A cseresznyében legnagyobb mennyiségben található karbonsavak szerkezeti képlete

\subsubsection{Antioxidánsok}

Amikor gyümölcsök vagy egyéb táplálékok biológiailag aktív hatóanyagairól beszélünk vagy olvasunk, gyakran találkozunk olyan fogalmakkal, mint pl. polifenolok, antocianinok, flavonoidok, antioxidánsok stb. Ezeknek a fogalmaknak a definíciója nem annyira magától értetődő, ezért mindenképpen érdemes szót ejteni az összefüggéseikről. Általános értelemben véve az antioxidánsok olyan elemek vagy vegyületek, amelyek más elemek vagy vegyületek oxidációját meggátolják. Eközben ők maguk oxidálódnak, tehát redukáló ágensnek tekinthetjük őket (Halliwell és GutTeridge 1984). E definíció szerint ez egy nagyon tág fogalom. A dolgozatomban tárgyalt, és a cseresznye szempontjából releváns, legfontosabb antioxidáns komponenscsoportok kapcsolatát a Mellékletben a 47. ábra (halmazábra) szemlélteti.

\subsubsection{Fenolok}

A bioaktív antioxidánsok egyik csoportja - avagy részhalmaza - növényi fenolikus vegyületek gyüjtőnév alatt ismert, melyek lehetnek egyszerü fenolok vagy polifenolok (BRAVO 1998, FERreres et al. 2009, Harborne és Williams 2000, HerRmann 1976, LugASi 2000, ShaHIDi és NACZK 2004, SUÁREZ et al. 2008, QUIDEAU 2006).

A polifenolok fogalma különösen zavaros, mivel több - egymásnak részben ellentmondó definíció van rá használatban. A legrégebbi, kb. 50 éves, de máig használatos meghatározás Theodore White nevéhez füződik, és eszerint a polifenolok olyan növényi vegyületek, amelyek cserző hatást fejtenek ki a bőrre. A népszerü White-Bate-Smith-Swain-Haslam (WBSSH) definíció szerint a polifenol név olyan vegyületekre alkalmazható, amelyek vízoldhatóak, molekulatömegük 500-4000 Da között van, 1000 relatív molekulatömegenként 12-16 fenolos hidroxilcsoportot és 5-6 aromás gyürüt tartalmaznak, továbbá adják a fenolokra jellemző, speciális reakciókat. QUIDEAU (2006) definíciója szerint a polifenolok közé olyan természetes komponensek tartoznak, amelyek bioszintézise a shikimát/fenilpropanoid és/vagy a poliketid útvonalon játszódik le, több mint egy fenolcsoportot tartalmaznak, és nincs bennük 
nitrogéntartalmú funkciós csoport. Sajnos a fenti meghatározások egyike sem fedi le tökéletesen mindazon komponenseket, amelyeket általában a tudományos hagyomány polifenolként tart számon.

Nagyon sok és sokféle növényi fenol létezik, a közelmúltig több mint 8000-et azonosítottak (HAvsteen 2002, Rice-Evans et al. 1997, XiUZHen et al. 2007). A 8. táblázat mutatja, hogy a természetes fenolokat általában milyen alcsoportokba szokták sorolni.

\section{8. táblázat: A természetes fenolok alcsoportjai}

\begin{tabular}{|l|}
\hline Fenolok \\
\hline Fenolsavak \\
\hline Hidroxi-fahéjsavak \\
\hline Flavonoidok \\
\hline Sztilbének \\
\hline Tanninok \\
\hline Kurkuminok \\
\hline
\end{tabular}

\subsubsection{Fenolsavak}

A fenolsavak fogalom az elfogadott definíció szerint olyan vegyületeket takar, amelyek egyaránt tartalmaznak fenol- illetve karboxil-csoportot. Ilyen például a galluszsav és a szalicilsav (BICUDO et al. 2014). Ugyanakkor a fenolsavak közé sorolják az ellágsavat is, annak ellenére, hogy nincs benne karboxilcsoport (3. ábra). Valójában az ellágsav a galluszsav dimerje, ahol az egyik savmolekula karboxil csoportja a másik savmolekula hidroxil csoportjával képez észtert, és viszont (ANDJElKOvić et al. 2006, KAWSAR et al. 2008, SCHUSTER és HERRMANn 1985, YANG et al. 2014).<smiles>O=C(O)c1cc(O)c(O)c(O)c1</smiles>

galluszsav<smiles>O=C(O)c1ccccc1O</smiles>

szalicilsav<smiles>O=C1Oc2c(O)c(O)cc3c2c(=O)oc2c(O)c(O)cc1c23</smiles>

ellágsav

3. ábra: Néhány fenolsav szerkezeti képlete

\subsubsection{Hidroxi-fahéjsavak}

A hidroxi-fahéjsavak a fahéjsavnak olyan származékai, amelyekben az aromás gyürühöz egy vagy több hidroxilcsoport kapcsolódik (VRHOVSEK 1998). Néhány példa látható a 4. ábrán.<smiles>O=C(O)/C=C/c1ccccc1</smiles>

fahéjsav<smiles>O=C(O)/C=C/c1ccc(O)cc1</smiles>

p-kumársav<smiles>O=C(O)/C=C/c1ccc(O)c(O)c1</smiles>

kávésav

4. ábra: Néhány fahéjsav szerkezeti képlete 
A hidroxi-fahéjsavak karboxil- és fenolcsoportot egyaránt tartalmaznak, ezért a fenolsavak részhalmazát képezik (KIM et al. 2006, VRHOVSEK 1998). Ennek köszönhető, hogy a szakirodalomban időnként az általánosabb „fenolsavak”, máskor a specifikusabb „hidroxifahéjsavak" gyüjtőnévvel hivatkoznak rájuk.

\subsubsection{Flavonoidok}

A flavonoidok a növényi metabolizmus másodlagos termékei. Számos funkciójuk ismert a növényvilágban: pigmentálás, az UV-fény, a mikroorganizmusok és egyéb növényi kártevők gombák, rovarok, csigák stb. - elleni védelem. Az élelmiszerként szolgáló növényi anyagokban természetes színezőanyagok, ízkomponensek, antioxidánsok (ABAD-GARCIA et al. 2009, BORS et al. 1990, CuAdra et al. 1997, Harborne 1986, Herrmann 1976, JäGER A. K. és SAABY 2011, Leth és Justesen 1998, Lugasi 2000, Lugasi és Hóvári 2002, NACZK és SHaHidi 2004, Tournaire et al. 1993, TreutTer 2005, YAO et al. 2004).

A flavonoid vegyületek közös jellemzője a flaván alapváz (5. ábra A), amelyhez különféle szubsztituensek, többek közt hidroxilcsoportok kapcsolódnak. Ez az alapszerkezet rendkívüli változatosságot biztosít mind a szubsztituensek, mind a C-váz szerkezete tekintetében: napjainkig több mint 6000 különböző szerkezetü flavonoidot azonosítottak (HUANG et al. 2015).

Vegyület-osztályozás szempontjából a flaván két legfontosabb módosulata a flavilium kation alapváz (5. ábra B) és a flavon alapváz (5. ábra C). A flavonoidokat alapvázuk szerint két csoportra oszthatjuk: az antocianinokra és az antoxantinokra (XIUZHEN et al. 2007).

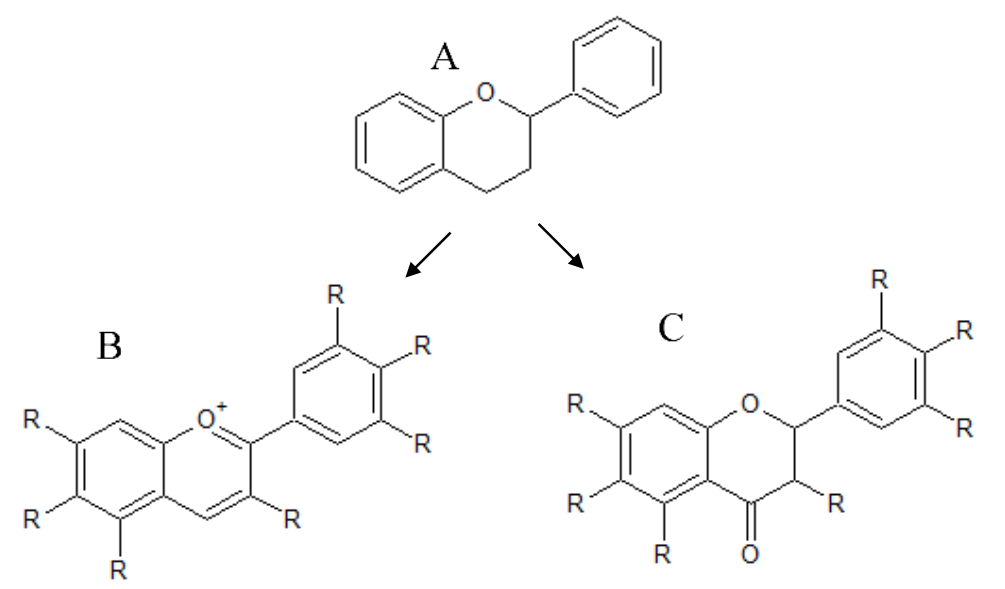

5. ábra: A) flaván alapváz; B) flavilium kation alapváz, C) flavon alapváz

\subsubsection{Antocianinok}

Az antocianin vegyületek alapja a flavilium kation (5. ábra B), amely egy ionos vegyület egyik fele, és ionpárképzője általában a klorid. Az R csoportok megfelelő behelyettesítésével kapjuk meg a különféle antocianidin vegyületeket (pl.: cianidin, peonidin, delfinidin, malvidin stb.). Ezen antocianidinek glükozidjai az antocianinok, más néven antociánok (ANTAL et al. 2003, OLIVEIRA et al., 2001; KONG et al., 2003). Az antocianidinek ugyanis mindig tartalmaznak egy vagy több hidroxilcsoportot. Amennyiben ezen hidroxilcsoportok valamelyikéhez egy 
cukormulekula kapcsolódik, akkor egy antocianin vegyületet kapunk (6. ábra). A hidroxilcsoportok számának növekedésével a kék színárnyalat erösödik a pelargonidin - cianidin - delfinidin irányba, míg a metoxi csoportok számának növekedése a piros színárnyalatot erősíti a peonidin - petunidin - malvidin irányba (GOMBKöTŐ és SAJGÓ, 1985, FlESCHHUT et al. 2006). Az antocianinok adják tehát a növényvilág rózsaszín, piros, kék, lila színét, többek között a cseresznye piros színét is (KonCZAK és ZHANG 2004, Lim 2012, MAZZA és MiniATi 1993, STRACK és WraY 1993).

$\begin{array}{cl}\text { Peonidin } & \begin{array}{l}\text { Peonidin }-3-\mathrm{O}-\text { glükozid } \\ \text { (antocianin típusú vegyület) }\end{array}\end{array}$<smiles></smiles>

6. ábra: Antocianidinek és antocianinek kapcsolata a peonidin konkrét példáján bemutatva

\subsubsection{Antoxantinok}

$\mathrm{Az}$ antoxantinok a flaván és flavon alapvázakból (5. ábra $\mathrm{A}$ és $\mathrm{C}$ ) származtathatók. $\mathrm{Az} \mathrm{R}$ csoportokat különféle ligandumokkal behelyettesítve nagyon változatos és sokféle antoxantin komponenst hozott létre a természet. A fóbb típusok a flavonok, flavonolok, flavanonok, flavanonolok, izoflavonok és glikozidjaik (CHANG et al. 2006, Li et al. 2008, TRIPOLI et al. 2007). Néhány jellemző példát mutat be a 7 . ábra.<smiles>O=c1c(O)c(-c2ccc(O)c(O)c2)oc2cc(O)cc(O)c12</smiles>

kvercetin<smiles>O=C1c2c(O)cc(O)cc2O[C@H](c2ccc(O)c(O)c2)[C@@H]1O</smiles>

katechin<smiles>O=c1c(O)c(-c2ccc(O)cc2)oc2cc(O)cc(O)c12</smiles>

kaempferol<smiles>O=C1c2c(O)cc(O)cc2O[C@H](c2ccc(O)c(O)c2)[C@@H]1O</smiles>

epikactechin<smiles>O=c1c(O)c(-c2cc(O)c(O)c(O)c2)oc2cc(O)cc(O)c12</smiles>

miricetin<smiles>COc1cc(O)cc2oc(-c3ccc(O)c(O)c3)c(O)c(=O)c12</smiles>

azaleatin

7. ábra: Néhány gyakoribb antoxantin szerkezeti képlete 


\subsubsection{A cseresznye jellemzö antioxidánsai}

Az antioxidánsok összes mennyiségét a gyümölcsökben általában az antioxidáns-kapacitással szokták jellemezni a kutatók (Alothman et al. 2009, ANTON et al. 2014, ChAOVANALIKIT és Wrolstad 2004, Chun et al. 2005, CONTESSA et al. 2013, D'EVOLI et. al. 2015, KANDASWAMI és MidDleton 1994, KeVERS et al. 2014, KIM et al. 2003, LEONG és Shui 2002, LeOPOLD et al. 2012, SiLva et al. 2004, SouzA et al. 2014, SzETO et al. 2002, WANG et al. 1996). Ez azonban nem egzakt mennyiség, használata megtévesztő lehet. Ugyanis, mint HUANG et al. (2005) rámutattak, számos módszer létezik az antioxidáns-kapacitás mérésére, amelyek mögött eltérö kémiai reakciók állnak. Az egyes reakciók szelektivitása más és más, így a rájuk alapozott mérések ugyanarra a mintára akár nagymértékben eltérö eredményeket is hozhatnak. Ebböl következik, hogy a különböző kutatók által publikált „totál antioxidáns-kapacitás” értékeket összehasonlítani félrevezető, amíg meg nem győződtünk arról, hogy ugyanazt a mérési módszert használták.

Jobb alapot ad az összehasonlításra, amikor ugyanazon cikken belül publikálnak antioxidáns-kapacitás adatokat különböző fajokról, fajtákról stb. Az ilyen kutatásokból egyértelmüen kiderül, hogy a cseresznye előkelő helyet foglal el az étkezési antioxidáns-források között. CHUN et al. (2005) összehasonlítottak 14 gyümölcsöt és 20 zöldséget: az összesített listán a cseresznye a 8. legmagasabb antioxidáns-kapacitással rendelkezik. PELLEGRINI et al. (2003) 30 féle gyümölcsöt és 34 féle zöldséget hasonlítottak össze. Úgy találták, a cseresznye a 12-16. helyezést éri el, attól függően, hogy melyik mérési módszert alkalmazzák az antioxidáns-kapacitás meghatározására.

Az antioxidáns-kapacitás mérési módszerek olyan tulajdonságokon alapulnak, amelyek az antioxidáns típusú komponensek közös jellemzői, mint például a FRAP (Ferric Reducing Antioxidant Power) vagy a TRAP (Total Radical-trapping Antioxidant Potential) (ELFALLEH et al. 2011, Gorinstein et al. 2011, MARTíneZ et al. 2012, PARK et al. 2014, PINTO et al. 2011, RuizRODRÍGUEZ et al. 2014, SCHLEISER et al. 2002, TSANTILI et al. 2011). Ezek a módszerek a teljes antioxidáns-mennyiséget mérik, azonban nem mondanak semmit az antioxidánsok jellegéröl, típusaikról, molekulaszerkezetükröl.

Egyedi polifenol, flavonoid stb. komponensek párhuzamos meghatározása csak kromatográfiás módszerekkel lehetséges. Ezen a téren elég gazdag irodalom áll rendelkezésre. GonÇALVES et al. (2005), JAKOBEK et al. (2009), KELEBEK és SELli (2011), Mozetič et al. (2004), Mozetič et al. (2006), OGah et al. (2014), SEeram et al. 2001, SERradilla et al. (2011), SERRANO et al. (2005), SÎRBU et al. (2012), USENIK et al. (2008) valamint Wu és PRIOR (2005) eredményei alapján elmondható, hogy a több ezer féle növényi fenolikus vegyület közül a cseresznyében alig több mint tucatnyi található meg számottevő mennyiségben. Ezen komponensek összefoglalása a 9. táblázatban található. 
9. táblázat: A cseresznye jellemző fenolikus komponensei

\begin{tabular}{|c|c|c|}
\hline Típus & Altípus & Komponens \\
\hline \multirow{13}{*}{ flavonoidok } & \multirow{7}{*}{ antocianinok } & cianidin 3-glükozid \\
\hline & & cianidin 3-rutinozid* \\
\hline & & pelargonidin 3-glükozid \\
\hline & & pelargonidin 3-rutinozid \\
\hline & & peonidin 3-glükozid \\
\hline & & peonidin 3-rutinozid \\
\hline & & cianidin 3-szoforozid \\
\hline & \multirow[t]{2}{*}{ antocianidinek } & cianidin-klorid \\
\hline & & malvidin-klorid \\
\hline & \multirow{3}{*}{ flavonolok } & kvercetin \\
\hline & & katechin \\
\hline & & epikatechin \\
\hline & flavonol-glikozidok & kvercetin 3-rutinozid (rutin) \\
\hline \multirow{8}{*}{ fenolsavak } & \multirow[t]{3}{*}{ egyszerü fenolsavak } & p-hidroxi-benzoesav \\
\hline & & sikimisav \\
\hline & & ellágsav \\
\hline & \multirow[t]{2}{*}{ fahéjsav-származékok } & p-kumársav \\
\hline & & ferulasav \\
\hline & \multirow[t]{3}{*}{ hidroxi-cinnamátok } & 3-p-kumaroil-kínasav \\
\hline & & klorogénsav \\
\hline & & neoklorogénsav \\
\hline
\end{tabular}

(vastag betüvel kiemelve a legfontosabbak, ezen belül is *-gal jelölve a kiemelkedő mennyiségü komponens)

\subsection{A cseresznye egészségvédő értékeinek tudományos bizonyítékai}

Régóta ismert, hogy a gyümölcsök és zöldségek fogyasztása jótékony hatással van az emberi szervezetre, és csökkenti egyes krónikus betegségek (rák, szív- és érrendszeri betegségek, Alzheimer-kór stb.) kockázatát (BOEING et al. 2012, DuTHIE et al. 2000, KNEKT et al. 1996, LAMPE 1999, PlATT et al. 2010). A 80-as években keletkezett az elmélet, amely alapján a kutatók zöme az egészségvédő hatásért a növényi antioxidáns vegyületeket teszi felelőssé, jóllehet a mai napig nem tisztázott, hogy tulajdonképpen mi is ennek a hatásmechanizmusa (MELTON 2006). Mindenesetre, az elmélet nagyon jól meggyökeresedett, mivel azóta is a növényi antioxidánsokkal foglalkozó publikációk elég nagy része tényként kezeli, hogy a „polifenolok”, a „,bioflavonoidok”, az ,antocianinok” stb. rendelkeznek gyógy-, illetve preventív hatással (BONNEFONT-RouSSELOTA 2010).

A kezdeti lelkesedés után aztán kezdtek felmerülni a kétségek, amikor egyes kutatási projektek, amelyek eredetileg az antioxidáns-tartalmú étrend-kiegészítők fogyasztása és különféle rákos megbetegedések csökkenése közötti összefüggést céloztak kimutatni, a várttal ellenkező eredményeket hoztak (AlBANES et al. 1995, MELTON 2006). Kiderült két fontos tény: 1) ha egy in vitro (kémcsőben, sejtkultúrán végzett) kísérlet kedvező eredményt hoz is, az még egyáltalán nem garantálja, hogy mindezek in vivo (az emberi szervezetben) is ugyanúgy müködnek, és 2) a természetes kontextusuktól megfosztott antioxidánsok (pl. szintetikus vitaminok, növényi kivonatok stb.) bevitele másképpen hat, mint az ugyanolyan célkomponenseket tartalmazó növényi táplálék elfogyasztása. 
Bár a hatásmechanizmust nem sikerült megfejteni, a tény ettől még tény maradt: a magas flavonoid-tartalmú étrend kedvező hatással van az egészségre, feltéve, hogy ez az étrend friss zöldségekből és gyümölcsökből, nem pedig táplálék-kiegészítő kapszulákból áll. Ennek alátámasztására számtalan publikáció született. A következőkben ismertetünk néhány újabbat a teljesség igénye nélkül.

GEYBELs et al. (2013) megállapították, hogy a flavonoidban dús étrend csökkenti a prosztatarák előrehaladott állapotának kialakulását. CASSIDY et al. (2011) kísérletében a magasabb antocianin-bevitel statisztikailag 8\%-kal csökkentette a magas vérnyomás kialakulását a kontrollcsoporthoz képest. HARDCASTLE et al. (2011) azt tanulmányozták, hogyan hat a magas flavonoidtartalmú étrend a posztmenopauzális nők csontsürüségre. Az öt vizsgált flavonoid-alcsoport közül a flavonolok, flavanolok, flavanonok és procianidinek (kondenzált katechin/epikatechin oligomerek) esetében erős pozitív korreláció volt kimutatható a flavonoid-bevitel és a csontsürűség között, míg a flavonok esetében nem volt összefüggés. MCCULLOUGH et al. (2012) egy hétéves kutatási projekt eredményeképpen kimutatták, hogy a magas flavonoid-tartalmú élelmiszerek fogyasztása 18\%-kal csökkenti a keringési rendszer eredetü elhalálozások kockázatát. BoEING et al. (2012) kritikai irodalmi szemléjükben megállapították: 1) erős, meggyőző bizonyítékok támasztják alá, hogy a zöldség- és gyümölcsfogyasztás segít megelőzni a magas vérnyomást, a stroke-ot és a szívinfarktust; 2) valószínű bizonyítékok vannak arra, hogy általában a rák megelőzésében is szerepe van; és 3) feltételezhetően segít kivédeni a túlsúlyt, egyes szembetegségeket, a demenciát, csontritkulást, asztmát, reumás arthritist, és a krónikus obstruktív tüdőbetegséget.

A cseresznye, mint flavonoidokban és egyéb növényi fenolokban gazdag élelmiszer, hasonlóan pozitív hatással bír. Színes karotinoidjai (béta-karotin, lutein és zeaxantin) és flavonoidjai jelentősen növelik a szervezet antioxidáns védelmét (GARRIDO et al. 2009, HARBORNE 1986, HertOG et al. 1995, JAYAPRAKASAM et al. 2005, KÜHNAU 1976, LUGASI és HóVÁRI 2002, MCNulty et al. 2009, Mulabagal et al. 2009, SERRANO et al. 2005). Az antocianinok továbbá erősítik és rugalmassá teszik az érfalat, gátolva az érelmeszesedés kialakulását. Az antocianin és antocianidin serkenti a kötőszövet újraképződését, és a C-vitaminnal, cinkkel együtt elősegíti a fehérjékből alkotott kollagénrostok erős, rugalmas fonadékká való összekapcsolódását (JAKOBEK et al. 2009). Az antocianin gyulladásokat mérséklő hatású azáltal is, hogy egyes biológiailag aktív anyagok - mint a hisztamin vagy prosztaglandin - mennyiségét csökkenti (JAYAPRAKASAM et al. 2005, Kelley et al. 2006, MARosi 2008, Mulabagal et al. 2009).

\subsubsection{A cseresznye alkalmazása in vivo humán gyógyászati kísérletekben}

A szakirodalomban nem találtunk olyan cikket, amely kimondottan a cseresznye gyümölcsének akut humán terápiás alkalmazásáról szólt volna. Az antioxidáns-tartalmú gyümölcsök, zöldségek fogyasztását szinte kizárólag betegségmegelőző, kockázatcsökkentő céllal ajánlják, vagy 
lábadozást segítő, kiegészítő kezelésként írják le, bár MCCuLlougH et al. (2012) statisztikai alapon megemlítik, hogy még kis mennyiségü, flavonoidban gazdag táplálék elfogyasztása is előnyös lehet a szív- és érrendszeri betegségek kivédésében.

Olyan munkákból is viszonylag kevés van, amely a cseresznye tényleges elfogyasztása és egészségügyi paraméterek, szervezeten belüli biokémiai változások között mutat ki összefüggést.

Ezek közül az egyik legérdekesebb GARRIDO et al. (2013) tanulmánya, amelyben többek közt az alábbi állítások szerepelnek:

- Megfelelő tápanyagbevitellel késleltethető, vagy akár megelőzhető az immunrendszernek az öregedéssel együtt járó leépülése.

- A cseresznyében gazdag diéta javítja az antioxidáns-szintet fiatal, középkorú és idős tesztalanyokban egyaránt, továbbá hangulatjavító (stresszoldó) és alvásszabályozó hatással bír. Ez utóbbiak valószínüleg a cseresznye magas melatonintartalmával függnek össze.

- A fenti hatások maximális kiaknázásához elengedhetetlen a tápanyagok bevitelének megfelelő időzítése (Chrononutrition), tekintettel arra, hogy az emberi szervezet belső biológiai órája napi ciklusokban müködik, amely ciklusok egyes szakaszaiban a testnek más és más tápanyagokra van szüksége.

JACOB et al. (2003) a cseresznyefogyasztás fiziológiai hatásait vizsgálták. Megállapították, hogy az urát koncentráció a vérplazmában 14,5\%-os csökkenést mutat a cseresznye elfogyasztása után 5 órával. Ezzel egy időben a vizelet urát-koncentrációja jelentősen megnövekszik. A húgysav és az urátsók magas koncentrációja a vérplazmában számos probléma kiváltó okai lehetnek, mint például köszvény, szív- és érrendszeri betegségek, cukorbetegség és vesekő-képződés. További eredmény, hogy egyes gyulladási biomarkerek (CPR és NO) mennyisége nem változott jelentősen a teljes 5 órás megfigyelés alatt, viszont a 3 órás mintákban marginális csökkenést mutattak. Ez összhangban van azzal a korábbi megfigyeléssel, hogy a cseresznyében lévő komponensek gátolnak egyes gyulladási folyamatokat.

Az előző eredményt alátámasztja ZHANG et al. (2012) tanulmánya, akik 633 köszvényes emberen végeztek klinikai kísérletet, és megállapították, hogy egy kétnapos cseresznyekúra 35\%kal csökkentette a köszvényrohamok kiújulásának valószínűségét.

KELLEY et al. (2006) a hosszú távú cseresznyefogyasztás plazmalipidekre és gyulladási biomarkerekre gyakorolt hatását vizsgálták 28 napos kísérletben, 18 egészséges emberből álló tesztcsoporton. Főbb megállapításaik a következők voltak:

- A 18-ból 12 személy esetében a vérplazma CRP (C-reactive protein) és NO (nitric oxide) koncentrációja csökkent, 6 személy esetében pedig nem változott, vagyis a szervezet válasza a cseresznyefogyasztásra egyedi sajátosságoktól függ.

- Ahol változás volt kimutatható, a CRP koncentráció 14 nap alatt átlagosan 8\%-kal, 28 nap alatt 25\%-kal csökkent. A NO-koncentráció már 14 nap után 18\%-kal csökkent, és ezt az értéket 
tartotta a kúra végéig. A RANTES (regulated upon activation, normal T-cell expressed, and secreted) koncentráció 28 nap alatt 21\%-kal csökkent.

- A cseresznyefogyasztás megszünése után a CRP és NO koncentráció lassú emelkedésbe kezdett, és a kísérlet végére a cseresznye által előidézett csökkenés egy része eltűnt.

Mivel a CRP megemelkedett szintje a gyulladás egyik legfontosabb jele, és jelentős kockázati faktor a szív- és érrendszeri betegségekben (CVD: cardiovascular disease), ezért valószínüsíthető, hogy a cseresznyefogyasztás csökkenti a CVD kockázatát. Hasonlóképpen, a megnövekedett NO koncentráció olyan betegségek jele, mint pl. a szisztémás lupus erythematosus (SLE), a reumás arthritis és az arthrosis. A NO csökkenés feltételezett mechanizmusából a szerzők azt a következtetést vonják le, hogy a cseresznyefogyasztás a NO csökkentésen keresztül kedvező hatást gyakorolhat az immunrendszerre, és csökkentheti az arthritis kockázatát.

PRIOR et al. (2007) a vérplazma hidrofil- és lipofil- antioxidáns-kapacitásának (H-AOC és L-AOC) változását vizsgálták meg különféle elfogyasztott gyümölcsök függvényében, 10 fős tesztcsoporton. A cseresznye elfogyasztását követően szignifikáns emelkedés volt kimutatható a plazma lipofil AOC-ban, ugyanakkor a hidrofil AOC a szignifikáns mértéket megközelítően csökkent. Ez némileg meglepö, mert korábbi kutatások eredményei szerint a gyümölcsökben általában kevés a lipofil antioxidáns. További megfigyelés, hogy a cseresznye elfogyasztása után 5 órával az L-AOC még enyhén emelkedő tendenciát mutatott, míg ugyanez az érték fekete áfonya elfogyasztása után 4 órával már elkezdett csökkenni.

A kísérletek eredményei alapján a kutatók javasolják, hogy - a redox egyensúly felborulását elkerülendő - minden egyes étkezésben szerepeljenek magas antioxidáns-tartalmú ételek. Szénhidrátok fogyasztását követően ugyanis szabad gyökök fokozott képződése várható. Amikor a szervezetben mozgósítható antioxidánsok nem képesek felvenni a harcot a szabad oxidatív gyökökkel, akkor beszélünk oxidatív stresszröl. Az oxidatív stressz föszerepet játszik az olyan szív- és érrendszeri rendellenességek kialakulásában és előrehaladásában, mint a hyperlipidemia, diabetes mellitus, magas vérnyomás, iszkémiás szívbetegség, krónikus szívelégtelenség.

Mindezen kutatások eredményei meggyőzően bizonyítják a cseresznye egészségvédő értékét. A hatás feltételezhetően a cseresznyében lévő antioxidánsokon, ezen belül is elsősorban a polifenolokon keresztül érvényesül, amely alapot szolgáltat arra, hogy vizsgáljuk ezen anyagok képződésének függését a különféle tényezőktől.

\subsection{Az alany és a virágritkítás hatása a cseresznyegyümölcsök minőségére, egészségvédő értékeire}

A gyümölcsök minősége számos faktortól függ, hatásuk mértékéről, irányáról sokszor a szakemberek sincsenek egységes állásponton.

Az például mindenki számára nyilvánvaló, hogy a cseresznye gyümölcsének méretét, állagát, keménységét, ízét, színét alapvetően befolyásolja maga a nemes fajtája, hiszen gyakran 
ezek a különbségek mérés nélkül, pusztán érzékszervekre hagyatkozva megállapíthatóak. Nem kevésbé egyértelmű, hogy a klimatikus körülmények is döntő befolyással bírnak (SOLTÉSz et al. 2004), ehhez elég megélni egy túlnyomóan napos, száraz, és egy túlnyomóan esős, hűvös évet egy gyümölcsös közelében. Bizonyos termesztéstechnológiai tényezők (pl. koronaalakítás, metszés, ültetvénysűrüség) befolyása szintén ismert a szakemberek körében (ARENA 2008, CAPRIO és QuAMme 2006, RoBARDS és ANTOLOVICH 1997, WANG et al. 2009, ZiMMERMANN és GALENSA 2007, HROTKÓ 2003).

Az viszont már nem annyira közismert, hogy - oltványok esetében - az alany milyen hatással bír, vagy egyáltalán van-e hatása a rá oltott nemes gyümölcsminőségre. A virágritkítás szintén egy olyan faktor, amelyről gyanítják, hogy változásokat okoz a termés minőségében, de a változás tényleges mértéke kérdéses. Ezekben, mint a későbbi fejezetekből ki fog derülni, nincs egyetértés a kutatók között.

\subsubsection{Az alany hatása a gyümölcsminöségre}

Az utóbbi 10-15 évben számos olyan nemzetközi publikáció jelent meg, melyek a cseresznyealanyok eltérő hatásait vizsgálják a rájuk oltott nemes fajták gyümölcseinek minőségi paramétereire, úgymint méret, tömeg, keménység, szín, összes vízoldható szárazanyag-tartalom (TSS), titrálható savtartalom (TA), cukrok, savak, polifenolok, antocianinok mennyisége stb. A következőkben megkíséreljük összefoglalni időrendi sorrendben az elmúlt évek szakirodalmát ebben a témában.

SzOT és MELAND (2001) különböző alanyok (vadcseresznye magonc, 'Colt', 'GiSelA 5') szignifikáns hatását mutatta ki 3 cseresznyefajta ('Van', 'Ulster', 'Burlat') gyümölcsének méretére, tömegére, titrálható savtartalmára (TA), teljes vízoldható szárazanyagtartalmára (TSS) és gyümölcskeménységére. Gyümölcsméret tekintetében a 'Van' fajta a vadcseresznye magoncon, az 'Ulster' fajta a 'Colt'-on, a 'Burlat' a 'GiSelA 5' alanyon mutatkozott a legjobbnak, míg a csontár/gyümölcshús arány minden fajta esetében a 'GiSelA 5' alanyon volt a legkedvezőbb. A legpuhább gyümölcsöket a vadcseresznye magoncon és a 'GiSelA 5' alanyon is az 'Ulster' fajta produkálta, míg a legkeményebb gyümölcse a 'Colt' alanyra oltott 'Van' fajtának volt. A három fajtát összehasonlítva a 'Burlat' gyümölcsei voltak a legpuhábbak. A legmagasabb TSS értéket 'Van' fajta esetében a 'Colt' alany, 'Ulster'-nél a 'GiSelA 5', 'Burlat'-nál a vadcseresznye magoncra oltott egyedek gyümölcseiben mértek, míg a három fajtát összehasonlítva a 'Van' fajta szárazanyag-tartalma volt a legmagasabb. A legmagasabb TA-t 'Van' fajtánál a 'Colt'-on, 'Ulster'-nél a magoncon, 'Burlat'-nál a 'Colt'-on figyelték meg. A fajtákat összehasonlítva az 'Ulster' gyümölcseinek savtartalma volt a legalacsonyabb.

JIMÉNEZ et al. (2004) a 'Sunburst' fajta gyümölcsminőségét tanulmányozták 8 különbözö alanyon ('CAB 6P', 'CAB 11E', 'MM 9', 'MaxMa 14', 'MaxMa 97', 'Damil', 'Colt' és 'SL 64'). Szignifikáns különbségeket találtak a gyümölcs cukortartalma, színe, tömege és keménysége 
között, míg titrálható savtartalomban és pH-ban nem találtak szignifikáns eltérést. A legkeményebb gyümölcsöket 'Damil' alanyra oltott nemes gyümölcsein mérték, őt követték a 'Colt', 'CAB 6P' és 'MaxMa 14' alanyok, míg a legpuhább gyümölcse a 'CAB 11E' alanyú fának volt. A TSS-t vizsgálva a legmagasabb koncentráció 'Damil', 'MaxMa 14' és 'Colt' alanyon mutatkozott, míg a legalacsonyabb 'SL 64' alanyon. A legmagasabb cukor/sav arányt szintén a 'Damil' alanynál számítottak. Gyümölcshéjszínt vizsgálva a 'MaxMa 14' alany adta a legsötétebb héjszínt, míg a 'CAB 11E' mutatta a legintenzívebb piros színt. JIMÉNEZ és munkatársai HPLC (High Performance Liquid Chromatography) vizsgálatokkal cukorkomponenseket is vizsgáltak. A legmagasabb glükóz és fruktóz koncentrációkat 'Damil' alanyon mérték, míg a legalacsonyabb értéket az 'SL 64' adta. A szorbitol koncentrációja szintén a 'Damil' alanynál volt a legmagasabb.

SiMON et al. (2004) 4 alanyfajta ('Colt', 'MxM 14', 'MxM 97' és 'SL 64') hatását mutatta ki két különböző nemes fajtára ('Germersdorfi FL 45' és 'Van') az alábbi paramétereknél: fák termésmennyisége, gyümölcsök tömege, keménysége, repedési hajlama, vízoldható szárazanyagtartalma. A 'MxM 14' és 'SL 64' alanyokon álló fák termésmennyisége szignifikánsan magasabb volt a többinél. A legnagyobb gyümölcstömeget 'Colt', míg a legalacsonyabbat 'MxM 14' alanyon mérték. A legmagasabb TSS érték 'Colt' és 'MxM 97' alanyokon volt mérhető. A TA-t vizsgálva nem tudtak szignifikáns különbséget kimutatni.

SPINARDI et al. (2005) 'Stella' és 'Lapins' fajtákat vizsgáltak az alábbi alanyokon: Prunus avium 'Sel Noisetec 4'; Prunus cerasus 'CAB 11E', 'Tabel ${ }^{\circledR}$ Edabriz' és 'Vladimir'; valamint Prunus padus magoncok. Vizsgálataik alapján kimutatták, hogy a cseresznye gyümölcsében felhalmozódó cukrok, savak, polifenolok, antocianinok és vitaminok mennyiségére nagy hatással van az oltvány alanykomponense is. Összehasonlítva a fajtákat a 'Stella' mutatta a magasabb almasav, polifenol és antocianin értékeket, míg a 'Lapins' fajta rendelkezett szignifikánsan magasabb vitamintartalommal. A legjobb alanynak a beltartalmi értékek tekintetében a 'Sel Noisetec 4' bizonyult, amely a legmagasabb glükóz, fruktóz, szorbitol és vitamin értékeket idézett elő a nemeseknél. Egy másik érdekes alanynak a 'CAB 11E' mutatkozott, mely hasonló cukorösszetétel mellett magasabb polifenol és antocianin értékeket adott, mint az elöbb említett 'Sel Noisetec 4' alany. Mindkét fajta esetében 'Vladimir' alanyon mérték a biokémiai összetevők legalacsonyabb koncentrációját. A legtöbb paramétert vizsgálva ugyancsak rosszul szerepelt a 'Tabel ${ }^{\circledR}$ Edabriz' alany, csak az antocianinok jelenlétére volt pozitív hatással.

GONÇALVES et al. (2005) különböző alany-nemes kombinációkat ('Burlat', 'Summit' és 'Van' fajtákat 5 féle alanyon: Prunus avium L. magonc, 'CAB 11E', 'Maxma 14', 'GiSelA 5', 'Tabel ${ }^{\circledR}$ Edabriz') vizsgáltak, és mérték többek között a gyümölcsök tömegét, keménységét, héjszínének világosságát, TSS és TA értékét. Kimutatták, hogy ugyanazon alany teljesen más hatással lehet a különböző nemesekre: míg az egyik fajtánál a legjobb választásnak bizonyulhat, addig egy másiknál az adhatja a leggyengébb értékeket. A legnagyobb átlagtömeget 'Summit' fajtánál mérték, a többi fajtánál nem tapasztaltak szignifikáns eltérést. Legkeményebbnek a 'Van' 
gyümölcsei bizonyultak, míg legpuhábbnak a 'Burlat' gyümölcsei. Ez utóbbinál azonban meg kell jegyezni, hogy alany-nemes kombinációnként eltérö eredmények születtek: ‘CAB 11E' alanyon a gyümölcsök puhák voltak, ám 'GiSelA 5' alanyon és vadcseresznye magoncon relatív kemény gyümölcsöket találtak. Gyümölcshéjszínt vizsgálva a legvilágosabb gyümölcsöket mindhárom fajta esetében a 'GiSelA 5' alanyon találták, míg a legsötétebbeket a 'Maxma 14' és 'CAB 11E' alanyoknál. A legmagasabb TSS-koncentrációt 'Tabel ${ }^{\circledR}$ Edabriz' alanyon álló 'Van' fajta gyümölcsei szolgáltatták, míg legalacsonyabbakat 'GiSelA 5'-ön, vadcseresznye magoncon és 'Tabel ${ }^{\circledR}$ Edabriz'-en álló 'Burlat' fajtánál mértek, tehát a 'Tabel ${ }^{\circledR}$ Edabriz' alany hol a legjobb, hol a legrosszabb értékeket produkálta. A nemesek közül a 'Burlat' fajtánál alacsony TA-t mutattak ki, míg a másik kettőnél közepes savtartalmat mértek. Az alanynak szignifikánsan nem volt hatása sem a titrálható savtartalomra, sem a pH-ra.

TAREEN és TAREEN (2006) pakisztáni vizsgálataik során szignifikáns különbségeket találtak a különböző alanyokon (vadcseresznye magonc és 'Colt') álló 'Rainier' fák terméshozása, gyümölcseinek héjszíne és TSS értéke között. A 'Colt' alanyon álló fák szignifikánsan magasabb termésmennyiséget produkáltak, és a gyümölcsök héjszíne is jóval sötétebb lett ezen az alanyon. TSS tekintetében azonban a vadcseresznye magonc produkálta a magasabb értékeket.

GRATACÓs et al. (2008) chilei vizsgálataikban 6 különböző alany ('Pontaleb', 'Colt', 'Cab 6P', 'MaxMa 14', 'GiSelA 6' és 'GiSelA 5') gyümölcsminőségre gyakorolt eltérő hatását igazolták 'Bing' és 'Lapins' cseresznyefajtáknál. A relatív termésmennyiség 2003-ban mindkét fajtánál 'GiSelA 6' és 'GiSelA 5' alanyokon volt a legmagasabb, míg 'Colt'-on a legalacsonyabb. 2004-ben a 'Pontaleb' alany mutatkozott a legjobbnak, míg a 'GiSelA 5' adta a legalacsonyabb értékeket. A gyümölcstömeget vizsgálva a 'Lapins' fajta a 'Colt'-on produkálta a legnagyobb átlagtömegü gyümölcsöket, a 'Bing' fajta gyümölcsei azonban ugyanezen az alanyon lettek a legkisebb tömegüek. Ez utóbbinál a 'Pontaleb' alany bizonyult a legjobb választásnak. Egy évvel később mindkét nemes a 'MaxMa 14' alanyon hozta a legnagyobb átlagtömegü gyümölcsöket. A TSS 2003-ban 'Bing' fajtánál 'Colt' alanyon, 'Lapins'-nál 'Cab 6P'-n volt a legmagasabb, míg 2004-ben 'Bing' esetében a 'Pontaleb' és a 'Cab 6P', 'Lapins' fajtánál a 'GiSelA 6' és a 'Maxma 14' bizonyult a legjobbnak. A TA is évjáratonként és alanyonként változó értékeket eredményezett.

CANTín et al. (2010) a 'Van’ és 'Stark Hardy Giant' fajták gyümölcsminőségét vizsgálták a következő alanyokon: 'Adara', 'CAB 6P', 'GiSelA 5', 'MaxMa 14', 'SL 64', 'SL 405' és 'Tabel ${ }^{\circledR}$ Edabriz'. Szignifikáns különbségeket tapasztaltak a gyümölcsméretben, TSS-ben, TA-ban, gyümölcshéjszínben és keménységben a különböző alanyokon álló fajták között. Általánosságban elmondható, hogy az 'Adara', a 'CAB 6P' és a 'MaxMa 14' gyümölcsei voltak a legnagyobb tömegüek, és a legattraktívabb színnel is ezek rendelkeztek. Az 'Adara'-ra oltott nemesek gyümölcsei ezeken túlmenően még magas gyümölcskeménységi értékkel is rendelkeznek. A 'CAB 6P' alany magasabb TA értékeket produkált a többinél. Bár a 'GiSelA 5' alany magasabb 
TSS-t és viszonylag kemény gyümölcsöket indukált, a gyümölcsök kis mérete és kevésbé attraktív héjszíne miatt érdektelenné vált CANTíN és munkatársai számára.

SITAREK és GRZYB (2010) 'Kordia' cseresznyefajtát oltottak 8 különböző alanyra ('GiSelA 5', 'P-HL A', 'P-HL B', 'P-HL C', 'Maxma 14', 'Weiroot 158', 'Tabel ${ }^{\circledR}$ Edabriz' és 'F 12/1'). Azt vizsgálták, hogy az alany milyen hatással van a termésmennyiségre, a gyümölcs tömegére és TSS értékére. A legnagyobb termésmennyiséget a 'P-HL B', 'Maxma 14' és 'GiSelA 5 ' alanyokon álló fáknál mérték, míg a legalacsonyabb értékeket 'Tabel ${ }^{\circledR}$ Edabriz' és 'F12/1' alanyoknál. Gyümölcstömeget vizsgálva a 'Tabel ${ }^{\circledR}$ Edabriz' alanyon találták a legkisebb tömegü gyümölcsöket, a többi alany szignifikánsan nem tért el egymástól. TSS szempontjából a legalacsonyabb értékek 'F12/1' és 'MaxMa 14' alanyon voltak mérhetők, míg a legmagasabbak 'Tabel ${ }^{\circledR}$ Edabriz' és 'Weiroot 158 ' alanyú fáknál.

USENIK et al. (2010) a 'Lapins' cseresznyefajta minőségi paramétereit vizsgálta 9 különböző alanyon ('F 12/1', 'Maxma 14', 'Piku 1', 'Tabel ${ }^{\circledR}$ Edabriz', 'GiSelA 5', 'GiSelA 195/20', 'Weiroot 13', 'Weiroot 158' és 'Weiroot 72'). A vizsgált paraméterek (gyümölcstömeg és -mennyiség, TSS, TA, gyümölcskeménység, valamint biokémiai paraméterek, mint cukrok, szerves savak és fenol komponensek) alanyonként mind szignifikáns eltéréseket mutattak. Az átlagos fánkénti terméshozam a 'Piku 1' alanynál volt a legmagasabb, míg 'GiSelA 5'-nél a legalacsonyabb. 'Weiroot 72' és 'Tabel ${ }^{\circledR}$ Edabriz' alanyok magas TSS-t és gyümölcskeménységet produkáltak. A 'GiSelA 5' alanyra oltott nemesek gyümölcseiben volt a legalacsonyabb a glükóz, fruktóz, szorbitol, szukróz és citromsav koncentrációja, míg az 'F 12/1' alany eredményezte a legmagasabb glükóz, fruktóz és sikimisav értékeket. A fenolvegyületek összességében a 'Weiroot 72' alanyon álló nemes gyümölcseiben voltak jelen a legnagyobb koncentrációban. Az antocianinok mennyisége szignifikánsan nem különbözött az eltérő alanyok esetében.

LANAUSKAS et al. (2012) 12 különböző alanyra ('GiSelA 4', 'Gi 497/8', 'Gi 209/1', 'Gi 148/8', 'Gi 195/20', ‘Gi 154/7', 'Gi 523/02', 'Weiroot 53', 'Weiroot 158', 'P-HL-A', 'Damil' és 'GiSelA 5') oltottak 'Lapins' cseresznyefajtát. 5 éves vizsgálataik alapján szignifikáns különbségeket mutattak ki az alábbi paraméterek vizsgálata során: növekedési erély, terméshozam, gyümölcsméret és -tömeg. 'Gi 154/7' és 'GiSelA 4' alanyon mutatták ki a legnagyobb átlagos fánkénti terméshozamot, míg a legkisebbet Gi 148/8, Damil, P-HL-A, Gi 195/20, GiSelA 5 és Weiroot 158 alanyokon. A legnagyobb gyümölcstömeg a 'P-HL-A' és a 'Gi 523/02' alanyokon volt mérhetö, míg a legkisebb gyümölcsöket a 'Gi 209/1', 'GiSelA 5' és 'Gi 195/20' alanyokon álló nemesek produkálták. TSS tekintetében nem találtak szignifikáns eltérést az alanyok hatása között.

SitAREK és BARTOSIEWICZ (2012) 5 különböző cseresznyealany ('GiSelA 3', 'GiSelA 5', 'Piku 4', 'Weiroot 72' és 'F 12/1') hatását vizsgálta 2 nemes cseresznyefajta ('Sylvia' és 'Karina') terméshozamára, gyümölcstömegére és TSS értékére. Mindkét fajta a 'GiSelA 5' alanyon hozta a 
legtöbb termést, míg 'GiSelA 3'-on a legkisebb gyümölcsöket. Az TSS tekintetében nem találtak szignifikáns különbséget az alanyok között.

AĞLAR és YILDIZ (2014) törökországi vizsgálataiban azt vizsgálta, hogy hogyan hat az alany ('GiSelA 5', 'GiSelA 6', 'MaxMa 14' and 'SL 64') a '0900 Ziraat' cseresznyefajta termésmennyiségére, gyümölcstömegére, TSS-ére. A legnagyobb termésmennyiséget a 'GiSelA 5' alany produkálta, míg a legkisebbet az 'SL 64'. A gyümölcsméret azonban pont fordítva alakult: 'GiSelA 5' alanyú fán termettek a legkisebb gyümölcsök, míg 'SL 64'-en a legnagyobbak. TSS tekintetében nem tudtak szignifikáns eltérést kimutatni.

Az elmúlt 15 év szakirodalmait összevetve észrevehető, hogy a kutatási eredmények gyakran ellentmondásosak, az alanyhatás nem egyértelmü.

Vegyük például a 'GiSelA 5' alany és a TSS kapcsolatát: CANTíN et al. (2010) szerint a 'GiSelA 5' alanyon álló fák gyümölcseiben a legnagyobb a TSS, USENIK et al. (2010) valamint GONÇALVES et al. (2005) szerint azonban ez az alany mutatta a legkisebb TSS értéket.

A 'GiSelA 5' alany szintén ellentmondásos eredményeket mutat terméshozam szempontjából a különböző szakirodalmakban: míg AĞLAR és YILDIZ (2014), valamint SITAREK és BARTOSIEWICZ (2012) szerint ez az alany produkálta a legnagyobb termésmennyiséget, addig USENIK et al. (2010) és LANAUSKAS et al. (2012) szerint 'GiSelA 5' alanyon lett a legkisebb a termésmennyiség.

JiMÉNEZ et al. (2004), GONÇALVES et al. (2005) és SiMON et al. (2004) nem találtak szignifikáns különbséget a TA értékekben a különböző alanyokon álló nemesek között, ezzel szemben CANTín et al. (2010), GRATACós et al. (2008) és SzOT és MELAND (2001) szignifikáns hatást mutatott ki az említett paraméternél.

SPINARDI et al. (2005) szerint az antocianin-tartalom függ az alanytól, USENIK et al. (2010) azonban nem mutattak ki szignifikáns eltérést az alanyok között, pedig kettejük esetében a nemes ('Lapins') is megegyezett a vizsgálatokban.

\subsubsection{A virágritkitás hatása a gyümölcsminőségre}

Virágritkítás hatására a fák számszerüen kevesebb termést hoznak. Az azonban nem biztos, hogy mindez összességében is kisebb termésmennyiséget eredményez, és az sem egyértelmü, hogy ritkítás hatására egyéb mennyiségi vagy minőségi változás történik-e a gyümölcsben. Ezért az utóbbi egy évtizedben több nemzetközi kutatás is irányult arra, hogy megállapítsák, milyen hatása van a virágritkításnak a fák különböző sajátosságaira, a gyümölcsök bizonyos mennyiségi és minőségi paramétereire. Vizsgálták többek között azt, hogy kimutatható-e szignifikáns eltérés a virágritkított és a nem ritkított fák gyümölcseinek tömege, keménysége, összes oldható szárazanyag-tartalma (TSS), titrálható savtartalma (TA) stb. között. A Prunus avium L. faj esetében azonban mindezidáig kevés irodalom született. A következőkben röviden ismertetjük ezek eredményeit. 
Whiting és LANG (2004) 2000-ben és 2001-ben 'GiSelA 5' alanyra oltott 'Bing' cseresznyefákon vizsgálta, hogy van-e hatása a mechanikai virágritkításnak a fák vegetatív növekedésére, a levelek gázcseréjére és a gyümölcsök minőségére. Szignifikáns különbséget mutattak ki a kontroll (nem ritkított) fák és a virágritkítással kezelt fák között. Azon fák gyümölcsei, amelyeken virágritkítás történt, 25\%-kal nagyobb átlagtömegüek és keményebbek is voltak, TSS tekintetében 20\%-kal mutattak magasabb értéket, és méret szerinti osztályozásukkor 315\%-kal több gyümölcs került a 'nagy' méretkategóriába ( $\geq 26,6 \mathrm{~mm})$ a kontroll fák terméseihez viszonyítva.

WhitiNG et al. (2006) tovább folytatták kísérleteiket, és 2002-ben és 2003-ban arra keresték a választ, hogy ugyanabban az ültetvényben a kémiai virágritkítás hogyan hat a termés mennyiségére és minőségére. A kémiai kezelések az alábbiak voltak: ammónium-tioszulfát ( $2 \%$ ATS), zöldségolaj emulzió (3-4\% VOE) és halolaj-mészkén (2\%-2,5\% FOLS) keverék. Mindkét évben az ATS és a FOLS csökkentette a termésmennyiséget 33-66\%-kal, a VOE 50\%kal 2002-ben, de 2003-ban nem volt hatása. 2002-ben az ATS és a FOLS hatására nőtt a gyümölcsök TSS értéke, de 2003-ban nem volt kimutatható szignifikáns különbség a kontrolhoz képest. A VOE-val kezelt fák gyümölcseinek TSS értéke pozitívan változott 2002-ben, 2003-ban viszont 12\%-os csökkenés volt tapasztalható. 2002-ben mindhárom kezelés erősen lecsökkentette a kisméretü ( $\leq 21,5 \mathrm{~mm})$ gyümölcsök kialakulását, ezzel szemben több mint 400\%-kal emelte a nagy gyümölcsökét ( $\geq 26,5 \mathrm{~mm}$ ). 2003-ban az ATS és a FOLS nem volt hatással a kis gyümölcsök mennyiségére, de 60\%-kal növelte a nagy gyümölcsök számát, míg a VOE a kis gyümölcsök számát növelte meg jelentősen a kontrollhoz viszonyítva.

SCHOEDL et al. (2009) kémiai virágritkítás (ammómium-tioszulfátos kezelés, ATS) hatását vizsgálta 'GiSelA 5' alanyra oltott 4 különböző nemes cseresznyefajta ('Blaze Star', 'Samba', 'Techlovan' és 'Merchant') gyümölcsminőségére. Az ATS-t különböző koncentrációkban és mennyiségben juttatták ki. Vizsgálták a termésmennyiséget, gyümölcsméretet és -tömeget, a termés hús/csontár arányát, TSS-ét, $\mathrm{pH}$-ját és TA-ját. Méréseik során arra jutottak, hogy szignifikánsan csak a termésmennyiségre gyakorolt hatás mutatható ki, a gyümölcsök méretére, tömegére és titrálható savtartalmára nincs hatással egyik kezelés sem. A hús/csontár arány csak a 'Blaze Star' esetében mutatott szignifikáns különbséget, a TSS pedig csak a ‘Techlovan' fajtánál.

AYALA és ANDRADE (2009) a kézi virágritkítás hatását vizsgálta a gyümölcsminőségre és a vegetatív növekedésre 'Lapins' fajta esetében 'F-12/1' alanyra oltva. Nem tudtak szignifikáns különbséget kimutatni sem gyümölcsméret, sem gyümölcstömeg, sem pedig TSS tekintetében.

VON BENNEWITZ et al. (2010) szintén 'Lapins' fajta gyümölcsminőségét vizsgálta virágritkított és kontroll fák összehasonlításában. Eredményeik szerint a virágritkítás pozitív hatást gyakorolt a gyümölcsök méretére és tömegére, negatív hatást a gyümölcsök TSS értékére, és nem volt hatása a gyümölcskeménységre és a TA értékére. 
CITTADINI et al. (2013) munkájuk során arra voltak kíváncsiak, hogyan befolyásolja a 'Sweetheart' és ‘Lapins' cseresznyefajták (alany: Prunus mahaleb) gyümölcsének mennyiségét és minőségét a virágritkítás ideje és/vagy intenzitása. A virágritkításnál 3 különböző intenzitási szintet $(30 \%, 60 \%$ és 90\%) állítottak be (kontroll mellett), valamint 3 féle virágritkítási időpontot jelöltek meg: 'Lapins' esetében 1, 24 és 47 nappal, 'Sweetheart'-nál pedig 7, 31 és 64 nappal a teljes virágzás után (szintén kontroll mellett). A termésmennyiség a ritkítás intenzitásától függően egyre csökkent, a ritkítás időpontja azonban nem befolyásolta. A ritkítás intenzitásával a 'Lapins' fajta esetében a gyümölcsök átlagos tömege és átméröje nőtt, míg a 'Sweetheart' fajta esetében nem volt kimutatható szignifikáns különbség. Ezzel szemben a ritkítás késleltetésének hatására ez utóbbinál csökkent a gyümölcsök tömege és mérete. Mindkét fajtánál a TTS nőtt a virágritkítás intenzitásának növekedésével. 'Lapins' esetében a gyümölcskeménységre nem volt hatással sem a ritkítás ideje, sem pedig intenzitása. Ezzel szemben a 'Sweetheart' fajta gyümölcskeménysége csökkent a ritkítás időpontjának késleltetésével.

BOYACI és ÇAĞLAR (2013) a rügypattanás elötti mechanikai ritkítás hatását vizsgálták 'GiSelA 5' alanyon álló 'Lapins' cseresznyefajta gyümölcsminőségére. Az első évben 4 különböző intenzitású ritkítási kezelést alkalmaztak (50\%, 33\%, 25\%,20\%), a második évben nem végeztek ritkítást. Első évben, amikor végeztek ritkítást, a gyümölcsök mérete kisebb lett a kontroll fákhoz viszonyítva, második évben, amikor nem történt ritkítás, nagyobbak lettek a gyümölcsök a kontrollnál.

Összességében az eddigi szakirodalmi adatok nem adnak kielégítő választ arra a kérdésre, hogy pontosan milyen hatása van a virágritkításnak a gyümölcsfák viselkedésére, illetve a termések mennyiségi és minőségi sajátosságaira.

WHITING és munkatársai (2004, 2006) szerint virágritkítás hatására nő a gyümölcsök tömege, mérete, keménysége és TSS értéke is, SCHOEDL et al. (2009) azonban nem tudott szignifikáns különbséget kimutatni sem a gyümölcsök méretére, sem tömegére, sem pedig titrálható savtartalmára. Az azonban igaz, hogy különböző fajtákat vizsgáltak: míg előbbi 'Bing’ fajtát, addig utóbbi 'Blaze Star', 'Samba', 'Techlovan' és 'Merchant' fajtákat értékeltek. Elképzelhető tehát, hogy a virágritkításra a különböző fajták különbözőképpen reagálnak.

Ennek azonban némiképpen ellentmond az, hogy a kutatók közül többen is a 'Lapins' fajtát vonták vizsgálat alá, mégsem mutatnak az eredmények egyértelmü tendenciát: CITTADINI et al. (2013) gyümölcsméret, gyümölcstömeg, és TSS tekintetében is igazolta a virágritkítás pozitív hatását, ezzel szemben AYALA és ANDRADE (2009) nem tudtak kimutatni szignifikáns különbséget a virágritkítással kezelt fák és a kontroll fák között egyik paraméternél sem. 


\section{CÉLKITÜZÉSEK}

Kutatásom célkitüzései az alábbi pontokban fogalmazhatók meg:

1)

a) Feltérképezni és jellemezni a 'Kordia' és 'Regina' nemes cseresznyefajták 'GiSelA 5', 'GiSelA 6', 'PHL-C', 'PiKu 1' és 'Weiroot 158' alanyokra oltott oltványkombinációinak gyümölcsminőségét különféle fizikai, kémiai és összetételi jellemzők (gyümölcsméret, gyümölcs- és csontártömeg, gyümölcskeménység, gyümölcshéjszín, kocsányszakítószilárdság, összes vízoldható szárazanyag-tartalom, összes titrálható savtartalom, egyedi cukor-, sav- és polifenol-profil) mérésén keresztül különböző időjárású években.

b) A gyümölcsminőség követése az érési folyamat során.

c) A feltérképezés során nyert adatok összehasonlító statisztikai elemzése segítségével választ kapni arra a kérdésre, hogy az alany hatással van-e a nemes gyümölcsminőségére, és ha igen, ez a hatás hogyan, milyen formában, milyen mértékben nyilvánul meg.

d) A vizsgálati eredmények alapján javaslatot tenni a különböző célokra legalkalmasabb alany-nemes kombináció(k)ra.

2)

a) Feltérképezni és jellemezni a 'GiSelA 5' alanyra oltott 'Bigarreau Burlat Schreiber', 'Bigarreau Burlat VG', 'Bigarreau Moreau', 'Hybrid 222' és 'Merton Premier' nemes cseresznyefajták virágritkítással kezelt, illetve kontroll fáinak gyümölcsminőségét a fent felsorolt paraméterek mérésén keresztül különböző időjárású években.

b) A gyümölcsminőség követése az érési folyamat során.

c) A feltérképezés során kapott adatok összehasonlító statisztikai elemzése segítségével választ kapni arra a kérdésre, hogy a virágritkítás hatással van-e a különböző nemes fajták gyümölcsminőségére, és ha igen, ez a hatás hogyan, milyen formában, milyen mértékben érvényesül.

d) A vizsgálati eredmények alapján javaslatot tenni az egyes termesztési céloknak megfelelően a virágritkítás alkalmazhatóságára a vizsgált alany-nemes kombinációk esetében. 


\section{ANYAG ÉS MÓDSZER}

\subsection{A szabadföldi kísérletek helyszíne}

A cseresznye gyümölcsöket Ausztriában, a Bécs területén található BOKU (Universität für Bodenkultur Wien) Haszonnövény Intézet (Department für Nutzpflanzenwissenschaften) Szőlészeti és Gyümölcsészeti Részlegének (Abteilung für Obst- und Weinbau) kísérleti ültetvényében szedtük meg. Az ültetvény Bécs északi-északkeleti szélén, Jedlersdorf városrészben található (Melléklet 48. ábra). Az ültetvény föépületének GPS-koordinátái a következők: $48^{\circ} 17^{\prime} 19.0^{\prime \prime} \mathrm{N} 16^{\circ} 25^{\prime} 43.6^{\prime \prime} \mathrm{E}$.

\subsection{Talaj}

A jedlersdorfi területen közepes humusztartalmú mélyrétegű csernozjom talaj található a Bundesforschungs- und Ausbildungszentrum für Wald, Naturgefahren und Landschaft (BFW 2015) szerint. A talaj felső rétegei meszesek és bázikus kémhatásúak. A talajerózió nem számottevő. A talaj vályog textúrájú, amelynek víztartó kapacitása magas, 220-300 mm/100cm.

\subsection{Klíma}

A kísérleti ültetvény tengerszint feletti magassága $162 \mathrm{~m}$. A klímát szubkontinentális klímahatás, meleg, száraz nyár és mérsékelten hüvös tél jellemzi. Az évi középhőmérséklet átlagosan $9,8^{\circ} \mathrm{C}$, a napsütéses órák száma évente átlagosan 1800 óra. Az évi átlagos csapadékmennyiség 500-600 mm, a legtöbb csapadék a nyári hónapokban hullik (BOKU 2015, ZAMG 2015).

\subsection{Időjárás}

A kísérleti ültetvény területén egy analóg időjárás állomás található, melynek segítségével folyamatosan rendelkezésünkre álltak ás állnak a legfontosabb időjárási paraméterek, úgymint a napsugárzás, hőmérséklet, páratartalom, csapadék adatok, szélsebesség, szélirány. A 10. táblázat mutatja az évenkénti fontosabb időjárási adatokat az adott területen, a 8. ábra pedig havi lebontásban mutatja a 4 év összesített időjárási adatait.

10. táblázat: Évenkénti időjárási paraméterek a jedlersdorfi kísérleti ültetvény területén (2010-2013)

\begin{tabular}{|c|c|c|c|c|}
\cline { 2 - 5 } \multicolumn{1}{c|}{} & $\begin{array}{c}\text { csapadékösszeg } \\
\mathrm{mm}\end{array}$ & $\begin{array}{c}\text { átlaghőmérséklet } \\
{ }^{\circ} \mathrm{C}\end{array}$ & $\begin{array}{c}\text { globálsugárzás-összeg } \\
\mathrm{W} / \mathrm{m}^{2}\end{array}$ & $\begin{array}{c}\text { átlagos relatív páratartalom } \\
\%\end{array}$ \\
\hline $\mathbf{2 0 1 0}$ & 717,2 & 9,58 & 14715,0 & 74,22 \\
\hline $\mathbf{2 0 1 1}$ & 385,4 & 10,54 & 45537,1 & 69,54 \\
\hline $\mathbf{2 0 1 2}$ & 415,0 & 10,93 & 40185,8 & 69,14 \\
\hline $\mathbf{2 0 1 3}$ & 456,4 & 10,45 & 47739,8 & 73,78 \\
\hline
\end{tabular}

A 10. táblázat és a 8. ábra is jól mutatja, hogy a 2010-es év időjárása nagyban különbözött a többi év időjárásától. A 2010-es évben 57-86\%-kal több csapadék hullott, mint az azt követő 3 
évben, a globálsugárzás-összeg, 63-69\%-kal volt kevesebb a 2011-2013-ban mért értékeknél, az átlaghőmérséklet pedig $0,87-1,35^{\circ} \mathrm{C}$-kal volt alacsonyabb a 2010-es évben a többihez képest.

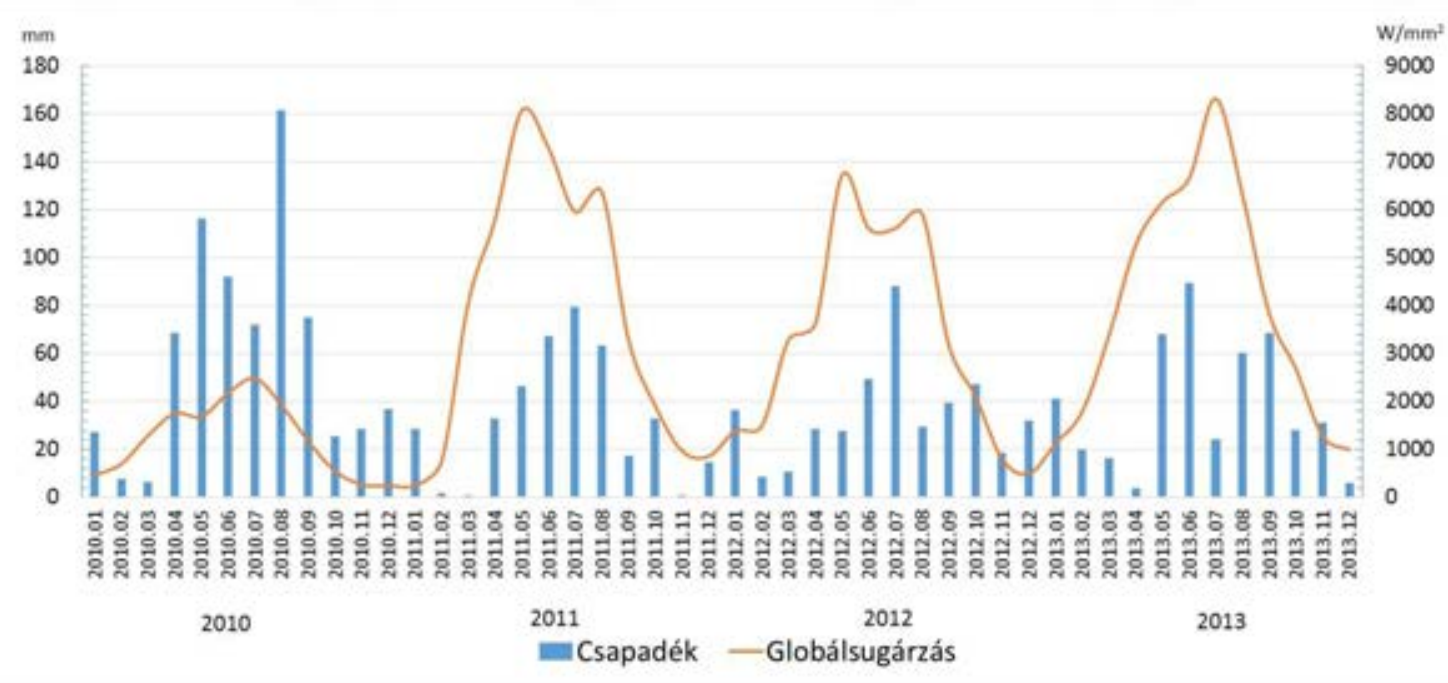

8. ábra: A csapadék és a globálsugárzás adatai havi lebontásban 2010 januárja és 2013 decembere között a kísérleti ültetvény területén

\subsection{A kísérleti elrendezés}

A kísérleti üzem területén belül két különböző termesztési technológiájú cseresznyeültetvényt vontunk be a vizsgálatokba: egy integrált gazdálkodású ültetvényt (továbbiakban: Q10 ültetvény), ahol főként az alanyhatást vizsgáltuk, valamint egy bioültetvényt (továbbiakban: Q26 ültetvény), ahol elsősorban a virágritkítás hatását vizsgáltuk (Melléklet 49. ábra).

\subsubsection{Q10 ültetvény (alanyhatás vizsgálatának helyszine)}

Az integrált gazdálkodású cseresznyeültetvény két féle nemes cseresznyefajta ('Regina' és 'Kordia') 5 féle alanyra ('GiSelA 5', 'GiSelA 6', 'PHL-C', 'PiKu 1' és 'Weiroot 158') történő oltásával, összesen 10 különböző alany-nemes kombinációjú fával lett telepítve 2006 tavaszán. Növényi alapanyagnak egyéves oltványokat használtak, a fákat orsó koronaformára nevelték. A telepítés olyan területre történt, ahol már az azt megelőző 15 évben is cseresznyefák álltak. A fák elrendezése véletlen blokk elrendezésben történt 6 sorban, soronként 16 fával, alany-nemes kombinációnként 9 ismétléssel, valamint soronként 1-1 pollenadó partnerrel ( $p l$. 'Duroni', 'Karina'). A sorok közötti távolság 4 m-re lett beállítva, a tőtávolság pedig 2,5 m-re. A fák elrendezését, illetve az alany-nemes kombinációkat a Melléklet 17. táblázata szemlélteti. Az évek folyamán 3 fa elpusztult, azokat egy vonal (-) jelzi a táblázatban (mindhárom 'Weiroot 158' alanyú: 2 db 'Regina', 1 db 'Kordia' fa).

Trágyázás az Q10 ültetvény területén egyszer történt még a telepítéskor: $100 \mathrm{~g} / \mathrm{m}^{2} \mathrm{NPK}$ $(12+10+15$, Vollkorn Rot, Bayer, Langenfeld, Németország), ez után már nem történt további tápanyag-utánpótlás. A sorokban a 3. évtől kezdődően minden tavasszal mechanikai gyomirtás történt, nyáron mulcsozás, majd vegyszeres gyomirtás (Basta 0,8\%, Bayer, Langenfeld, 
Németország), míg a sorközöket rendszeresen kaszálták. A növényvédelem az integrált termesztési irányelveknek megfelelően zajlott. Minden évben a virágzást követően rovarölő szeres kezelést (Perfekthion S 0,05\%, BASF, Bécs, Ausztria) alkalmaztak gombaölő szerrel (Syllit 0,1\%, Kwizda, Bécs, Ausztria) kombinálva. Ezeken kívül a cseresznyelégy (Rhagoletis cerasi) ellen évente egy-két alkalommal Mospilan 20 SG (0,025\%, Kwizda, Wien, Ausztria) típusú rovarölőszert használtak.

\subsubsection{Q26 ültetvény (virágritkitás hatásának vizsgálati helyszine)}

A bioültetvény 13 különböző nemes cseresznyefajtával került eltelepítésre, melyek a következők: 'Bigarreau Burlat Schreiber', 'Bigarreau Burlat VG', 'Bigarreau Moreau Schreiber', 'Bigarreau Moreau VG', 'Early Lory', 'Hybrid 222', 'Merchant', 'Merton Premier', 'Valeska', 'Summertime', 'Langstielige', 'Marzer Kirsche' és 'Schachl' (18. táblázat). A fákat 4 sorba helyezték el. Minden sor első két fája a déli oldalon, illetve első fája az északi oldalon csak szegélyfa, nem vettek részt a kísérletben. Mindegyik fajtából $8 \mathrm{fa}$ állt rendelkezésünkre. Az ültetvény létesítésekor egyéves oltványok kerültek eltelepítésre 2003 őszén. Az alany minden esetben 'GiSelA 5' alanyfajta volt. A sorok közötti távolság 4 m-re lett beállítva, a tőtávolság pedig 2,5 m-re. A 'VG' és 'Schreiber' jelölés a ,Bigarreau Burlat' és ,Bigarreau Moreau’ fajtáknál a növényi alapanyag eredetére utal. A 'VG' jelölésủ fajta a jedlersdorfi faiskola bioültetvényéböl, míg a 'Schreiber' jelölésűek a hagyományos faiskolájából származnak.

A fákat orsó koronaformára nevelték, az első négy évben csak a konkurens hajtások kerültek eltávolításra. Az első metszés 2008 júliusában történt, majd ezt követően minden évben szüret után nyáron. A facsíkokban mechanikai gyomirtás történt, a sorközökben kaszálás. A terület semmilyen trágyázást, tápanyag-utánpótlást nem kapott, és nem történt semmiféle vegyszeres növényvédelmi eljárás sem. Operophtera brumata (kis téli araszoló) ellen évente egy kezelés történt Bacillus thuringiensis baktérium segítségével, illetve káliszappannal (Neudosan, 2\%) virágzás után. 2010 után neemfaolajat (Azadirachta indica, Meliaceae) használtunk levéltetvek ellen (Myzus cerasi P. és Myzus pruniavium P.). Virágzás után 2-3 héttel patogén gombák ellen kénes lemosó permetezést alkalmaztunk.

\subsection{A vizsgálatokban résztvevő nemesfajták jellemzése}

\subsubsection{Q10 ültetvény}

Az Q10 ültetvény összes alany-nemes kombinációját bevontuk a vizsgálatokba (Melléklet 17. táblázat). A következőkben a nemes fajták rövid jellemzései olvashatók.

\subsubsection{1. 'Kordia'}

A 'Kordia' fajtát (9. ábra) a csehországi Techlovicében nemesítették. Június közepén-végén érik. Gyümölcse középnagy-nagy méretü (24-26 mm, 6 g), szív alakú, kemény húsú, ropogós, frissítően 
savas-édes ízü, közepesen lédús, héja fényes sötétbordó színü. Csontárja kicsi (kb. 4,5m/m\%). Frissfogyasztásra és befőzésre egyaránt alkalmas. Koronája szétterülő ágrendszerü. Bőtermő, gyümölcsei viszonylag hosszabb ideig a fán hagyhatók, repedésre nem hajlamosak. Önmeddö, ezért porzópartner szükséges mellé (SPORNBERGER és MODL 2009, APOSTOL 2003).

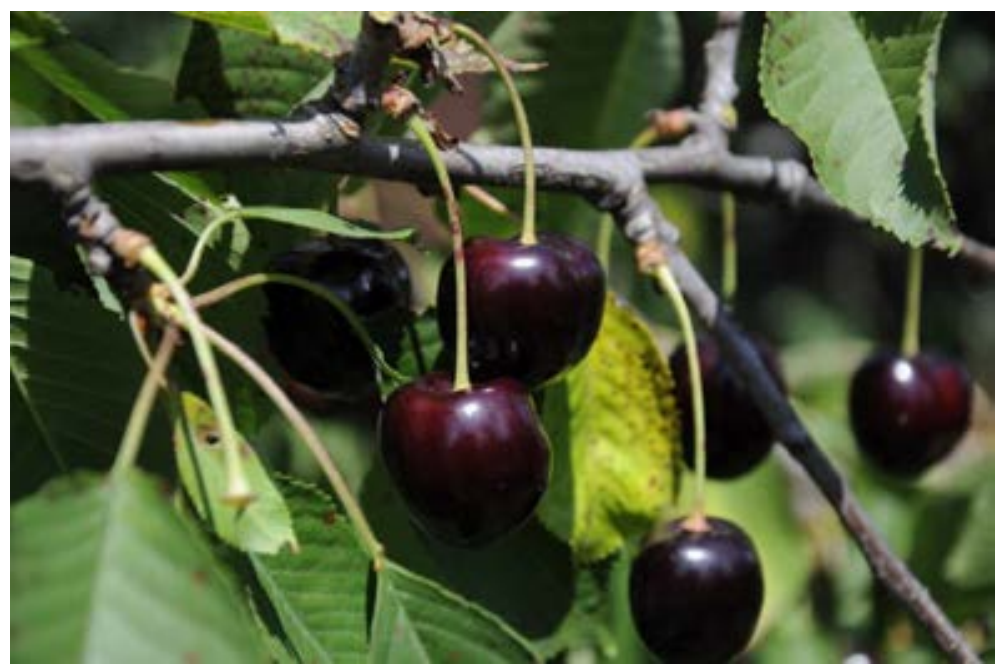

9. ábra: 'Kordia' (fotó: ANDREAS SPORNBERGER)

\subsubsection{2. 'Regina'}

A 'Regina' (10. ábra) német eredetủ fajta, a jorki kutatóintézetben állították elő a 'Schneiders Späte Knorpelkirsche' $\times$ 'Rube' kombinációjából. Június végén - július elején érik. Gyümölcse nagyméretű (24-28 mm, 8-11 g, BÄDER 2006), szívalakú, közepesen piros, fényes héjú, kemény húsú, ropogós, lédús, gazdag aromájú. Fája középerős növekedésű. Virágai későn nyílnak, érzékenyek a fagyra, önmeddőek, jó pollenadói pl. a 'Kordia', 'Sam', 'Sylvia', 'Duroni’ fajták (SPORNBERGER és Modl 2009, Apostol 2003).

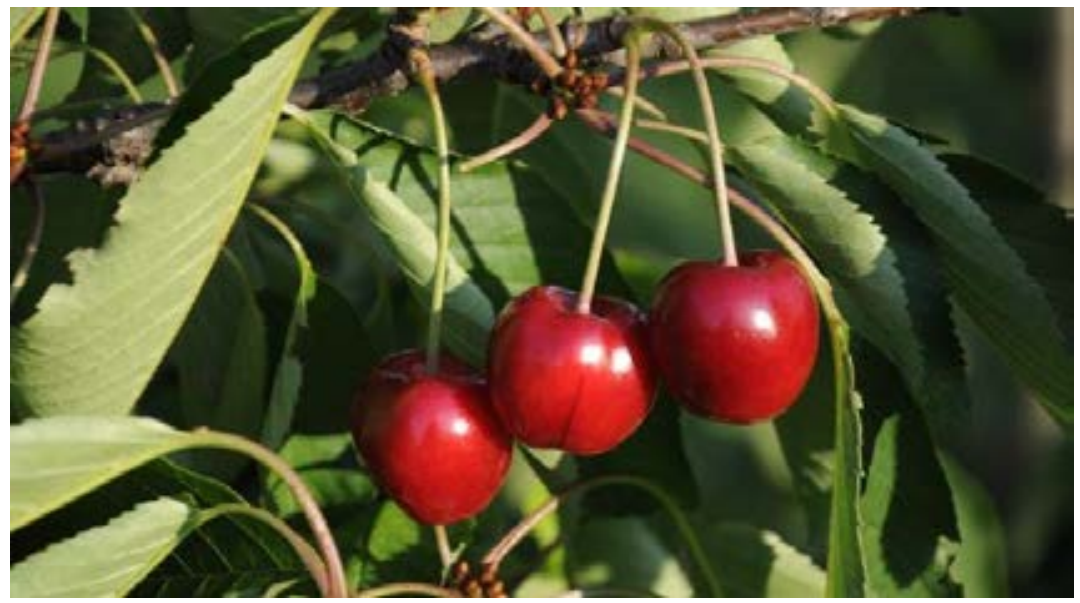

10. ábra: 'Regina' (fotó: ANDREAS SPORNBERGER) 


\subsubsection{Q26 ültetvény}

A bioültetvény (Q26) rendelkezésre álló 13 nemes fajtájából 5-öt választottunk ki a vizsgálatainkhoz, amelyek mindegyike a korai érésű cseresznyefajták közé sorolható. A kiválasztott 5 nemes fajta illetve típus a következő: ‘Bigarreau Burlat Schreiber', 'Bigarreau Burlat VG', 'Bigarreau Moreau Schreiber', 'Merton Premier' és 'Hybrid 222' (Melléklet 18. táblázat vastagon szedett fajtái).

\subsubsection{1. 'Bigarreau Burlat'}

Ez a fajta dél-franciaországi tájfajta-szelekcióból származik. Első leírójáról, Burlat-ról kapta nevét, a bigarreau kifejezés a gyümölcs ropogós jellegét mutatja. Az első nagyméretü cseresznyegyümölcs a magyar és az osztrák piacon egyaránt, ennek köszönhetően primőr áron értékesíthető, javasolt üzemi telepítésre is (APOSTOL 2003).

A 'Bigarreau Burlat' (11. ábra) május végén - június elején érik. Gyümölcse 24-26 mm átmérőjü, tömege $9 \mathrm{~g}$ is lehet (BÄDER 2006), alakja széles tompa kúp, amelynek hasi varratánál lapított, enyhén kiemelkedő bordája van. Héja fényes, vékony, héjszíne a fogyasztási érettség kezdetén piros, majd az érés előrehaladtával sötétbordó lesz. Húsa középkemény, ropogós, tömött, igen lédús. Íze kellemesen édes-savanykás. Rövid vagy középhosszú kocsánya van. Csontárja kicsi vagy középnagy, félig vagy akár teljesen magvaváló. Kiváló minőségü étkezési gyümölcs (Apostol 2003, Möller 2006, SPORNBERGER és Modl 2009).

Fája erős növekedésű, kevés elágazású, merev ágrendszerü koronája kezdetben feltörekvő, majd a termés tömege alatt szétterülö. Meleg és fagymentes fekvésü területet igényel (SPORNBERGER és MODL 2008). Korai, elhúzódó virágzású. Önmeddő, ezért pollenpartnerre van szüksége. Termőképessége közepes, egyes években nagy (APOSTOL 2003).

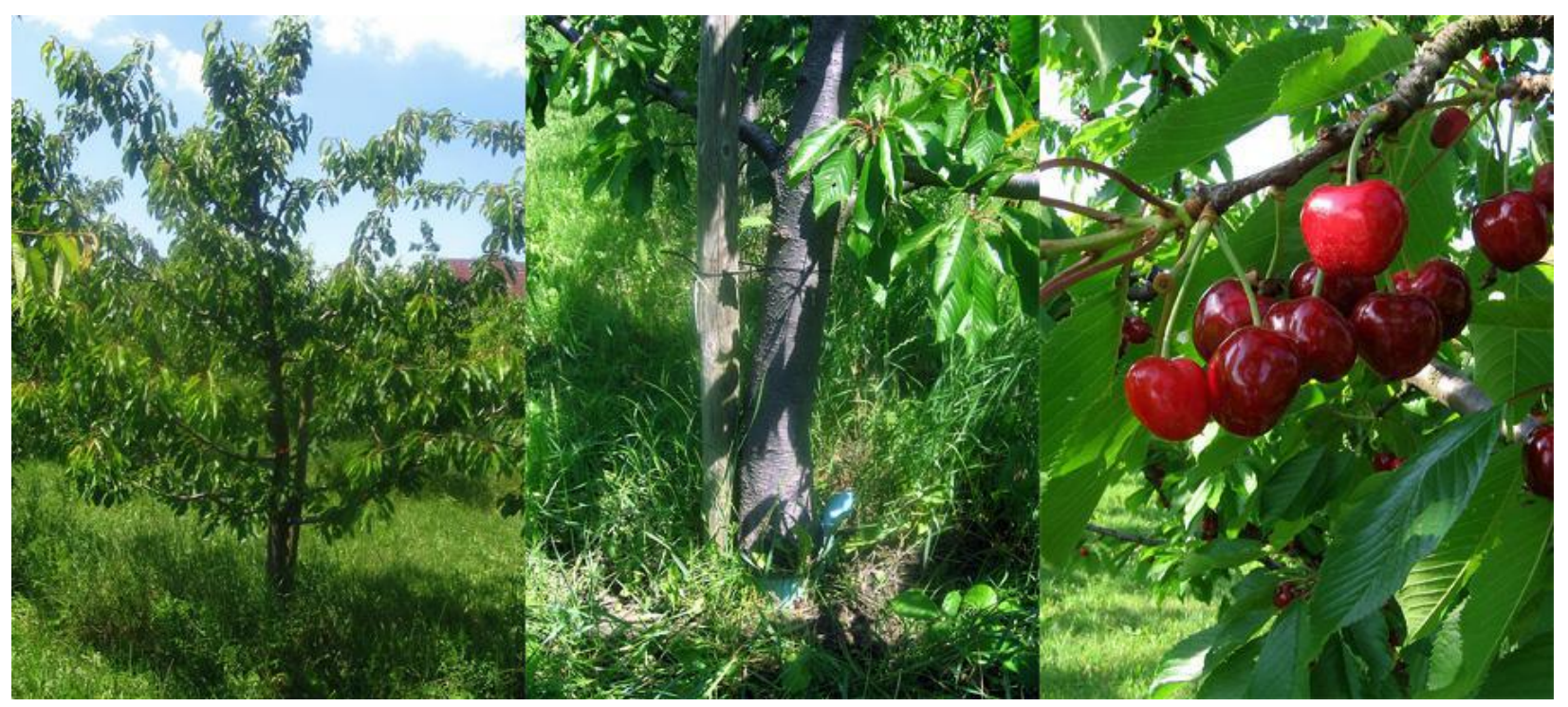

11. ábra: 'Bigarreau Burlat' (fotó: SLAVEN OSTOJIC és JOSEF TELFSER) 


\subsubsection{2. 'Bigarreau Moreau'}

A 'Bigarreau Moreau' (12. ábra) véletlen franciaországi tájszelekció eredménye. Felismerhető szívalakú, középnagy-nagy gyümölcsméretéröl (6-8 g, WINTER 2002), sötétbordó vagy feketésbordó, fényes héjszínéről és jellegzetesen rövid kocsányáról. A gyümölcs közepesen kemény vagy kemény, ropogós, lédús, kellemesen édes, jó ízü. Május végén - június elején érik. Fája erőteljes növekedésü, kissé felfelé törő, közepes elágazódási hajlamú. Önmeddő, ezért pollenadó szükséges hozzá. Virága érzékeny a fagyra (SPORNBERGER és MODL 2009).

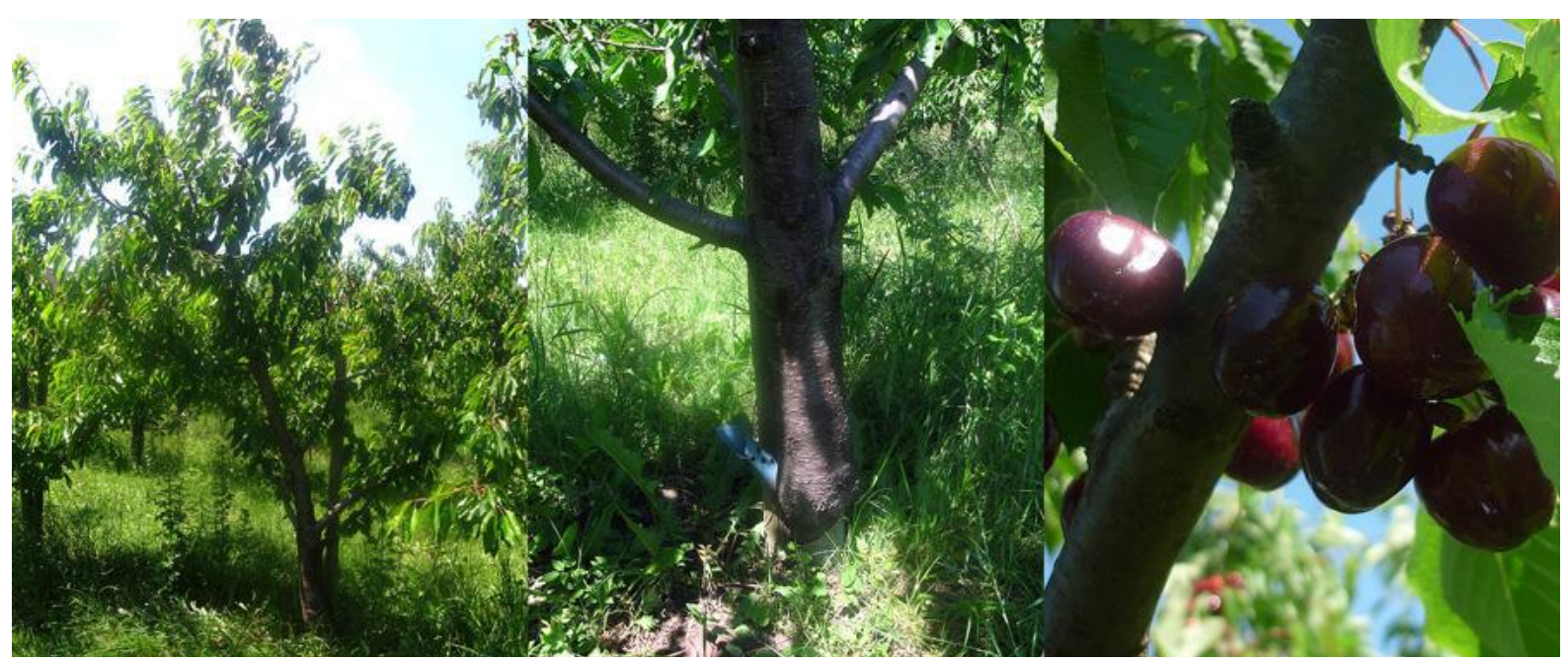

12. ábra: 'Bigarreau Moreau' (fotó: SLAVEN OSTOJIC és JOSEF TELFSER)

\subsubsection{1. 'Hybrid 222'}

A 'Hybrid 222' fajta (13. ábra) pontos eredete a mai napig ismeretlen. OSTOJIC és TELFSER (2011) leírásai szerint a fajta Franciaországból származik, a gyümölcs középnagy - nagy méretü, alakja gömbölyded vagy szív alakú, hasi varrata sötétebb színü és lapított, fényes héja sötétbordótól feketés bordóig terjed. A gyümölcshús közepesen kemény, igen lédús, kellemes aromájú, erősen savas ízü. Május végén - június elején érik. Fája középerős növekedésű.

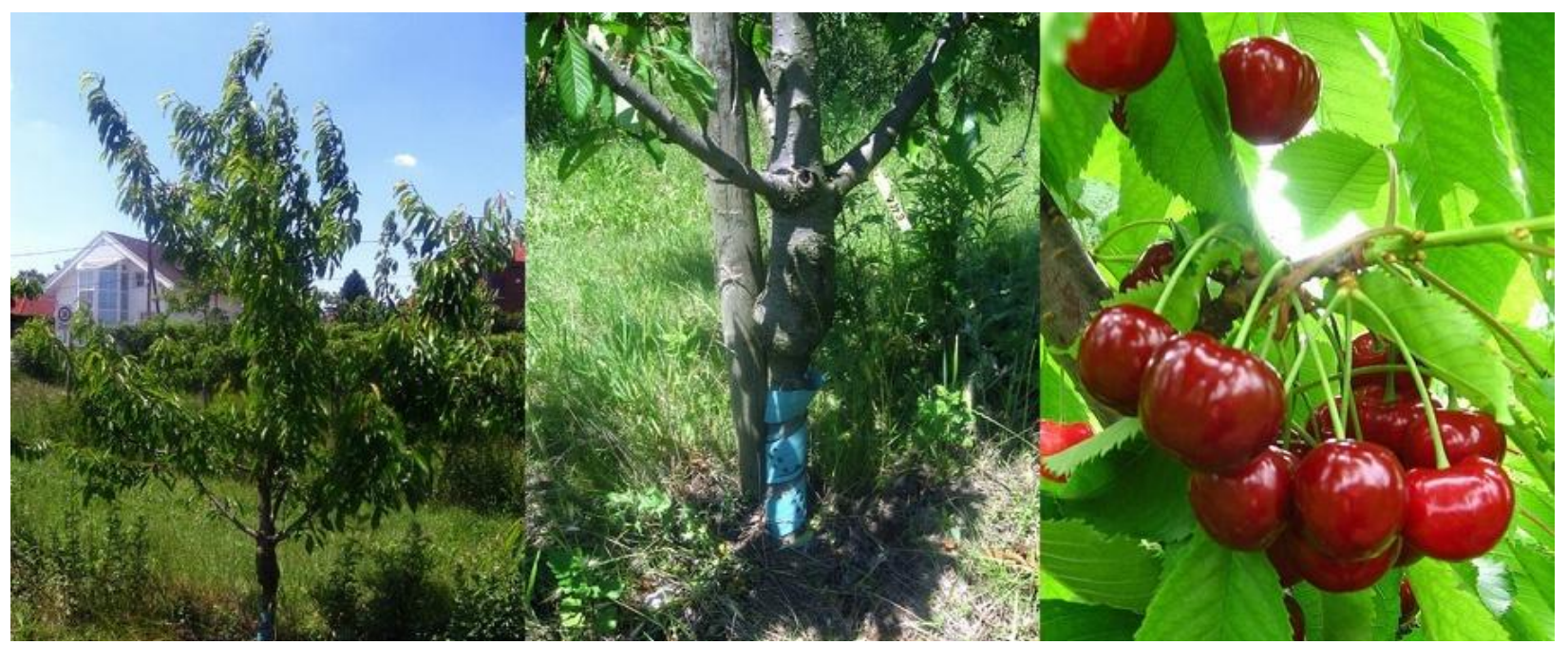

13. ábra: 'Hybrid 222' (fotó: SLAVEN OSTOJIC és JOSEF TELFSER) 


\subsubsection{2. 'Merton Premier'}

Az angliai Norwich területén állították elő az ,Emperor Francis' $x$,Bedford Prolific' keresztezésével. A 'Merton' család tagja, melyek mind eltérő ízzel, színnel, érési idővel rendelkeznek. A 'Merton Premier’ (14. ábra) gyümölcse június elején - közepén érik, középnagy méretü (6 g), sötétpiros héjszínü, oldalról lapított, igen lédús, jó ízü, füszeres aromájú. Sokat és rendszeresen terem. Gyümölcshúsa közepesen kemény. Fája középerős növekedésü, gazdag elágazódási hajlamú, robosztus, erőteljes metszést igényel. Önmeddő, ezért pollenadó szükséges (SPORNBERGER és MODL 2009).

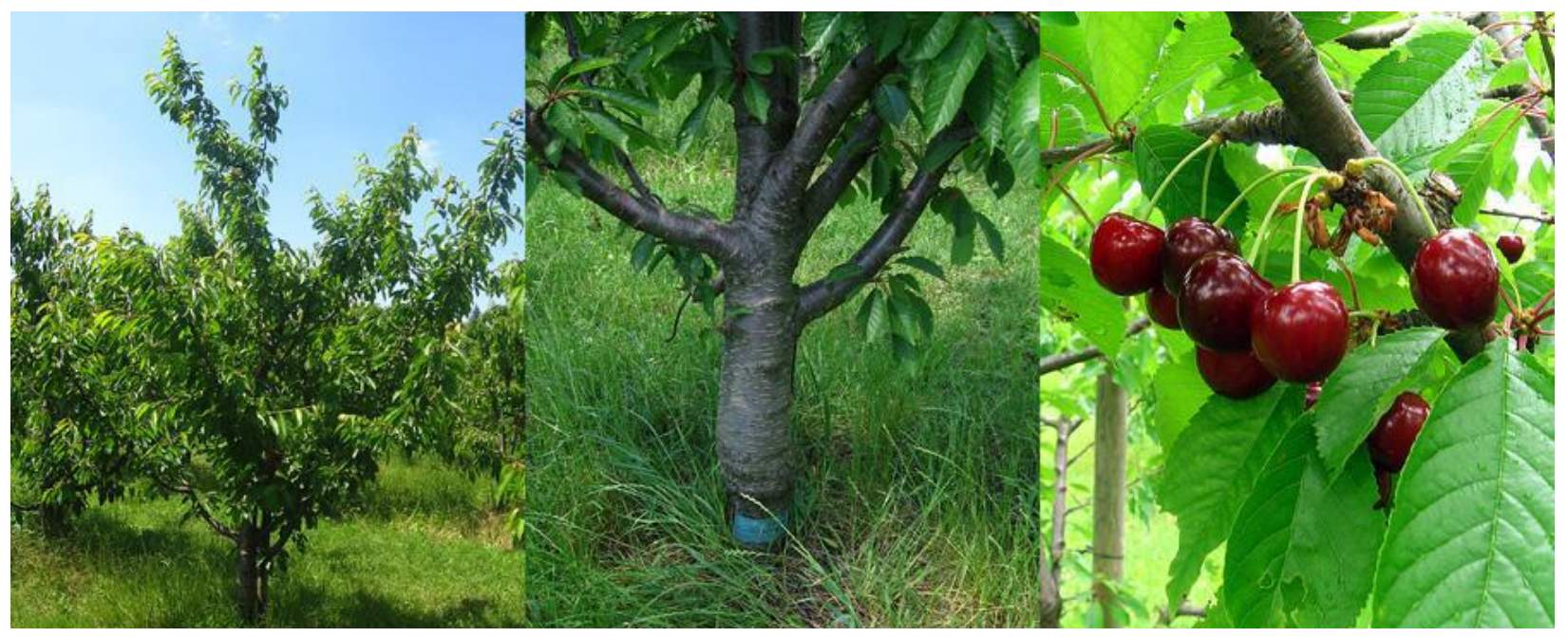

14. ábra: 'Merton Premier' (fotó: SLAVEN OSTOJIC és JoSEF TELFSER)

\subsection{A vizsgálatokban résztvevő alanyfajták jellemzése}

\subsection{1. 'GiSelA 5' alany}

Németországban a giesseni Justus Liebig Egyetemen végzett fajtakeresztezésekkel állították elő 1965 és 1971 között a Prunus cerasus x Prunus canescens hibridjeként (148/2). Több mint 6000 típus közül szelektálták (KEPPEL et al. 1998). Nevét is innen kapta: „Gießener Selektion Artenkreuzung“ (EBERHARD et al. 2006). Szaporítását általában in vitro módszerekkel végzik, de jól meggyökereztethető hajtásdugványozással is (HROTKÓ 2003). Jó a kompatibilitása a legtöbb cseresznyefával, nem vagy csak kevéssé sarjadzik az alany. Féltörpe-törpe növekedési erélyü, így az oltványok növekedése gyengébb lesz ezen az alanyon: a fák méretét 50-60 \%-kal mérsékli. Közepesen fagytürő és vírustoleráns, a pangó vizet azonban nem bírja. Az oltvány termőképessége jó, gyümölcseinek mérete nagy (WINTER et al. 2002). Dél-Németországban $5 \times 3 \mathrm{~m}$ térállásba javasolják telepítését. Szélvédett helyeken a gyökér rögzítése megfelelö, egyéb területeken karózása javasolt (ANDERSEN et al. 1999, GRUPPE 1985, PERRY 1987, VOGEL 1994). 


\subsection{2. 'GiSelA 6’ alany}

Szintén a németországi giesseni egyetemen végzett fajtakeresztezésekkel állították elő 1965 és 1971 között a Prunus cerasus x Prunus canescens hibridjeként (148/1). Középerős növekedési erélyű alany, a fák méretét 30-40 \%-kal mérsékli (WEBSTER 1997). Az ajánlott ültetési sűrüség 600-1200 fa/ha. Az oltvány 'GiSelA 6' alanyon korán termőre fordul, a 3. évben már szüretelhetö, az 5. évben elérheti a legnagyobb terméshozamot. A megfelelö gyümölcsméret és -minőség fenntartása érdekében a 'GiSelA 6' alanyon álló fákat rendszeresen metszeni kell már a korai időszaktól kezdve. Közepes vagy alacsony termőképességü fajtákkal, mint például a 'Bing', 'Skeena' és 'Regina', könnyebben elérhető a prémium gyümölcsminőség, nagy termőképességü fajták esetében kevésbé. A vadcseresznye alanyhoz képest valamivel előbbre hozza a virágzást és a gyümölcsérést (ANDERSEN et al.1999).

\subsection{3. 'PHL-C' alany}

Csehországban állították elö a Prunus cerasus x Prunus avium hibridjeként. Középerös-erös növekedési erélyü, a rá oltott fák növekedését kb. 20 \%-kal mérsékli (ASĂNICĂ et al. 2013). Szaporítása csak in vitro módszerekkel eredményes, mivel gyengén gyökeresednek a hajtásdugványok, illetve gyengén fejlődnek gyökeresedés után. Fagytürése az észak-csehországi viszonyok között nem volt kielégítő (KLOUTVOR 1991).

\subsection{4. 'PiKu l' alany ( $P i-K u$ 4,20)}

Németországban, Pillnitzben szelektálta Wolfram (1996) a Prunus avium x (Prunus canescens $x$ Prunus tomentosa) hibridek közül. Törpítő hatása gyakran csak néhány év múlva jelentkezik az oltványokon, ekkorra kb. 30-40 \%-kal lesznek kisebbek a fák a vadcseresznyére oltott fákhoz képest (GYEVIKI et al. 2008, WOLFRAM 2004). Öntözés nélkül is jól szerepel homokos talajon, föleg gyümölcsméret tekintetében. Metszés, trágyázás és öntözés mellett megfelelő helyen és nemes fajtával kombinálva magas hozam és jó gyümölcsminőség érhető el (HROTKÓ 2003). Fagytürése igen jó, Cytosporá-val szemben toleráns (WOLFRAM 2004).

\subsection{5. 'Weiroot 158 ' alany}

A Müncheni Müszaki Egyetem Gyümölcstermésztési Intézetében, Weihenstephanban szelektálták helyi bajor fajták közül (HROTKÓ 2003). Féltörpe növekedési erélyü, a vadcseresznye alanyhoz képest a fák méretét kb. 50-60\%-kal mérsékli. Csak a legjobb termőhelyeken, megfelelö vízellátottság mellett érzi jól magát. Szélvédett helyeken a fát megfelelően rögzíti, másutt azonban karózást igényel. A rá oltott cseresznyefák korán termőre fordulnak és bőven teremnek. DélNémetországban 5x3 m-es térállásba javasolják telepíteni (VoGEL 1994). 


\subsection{Termesztéstechnológiai beavatkozások}

\subsubsection{Virágritkitás}

A Q26 ültetvény területén 2010 óta minden évben virágritkítást végeztünk egy francia gyártmányú hordozható elektromos ritkító készülékkel (Electroflor, Infaco, Cahuzac sur Ve`re, France, 15. ábra). A készülék elemmel müködik, és egy nejlonzsinórra felfüzött, kihegyezett végekkel rendelkező forgó kefe segítségével távolítja el a virágokat (JAY et al. 2009).

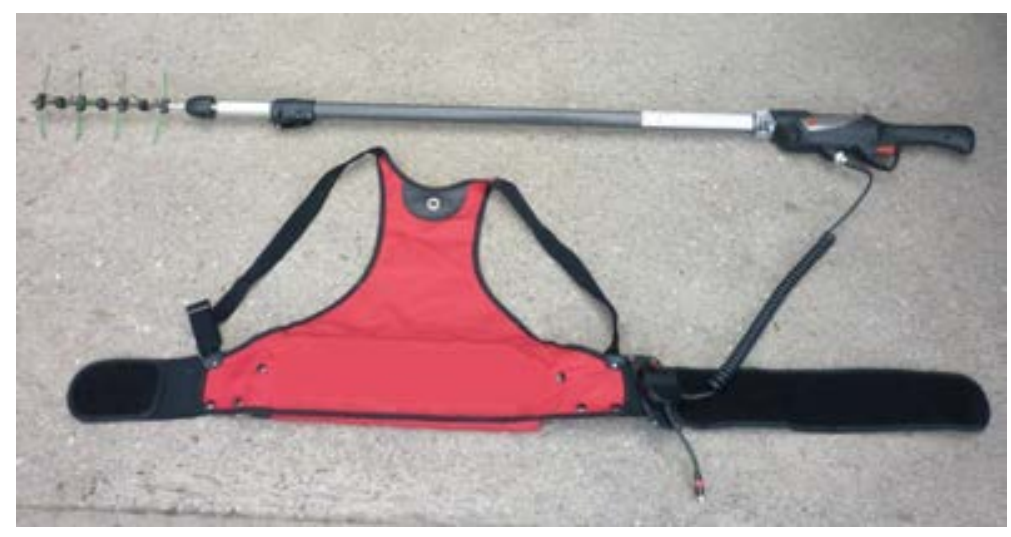

15. ábra: Elektromos virágritkító készülék, Electroflor, Infaco

A virágritkítást teljes virágzásban végeztük április közepe táján a fák koronájának teljes magasságában, melynek eredményeképpen a virágok kb. 40 \%-át távolítottuk el (BLANKE 2009). A ritkítás előtti és utáni állapotot a 16. ábra szemlélteti. A Q26 ültetvény rendelkezésre álló 4 sorából a két középsőn végeztük el a ritkítást, a másik kettőt érintetlenül meghagytuk kontrollként, így minden cseresznyefajta 8 fájából 4 fa virágait ritkítottuk, 4 fa virágait meghagytuk. Évről évre ugyanazokon a fákon végeztük el a virágritkítást.
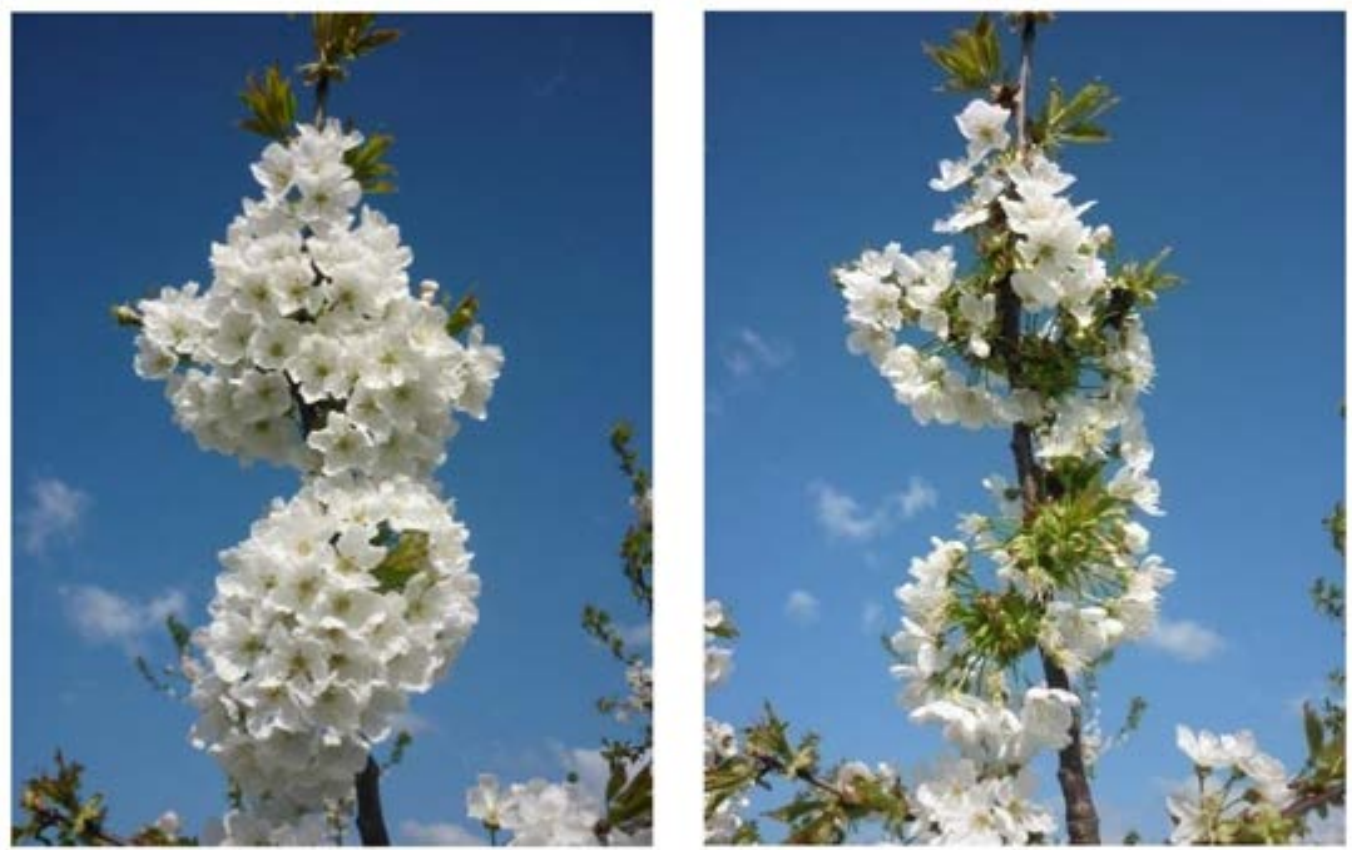

16. ábra: Cseresznyefa virágai virágritkítás előtt (balra) és után (jobbra) 


\subsection{A mintavétel módja}

Vizsgálataink során a Q10 ültetvény gyümölcseit 4 egymást követő évben (2010-2013), a Q26 ültetvény gyümölcseit pedig 3 egymást követő évben (2010-2012), az érés három stádiumában szedtük meg (Melléklet 50. ábra): színeződés kezdetén (Terminus 1, T1), színeződés második felében (Terminus 2, T2), teljes érettségben (Terminus 3, T3).

Vizsgálataink során az alábbi mintavételi eljárást követtük:

- a gyümölcsök szedése mindig kocsánnyal együtt, kézzel történt, lehetőség szerint a korona minden részéről: alacsonyabb és magasabb ágakról egyaránt, illetve minden égtájról

- alany-nemes kombinációnként 8-9 fáról gyüjtöttünk mintát, mindegyikről érési stádiumonként 80-100 darabot

- a láthatóan sérült (pl. madártól megcsípett, rothadó félben lévő, vagy élősködővel fertőzött stb.) gyümölcsöket nem vizsgáltuk, mivel célunk az egészséges cseresznyék paramétereinek meghatározása volt

- a különböző fákról begyüjtött gyümölcsöket mind külön mintatasakba gyüjtöttük, feliratoztuk, majd azonnal a fizikai és fizikokémiai mérések helyszínére szállítottuk

\subsection{Gyümölcsök fizikai tulajdonságainak meghatározása}

A cseresznye gyümölcsök fizikai paramétereinek vizsgálata a BOKU Gyümölcs- és zöldséganalitikai Laboratóriumában (A-1190 Wien, Peter-Jordan-Straße 82) történt rögtön a mintavételt követően. A mintatasakok mindegyikéből véletlenszerüen 8-8 gyümölcsöt emeltünk ki a fizikai vizsgálatokra 4 ismétlésben.

A következőkben az általunk végzett fizikai vizsgálatok leírása olvasható.

\subsubsection{Gyümölcsméretek és gyümölcstérfogat}

A cseresznye gyümölcsöknek 3 irányú átméröjét mértük: szélesség (sz), magasság (m), vastagság (v) (17. ábra). A magasságot a kocsánymélyedés és a bibepont távolságaként definiáltuk. A szélesség és a vastagság a két leghosszabb egymásra merőleges átmérő, melyek a bibepontnál metszik egymást. A 3 átmérő meghatározására digitális tolómérőt használtunk, amely $0,01 \mathrm{~mm}$ pontosságú mérést tett lehetővé.

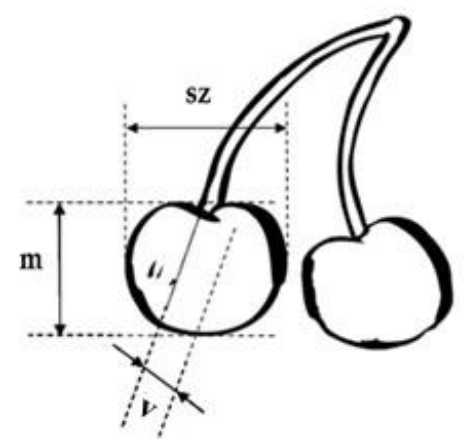

17. ábra: A cseresznye szélessége (sz), magassága (m), vastagsága (v) 
Mivel a gyümölcsök háromféle átméröje önmagában nem hordoz teljes értékű információt a tényleges méretről, így az átmérőkből számítottunk egy származtatott mennyiséget, a gyümölcstérfogatot, a cseresznyéket ellipszoid testtel modellezve (SHAHBAZI és RAHMATI 2013) a követező képlet felhasználásával:

$$
V=\frac{4 \pi}{3}\left(\frac{m}{2}\right)\left(\frac{s Z}{2}\right)\left(\frac{v}{2}\right)
$$

A kapott térfogatokat 8 gyümölcsönként összegeztük, és párba állítottuk a korábban ugyanarra a 8 gyümölcsre mért tömeggel, majd az adatpárokat grafikonon ábrázoltuk (18. ábra). A grafikonon jól látszik, hogy a két mennyiség nagyon erősen korrelál $\left(\mathrm{R}^{2}=0,9629\right)$, ebből pedig következik, hogy a számított térfogat - ha abszolút értékben nem is feltétlenül, de arányaiban mindenképpen - jól jellemzi a cseresznye gyümölcsök tényleges méretét.

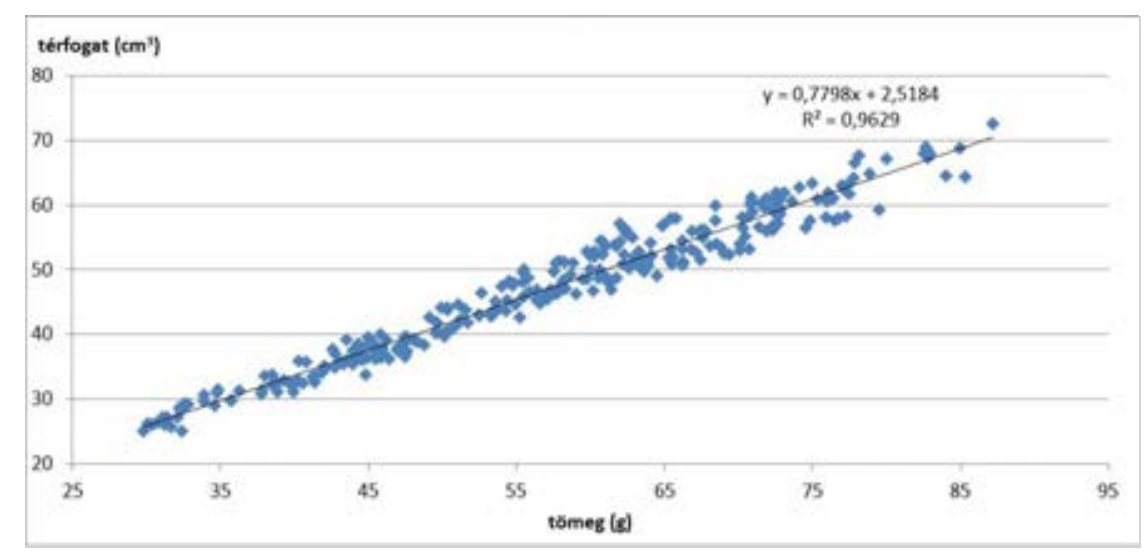

18. ábra: Cseresznye gyümölcsök tömeg-térfogat diagramja (Regina' és 'Kordia')

\subsubsection{Gyümölcs-és csontártömeg, hasznos gyümölcs arány}

A tömegeket sorozatonként határoztuk meg, azaz $8 \mathrm{db}$ gyümölcs együttes tömegét, valamint a belölük kiszedett $8 \mathrm{db}$ csontár (a magot is tartalmazó, kősejtekből álló endokarpium, köznapi nevén „cseresznyemag”) együttes tömegét. A méréseket kombinációnként és terminusonként 4 ismétlésben végeztük 0,01g pontossággal. A méréshez digitális táramérleget (FA-2000S, Sartorius Mechatronics Ausztria GmbH) használtunk. A csontárokat (miután a kocsány szakítószilárdságát, a gyümölcsök héjszínét és keménységét előzőleg lemértük) kézi magozóval távolítottuk el a gyümölcsökből. A csontártömeg mérése előtt a csontárról a gyümölcs húsát és levét szürőpapírral itattuk fel. A hasznos gyümölcs arányt (HGyA) ezek után a következő képlettel számoltuk ki:

$$
H G y A[\%]=\frac{\text { gyümölcstömeg }[g]-\text { csontártömeg }[g]}{\text { gyümölcstömeg }[g]} \cdot 100
$$

\subsubsection{Kocsány-szakitószilárdság}

A kocsány-szakítószilárdságot (KSzSz) úgy definiáljuk, mint az az erő, amely ahhoz szükséges, hogy a gyümölcsből a kocsányt kiszakítsuk. Ennek az erőnek a meghatározását kezdetben (2010- 
ben) egyszerü rugós erőmérővel végeztük. Mivel azonban a cseresznyék KSzSz értéke az esetek többségében nem fért bele az eszköz mérési tartományába, a 2010-es adatokat nem használtuk fel a kiértékelés során. A további években (2011-2013) Mechmesin AFG 500N típusú húzó-nyomó erőmérő készülék (19. ábra) segítségével végeztük a méréseket.

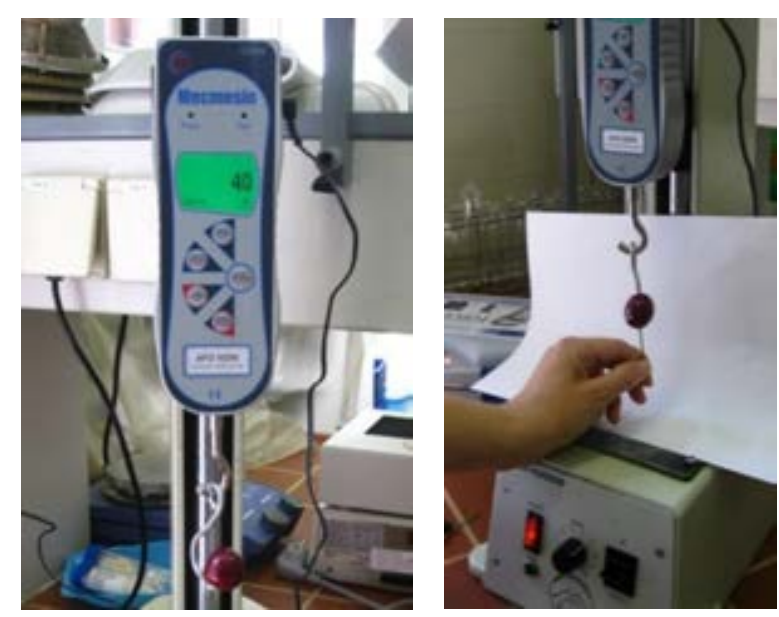

19. ábra: AFG 500N típusú húzó-nyomó erőmérő készülék (balra) és a kocsány szakítószilárdság-mérésének folyamata (jobbra)

\subsubsection{Gyümölcsök héjszíne}

A gyümölcsök héjszínét Konica Minolta CR-400 típusú tristimulusos színmérő müszerrel határoztuk meg a cseresznye felületén végrehajtott direkt méréssel. A müszer kalibrálásához a gyártó által készített kalibráló fehér csempe etalont használtuk. A méréseket a gyümölcsöknek mindig ugyanazon részén végeztük: a hasi varrattal szemközti oldalon, középen.

Az alábbi paramétereket határoztuk meg: L* (világosság/sötétség), a* (vörös/zöld összetevő), b* (sárga/kék összetevő). A színmérő müszert és annak elméleti hátterét a 20. ábra szemlélteti. Az ábra függőleges tengelyén a világosság ( $\left.\mathrm{L}^{*}\right)$ számértéke 0 (fekete) és 100 (fehér) között változik. Az L* síkra merőleges a* és b* színkoordináták két egymásra meröleges tengelyen $(0 \pm 100)$ helyezkednek el, ahol az előjelektől függően $+a^{*}$ piros, -a* zöld, +b* sárga, -b* kék színeket jellemez (Voss 1992).

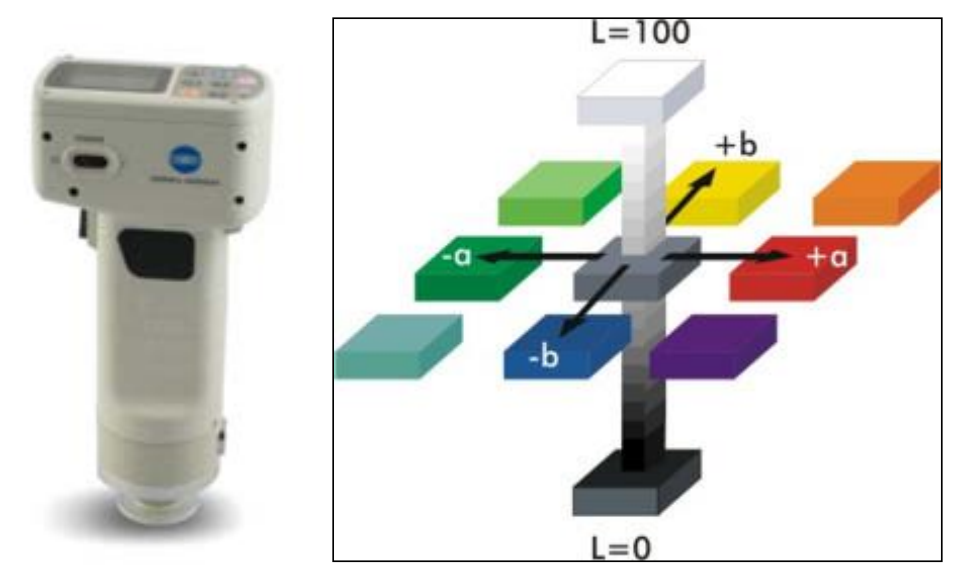

20. ábra: Konica Minolta CR-400 típusú színmérő müszer (balra) és elméleti háttere (jobbra) 


\subsubsection{Gyümölcskeménység}

A gyümölcskeménység megmutatja az exokarpium átszakításához szükséges erőt. Az erő meghatározását a már fent említett Mechmesin AFG 500N típusú húzó-nyomó erőmérő készülék (21. ábra) segítségével végeztük, melyet - a gyümölcsök méretéhez igazodva - kis felületü $\left(0,5 \mathrm{~cm}^{2}\right)$ hengeres nyomófejjel szereltünk fel (WEISSINGER et al. 2010). A méréseket a gyümölcsöknek mindig ugyanazon részén végeztük: a hasi varrattal szemközti oldalon, középen. Az eredményeket $\mathrm{kg} / \mathrm{cm}^{2}$ mértékegységben adtuk meg.
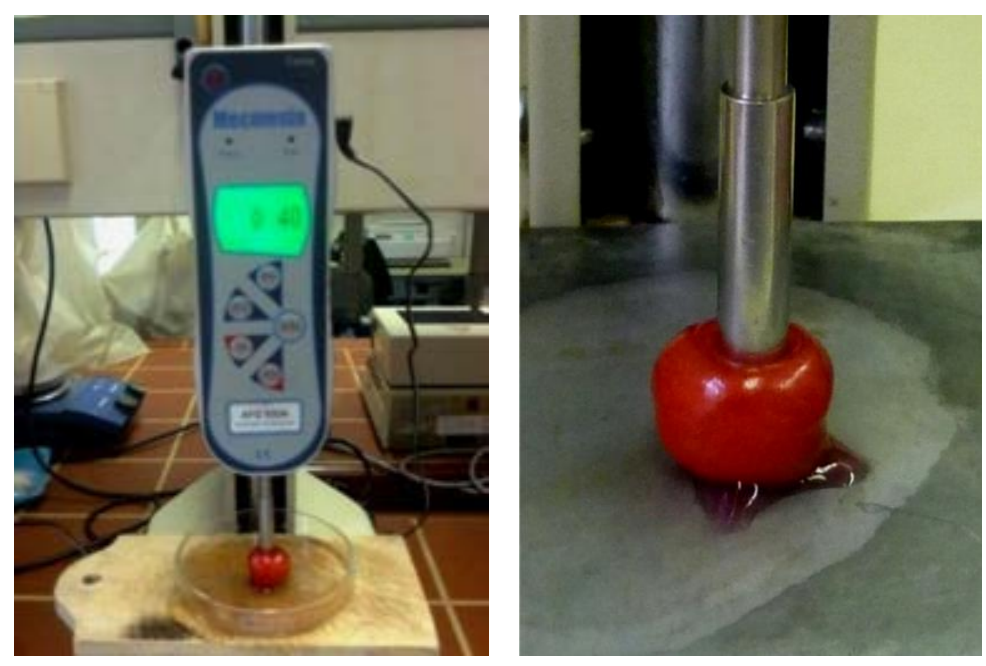

21. ábra: AFG 500N típusú húzó-nyomó erőmérő készülék (balra) gyümölcskeménység méréséhez és müködése (jobbra)

\subsection{1. Általános fizikokémiai paraméterek meghatározása}

A cseresznye gyümölcsök fizikokémiai paramétereinek vizsgálata a BOKU Gyümölcs- és Zöldséganalitikai Laboratóriumában (Peter-Jordan-Straße 82, 1190 Wien) történt közvetlenül a fizikai paraméterek vizsgálata után.

\subsubsection{Minta-elökészités}

A fizikokémiai jellemzőket szintén sorozatonként határoztuk meg 4 ismétlésben, ahol minden sorozat 20-25 gyümölcsből állt, mely tartalmazta az előzőleg megvizsgált 8 db gyümölcsöt is. A kiegészítésre azért volt szükség, hogy a vizsgálatok céljára elegendő gyümölcslevet kapjunk.

A kimagozott cseresznyéből gyümölcscentrifuga segítségével (BRAUN-MP80) nyertünk levet, melyet aztán szürőpapírral (grade 3, 20-25 $\mu \mathrm{m}$, Whatman GmbH, D-37586 Dassel) leszürtünk. A méréseket az üledéktől és lebegő szennyeződéstől mentes, tiszta gyümölcsléből végeztük el.

A fizikokémiai mérések után fel nem használt gyümölcsleveket valamint egész gyümölcsöket külön, lezárt edényekben azonnal lefagyasztottuk, és $-30^{\circ} \mathrm{C}$-on hütve tároltuk a folyadékkromatográfiás mérések helyszínére történő szállításig. 


\subsection{2. Összes vízoldható szárazanyag-tartalom}

Az összes vízoldható szárazanyag-tartalmat (TSS) ATAGO típusú digitális refraktométer (PR-101) segítségével határoztuk meg. A méréshez a leszürt gyümölcsléből néhány cseppet cseppentünk a müszerre. Az eredményt ${ }^{\circ}$ brix-ban adtuk meg (KHAZAEI et al. 2008, MELTSCH et al. 2006).

\subsection{3. Összes titrálható savtartalom}

A titrálható savtartalom méréséhez a leszürt gyümölcsléből $5 \mathrm{~cm}^{3}$-t kipipettáztunk, és desztillált vízzel $20 \mathrm{~cm}^{3}$-re hígítottuk. Ezután a mintát $\mathrm{pH} 8.1$-ig titráltuk $0,1 \mathrm{~mol} / \mathrm{dm}^{3} \mathrm{NaOH}$ reagenssel (THYBo et al. 2006). A titrálást TitroLine Alpha Plus (22. ábra) automata titrátorral (Model: SCHOTT TA20 plus) végeztük. A titrálható savtartalom értékét a $\mathrm{NaOH}$ fogyásának függvényében az OECD szabványa alapján almasav-egyenértékben (g MAE/l) adtuk meg a következő képlet segítségével:

$$
[\mathrm{g} / \mathrm{l}] \text { almasav }=[\mathrm{ml}] \mathrm{NaOH} \cdot 0,67 \cdot 2
$$

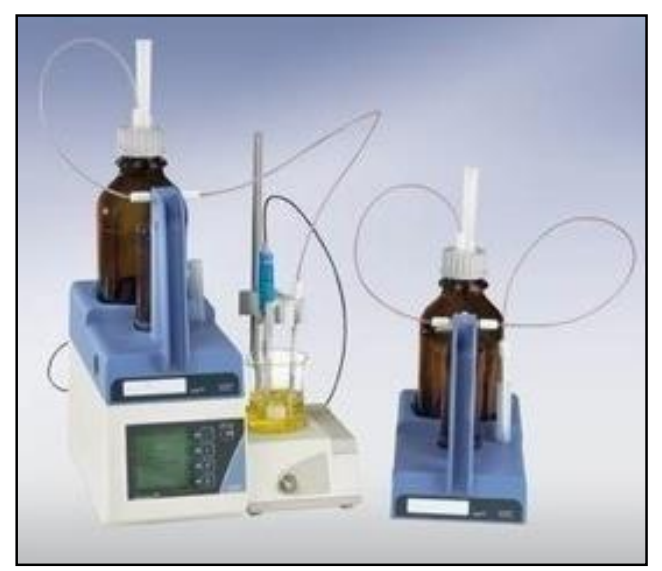

22. ábra: TitroLine Alpha Plus automata titrátor

\subsection{Egyedi komponensek és komponenscsoportok meghatározása}

$\mathrm{Az}$ egyedi komponensek és komponenscsoportok meghatározását nagyhatékonyságú folyadékkromatográfiás (HPLC) technikával végeztük. Ehhez a mintákat át kellett szállítanunk a BOKU Gyümölcs- és Zöldséganalitikai laboratóriumából a Budapesti Corvinus Egyetem Kertészettudományi Karának Gyümölcstermő Növények Tanszékén található HPLC laboratóriumába. A lefagyasztott minták szállítása jégakkukkal bélelt hűtőládákban történt. A HPLC-s mérések elvégzéséig a mintákat $-30^{\circ} \mathrm{C}$-on tároltuk.

\subsubsection{Müszerezés}

Az alkalmazott müszer egy Waters gyártmányú nagyhatékonyságú folyadékkromatográf (HPLC: High Performance Liquid Chromatography) volt (Waters Corporation, 34 Maple Street, Milford, MA 01757, USA), mely az alábbi elemekből épült fel: 
- 1525 bináris HPLC pumpa

- Kolonna termosztát

- $\quad 717^{\text {plus }}$ szabályozható hőmérsékletü, automata mintaadagoló

- 2414 refraktív index detektor, illetve 2487 duál hullámhossz abszorbancia detektor

- EMPOWER ${ }^{\mathrm{TM}} 2$ vezérlő szoftver

\subsubsection{Cukorfrakciók meghatározása}

Vegyszerek:

Az analitikai tisztaságú glükóz (CAS szám: [50-99-7]), fruktóz (CAS szám: [57-48-7]) és szorbitol (CAS szám: [50-70-14]) standardokat a Sigma Aldrich Chemical Kft-től szereztük be. Az oldószerként használt vizet MILLEX víztisztító berendezéssel állítottuk elö, melynek utolsó szürője $0,22 \mu \mathrm{m}$ Millipore-filter volt. A standardokat vízben oldottuk fel, majd ismételt szürést követően injektáltuk a HPLC-berendezésbe.

Minta-előkészítés:

A $-30^{\circ} \mathrm{C}$-on tárolt gyümölcslevekböl $\mathrm{kb} .10 \mathrm{ml}-\mathrm{t}$ a mérés megkezdése előtt felolvasztottunk, amiböl mintánként 4 ismétléssel 1,5 ml-t egy-egy eppendorf csőbe töltöttük. Hettich 23R típusú ultracentrifugával 5 percig centrifugáltuk 15000 rpm fordulatszámon. Az oldat felülúszóját 0,45 $\mu \mathrm{m}$ pórusátmérőjű PVDF szürővel (Millipore Siringe Filter Unit SLHN-13) szürtük. Az így előkészített mintákból 1-1 $\mathrm{cm}^{3}$-t pipettáztunk ki analitikai (HPLC) célokra, majd helyeztünk el a mintaadagolóba. Az elemzett komponensek többsége fényre és/vagy oxidációra érzékeny, ezért az előkészített mintát azonnal felhasználtuk, vagy felhasználásig lezárt, sötét üvegben, hütőszekrényben tároltuk.

HPLC kromatográfiás körülmények:

A cukrok elválasztása Sugar-Pak ${ }^{\mathrm{TM}}$ kolonnán történt, $90^{\circ} \mathrm{C}$-on. A mozgófázis Ca-EDTA $0.0001 \mathrm{M}$ koncentrációjú vizes oldata volt, $0,5 \mathrm{ml} / \mathrm{min}$ térfogati sebességgel. Az injektált mintamennyiség $20 \mu \mathrm{l}$ volt, a detektálást $40^{\circ} \mathrm{C}$-ra termosztált törésmutató detektorral végeztük. Egy minta mérése ilyen körülmények között 30 percig tartott. Analitikai standardokkal határoztuk meg a cukor-komponensek retenciós idejét (11. táblázat). A cseresznyeminták kromatogramjában a cukor-komponensek azonosítását - a szelektív detektáláson kívül - csúcsprofil és retenciós idők segítségével, valamint standard addícióval végeztük.

11. táblázat: Az egyes cukorkomponensek retenciós ideje

\begin{tabular}{|l|c|}
\hline Cukorkomponensek & Retenciós idő (min) \\
\hline glükóz & 10,328 \\
\hline fruktóz & 12,2 \\
\hline szorbitol & 17,101 \\
\hline
\end{tabular}




\subsubsection{Savfrakciók meghatározása}

Vegyszerek:

Az analitika tisztaságú almasav (CAS szám: [97-67-6]), borostyánkősav (CAS szám: [11015-6]) és citromsav (CAS szám: [77-92-9]) standardokat a Sigma Aldrich Chemical Kft-töl szereztük be. Az oldószerként használt vizet MILLEX víztisztító berendezéssel állítottuk elő, melynek utolsó szüröje 0,22 $\mu \mathrm{m}$ Millipore-filter volt. A standardokat vízben oldottuk fel, majd ismételt szürést követően injektáltuk a HPLC-berendezésbe.

Minta-előkészítés:

A cukorfrakciók mérésénél leírt minta-előkészítéssel megegyezően történt.

HPLC kromatográfiás körülmények:

A savak elválasztására Shodex RSpak KC-811 (8 mm ID x 300 mm) analitikai-, és Shodex RSpak KC-G előtét-kolonnát használtunk, $40^{\circ} \mathrm{C}$-ra termosztálva. A mozgófázis foszforsav 0,1 tömeg\%-os, MilliQ vizes oldata volt, $1 \mathrm{ml} / \mathrm{min}$ térfogatsebességgel. Az injektált mintamennyiség $20 \mu \mathrm{l}$ volt, a detektálást UV tartományban, 220nm-en végeztük. Egy minta mérése ilyen körülmények között 15 percig tartott. Analitikai standardokkal határoztuk meg az egyes savkomponensek retenciós idejét, melyek az 12. táblázatban láthatóak. A cseresznyeminták kromatogramjában a savkomponensek azonosítását - a szelektív detektáláson kívül -csúcsprofil és retenciós idők segítségével, valamint standard addícióval végeztük.

12. táblázat: Az egyes savkomponensek retenciós ideje

\begin{tabular}{|l|c|}
\hline Savkomponensek & Retenciós idő (min) \\
\hline citromsav & 6,9 \\
\hline almasav & 7,78 \\
\hline borostyánkősav & 8,86 \\
\hline
\end{tabular}

\subsubsection{Polifenolok meghatározása}

Vegyszerek:

A cianidin-3-O-rutinozid (CAS szám: [18719-76-1]), kvercetin (CAS szám: [117-395]), kvercetin-3-rutinozid (rutin) (CAS szám: [153-18-4]), klorogénsav (CAS szám: [327-979]), neoklorogénsav (CAS szám: [906-33-2]), katechin (CAS szám: [154-23-4]), 3-p-kumaroil-kínasav (CAS szám: [1899-30-5]), az oldószerként használt metanol (MeOH), illetve a foszforsav, a sósav és a BHT (2.6-di-terc-butil-4-methilfenol) a Sigma Aldrich Chemical Co-tól került beszerzésre (St. Louis, MO, USA). A standardok $(0.5 \mathrm{mg} / \mathrm{ml})$ elöször 0,1 térfogat \% sósavat tartalmazó metanolban kerültek feloldásra, majd ebböl a törzsoldatból 50x hígítást használtunk a HPLC méréseknél. Injektálás előtt a standardokat szürtük, majd injektáltuk a HPLCberendezésbe. 
Minta-előkészítés:

Mivel a polifenolok a vizsgált vegyületek közül a legérzékenyebbek, ezért kivonásuk csak közvetlenül a mérés előtt, a sértetlenül megőrzött gyümölcsmintákból történt. A lefagyasztott egész gyümölcsökből felolvasztottunk mintánként 8-10 darabot (4 ismétlésben), azokat kimagoztuk, majd dörzsmozsár segítségével homogenizáltuk. A kapott pépből $5 \mathrm{~g}$ körüli mennyiséget kimértünk, majd hozzáadtunk $5 \mathrm{ml}$ metanolt, amely $1 \%$ sósavat és $1 \%$ BHT-t tartalmazott. Az elegyet extrakció céljából 30 percre ultrahangos fürdőbe helyeztük sötét falú, lezárt üvegben. Extrakció után a mintából 1,5 ml-t Eppendorf csőbe pipettáztunk, majd Hettich 23R típusú ultracentrifugával 10 percig centrifugáltuk $15000 \mathrm{rpm}$ fordulatszámon. A letisztult oldat felülúszóját 0,45 $\mu \mathrm{m}$ pórusátmérőjü PVDF szürővel (Millipore Siringe Filter Unit SLHN13) szürtük. Az így elökészített mintákból 1-1 $\mathrm{cm}^{3}$-t pipettáztunk ki analitikai (HPLC) célokra, majd helyeztünk el a mintaadagolóba.

HPLC kromatográfiás körülmények:

A polifenolokat Kinetex C18 (4,6x150mm méretü, 2,6 4 m szemcseméretü) kolonnán elemeztük. A kolonnatermosztát $25^{\circ} \mathrm{C}$-os volt. Gradiens elválasztást alkalmaztunk, ahol az eluensek a következők voltak: A) foszforsav 0,01M vizes elegye és B) 100\% metanol. Az áramlási sebesség 1ml/min volt. Az eluens összetétele többlépcsős lineáris gradiens mentén változott a 13. táblázat szerint. Az injektált mintamennyiség $20 \mu \mathrm{l}$ volt. Az antocianinok detektálása $530 \mathrm{~nm}$-en történt, a többi polifenolé pedig 280nm-en, $10 \mathrm{~Hz}$-es mintavételi adatsürüséggel. Egy minta mérése ilyen körülmények között 30 percig tartott.

13. táblázat: Az eluens összetételének változása többlépcsős lineáris gradiens mentén

\begin{tabular}{|c|c|c|}
\hline idö (perc) & A (\%) & B (\%) \\
\hline 0 & 95 & 5 \\
\hline 10 & 50 & 50 \\
\hline 15 & 30 & 70 \\
\hline 20 & 20 & 80 \\
\hline 25 & 0 & 100 \\
\hline 25,50 & 95 & 5 \\
\hline 30 & 95 & 5 \\
\hline
\end{tabular}

Analitikai standardokkal határoztuk meg az egyes polifenol-komponensek retenciós idejét (14. táblázat). A minták kromatogramjában a komponensek azonosítását a szelektív detektáláson kívül csúcsprofil és retenciós idők segítségével, valamint standard addícióval végeztük.

14. táblázat: Polifenol-komponensek retenciós ideje $280 \mathrm{~nm}$-en ( $* 530 \mathrm{~nm}$-en)

\begin{tabular}{|l|c|}
\hline Polifenol-komponensek & Retenciós idő (min) \\
\hline neoklorogénsav & 7,545 \\
\hline catechin & 8,789 \\
\hline 3-p-kumaroil-kínasav & 9,361 \\
\hline klorogénsav & 10,013 \\
\hline cianidin-3-rutinozid & $11,324^{*}$ \\
\hline kvercetin-3-rutinozid & 13,551 \\
\hline kvercetin & 14,49 \\
\hline
\end{tabular}




\subsection{Statisztikai kiértékelés}

Az eredmények kiértékeléséhez IBM SPSS Statistics 22.0.0.0 programcsomagot használtunk. A paramétereket először az alábbi összefüggő csoportokba rendeztük:

- gyümölcsök méretparaméterei (szélesség, magasság, vastagság), gyümölcsök térfogata;

- gyümölcsök színparaméterei (L*, a* és b*);

- gyümölcsök kocsány-szakítószilárdsága, keménysége;

- gyümölcstömeg, csontártömeg, hasznos gyümölcs arány;

- gyümölcsök összes titrálható savtartalma, gyümölcsök összes vízoldható szárazanyagtartalma;

- gyümölcsök egyedi savkomponensei (almasav, borostyánkősav, citromsav);

- gyümölcsök egyedi cukorkomponensei (glükóz, fruktóz, szorbitol);

- gyümölcsök egyedi polifenol komponensei (neoklorogénsav, catechin, 3-p-kumaroilkínasav, cianidin, cianidin-3-rutinozid, kvercetin-3-rutinozid, kvercetin)

A csoportba rendezést követően az egymással korreláló változókat együtt elemeztük. A többváltozós kiugró értékeket a Mahalanobis-távolságok alapján Khi-négyzet teszttel szürtük (FILZMOSER et al. 2008). Az összehasonlítást többváltozós ANOVA modellel végeztük, négy faktorral. A faktorok a Q10 ültetvényből származó gyümölcsminták esetén a következők voltak:

- nemes ('Kordia', 'Regina');

- $\quad$ alany ('GiSelA 5', 'GiSelA 6', 'PHL-C', 'PiKu 1', 'Weiroot 158');

- érési terminus (T1, T2, T3);

- évjárat (2010, 2011, 2012, 2013).

A faktorok a Q26 ültetvényből származó minták esetén az alábbiak voltak:

- nemes ('Bigarreau Burlat Schreiber', 'Bigarreau Burlat VG', 'Bigarreau Moreau Schreiber', 'Hybrid 222', 'Merton Premier');

- kezelés (kontroll, virágritkított);

- érési terminus (T1, T2, T3);

- évjárat (2010, 2011, 2012).

Szignifikáns MANOVA eredmény esetén változónként is teszteltük a faktorhatásokat. A hibatagok normalitását a Shapiro-Wilk teszt vagy - ha az szignifikáns volt - a ferdeség és csúcsosság alapján fogadtuk el (D’AGOSTiNO et al. 1990, TABACHNicK és FidelL 2013). A szórások homogenitását Levene-teszttel ellenőriztük. A szóráshomogenitás teljesülése esetén Tukey, sérülése esetén Games-Howell post hoc tesztet végeztünk el. 


\section{EREDMÉNYEK}

\subsection{A gyümölcsök fizikai tulajdonságai}

\subsubsection{A Q10 ültetvény}

\subsubsection{Gyümölcsméretek és gyümölcstérfogat}

A Q10 ültetvény cseresznyegyümölcseinek méretparamétereit (magasság, vastagság, szélesség) 4 egymást követő évben (2010-2013) mértük, majd azokból gyümölcstérfogatot számoltunk. A Melléklet 19. táblázata tartalmazza a gyümölcsméretek, 20. táblázata a térfogatok összesített adatait.

$\mathrm{Az}$ érési terminusok eredményeit összevetve láthatjuk, hogy évenként és alany-nemes kombinációnként a cseresznye gyümölcsök 3 méretparamétere (és ezáltal térfogata) az érés során $(\mathrm{T} 1 \rightarrow \mathrm{T} 2 \rightarrow \mathrm{T} 3)$ szignifikánsan nö.

A két fajtát összehasonlítva általánosságban elmondható, hogy 2010-ben és 2013-ban a 'Regina' fajta gyümölcsei, a köztes években pedig a 'Kordia' fajta gyümölcsei voltak szignifikánsan nagyobbak (egyetlen kivétel a 'PHL-C' alany 2011-ben).

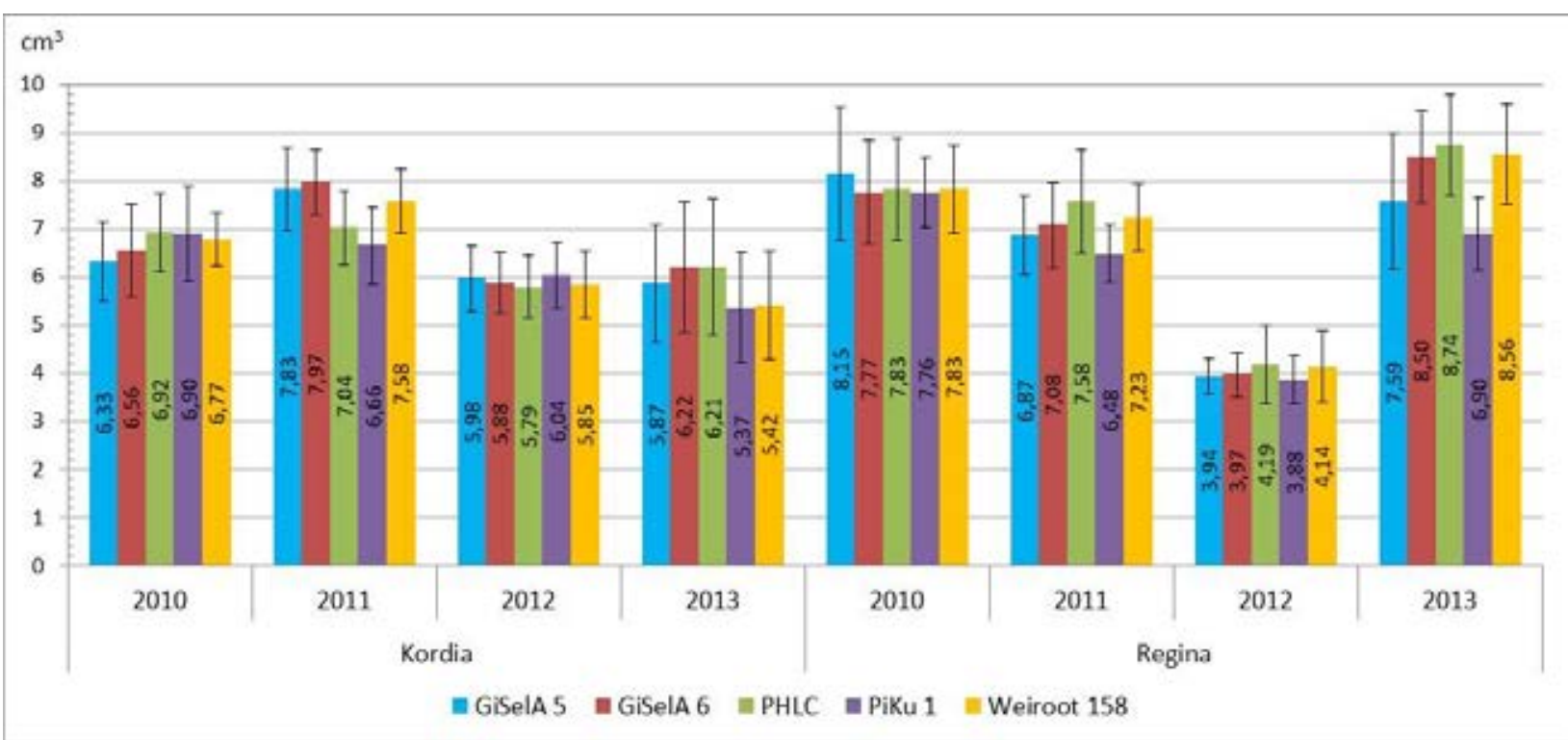

23. ábra: 'Regina' és 'Kordia' cseresznyefajták átlagos gyümölcstérfogata különböző alanyokon T3-as érési stádiumban 2010 és 2013 között

Gyümölcstérfogat tekintetében az eredmények 62,5\%-ánál, míg gyümölcsméretek tekintetében 61,11\%-ánál tudtuk szignifikáns alanyhatást kimutatni. A T3-as érési stádiumban (23. ábra) a legnagyobb átlagos gyümölcsméretet 'Regina' fajtánál legtöbbször 'PHL-C' alanyon mértük: 2011-ben, 2012-ben és 2013-ban az első helyre került, 2010-ben pedig a másodikra, míg a legkisebb átlagos gyümölcsméretet mind a 4 évben 'PiKu 1' alanyon mértük (az eredmény 2011ben és 2013-ban volt szignifikáns). A 'Kordia' fajta 2011-ben és 2013-ban a 'GiSelA 6' alanyon, 
2010-ben 'PHL-C'-n, 2012-ben pedig 'PiKu 1'-en produkálta a legnagyobb gyümölcsöket, míg a legkisebbeket 2011-ben és 2013-ban 'PiKu 1' alanyon, 2010-ben 'GiSelA 5'-ön, 2012-ben pedig 'PHL-C'-n (csak a 2011-es év eredménye volt szignifikáns).

A négy év eredményeit összevetve T3-as érési stádiumban (23. ábra) a legnagyobb gyümölcsöt a nemes-alany kombinációk közül a 'Regina'-'PHL-C' kombináció produkálta a 2013-as évben (legnagyobb átlagos átmérő: 28,01 $\pm 1,21 \mathrm{~mm}$, átlagos térfogat: 8,74 $\pm 1,06 \mathrm{~cm}^{3}$ ). A legkisebb gyümölcse mindent összevetve a 'Regina'-'PiKu 1' kombinációnak volt a 2012-es évben $\left(20,67 \pm 1,16 \mathrm{~mm}, 3,88 \pm 0,50 \mathrm{~cm}^{3}\right)$. A 'Kordia' fajta a négy év alatt 2011-ben produkálta a legnagyobb gyümölcsöket 'GiSelA 6' alanyon (26,52 $\left.\pm 0,96 \mathrm{~mm}, 7,97 \pm 0,69 \mathrm{~cm}^{3}\right)$ és 2013-ban a legkisebbeket 'PiKu 1' alanyon $\left(23,27 \pm 1,60 \mathrm{~mm}, 5,37 \pm 1,15 \mathrm{~cm}^{3}\right)$.

\subsubsection{Gyümölcs- és csontártömeg, hasznos gyümölcs arány}

A Q10 ültetvény cseresznyegyümölcseinek gyümölcs- és csontártömegét 4 egymást követő évben (2010-2013) mértük, majd azokból hasznos gyümölcs arányt számoltunk. A Melléklet 21. táblázata tartalmazza a háromféle érték összesített adatait.

Mivel a gyümölcstömeg erősen összefügg a gyümölcsök méretparamétereivel és térfogatával, az ott leírtakhoz teljesen hasonló eredményeket kaptunk, így a továbbiakban csak összefoglaljuk a legfontosabbakat.

A gyümölcsök átlagos tömege az érés előrehaladtával szignifikánsan nőtt minden évben és minden alany-nemes kombinációnál. A fajtákat összehasonlítva megállapítható, hogy a 'Regina' fajta gyümölcseinek átlagtömege szinte minden esetben szignifikánsan nagyobb a 'Kordia' fajta gyümölcseinél (2010, 2011 és 2013 évek).

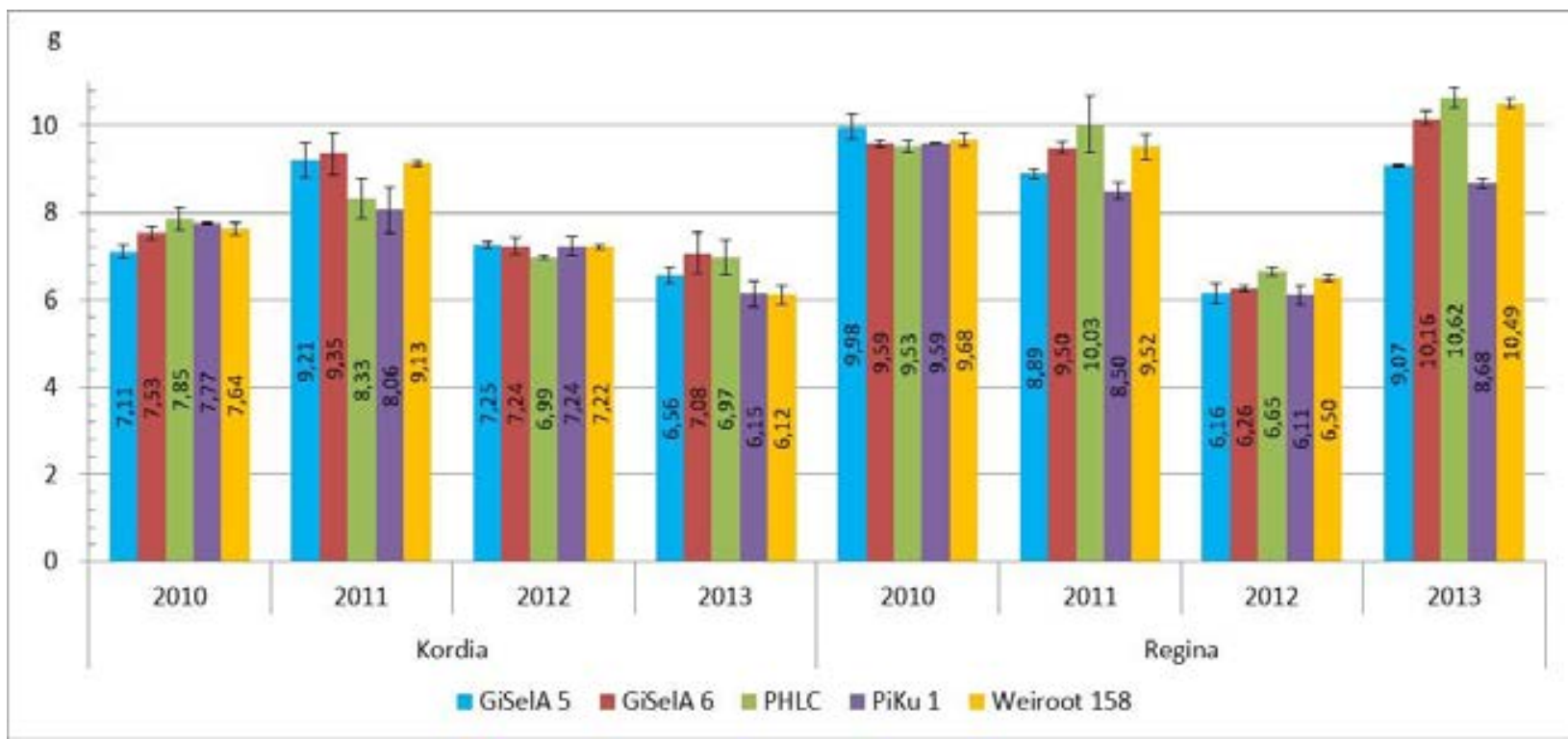

24. ábra: 'Regina' és ‘Kordia' cseresznyefajták átlagos gyümölcstömege különböző alanyokon T3-as érési stádiumban 2010 és 2013 között 
Alanyhatás tekintetében 91,99\%-ban szignifikáns különbséget tudtunk kimutatni az gyümölcsök átlagtömegre vonatkozóan. A gyümölcsöket teljes érettségben vizsgálva (24. ábra) a 'Regina' fajta gyümölcsei legtöbbször a 'PHL-C' alanyon álló fákon mutatták a legnagyobb átlagos gyümölcstömeget, míg a legkisebbeket minden évben a 'PiKu 1' alanyon mértük (az eredmények 75\%-a volt szignifikáns). A 'Kordia' fajta átlagos gyümölcstömege évjáratonként és alany-nemes kombinációnként változó értéket mutatott.

A négy évet összehasonlítva a T3-as érési stádiumban (24. ábra) a legnagyobb átlagos gyümölcstömege a 'Regina'-'PHL-C' (10,62 \pm 0,23 g) és a 'Regina'-'Weiroot 158' (10,49 \pm 0,11 g) kombinációknak 2013-ban, míg a legkisebb a 'Kordia'-'Weiroot 158' (6,12 $\pm 0,22$ g) és a 'Kordia'-'PiKu 1' (6,15 \pm 0,29 g) kombinációknak 2013-ban, valamint a 'Regina'-'PiKu 1' (6,11 $\pm 0,22 \mathrm{~g})$ és a 'Regina'-'GiSelA 5’ (6,16 $\pm 0,23 \mathrm{~g})$ kombinációknak volt 2012-ben.

Az érési terminusok eredményeit összevetve nem tudtunk egyértelmü tendenciát kialakítani a különböző évek és alany-nemes kombinációk átlagos csontártömege között, vagyis az érés elörehaladtával $(\mathrm{T} 1 \rightarrow \mathrm{T} 2 \rightarrow \mathrm{T} 3)$ nem tapasztaltunk sem egyértelmü növekedést, sem egyértelmü csökkenést a csontár átlagtömegében.

A két fajtát összehasonlítva elmondható, hogy a 'Regina' fajta gyümölcseiben a csontár átlagos tömege minden évben, alanyon és érési terminusban szignifikánsan nagyobb volt, mint a 'Kordia' gyümölcseiben.

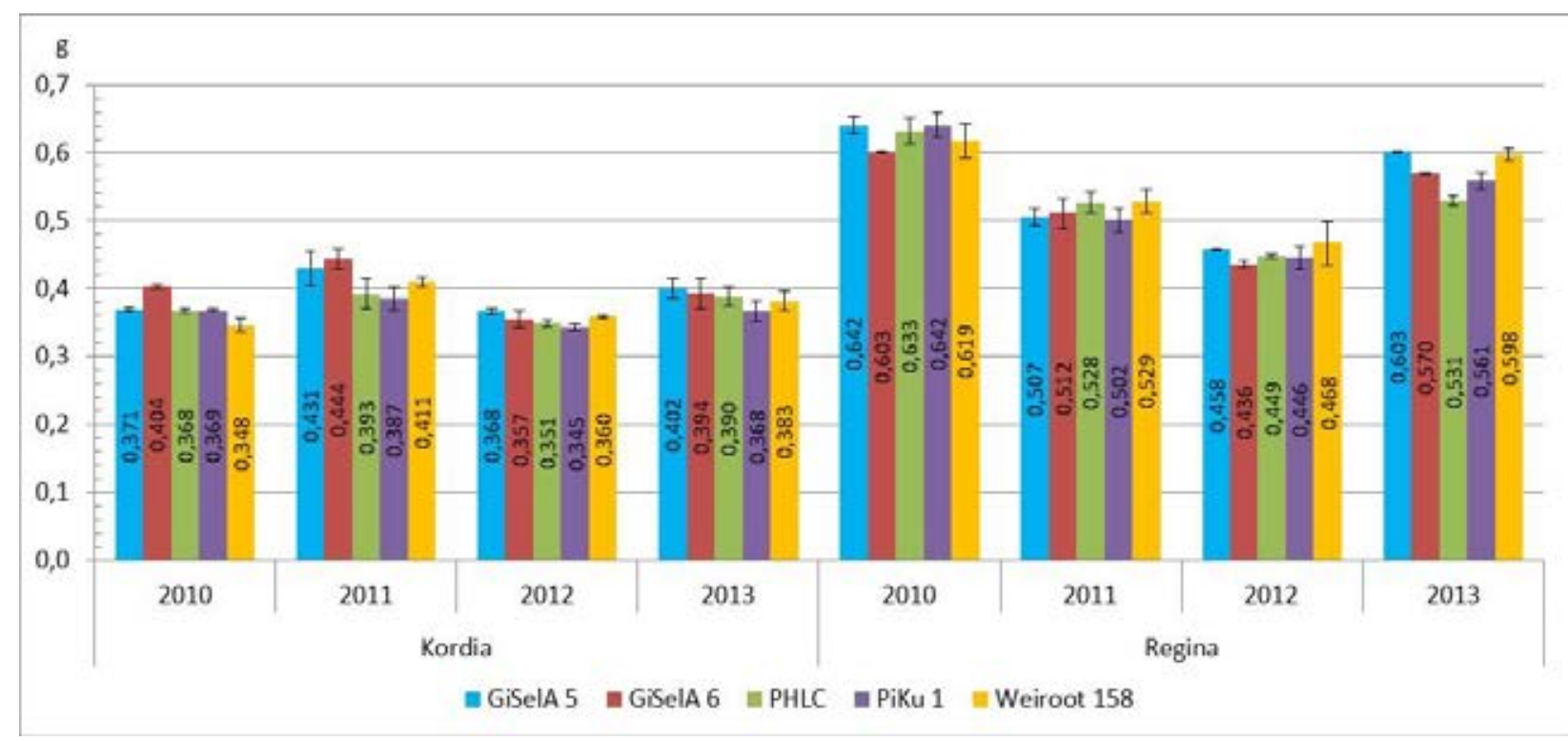

25. ábra: 'Regina' és ‘Kordia' cseresznyefajták gyümölcseinek átlagos csontártömege különböző alanyokon T3-as érési stádiumban 2010 és 2013 között

Az alanyhatást vizsgálva az eredmények 70,83\%-ánál szignifikáns különbséget tudtunk kimutatni az átlagos csontártömeg tekintetében. A T3-as érési stádiumot vizsgálva (25. ábra) a 'Kordia' fajtánál a legnagyobb átlagos csontártömeget minden évben a 'GiSelA 6' és 'GiSelA 5' alanyokon mértük (bár 2013-ban nem tudtunk szignifikáns különbséget kimutatni), míg a 
legkisebbet 3 egymás utáni évben (2011-2013) a 'PiKu 1' alanyon. 'Regina' fajtánál a legtöbb esetben 'GiSelA 5' és 'Weiroot 158' alanyokon találtuk a legnagyobb átlagtömegü csontárokat (ebböl 66\% volt szignifikáns), míg a legkisebbeket 2 évben (2010-ben és 2012) a 'GiSelA 6' alanyon, míg a másik két évben különböző alanyokon.

A négy év eredményeit összevetve T3-as érési stádiumban (25. ábra) a szignifikánsan legnagyobb átlagos csontártömeget a 'Regina'- 'GiSelA 5' (0,642 $\pm 0,012$ g) és 'Regina'-'Piku 1' $(0,642 \pm 0,018 \mathrm{~g})$ nemes-alany kombinációkon mértük 2010-ben. A legkisebb szignifikáns értéket a 'Kordia'-'PiKu' $(0,345 \pm 0,005$ g) és a 'Kordia'-PHL-C' $(0,351 \pm 0,005$ g) kombinációknál 2012-ben, valamint a 'Kordia'-'Weiroot 158' (0,348 \pm 0,011 g) esetében 2010-ben kaptuk.

$\mathrm{Az}$ érési terminusok eredményeit vizsgálva kiderül, hogy évenként és alany-nemes kombinációnként a cseresznye gyümölcsök hasznos gyümölcs aránya az érés során $(\mathrm{T} 1 \rightarrow \mathrm{T} 2 \rightarrow \mathrm{T} 3)$ szignifikánsan nő (kivéve a 'Regina' fajta 2010-es eredményeit, ahol nincs szignifikáns változás).

A két fajtát összehasonlítva a T3-as érési stádiumban (26. ábra) elmondható, hogy a 'Kordia' fajta hasznos gyümölcs aránya minden évben és alany-nemes kombinációnál szignifikánsan nagyobb, mint a 'Regina' fajtáé (kivéve 2013-ban a 'PHL-C' alanynál).

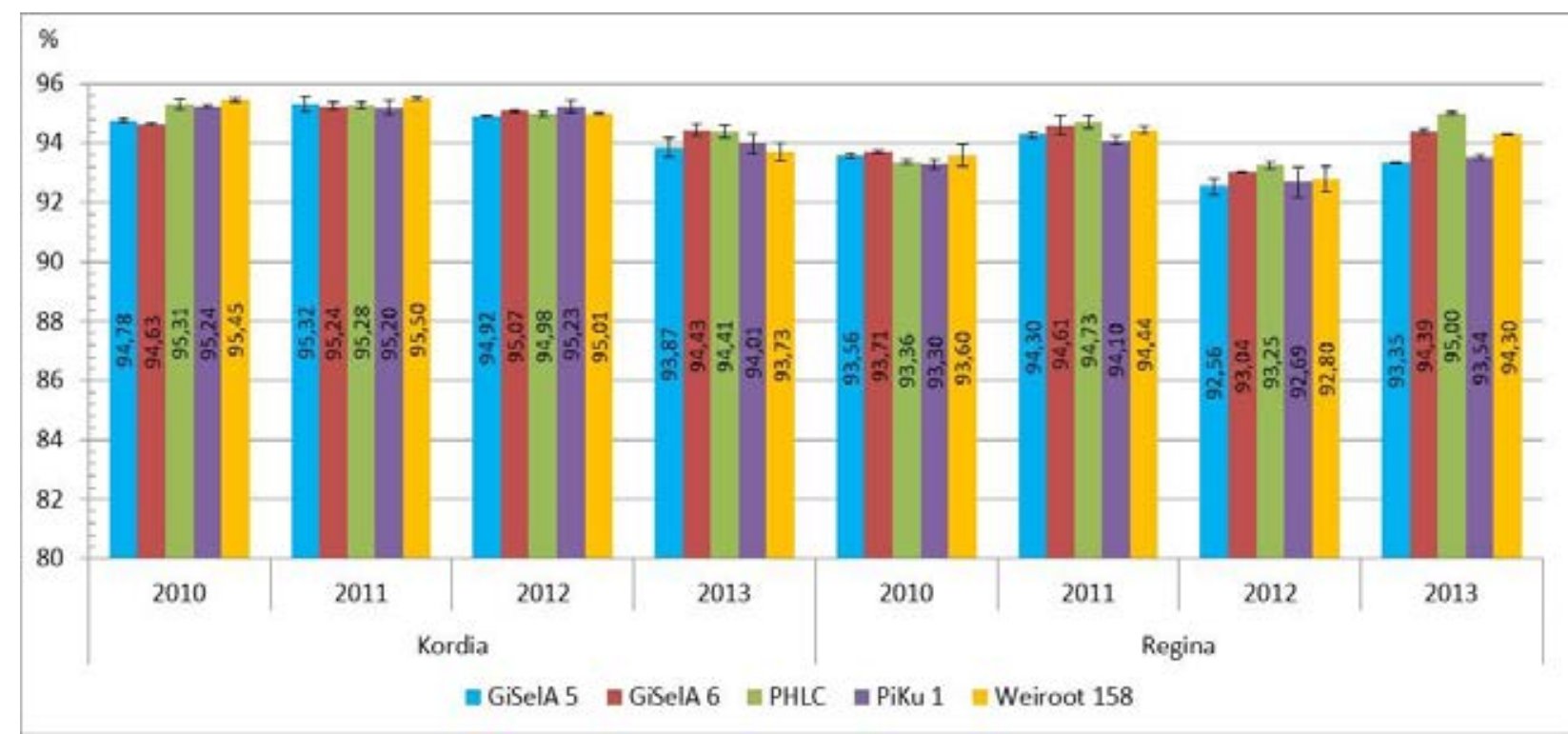

26. ábra: 'Regina' és ‘Kordia' cseresznyefajták hasznos gyümölcs aránya különböző alanyokon T3-as érési stádiumban 2010 és 2013 között

Az alanyhatást vizsgálva összességében az adatok 79,17\%-ánál találtunk szignifikáns eltérést a hasznos gyümölcs arány tekintetében. A T3-as érési stádiumban (26. ábra) 'Kordia' fajtánál nem találtunk egyértelmü tendenciát, a hasznos gyümölcs arány minden évjáratban más eredményt hozott (bár 2010-ben és 2011-ben is a 'Weiroot 158' alanyon mértük a legnagyobb értékeket, de 2011-ben az eredmény nem volt szignifikáns). 'Regina' fajtánál az alanyhatás szembetűnőbb: legtöbbször (2011-2013) a 'PHL-C' alany adta a szignifikánsan legnagyobb eredményeket, míg a 'GiSelA 5' és 'PiKu 1' alanyok a legkisebbeket. 
A négy év eredményeit összevetve a T3-as érési stádiumban (26. ábra) a legnagyobb hasznos gyümölcs arányt a 'Kordia'-’Weiroot 158' kombináció produkálta a 2010-es és 2011-es évben $(95,5 \pm 0,05$ és 95,5 \pm 0,08\%). A legkisebb értéket 2012-ben kaptuk a 'Regina'-'GiSelA 5', kombinációnál $(92,6 \pm 0,28 \%)$.

\subsubsection{Kocsány-szakitószilárdság (KSzSz)}

Az integrált ültetvény cseresznyegyümölcseinek kocsány-szakítószilárdság adatai 3 évböl állnak rendelkezésünkre (2011-2013), ezeknek összesítését a Melléklet 20. táblázata tartalmazza.

Az érési terminusok eredményeit vizsgálva kiderül, hogy minden évben és alany-nemes kombinációnál a cseresznye gyümölcs $\mathrm{KSzSz}$ értéke szignifikánsan csökken az érés előrehaladtával $(\mathrm{T} 1 \rightarrow \mathrm{T} 2 \rightarrow \mathrm{T} 3)$.

A két fajtát összehasonlítva általánosságban elmondható, hogy a 'Regina' fajta gyümölcseinek kocsánytól való elválasztásához minden év - alany - terminus kombináción belül szignifikánsan nagyobb erőre volt szükség, mint a 'Kordia' fajta esetében.

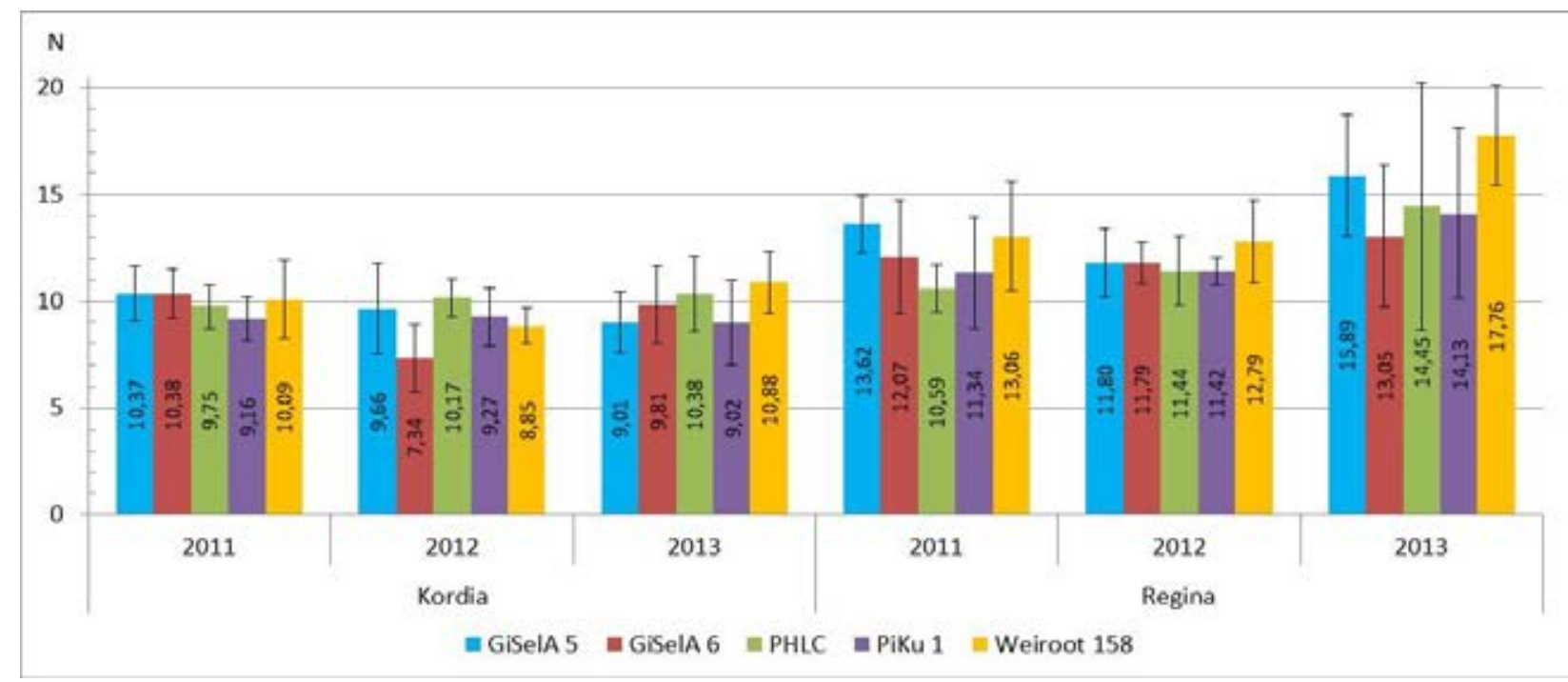

27. ábra: 'Regina' és ‘Kordia' cseresznyefajták gyümölcseinek kocsány-szakítószilárdsága különböző alanyokon T3-as érési stádiumban 2011 és 2013 között

Az alanyhatást vizsgálva a T3-as érési stádiumban (27. ábra) az adatok 54,16\%-ánál találtunk szignifikáns különbséget a KSzSz értékekben. Az eredmények között azonban nem tudtunk egyértelmü tendenciát azonosítani: az alanyok évjáratonként és terminusonként más-más hatással voltak a fajták KSzSz értékeire, és hol kimutatható volt szignifikáns eltérés, hol nem. Az bizonyos, hogy mindkét fajta leggyakrabban a 'PiKu 1' alanyon mutatta a legkisebb KSzSz értékeket érési stádiumtól függetlenül, de az változó volt, hogy mikor melyik alany-nemes kombináció esetében kellett a legnagyobb erő a gyümölcs kocsánytól való elválasztásához.

A négy év eredményeit összevetve a T3-as érési stádiumban (27. ábra) a legnagyobb KSzSz értéke a 'Regina'-'Weiroot 158' $(17,76 \pm 2,35 \mathrm{~N})$ és a 'Regina'-'GiSelA 5' $(15,89 \pm 2,84 \mathrm{~N})$ alany- 
nemes kombinációnak volt 2013-ban. A legkisebb értéket összességében a 'Kordia'-'GiSelA 6' (7,34 \pm 1,55 N) kombinációnál mértük 2012-ben.

\subsubsection{Gyümölcsök héjszíne}

Az integrált ültetvény cseresznyegyümölcseinek színparamétereit $\left(\mathrm{L}^{*}, \mathrm{a}^{*}, \mathrm{~b}^{*}\right)$ négy egymást követő évben (2010-2013) vizsgáltuk. A Melléklet 22. táblázata tartalmazza a színparaméterek összesített adatait.

Az érési terminusok eredményeit figyelembe véve láthatjuk, hogy évenként és alany-nemes kombinációnként a cseresznye gyümölcsök mindhárom színparamétere szignifikánsan csökken az érés során $(\mathrm{T} 1 \rightarrow \mathrm{T} 2 \rightarrow \mathrm{T} 3)$, vagyis a cseresznye gyümölcsök az érés előrehaladtával egyre sötétednek, valamint csökken bennük a piros színárnyalat és erösödik a kék.

A két fajtát összehasonlítva általánosságban elmondható, hogy minden évben, érési stádiumban és alanyon a 'Kordia' fajta gyümölcseinek $L^{*}$, $a^{*}$ és $b^{*}$ értékei alacsonyabbak a 'Regina' értékeinél (kivéve a 2012-es év egyes adatait). Az L* paraméter esetében ez azt jelenti, hogy a 'Kordia' fajta gyümölcsei sötétebb színűek, az a* paraméter alapján a 'Regina' fajta gyümölcseiben intenzívebb a piros szín, míg a b* paramétert tekintve a 'Kordia' gyümölcseiben több a kék színösszetevő.

Az alanyhatást vizsgálva az L* paraméter esetében az eredmények 100\%-ában, az a* paramétert vizsgálva az eredmények 70,83\%-ában, míg a b* paramétert vizsgálva az eredmények 91,67\%-ában tudtunk szignifikáns különbséget kimutatni. Az L* paramétert vizsgálva a T3-as érési stádiumban (28. ábra) a 'Regina' fajta gyümölcsei 2010-ben és 2012-ben 'GiSelA 5' alanyon lettek a legvilágosabbak, és ez az alany 2013-ban is a legmagasabb (legvilágosabb) szignifikáns csoportba került a 'PHL-C'-vel és a 'Weiroot 158'-tal. A legsötétebb gyümölcsöket 2010-ben és 2012-ben a 'PiKu 1' alanynál mértük (ezek közül 2012-ben a 'Weiroot 158' is egy szignifikáns csoportba került vele), míg 2011-ben a 'GiSelA 5', 2013-ban pedig a 'GiSelA 6' alanyon álló fák gyümölcsei bizonyultak a legsötétebbnek. A 'Kordia' fajta gyümölcsei 3 egymást követő évben (2011-2013) is a 'PHL-C' alanyon kerültek a legsötétebb szignifikáns csoportba, míg a legvilágosabb színt általában a 'Weiroot 158' és a 'GiSelA 5' alanyon mutatták. Az a* paraméter tekintetében a 'Regina' fajta gyümölcsei legtöbbször 'GiSelA 5', 'GiSelA 6' és 'Weiroot 158' alanyokon adták a legintenzívebb piros színt, míg 'PiKu 1'-en a legkevésbé intenzívet. A 'Kordia' esetében legtöbbször a 'GiSelA 6' alanyon álló fák gyümölcsei lettek a legintenzívebb piros színűek, míg a legkevésbé intenzív piros színt a 'PHL-C' alanyon mértük. A b* paraméter esetén a 'Regina' fajta gyümölcseinek héjszínében általában a 'PiKu 1' alanyú fák esetében találtuk a legtöbb kék színkomponenst, míg a legkevesebbet a 'GiSelA 5' és 'GiSelA 6' alanyoknál. A 'Kordia' esetében leggyakrabban a 'PHL-C' alanyon álló fák gyümölcseinek héjában volt a legtöbb kék színkomponens, míg a legkevesebb általában a 'GiSelA 6' alanynál volt megfigyelhető. 

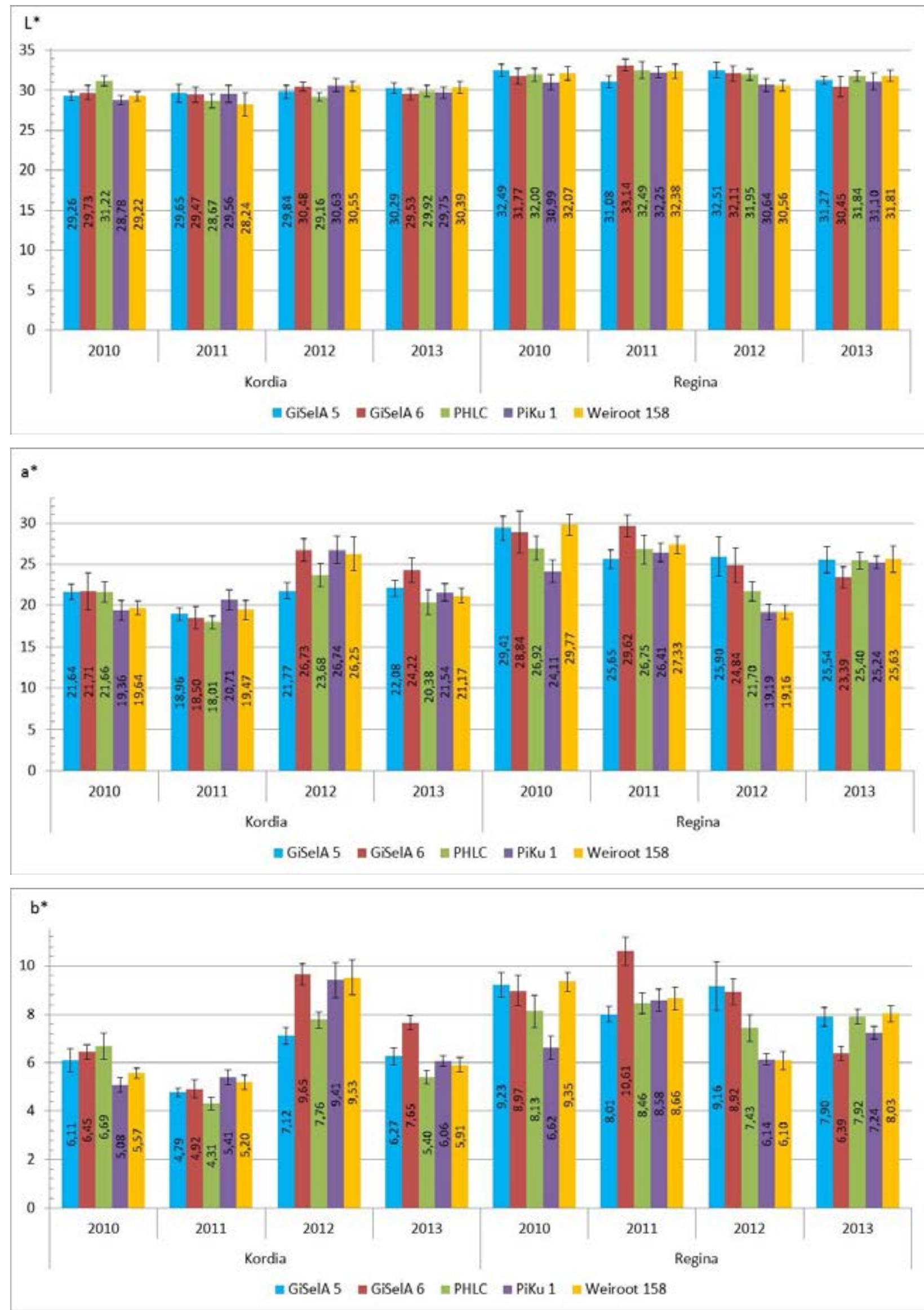

28. ábra: 'Regina' és 'Kordia' cseresznyefajták gyümölcseinek $L^{*}, a^{*}$ és b* értékei különböző alanyokon T3as érési stádiumban 2010 és 2013 között 
A négy év eredményeit összevetve (28. ábra) a legsötétebb gyümölcsöt a 'Kordia'-'PHL-C' és a 'Kordia'-’Weiroot 158' nemes-alany kombinációk produkálták 2011-ben (L* 28,67 \pm 0,89 illetve 28,24 $\pm 1,45)$. A legvilágosabbat a 'Regina'-'GiSelA 6' kombináció 2011-ben (L*33,14 \pm 0,68). A legintenzívebb piros színt a 'Regina'-'GiSelA 6' kombináció 2011-ben (a*29,62 $\pm 1,29)$, valamint a 'Regina'-'Weiroot 158' és a 'Regina'-'GiSelA 5' kombináció 2010-ben adta (a* 29,77 $\pm 1,27$ és $29,41 \pm 1,46)$. A legtöbb kék színkomponenst a 'Kordia'-'PHL-C' kombináció gyümölcshéjában mértük 2011-ben (b* 4,31 $\pm 0,26$ ).

\subsubsection{Gyümölcskeménység}

Az integrált cseresznyeültetvény gyümölcseinek keménységét 4 egymást követő évben (20102013) vizsgáltuk. A Melléklet 24. táblázata tartalmazza a gyümölcsök keménységértékeinek összesített adatait.

Az érési terminusok eredményeit figyelembe véve látható, hogy mind a 4 évben és mind a 10 alany-nemes kombinációnál a cseresznye gyümölcsök átlagos keménysége az érés folyamán $(\mathrm{T} 1 \rightarrow \mathrm{T} 2 \rightarrow \mathrm{T} 3)$ szignifikánsan csökken.

A fajtákat összehasonlítva elmondható, hogy a 'Regina' fajta gyümölcsei T3-as érési stádiumban (29. ábra) mind a 4 évben szignifikánsan keményebbek voltak a 'Kordia' fajta gyümölcseinél (kivétel 2011-ben a 'GiSelA 6', 2012-ben a 'PHL-C' és a 'GiSelA 5' alanyok).

Az alanyhatást vizsgálva a gyümölcsök keménységére összességében az eredmények 62,5\%-ánál tudtunk szignifikáns különbséget kimutatni. A T3-as érési stádium eredményei (29. ábra) alapján a 'Kordia' fajta a legtöbb évben és érési stádiumban 'Weiroot 158' alanyon nevelte a szignifikánsan legpuhább gyümölcsöket, míg 'GiSelA 5'-ön, 'PHL-C'-n és 'GiSelA 6'-on a legkeményebbeket. A 'Regina’ fajtánál a legpuhább gyümölcsöket évjáratonként más és más alany produkálta, a legkeményebbeket 'GiSelA 6’ alanyon mértük (kivéve 2011-ben).

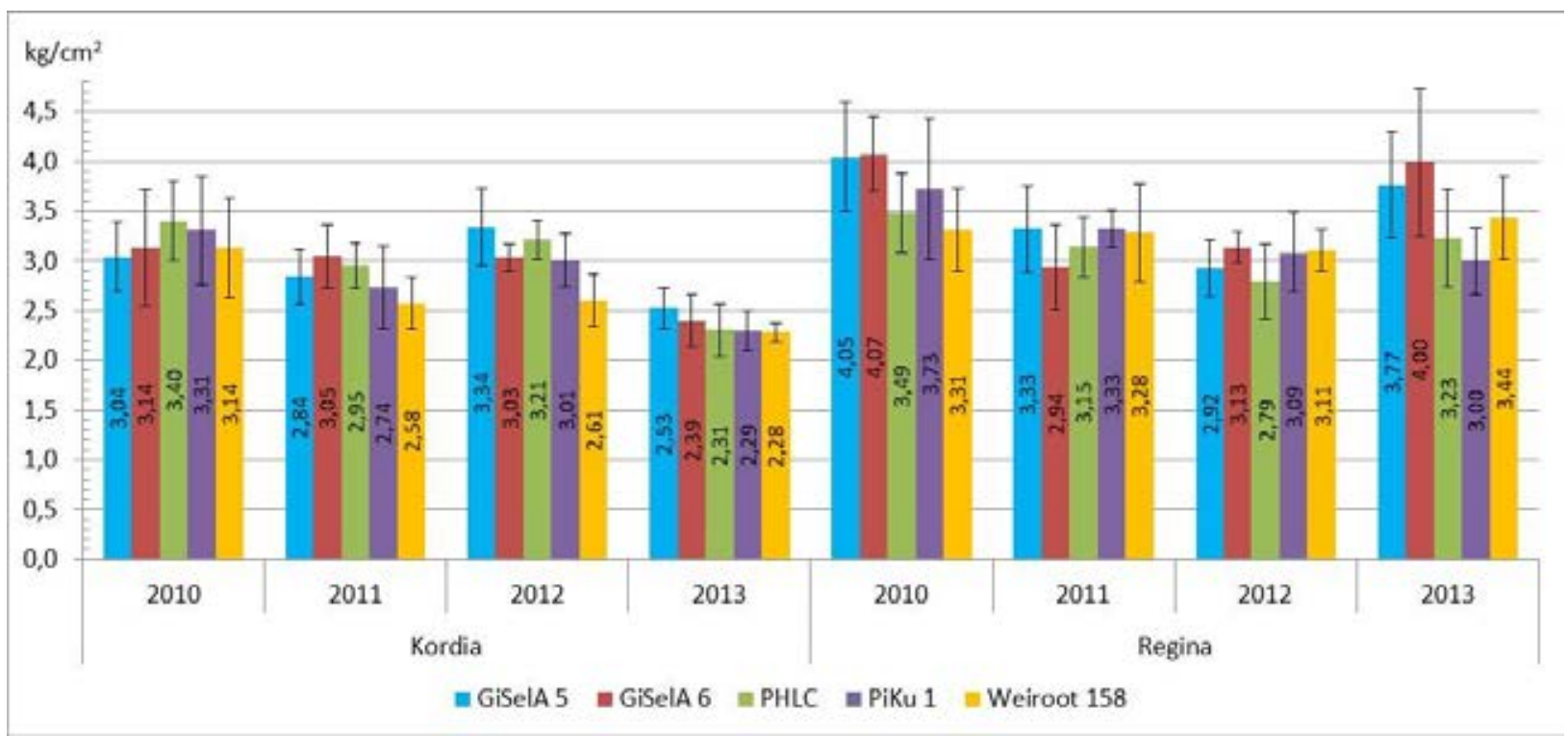

29. ábra: 'Regina' és ‘Kordia' cseresznyefajták gyümölcskeménysége különböző alanyokon T3-as érési stádiumban 2010 és 2013 között 
A négy év eredményeit összevetve T3-as érési stádiumban (29. ábra) a legkeményebb gyümölcsöt a 'Regina'-'GiSelA 6' nemes-alany kombináció produkálta 2010-ben $(4,07 \pm 0,37$ $\left.\mathrm{kg} / \mathrm{cm}^{2}\right)$ és 2013-ban $\left(4,00 \pm 0,74 \mathrm{~kg} / \mathrm{cm}^{2}\right)$, de jól szerepelt a 'Regina'-'GiSelA 5' kombináció is (2010: 4,05 $\pm 0,54 \mathrm{~kg} / \mathrm{cm}^{2} ; 2013: 3,77 \pm 0,53 \mathrm{~kg} / \mathrm{cm}^{2}$ ). A legpuhább gyümölcse összességében a 'Kordia'-'Weiroot 158' kombinációnak volt 2013-ban $\left(2,28 \pm 0,09 \mathrm{~kg} / \mathrm{cm}^{2}\right)$. A 'Kordia' fajta gyümölcskeménysége a 'PHL-C' alanyon $\left(3,40 \pm 0,39 \mathrm{~kg} / \mathrm{cm}^{2}\right)$ és a 'PiKu 1'-en $(3,31 \pm 0,55$ $\left.\mathrm{kg} / \mathrm{cm}^{2}\right)$ 2010-ben, valamint a 'GiSelA 5' alanyon 2012-ben $\left(3,34 \pm 0,39 \mathrm{~kg} / \mathrm{cm}^{2}\right)$ bizonyult a legmagasabbnak.

\subsubsection{A Q26 ültetvény}

A vizsgálatban résztvevő 5 nemes fajta nevét ettől a fejezettől kezdve az egyszerüség és az átláthatóság kedvéért rövidítve közöljük a dolgozatban ('Bigarreau Burlat Schreiber', a továbbiakban 'BBS'; 'Bigarreau Burlat VG', a továbbiakban 'BBVG'; 'Bigarreau Moreau Schreiber', a továbbiakban 'BMS'; 'Hybrid 222', a továbbiakban 'H222'; 'Merton Premier', a továbbiakban 'MP').

\subsubsection{Gyümölcsméretek és gyümölcstérfogat}

A Q26 cseresznyeültetvényben 5 különböző nemes fajta gyümölcsméret-paramétereit (magasság, vastagság, szélesség) vizsgáltuk 3 egymást követő évben (2010-2012) virágritkított és kontroll fákon, majd azokból gyümölcstérfogatot számoltunk. A Melléklet 23. táblázata tartalmazza a gyümölcsméretek, 24. táblázata a térfogatok összesített adatait.

Az érési terminusok eredményeit összehasonlítva jól látszik, hogy mind az öt nemes fajta gyümölcsének méretparaméterei (és ezáltal térfogata) évtől és a virágritkítás alkalmazásától függetlenül szignifikánsan nőnek az érés elörehaladtával $(\mathrm{T} 1 \rightarrow \mathrm{T} 2 \rightarrow \mathrm{T} 3)$.

A három év eredményeit összevetve a T3-as érési stádiumban (30. ábra) láthatjuk, hogy a fajták különböző módon reagáltak az évjárathatásra: míg a 'BBS' és a 'BMS' a 2010-es évben produkálta a legnagyobb gyümölcsöket, addig a másik 3 fajta gyümölcsei ('BBVG', 'H222' és 'MP') 2011-ben lettek a legnagyobbak. A legkisebb gyümölcsöket azonban mind az 5 fajta 2012ben hozta.

A nemeseket összehasonlítva a legnagyobb gyümölcstérfogatokat a T3-as érési stádiumban (30. ábra) minden évben a 'BBS' és a 'BMS' fajtáknál mértük (kivétel 2011-ben a kontroll 'BBS' fák valamint a ritkított és a kontroll 'BMS' fák).

A virágritkítás hatása szembetünő: a nemesek a 3 évben és három érési stádiumban összesen az esetek 87,5\%-ában produkáltak nagyobb gyümölcsöket a ritkított fákon a kontroll fákhoz képest, és mindezen mérések közül 61,36\% adott szignifikáns eltérést.

A T3-as érési stádiumban (30. ábra) a legkiemelkedőbb különbség ritkított és nem ritkított fák gyümölcsmérete között a 'BMS' fajtánál volt megfigyelhető: 2010-ben 20,42\%-kal, 2011-ben 17,15\%-kal, 2012-ben pedig 16,2\%-kal volt nagyobb a ritkított fák gyümölcseinek térfogata a 
kontroll fák gyümölcseihez képest. Viszonylag jó eredményeket produkált a 'BBS' fajta is: 2012ben 16,2\%-kal, 2011-ben 7,53\%-kal nagyobb gyümölcsméreteket kaptunk (2010-ben viszont a kontroll fák gyümölcsei voltak nagyobbak 3,25\%-kal).

Összességében elmondható, hogy a három év adatait figyelembe véve a T3-as érési stádiumban (30. ábra) a legnagyobb gyümölcstérfogattal a virágritkított 'BMS' $(26,16 \pm 1,42 \mathrm{~mm}$, $\left.7,43 \pm 1,21 \mathrm{~cm}^{3}\right)$, a kontroll 'BBS' $\left(25,52 \pm 1,23 \mathrm{~mm}, 7,00 \pm 0,83 \mathrm{~cm}^{3}\right)$ és a ritkított 'BBS' $(25,19$ $\pm 1,35 \mathrm{~mm}, 6,78 \pm 0,98 \mathrm{~cm}^{3}$ ) fajták rendelkeztek 2010-ben. A legkisebb gyümölcsöket a kontroll 'BBVG' $\left(20,69 \pm 1,23 \mathrm{~mm}, 3,56 \pm 0,48 \mathrm{~cm}^{3}\right)$ és a kontroll 'H222' $(20,68 \pm 0,92 \mathrm{~mm}, 3,57 \pm 0,42$ $\mathrm{cm}^{3}$ ) produkálta 2012-ben.

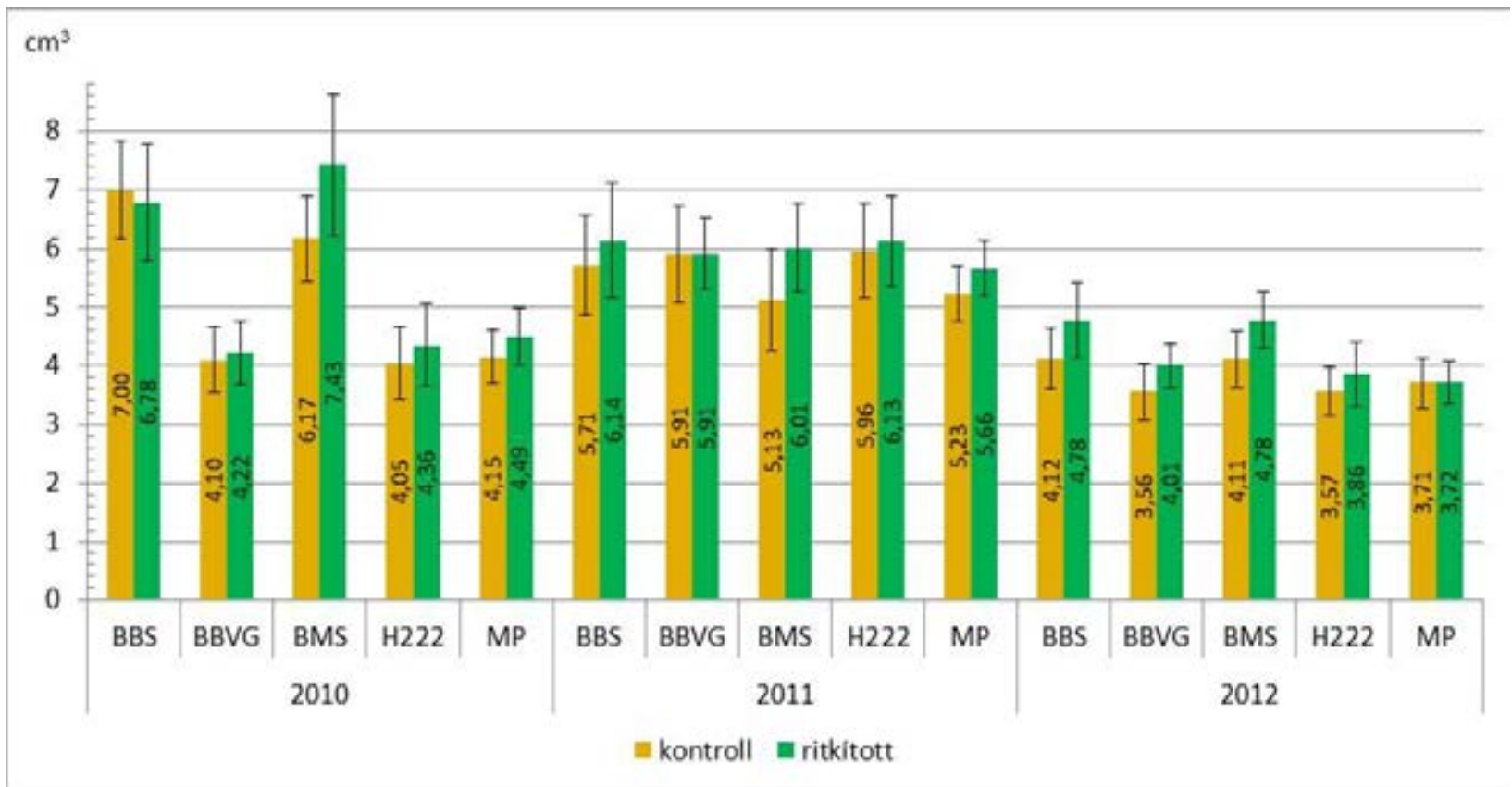

30. ábra: Virágritkított és kontroll cseresznyefajták átlagos gyümölcstérfogata T3-as érési stádiumban 2010 és 2012 között

\subsubsection{Gyümölcs- és csontártömeg, hasznos gyümölcs arány}

A Q26 cseresznyeültetvényben 5 különböző nemes fajta gyümölcs- és csontártömegét mértük 3 egymást követő évben (2010-2012) a virágritkítás függvényében, majd azokból hasznos gyümölcs arányt számoltunk. A Melléklet 25. táblázata tartalmazza a három féle érték összesített adatait.

Mivel a gyümölcstömeg erösen összefügg a gyümölcsök méretparamétereivel és térfogatával, az ott leírtakhoz teljesen hasonló eredményeket kaptunk, így a továbbiakban csak összefoglaljuk a legfontosabbakat.

Az érési terminusok eredményeit összehasonlítva jól látszik, hogy mind az öt nemes fajta gyümölcsének átlagos tömege évtől és a virágritkítás alkalmazásától függetlenül szignifikánsan nő az érés előrehaladtával. A három év eredményeit összevetve a T3-as érési stádiumban (31. ábra) láthatjuk, hogy a 'BBS' és a 'BMS' a 2010-es évben, míg a 'BBVG', a 'H222' és a 'MP' a 2011es évben produkálta a legnagyobb átlagtömegü gyümölcsöket. A legkisebb átlagtömegeket minden 
fajtánál és minden évben 2012-ben mértük. A nemesek összehasonlításában a legnagyobb átlagos gyümölcstömeget a T3-as érési stádiumban (31. ábra) 2010-ben és 2012-ben a 'BBS' és a 'BMS' fajtáknál mértük.

A virágritkítás hatása szembetűnő: a nemesek a 3 évben és három érési stádiumban összesen az esetek 90,9\%-ában produkáltak nagyobb átlagtömegü gyümölcsöket a ritkított fákon a kontroll fákhoz képest, és mindezen különbségek közül 70,0\% volt szignifikáns.

A T3-as érési stádiumban (31. ábra) a legkiemelkedőbb különbség ritkított és nem ritkított fák átlagos gyümölcstömege között a 'BMS' fajtánál volt megfigyelhetö. Viszonylag jó eredményeket produkált a 'BBS' fajta is (bár 2010-ben - nem szignifikánsan ugyan, de - a kontroll fák gyümölcsei voltak nagyobb tömegüek).

Összességében elmondható, hogy a három év adatait figyelembe véve a T3-as érési stádiumban (31. ábra) a legnagyobb átlagos gyümölcstömeggel a virágritkított 'BMS' $(8,47 \pm 0,44$ g), a kontroll 'BBS' $(8,45 \pm 0,48 \mathrm{~g})$ és a ritkított 'BBS' $(8,00 \pm 0,63 \mathrm{~g})$ fajták rendelkeztek 2010ben. A legkisebb átlagos gyümölcstömeget a kontroll 'BBVG' $(4,76 \pm 0,24 \mathrm{~g})$ és a kontroll 'H222' (4,75 $\pm 0,14 \mathrm{~g})$ produkálta 2012-ben.

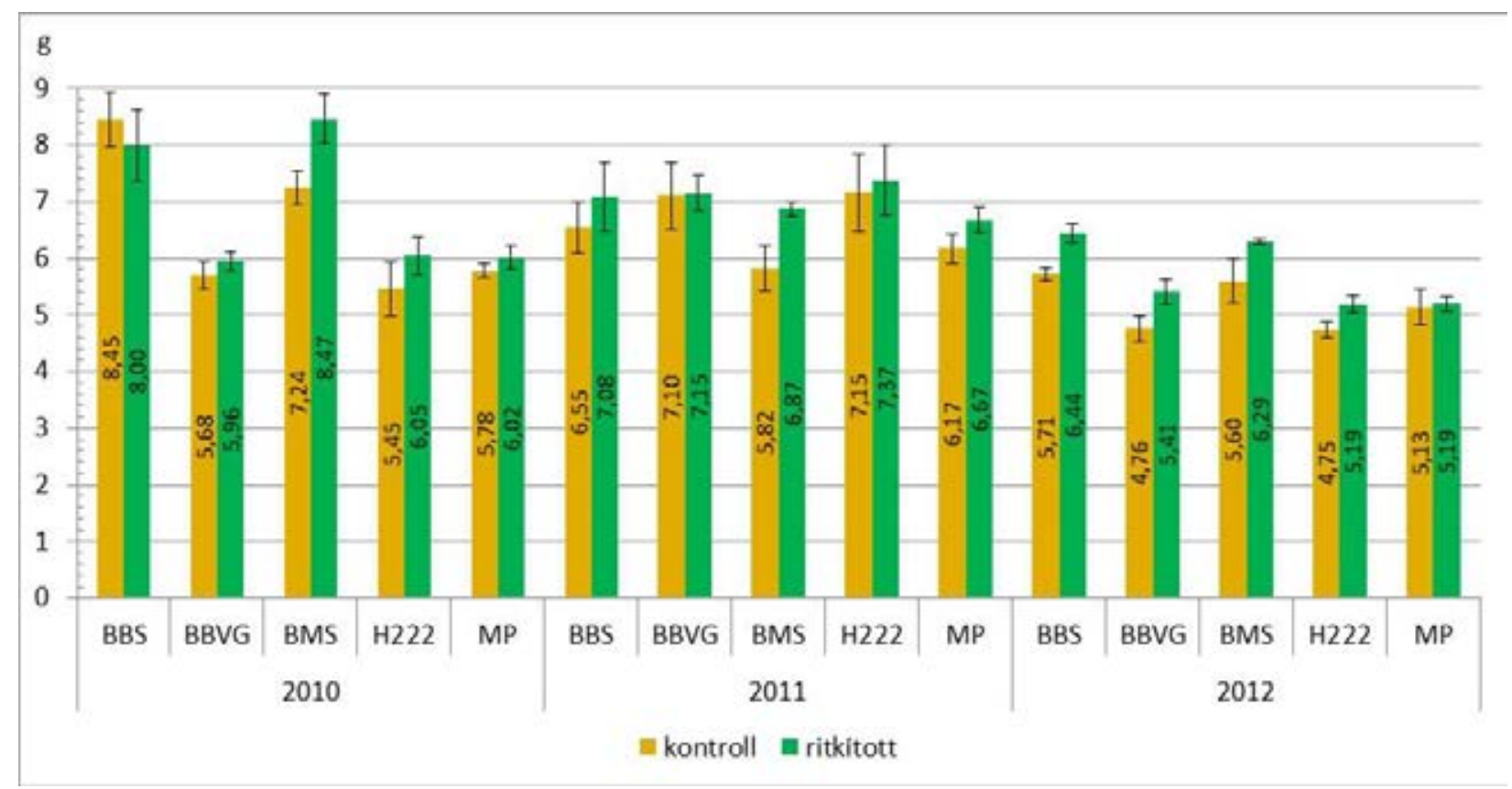

31. ábra: Virágritkított és kontroll cseresznyefajták átlagos gyümölcstömege T3-as érési stádiumban 2010 és 2012 között

Az érési terminusok eredményeit összehasonlítva szignifikáns különbséget tudtunk kimutatni a kontroll és a ritkított fák átlagos csontártömeg-változása között az érés előrehaladtával $(\mathrm{T} 1 \rightarrow \mathrm{T} 2 \rightarrow \mathrm{T} 3)$. A kontroll fák átlagos csontártömege a három év összesítésében az esetek 73,33\%ában csökkent, 20,0\%-ában nőtt, a maradék esetben nem volt egyértelmü a tendencia. Ezzel szemben a ritkított fák átlagos csontártömege csak az esetek 33,33\%-ában csökkent, 13,33\%-ában nőtt, míg az esetek többségében nem volt egyértelmü a változás. 
A három év eredményeit összevetve a T3-as érési stádiumban (32. ábra) a legnagyobb átlagos csontártömegeket minden fajta esetében a 2010-es évben mértük (kivétel a ritkított 'BBS', ahol 2012-ben), a legkisebb átlagos csontártömegeket azonban fajtánként különböző években kaptuk: a 'BBS' és a 'BMS' fák gyümölcseinek csontárja 2011-ben, a 'BBVG', 'H222' és 'MP' fajtáké pedig 2012-ben volt a legkisebb átlagtömegü.

A virágritkítás hatását vizsgálva a nemesek a 3 évben és három érési stádiumban összesen az esetek 90,91\%-ában produkáltak nagyobb átlagos csontártömeget a ritkított fákon a kontroll fákhoz képest, de mindezen különbségek közül csak 40,91\% volt szignifikáns.

A fajtákat összehasonlítva a T3-as érési stádiumban (32. ábra) a legkiemelkedőbb különbség ritkított és nem ritkított fák átlagos csontártömege között a 'BMS' fajtánál volt megfigyelhető: 2010-ben 13,4\%-kal, 2011-ben 11,0\%-kal, 2012-ben pedig 11,63\%-kal volt nagyobb a ritkított fák gyümölcseinek átlagos csontártömege a kontroll fákéhoz viszonyítva.

Összességében elmondható, hogy a három év adatait figyelembe véve a T3-as érési stádiumban (32. ábra) a legnagyobb átlagos csontártömeget a virágritkított 'BBS' $(0,545 \pm 0,042$ g) 2012-ben, valamint a virágritkított 'BMS' $(0,523 \pm 0,031 \mathrm{~g})$ és a kontroll és ritkított 'BBS' $(0,517 \pm 0,03$ és $0,513 \pm 0,006 \mathrm{~g})$ nemesek adták 2010-ben. A legkisebb átlagos csontártömeggel a 'H222' $(0,308 \pm 0,01$ és $0,313 \pm 0,007 \mathrm{~g})$ és a 'BBVG' $(0,318 \pm 0,024$ és $0,335 \pm 0,02 \mathrm{~g})$ kontroll és ritkított fái rendelkeztek 2012-ben.

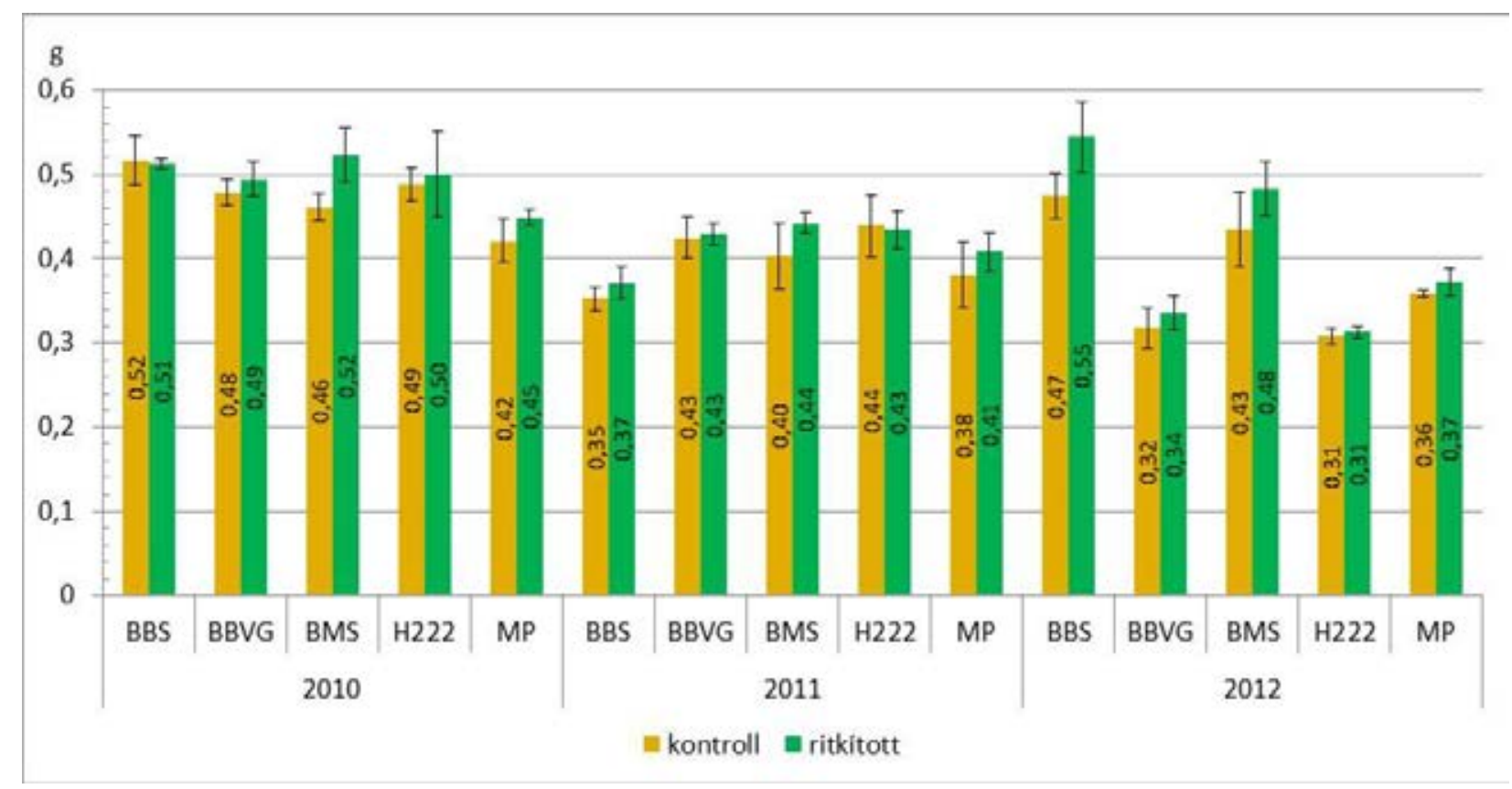

32. ábra: Virágritkított és kontroll cseresznyefajták gyümölcseinek csontártömege T3-as érési stádiumban 2010 és 2012 között

Az érési terminusok eredményeit vizsgálva kiderül, hogy minden évet és nemest összevetve a kontroll fák 86,67\%-ánál, a virágritkított fák 60\%-ánál nő a cseresznye gyümölcsök hasznos 
gyümölcs aránya $(\mathrm{HGyA})$ az érés során $(\mathrm{T} 1 \rightarrow \mathrm{T} 2 \rightarrow \mathrm{T} 3)$, melyek közül a kontroll fáknál 76,92\% volt szignifikáns, a virágritkított fáknál pedig $100 \%$.

A három évet összevetve a T3-as érési stádiumban (33. ábra) a legnagyobb HGyA-t minden fajta esetében a 2011-es évben mértük (kivétel a 'BMS'), a legkisebb eredményeket azonban fajtánként különböző években kaptuk: a 'BBS' és a ‘BMS' fák gyümölcseinek HGyA-a 2012-ben, a 'BBVG', 'H222' és 'MP' fajtáké pedig 2010-ben volt a legkisebb.

A virágritkítás hatását vizsgálva a nemesek a 3 évben és három érési stádiumban összesen az esetek 82,5\%-ában produkáltak nagyobb HGyA-t a ritkított fákon a kontroll fákhoz képest, de mindezen különbségek közül csak 41,86\% volt szignifikáns.

Összességében elmondható, hogy a három év adatait figyelembe véve a T3-as érési stádiumban (33. ábra) a legnagyobb HGyA-t a kontroll és a virágritkított 'BBS' fák adták (94,6 \pm 0,19 és 94,7 \pm 0,26\%) 2011-ben, míg legkisebb HGyA-a a kontroll 'H222’ fajtának volt 2010-ben $(91,0 \pm 0,54 \%)$.

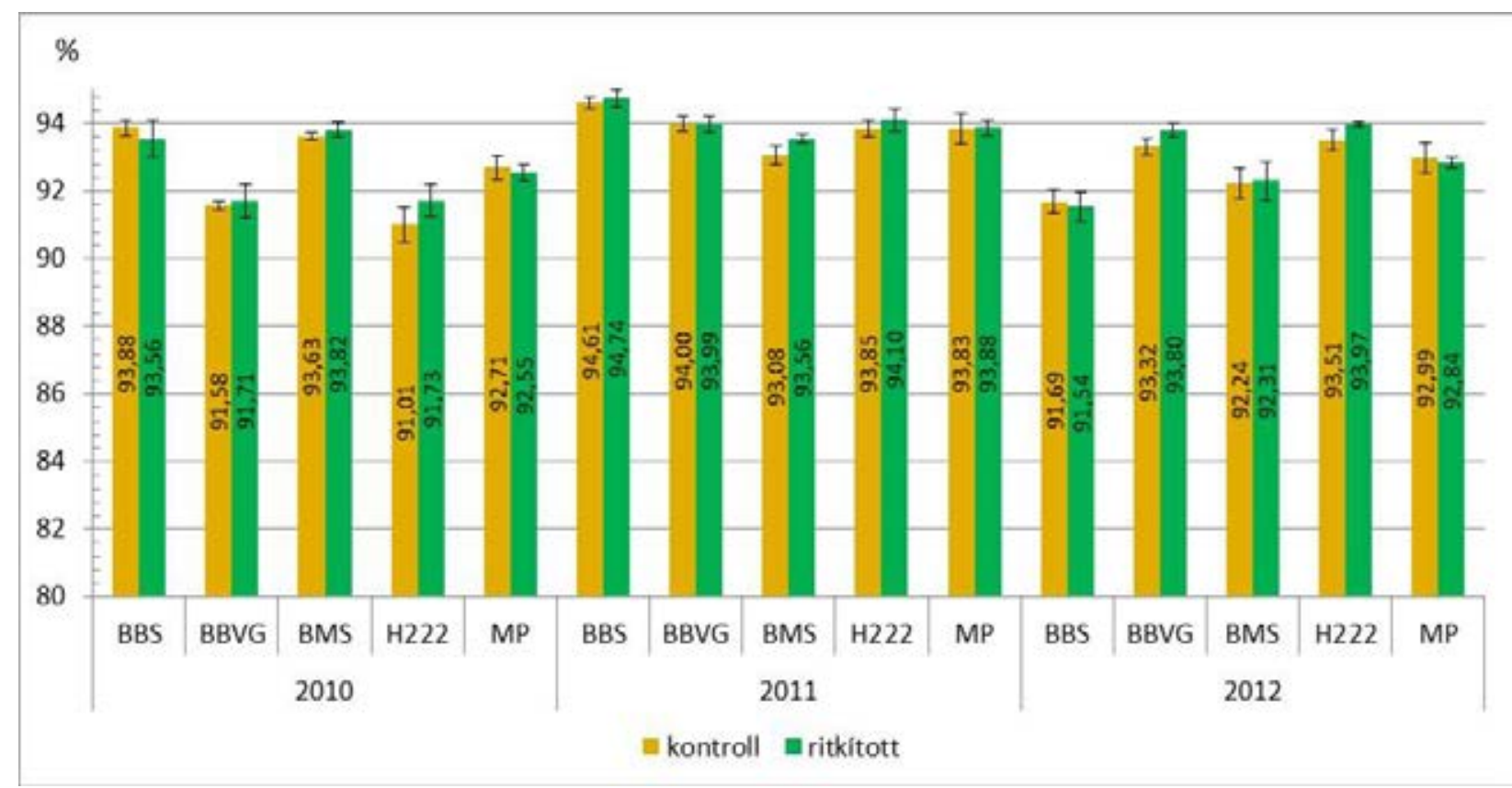

33. ábra: Virágritkított és kontroll cseresznyefajták hasznos gyümölcs aránya T3-as érési stádiumban 2010 és 2012 között

\subsubsection{Kocsány-szakitószilárdság $(\mathrm{KSzSz})$}

A Q26 cseresznyeültetvényben 5 különböző nemes fajta gyümölcsének kocsányszakítószilárdságát vizsgáltuk 2 egymást követő évben (2011-2012) a virágritkítás függvényében. A Melléklet 24. táblázata tartalmazza a KSzSz adatok összesített eredményeit.

Az érési terminusok eredményeit összehasonlítva jól látszik, hogy mind az öt nemes fajta gyümölcsének KSzSz értékei évtől és a virágritkítás alkalmazásától függetlenül szignifikánsan csökkennek az érés elörehaladtával $(\mathrm{T} 1 \rightarrow \mathrm{T} 2 \rightarrow \mathrm{T} 3)$. 
A két évet összehasonlítva a T3-as érési stádiumban (34. ábra) elmondható, hogy mind az 5 nemes fajta KSzSz értéke 2011-ben volt alacsonyabb, 2012-ben magasabb.

A virágritkítás hatását vizsgálva a nemesek a 3 évben és három érési stádiumban összesen az esetek 86,21\%-ában produkáltak nagyobb KSzSz értéket a ritkított fákon a kontroll fákhoz képest, de az eseteknek csak elenyésző része volt szignifikáns (20,69\%).

A nemeseket összehasonlítva a T3-as érési stádiumban (34. ábra) mindkét évben a 'BMS' fajta KSzSz értékei bizonyultak a legnagyobbnak (bár 2012-ben a 'BBS' is jól szerepelt).

Összességében elmondható, hogy a három év adatait figyelembe véve a T3-as érési stádiumban (34. ábra) a legnagyobb KSzSz értéket a virágritkított 'BBS' (10,7 $\pm 3,5 \mathrm{~N})$, és 'BMS' $(10,5 \pm 2,7 \mathrm{~N})$ nemesek adták 2012-ben, míg a legkisebb KSzSz értéket a ritkított és a kontroll 'MP' mutatta ugynebben az évben ( $5,2 \pm 1,9 \mathrm{~N}$ és $5,4 \pm 2,2 \mathrm{~N})$.

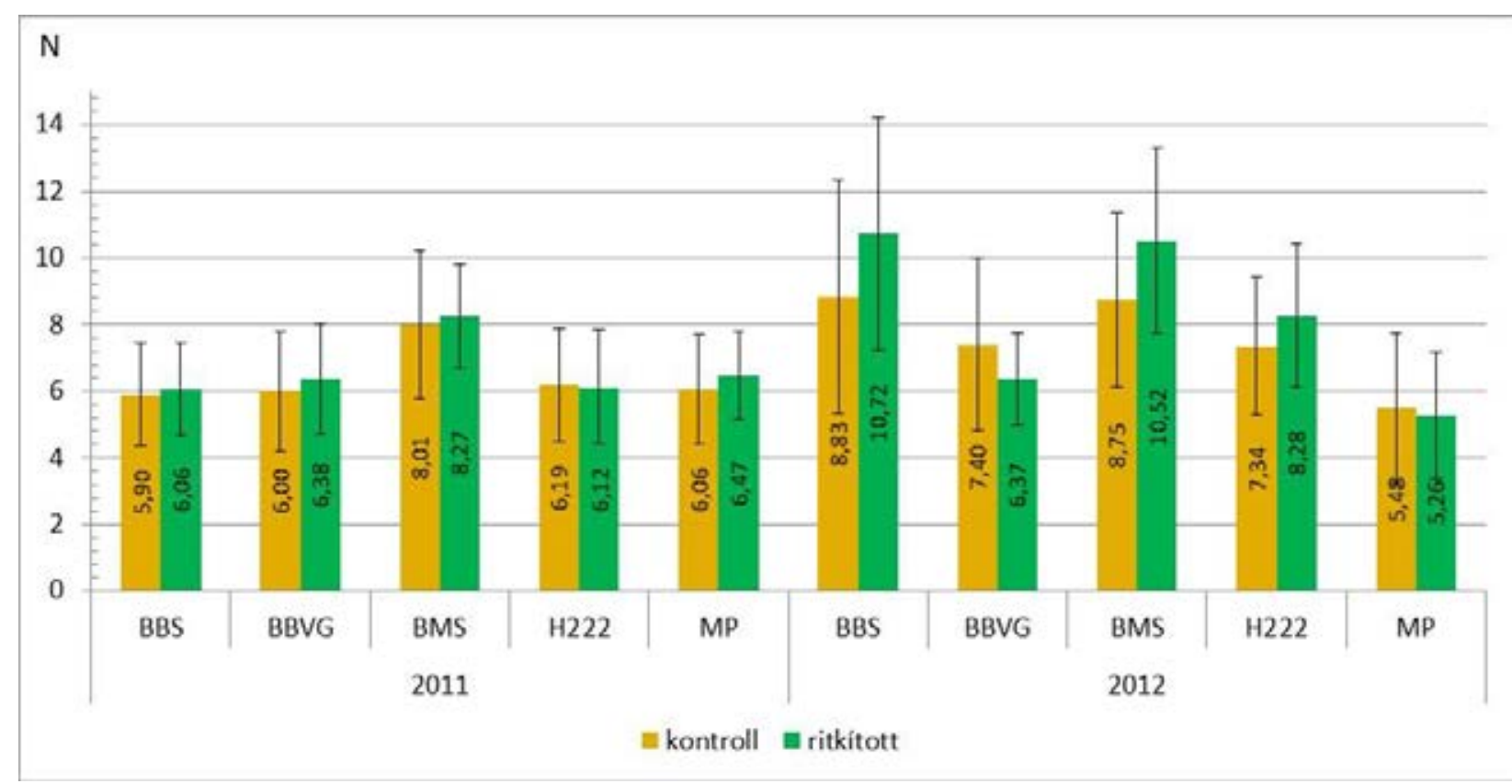

34. ábra: Virágritkított és kontroll cseresznyefajták gyümölcseinek kocsány-szakítószilárdsága T3-as érési stádiumban 2011 és 2012 között

\subsubsection{Gyümölcsök héjszíne}

A Q26 cseresznyeültetvényben 5 különböző nemes fajta gyümölcsének színparamétereit (L*, a*, $b^{*}$ ) vizsgáltuk 3 egymást követő évben (2010-2012) a virágritkítás függvényében. A Melléklet 26. táblázata tartalmazza a színparaméterek összesített adatait.

$\mathrm{Az}$ érési terminusok eredményeit figyelembe véve láthatjuk, hogy évtől és a virágritkítás alkalmazásától függetlenül a cseresznye gyümölcsök mindhárom színparamétere az érés során $(\mathrm{T} 1 \rightarrow \mathrm{T} 2 \rightarrow \mathrm{T} 3)$ szignifikánsan csökken, vagyis a cseresznye gyümölcsök az érés elörehaladtával egyre sötétednek, valamint csökken bennük a piros színárnyalat és erősödik a kék. 

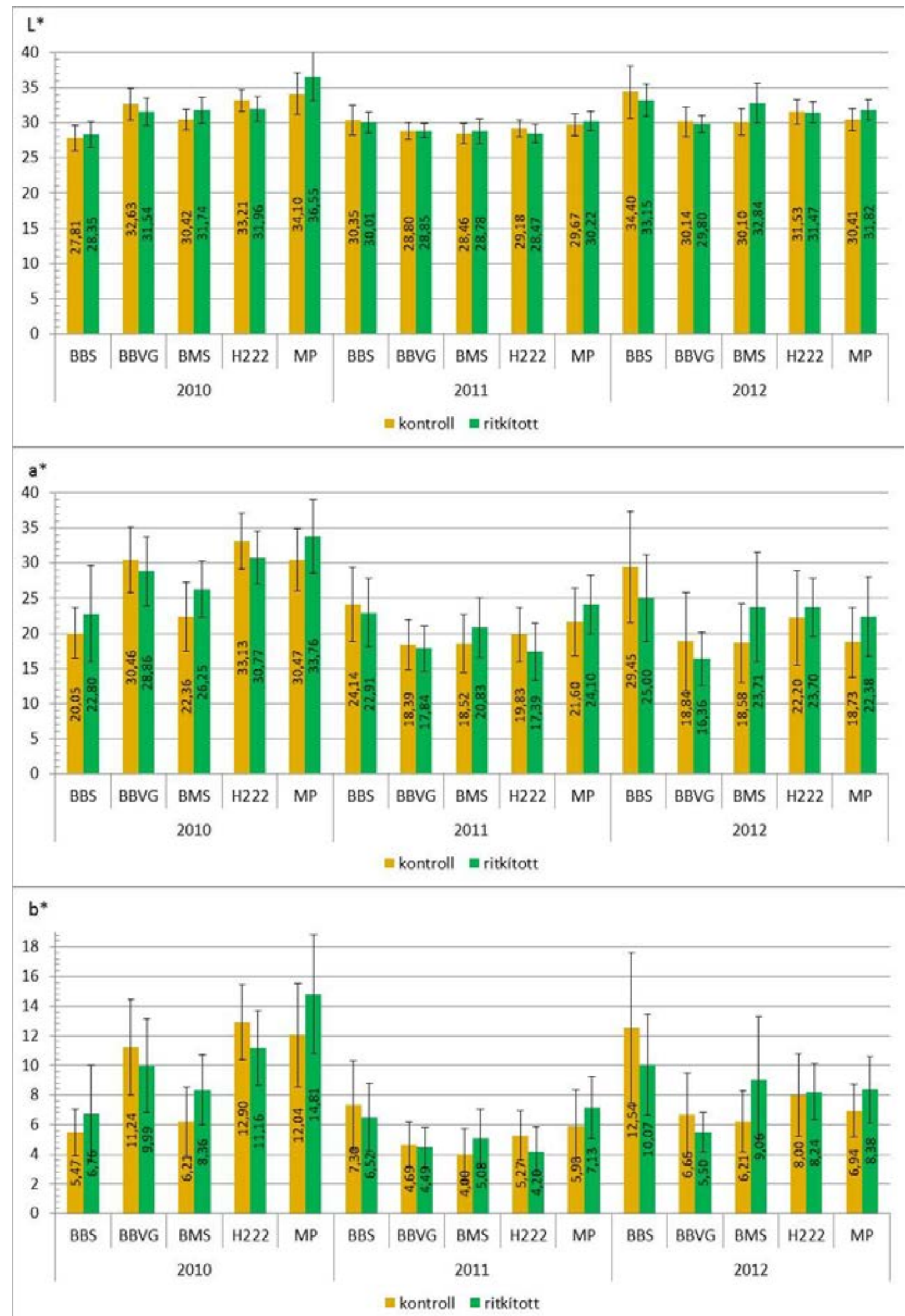

35. ábra: Virágritkított és kontroll cseresznyefajták gyümölcseinek színparaméterei T3-as érési stádiumban 2010 és 2012 között 
A három évet összehasonlítva a T3-as érési stádiumban (35. ábra) elmondható, hogy mind az 5 nemes fajta gyümölcsei 2011-ben voltak a legsötétebbek (L*) (kivétel a 'BBS' fajta). A legnagyobb L* értékeket fajtánként különböző években kaptuk. A 'BBS' 2012-ben, a 'BBVG', a 'H222' és a 'MP' 2010-ben, míg a 'BMS' virágritkított fája 2012-ben, kontroll fája 2010-ben mutatta a legvilágosabb gyümölcsöket.

A legintenzívebb piros színt (a*) a 'BBS' fajtánál 2012-ben, a többi fajta esetében 2010-ben mértük, míg a legalacsonyabb értéket általában 2011-ben kaptuk (kivéve 'BBS' és ritkított 'BBVG'). A kékes árnyalat (b*) minden fajtánál 2011-ben volt a legalacsonyabb (kivétel a kontroll 'BBS'), míg a legmagasabb eredményeket 'BBS' és 'BMS' esetében 2012-ben, a többi fajtánál 2010-ben mértük.

A fajtákat összehasonlítva a T3-as érési stádiumban (35. ábra) egyik paraméternél sem tudtunk egyértelmü tendenciát azonosítani: minden évben más nemes mutatta a legmagasabb és legalacsonyabb L*, a* és b* értékeket.

A virágritkítás hatását vizsgálva a nemesek a 3 évben és három érési stádiumban összesen az esetek 55,81\%-ában produkáltak világosabb gyümölcsöket (nagyobb L* értéket) a ritkított fákon a kontroll fákhoz képest, és az azoknak 45,83\%-a volt szignifikáns. A piros szín (a* paraméter) az eredmények 51,16\%-ánál volt intenzívebb a virágritkított fáknál, ebből 52,38\% volt szignifikáns. A kék árnyalat (b* paraméter) az esetek 58,14\%-ában volt erőteljesebb a ritkított fáknál, amiből $66,67 \%$ volt szignifikáns.

Összességében elmondható, hogy a három év adatait figyelembe véve a T3-as érési stádiumban (35. ábra) a legvilágosabb gyümölcsöt a virágritkított 'MP' fajtánál ( $\left.L^{*} 36,55 \pm 3,49\right)$, míg a legsötétebbet a kontroll 'BBS' fajtánál találtuk 2010-ben ( $\left.\mathrm{L}^{*} 27,81 \pm 1,82\right)$. A legintenzívebb piros színnel a virágritkított 'MP' fajta ( $\left.\mathrm{a}^{*} 33,76 \pm 5,24\right)$ és a kontroll 'H222' fajta $\left(a^{*} 33,13 \pm 3,98\right)$ rendelkezett 2010-ben, míg a legkisebb értéket a ritkított 'BBVG' fajta mutatta 2012-ben ( $\left.a^{*} 16,36 \pm 3,79\right)$. A legnagyobb b* értéket a virágritkított 'MP' fajta adta 2010-ben (b* 14,81 $\pm 4,03)$, míg a legkisebb értéket a kontroll 'BMS' fajta produkálta 2011-ben ( $\left.b^{*} 4,00 \pm 1,77\right)$.

\subsubsection{Gyümölcskeménység}

A Q26 cseresznyeültetvényben 5 különböző nemes fajta gyümölcseinek keménységét vizsgáltuk 3 egymást követő évben (2010-2012) virágritkított és kontroll fákon. A Melléklet 24. táblázata tartalmazza a keménységmérések összesített adatait.

Az érési terminusok eredményeit összehasonlítva jól látszik, hogy mind az öt nemes fajta gyümölcsének keménysége évtől és a virágritkítás alkalmazásától függetlenül szignifikánsan csökken az érés elörehaladtával $(\mathrm{T} 1 \rightarrow \mathrm{T} 2 \rightarrow \mathrm{T} 3)$.

A három év eredményeit összevetve a T3-as érési stádiumban (36. ábra) láthatjuk, hogy a fajták különböző módon reagáltak az évjárathatásra: míg a 'BBS', 'BBVG' és 'BMS' fajták a 2012-es évben produkálták a legkeményebb gyümölcsöket, addig a 'H222' 2011-ben, a 'MP' 
pedig 2010-ben bizonyult a legkeményebbnek. A legpuhább gyümölcsöket 'BBS' és 'BMS' fajták esetében 2011-ben, 'BBVG' és 'H222' fajtáknál 2010-ben, míg 'MP'-nél a kontroll fáknál 2012ben, a ritkított fáknál 2011-ben mértük.

A nemeseket összehasonlítva a legnagyobb gyümölcskeménységet a T3-as érési stádiumban (36. ábra) általában a 'BMS' fajtánál mértük (2011-ben a második helyezést érte el, a többi évben első volt), a legpuhább gyümölcsöt azonban minden alkalommal máshol találtuk.

A virágritkítás hatását vizsgálva a nemesek a 3 évben és három érési stádiumban összesen az esetek $86,36 \%$-ában produkáltak keményebb gyümölcsöket a ritkított fákon a kontroll fákhoz képest, és mindezen mérések közül 50,0\% volt szignifikáns.

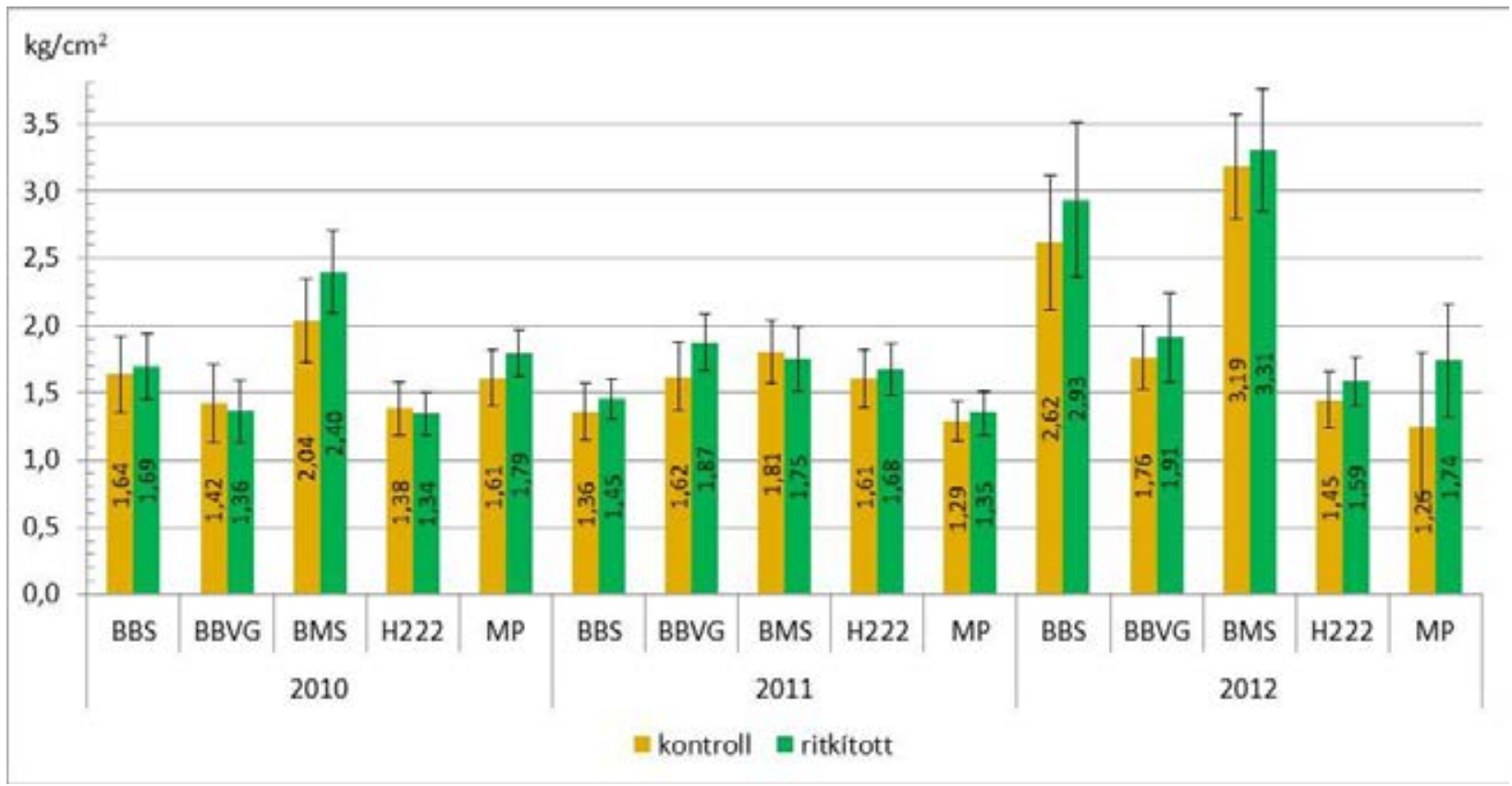

36. ábra: Virágritkított és kontroll cseresznyefajták gyümölcskeménysége T3-as érési stádiumban 2010 és 2012 között

A T3-as érési stádiumban (36. ábra) a legkiemelkedőbb különbség ritkított és nem ritkított fák gyümölcskeménysége között a 'MP' fajtánál volt megfigyelhető 2012-ben: 38,1\%-kal voltak keményebbek a ritkított fák a kontroll fák gyümölcseihez képest (bár 2010-ben 12,5\%, 2011-ben pedig csak 4,62\% volt a különbség). Viszonylag jó eredményt produkált a 'BMS' fajta 2010-ben: 17,65\%-kal volt keményebb a gyümölcse a ritkított fáknak a kontrollhoz képest, de a többi évben nem volt ekkora különbség.

Összességében elmondható, hogy a három év adatait figyelembe véve a T3-as érési stádiumban (36. ábra) a legkeményebb gyümölcsöt a virágritkított és kontroll 'BMS' fajták produkálták 2012-ben $\left(3,31 \pm 0,45\right.$ és $\left.3,19 \pm 0,39 \mathrm{~kg} / \mathrm{cm}^{2}\right)$. A legpuhább gyümölcsei a 'MP' kontroll fáinak 2012-ben $\left(1,25 \pm 0,55 \mathrm{~kg} / \mathrm{cm}^{2}\right)$, valamint kontroll és virágritkított fáinak 2011-ben $\left(1,29 \pm 0,15\right.$ és $\left.1,35 \pm 0,17 \mathrm{~kg} / \mathrm{cm}^{2}\right)$ voltak. 


\subsection{A gyümölcsök általános fizikokémiai paraméterei}

\subsubsection{A Q10 ültetvény}

\subsubsection{1. Összes vizoldható szárazanyag-tartalom (TSS)}

A Q10 cseresznyeültetvény gyümölcseinek összes vízoldható szárazanyag-tartalmát (TSS) 4 egymást követő évben (2010-2013) mértük. A Melléklet 27. táblázata tartalmazza a TSS értékek összesített adatait.

Az érési terminusok eredményeit összevetve kiderül, hogy évenként és alany-nemes kombinációnként a cseresznye gyümölcsök TSS értéke az érés során $(\mathrm{T} 1 \rightarrow \mathrm{T} 2 \rightarrow \mathrm{T} 3)$ minden esetben (100\%) szignifikánsan nő (ezek közül 90\% monoton nő).

A két fajtát összehasonlítva a 'Regina' gyümölcseinek TSS értéke a 4 évből háromban (2010, 2011 és 2013) szignifikánsan magasabb értékeket mutatott, mint a 'Kordia' fajta gyümölcsei, vagyis azok édesebbnek bizonyultak.

Az éveket összehasonlítva megfigyelhető, hogy a 'Kordia' fajta nagyon szélsőségesen szerepelt a különböző években: 2010-ben a TSS értékei még T3-as érési stádiumban sem érték el a $14^{\circ}$ Brix értéket, míg 2012-ben már a T1-es érési stádium TSS értékeinek többsége felülmúlta azt. Sőt, ebben az évben a 'Kordia' fajta olyan jól szerepelt, hogy a négy év összesítésében is ez produkálta a legmagasabb TSS értéket. A 'Regina' fajta kevésbé mutatott érzékenységet az évjárathatásra. 2010-ben és 2011-ben ugyan szignifikánsan magasabb refrakció értékeket mértünk ennél a fajtánál a másik két évhez viszonyítva, de ezekben az években is $16^{\circ}$ Brix fölötti értékeket kaptunk (kivétel a 'PiKu 1' alany 2012-ben).

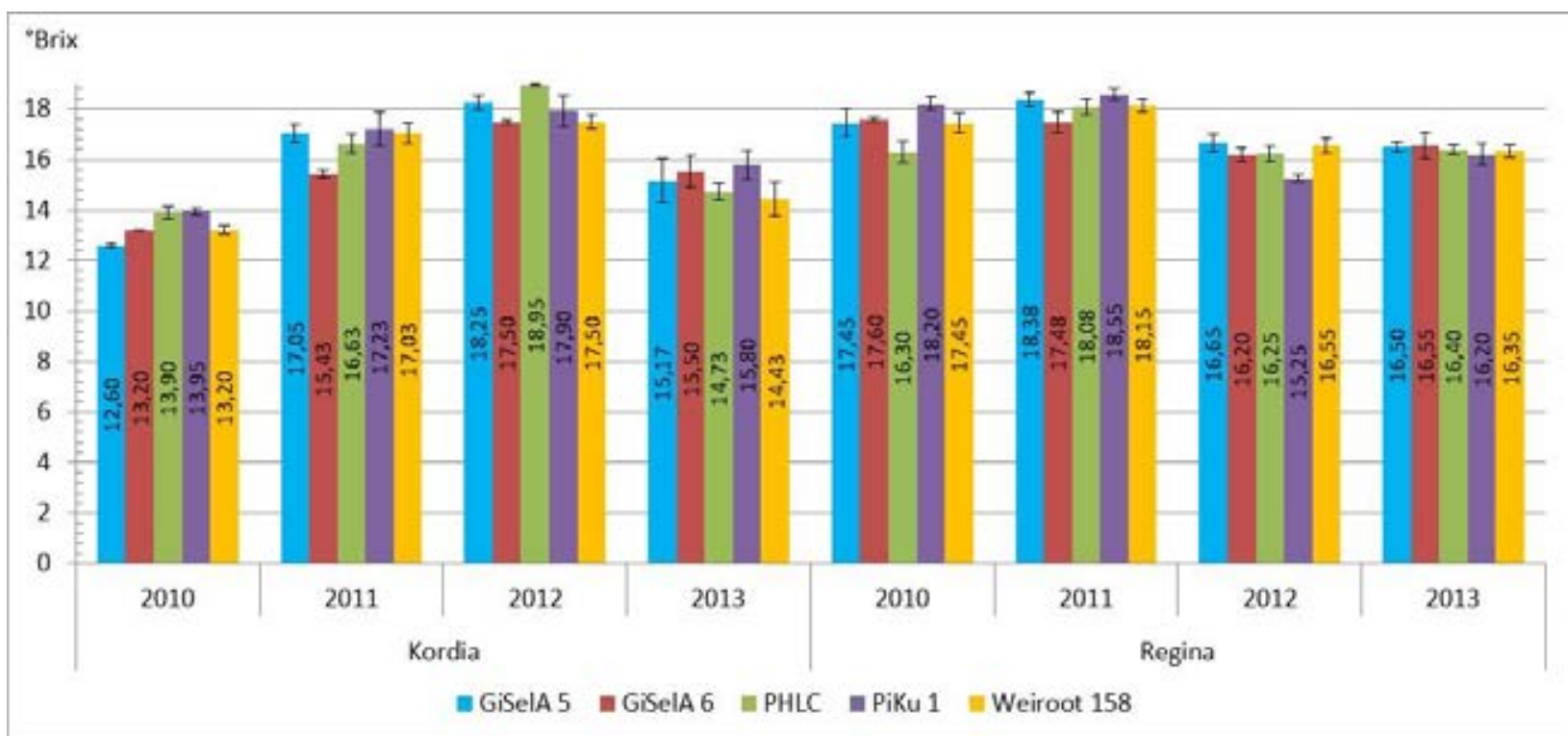

37. ábra: 'Regina' és 'Kordia' cseresznyefajták gyümölcseinek TSS értéke különböző alanyokon T3-as érési stádiumban 2010 és 2013 között

Az egyes alanyok hatása között az eredmények 87,5\%-ban szignifikáns különbséget tudtunk kimutatni a TSS értékek tekintetében. A T3-as érési stádiumban (37. ábra) megfigyelhető volt, 
hogy a hatás évjáratonként és alany-nemes kombinációnként eltért. Láthatjuk, hogy a 'Kordia' fajta gyümölcsei 3 évjáratban is (2010, 2011 és 2013) a 'PiKu 1' alanyon mutatták a szignifikánsan legmagasabb TSS értéket. A 'Regina' fajta 2010-ben és 2011-ben szintén a 'PiKu 1' alanyon adta a legmagasabb refrakció értékeket, de az azt követő két évben ez az alany bizonyult a legrosszabbnak TSS szempontjából.

Összességében a négy év T3-as értékei alapján (37. ábra) elmondható, hogy szignifikánsan a legmagasabb TSS értékkel a 'Kordia'-'PHL-C' kombináció 2012-ben (18,95 \pm 0,04 ${ }^{\circ}$ Brix), valamint a 'Regina'-PiKu 1' kombináció 2011-ben $\left(18,20 \pm 0,27\right.$ és 18,55 $\pm 0,25{ }^{\circ}$ Brix $)$ rendelkezett. A legalacsonyabb TSS értékeket a 'Kordia'-'GiSelA 5' kombinációnál mértük 2010ben $\left(12,60 \pm 0,08^{\circ}\right.$ Brix $)$.

\subsubsection{2. Összes titrálható savtartalom (TA)}

A Q10 cseresznyeültetvény gyümölcseinek összes titrálható savtartalmát (TA) 4 egymást követő évben (2010-2013) mértük. A Melléklet 27. táblázata tartalmazza a TA értékek összesített adatait.

Az érési terminusok eredményeit összevetve kiderül, hogy évenként és alany-nemes kombinációnként a cseresznye gyümölcsök TA értéke az érés során $(\mathrm{T} 1 \rightarrow \mathrm{T} 2 \rightarrow \mathrm{T} 3)$ az eredmények 80,0\%-ánál szignifikánsan csökken (ezek közül 81,25\% monoton csökken).

A két fajtát összehasonlítva elmondható, hogy 2012-ben és 2013-ban a 'Kordia' fajta gyümölcseinek volt szignifikánsan magasabb TA értéke, 2010-ben a 'Regina' fajtának, míg 2011ben nem volt szignifikáns különbség a két fajta között.

Az alanyhatást vizsgálva az esetek 87,5\%-ánál szignifikáns különbséget tudtunk igazolni a TA értékek tekintetében. Az alanyok azonban nem egyformán hatottak a két nemesre. A T3-as érési stádiumban (38. ábra) a 'Regina' fajta TA értékei 2010-ben és 2012-ben is 'Weiroot 158' alanyon voltak a legmagasabbak, emellett 2013-ban is jól szerepelt az alany: a második legmagasabb értéket produkálta (de szignifikánsan nem maradt le az első helyen álló 'PHL-C' alanytól). A legalacsonyabb összes savtartalmat 3 egymást követö évben is a 'GiSelA 5' alany produkálta (2010, 2011, 2012), melyek közül mind szignifikáns, és 2013-ban is a legalacsonyabb szignifikáns csoportba került a 'PiKu 1' alannyal. A 'Kordia' fajtát vizsgálva nem tudtunk

egyértelmü tendenciát kialakítani: minden évben más alany produkálta a legmagasabb és legalacsonyabb TA értékeket.

A négy év T3-as értékeit összehasonlítva (38. ábra) elmondható, hogy szignifikánsan a legmagasabb savtartalommal a 'Kordia'-'GiSelA 6' (9,26 \pm 1,46 mg MAE/ml), a 'Kordia''PiKu 1' $(9,10 \pm 2,03 \mathrm{mg} \mathrm{MAE} / \mathrm{ml})$ és a 'Kordia'-'GiSelA 5' (8,97 $\pm 1,64 \mathrm{mg} \mathrm{MAE} / \mathrm{ml})$ kombinációk rendelkeztek 2013-ban. A legalacsonyabb TA értékeket a 'Regina'-'GiSelA 5' (5,02 $\pm 0,03 \mathrm{mg} \mathrm{MAE} / \mathrm{ml})$ és a 'Regina'-'PiKu 1' (5,26 \pm 0,03 mg MAE/ml) kombinációknál mértük 2012-ben. 


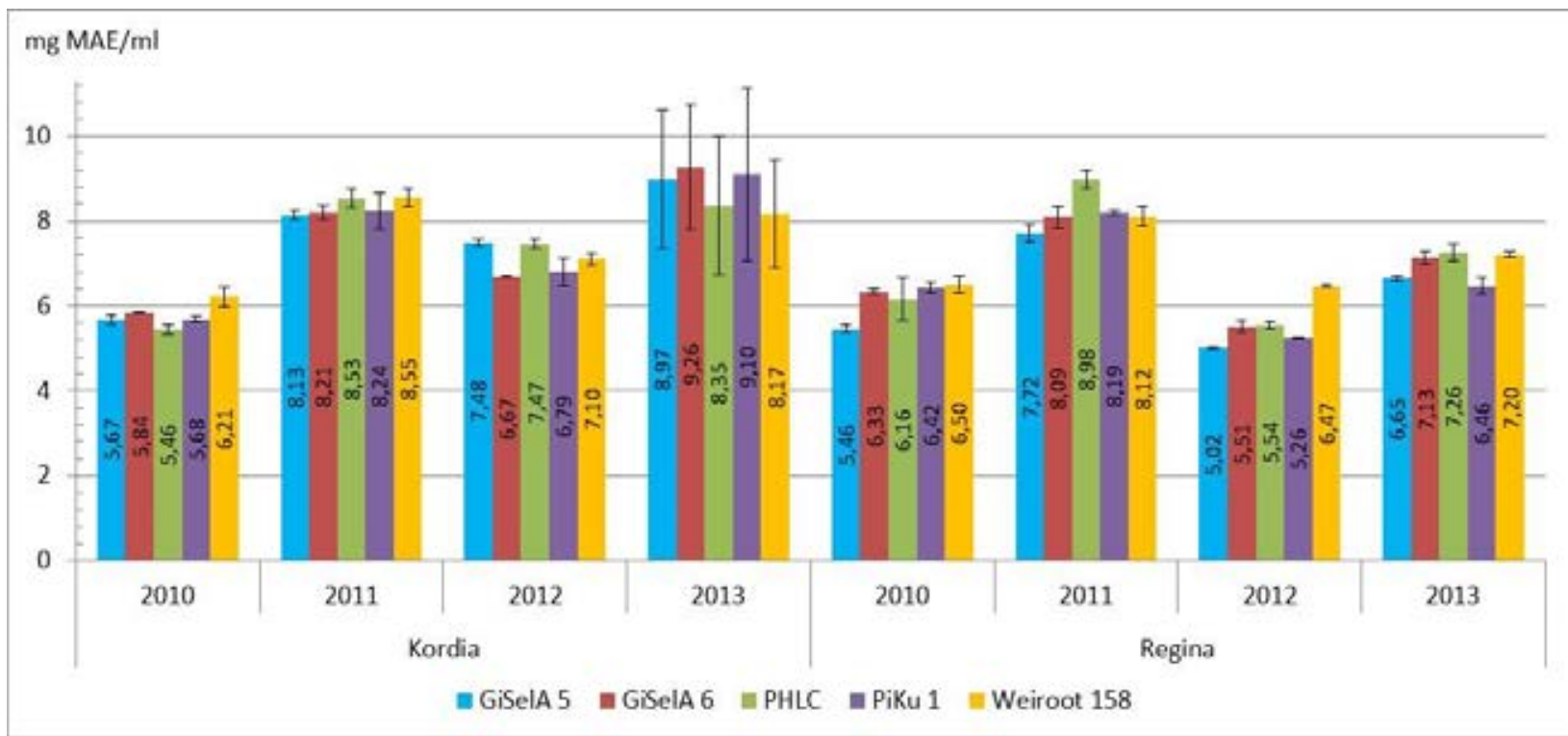

38. ábra: 'Regina' és 'Kordia' cseresznyefajták gyümölcseinek összes titrálható savtartalma (TA) különböző alanyokon T3-as érési stádiumban 2010 és 2013 között

\subsubsection{TSS-TA viszony}

A szakirodalomban elterjedt gyakorlat, hogy a gyümölcs ízének jellemzésére egy skaláris mennyiséget, a TSS/TA arányt használják. Mivel a cukrok mennyisége az érés során nő, a savaké pedig általában (bár ezzel ellentétes eredmények is vannak) csökken, a magasabb TSS/TA arány előrehaladottabb érettségi állapotot, következésképpen jobb ízértéket mutat.

Véleményünk szerint azonban a TSS/TA arányszám legfeljebb adott gyümölcsfajok érési stádiumainak jellemzésére és összehasonlítására alkalmazható, különböző fajták, alany-nemes kombinációk összehasonlítására nem, mivel az arány nem jellemzi a TSS és TA értékek konkrét nagyságát. Ugyanazzal a TSS/TA aránnyal egy gyümölcs lehet ízetlen és nagyon ízletes is. Ha pl. TSS:TA $=18: 9$ vagy TSS:TA $=6: 3$, mindkettő számszerü eredménye 2 lesz, pedig az egyik nagyon ízletes, a másik pedig teljesen ízetlen gyümölcsöt takar. Az egyszerü TSS/TA aránynál sokkal szemléletesebbnek tủnik, ha a TA értéket a TSS függvényében ábrázoljuk egy grafikonon, mert abból nem csak az arányok, hanem a tényleges értékek is leolvashatók.

Ezzel a megközelítéssel szemlélteti a 39. ábra a TSS-TA viszony alakulását éves bontásban. Minden vonal egy-egy alany-nemes kombináció három terminusát köti össze. Ebből látható, hogyan alakul a viszony az érés során. A magasabb TA és TSS értékek a grafikon jobb felső sarkában találhatók, ez a tartomány a kedvezőbb ízértéket jelképezi, míg az alacsonyabb értékek a grafikon bal alsó sarkában láthatók, ami az ízetlenség, a kevésbé ízletesség tartománya.

A grafikonokat összehasonlítva rögtön szembetünő, hogy az évjárat nagyon erős hatással van a TSS-TA viszony alakulására: a vizsgált 4 év között nincs két hasonló. A görbék lefutásából általánosságban elmondható, hogy a TSS érték az érés során monoton nő, erre egyetlen kivétel a ‘Kordia' viselkedése 2010-ben. A savak mennyiségének változása nem ilyen egyértelmü. 
Évjáraton belül általában (2011-et kivéve) jól elkülöníthetők a 'Kordia' és a 'Regina' vonalai. A Reginát legtöbbször alacsonyabb TA és magasabb TSS jellemzi, mint a Kordiát, de az évjárathatás ezt is jelentősen befolyásolhatja. Évjáraton és nemes fajtán belül a görbék alakja nagyon hasonló, egy két kivételtől eltekintve analógnak mondhatók. Azonban a görbék elhelyezkedése a koordináta-rendszerben különböző, ami az alany - helyenként szignifikáns hatását mutatja.

2010-ben a 'Kordia' gyümölcsök TSS-TA viszonyában (39. ábra) éles törés látható, mely azt mutatja, hogy a savak monoton csökkenése mellett T2-töl T3-ig a TSS érték is csökkent, alanytól függetlenül. A 'Regina' gyümölcsök TSS és TA értéke viszont egyaránt monoton nőtt az érés során. A legjobb ízértékü gyümölcsöket a 'Regina' nemes valamint a 'GiSelA 6', a 'PiKu 1' és a 'Weiroot 158 ' alanyok kombinációja eredményezte.

2011-ben a 'Kordia' gyümölcsök savtartalmát (39. ábra) meredek csökkenés jellemezte T1ből T2-be menet, majd a csökkenés kevésbé meredeken folytatódott. 'Regina' ezzel szemben enyhe savcsökkenéssel kezdett, amely átfordult enyhe növekedésbe. T3-ban a 'Regina' és 'Kordia' gyümölcsök ízértéke megközelítőleg azonos szintű volt, mert mindkettő magas cukor és savtartalommal bírt. A 'Regina' kicsit édesebb, a 'Kordia' kicsit savanykásabb volt, a kettő között az egyéni ízlés tud csak sorrendet felállítani. Említésre méltó még a mezőnyből szignifikánsan kiemelkedő 'Regina'-'PHL-C' kombináció, amely 2011-ben a legjobb ízértéket produkálta. Az sem elhanyagolható azonban, hogy a 2011-es év minden alany-nemes kombinációján a 2010 legjobbjait megközelítő, vagy azokat túlszárnyaló ízértékü gyümölcsök termettek (kivétel a 'Kordia'-GiSelA 6' kombináció, amely alacsony TSS értékével kicsit lemaradt a mezőnytől).

A 2012-es évről elmondható (39. ábra), hogy az kimondottan a 'Kordia' nemesnek kedvezett a Reginával szemben: a TSS-TA grafikonon jól látszik, hogy a 'Kordia' görbék a 'Regina' fölött vannak mind TSS, mind TA tekintetében, továbbá a 'Kordia' gyümölcsök cukortartalma a 4 éves viszonylatban itt a legmagasabb. A legízletesebb gyümölcsök ebben az évben a 'Kordia'-'PHLC' és a 'Kordia'-'GiSelA 5' kombinációkon teremtek. A 'Regina' tekintetében az alanyok közül kiemelkedik a 'Weiroot 158', amelynél a gyümölcsök csoportjukban - a viszonylag magas TSS mellett - a legmagasabb savtartalommal bírnak, elmarad viszont a mezőnytől a 'PiKu 1', mind TSS mind TA értékét tekintve. A többi 'Regina' gyümölcsről elmondható, hogy a 2010-es év legjobbjaival összemérhető ízértéket értek el.

TSS szempontjából 2013 közepes év volt (39. ábra), TA szempontjából viszont erős, emiatt az ízértékek 4 év viszonylatában a savanykásabb irányba tolódtak el. 2013-ban a TSS növekedését minden esetben a TA csökkenése kísérte. A 'Regina' oltványok görbéinek lefutása nagyon hasonló. A T3-as gyümölcsök közül a 'Weiroot 158', a 'GiSelA 6' és a 'PHL-C' kis mértékben, de szignifikánsan jobb ízértéket mutat. A 'Kordia' fajtánál szintén 3 alany ('GiSelA 5', 'GiSelA 6', 'PiKu 1') eredményezte a legízletesebb gyümölcsöket. 

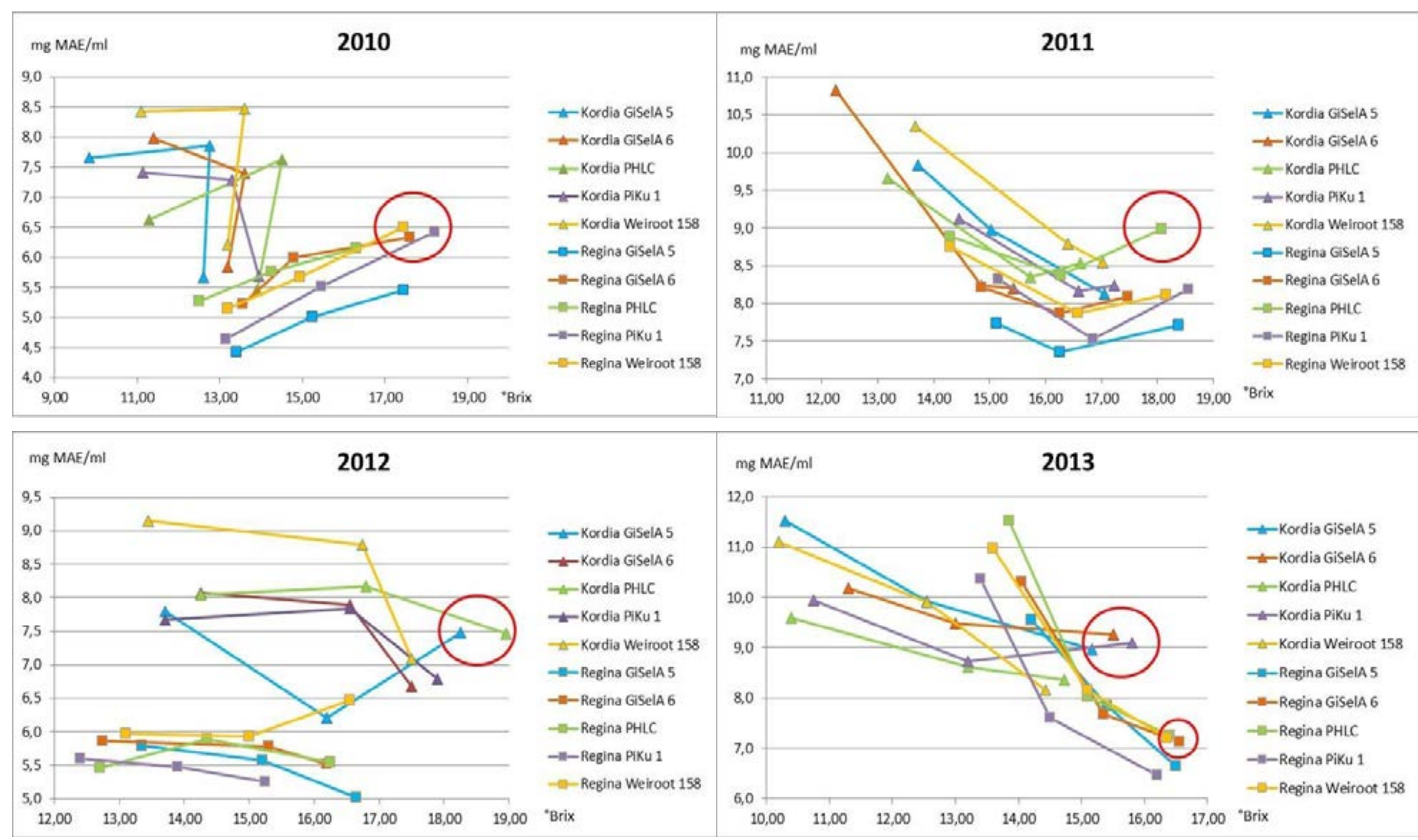

39. ábra: 'Regina' és 'Kordia' cseresznyefajták gyümöleseinek TSS-TA viszonya különböző alanyokon T1, T2 és T3-as érési stádiumban 2010 és 2013 között 


\subsubsection{A Q26 ültetvény}

\subsubsection{1. Összes vizoldható szárazanyag-tartalom}

A Q26 cseresznyeültetvényben 5 különböző nemes fajta gyümölcsének összes vízoldható szárazanyag-tartalmát (TSS) vizsgáltuk 3 egymást követő évben (2010-2012) virágritkított és kontroll fákon. A Melléklet 28. táblázata tartalmazza a TSS étékek összesített adatait.

Az érési terminusok eredményeit összehasonlítva jól látszik, hogy mind az öt nemes fajta gyümölcsének TSS értéke évtől és a virágritkítás alkalmazásától függetlenül az érés elörehaladtával $(\mathrm{T} 1 \rightarrow \mathrm{T} 2 \rightarrow \mathrm{T} 3$ ) minden esetben (100\%) szignifikánsan nő (ebből 86,67\% monoton nő).

A három év eredményeit összevetve a T3-as érési stádiumban (40. ábra) mind az 5 fajta gyümölcseinek ${ }^{\circ}$ Brix értéke 2010-ben volt a legalacsonyabb, és 2012-ben a legmagasabb.

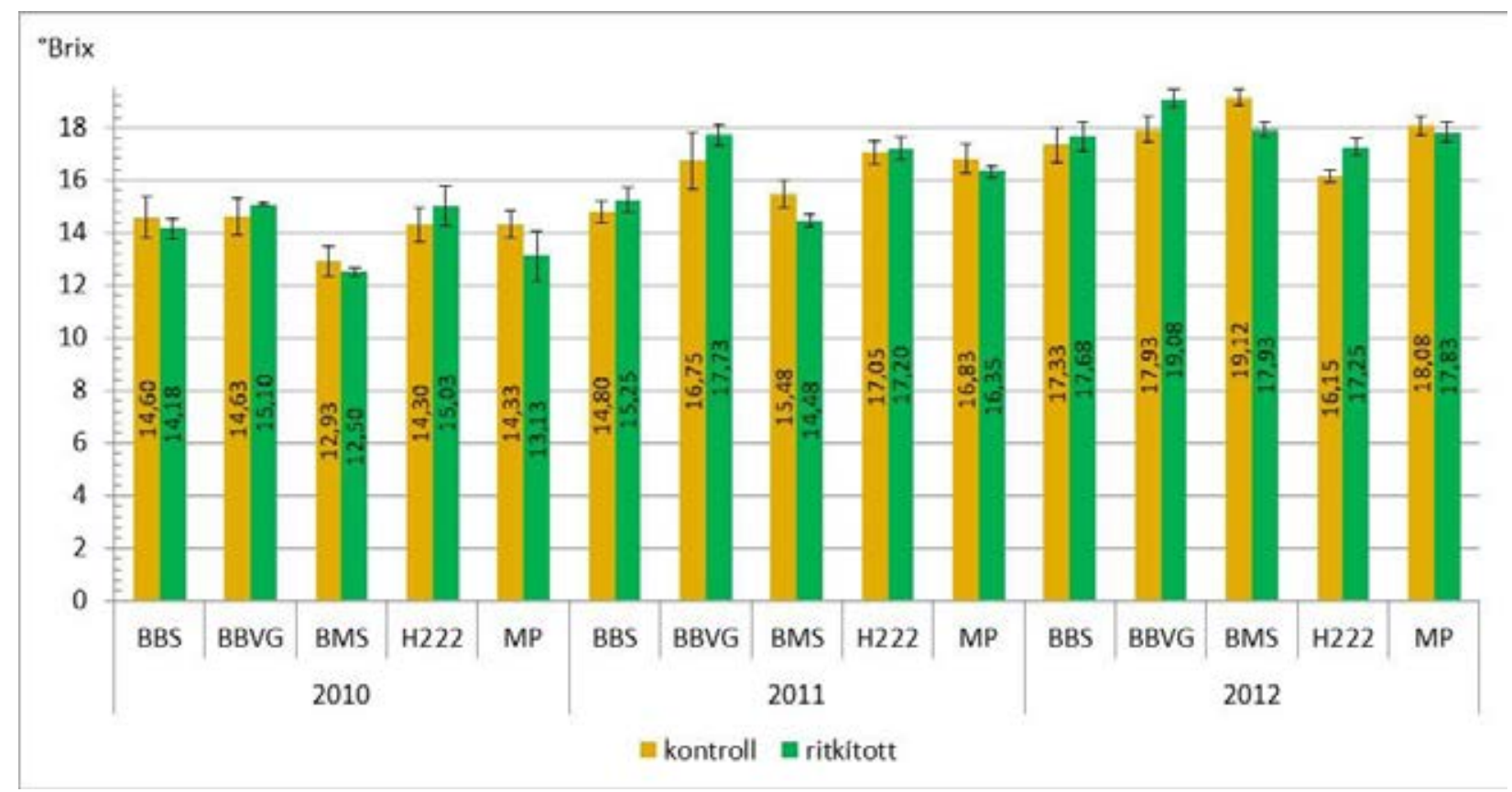

40. ábra: Virágritkított és kontroll cseresznyefajták gyümölcseinek összes vízoldható szárazanyag-tartalma (TSS) T3-as érési stádiumban 2010 és 2012 között

A nemeseket összehasonlítva a szignifikánsan legnagyobb TSS értékeket a T3-as érési stádiumban (40. ábra) mindhárom évben a 'BBVG' fajtánál mértük, de a 'H222' is jól szerepelt 2010-ben és 2011-ben is, vagyis ezek bizonyultak a legédesebbnek. A legalacsonyabb ${ }^{\circ}$ Brix értéket 2010-ben és 2011-ben 'BMS' fajtánál, 2012-ben 'H222'-nél kaptuk. Érdekesség, hogy a 'BMS' fajta TSS értéke az esetek 100\%-ában a kontroll fákon volt nagyobb, bár az értékeknek csak $25 \%$-a volt szignifikáns.

A virágritkítás hatását vizsgálva a nemesek a 3 évben és három érési stádiumban összesen az esetek 52,27\%-ában produkáltak magasabb TSS értéket a gyümölcsökben a ritkított fákon a kontroll fákhoz képest, és mindezen mérések közül 61,91\% volt szignifikáns. 
A T3-as érési stádiumban (40. ábra) a legkiemelkedőbb különbség ritkított és nem ritkított fák TSS értéke között a 'MP' fajtánál volt megfigyelhető 2010-ben: a kontroll fák gyümölcseiben 9,14\%-kal volt magasabb a TSS érték a ritkított fák gyümölcseihez képest.

Összességében elmondható, hogy a három év adatait figyelembe véve a T3-as érési stádiumban (40. ábra) a kontroll 'BMS' $\left(19,12 \pm 0,30{ }^{\circ}\right.$ Brix) és a ritkított 'BBVG' $(19,08 \pm 0,33$ ${ }^{\circ}$ Brix) fajták gyümölcsei bizonyultak a legédesebbnek 2012-ben. A legkisebb TSS értéket a ritkított 'BMS' fajtánál mértük (12,50 $\pm 0,17^{\circ}$ Brix) 2010-ben.

\subsubsection{2. Összes titrálható savtartalom}

\subsubsection{1. Ö̈sszes titrálható savtartalom}

A Q26 cseresznyeültetvényben 5 különböző nemes fajta gyümölcsének összes titrálható savtartalmát (TA) vizsgáltuk 3 egymást követő évben (2010-2012) virágritkított és kontroll fákon. A Melléklet 28. táblázata tartalmazza a TA étékek összesített adatait.

Az érési terminusok eredményeit összehasonlítva látszik, hogy mind az öt nemes fajta gyümölcseinek titrálható savtartalma évtől és a virágritkítás alkalmazásától függetlenül az érés elörehaladtával $(\mathrm{T} 1 \rightarrow \mathrm{T} 2 \rightarrow \mathrm{T} 3)$ az esetek 83,33\%-ában szignifikánsan nő (ezek közül 52\% monoton növekedés).

A három év eredményeit összevetve a T3-as érési stádiumban (41. ábra) láthatjuk, hogy az 5 fajtából 4 fajta ('BBS', 'BBVG', 'BMS', 'H222') gyümölcseinek TA értéke 2010-ben volt a legalacsonyabb, és 2012-ben a legmagasabb. A 'MP' gyümölcseinél ennek ellenkezőjét tapasztaltuk: a legalacsonyabb TA értéket 2012-ben, a legmagasabbat 2010-ben mértük (kivétel a kontroll fajta, ott 2011-ben).

A nemeseket összehasonlítva a T3-as érési stádiumban (41. ábra) a szignifikánsan legmagasabb TA értékeket 2010-ben és 2011-ben a 'MP' fajtánál, 2012-ben pedig a 'BMS' fajtánál mértük (a 'BMS' fajta TA értéke a másik két évben a második helyre került). A legalacsonyabb összes titrálható savtartalommal 2010-ben és 2011-ben a 'BBS', 2012-ben a 'BBVG' fajta rendelkezett.

A virágritkítás hatását vizsgálva a nemesek a 3 évben és három érési stádiumban összesen az esetek 59,09\%-ában produkáltak magasabb TA értéket a gyümölcsökben a ritkított fákon a kontroll fákhoz képest, de mindezen mérések közül csak 30,77\% volt szignifikáns.

A T3-as érési stádiumban (41. ábra) a legkiemelkedőbb különbség ritkított és nem ritkított fák TA értéke között a 'MP' fajtánál volt megfigyelhető 2011-ben: a kontroll fák gyümölcseiben 11,23\%-kal volt magasabb a TA érték a ritkított fák gyümölcseihez képest.

Összességében elmondható, hogy a három év adatait figyelembe véve a T3-as érési stádiumban (41. ábra) a legtöbb titrálható savat a kontroll és ritkított 'BMS' (9,72 $\pm 0,59$ és 9,26 \pm 0,34 mg MAE/ml) fák gyümölcseiben 2012-ben, valamint a kontroll 'MP' $(9,41 \pm 1,21 \mathrm{mg}$ 
MAE/ml) fáknál 2011-ben találtuk. A legalacsonyabb savtartalommal a kontroll és ritkított 'BBS' fajta gyümölcsei rendelkeztek 2010-ben (5,01 $\pm 0,29$ és 4,98 $\pm 0,25 \mathrm{mg} \mathrm{MAE} / \mathrm{ml})$.

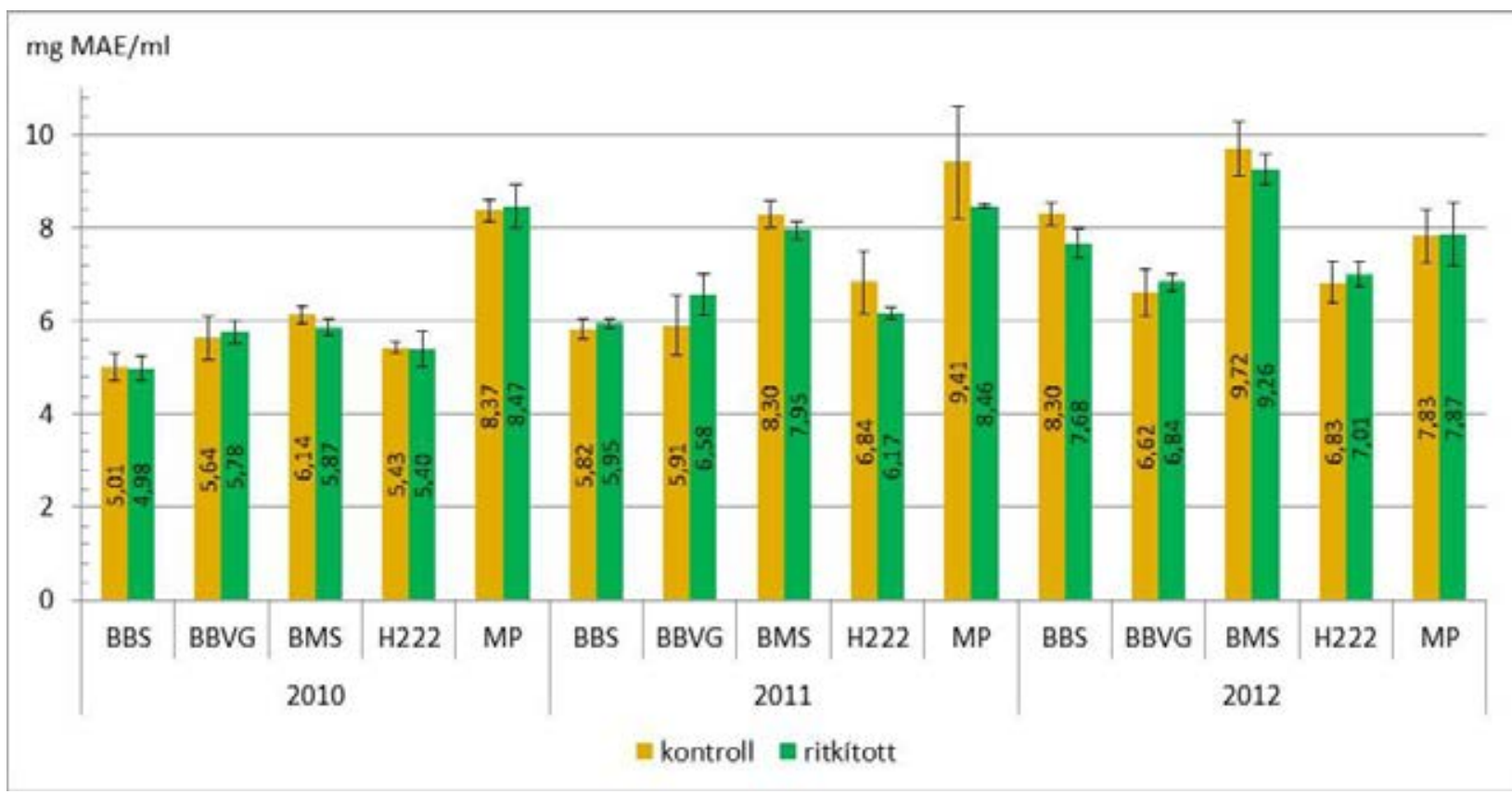

41. ábra: Virágritkított és kontroll cseresznyefajták gyümölcseinek összes titrálható savtartalma (TA) T3-as érési stádiumban 2010 és 2012 között

\subsubsection{TSS-TA viszony}

A TSS-TA grafikon (Melléklet 51. ábra) kiváló eszköz a fajták közötti hasonlóságok és különbségek szemléltetésére. Az ábrákat elemezve kitünik, hogy az egyes fajták általában az éves grafikonoknak ugyanabban a rájuk jellemző szegmensében helyezkednek el.

A 'BBVG' és a 'H222' a koordináta rendszer jobb alsó részében, nagymértékben együtt mozognak. Mind TSS, mind TA szempontból nagyjából ugyanakkora mértékü fejlődésen mennek keresztül az érés során: a savtartalmuk alig változik, a fő elmozdulást a grafikonon a TSS érték növekedése jelenti. Mindkét fajtánál a TSS 12-14 ${ }^{\circ}$ Brix között kezdődik T1 terminusban, aztán évjárathatástól függően 15-19 Brix között áll meg. A kettő közül 3 éves átlagban a 'BBVG'-nek nagyobb a TSS értéke, a 'H222'-nek pedig a TA értéke, de a kettő általában olyan közel van egymáshoz, hogy a különbség nem szignifikáns.

A 'BBS' 2010-11-ben ugyanabban a TA tartományban mozgott, mint a 'BBVG' és a 'H222', a TSS koordináta mentén pedig kicsit balra csúszva, tehát alapvetően gyengébb ízminőségü gyümölcsöt produkálva hozzájuk képest. 2012-ben azonban a 'BBS' TSS értéke is megemelkedett a másik kettő szintjére, a savtartalma pedig azok fölé nőtt, így összességében finomabb gyümölcsöket eredményezve.

A 'BMS' az eddig jellemzett fajtáktól jól elkülönül a TSS-TA koordináta-rendszerben, általában a bal felső sarok (kisebb TSS, nagyobb TA) felé helyezkedve. Megállapítható, hogy az öt vizsgált fajta közül a 'BMS' az, amelynek gyümölcse a legextrémebb eltéréseket produkálta az egyes évek között. 2012-ben a legjobb ízminőségü cseresznyék (még a Regina-Kordia párost is 
beleértve is) a 'BMS'-en teremtek, 2010-ben viszont az érett 'BMS' gyümölcs TSS értéke (átlagosan $11,5^{\circ}$ Brix) messze elmaradt a fogyasztói várakozásoktól, amelynek minimuma $15^{\circ}$ Brix (ROMANO et al., 2006), így a frisspiacon gyakorlatilag az eladhatatlan kategóriába került volna.

A 'MP' fajta gyümölcse megbízhatóan magas savtartalmával minden évben a grafikon felső szegmensében helyezkedett el, és TSS értéke is mindig a legjobbak között volt az öt fajtát tekintve. Az évjárathatásra mutatott érzékenysége kicsit erősebb, mint a 'BBVG'-'H222' párosé, mert bár TSS szempontjából együtt mozgott velük az évek során, TA értéke jobban ingadozott. Mindazonáltal az 'MP' gyümölcs ízminősége bármelyik évben jobb volt, mint a 'BBVG' és a 'H222'.

\subsection{A gyümölcsök egyedi komponensei és komponenscsoportjai}

\subsubsection{A Q10 ültetvény}

\subsubsection{Cukorfrakciók}

A Q10 cseresznyeültetvény gyümölcseiben az egyedi cukorkomponensek (fruktóz, glükóz, szorbitol) koncentrációját 4 egymást követő évben (2010-2013) mértük, majd azokból totál kromatográfiás cukortartalmat (TKC) számoltunk. A Melléklet 32. táblázata tartalmazza az eredmények összesítését.

$\mathrm{Az}$ egyedi cukorkomponenseket vizsgálva összességében elmondható, hogy a Q10 ültetvényből származó cseresznye gyümölcsökben szignifikánsan a legmagasabb a glükóz koncentrációja, azt követi a fruktóz, majd a szorbitol. Bár évenként és alany-nemes kombinációnként kisebb-nagyobb eltérések előfordulnak, az érett cseresznye glükózkoncentrációja átlagosan 59,82-103,29 mg/ml, a fruktóz-koncentrációja 41,73-80,42 mg/ml, a szorbitolé pedig 15,91-33,69 mg/ml között mozgott, míg az összes kromatográfiás cukortartalom $121,48-212,38 \mathrm{mg} / \mathrm{ml}$ között változott.

Az érési terminusok eredményeit összevetve kiderül, hogy évenként és alany-nemes kombinációnként a cseresznye gyümölcsök összes kromatográfiás cukortartalma az érés során $(\mathrm{T} 1 \rightarrow \mathrm{T} 2 \rightarrow \mathrm{T} 3)$ az esetek 97,5\%-ában szignifikánsan nö (ezek közül 67,5\% monoton nő). Ez az eredmény teljes összhangban van a korábban mért TSS értékekkel.

A két fajtát összehasonlítva a T3-as érési stádiumban (42. ábra) a gyümölcsök egyedi cukorkomponensei nem teljesen együtt mozogtak: a fruktóz és a glükóz koncentrációja az első két évben a 'Regina', a másik két évben a 'Kordia' fajtánál volt szignifikánsan magasabb, a szorbitol koncentrációja azonban egymás után három évben is (2011-2013) a Kordia’ fajta gyümölcseiben volt a legtöbb.

Az éveket összehasonlítva a T3-as érési stádiumban (42. ábra) az összes cukorkomponens koncentrációja mindkét fajtánál 2011-ben volt a legmagasabb, bár a 'Kordia’ fajtánál a 2012-es év is hasonló eredményeket hozott, szignifikáns különbség nem volt kimutatható. 

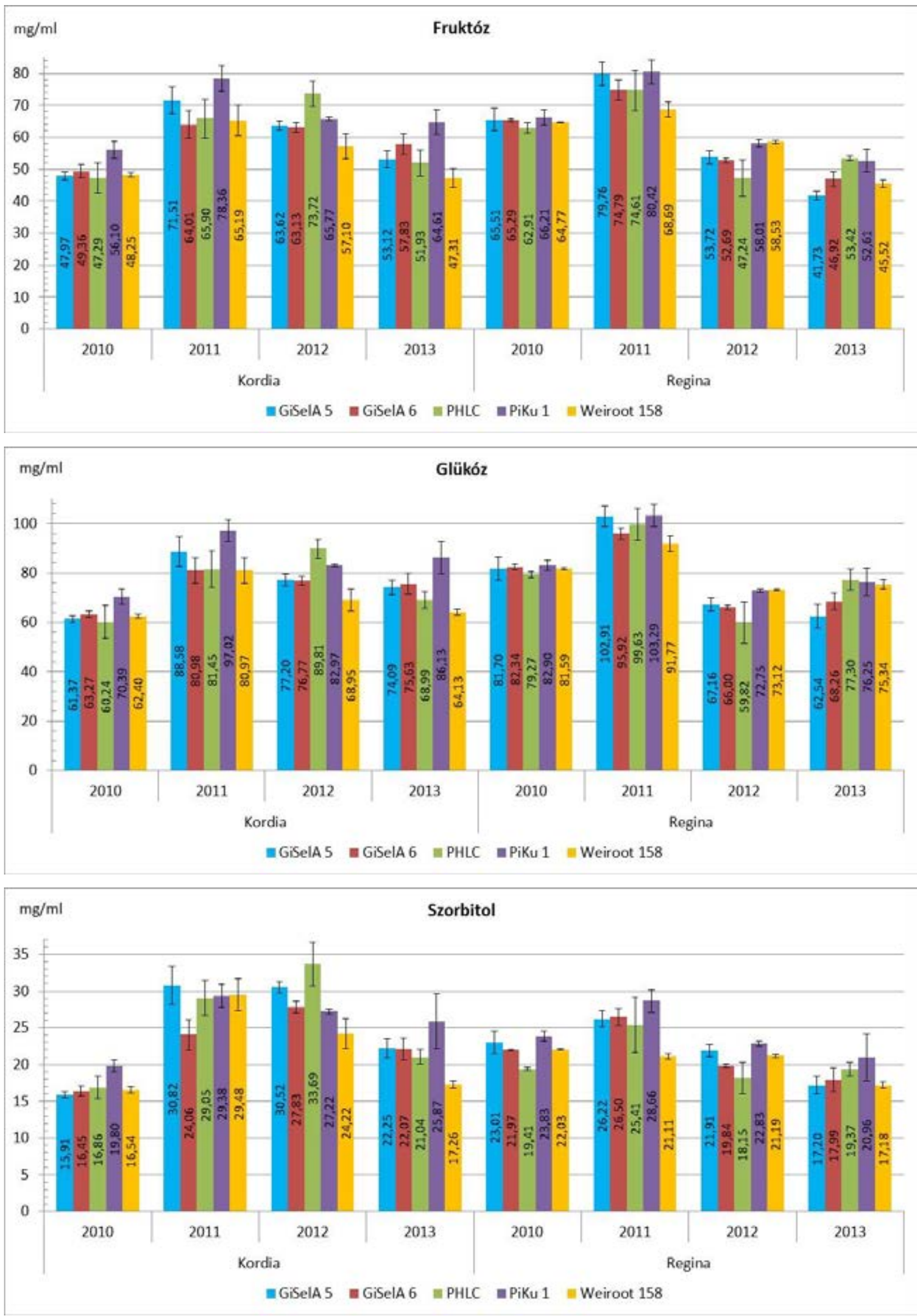

42. ábra: 'Regina' és 'Kordia' cseresznyefajták gyümölcseiben az egyedi cukorkomponensek (fruktóz, glükóz, szorbitol) koncentrációja különböző alanyokon T3-as érési stádiumban 2010 és 2013 között 
Az egyes alanyok hatása között az eredmények 95,83\%-ában szignifikáns különbséget tudtunk kimutatni a cukorkomponensek tekintetében. A T3-as érési stádiumban (42. ábra) megfigyelhető volt, hogy a 'Kordia' fajta fruktóz és a glükóz koncentrációja legtöbbször a 'PiKu 1' alanyon volt a legmagasabb (2010-ben, 2011-ben és 2013-ban első helyen végzett, 2012-ben másodikon a 'PHL-C' mögött). A szorbitol hasonlóan alakult annyi kivétellel, hogy a 2011-es évben a 'GiSelA 5' alany emelkedett ki a leginkább.

'Regina' fajtánál a legmagasabb fruktóz és glükóz koncentrációt 2011-ben a 'PiKu 1' és a 'GiSelA 5' alanyok eredményezték, 2012-ben a 'PiKu 1' és a 'Weiroot 158', 2013-ban pedig a 'PHL-C' és a 'PiKu 1', míg 2010-ben nem volt szignifikáns különbség, vagyis a 'PiKu 1' alany ennél a fajtánál is mindig előkelő helyen szerepelt. A legmagasabb szorbitol koncentrációt minden esetben a 'PiKu 1' alanyon lévő fák gyümölcseiben mértük, de 2010-ben és 2012-ben a 'GiSelA 5' is magas értéket produkált (azonos szignifikáns csoportba kerültek). 'Kordia' fajtánál a legtöbb esetben mindhárom cukorkomponens a 'Weiroot 158' alanyon mutatta a legkisebb értékeket, míg a 'Regina' fajtánál nem volt egyértelmü a tendencia.

Összességében a négy év T3-as érési stádiumának eredményei alapján (42. ábra) elmondható, hogy szignifikánsan a legmagasabb fruktóz és glükóz koncentrációt a 'Regina''PiKu 1' (80,42 \pm 3,76 és 103,29 \pm 4,44 mg/ml) és a 'Regina'-'GiSelA 5' (79,76 \pm 3,65 és 102,91 \pm 4,02 mg/ml) kombinációk, valamint a 'Kordia'-'PiKu 1' (78,36 $\pm 3,97$ és 97,02 \pm 4,46 mg/ml) kombináció mutatta 2011-ben. A legmagasabb szorbitol koncentrációt a 'Kordia'-'PHL-C' (33,69 $\pm 2,98 \mathrm{mg} / \mathrm{ml})$ és a 'Kordia'-'GiSelA 5' (30,52 \pm 0,76 mg/ml) kombinációnál 2012-ben, valamint a 'Kordia'-'GiSelA 5' (30,82 $\pm 2,57$ mg/ml) kombinációnál 2011-ben mértük. A legalacsonyabb koncentráció értékeket fruktóz esetében a 'Regina'-'GiSelA 5' (41,73 $\pm 1,42 \mathrm{mg} / \mathrm{ml})$ kombinációnál 2013-ban, glükóz esetében a 'Kordia'-'Weiroot 158' (64,13 $\pm 1,08$ mg/ml) kombinációnál 2010-ben, míg szorbitol esetében a 'Kordia'-'GiSelA 5' (15,91 \pm 0,48 mg/ml) kombinációnál 2010-ben kaptuk.

\subsubsection{Savfrakciók}

A Q10 cseresznyeültetvény gyümölcseiben az egyedi savkomponensek (almasav, borostyánkősav, citromsav) koncentrációját 4 egymást követő évben (2010-2013) mértük, majd azokból totál kromatográfiás savtartalmat (TKS) számoltunk. A Melléklet 30. táblázata tartalmazza az eredmények összesítését.

Az egyedi savkomponenseket vizsgálva elmondható, hogy a Q10 ültetvényből származó cseresznye gyümölcsökben szignifikánsan a legmagasabb az almasav koncentrációja, azt követi a borostyánkősav, majd a citromsav. Bár évenként és alany-nemes kombinációnként kisebbnagyobb eltérések előfordulnak, az érett cseresznye almasav koncentrációja átlagosan 2,8-6,94 $\mathrm{mg} / \mathrm{ml}$, borostyánkősav koncentrációja $0,57-2,27 \mathrm{mg} / \mathrm{ml}$, a citromsav koncentrációja pedig 0,45$1,22 \mathrm{mg} / \mathrm{ml}$ között mozgott, míg az összes kromatográfiás savtartalom 3,77-10,3 mg MAE/ml között változott. 
$\mathrm{Az}$ érési terminusok eredményeit összevetve láthatjuk, hogy évenként és alany-nemes kombinációnként a cseresznye gyümölcsök mindhárom egyedi savkomponensének koncentrációja szignifikánsan csökken az érés elörehaladtával: az almasav koncentrációja az esetek 87,5\%-ában (ebböl 68,57\% monoton), a borostyánkősav koncentrációja az eredmények 77,5\%-ánál (ebböl $77,42 \%$ monoton), míg a citromsav koncentrációja az esetek 75\%-ánál (melyből 80\% monoton).

A két fajtát összehasonlítva a T3-as érési stádiumban (43. ábra) a gyümölcsök egyedi savkomponensei nem teljesen együtt mozogtak. Az almasav koncentrációja 2010-ben, 2012-ben és 2013-ban a 'Kordia', 2011-ben pedig a 'Regina' fajta gyümölcseiben volt a magasabb. A borostyánkősav koncentrációja 2010-ben és 2011-ben a 'Regina', 2013-ban a 'Kordia' fajtánál volt magasabb, míg 2012-ben nem találtunk szignifikáns eltérést. A citromsav koncentrációja 2012-ben és 2013-ban 'Kordia', 2011-ben 'Regina' fajtánál bizonyult magasabbnak, míg 2010ben nem volt szignifikáns különbség.

Az éveket összehasonlítva a T3-as érési stádiumban (43. ábra) a gyümölcsök egyedi savkomponenseinek koncentrációja az évjárat hatására különbözően változott. Az almasav koncentrációja 'Kordia' fajtánál 2012-ben és 2013-ban, 'Regina' fajtánál 2011-ben és 2012-ben volt a legmagasabb. A borostyánkősav koncentrációja 'Kordia' fajta esetében 2013-ban, 'Regina' esetében 2011-ben volt a mutatta a legmagasabb értéket. A legnagyobb citromsav koncentrációt 'Kordia' fajtánál 2012-ben, 'Regina' fajtánál pedig 2011-ben és 2012-ben mértük.

Az egyes alanyok hatása között az eredmények 95,83\%-ában szignifikáns különbséget tudtunk kimutatni a savkomponensek koncentrációjában. A T3-as érési stádiumban (43. ábra) a 'Kordia' fajta almasav és citromsav koncentrációja 2010-ben és 2013-ban a 'GiSelA 6' alanyon, 2011-ben a 'PiKu 1'-en, 2012-ben pedig a 'GiSelA 5' alanyon volt a legmagasabb. Almasav esetén a legalacsonyabb szignifikáns csoportban mindig ott szerepelt a 'Weiroot 158', míg citromsavnál legtöbbször a 'PHL-C' és 'Weiroot 158' alany mutatta a legalacsonyabb értékeket. A borostyánkősav koncentrációja legtöbbször 'GiSelA 6' alanyon volt a legmagasabb.

A 'Regina' fajta almasav és citromsav koncentrációja teljesen együtt mozgott: a legmagasabb koncentrációkat 2010-ben és 2011-ben a 'GiSelA 6' alanynál mértük (bár 2011-ben nem volt szignifikáns), 2012-ben a 'Weiroot 158', 2013-ban a pedig a 'PiKu 1' alanynál. A borostyánkősav koncentrációja 'Regina' fajtánál legtöbbször a 'PiKu 1' fajtánál volt a legmagasabb (2010, 2011, 2013), míg 2012-ben nem tudtunk szignifikáns különbséget detektálni. 'Regina' fajtánál a legalacsonyabb koncentráció értéket mindhárom savkomponensnél legtöbbször a 'GiSelA 6' alanyon álló fák gyümölcseiben mértük (2010, 2011, 2012). 

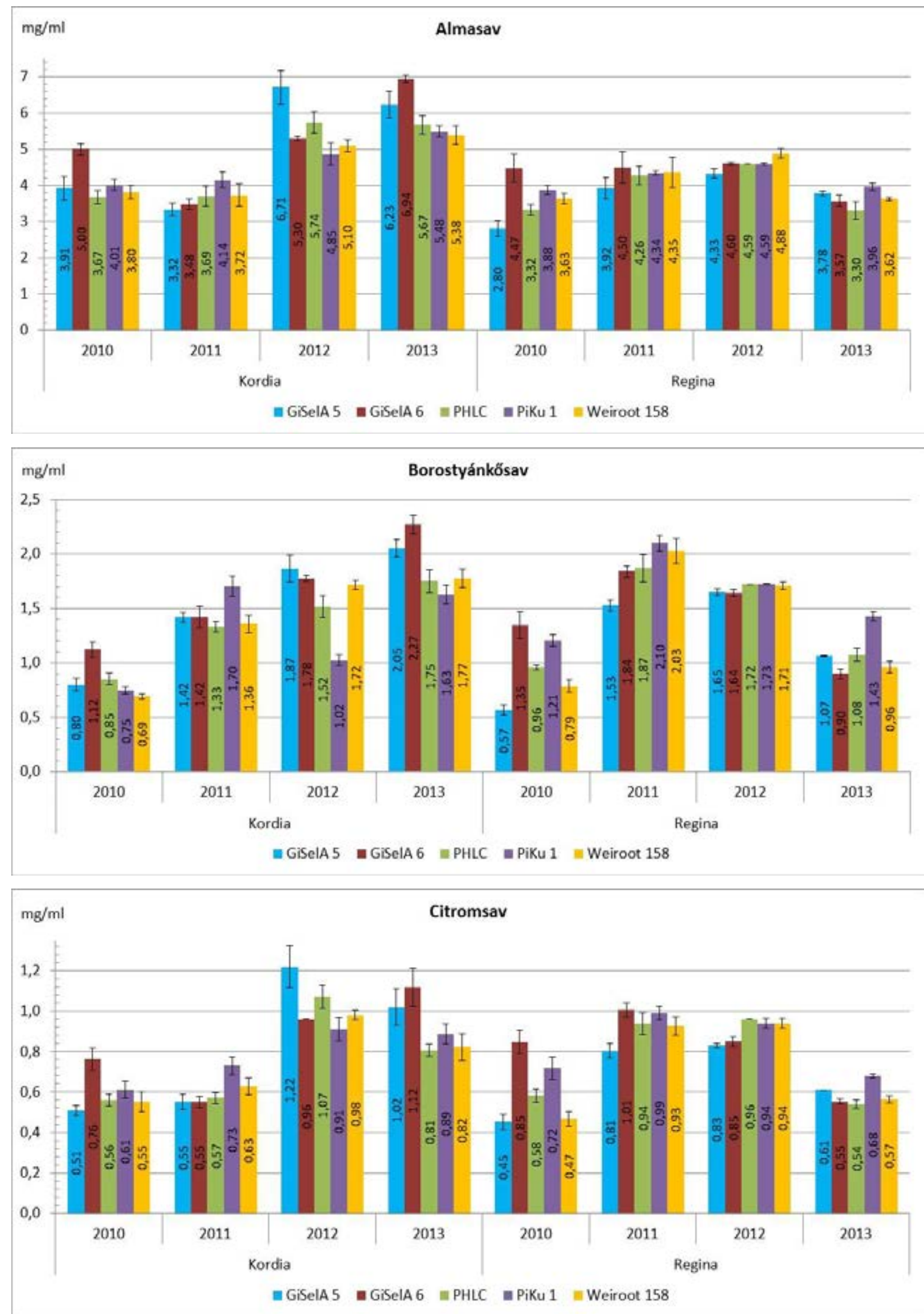

43. ábra: 'Regina' és 'Kordia' cseresznyefajták gyümölcseiben az egyedi savkomponensek (almasav, borostyánkősav, citromsav) koncentrációja különböző alanyokon T3-as érési stádiumban 2010 és 2013 között 
Összességében a négy év T3-as érési stádiumának eredményei alapján (43. ábra) elmondható, hogy szignifikánsan a legmagasabb almasav és citromsav koncentrációt a 'Kordia''GiSelA 5' kombináción 2012-ben (6,71 $\pm 0,47$ és $1,22 \pm 0,10 \mathrm{mg} / \mathrm{ml})$, valamint a 'Kordia''GiSelA 6' kombináción 2013-ban mértük (6,94 $\pm 0,11$ és $1,12 \pm 0,09 \mathrm{mg} / \mathrm{ml})$, míg a legalacsonyabbat a 'Regina'-'GiSelA 5' kombináció esetében kaptuk 2010-ben $(2,80 \pm 0,22$ és $0,45 \pm 0,04 \mathrm{mg} / \mathrm{ml})$. A legmagasabb borostyánkősav koncentrációt a 'Kordia'-'GiSelA 6' (2,27 \pm 0,08 mg/ml) kombinációnál mértük 2013-ban, míg a legalacsonyabbat a 'Regina'-'GiSelA 5' (0,57 $\pm 0,05 \mathrm{mg} / \mathrm{ml}$ ) kombináció eredményezte 2010-ben.

\subsubsection{Polifenol-frakciók}

A Q10 cseresznyeültetvény gyümölcseiben az egyedi polifenol-komponensek koncentrációját 3 egymást követő évben (2011-2013) mértük, majd azokból totál kromatográfiás polifenol-tartalmat (TKPF) számoltunk. A Melléklet 31. táblázata tartalmazza az eredmények összesítését.

Az általunk azonosított 7 egyedi polifenol-komponensre a továbbiakban gyakorlati megfontolásból az alábbiak szerint fogunk hivatkozni: cianidin-3-O-rutinozid (továbbiakban: cianidin), kvercetin (továbbiakban: kvercetin), kvercetin-3-rutinozid (továbbiakban: rutin), klorogénsav (továbbiakban: klorogénsav), neoklorogénsav (továbbiakban: neoklorogénsav), epikatechin (továbbiakban: epikatechin), 3-p-kumaroil-kínasav (továbbiakban: kínasav).

Méréseink alapján a Q10 cseresznyeültetvényből származó gyümölcsök egyedi polifenolkomponensei gyümölcsszíneződés kezdetén (T1 érési stádium) az alábbi sorrendbe állíthatók fel koncentrációjuk alapján (legelöl a legmagasabb koncentrációjú): 1. neoklorogénsav, 2. cianidin, 3. kínasav, 4. klorogénsav, 5. epikatechin, 6. kvercetin, 7. rutin. Ezzel szemben a T3-as érési stádiumra kicsit átalakul a sorrend: 1. cianidin, 2. neoklorogénsav, 3. kínasav, 4. klorogénsav, 5. kvercetin, 6 rutin, 7. epikatechin (tehát az érés elörehaladtával helyet cserél a neoklorogénsav a cianidinnel, valamint az epicatechin az 5. helyröl a 7. helyre kerül).

Bár évenként és alany-nemes kombinációnként kisebb-nagyobb eltérések előfordultak, az érett cseresznye cianidin koncentrációja átlagosan 176,29-1374,08 mg/kg, a neoklorogénsavé 105,43-398,72 mg/kg, kínasavé 32,93-139,6 mg/kg, klorogénsavé 29,61-93,25 mg/kg, kvercetiné 6,88-44,92 mg/kg, a rutiné 6,81-39,98 mg/kg, az epikatechiné pedig 10,58-26,1 mg/kg között mozgott. Az összes kromatográfiás polifenol-tartalom átlagosan 437,24-2101,32 mg/kg között változott.

Az érési terminusok eredményeit összevetve láthatjuk, hogy az egyedi polifenolkomponensek koncentrációja az érés elörehaladtával $(\mathrm{T} 1 \rightarrow \mathrm{T} 2 \rightarrow \mathrm{T} 3)$ különböző irányba változott. A cianidin, a klorogénsav és a rutin koncentrációja az érés során szignifikánsan nőtt: a cianidin az esetek 100\%-ában (ebből mind monoton), a klorogénsav és a rutin az esetek 70\%-ában (ezekből 19,05\% illetve 52,38\% volt monoton). Ezzel szemben a neoklorogénsav, az epikatechin, a kínasav és a kvercetin koncentrációja az érés előrehaladtával szignifikánsan csökkent: a neoklorogénsav és az epikatechin koncentrációja az esetek 100\%-ában (ezekből 46,67\% illetve 
$30 \%$ volt monoton), a kínasav koncentrációja az esetek 96,67\%-ában (ebből 55,17\% volt monoton), a kvercetiné pedig az esetek 70\%-ában (ebböl 42,86\% volt monoton). Az összes kromatográfiás polifenol-tartalom az érés során az esetek 66,67\%-ában szignifikánsan nőtt (ennek $65 \%$-a volt monoton).

A két fajtát összehasonlítva a T3-as érési stádiumban (Melléklet 52. ábra) a gyümölcsök egyedi polifenol-komponenseinek koncentrációja az esetek 88,57\%-ában a 'Kordia' fajtán volt szignifikánsan magasabb, de a különböző komponensek között évjáratonként és alanyonként különbségek mutatkoztak. A cianidin, a neoklorogénsav a klorogénsav, kínasav és a rutin koncentrációja minden évben a 'Kordia' fajtán volt a legmagasabb. Az epikatechin koncentrációja 2011-ben és 2012-ben szintén a 'Kordia' fajtán mutatta a legmagasabb értékeket, míg 2013-ban nem volt szignifikáns különbség. A kvercetin esetében 2011-ben a 'Kordia' fajtán mértük a legnagyobb koncentrációkat, 2012-ben a 'GiSelA 5' és a 'GiSelA 6' alanyok esetében a 'Regina' fajta bizonyult jobbnak, a többi alanynál a 'Kordia' fajta, míg 2013-ban minden alany esetében a 'Regina'.

Az éveket összehasonlítva a T3-as érési stádiumban (Melléklet 52. ábra) a gyümölcsök mind a 7 egyedi polifenol-komponensének koncentrációja együtt változott: koncentrációjuk mind 'Regina', mind pedig 'Kordia' fajta esetében 2012-ben volt a legmagasabb (bár a 'Regina' fajta gyümölcseinek epikatechin koncentrációja 2013-ban, valamint rutin koncentrációja 2011-ben egy szignifikáns csoportba került a 2012-es eredményekkel).

Az egyes alanyok hatása között minden évet és érési terminust figyelembe véve a 7 polifenol-komponens közül 6-nál az eredmények 100\%-ában szignifikáns különbséget tudtunk kimutatni (a kínasav esetében az eredmény 94,44\% volt). Összességében elmondható, hogy a fajták gyümölcsei eltérő alanyokon mutatták a legmagasabb polifenol-koncentrációkat. A 'Kordia' fajta gyümölcseiben a különbözö polifenol-komponensek koncentrációja az esetek 71,43\%-ában a 'Weiroot 158' alanyon volt szignifikánsan a legmagasabb, de a 'GiSelA 5' alany is jól szerepelt, az esetek 57,14\%-ában ez az alany is a legmagasabb szignifikáns csoportba került. A 'Regina' fajta kevésbé mutatott egyértelmü tendenciát: leggyakrabban a 'PiKu 1' alanyon mértük a legmagasabb polifenol-koncentrációkat, de jóval alacsonyabb arányban, mint a 'Kordia’ fajtánál (38,1\%), és évjárattól valamint komponenstől függően nagy változatosságot tapasztaltunk.

A következőkben külön-külön részletezzük, hogy a két fajtánál melyik egyedi komponens melyik alanynál mutatta a legmagasabb koncentrációkat.

A 'Kordia' fajtát vizsgálva T3-as érési stádiumban (Melléklet 52. ábra) a legmagasabb cianidin koncentrációt 2011-ben a 'GiSelA 5' és a 'Weiroot 158' alanyokon, 2012-ben a 'Weiroot 158'-on, 2013-ban pedig a 'GiSelA 5', 'PHL-C' és 'Weiroot 158' alanyokon álló fák gyümölcseiben mértük. Az epicatechin koncentrációja a cianidinéhez hasonlóan változott az alanyoknál: 2011-ben a 'GiSelA 5' és 'GiSelA 6', 2012-ben és 2013-ban a 'GiSelA 5', 'GiSelA 6' és 'Weiroot 158' alanyokon álló fák gyümölcseiben mértük a legmagasabb értéket. A 
neoklorogénsav koncentrációja 2011-ben a 'GiSelA 5' és 'GiSelA 6', 2012-ben a 'GiSelA 5' és 'Weiroot 158', 2013-ban pedig a 'GiSelA 5' alanyon volt a legmagasabb, míg a klorogénsavé 2011-ben 'PiKu 1', 'PHL-C' és 'Weiroot 158', 2012-ben 'Weiroot 158', 2013-ban pedig 'Weiroot 158' és 'PHL-C' alanyokon. A kínasav koncentrációja 2011-ben 'GiSelA 6', 2012-ben 'Weiroot 158', 2013-ban pedig 'GiSelA 5' alanyon mutatta a legmagasabb értéket, míg a rutin 2011-ben és 2012-ben is 'Weiroot 158' alanyon, 2013-ban pedig 'PHL-C', 'GiSelA 5' és 'Weiroot 158' alanyokon. A kvercetin 2011-ben 'GiSelA 5', 'Weiroot 158' és PiKu 1', 2012-ben 'GiSelA 5' és 'Weiroot 158', 2013-ban pedig 'PHL-C'-n lett a legmagasabb koncentráció-értékü.

A 'Regina' fajtát vizsgálva T3-as érési stádiumban (Melléklet 52. ábra) a legmagasabb cianidin koncentrációt 2010-ben a 'PiKu 1', 2012-ben a 'PHL-C', 2013-ban a 'Weiroot 158' és 'PiKu 1' alanyokon találtuk. Az epikatechin koncentrációja 2011-ben a 'PHL-C' és 'PiKu 1', 2012-ben a 'Weiroot 158', 2013-ban pedig a 'GiSelA 5' alanyon volt a legmagasabb (bár 2012ben nem volt szignifikáns). A neoklorogénsav koncentrációja 2011-ben a 'PHL-C' és 'PiKu 1', 2012-ben a 'GiSelA 5', 2013-ban pedig a 'GiSelA 5' és 'GiSelA 6' alanyokon mutatta a legmagasabb értéket (bár 2012-ben nem volt szignifiáns), míg a klorogénsav koncentrációja 2011ben a 'PiKu 1', 2012-ben a 'PHL-C', 2012-ban pedig a 'GiSelA 5' és 'PHL-C' alanyokon volt a legmagasabb. A kínasav koncentrációja 2011-ben 'PiKu 1', 2012-ben 'GiSelA 5' és 'PHL-C', 2013-ban pedig 'GiSelA 6' alanyon volt a legnagyobb, míg a rutiné 2011-ben a 'PHL-C', 2012ben a 'GiSelA 5', 2013-ban pedig a 'PiKu 1' alanyokon. A kvercetin 2011-ben 'GiSelA 5' és 'PiKu 1', 2012-ben és 2013-ban pedig 'GiSelA 5' alanyon álló fák gyümölcseiben mutatta a legmagasabb koncentrációt.

Ha arányaiban kifejezzük a különbséget a két fajta között a különböző alanyokon, akkor egyes komponensek koncentrációjában nagyságrendi eltérést is tapasztalhatunk. A legnagyobb különbségeket a 'Kordia' fajta javára T3-as érési stádiumban (Melléklet 52. ábra) a cianidin-, a rutin- és a kínasav-koncentrációban tapasztaltuk. Mind az öt alanyon a 'Kordia' fák gyümölcseinek cianidin-koncentrációja többszörösen meghaladta a 'Regina' gyümölcseinek cianidin-értékeit azonos évben és terminusban. A 'GiSelA 5' alanyt vizsgálva teljes érettségben például a cianidin-koncentráció a 'Kordia' fajta gyümölcseiben 2011-ben 206,39\%-kal magasabb volt, mint a 'Regina' gyümölcseiben, 2012-ben a 34,47\%-kal, míg 2013-ban 149,34\%-kal. A 'Weiroot 158' alanyt vizsgálva ugyanezek az arányok így alakultak: 2011-ben 173,9\%, 2012-ben 123,93\%, míg 2013-ban 149,34\% volt a különbség szintén a 'Kordia' fajta javára. A rutint vizsgálva ugyancsak nagy különbséget tapasztaltunk: a 2012-es évben 'Weiroot 158' alanyon a 'Kordia' fajta gyümölcseinek rutin-koncentrációja 83,82\%-kal volt magasabb a 'Regina' fajta gyümölcseiben mért rutin-koncentrációnál (ugyanez a többi évben alacsonyabb volt, de szintén jelentős: 2011-ben 66,17\%, 2013-ban pedig 62,29\%). A kínasavat vizsgálva helyenként szintén nagy volt a különbség: 2013-ban 'GiSelA 5' alanyon a 'Kordia' fajta gyümölcseinek kínasavkoncentrációja 149,14\%-kal volt magasabb a 'Regina' fajta gyümölcseiben mért koncentrációnál 
(ugyanez a többi évben alacsonyabb volt, de szintén jelentős: 2011-ben 48,81\%, 2012-ben pedig 60,14\%).

Az alanyok hatását összevetve egy nemesen belül a T3-as érési stádiumban (Melléklet 52. ábra) helyenként (cianidin, epikatechin, rutin, kvercetin kompponensek) szintén nagy különbségeket figyeltünk meg. A 2012-es évet vizsgálva a 'Weiroot 158' alanyon álló 'Kordia' fák gyümölcseinek cianidin koncentrációja a 'GiSelA 6' alanyon álló fák gyümölcseinél 96,96\%-kal volt magasabb (ugyanez a 2013-as évben 32,1\%, 2011-ben pedig 25,5\% volt). A 'Regina' fajta alanyait összehasonlítva általában kisebb volt az eltérés, de nem elhanyagolható: 2012-ben 41,33\%-os különbséget kaptunk a 'PHL-C' és a 'GiSelA 6' alanyokon álló fák gyümölcseinek cianidin koncentrációi között, míg 2011-ben 38,74\%-ot a 'PiKu 1' és a 'PHL-C' alanyokon álló fák között, mindkét esetben a 'PHL-C' javára. Szintén viszonylag nagy különbséget kaptunk az alanyok tekintetében az epikatechint vizsgálva: a 'Kordia' fajtánál 2011ben 76,75\%-kal, 2012-ben 38,25-5-kal, 2013-ban pedig 58,25\%-kal volt magasabb a 'GiSelA 5' alanyon álló fák gyümölcseinek epikatechin-koncentrációja a 'PHL-C' alanyon álló fák gyümölcseihez képest. A 'Regina' fajtánál nem volt ilyen szembetünő a különbség. A rutint vizsgálva szintén nagy különbséget találtunk a 'GiSelA 6' és 'Weiroot 158' alanyok között 2012ben 'Kordia' fajtánál (121,62\%) utóbbi javára (2011-ben ugyanez 31,9\%-os különbséget mutatott, 2013-ban pedig nem volt szignifikáns különbség). A 'Regina' fajtánál szintén kisebb különbségeket találtunk: 2012-ben a 'GiSelA 5' alanyon álló fák gyümölcseinek rutinkoncentrációja 44,9\%-kal volt magasabb a 'PHL-C' alanyon álló fák gyümölcseihez képest (2011ben ugyanez 17,1\% volt, 2013-ban nem találtunk szignifikáns eltérést). A kvercetin koncentrációja a 'Kordia' fajta gyümölcseiben 2012-ben 63,4\%-os, 2011-ben 31,12\%-os, 2013 ban pedig 18,17\%-os különbséget mutatott a 'Weiroot 158' alanynál a 'GiSelA 5' alanyhoz képest. A 'Regina' fajtánál 2012-ben 121,28\%-os különbséget kaptunk a 'GiSelA 5' és a 'PHL-C' alanyokon álló fák gyümölcseinek kvercetin-koncentrációja között az elöbbi javára (ugyanez 2011-ben 23.37\% volt, 2013-ban azonban nem volt számottevő).

Összességében a három év T3-as érési stádiumának eredményei alapján (Melléklet 52. ábra) elmondható, hogy a 'Kordia'-'Weiroot 158' nemes-alany kombinációnál mértük szignifikánsan a legmagasabb cianidin, klorogénsav, kínasav és rutin koncentrációkat 2012-ben (1374,08 \pm $65,01,93,25 \pm 3,28,139,60 \pm 3,67$ és $39,98 \pm 1,97 \mathrm{mg} / \mathrm{kg})$. A legalacsonyabb cianidin koncentrációt a 'Regina'-'GiSelA 5' (179,90 \pm 7,12 mg/kg) és 'Regina'-'GiSelA 6' (176,29 \pm 7,65 $\mathrm{mg} / \mathrm{kg}$ ) kombinációknál, a legalacsonyabb klorogénsav koncentrációt a 'Regina'-'PiKu 1' (30,41 $\pm 1,15 \mathrm{mg} / \mathrm{kg})$ és 'Regina'-'Weiroot 158 ' $(29,61 \pm 1,67 \mathrm{mg} / \mathrm{kg})$, míg a legalacsonyabb rutin koncentrációt a 'Regina'-'GiSelA 6' (6,81 $\pm 0,15 \mathrm{mg} / \mathrm{kg})$, kombinációknál mértük 2013-ban. A kínasav koncentrációja a 'Regina'-'Weiroot 158' kombináción volt a legalacsonyabb 2011-ben $(32,93 \pm 0,37 \mathrm{mg} / \mathrm{kg})$. A legmagasabb epicatechin koncentrációt 2012-ben mértük a 'Kordia''GiSelA 5' $(26,10 \pm 1,28 \mathrm{mg} / \mathrm{kg})$, a 'Kordia'- 'GiSelA 6' $(25,73 \pm 1,24 \mathrm{mg} / \mathrm{kg})$ és a 'Kordia'- 
'Weiroot 158' (24,99 \pm 1,62 mg/kg) kombinációknál 2012-ben, míg a legalacsonyabbat a 'Regina'-'Weiroot 158' kombinációnál 2011-ben (10,58 $\pm 0,41 \mathrm{mg} / \mathrm{kg})$. A legmagasabb neoklorogénsav koncentrációt a 'Kordia'-'GiSelA 5' (398,72 $\pm 22,58$ mg/kg) és 'Kordia''Weiroot 158' (390,60 \pm 16,78 mg/kg) kombinációknál kaptuk 2012-ben, míg a legalacsonyabbat a 'Regina'-'GiSelA 5' kombinációnál 2011-ben $(105,43 \pm 6,15 \mathrm{mg} / \mathrm{kg})$. Végül a legmagasabb kvercetin koncentrációt a 'Regina'-'GiSelA 5' kombináció eredményezte 2012-ben (44,92 \pm 1,50 mg/kg), a legalacsonyabbat pedig a 'Kordia'-'PiKu 1' kombináció 2013-ban (6,88 \pm 0,35 mg/kg).

\subsubsection{A Q26 ültetvény}

\subsubsection{Cukorfrakciók}

A Q26 cseresznyeültetvény 5 különböző nemes fajtájának gyümölcseiben az egyedi cukorkomponensek (fruktóz, glükóz, szorbitol) koncentrációját 3 egymást követő évben (20102012) mértük virágritkított és kontroll fákon, majd azokból totál kromatográfiás cukortartalmat (TKC) számoltunk. A Melléklet 32. táblázata tartalmazza az eredmények összesítését.

Az egyedi cukorkomponenseket vizsgálva összességében elmondható, hogy a Q26 ültetvény cseresznyegyümölcseiben (is) szignifikánsan a legmagasabb a glükóz koncentrációja, azt követi a fruktóz, majd a szorbitol. Bár évtől és a ritkítás alkalmazásától függően kisebb-nagyobb eltérések előfordulnak, az érett cseresznye glükóz-koncentrációja átlagosan 55,53-102,28 mg/ml, a fruktózkoncentrációja 50,45-87,99 mg/ml, a szorbitolé pedig $23.6 \mathrm{mg} / \mathrm{ml}$ között mozgott, míg az összes kromatográfiás cukortartalom 113,1-213,87 mg/ml között változott.

Az érési terminusok eredményeit összevetve kiderül, hogy évtől és a ritkítás alkalmazásától függetlenül a cseresznye gyümölcsök összes kromatográfiás cukortartalma az érés során $(\mathrm{T} 1 \rightarrow \mathrm{T} 2 \rightarrow \mathrm{T} 3)$ az esetek 100\%-ában szignifikánsan nő (ezek közül 93,33\% monoton nő). Ez az eredmény összhangban van a korábban mért TSS értékekkel.

Az öt fajtát összehasonlítva a T3-as érési stádiumban (44. ábra) a gyümölcsök egyedi cukorkomponenseinek koncentrációja legtöbbször a 'H222' és a 'BBVG' fajtáknál volt a legmagasabb, bár az évtől és a ritkítás alkalmazásától függően változást mutatott a komponensek között. A fruktóz és glükóz koncentrációja 2010-ben a ritkított és kontroll fáknál is 'H222' fajtánál, 2011-ben és 2012-ben a ritkított fáknál 'BBVG' fajtánál, a kontroll fáknál 'H222' majd 'BMS' fajtáknál, míg 2013-ban a ritkított fák esetében 'BMS', a kontroll fák esetében 'BBVG' fajtáknál volt a legmagasabb. A szorbitol 2010-ben a kontroll fák gyümölcseiben a 'BBS', ritkított fák esetében 'H222' fajtánál, 2011-ben kontroll fajták esetében a 'BBVG', 'BMS' és 'H222' fajtáknál, ritkított fák esetében 'MP' fajtánál, míg 2012-ben kontroll és ritkított fák esetében is 'BBVG' fajtánál mutatta a legmagasabb értéket.

Az éveket összehasonlítva a T3-as érési stádiumban (44. ábra) a három fö cukorkomponens koncentrációja különbözően alakult. A fruktóz és glükóz koncentrációja 'BBS' fajtánál mindhárom évben kiegyenlített volt, 'BBVG', 'BMS' és 'MP' esetében 2011-ben és 2012-ben, 
míg 'H222' fajtánál 2011-ben és 2012-ben volt a legmagasabb. A szorbitol koncentrációja 'BBS' fajtánál 2010-ben és 2012-ben, 'BBVG' és 'BMS' fajtáknál 2012-ben, 'H222' fajtánál ritkított fáknál 2010-ben, kontroll fáknál 2011-ben és 2012-ben, míg 'MP' fajtánál 2011-ben és 2012-ben volt a legmagasabb.

A virágritkítás hatását vizsgálva a nemesek a 3 évben és három érési stádiumban összesen az esetek 59,09\%-ában produkáltak magasabb fruktóz koncentrációt a gyümölcsökben a ritkított fákon a kontroll fákhoz képest, és mindezen mérések közül 65,39\% volt szignifikáns. A glükóz a virágritkítás hatására az esetek 65,91\%-ában mutatott magasabb értékeket a kontroll fákhoz viszonyítva, melyből 65,52\% volt szignifikáns. A szorbitol a virágritkított fákon az esetek 59,09\%ában mutatott magasabb koncentrációt, melyek közül 76,92\% volt szignifikáns.

A T3-as érési stádiumban (44. ábra) a legnagyobb különbség ritkított és kontroll fák fruktóz koncentrációja között a 'H222' fajtánál volt megfigyelhető 2010-ben: a ritkított fák gyümölcseiben 34,4\%-kal volt magasabb a fruktóz érték a kontroll fák gyümölcseihez képest, a többi évben viszont nem tudtunk szignifikáns különbséget kimutatni. Egy másik kiemelkedő különbség a 'BBVG' fajtánál volt megfigyelhető: 2010-ben 7,0\%-kal, 2011-ben 16,07\%-kal, 2012-ben 16,09\%-kal volt magasabb a fruktóz koncentráció a ritkított fákon, tehát ez a fajta évjárattól függetlenül mindig viszonylag magas értéket mutatott a ritkított fáknál a kontroll fákhoz képest.

A glükóz koncentrációjának változása a fruktózéhoz hasonló tendenciát mutatott a ritkított és kontroll fák összehasonlításában: a ritkított fák gyümölcsében a 'H222' fajtánál 2010-ben 32,12\%-kal, míg a 'BBVG' fajtánál 2011-ben 18,84\%-kal volt magasabb a glükóz koncentráció, de a többi évben egyik fajtánál sem volt szignifikáns különbség. A szorbitol koncentrációja a ritkított fák gyümölcseiben a kontroll fákhoz képest a 2010-ben a 'H222' fajtánál 90,78\%-kal volt magasabb, de 2011-ben ezzel teljesen ellentétes eredményt kaptunk: a kontroll fák szorbitol koncentrációja volt magasabb 41,1\%-kal (2012-ben nem volt szignifikáns különbség). A 2011 -es év másik két cseresznyefajta gyümölcseinek szorbitol koncentrációjában is nagy különbséget hozott a ritkítástól függően: a 'BMS' fajta 46,96\%-kal, míg a 'MP' fajta 40,54\%-kal mutatott magasabb koncentrációt a kontroll fákon.

Összességében a három év T3-as érési stádiumának eredményei alapján (44. ábra) elmondható, hogy szignifikánsan a legmagasabb fruktóz, glükóz és szorbitol koncentrációt is a ritkított 'H222' fajtánál $(87,99 \pm 0,48,102,28 \pm 0,60$ és $23,60 \pm 0,12 \mathrm{mg} / \mathrm{ml})$, míg a legalacsonyabbat a kontroll és ritkított BMS' fajtánál (fruktóz: 50,45 $\pm 0,22$ és 53,25 $\pm 0,26 \mathrm{mg} / \mathrm{ml}$; glükóz: $55,53 \pm 0,28$ és $58,60 \pm 0,32 \mathrm{mg} / \mathrm{ml}$; szorbitol: 7,13 $\pm 0,07$ és $8,14 \pm 0,06 \mathrm{mg} / \mathrm{ml})$ kaptuk 2010-ben. 


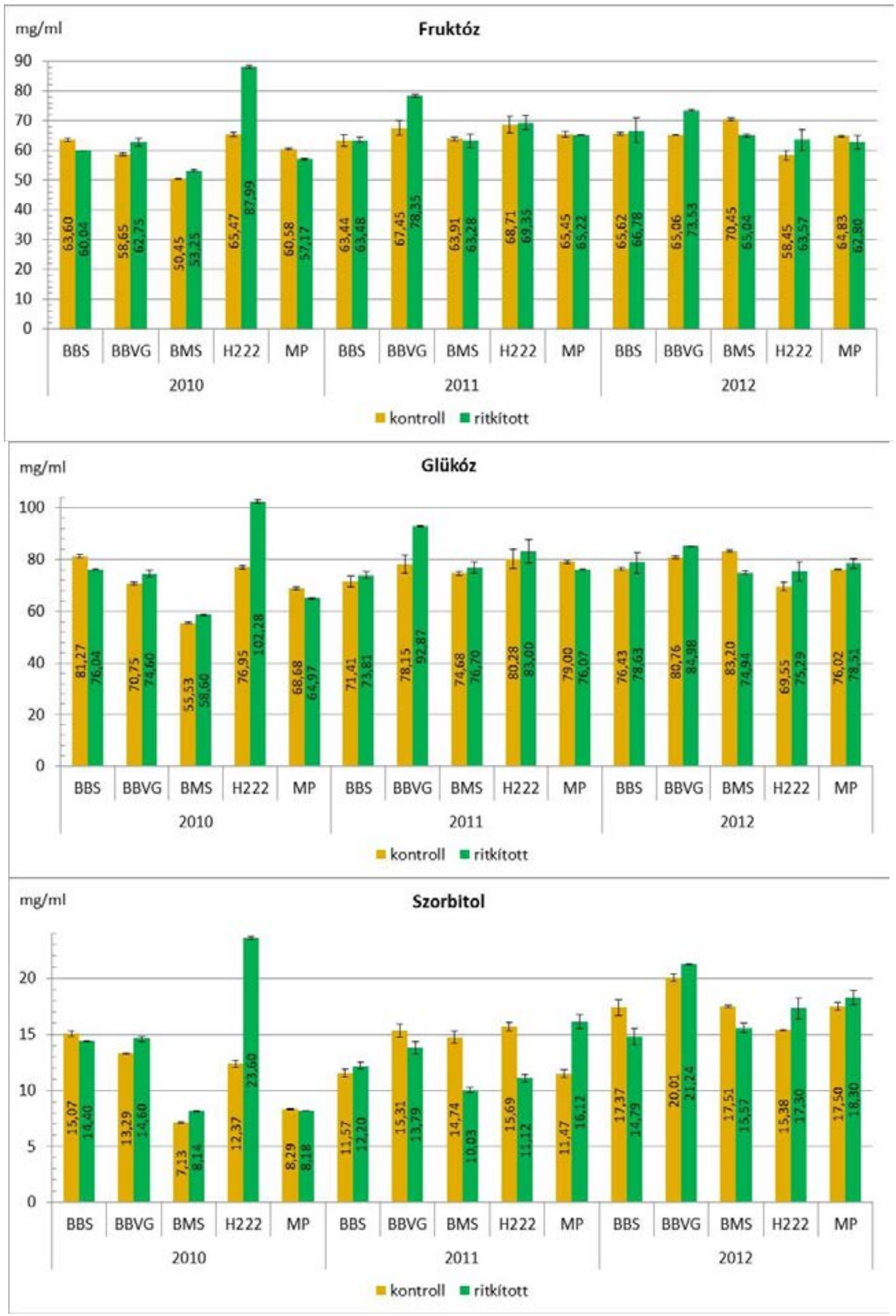

44. ábra: Virágritkított és kontroll cseresznyefajták gyümölcseiben az egyedi cukorkomponensek (fruktóz, glükóz, szorbitol) koncentrációja T3-as érési stádiumban 2010 és 2012 között 


\subsubsection{Savfrakciók}

A Q26 cseresznyeültetvény 5 különböző nemes fajtájának gyümölcseiben mértük az egyedi savkomponensek (almasav, borostyánkősav, citromsav) koncentrációját 3 egymást követő évben (2010-2012) virágritkított és kontroll fákon, majd azokból totál kromatográfiás savtartalmat (TKS) számoltunk. A Melléklet 33. táblázata tartalmazza az eredmények összesítését.

Az egyedi savkomponenseket vizsgálva összességében elmondható, hogy a Q26 ültetvény cseresznyegyümölcseiben (is) szignifikánsan a legmagasabb az almasav koncentrációja, azt követi a borostyánkősav, majd a citromsav. Bár évenként és alany-nemes koncentrációnként kisebbnagyobb különbség előfordulhat, az érett cseresznye almasav koncentrációja átlagosan 2,63-5,97 $\mathrm{mg} / \mathrm{ml}$, borostyánkősav koncentrációja 0,37-1,94 mg/ml, a citromsav koncentrációja pedig 0,3$1,21 \mathrm{mg} / \mathrm{ml}$ között mozgott, míg az összes kromatográfiás savtartalom 3,25-8,85 mg MAE/ml között változott.

Az érési terminusok eredményeit összevetve kiderül, hogy évtől és a ritkítás alkalmazásától függetlenül a cseresznye gyümölcsök mindhárom egyedi savkomponensének koncentrációja szignifikánsan nő az érés elörehaladtával $(\mathrm{T} 1 \rightarrow \mathrm{T} 2 \rightarrow \mathrm{T} 3)$ : az almasav koncentrációja az esetek 80,0\%-ában (ezek közül 66,67\% monoton), a borostyánkősav koncentrációja az eredmények 66,67\%-ánál (ebből 45,0\% monoton), míg a citromsav koncentrációja az esetek 73,33\%-ánál (melyböl 68,18\% monoton).

Az öt fajtát összehasonlítva a T3-as érési stádiumban (45. ábra) a gyümölcsök egyedi savkomponenseinek koncentrációja minden évben a 'BBVG' és a 'H222' fajtáknál volt a legmagasabb, míg a legalacsonyabb savkoncentrációt a legtöbb esetben a 'MP' fajtánál tapasztaltuk.

Az éveket összehasonlítva a T3-as érési stádiumban (45. ábra) mindhárom savkomponens koncentrációja 2012-ben volt a legmagasabb, míg 2010-ben a legalacsonyabb, bár a 'BBVG' és 'H222' fajták kevésbé voltak érzékenyek az évjárathatásra: mindkét fajta jó eredményeket produkált almasav és borostyánkősav koncentráció tekintetében 2010-ben is (szignifikáns különbség nem volt tapasztalható a 2010-es és 2011-es év eredményei között).

A virágritkítás hatását vizsgálva a nemesek a 3 évben és három érési stádiumban összesen az esetek 56,82\%-ában produkáltak magasabb almasav koncentrációt a gyümölcsökben a ritkított fákon a kontroll fákhoz képest, és mindezen mérések közül 56,0\% volt szignifikáns. A borostyánkősav a virágritkítás hatására az esetek 55,81\%-ában mutatott magasabb értékeket a kontroll fákhoz viszonyítva, melyből 50,0\% volt szignifikáns. A citromsav a virágritkított fákon az esetek 65,12\%-ában mutatott magasabb koncentrációt, melyek közül azonban csak 39,3\% volt szignifikáns. 

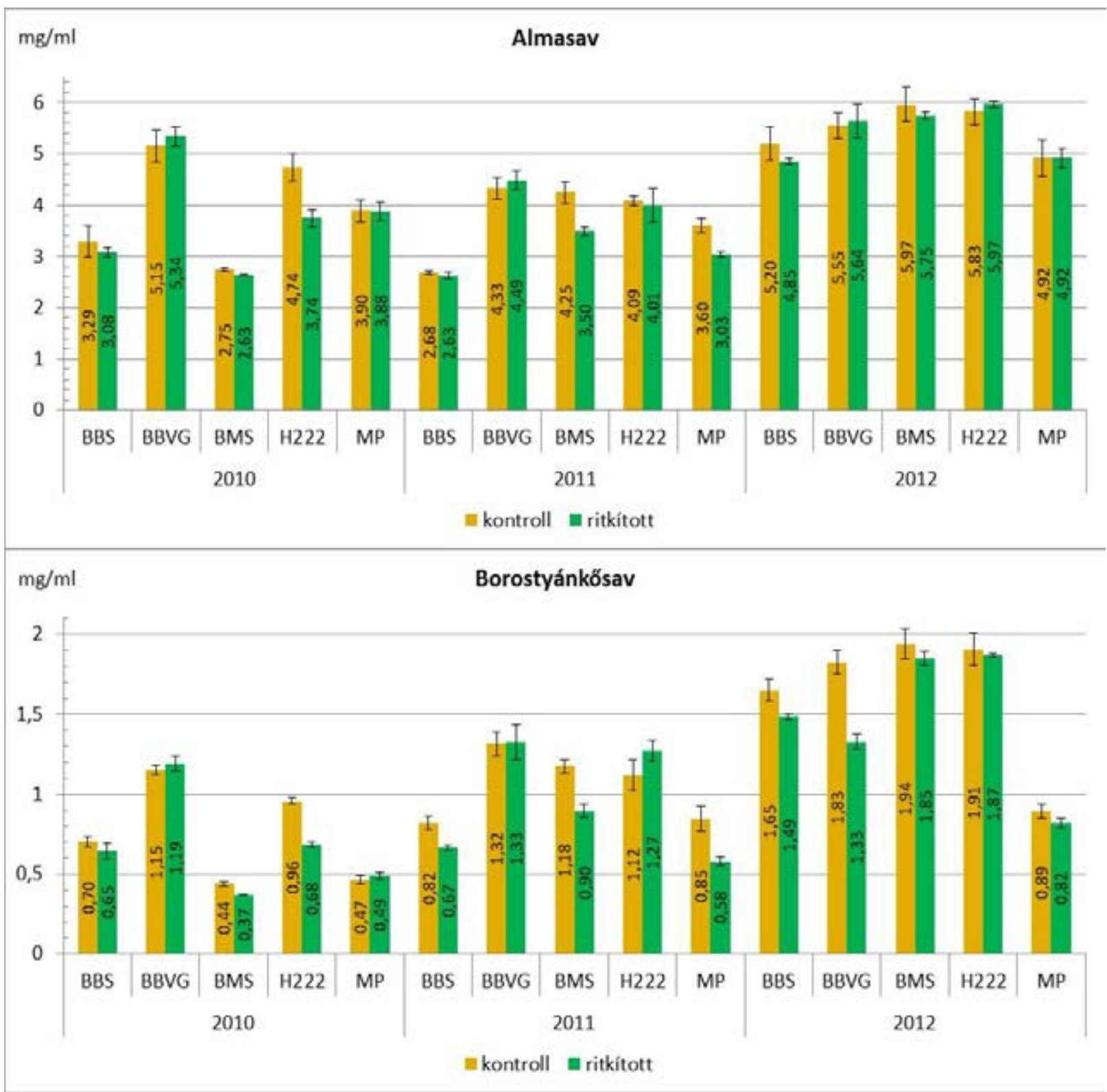

$\mathrm{mg} / \mathrm{ml} \quad$ Citromsav

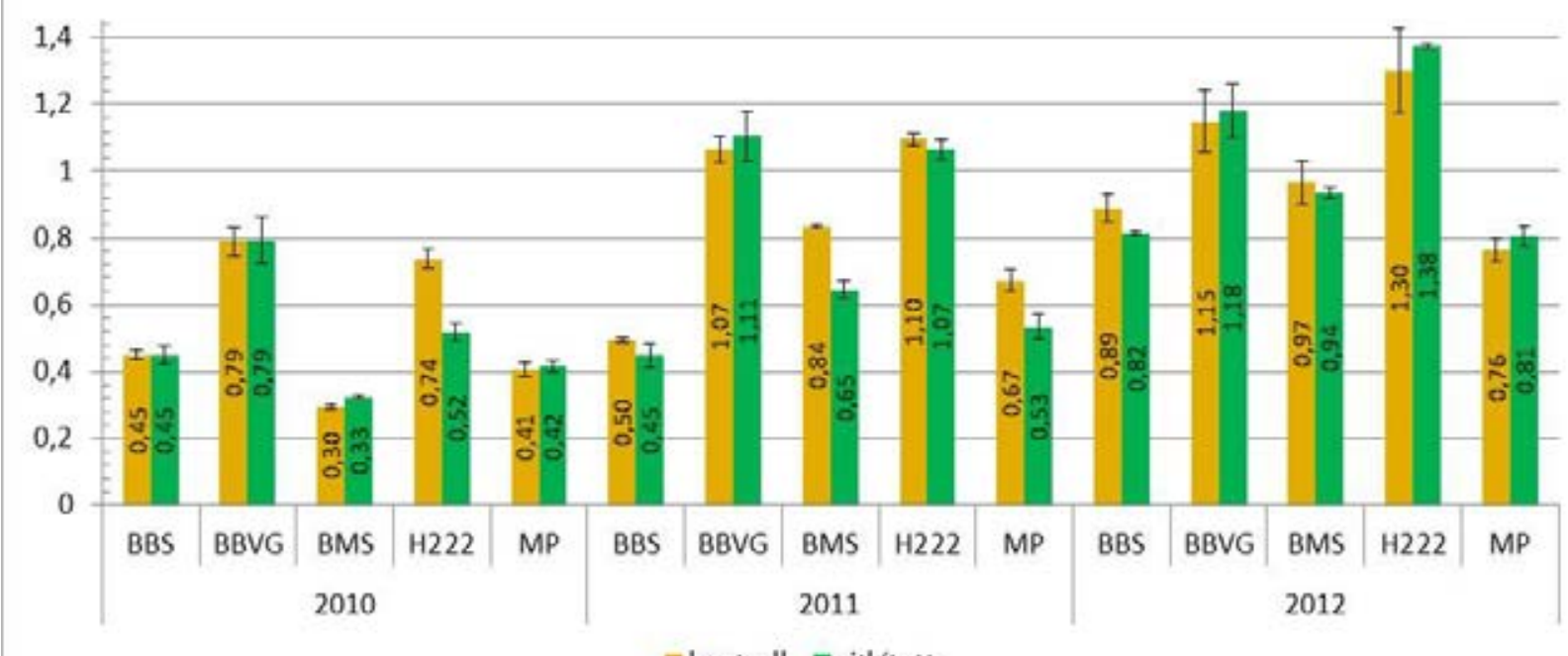

= kontroll $\equiv$ ritkított

45. ábra: Virágritkított és kontroll cseresznyefajták gyümölcseiben az egyedi savkomponensek (almasav, borostyánkősav, citromsav) koncentrációja T3-as érési stádiumban 2010 és 2012 között 
A T3-as érési stádiumban (45. ábra) esetenként igen nagy különbség mutatkozott a virágritkított és a kontroll fák almasav koncentrációja között bizonyos fajtáknál (a kontroll fák javára!), de ez a különbség mindenhol csak egy évjáratban mutatkozott, a többi évben elhanyagolható volt.

A három féle savkomponens mindegyike nagy koncentráció-különbséggel reagált a 'H222' fajta esetében 2010-ben: az almasav 26,74\%-kal, a borostyánkősav 41,18\%-kal, míg a citromsav 42,31\%-kal volt magasabb a kontroll fákon a ritkított képest. Ezen kívül a borostyánkősav és a citromsav koncentráció-különbsége 2011-ben magasabbnak mutatkozott a kontroll BMS (31,11\% és $29,23 \%$ ) és 'MP' fajtáknál $(46,55 \%$ és $26,42 \%)$ is a ritkítottakhoz viszonyítva. Szintén viszonylag nagy különbséget mutatott a borostyánkősav koncentrációjában a kontroll 'BBVG' fajta 2012-ben $(37,59 \%)$.

Összességében a három év T3-as érési stádiumának eredményei alapján (45. ábra) elmondható, hogy szignifikánsan a legmagasabb almasav és borostyánkősav koncentrációt a kontroll 'BMS' (5,97 \pm 0,34 és 1,94 $\pm 0,09 \mathrm{mg} / \mathrm{ml})$, valamint a ritkított 'BMS' fáknál, továbbá kontroll 'H222' (5,83 $\pm 0,25$ és 1,91 $\pm 0,10 \mathrm{mg} / \mathrm{ml})$ és ritkított 'H222' $(5,97 \pm 0,06$ és 1,87 $\pm 0,01$ $\mathrm{mg} / \mathrm{ml}$ ) fajtáknál mértük 2012-ben. A citromsav koncentráció szintén a kontroll és ritkított 'H222' fajta esetében volt a legmagasabb 2012-ben (1,30 $\pm 0,13$ és 1,38 $\pm 0,01 \mathrm{mg} / \mathrm{ml})$. A legalacsonyabb almasav, borostyánkősav és citromsav koncentráció értékeket a kontroll 'BMS' $(2,75 \pm 0,03,0,44$ $\pm 0,01$ és $0,30 \pm 0,01 \mathrm{mg} / \mathrm{ml})$, valamint a ritkított 'BMS' $(2,63 \pm 0,01,0,37 \pm 0,00$ és $0,33 \pm 0,01$ $\mathrm{mg} / \mathrm{ml}$ ) fajtánál mértük 2010-ben. Az almasav ezeken túlmenően alacsony értéket mutatott a kontroll és ritkított 'BBS' fáknál is 2011-ben (2,68 $\pm 0,02$ és 2,63 $\pm 0,06 \mathrm{mg} / \mathrm{ml})$.

\subsubsection{Polifenol-frakciók}

A Q26 cseresznyeültetvény 5 különböző nemes fajtájának gyümölcseiben az egyedi polifenolkomponensek (cianidin, kvercetin, rutin, klorogénsav, neoklorogénsav, epikatechin, kínasav) koncentrációját 2 egymást követő évben (2011-2012) mértük, majd azokból totál kromatográfiás polifenol-tartalmat (TKPF) számoltunk. A Melléklet 34. táblázata tartalmazza az eredmények összesítését.

Méréseink alapján a Q26 cseresznyeültetvényből származó gyümölcsök egyedi polifenolkomponensei gyümölcsszíneződés kezdetén (T1 érési stádium) az alábbi sorrendbe állíthatók fel koncentrációjuk alapján (legelöl a legmagasabb koncentrációjú): 1. neoklorogénsav, 2. cianidin, 3. kínasav, 4. klorogénsav, 5. kvercetin, 6. rutin, 7. epikatechin. Ezzel szemben a T3-as érési stádiumra kicsit átalakul a sorrend: 1. cianidin, 2. neoklorogénsav, 3. kínasav, 4. klorogénsav, 5. rutin, 6 kvercetin, 7. epikatechin (tehát az érés elörehaladtával helyet cserél a neoklorogénsav a cianidinnel, valamint a kvercetin a rutinnal).

Bár évenként és fajtánként kisebb-nagyobb eltérések előfordultak, a Q26 ültetvényből származó érett cseresznye cianidin koncentrációja átlagosan 292,52-1201,31 mg/kg, a neoklorogénsavé 108,47-943,04 mg/kg, kínasavé 31,48-288,31 mg/kg, klorogénsavé 31,19- 
$119,63 \mathrm{mg} / \mathrm{kg}$, a rutiné $16,12-49,15 \mathrm{mg} / \mathrm{kg}$, kvercetiné 7,64-42,04 mg/kg, az epikatechiné pedig 8,33-36,75 mg/kg között mozgott. Az összes kromatográfiás polifenol-tartalom átlagosan 555,33$2536,27 \mathrm{mg} / \mathrm{kg}$ között változott.

$\mathrm{Az}$ érési terminusok eredményeit összevetve láthatjuk, hogy az egyedi polifenolkomponensek koncentrációja az érés előrehaladtával $(\mathrm{T} 1 \rightarrow \mathrm{T} 2 \rightarrow \mathrm{T} 3)$ különböző irányba változott. A cianidin, a klorogénsav, a kínasav és a rutin koncentrációja az érés során szignifikánsan nőtt: a cianidin az esetek 100\%-ában (ebből mind monoton), a klorogénsav az esetek 95\%-ában (melyekböl 61,11\% volt monoton), kínasav az esetek 90\%-ában (ebből 44,44 \% volt monoton), a rutin az esetek 85\%-ában (ebből 44,44\% volt monoton). Ezzel szemben a neoklorogénsav, az epikatechin és a kvercetin koncentrációja az érés elörehaladtával szignifikánsan csökkent: a neoklorogénsav az esetek 100\%-ában (ebből 94,44\% volt monoton), az epikatechin az esetek 60\%ában (ebböl 33,33\% volt monoton), a kvercetiné pedig az esetek 65\%-ában (ebböl 39,89\% volt monoton). Az összes kromatográfiás polifenol-tartalom az érés során az esetek 95\%-ában szignifikánsan nött (ezek közül 33,33\% volt monoton).

Az öt fajtát összehasonlítva a T3-as érési stádiumban (Melléklet 53. ábra) a gyümölcsök egyedi polifenol-komponenseinek koncentrációja az esetek 71,43\%-ában a 'BMS' fajtán volt szignifikánsan magasabb (azon belül is többször a kontroll fán), de a komponensek között évjáratonként különbségek mutatkoztak. A cianidin és a kínasav koncentrációja 2011-ben a 'BMS' fajta, 2012-ben pedig a 'BMS' és a kontroll 'BBVG' fajta gyümölcseiben, míg az epikatechin koncentrációja mindkét évben a 'BMS' fajta gyümölcseiben volt a legmagasabb. A neoklorogénsav koncentrációja 2011-ben és 2012-ben a 'BBVG' és 'H222' fajták gyümölcseiben volt a legmagasabb, de 2011-ben a 'BMS' fajta is az első helyre került. A klorogénsav koncentrációja 2011-ben a kontroll 'H222' fajta gyümölcseiben, 2012-ben pedig a 'H222' és a kontroll 'MP' gyümölcseiben volt a legmagasabb. 2011-ben a rutin és a kvercetin koncetrációja is a 'BMS' fajtán volt a legmagasabb, míg 2012-ben a rutin a kontroll 'BMS' fán, a kvercetin pedig a kontroll 'BBVG' fán.

Az éveket összehasonlítva a T3-as érési stádiumban (Melléklet 53. ábra) általánosságban elmondható, hogy a gyümölcsök 7 egyedi polifenol-komponenséböl 6-nak (cianidin, epikatechin, neoklorogénsav, klorogénsav, kínasav és kvercetin) a koncentrációja együtt változott az évjárat függvényében: mind az öt fajta esetén a 2012-es évben volt magasabb, bár a különbség nem minden esetben volt szignifikáns (egyetlen kivétel a kvercetin esetében a 'BMS' fajtánál volt megfigyelhetö, ott a 2011-es évben volt magasabb a koncentráció). A rutin koncentrációja a többi polifenoltól eltérően a 2011-es évben volt magasabb.

A virágritkítás hatását vizsgálva a T3-as érési stádiumban (Melléklet 53. ábra) a különböző polifenol-komponensek eltérően reagáltak: az epikatechin, a neoklorogénsav és a kínasav koncentrációja általában a virágritkított fák gyümölcseiben volt magasabb, míg a cianidin, a klorogénsav, a rutin és a kvercetin koncentrációja a kontroll fák gyümölcseiben. Az epicatechin 
a virágritkítás hatására az esetek 57,9\%-ában mutatott magasabb koncentráció-értékeket a kontroll fákhoz viszonyítva, melyből 73,68\% volt szignifikáns, míg a neoklorogénsav és a kínasav az esetek 60\%-ában mutatott magasabb koncentrációt virágritkítás hatására, melyeknél 66,67\% volt szignifikáns. A cianidin és a klorogénsav koncentrációja a kontroll fák gyümölcseiben az esetek $56,67 \%$-ában mutatott magasabb értéket a virágritkított fákhoz képest, melyből cianidin esetén $76,47 \%$, klorogénsav esetén $64,71 \%$ volt szignifikáns.

A rutin a kontroll fákon az esetek 75,33\%-ában mutatott magasabb értékeket a virágritkított fákhoz viszonyítva, és ebből 68,18\% volt szignifikáns, a kvercetin pedig az esetek 76,67\%-ában mutatott magasabb értékeket a kontroll fákon, melyből $65 \%$ volt szignifikáns.

A virágritkítás hatását vizsgálva $\mathrm{T} 3$-as érési stádiumban az öt fajta gyümölcseinek különböző polifenol-komponenseire eltérő eredményeket kaptunk. A 'BBS' fajtát vizsgálva az esetek 71,43\%-ában a ritkított fák gyümölcseiben találtuk a magasabb polifenol-koncentrációkat: a cianidin, a klorogénsav és a rutin koncentrációja mindkét évben a ritkított fákon volt magasabb, a többi polifenolé csak az egyik évben. A 'BMS' fajta ezzel szemben az esetek 92,86\%-ában a kontroll fák gyümölcseinél produkálta a magasabb értékeket: mind a 7 komponens koncentrációja mind a két évben a kontroll fákon volt magasabb (egyetlen kivétel a klorogénsav 2010-ben). A 'BBVG' és a 'MP' fajtáknál az esetek 50-50\%-ában találtunk magasabb polifenol-koncentrációt a virágritkított és a kontroll fákon: epikatechin, neoklorogénsav és kínasav esetén mindkét évben a ritkított fák gyümölcseiben találtuk a magasabb koncentráció-értéket, cianidin esetében csak az egyik évben, míg a többi komponens esetében mindkét évben a kontroll fák koncentráció-értékei bizonyultak magasabbnak. A 'H222' esetében a kontroll fák eredményeit találtuk jobbnak: az esetek 64,25\%-ánál mutattak magasabb polifenol-koncentrációkat a kontroll fákon, de a komponensek közül csak a cianidin és a rutin értékei voltak mindkét évben magasabbak, a többi komponensnél csak az egyik év eredményezett magasabb koncentrációkat a kontroll fákon.

A különböző polifenol-komponensek koncentrációját összehasonlítva a ritkított és a kontroll fák között néhány esetben kiemelkedö különbséget találtunk (Melléklet 53. ábra). A kvercetin koncetráció-különbsége a 'BMS' fajta fáinak gyümölcsei között 42,21-75,53\% volt a kontroll javára. A klorogénsav koncentrációja 20,0-55,43\%-kal volt magasabb a kontroll fákon a 'MP' fajtánál. A cianidin koncentráció a 'H222' fajta esetében a kontroll fáknál volt magasabb 16,5349,67\%-kal, ezzel szemben a 'BBS' fajtánál 16,33-27,16\%-kal a ritkított fák gyümölcseinek koncentráció-értéke bizonyult magasabbnak. Az epicatechin koncentrációja a 'MP' fajta esetében 14,23-51,85\%-kal, míg a neoklorogénsav koncentrációja a 'BBVG' esetében 10,42-37,5\%-kal mutatott magasabb értékeket a ritkított fákon. A rutin koncentrációja a kontroll fákon 22,9233,85\%-kal volt magasabb. A kínasav koncentráció-értéke 'BMS' fajta esetében 13,14-27,75\%kal volt magasabb a kontroll fák gyümölcseiben a ritkított fák gyümölcseihez képest.

Összességében a két év T3-as érési stádiumának eredményei alapján (Melléklet 53. ábra) elmondható, hogy a legmagasabb cianidin koncentrációt a kontroll és ritkított 'BBVG' (1187,3 \pm 
102,1 és $1168,4 \pm 38,4 \mathrm{mg} / \mathrm{kg}$ ), valamint a kontroll 'BMS' (1201,3 $\pm 23,5 \mathrm{mg} / \mathrm{kg}$ ) fajtánál mértük 2012-ben, míg a legalacsonyabb értéket a kontroll és virágritkított 'BBS' fajta eredményezte 2011ben $(292,5 \pm 19,6$ és $372,3 \pm 17,5 \mathrm{mg} / \mathrm{kg})$. Az epikatechin koncentrációja a kontroll és ritkított 'BMS' fajtánál volt a legmagasabb 2012-ben (36,75 $\pm 0,99$ és 35,68 $\pm 0,01 \mathrm{mg} / \mathrm{kg})$, míg a legalacsonyabb koncentrációt a kontroll 'H222' fáknál 2012-ben (8,33 $\pm 0,20 \mathrm{mg} / \mathrm{kg})$, valamint a ritkított 'H222' fáknál 2011-ben $(8,40 \pm 0,11 \mathrm{mg} / \mathrm{kg})$ mértük. A neoklorogénsav koncentrációja a kontroll és ritkított 'BBVG' fáknál $(854,0 \pm 3,7$ és 943,0 $\pm 12,5 \mathrm{mg} / \mathrm{kg})$, valamint a ritkított 'H222' fáknál $(907,5 \pm 35,0 \mathrm{mg} / \mathrm{kg})$ volt a legmagasabb 2012-ben, míg a legalacsonyabb értéket a kontroll 'BBVG' produkálta 2011-ben (302,0 \pm 13,6 mg/kg). 2012-ben mértük a legmagasabb klorogénsav koncentrációkat a kontroll és ritkított 'H222' (109,31 $\pm 1,02$ és 119,63 $\pm 11,47$ $\mathrm{mg} / \mathrm{kg}$ ), valamint a kontroll 'MP' fákon (110,28 \pm 4,84 mg/kg), míg 2011-ben a legalacsonyabbakat kontroll és virágritkított 'MP' fák gyümölcseiben $(37,43 \pm 1,60$ és 31,19 \pm $1,52 \mathrm{mg} / \mathrm{kg})$. A kínasav koncentrációja a ritkított 'BBVG' $(283,51 \pm 10,74 \mathrm{mg} / \mathrm{kg})$ és a kontroll 'BMS' fákon (288,31 \pm 12,32 mg/kg) volt a legmagasabb 2012-ben, míg a ritkított 'BBS' fákon a legalacsonyabb 2011-ben $(31,48 \pm 2,47 \mathrm{mg} / \mathrm{kg})$. A legmagasabb rutin és kvercetin koncentrációt a kontroll 'BMS' fákon mértük 2011-ben (49,15 $\pm 1,32$ és 42,04 $\pm 2,68 \mathrm{mg} / \mathrm{kg})$, míg a legalacsonyabbat ritkított 'MP' fákon, méghozzá rutin esetében 2012-ben (16,12 $\pm 1,41 \mathrm{mg} / \mathrm{kg})$, kvercetin esetében pedig 2011-ben (7,64 $\pm 0,02 \mathrm{mg} / \mathrm{kg})$. 


\section{EREDMÉNYEK ÉRTÉKELÉSE, KÖVETKEZTETÉSEK}

Kutatásaink négy éve alatt több mint 55.000 mérési adatot gyüjtöttünk és dolgoztunk fel annak érdekében, hogy megállapítsuk, milyen hatással van a cseresznye gyümölcs minőségi paramétereire - többek között - az alany, a nemes, vagy a virágritkítás. Összefüggéseket, szabályszerüségeket, tendenciákat kerestünk, amelyek alapján rangsorolni lehet az alanyokat, a nemeseket és a technológiát (értsd: virágritkított vs. kontroll fa).

Az eredményeket összességében szemlélve az egyik legfontosabb következtetés az, hogy egyetlen év adataiból lehetetlen a gyümölcsök minőségi paramétereit elöre jelezni. Az évjárathatás - amely magában foglal számtalan ismert és ismeretlen, nem kontrollálható faktort nagymértékben befolyásolja a gyümölcsfák viselkedését, amelynek következményeként az egyik évben érvényes tendenciák a következő évben gyakran megfordulnak.

Ez lehet az egyik fö oka annak a jelenségnek, amit az irodalmi áttekintésben a citromsav kapcsán említettünk, miszerint a számszerü szakirodalmi adatok között időnként extrém nagy eltérések tapasztalhatók, máskor pedig független kutatók fordított irányú trendeket figyelnek meg. Ez utóbbira példa, hogy az összes titrálható savtartalom a cseresznye gyümölcsben az érés folyamán MAHMOOD et al. (2012a), WANI et al. (2014) és AGULHEIRO-SANTOS et al. (2012) szerint növekszik, TUDELA et al. (2005), ZHANG et al. (2008) és FICZEK (2012) szerint viszont csökken.

A gyümölcsparaméterek ily nagyfokú változékonysága felértékeli a stabilitást és a kiszámíthatóságot, és a gyümölcsfa egyik legfontosabb tulajdonságává az lép elő, hogy mennyire tud független maradni a környezeti hatásoktól. Ez a képesség várhatóan különösen értékes lesz a jövőben, mivel a globális klímaváltozás hatására nagyon különbözö időjárású évek váltják egymást, melyek között egyértelmü különbségek láthatók terméshozam és termésminőség szempontjából (CHMiELEwSKi et al. 2004, MENZEL et al. 2006). Ennek megfelelően értékelésünkben kiemelt figyelmet fordítottunk arra, hogy az adatok hagyományos szempontok (pl. melyik gyümölcs nagyobb, keményebb, sötétebb színü, ízletesebb, melyik tartalmaz több polifenolt) szerinti elemzése közben megvizsgáljuk, melyik alany-nemes kombináció függ legkevésbé az évjárathatástól.

A másik fontos következtetés az, hogy nincs „legjobb alany”, „legjobb nemes”, „legjobb technológia”. Még ha csak adott éven belül nézzük is az eredményeket, gyakran előfordul, hogy a gyümölcs egyik elönyös tulajdonságát az egyik alany domborítja ki legjobban, a másikat a másik, és ilyenkor mérlegelni kell, melyik tulajdonság ér többet. Ezt a mérlegelést csak a felhasználás céljának ismeretében lehet elvégezni (ROMANO et al. 2006, KADER 1999). A friss piacra termelő gazdának a gyümölcsméret és a szín az elsődlegesek, a házikerti termesztésben elötérbe kerülnek a tápérték és az egészségvédő hatások is, a feldolgozóipari célokra termelőknek pedig inkább az számít, hogy a gyümölcs megfeleljen a vonatkozó szabványban elöírt minimumnak, és ez párosuljon minél magasabb terméshozammal. Az egyes alanyok, nemesek, technológiák komplex 
értékelésénél tehát a felhasználás céljától függően súlyozni kell a minőségi paraméterekre gyakorolt kedvező hatást.

A következő fejezetekben bemutatjuk az alanyok, nemesek, technológiák összehasonlító elemzését. Elöljáróban megjegyzendő, hogy az elemzéseket általában a T3-as érési terminus adatai alapján végeztük, lévén hogy ez az az állapot, amely piaci szempontból a legfontosabb. Az ettől való eltérést külön jelezzük. Az alanyok hatásának tekintetében a 'Regina' és a 'Kordia' tendenciái általában nem teljesen egységesek, ezért a két nemest rendszerint külön tárgyaljuk.

\subsection{Gyümölcsök fizikai tulajdonságainak összehasonlító értékelése}

\subsubsection{Gyümölcsméretek, gyümölcstérfogat}

A méret az egyik legkézzelfoghatóbb tulajdonsága a cseresznye gyümölcsnek. Jelentősége a gyümölcs fogyasztói megítélésében a társadalmi háttértől függ, így például egy japán felmérés szerint csak kis súllyal esik latba a vásárlói döntésekben (DEVER et al. 1996), míg az európai típusú társadalmakban (pl. Európa, USA) a legtöbb esetben a fogyasztók számára elsődleges fontosságú a méretparaméter (TURNER et al. 2008).

\subsubsection{Q10 ültetvény}

A nemes fajtákat összehasonlítva elmondhatjuk, hogy a 'Regina' többéves átlagban nagyobb gyümölcsöket terem, mint a 'Kordia', és minden pozitív méretrekord a Reginához köthető. Méréseinket a szakirodalom is megerősíti: LONG et al. (2005) szintén nagyobb méretü gyümölcsöket talált a 'Regina' fajtán (legnagyobb átmérö: 31,0 mm) a 'Kordia' fajtához (legnagyobb átmérő: 29,1 mm) képest. Mi valamivel alacsonyabb értékeket mértünk, de az arányok nagyjából megegyeznek ('Regina': 28,01 mm, ill. 8,74 cm³; 'Kordia': 26,5 mm, ill. 7,97 $\left.\mathrm{cm}^{3}\right)$.

Ugyanakkor az adatokból az is látszik, hogy a 2012-es évben a 'Regina' gyümölcsök méretparaméterei minden szempontból messze alulmúlták az átlagokat, ezáltal a negatív méretrekordok is hozzá kapcsolhatók (20,42 mm). Ebből azt a következtetést vonhatjuk le, hogy a 'Regina' érzékenyebb az évjárathatásra. Így tehát annak, aki stabilan 6-8 $\mathrm{cm}^{3}$ közötti térfogatú cseresznyékre számít, a 'Kordia' fajta a jó választás. Aki inkább 7-9 cm³ közötti méreteket szeretne, és ezért cserébe vállalja annak kockázatát, hogy a gyümölcstérfogat időnként $5 \mathrm{~cm}^{3}$ alá is eshet, a 'Regina' fajtát ajánljuk.

Az alanyhatást vizsgálva a szakirodalmi adatokkal megegyezően szignifikáns különbséget tudtunk kimutatni a gyümölcsök méretére (AĞLAR és YILDIZ 2014, GADŽE et al. 2010, SzOT és MELAND 2001). Ha az alanyok egymáshoz viszonyított teljesítményét vizsgáljuk, a 'Kordia' esetében megállapítható, hogy a 'GiSelA 6' két évben, a 'GiSelA 5', a 'PHL-C' és a 'Weiroot 158' alanyok pedig egy-egy évben haladták meg szignifikáns mértékben az öt alany átlagát, a 'PiKu-1' ellenben sosem tudott kiemelkedni a mezőnyből. Így tehát - adataink alapján - a legnagyobb 
gyümölcsméretek elérésének 'Kordia' nemesen a 'GiSelA 6' alannyal kombinálva legnagyobb a valószínüsége, a 'PiKu-1' alany pedig a legkevésbé ajánlható. A 'GiSelA 6' egyik évben sem tért el jelentős mértékben negatív irányba az öt alany átlagától, ezért kijelenthetjük, hogy az évjárathatás nem rejt nagyobb kockázatokat a 'GiSelA 6'-ra, mint a többi alanyra nézve.

ROBINSON és HOYING (2005) 11 éves vizsgálatukban a 'Hedelfingeni óriás' fajta gyümölcsméretét hasonlította össze 3 különböző alanyon, melyek közül eredményeik alapján szintén a 'GiSelA 6' alanyon álló fák gyümölcsei bizonyultak a legnagyobbnak (míg a 'GiSelA 5' alanyon álló fák gyümölcsei a legkisebbnek). Mi 'Kordia' fajtára vonatkozóan bizonyítottuk ugyanezt.

A 'Regina' nemes adatait hasonló módszerrel elemezve arra jutottunk, hogy a 'GiSelA 6', a 'PHL-C' és a 'Weiroot 158' alanyokon nagyobb valószínüséggel lesznek nagyobb méretü gyümölcsök. A három közül is a 'PHL-C' hozta a legmagasabb átlagos gyümölcstérfogatokat, azonban a térfogatmérés viszonylag nagy szórása miatt nem tehető közöttük statisztikailag egyértelmü különbség. Az viszont kijelenthető, hogy méret tekintetében a 'PiKu 1' alany az, amely a legkevésbé ajánlható. Az éves átlagok relatív szórása a három ajánlott alany közül a 'Weiroot 158' esetében a legkisebb, tehát az évjárathatásból adódó becsült kockázatok is itt a legkisebbek. A szakirodalomban eddig nem találtunk erre vonatkozó megállapítást 'Regina' fajta esetében.

Az általunk vizsgált alany-nemes kombinációk esetében ebben a témában mindezidáig nem találtunk szakirodalmi forrást.

\subsubsection{Q26 ültetvény}

Az öt nemes fajta T3-as érési stádiumú gyümölcseinek összehasonlításából megállapítható, hogy a 'BBVG', a 'H222' és a 'MP' mindhárom vizsgált évben gyakorlatilag egyforma méretü cseresznyéket hozott (3 éves átlag: 22,06-22,72 mm). A 'BBS' és a 'BMS' három évből kettőben kiemelkedett a mezőnyből, és a 3 év átlagában a legnagyobb gyümölcsöket produkálták $(22,94$ $24,38 \mathrm{~mm}$ ). Ez a kiemelkedés egyben azt is jelenti, hogy ez a két nemes a legérzékenyebb az évjárathatásra, viszont az ezzel járó kockázat minimális, hiszen a leggyengébb évben sem múlták alul a három gyengébben teljesítő fajtát.

OSBORNE (2008) öt féle őszibarackfajta esetén ('Babygold 5', 'Redhaven', 'Zee Lady', 'Arkansas 9', 'Rising Star') igazolta a virágritkítás pozitív hatását a gyümölcsök méretére. STOVER et al. (2001) ugyanezt bizonyította az 'Empire' almafajta esetén. A cseresznye fajt vizsgálva a szakirodalomban eddig kevés eredmény látott napvilágot, és azok is ellentétes eredményeket közölnek. Whiting és LANG (2004) szerint a virágritkított 'GiSelA 5' alanyú 'Bing' cseresznyefák gyümölcseinek mérete szignifikánsan nagyobb a kontroll fák gyümölcseihez képest (kontroll: 24,8 mm, ritkított: 28,0 mm). VON BENNEWITZ et al. (2010) 'Lapins' fajta esetében bizonyította ugyanezt (kontroll: 22,3 mm, ritkított: 27,8 mm). CITTADINI et al. (2013) is hasonló eredményre jutott 'Lapins' fajta esetén, ugyanakkor 'Sweetheart' fajtánál már nem tudott 
szignifikáns különbséget kimutatni az említett paraméterre vonatkozóan, mint ahogyan SCHOEDL et al. (2009) és AYALA és ANDRADE (2009) sem saját vizsgálataik során (előbbi 'Blaze Star', 'Samba', 'Techlovan' és 'Merchant' fajtákat, utóbbi 'Lapins' fajtát vont be vizsgálataiba). Saját vizsgálataink alapján a virágritkítás cseresznyegyümölcsök méretére gyakorolt pozitív hatása mellett foglalunk állást, legalábbis a vizsgált fajtákat illetően.

A virágritkítás hatásáról elmondható, hogy azokban az esetekben, amikor a ritkított és kontroll fák gyümölcse között szignifikáns különbség van (az esetek 61,36\%-ában), akkor kivétel nélkül mindig a kezelt fa gyümölcse nagyobb méretü. T3-as érési fázisban a 3 év alatt átlagosan a fajták 46,7\%-a reagált nagyobb gyümölcsökkel a virágritkítási beavatkozásra. Valószínüsíthető, hogy az évjárathatás a virágritkítás hatását is befolyásolja, mivel 2012-ben a korábbi évekhez képest 37\%-kal emelkedett a pozitív reakciók mennyisége. Kitünik továbbá, hogy a nemesek közül a 'BMS' volt az egyetlen, amelyik következetesen minden évben pozitívan reagált a virágritkításra, a 'MP' háromból kétszer, a többi fajta csak egyszer.

A fentiek alapján az 5 nemes közül a 'BMS' fajta, azon belül is a virágritkított fák teljesítettek a legjobban. Ajánlható még a 'BBS' fajta is, ennél a fajtánál azonban már megkérdőjelezhető, hogy érdemes-e a virágritkítást alkalmazni.

Hasonló vizsgálatot az általunk vizsgálatba vont fajták esetében eddig még nem találtunk a szakirodalomban.

\subsubsection{Gyümölcs- és csontártömeg, hasznos gyümölcs arány}

\subsubsection{Q10 ültetvény}

A gyümölcstömegek elemzésekor a térfogatok eredményeivel analóg tendenciákat kaptunk. A fajták összehasonlításában ez azt jelenti, hogy a 'Regina' többéves átlagban nagyobb tömegü gyümölcsöket terem, mint a 'Kordia', és ezt LICHEV et al. (2004) is így találták ('Regina': 10,5 g, 'Kordia': 9,5 g).

Az alanyhatást vizsgálva a szakirodalommal megegyezően szignifikáns különbséget tudtunk kimutatni a gyümölcsök tömegére vonatkozóan (CANTín et al. 2010, GADŽE et al. 2010, GRATACós et al. 2008, GYEVIKI et al. 2008, LANAUSKAS et al. 2012, SiMON et al. 2004, SiTAREK és GRZYB 2010, VERCAMMEN és VANRYKEL 2014). Az alanyokat összehasonlítva a 'Kordia' fajta esetében gyümölcstömeg tekintetében továbbra is a 'GiSelA 6' alany bizonyult a legjobb választásnak, míg a 'PiKu 1' a legkevésbé jónak. Viszont - amint az a grafikonokon jelzett szórásokból is jól látszik - vizsgálataink szerint a gyümölcstömeg mérési bizonytalansága jóval kisebb, mint a méretparamétereké. Például a 'Kordia'-'GiSelA 6' kombináció 2011-ben: a térfogatmérés relatív szórása 11,1\%, míg ugyanez a tömegmérésnél csak 4,22\%. Ennek következtében az alanyok közötti különbségek hangsúlyosabbak lettek, mint a térfogatadatok elemzésekor. SiTAREK és GRZYB (2010) szintén 'Kordia' fajtát vizsgált 'GiSelA 5', 'Weiroot 158' és 'PHL-C' alanyokon, ők azonban nem tudtak szignifikáns különbséget kimutatni az alanyok 
között gyümölcstömegre vonatkozóan $(9,7$ g, 9,5 g, 9,5 g), adataik azonban a 2004-2010 közötti évekre vonatkoznak, lengyelországi körülmények között (Dabrowice). Ezzel szemben GRATACós et al. (2008) 'Lapins' és 'Bing' fajtákat vizsgálva arra jutott, hogy a 'GiSelA 6' alanyon álló fák gyümölcseinek tömege (9 és $12 \mathrm{~g}$ ) nagyobb a 'GiSelA 5' alanyú fák (7,9 és 11,8 g) gyümölcseihez képest (2003-2004, Chile). Közép-európai viszonylatban sikeresen bizonyítottuk ugyanezt 'Kordia' fajta esetében.

A méretparaméterekhez viszonyított kisebb relatív szórásoknak köszönhetően a 'Regina' nemes esetében már megállapítható a három ajánlott alany közötti sorrend gyümölcstömegre vonatkozóan: 1. 'PHL-C', 2. 'Weiroot 158', 3. 'GiSelA 6'. 'Regina' fajta esetében mindezidáig nem találkoztunk hasonló vizsgálattal a szakirodalomban.

Kijelenthetjük tehát, hogy eredményeink alapján mindkét nemes fajta esetében a ' $\mathrm{PiKu} 1$ ' alany teljesített a leggyengébben gyümölcstömeg (és ezzel összefüggésben gyümölcsméret) szempontjából. Ezzel a megállapítással azonban némileg ellentmondó szakirodalmakat találtunk: GADŽE et al. (2010) és GYEVIKI et al. (2008) különböző alanyok hatását vizsgálta a gyümölcsök tömegére, és mindkét vizsgálat alapján szignifikánsan jobbnak bizonyult a 'PiKu 1' alany például a 'GiSelA 5' alanyhoz képest (GADŽE és munkatársai esetében 'PiKu 1': 8,08 g; 'GiSelA 5': 7,68 g). Az ellentmondás oka valószínűleg az, hogy a különböző nemesek eltérő módon reagálnak az alanyhatásra: GADŽE et al. (2010) 'Lapins', míg GYEVIKI et al. (2008) 'Vera' cseresznyefajtát vizsgált, szemben az általunk vizsgálatba vont 'Kordia' és 'Regina' fajtákkal.

A csontártömegek tekintetében elmondható, hogy a 'Kordia' nemes átlagos csontártömegei az évjárathatástól nagymértékben függetlenek, különösen, ha a 'Regina' fajtához viszonyítjuk, amelynek adataiban az évjárat hatása erőteljesen jelentkezik. Az egyes alanyok között mindkét nemes kombinációiban vannak statisztikailag szignifikáns különbségek, de véleményünk szerint ezek gyakorlati jelentősége elhanyagolható.

Az irodalomban a gyümölcshús és a csontár viszonyának szemléltetésére általában a gyümölcs/csontár arányt szokták használni (AĞLAR és YILDIZ 2014, KALYONCU et al. 2009, MrATINiĆ et al. 2011, SzOT és MELAND 2001, VurSAVUŞ et al. 2006). Véleményünk szerint ennél szemléletesebb a hasznos gyümölcs hús aránya a teljes gyümölcstömeg százalékában kifejezve.

A hasznos gyümölcs arányok tekintetében egyértelmü, szignifikáns különbség látható a 'Regina' és a 'Kordia' fajták között. A ‘Kordia' 4 éves átlagban 94,88\%-os, a 'Regina' ugyanitt 93,73\%-os eredményt mutat. Az 1,15\%-os különbség első látásra nem tủnik jelentősnek, főleg ha csak háztartási mennyiségekröl beszélünk. Ebben az esetben a különbség valóban elhanyagolható mértékü. Ha azonban nagyüzemi méretekben gondolkodunk, az 1,15\% jelentősége igencsak felértékelődhet. ${ }^{1}$ A 'Kordia' gyümölcsének adataiban az éves átlagok relatív szórása 0,57\%

\footnotetext{
${ }^{1}$ Egy olyan élelmiszeripari cég szempontjából, mint például a Sio-Eckes Kft., amely éves szinten 10-13 ezer tonna gyümölcsöt dolgoz fel, és csak a magyarországi alapanyagra 3-3,5 Mrd HUF nagyságrendben költ (MTI 2014), az 1,15\% különbség nyersanyag szinten 34-40 millió HUF veszteséget jelent, s ha ehhez hozzávesszük a termék hozzáadott értékét, a veszteség ennek háromszorosa is lehet.
} 
szemben a 'Regina' 0,74\%-os adatával, tehát a 'Kordia' időben stabilabb, jobban ellenáll az évjárathatásnak. Ezzel szemben a 'Regina' jobban fluktuál, így amellett, hogy átlagértékben kedvezőtlenebb, még nagyobb kockázatot is jelent nyersanyagveszteség szempontjából.

A 'Kordia' azért is előnyösebb, mert alanyhatás szempontjából is állandóbb képet mutat, tehát az egyes alanyok közötti különbség átlagosan kisebb, mint a 'Regina' esetében. A 'Kordia' nemes a legjobb hasznos gyümölcs arányt a 4 év viszonylatában a 'PHL-C' alanyon mutatta, a legkevésbé ajánlható alany a 'GiSelA 5'. A 'Regina' kombinációi közül az egyik favorit szintén a 'PHL-C', a másik a 'GiSelA 6', míg a leggyengébben a 'GiSelA 5' és a 'PiKu 1' teljesített. A legjobb ('Kordia'-'PHL-C') és a leggyengébb ('Regina'-'PiKu 1') kombináció közötti különbség 4 éves átlagban $1,58 \%$ volt. Cseresznye faj esetében mindezidáig nem találkoztunk hasonló vizsgálattal a szakirodalomban.

Ebben a témában az általunk vizsgált alany-nemes kombinációk esetében mindezidáig nem született szakirodalom.

\subsubsection{Q26 ültetvény}

A Q26 ültetvényből származó cseresznye gyümölcsök tömegadataiból nyerhető összkép a várakozásnak megfelelően nagymértékben megegyezik azzal, ami a térfogatadatokból kirajzolódott. A nagyobb precizitású tömegmérés hatására a különbségek élesebbé, és több esetben szignifikánssá váltak olyan nemesnél is, ahol a térfogatmérés nem mutatott eltérést a virágritkított és a kontroll fák között. Ennek következtében - a térfogatmérés alapján számított 46,7\%-hoz képest - a fák 73,3\%-a reagált pozitívan a ritkításra a T3-as érési stádiumban (ez a szám mindhárom érési stádium eredményeit összevetve 90,9\%).

A szakirodalom eredményei ebben a témában - mivel a két paraméter erősen összefügg hasonlóak a gyümölcsméretnél leírtakhoz: viszonylag kevés a forrás, és nincs egyetértés a kutatók között. 'Újfehértói fürtös' meggyfajtát vizsgálva DAVARYNEJAD et al. (2008) szerint a gyümölcsök tömege 31\%-kal nőtt virágritkítás hatására. WHITING és LANG (2004) eredményei alapján a 'Bing' cseresznyefajta tömege 26\%-kal (7,6 g-ról 9-6 g-ra) lett nagyobb a kezelés hatására. VON BENNEWITZ et al. (2010) 'Lapins' fajta esetén bizonyította a virágritkítás pozitív hatását a gyümölcstömegre (kontroll: 6,8 g, virágritkított: 8,8 g). SCHOEDL et al. (2009), valamint AYALA és ANDRADE (2009) azonban nem tudtak kimutatni szignifikáns különbséget különböző cseresznyefajták gyümölcstömegre vonatkozóan. Saját vizsgálataink alapján is a virágritkítás gyümölcstömege gyakorolt pozitív hatása mellett foglalunk állást a vizsgált fajták tekintetében.

A gyümölcstömegek alapján a 'BMS' továbbra is az egyetlen fajta, amely mindhárom évben szignifikánsan nagyobb gyümölcsöt hozott a virágritkított fákon, ám az összes többi fajta is 2-2 évben pozitívan reagált, igaz, nem mind ugyanabban az évben. Az évjárathatásra most is a 'BBS' és a 'BMS' a legérzékenyebb, de ez nem rejt különösebb kockázatot a térfogatoknál ismertetett okok miatt. 
A 'BBS' és a 'BMS' gyümölcstömeg szempontjából is átlag felett teljesített. A 'BMS' kontroll fái ugyan kisebb gyümölcsöket teremtek, de mivel ennél a fajtánál a virágritkítás mindig pozitív eredménnyel járt, a kontroll fák viselkedése a végső javaslat szempontjából érdektelen.

Értékelésünk szerint, ha a gyümölcstömeg elsődleges, akkor a 'BBS' és 'BMS' fajták a leginkább ajánlhatóak termesztésre. A 'BMS' esetében mindenképpen érdemes elvégezni a virágritkítást, mert azzal csak nyerhetünk. A 'BBS' esetében a virágritkítás nagyobb eséllyel növeli a gyümölcsök tömegét a kontrollhoz képest, de előfordulhat az is, hogy nem történik változás, vagy esetleg csökkenést tapasztalunk. A többi három fajta esetében a virágritkítás várhatóan előnyös hatással jár.

Eredményink alapján megállapítható, hogy a csontártömegek alakulása önmagában viszonylag kevés információt hordoz. Annyi elmondható, hogy - a gyümölcsök méretadataihoz hasonlóan - a virágritkítás nem mindig okoz szignifikáns hatást (az esetek 40,91\%-ában), de amikor igen, akkor kivétel nélkül minden esetben a csontártömeg növekedését hozza magával. Ez azonban most nem előnyként jelentkezik, mivel a csontár alapvetően szükségtelen a további felhasználás szempontjából. A 'BBS' és a 'BMS' fajta ebből a szempontból is átlag feletti értékeket mutat, a többi fajta 3 éves átlagban együtt mozognak.

A gyümölcs-csontár viszony vizsgálata során megállapítottuk, hogy a virágritkítással összefüggésben a 'BBVG', 'BMS' és 'H222' fajták esetében - 3 éves átlagban - a hasznos gyümölcs aránya 0,3-0,5\% közötti mértékben javult, az évjárathatásra való érzékenység pedig 16,5-64,3\% közötti mértékben csökkent. A 'BBS' a hasznos tömeg szempontjából, a 'MP' az évjárathatás csökkentése szempontjából nem volt érzékeny a virágritkításra.

Összesítve elmondható, hogy a méretet és a hasznos gyümölcstömeget vizsgálva a virágritkítás az esetek többségében pozitív változást hozott, kisebb részben pedig nem okozott változást. A leginkább ajánlott kombináció az összesítés alapján is a virágritkítással kezelt BMS, azután a 'BBS' kezelt vagy kezeletlen fái. A többi nemes között nehéz különbséget tenni, gyengébb méretadataik miatt nem igazán tudjuk ajánlani őket.

A szakirodalomban hasonló vizsgálatot az általunk összehasonlított fajták esetében eddig nem találtunk.

\subsubsection{Kocsány-szakitószilárdság (KSzSz)}

A KSzSz értékelésénél érdemes elgondolkodni a tulajdonság gyakorlati jelentőségén. NiKLAS (2002) rámutat arra, hogy a gyümölcshozamok szempontjából az erős szél nagy kockázatot rejt, mivel könnyen lesodorhatja a fákról a gyümölcsöket, jelentős károkat okozva ezzel. Ebből a szempontból a nagyobb KSzSz érték nyilvánvalóan előnyt jelent.

A másik fontos hatása a kocsány-gyümölcs tapadásnak az, hogy minél nagyobb a $\mathrm{KSzSz}$ értéke, annál jobban megnehezíti a gépi szüretelést, és az erőteljesebb rázás a fák és a gyümölcs nagyobb mértékű sérüléséhez vezethet. A nagyüzemi méretekben történő termesztés és gépi szüretelés szempontjából tehát a kisebb KSzSz érték előnyösebb. 
Mivel azonban a gépi szüretelés nagy eséllyel károsíthatja a gyümölcsöt, ezért többen a kézi szüretelést tartják optimálisnak (DEMIRCAN et al. 2006), nem beszélve arról, hogy a gépi szüretelés a termelők egy része számára nem is elérhető opció. A gyümölcs frisspiaci értéke ugyancsak kocsánnyal együtt magasabb, mivel szállíthatósága, eltarthatósága is jobb akkor, ha kocsánnyal együtt szüretelik (WIRCH et al. 2009). Kézi szüretelés esetén tehát a nagyobb KSzSz értékek a kedvezőbbek.

\subsubsection{Q10 ültetvény}

A fentiek értelmében az alany-nemes kombinációk értékelése, rangsorolása csak akkor végezhető el, ha előzőleg rögzítjük a szüretelés módját, amely pedig az ültetvény méretétől és a végfelhasználás céljától is függ.

Eredményeink szerint KSzSz szempontjából a 'Regina' minden évben magasabb átlagértékeket mutatott, mint a 'Kordia', bár a magasabb értékekhez jóval nagyobb szórás is tartozott, így a különbség nem mindig tekinthető statisztikailag szignifikánsnak. Megfigyelhető az is, ami már korábban többször megmutatkozott, miszerint a 'Kordia' viszonylag jól ellenáll az évjárathatásnak, míg a 'Regina' éves átlagok tekintetében jobban ingadozik. Ugyanez igaz az alanyhatásra is: a 'Regina' fajtánál az egyes alanyok között nagyobb ingadozás látható, mint a 'Kordia' fajtánál. Sőt, a 'Regina' nemesnél évjáraton és alanyon belül is nagyobb a KSzSz mérés szórása, mint a 'Kordia' fajtánál, mely szembeötlően jelentkezik a 2013-as évben. Összefoglalva elmondható, hogy KSzSz tekintetében a 'Regina' minden szinten változékonyabb képet mutat a 'Kordia' fajtánál.

A 'Kordia' fajta esetében a legnagyobb kocsány-szakítószilárdságot 3 éves átlagban a 'Weiroot 158' és a 'PHL-C' alanyok produkálták (10,11 N illetve 10,06 N), a legkisebbet a 'PiKu 1' (9,14 N). 'Regina' fajtán a legmagasabb KSzSz érték a 'Weiroot 158' alanyhoz kapcsolódik, ahol átlagosan 14,02 N erö volt szükséges a gyümölcsök kocsányról való leválasztásához, a legkisebb átlagértéket pedig a 'PHL-C' alaánynál mértünk (11,93 N).

Eredményeinket a szakirodalmakkal összevetve azt találtuk, hogy mindezidáig csak egyetlen kutató (WIRCH et al. 2009) végzett vizsgálatokat az alanyhatás és a KSzSz érték összefüggésében, tehát ez a terület még kevésbé kutatottnak tekinthető. WIRCH et al. (2009) szerint az alanynak nincsen hatása a nemes fák gyümölcseinek KSzSz értékeire, de vizsgálataiban nem szerepelt egy sem az általunk vizsgált alany-nemes kombinációk közül, tehát eredményeink ebben a témában újkeletünek tekinthetők.

\subsubsection{Q26 ültetvény}

A kocsány-szakítószilárdság méréseinek eredményeiből csak kétévnyi adat áll rendelkezésünkre. Maga a mérés precizitása sem tűnik túl jónak, mivel a szórásértékek viszonylag nagyok. Mindez a levonható következtetések mennyiségét, értékét és valószínűségét egyaránt csökkenti. 
Vizsgálataink szerint - két éves átlag alapján - a 'MP' fajta alacsonyabb, a 'BBS' és 'BMS' fajták pedig magasabb KSzSz értékkel bírnak, mint a többi fajta, amelyek ebből a szempontból nagyjából egyforma értéket mutatnak. A virágritkítás az egyik évben egyáltalán semmi hatással nem volt a paraméter alakulására, a másik évben a 'BBS' és 'BMS' esetében valószínüsíthető jelentősebb pozitív korreláció.

Évjárathatás szempontjából a 'BBS' ingadozása a legnagyobb, a 'BMS'-é és a 'H222' -é közepes szintü, a 'BBVG' és a 'MP' pedig egészen stabil viselkedést mutat, már amennyire ezt két év adataiból meg lehet ítélni.

Értékelésünk szerint, amennyiben a nagyobb KSzSz a cél, elsősorban a 'BMS', másodsorban a 'BBS' fajta ajánlott, és a virágritkítás valószínűleg javítani fogja az értéket. A 'BBVG' és 'MP' fajták esetében enyhe kockázata van annak, hogy a virágritkítás csökkenti a KSzSz-t.

A szakirodalomban hasonló vizsgálatot cseresznye esetében ezidáig nem találtunk.

\subsubsection{Gyümölcsök héjszíne}

A szín a méret mellett a cseresznye gyümölcs másik nyilvánvaló külső jegye, amelynek fogyasztói elégedettség szempontjából szintén elsődleges fontossága van. CRISOSTO et al. (2003) kutatása szerint a vásárlói döntéseket a TSS mellett elsősorban a szín befolyásolja: felmérése alapján a vásárlóknak a mélysötét, bordó, közel fekete cseresznyék a legvonzóbbak. A sötétebb színárnyalat mellett ROMANO et al. (2006) szerint az is lényeges, hogy a gyümölcsök színe mennyire egységes. Ha egy láda cseresznye szín tekintetében heterogén benyomást kelt, tehát pl. az egyik gyümölcs sötétebb, a másik világosabb, az negatív irányba befolyásolja a vásárlói döntést.

\subsubsection{Q10 ültetvény}

A két nemes T3 állapotát a CIE-L*ab színtérben összehasonlítva elmondható, hogy a 'Kordia' gyümölcse általában sötétebb, továbbá kevesebb piros és több kék színösszetevőt tartalmaz, mint a 'Regina' fajtáé (ezek az eredmények alátámasztják az érzékszervi megfigyelést). A vizsgált évek során - a 2012-es évet kivéve - mindkét nemes mindhárom színkoordináta mentén viszonylag kiegyensúlyozott viselkedést mutatott, ha az alanyhatástól eltekintünk. 2012-ben azonban a nemesek egymás irányába mozdultak el: a 'Kordia' gyümölcsein a színek világosodását, a 'Regina' gyümölcsein pedig a színek mélyülését tapasztaltuk, amely különösen az a* és b* értékekből tünik ki jól.

Amennyiben elfogadjuk CRISOSTO et al. (2003) eredményeit, miszerint a vásárlók demográfiai különbségektől függetlenül - a mélysötét, bordó, közel fekete cseresznyéket találják a legvonzóbbnak, ebben az összehasonlításban a 'Kordia' egyértelműen kedvezőbb tulajdonságokkal rendelkezik, tehát jobban ajánlható, mint a 'Regina'. Másfelől viszont az is elmondható, hogy az éves átlagos színértékek tekintetében a 'Kordia' lényegesen nagyobb ingadozást mutat: az a* koordináta évenkénti átlagainak relatív szórása 'Kordia' esetében 11,5\%, 'Regina' esetében $10,0 \%, b^{*}$ koordinátánál 'Kordia' esetében $24,7 \%$, 'Regina' esetében pedig 
8,4\%. Más szavakkal ez azt jelenti, hogy a 'Kordia' gyümölcseinek színe érzékenyebb az évjárathatásra.

Az alanyok hatása a színek alakulására adott éven belül szinte mindig szignifikáns mindkét nemesnél. CANTín et al. (2010), GADŽE et al. (2010) és GonÇALVES et al. (2005) szintén szignifikáns különbséget talált az alanyok között. Az alanyhatásra való érzékenység a 'Regina' esetében nagyobb, ugyanis az alanyok által gerjesztett ingadozás az a* és b* értékek tekintetében szignifikánsan nagyobb, míg az L* tekintetében nincs különbség.

Az egyes alanyok rangsorolásakor azt az - általunk kialakított - elvet követtük, hogy az a kedvezőbb alany, ami a CIE-L*ab színtérben magasabb $L^{*}$, a* és b* értékeket indukál a gyümölcsben. Megfigyeltük ugyanis, hogy a különböző színkomponensek diagramjai nagyfokú párhuzamosságot mutatnak, együtt mozognak. Amikor pl. az L* értéke csökken, tehát a gyümölcs sötétebb, akkor ezzel párhuzamosan a b* értéke is csökken (a kék szín intenzitása nő), és az a* értéke is (a piros szín intenzitása csökken). Ugyanez a tendencia figyelhető meg az érés előrehaladtával is. Ezért a rangsorolás alapját képező elv leegyszerüsíthető egyetlen színkoordinátára, és kijelenthető, hogy minél sötétebb a gyümölcs, annál kedvezőbb a szín megítélése szempontjából. Ezek alapján a 'Kordia' nemeshez leginkább ajánlott alany, amely legtöbbször és legintenzívebben indukálta a sötét gyümölcshéjszínt, a 'PHL-C'. Az azonban, aki inkább a világosabb, élénkpiros színű cseresznyét kedveli, válassza a 'GiSelA 6'-ot ehhez a nemeshez. 'Regina' fajta esetében a gyümölcsök sötét tónusát leginkább a 'PiKu 1' alany támogatja, világosabb gyümölcsökhöz pedig a 'GiSelA 5' és 'GiSelA 6' javasolható.

A szakirodalomban nem találtunk olyan forrást, mely ezt a témát korábban már feldolgozta volna, csak részeredményekre bukkantunk: GONÇALVES et al. (2005) 5 alany hatását vizsgálva 3 nemes ('Burlat', Summit', 'Van') gyümölcseinek L* értékére arra jutott, hogy minden esetben a 'GiSelA 5' alanyon álló fák mutatták a legmagasabb értékeket, tehát a legvilágosabb gyümölcsöket. CANTín et al. (2010) ugyanerre a következtetésre jutott 7 féle alanyra oltott 2 nemes ('Van' és 'Stark Hardy Giant') fajta gyümölcseinek világosságára vonatkozóan, valamint GADŽE et al. (2010) eredményei is ezekkel egybehangzóak 'Lapins' fajtát vizsgálva (alanyok: 'GiSelA 5', 'Weiroot 158', 'PiKu 1').

\subsubsection{Q26 ültetvény}

A Q26 ültetvény gyümölcsei színkoordináták tekintetében mind fajta szempontból, mind virágritkítás szempontjából nagy változatosságot mutatnak. Az integrált művelési rendszerü fajtákhoz hasonlóan itt is teljesül, hogy magasabb L* értékhez (világosabb szín) rendszerint magasabb a* és b* érték (több piros és kevesebb kék színösszetevő) párosul.

Az L* paraméter értéke szerint 3 éves átlagban a 'MP' gyümölcse világosabb színủ a többi fajta gyümölcseinél. A 'BBS' és a 'MP' esetében az éves átlagok szórása (8,8-9,2\%) kb. 2-szer akkora, mint a többi fajtánál (4,9-5,4\%), ami az évjárathatásra való nagyobb érzékenységre utal. A virágritkításra a 'BMS' és a 'MP' fajták következetesen pozitív választ adtak mindhárom évben 
(bár 2011-ben a különbség minimális volt), ez azonban a gyümölcs világosodását jelenti, ami az érték szempontjából CRISOSTO et al. (2003) felmérése szerint kedvezőtlen. A többi 3 nemes esetében változó, illetve nem szignifikáns hatások születtek.

Három éves átlagban a virágritkítás mindegyik fajta esetében szignifikánsan befolyásolta az a* paraméter értékét. A 'BBS', a 'BBVG' és a 'H222' negatívan reagált, a 'BMS' és a 'MP' pozitívan, melyek utóbbi azoknak kedvez, akik a világosabb, élénkpiros színü cseresznyét kedvelik, míg előbbi a sötétebb színü cseresznyét kedvelőknek. A legmagasabb értéket a virágritkított MP, a legalacsonyabbat a kontroll 'BMS' érte el.

Az évjárathatásra való érzékenység a 'BMS' esetén volt a legkisebb a kontrol fák esetében: az éves átlagok relatív szórása 11,1\% volt. A 'BBS' ennél 2-szer, a többiek 2,5-3-szor nagyobb relatív szórást mutattak. Érdekesség, hogy a 'BBS' a* színkoordinátáját a virágritkítás „stabilizálta”: az éves átlagok közötti relatív szórás 72,6\%-kal csökkent a kontroll fákhoz képest. A többi fajta évjárathatásra való érzékenységét a virágritkítás nem befolyásolta.

A b* színkoordináta az a*-val majdnem teljes mértékben megegyező viselkedést mutatott a 3 év során. A megállapítások ugyanazok, csak itt a kontroll 'BMS' évjárathatásra való érzékenysége 23,3\%-os relatív szórásban nyilvánult meg, a többi fajta ennek az értéknek kb. dupláját mutatta, és a 'BBS' szórása 41,4\%-kal csökkent a virágritkítás hatására.

Összegzésként elmondható, hogy a BBS, 'BBVG' és 'H222' fajták színében a virágritkítás sötétebb gyümölcsöt produkál, amit a 'BBS' esetében kiegészít az, hogy az évjárathatásra való érzékenység jelentős mértékben csökken. A 'BMS' és a 'MP' gyümölcsei virágritkítás hatására világosabbak lesznek, élénkebb piros színnel. A legsötétebb színt 3 éves átlagban a kontroll fák közül a BMS, a kezelt fák közül a 'BBVG' adta, a kettő közül a kontroll 'BMS' volt a sötétebb.

A szakirodalomban hasonló vizsgálatot ezidáig nem találtunk.

\subsubsection{Gyümölcskeménység}

Általános érvényességgel elmondható, hogy a nagyobb gyümölcskeménységi érték - a gyakorlati limiteken belül - mindig jobb. A gyümölcs szállíthatóságát kedvezően befolyásolja (SAN MARTINO et al. 2008), és a fogyasztói elvárásokat is a magasabb értékek szolgálják ki legjobban (KAPPEL et al. 1996, GARCIA-MONTIEL et al. 2010).

\subsubsection{Q10 ültetvény}

Gyümölcskeménység szempontjából a 'Regina' egyértelmüen kedvezőbb, hiszen a 4 év alatt az esetek 85\%-ában nagyobb átlagos keménységadatokat mutatott, mint a 'Kordia'. Ennél a paraméternél is igaz, hogy a 'Regina' érzékenyebb az évjárathatásra és az alanyhatásra is, ám ezzel együtt is ajánlható termesztésre (legalábbis gyümölcskeménység alapján), mivel a leggyengébb évben is többnyire jobban teljesített a Kordiánál. LONG et al. (2005) vzsgálatainak eredményei egybevágnak a mieinkkel: a két fajtát összehasonlítva náluk is a 'Regina' fajta gyümölcsei $(3,14$ $\left.\mathrm{kg} / \mathrm{cm}^{2}\right)$ bizonyultak keményebbnek a 'Kordia' gyümölcseivel szemben $\left(2,92 \mathrm{~kg} / \mathrm{cm}^{2}\right)$. 
Az alanyhatást vizsgálva a szakirodalmi adatokkal megegyezően szignifikáns különbséget tudtunk kimutatni a gyümölcsök keménységére vonatkozóan (CANTíN et al. 2010, GoNÇALVES et al. 2005, JiMÉNEZ et al. 2004, SzOT és MELAND 2001, UsEniK et al. 2010). A 'Regina' esetében az alanyhatást vizsgálva megállapítható, hogy keménység szempontjából a leginkább ajánlott alanyok a 'GiSelA 5' és 'GiSelA 6'. Ha csak a kedvező éveket tekintjük, a 'GiSelA 6' valamivel jobb átlagértékeket adott, ugyanakkor érzékenyebb volt az évjárathatásra, és a 4 év második leggyengébb átlagos gyümölcskeménység értéke is hozzá köthető. A 'GiSelA 5' ezzel szemben általában kicsit alacsonyabb átlagokat mutat az évek során, viszont kevésbé ingadozik az évjárathatás következtében, és így a teljes 4 éves gyümölcskeménység átlaga $\left(3,51 \mathrm{~kg} / \mathrm{cm}^{2}\right)$ magasabb, mint a 'GiSelA 6' alanyé $\left(3,45 \mathrm{~kg} / \mathrm{cm}^{2}\right)$. Átlagosan a legpuhább gyümölcsöket a 'PHLC' alanynál mértük.

A 'Kordia' alanyai közül az ajánlottak körét 3-ra sikerült leszükíteni a 4 év teljesítménye alapján. A legkeményebb gyümölcsök a 'GiSelA 5'-ön, 'PHL-C'-n és 'GiSelA 6'-on teremtek, azonban a vizsgált időtartományban nem figyelhetők meg olyan trendek, amelyek alapján szignifikáns különbséget lehetne tenni közöttük. A legpuhább gyümölcsöket a 'Weiroot 158' alany produkálta.

GONÇALVES et al. (2005) 5 különböző nemes hatását vizsgálta 3 nemes fajta gyümölcseinek keménységére. Eredményeik szerint a 'GiSelA 5' alanyú fák gyümölcsei lettek a legkeményebbek $\left(2,38 \mathrm{~kg} / \mathrm{cm}^{2}\right)$. Megállapításuk harmóniában van a mi megfigyeléseinkkel $\left(3,13 \mathrm{~kg} / \mathrm{cm}^{2}\right)$, csakúgy, mint CANTín et al. (2010) eredményei, ahol 7 különböző alany hatását vizsgálva szintén a 'GiSelA 5' alanyon álló fák gyümölcsei lettek a legkeményebbek. Meg kell azonban jegyezni, hogy mindkét kutatócsoport más nemeseket vont be vizsgálataiba, 'Kordia' és 'Regina' fajtára vonatkozóan még nem publikáltak hasonló vizsgálatokat.

Mindent összevetve eredményeink alapján a leginkább ajánlható kombinációk a 'Regina''GiSelA 5' és a 'Regina'-'GiSelA 6', a legkevésbé ajánlhatók pedig a 'Kordia'-'PiKu 1' és a 'Kordia'-'Weiroot 158'.

\subsubsection{Q26 ültetvény}

A Q26 ültetvény gyümölcseinek keménység-alakulása kapcsán is elmondható az, ami a méretekben megmutatkozott: amikor a virágritkításnak szignifikáns hatása van a gyümölcs keménységére (az esetek 42,22\%-ában), akkor az az eredmények 100\%-ában pozitív. Ebből következik, hogy - szigorúan a keménység szempontjából - hátrány nem származhat belőle, ha elvégezzük a kezelést.

A szakirodalom gyümölcskeménység tekintetében is ellentétes eredményeket közöl. LENAHAN et al. (2006) kémiai virágritkítás (gibberellinsav) hatását vizsgálta 'Bing' cseresznyefajták gyümölcseinek keménységére. Eredményeik alapján minél magasabb koncentrációban juttatták ki a gibberellinsavat (GA) gyümölcskötődéskor, annál puhább gyümölcsöket kaptak (kontroll: 3,16 kg/cm²; $50 \mathrm{mg} / 1 \mathrm{GA}: 2,4 \mathrm{~kg} / \mathrm{cm}^{2} ; 100 \mathrm{mg} / 1 \mathrm{GA}: 1,38 \mathrm{~kg} / \mathrm{cm}^{2}$ ). 
WhitiNG és LANG (2006) szerint ezzel szemben a 'Bing' cseresznyefajták gyümölcskeménysége 25\%-kal nőtt virágritkítás hatására, míg CiTTADINI et al. (2013) és VoN BENNEWITZ et al. (2010) szerint a 'Lapins' cseresznyefák gyümölcstömegét vizsgálva nincs szignifikáns különbség a virágritkított és a kontroll fák között. Saját eredményeink alapján a virágritkítás gyümölcskeménységre gyakorolt pozitív hatása mellett foglalunk állást a vizsgált fajták tekintetében.

Méréseinkben az öt fajta közül háromnak ('BBVG', 'H222', 'MP') a T3 stádiumú adatai a vizsgálat három éve során viszonylag egyenletes eloszlást mutatnak. Az éves átlagok relatív szórása 8-18\% között mozog, mutatva az évjárathatással szembeni viszonylagos közömbösséget. A mezőnyből - nem túl meglepő módon - ezúttal is a 'BBS' és a 'BMS' emelkedik ki, elsősorban 2010-ben és 2012-ben. Ez a kiemelkedés azt jelzi, hogy mindkét fajta érzékenyebb az évjárathatásra (éves átlagok relatív szórása 31-40\% között van), ugyanakkor ez nem rejt jelentős kockázatot, mivel a leggyengébb évben sem gyengébbek az átlagnál.

Bár a virágritkítás mindegyik fajtánál pozitív hatással jár, talán a hatás mértéke sem lényegtelen. Három éves átlagban a beavatkozás 17,9\%-kal növelte a 'MP' gyümölcs keménységét, 12,4\%-kal a 'BBS'-ét, és 3,6-7,2\% között a többi háromét.

Gyümölcskeménység szempontjából a leginkább ajánlható fajta a 'BMS', annak is a virágritkított változata. A 'BMS'-nek már a kontroll fái is jobb gyümölcskeménység átlagokat értek el, mit a többi fajta a kezelés után, és ezen a ritkítás még 3,6\%-ot javít. Legkevésbé ajánlható a kezeletlen fák közül a 'MP', a kezeltek közül pedig a 'H222' fajta.

A szakirodalomban hasonló vizsgálatot az általunk vizsgálatba vont fajták esetében eddig nem találtunk.

\section{2. Általános fizikokémiai paraméterek összehasonlító értékelése}

\subsubsection{Vizoldható szárazanyag-tartalom (TSS), titrálható savtartalom (TA), TSS-TA viszony}

A fogyasztói megítélésben a cseresznye íze kiemelt fontosságú jellemző (TURNER et al. 2008, GARCIA-Montiel et al. 2010, DeVER et al. 1996), mely elsősorban a gyümölcs cukor- és savtartalmának harmonikus, kiegyensúlyozott kombinációjától függ. REVELL (2008) szerint a cseresznye esetében ez akkor teljesül, ha a gyümölcsben magas a cukortartalom és a savtartalom, melyek mérőszámául a TSS és a TA érték szolgál (GIRARD és KOPP 1998, TURNER et al. 2008, VURSAVUŞ et al. 2006).

A szakirodalom ellentétes véleményeket közöl arra vonatkozóan, hogy az érés elörehaladtával a gyümölcsök savtartalma milyen irányba változik. TUDELA et al. (2005), ZHANG et al. (2008) és FICZEK (2012) szerint a TA az érés folyamán csökken, míg MAHMOOD et al. (2012a), WANi et al. (2014) és AGULHEIRO-SANTOS et al. (2012) szerint növekszik. Eredményeink alapján a Q26 ültetvényből származó cseresznyefajták esetében a gyümölcsök TA értékének érés 
során történő emelkedése, míg a Q10 ültetvényböl származó cseresznyefák gyümölcseinek esetében a TA érték csökkenése mellett foglalunk állást.

\subsubsection{Q10 ültetvény}

A két nemes gyümölcseinek T3-as érettségi állapotát összehasonlítva elmondható, hogy a 'Regina' gyümölcseire általában magasabb TSS és alacsonyabb TA érték (4 éves átlagban 17,0 ${ }^{\circ}$ Brix illetve 6,72 mg MAE/ml) volt jellemzö, mint a 'Kordia' gyümölcseire (15,7 ${ }^{\circ}$ Brix illetve 7,64 mg MAE/ml). A legmagasabb TSS adat ugyan a 'Kordia' fajtához kapcsolódik (2012, 'Kordia'-'PHLC'), azonban a 'Regina' a 4 év során sokkal kiegyensúlyozottabb viselkedést mutatott, tehát az évjárathatásra kevésbé volt érzékeny, ezért átlagban is jobban teljesített. Az egyes éveken belül a 'Regina' alanyhatásra mutatott érzékenysége is 3 évben szignifikánsan kisebb volt, mint a Kordiáé, 2012-ben pedig statisztikailag azonos volt a kettő. Így TSS szempontból a 'Regina' adott kedvezőbb értékeket a 'Kordia' fajtával szemben.

TA tekintetében kicsit másként alakul a kép. A két nemes egyaránt erős kitettséget mutatott az évjárathatásnak: az éves átlagok relatív szórása 'Regina’ és 'Kordia' esetében 17\% illetve 18\%, itt tehát nincs statisztikailag szignifikáns különbség. Adott éveken belül azonban 4 évből 3-ban a 'Regina' nagyobb érzékenységet mutatott az alanyhatásra, más szóval az alanyok átlagértékei közötti szórás szignifikánsan nagyobb volt, mint a 'Kordia' releváns értéke.

Ha a két nemes rangsorolását az ízérték (TSS-TA viszony) alapján végezzük el, azt mondhatjuk, hogy 2010-ben egyértelmüen a 'Regina' volt jobb, 2012-ben pedig a 'Kordia'. 2011ben ugyan a 'Regina'-'PHL-C' kimagaslott a mezőnyböl, de ettől eltekintve a 2011-es és 2013-as évet csak a „döntetlen” szóval tudnánk jellemezni. Mindkét évben mindkét nemes viszonylag jó értékeket mutatott mind TSS, mind TA szempontjából, csak a 'Regina' esetében a TSS volt kicsit magasabb, a 'Kordia' esetében pedig a TA. Véleményünk szerint ezen a ponton az egyéni ízlés döntheti el a sorrendet.

Az alanyhatást vizsgálva a TSS és TA értékre a szakirodalomban mindezidáig ellentmondásos eredményeket találtunk, ahogy azt az Irodalmi áttekintés fejezetben már megemlítettük. Szot és MELAnd (2001), JimÉnEz et al. (2004), SimON et al. (2004), GratACós et al. (2008), CANTín et al. (2010) és SITAREK és GRYZB (2010) szerint a cseresznye gyümölcsök TSS értékére hatással van az oltvány alany-komponense is, ezzel szemben LANAUSKAS et al. (2012), SiTAREK és BARTOSIEWICZ (2012) és AĞLAR és YILDIZ (2014) nem találtak szignifikáns eltérést az alanyok hatása között. A gyümölcsök TA értékére vonatkozóan SzOT és MELAND (2001), GRATACÓs et al. (2008) és CANTíN et al. (2010) sikeresen kimutatta az alanyhatást, míg JIMÉNEZ et al. (2004), SIMON et al. (2004) és GONÇALVES et al. (2005) nem találtak szignifikáns eltérést a különböző alanyok hatása között. Eredményeinkkel mindkét esetben az alanyhatás mellett foglaltunk állást, vagyis szignifikáns különbséget tudtunk kimutatni a különböző alanyokon álló fák gyümölcseinek TSS és TA értékei tekintetében. 
Az alanyok értékelésénél a TSS és TA alakulására kifejtett hatást komplex módon kell figyelembe venni. Legkedvezőbb az, ha egy alany mindkét paraméterre pozitív hatást gyakorol, legkedvezőtlenebb pedig az, ha mindkettővel negatív korrelációt mutat. Ezen az elven a 'Kordia' kombinációk közül a legjobb értékelést a 'GiSelA 5' kapta, amely a 4 évből kétszer mindkét paraméter értékét javította, két évben pedig nem volt számottevő hatása. A leggyengébben a 'GiSelA 6' szerepelt, amely általában az átlaghoz képest lefelé mozdította a TSS és TA értékeket. A 'Regina' kombinációk közül az előbbi levezetés alapján a legjobb teljesítményt a 'Weiroot 158' mutatta, amely minkét paraméter szempontjából átlagon felül teljesített, a legkevésbé pedig a 'GiSelA 5' ajánlható, amelynél a savtartalom minden évben elmaradt az átlagtól.

Megjegyezzük azonban, hogy ha az általunk vitatott, ám sokak által használt TSS/TA arány alapján végeznénk az értékelést, egészen más eredményeket kapnánk. A 'GiSelA 5' alanyon a 'Regina' gyümölcseinek TSS tartalma mind a 4 évben átlagos, vagy azt kicsit meg is haladó volt, TA értéke pedig általában szignifikáns mértékben elmaradt a mezőnytől. Pusztán ez utóbbi miatt azonban a 'GiSelA 5' TSS/TA aránya kimagasló eredményt mutat, tehát a hagyományos értékelés szerint a legjobb minősítést kapta volna. Az általunk javasolt módszer szerint viszont a legrosszabbat.

Korábbi szakirodalmi munkákban nem találtunk ahhoz hasonló komplex értékelést a TSSTA viszony jellegét illetően, mint amelyet mi javasoltunk. Csak olyan írások születtek, amelyek vagy különállóan kezelik a TSS illetve a TA értéket, vagy TSS/TA arányt is számolnak, de véleményünk szerint ezek nem mutatnak pontos képet az ízértékről. Így eredményeinket legfeljebb részben tudjuk összevetni a szakirodalommal. SzOT és MALAND (2001) 3 különböző alanyfajta hatását vizsgálta 3 nemes fajta gyümölcseinek TSS és TA értékeire, és arra jutottak, hogy 'Ulster' fajta esetében a 'GiSelA 5' alanyon álló fák mutatták a legmagasabb TSS értékeket (17,26 ${ }^{\circ}$ Brix), 'Van' fajta esetében pedig ugyanez az alany produkálta a legalacsonyabb TA eredményeket (4,08 $\mathrm{mg} / \mathrm{ml}$ ). Vagyis a 'GiSelA 5' alany hasonló hatást fejtett ki az 'Ulster' fajta TSS értékére és a 'Van' fajta TA értékére, mint nálunk a 'Kordia' és 'Regina' fajta TSS-ére és a 'Regina' TA-jára (az eredmények nálunk: 'Kordia' TSS: 15,77 Brix, 'Regina' TSS 17,25 Brix, 'Regina' TA: 6,21 mg/ml). GRATACós et al. (2005) 6 különbözö alany, köztük a 'GiSelA 5' és a 'GiSelA 6' hatását vizsgálta a 'Bing' és 'Lapins' cseresznyefajták gyümölcseinek TSS és TA értékeire, és eredményeik alapján a 'GiSelA 5' alany eredményezte a magasabb TSS, valamint az alacsonyabb TA értékeket a 'GiSelA 6' alanyhoz viszonyítva, ami szintén korrelál a mi eredményeinkkel.

\subsubsection{Q26 ültetvény}

Az öt fajtát TSS-TA szempontból komplex módon összehasonlítva az alábbi megállapításokra jutottunk. A legkedvezőbb ízminőség nagy valószínüséggel a 'MP' fajtán érhető el, amelynek TSS értéke mindig a legjobbak között szerepelt, savtartalma pedig megfelelően magas volt. A 'BBVG' és a 'H222' fajták gyümölcse TSS szempontjából szintén kedvező, savtartalmuk viszont kissé alacsonyabb, így az édes, de kevésbé karakteres ízeket kedvelő vásárlókat célozhatják meg. A 
'BMS' alkalmazása szerencsés körülmények között (jó évjáratban) nagyon jó ízminőségü gyümölcsöket eredményezhet, azonban nagyon kockázatos is az évjárathatásra való nagyfokú érzékenysége miatt, ezért intenzív ültetvénybe kevésbé, inkább házikerti termesztésre ajánljuk. A 'BBS' fajta összességében - a vizsgálat 3 éve alapján - a legkevésbé ajánlható fajta, mert gyümölcseinek TSS- és TA-tartalma a legtöbb esetben az öt fajta átlaga alatt volt.

WHITING és LANG (2004) kísérleteiben a 'Bing' cseresznyefajta gyümölcseinek TSS értéke 20\%-kal emelkedett virágritkítás hatására a kontroll fákhoz képest. SCHOEDL et al. (2009) 4 különböző nemes fajta ('Blaze Star', 'Merchant', 'Samba', 'Techlovan') gyümölcseinek TSS és TA értékét vizsgálta, melyek közül csak egyetlen nemesnél ('Techlovan') tudta igazolni a virágritkítás pozitív hatását, és azt is csak TSS esetében (kontroll: 13,63ํำ, virágritkított: $16,03^{\circ}$ Brix), a többi fajtánál nem tapasztaltak szignifikáns különbséget. AYALA és ANDRADE (2009) szintén nem tudtak szignifikáns eltérést kimutatni a 'Lapins' fajta gyümölcseinek TSS értékére. VON BENNEWITZ et al. (2010) szintén 'Lapins' fajtát vizsgált, és arra jutott, hogy a gyümölcsök TSS értéke a ritkítás hatására szignifikánsan csökken (kontroll: $19^{\circ}$ Brix, virágritkított: $17,6^{\circ} \mathrm{Brix}$ ), a TA értékre azonban nincs hatással. Eredményeinket összevetve a szakirodalmakkal valószínüsíthető, hogy a fajták különböző módon reagálnak a virágritkításra.

Összességében megállapítható, hogy a virágritkítás különbözően hat (vagy nem hat) az egyes fajtákra. A 'BBVG' esetében a beavatkozás javítja a gyümölcs ízminőségét, 'BMS' esetében általában rontja, a többi fajtánál pedig évjárattól függően változó a hatás, így általános érvényü következtetést nem tudtunk levonni.

\subsection{Egyedi komponensek és komponenscsoportok összehasonlító értékelése}

\subsubsection{Cukorfrakciók}

A korábbi fejezetekben már említést tettünk arról, hogy a magasabb cukortartalom javítja a cseresznye gyümölcs piaci értékét, a vásárlói döntéseket pedig pozitívan befolyásolja, különösen a visszatérő vásárlások esetében. Ebből következően a kromatográfiás cukormérések eredményeinek összehasonlító elemzése során a nemeseket, alanyokat, ill. a virágritkítás szükségességét aszerint értékeltük, hogy melyik segíti elő nagyobb mértékben a cukorkomponensek képződését.

Ezeken túlmenően az egyes cukorkomponensek koncentráció-értékeinek ismerete rendkívül fontos bizonyos betegségek kialakulása vagy megléte esetén, mint például a II. típusú diabétesz mellitusz (FiczeK 2012, Ford és MoKDAd 2001, STANHOPE et al. 2009, TAPPy 2012). A téma azért is annyira aktuális, mert a Nemzetközi Diabétesz Szövetség felmérése szerint (IDF 2014) a világon ma 387 millió ember szenved cukorbetegségben, és becsléseik alapján ez a szám 2035-re akár 592 millióra is nőhet. 


\subsubsection{Q10 ültetvény}

Az egyedi cukorkomponensek kromatográfiás analízise esetünkben három szénhidrátra terjedt ki, melyek közül a glükóz és a fruktóz volt mennyiségileg domináns, mellettük a szorbitol csak kisebb szerephez jutott. A szorbitol átlagos aránya az összes kromatográfiás cukortartalomhoz (TKC) viszonyítva 12-18\% között, a fruktózé 33-39\% között, a glükózé 45-55\% között mozgott. Eredményeink összhangot mutatnak a szakirodalommal: JIMÉNEZ et al. (2004) szerint a 'Sunburst' cseresznyefajta gyümölcseiben a szorbitol aránya 16,1-18,1\%, a fruktózé 37,13-37,63\% a glükózé pedig 44,76-46,27\% különbözö alanyokon a TKC függvényében, míg UsENIK et al. (2008) eredményei alapján a szorbitol 3,91-11,37\%, a fruktóz 41,81-43,21\%, a glükóz pedig 45,4254,28\% között mozgott 8 különböző cseresznyefajta összehasonlításában.

A glükóz és a fruktóz mennyiségi alakulásában nagyfokú párhuzamosság fedezhető fel: ha egy alany-nemes kombináció (T3 érettségi állapotú) gyümölcsében a glükóztartalom magas, akkor a fruktóz is magas, ha a glükóz alacsony, a fruktóz is alacsony. Az összes alany-nemes kombináció mindössze 7,5\%-ánál figyelhető meg, hogy a két szénhidrát relatív mennyisége másképp alakul, és akkor sem jelentős az eltérés. A szorbitol esetében szintén megfigyelhető a párhuzamosság a másik két komponenssel, de kisebb mértékben: az alany-nemes kombinációk 35\%-ánál találtunk meg kisebb-nagyobb eltérést a szorbitol és a glükóz lefutása között. A szorbitol relatíve kisebb mennyisége miatt azonban ezek az eltérések kevéssé befolyásolták a TKC alakulását.

A két nemes teljesítményét összehasonlítva megállapítható, hogy - T3-as érési stádiumbana 'Regina' fajta gyümölcseinek átlagos TKC-tartalma 2010-ben és 2011-ben szignifikánsan magasabb, 2012-ben és 2013-ban pedig szignifikánsan alacsonyabb volt a 'Kordia' megfelelő értékeinél. Négyéves átlagban a 'Regina' kissé magasabb TKC értéket mutatott $(162,4 \mathrm{mg} / \mathrm{ml}$ vs. $159,18 \mathrm{mg} / \mathrm{ml}$ ), de a különbség nem szignifikáns. A TKC éves átlagok relatív szórása 'Kordia' esetében $15 \%$, 'Regina' esetében 17\% volt, ami szintén nem jelentős különbség. Ezek alapján tehát a két nemes között nem állapítható fel rangsor. USENIK et al. (2009) egy évben (2006) vizsgálta ugyanezen fajták cukorkomponenseinek koncentrációját, és eredményei szerint a két fajta összehasonlításában a 'Regina' gyümölcseinek TKC értéke volt szignifikánsan magasabb (223,6 $\mathrm{mg} / \mathrm{ml})$ a 'Kordia' fajtához képest $(175,6 \mathrm{mg} / \mathrm{ml})$. A mi értékeink első ránézésre ezeknél alacsonyabbak, de a teljességhez hozzá tartozik, hogy kedvező év esetén (ha nem a 4 éves átlagot számoljuk), nálunk is hasonló eredmények születtek: 'Regina' esetén 208,89 mg/ml, 'Kordia' esetén 204,76 mg/ml volt a TKC koncentrációja.

Az alanyhatást vizsgálva arra a következtetésre jutottunk, hogy 4 éves átlagban mindkét nemesre a 'PiKu 1' alany volt a legjobb hatással, szignifikánsan a legmagasabb cukorszinteket eredményezve. A 'Kordia' esetében egyértelmüen megállapítható volt, hogy TKC szempontból a 'Weiroot 158' a legkevésbé ajánlható alany. A 'Regina' fajtánál e tekintetben nem volt szignifikáns különbség a négy gyengébb alany között. 
Az éves átlagos TKC értékek ingadozását tekintve elmondható, hogy a 'Kordia' esetében a 'GiSelA 6' mutatta a legstabilabb viselkedést, és a 'PHL-C' fluktuált a legjobban. A stabilitás hiánya hátrány lehet, de a 'PHL-C' alanyhoz minden évben magasabb TKC értékek társultak, mint a 'Weiroot 158'-hoz, ezért az értékek ingadozása nem módosítja a korábbi megállapítást, miszerint a 'Weiroot 158 ' a legkevésbé ajánlott alany. 'Regina' esetében a legnagyobb ingadozás a 'GiSelA 5' alanyon volt megfigyelhetô, a legkisebb a 'Weiroot 158'-on. Miután a TKC-tartalom alapján nem tudtunk különbséget tenni a négy gyengébben teljesítő alany között, a sorrendet végül az évjárathatásra tanúsított érzékenység alapján állítottuk fel. Így tehát a 'Regina' nemeshez TKC tartalom szempontjából legkevésbé az 'GiSelA 5' alanyt javasoljuk.

USENIK et al. (2010) 'Lapins' cseresznyefajta gyümölcseiben vizsgálta a cukorkomponensek koncentrációit. Eredményei szerint az általunk is vizsgálatba vont 'GiSelA 5', 'PiKu 1' és 'Weiroot 158' alanyok közül a legmagasabb koncentráció értékeket a 'Weiroot 158' alanynál (157,7 mg/ml), míg a legalacsonyabbakat a 'GiSelA 5' esetében mérték $(94,39 \mathrm{mg} / \mathrm{ml})$, tehát a 'PiKu 1' a második helyre „szorult” (144,13 mg/ml). Feltehetőleg a 'Lapins' fajtánál az alanynemes kölcsönhatások másként alakulnak, mint 'Regina' és 'Kordia' esetében, emellett az időjárási és földrajzi viszonyok is nyilvánvalóan eltérnek, és meg kell említenünk azt is, hogy USENIK et al. (2010) mindössze egy év (2008) eredményeit közölte. Az általunk vizsgált alanynemes kombinációk esetében ebben a témában mindezidáig nem született szakirodalom.

\subsubsection{Q26 ültetvény}

A Q26 ültetvény fajtáinak kromatográfiás cukortartalmát elemezve megállapítható, hogy a kontroll fák 3 éves átlag TKC értéke nagyon hasonló, mindegyik fajta esetén a 145-155 mg/ml tartományba esik, tehát ez alapján nem tehető nagy különbség a fajták között. Az évjárathatásra való érzékenység szempontjából egy kiugró értéket figyeltünk meg: a 'BMS' esetében az éves átlagok relatív szórása 20,4\%, míg a többi fajtáé 4,9-7,8\% között mozog (a különbség 2,6-4,1szeres).

Roussos et al. (2011) 3 féle almafajta ('Bebecou', 'Nafsika' és 'Niove') cukorkomponenseit tanulmányozta, és mindhárom fajta esetében szignifikáns emelkedést tapasztalt a TKC értékében virágritkítás hatására $(10,4-10,7 \%)$. A szakirodalomban nem találtunk olyan írást, mely a cseresznyefajták gyümölcseinek egyedi cukor komponenseit vizsgálja virágritkítás hatására. Véleményünk szerint a virágritkítás befolyása cseresznye fajták esetében nem egyforma, de vannak olyan fajták, melyeknél jól látható a szignifikáns hatás.

A virágritkítás hatása egyértelmủen megmutatkozik a BBVG és 'H222' fajták esetében, ugyanis ezek gyümölcsének TKC tartalma 3 éves átlagban 172,2 mg/ml illetve 177,8 mg/ml értékre ugrott a technológiai beavatkozással összefüggésben. A többi fajta nem mutatott szignifikáns különbséget.

További megállapítás, hogy a virágritkítás hatására a 'BBVG', a 'H222' és a 'MP' fajták esetében az éves átlagok relatív szórása jelentősen emelkedett, amely arra utal, hogy a beavatkozás 
szignifikánsan növeli az évjárathatásra való érzékenységet. A 'BMS' esetében a szórás jelentősen csökkent, a 'BBS' esetében pedig gyakorlatilag nem változott.

Az egyedi cukorkomponensek alakulását tekintve elmondható, hogy mindegyik (virágritkított és kontroll) fajta gyümölcsében a fruktóz aránya a TKC-hez viszonyítva $42 \pm 1 \%$, a glükózé $49 \pm 1 \%$, a szorbitolé pedig $9 \pm 2 \%$. Ez annyit jelent, hogy a cukrok aránya szempontjából nincs különbség a fajták között, így egyik fajta sem kedvezőbb vagy kockázatosabb a másiknál a gyümölcsök cukorösszetételére érzékeny vásárlók számára.

A fentieket összefoglalva elmondható, hogy - TKC szempontjából - a virágritkítás a 'BBVG' és 'H222' fajtákra pozitív hatással van, ezeknél tehát érdemes elvégezni a beavatkozást (a többi fajtánál nem), és ök ketten egyformán ajánlhatók termesztésbe vonásra. Ha nincs virágritkítás, akkor a 'BBS' alkalmazása a legkedvezőbb, pusztán az évek tekintetében mutatott kisebb változékonysága miatt.

\subsubsection{Savfrakciók}

A gyümölcsök íze szempontjából, mint azt már korábban említettük, a cukor mellett a savtartalom a legfontosabb. Ugyanakkor az élelmiszeripar számára is fontos az alapanyag összetételének minél pontosabb ismerete. A különböző savkomponensek megoszlása többek közt befolyásolhatja a gyümölcsöt feldolgozó ipari berendezések korróziós folyamatait (illetve azok kontrollját), a vásárlói elvárásoknak megfelelö, megbízhatóan állandó minőségü termék minőségének beállítására használt segédanyagok (pl. citromsav) mennyiségét, valamint a feldolgozás során keletkező ipari szennyvíz és egyéb hulladékok kezelési lehetőségeit (STABNIKOVA et al. 2005).

\subsubsection{Q10 ültetvény}

Az egyedi savkomponensek kromatográfiás analízise esetünkben három vegyületre terjedt ki: almasavra, borostyánkősavra és citromsavra. A savak eloszlásában a cukrokhoz hasonló trendeket találtunk: a savkomponensek mennyiségének alakulásában nagyfokú hasonlóság ismerhető fel, a három sav mennyisége többé-kevésbé együtt mozgott. Az almasav minden alany-nemes-év kombináció esetében domináns volt, aránya az összes kromatográfiás savtartalomhoz (TKS) képest 59-76\% között mozgott, míg a borostyánkősav 14-28\%-ot, a citromsav 10-14\%-ot tett ki. SERRADILLA et al. (2011) mérései összhangban vannak a mi eredményeinkkel: vizsgálataik alapján az 'Ambrunés' cseresznyefajta gyümölcseinek almasav koncentrációja 65,74-66,27\%, borostyánkősav koncentrációja 21,62-22,46\%, citromsav koncentrációja pedig 11,79-12,11\% között alakult.

A 'Kordia' összes kromatográfiás savtartalma $(6,25-8,34 \mathrm{mg} / \mathrm{ml})$ a négyéves átlagot, és egy év kivételével - az éves átlagokat tekintve is mindig magasabb volt, mint a 'Regina' megfelelő értéke (5,42-6,89 mg/ml). Ez a TA méréssel összhangban van, tehát kijelenthető, hogy a 'Kordia' fajta gyümölcseiben erőteljesebb a savas karakter, mint a 'Regina' gyümölcseiben. Ezt a véleményt a szakirodalom is alátámasztja: USENIK et al. (2009) szerint a 'Kordia’ fajta TKS értéke 
átlagosan 4,3-5,6 mg/ml, míg ugyanez 'Regina' esetében csak 4,0-4,5 mg/ml volt, tehát a savas karakter erősebb a 'Kordia' gyümölcseiben. Ezek a TKS értékek összességében ugyan alacsonyabbak, mint az általunk mért eredmények, de hozzá kell tennünk, hogy USENIK és munkatársai csak a 2006-os év eredményeit közölték. Ha mi is kiemeljük például a 2010-es év értékeit, teljesen hasonló eredményeket kapunk (4,97-6,8 mg/ml és 3,77-5,59 mg/ml).

A vizsgálati évek összehasonlításából kiderül, hogy a savkomponensek koncentrációja a gyümölcslében szignifikánsan változik az évjárattal. Mindhárom sav tekintetében a 'Kordia' ingadozása nagyobb, tehát a 'Kordia' érzékenyebb az évjárathatásra.

Az alanyokat összehasonlítva említésre méltó a 'GiSelA 6' és a 'PiKu 1' kimagasló teljesítménye. A gyümölcsök legnagyobb almasav-, borostyánkősav- vagy citromsav-tartalma az összes esetek 45,83\%-ában a 'GiSelA 6' alanyon, 33,34\%-ban pedig a 'PiKu 1' alanyon volt mérhető. A többi három alany osztozott a maradék 20,83\%-on. A fajták összehasonlításában a 'Kordia' gyümölcs savtartalmának emelésére mindhárom savkomponens esetében elsősorban a 'GiSelA 6' ajánlható, emellett a 'GiSelA 5' is viszonylag magas értékeket mutatott. 'Regina' esetében leginkább a 'PiKu 1' alany ajánlható, a második helyet pedig a 'GiSelA 6'-nak ítéltük.

USENIK et al. (2010) 'Lapins' cseresznyefajták gyümölcseiben mérte az egyedi savkomponensek koncentrációját 9 különböző alanyon, többek között az általunk vizsgálatba volt 'GiSelA 5', 'PiKu 1' és 'Weiroot 158' alanyokon. Eredményeik szerint a 3 alany közül a 'Weiroot 158' TKS értéke lett a legmagasabb, míg a 'PiKu 1' értéke a legalacsonyabb. Ezek az eredmények a 'Kordia' fajta esetén a mi 2012-ben és 2013-ban mért értékeinkkel hozhatók párhuzamba, a másik két év eredményeivel, illetve a 'Regina' fajtára vonatkozó megállapításainkkal azonban nem. A különbség egyrészt az eltérő fajtával, másrészt az eltérő termőhelyi adottságokkal magyarázható, továbbá nem elhanyagolható az sem, hogy USENIK és munkatársai csak egy év adatait (2008) közölték. Az általunk vizsgált alany-nemes kombinációk esetében ebben a témában mindezidáig nem született szakirodalom.

\subsubsection{Q26 ültetvény}

A kromatográfiás savtartalom (TKS) összevetéséből megállapítható, hogy kevésbé kapunk egységes képet, mint a glükóz-fruktóz-szorbitol tekintetében. Az öt cseresznyefajta kontroll fái három kategóriába oszthatók a TKS értékek 3 éves átlaga alapján. A legalacsonyabb TKS értékü fajták a 'BBS' és a 'MP' voltak (5,35-5,40 mg/ml), a középső szintet a BMS képviselte $(6,15$ $\mathrm{mg} / \mathrm{ml})$, a legmagasabb értékekkel pedig a 'H222' és 'BBVG' fajták rendelkeztek (7,12-7,33 $\mathrm{mg} / \mathrm{ml})$.

Roussos et al. (2011) 3 féle almafajta ('Bebecou', 'Nafsika' és 'Niove') savkomponenseit tanulmányozta, de egyik fajta esetében sem tapasztalt szignifikáns változást a TKC értékében. A szakirodalomban nem találtunk olyan írást, mely a cseresznyefajták gyümölcseinek egyedi savkomponenseit vizsgálja virágritkítás hatására. Véleményünk szerint a virágritkítás hatására a 
gyümölcsök egyedi savkomponenseinek koncentrációja általában csökken, de - mint a legtöbb paraméter esetében - valószínűsíthetően ez is fajtafüggő.

A virágritkítás hatására 3 éves átlagban mindegyik fajta gyümölcsének TKS értéke 6-10\% közötti mértékben lecsökkent, kivéve a 'BBVG' fajtát, amelynek kromatográfiás savtartalma nem változott. A fajták sorrendjét a csökkenés nem változtatta meg.

A TKS szint a 3 év alatt mindegyik fajta kontroll fái esetében erősen ingadozott, az éves átlagok relatív szórása 13,2\% ('BBVG') és 43,8\% ('BMS') között változott, ami részben az évjárathatásra való nagyon erős érzékenységet is jelezheti, de ebben az alacsony koncentrációtartományban maga a kromatográfiás mérés bizonytalansága is nagyobb, mint a cukrok esetében.

A virágritkítással összefüggésben a 'BBVG' relatív szórás értéke 8,3\%-ra csökkent, a többi fajtáé viszont szignifikánsan emelkedett, tehát a beavatkozás rontotta a TKS szintek stabilitását.

A savak eloszlása tekintetében az egyik nemes jelentősen különbözött a többitől: a 'MP' gyümölcseinek TKS értékéből az almasav 3 év átlagában 77\%-ért, a borostyánkősav 13\%-ért volt felelős. A többi nemes esetében az almasav 68-71\% között, a borostyánkősav 18-19\% között változott. A citromsav mindegyik fajtánál 11-15\% közötti hányadot képviselt. A virágritkítás a savak eloszlását nem befolyásolta egyik fajtánál sem. Az évjárat annál inkább: a 2010-es évben az almasav koncentrációja megemelkedett 8-16\%-kal a másik két sav rovására, és ez a tendencia virágritkítástól függetlenül - minden fajtánál megmutatkozott.

Összegezve a fentieket, mivel ízminőség-definíciónk szerint a magasabb savtartalom kedvezőbb a vásárlói megítélés szempontjából, az öt fajta közül - virágritkítás nélkül - leginkább a 'BBVG' és a 'H222' ajánlható, legkevésbé a 'BBS' és a 'MP'. A virágritkításnak nincs számottevő pozitív hatása, elvégzése TKS szempontjából nem indokolt. A ‘MP' almasav-tartalma kb. 10\%-kal magasabb a többi fajtáénál, ami feldolgozás szempontjából érdekes lehet.

\subsubsection{Polifenol-frakciók}

A cseresznye gyümölcs polifenol-tartalmának számos fontos pozitív egészségügyi vonzata van, ahogy arról korábban az Irodalmi áttekintés c. fejezetben már részletesen szót ejtettünk, így a továbbiakban csak röviden megemlítjük a legfontosabbakat.

A polifenolok igen széles körü kémiai és biológiai aktivitással rendelkeznek, a legtöbb vegyület nagy valószínűséggel képes számos betegség kialakulását megelőzni, visszaszorítani (LUGASI 2000). A polifenolok kedvező hatásai a következő biokémiai folyamatok köré csoportosíthatók: antioxidáns hatás és/vagy szabadgyök-befogás; antivirális, antibakteriális hatás; asztmaellenes és antiallergén hatás; enzimek aktivitásának módosítása, általában gátlása; hepatoprotektív hatás; immunmoduláns és gyulladáscsökkentő hatás; mutagenezist és karcinogenezist befolyásoló hatás; ösztrogén aktivitás (izoflavonoidok); véredényrendszer működését, állapotát befolyásoló hatás, vascularis permeabilitás módosítása (DUTHIE et al. 2000, Ferretti et al. 2010, Hardcastle et al. 2011, HuAng és Ferraro 1992, JacoB et al. 2003, Kandaswami és Middleton 1994, Kuppusamy et al. 1990, Rong 2010, YaO et al. 2004). 
Nagy általánosságban elmondható, hogy minél magasabb a polifenolok koncentrációja a friss gyümölcsökben illetve zöldségekben, annál kedvezőbb a gyümölcs egészségre gyakorolt hatása. Továbbá amellett, hogy a tudatos és egészséges táplálkozás fogalma egyre elterjedtebb a modern társadalmakban, Hu (2007) kutatása szerint az emberek az életkor előrehaladtával egyre érzékenyebbek lesznek erre a témára, és vásárlási szokásaik pozitívan változnak az egészségesebbnek tartott, magasabb polifenol-tartalmú gyümölcsök irányába.

TREUTTER (2006) szerint mindemellett szót érdemel az a tény is hogy a polifenolok szintézise a növények védekezési stratégiájának is részét képezi. VILLARINO et al. (2011) kimutatták például, hogy az éretlen őszibarack gyümölcs magas klorogénsav- és neoklorogénsavtartalma növeli a gyümölcs ellenálló-képességét Monilinia laxa kórokozóval szemben. A hatás mechanizmusa azon alapul, hogy a klorogénsavak gátolják a melanin szintézisét a gombafonalakban, ezért valószínüsíthetően a cseresznye fajra is érvényesek a kutatás megállapításai, ugyanis a klorogénsavnak nincs gombafaj-specifikus hatása.

\subsubsection{Q10 ültetvény}

Vizsgálataink során 7 polifenol komponens koncentrációját mértük minden alany-nemes-évterminus kombinációban. A kapott értékek ismeretében elmondható, hogy az összes kromatográfiás polifenol-tartalom (TKPF) értékét két komponens dominálja: a neoklorogénsav és a cianidin $^{2}$, mivel ezek koncentrációja általában egy-két, olykor három nagyságrenddel meghaladja a többi komponensét. A két fó polifenol-komponens koncentrációja az érés során ellentétes irányba változik: a neoklorogénsav csökken, a cianidin monoton nő, és egyensúlyuk határozza meg döntő mértékben a TKPF alakulását. Megállapításainkat a szakirodalom is alátámasztja (JAKOBEK et al. 2009, KELEBEK és SELli 2011, MozeTič et al. 2004, SERRADiLla et al. 2011).

A nemes fajták összehasonlításában az összes alany-év-terminus kombinációt ( 5 alany x 3 év x 3 terminus = 45 eset) tekintve a 'Kordia' TKPF-tartalma az esetek 97,8\%-ában szignifikánsan magasabb volt, mint a 'Regina' megfelelő értéke. A T1-es érési terminusban az egymásnak megfelelő 'Kordia'-alany és 'Regina'-alany kombinációk közti átlagos különbség 66\% volt a 'Kordia' javára, míg T3-as terminusban ennél is magasabb: 80\%. USENIK et al. (2009) vizsgálataik során szintén nagy különbségeket találtak a 'Regina' és 'Kordia' fajták polifenol-komponenseinek koncentrációjában: komponenstől függően 40,2-84,1\% volt az eltérés a 'Kordia' fajta javára.

Ha VILLARINO et al. (2011) javaslata alapján a klorogénsav és neoklorogénsav összességét vizsgáljuk az éretlen gyümölcsök (T1-es érési stádium) vonatkozásában, az derül ki, hogy (3 év alatt az 5-5 alany-nemes kombináció összehasonlításában) az esetek 93,3\%-ában a 'Kordia' gyümölcsökben magasabb a klorogénsav+neoklorogénsav érték, és a különbség a 'Kordia' javára 25-168\% között változik.

\footnotetext{
${ }^{2}$ A komponensek jelölésére továbbra is az Eredmények c. fejezetben bevezetett rövidített neveket alkalmazzuk.
} 
T3-as stádiumban a polifenol-tartalom legnagyobb része a cianidinből adódik, így a 'Kordia' egyértelmű előnyét jelző TKPF adatok jól korrelálnak a színkoordináták elemzésekor kapott eredményekkel. ${ }^{3}$

Az évjárathatás mindkét nemes viszonylatában erőteljesen jelentkezik. A 'Regina' T1-es stádiumban még kicsit kevésbé érzékeny az évjárathatásra, mint a 'Kordia', ám az érés fokozott beindulásával a 'Regina’ fajtán szignifikánsan nagyobb lesz az éves átlagok szórása.

A fentiek alapján tehát kijelenthető, hogy a nemesek több szempontú összehasonlításában polifenol tekintetben - igen nagy különbséggel a 'Kordia' bizonyult jobbnak, a 'Regina' pedig kevésbé ajánlható.

Az alanyok összehasonlításában a T3-as érési stádiumban mért TKPF adatokat elemezve megállapítottuk, hogy 'Kordia' nemessel kombinálva a legnagyobb TKPF-tartalmú érett gyümölcsök a 'GiSelA 5' alanyon várhatók, ezen kívül még a 'Weiroot 158' is ajánlható. A 'Regina' fajta esetében a 'PHL-C' alany bizonyult a legjobbnak, de közte és a következö két helyezett ('PiKu 1' és 'GiSelA 5') között nincs statisztikailag szignifikáns különbség. UsENIK et al. (2010) kutatásai részben megfeleltethetők a mi eredményeinkkel: a legmagasabb TKPF értéket 7 alany közül ök is a 'Weiroot 158' és a 'GiSelA 5' alanyokon mérték a 2008-as évben 'Lapins' fajtán. Az általunk vizsgált alany-nemes kombinációk esetében ebben a témában mindezidáig nem született szakirodalom.

Ha a T3 fázisban megvizsgáljuk külön csak a cianidin-tartalmat a 'Kordia' fajta viszonylatában, azt tapasztaljuk, hogy itt a 'Weiroot 158' és a 'GiSelA 5' hozza a legkedvezőbb értékeket, ebben a sorrendben. A 'Regina' esetében cianidin-tartalom szempontjából a 'PHL-C' és a 'PiKu 1' javasolható. Ezek az eredmények nem teljesen egyeznek a színkoordináták vizsgálatából kapott adatokkal. A jelenség egyik lehetséges magyarázata az, hogy a színt a gyümölcs héjából (exokarpium) mértük, a polifenolokat azonban a teljes gyümölcsből, és a polifenolok koncentrációja a héjban és a teljes gyümölcsben nem feltétlenül korrelál egymással. Ennek felderítése egy későbbi kutatás célja lehet.

A klorogénsavak tekintetében nem teljesen egyértelmü a helyzet. Az összes nemes-év kombinációban, mindhárom terminust figyelembe az esetek 38\%-ában a 'GiSelA 5' alanyon mértük a legnagyobb CGA+NCGA összeget. Ám a cianidinnel ellentétben a klorogénsavak vizsgálatakor elsősorban a T1-es terminus érdekes, mivel VILLARINO et al. (2011) szerint ez a legfontosabb a növény önvédelmi mechanizmusa szempontjából. Külön csak a T1-es terminust vizsgálva azt kaptuk, hogy az esetek 66,7\%-ában 'GiSelA 6' alanyon volt a legkedvezőbb a klorogénsavak összes mennyisége.

Az évek közötti fluktuáció szempontjából megállapítható, hogy a 'Kordia' nemes a 'GiSelA 5' és 'GiSelA 6' alanyokkal kombinálva szignifikánsan kevésbé érzékeny az

\footnotetext{
${ }^{3}$ A cianidin felelős ugyanis legnagyobb mértékben a gyümölcsszín alakulásáért (GOMBKÖTŐ és SAJGó 1985, FLESCHHUT et al. 2006).
} 
évjárathatásra, mint a többi három alanyon. A 'Regina' nemes a 'PHL-C' alanyon legérzékenyebb az évjárathatásra, a többi alany között nincs szignifikáns különbség.

Mindent összevetve a legkedvezőbb polifenol-tartalmat a cseresznye gyümölcsökben 'Kordia' nemes fajta esetében a 'GiSelA 5' és 'GiSelA 6' alanyok ígérik, 'Regina' fajtához pedig a 'PiKu 1' és 'PHL-C' alanyok ajánlottak.

\subsubsection{Q26 ültetvény}

A Q26 ültetvényből származó gyümölcsök polifenol-elemzési adatai két évből állnak rendelkezésünkre. Ez a levonható következtetések mennyiségét, értékét és valószínüségét egyaránt csökkenti, föleg az évjárathatásra vonatkozóan.

A T3-as érési fázis TKPF szintjének alakulása mind a vizsgálati évek, mind pedig a fajták vonatkozásában nagyfokú változatosságot mutatott. A két év átlagában a legmagasabb TKPF értékeket a 'BBVG', a 'BMS' és a 'H222' fajták érték el (1790-1650mg/kg között), őket követi a 'MP' és a 'BBS' (1100 mg/kg illetve $860 \mathrm{mg} / \mathrm{kg}$ értékkel).

A szakirodalomban nem találtunk olyan írást, mely a virágritkítás hatását vizsgálta volna cseresznye fajták gyümölcseiben a polifenol-komponensek koncentrációjára. Roussos et al. (2011) két almafajta ('Nafsika' és 'Niove') esetében bizonyított szignifikáns pozitív hatást a TKPF értékre, míg 'Bebecou' fajta esetében nem talált különbséget a kontroll és ritkított fák között. A 'Nafsika' fajta TKPF értéke 241,1 mg/kg értékröl 289,2 mg/kg értékre emelkedett, míg ugyanez 'Niove' esetén 365,1 mg/kg-ról 434,1 mg/kg-ra változott. Látható az is, hogy az alma faj gyümölcseiben jóval alacsonyabb az összes kromatográfiás polifenol-tartalom, mint cseresznye esetében.

A BMS virágritkított és a kontroll változata, valamint a virágritkított 'MP' igen stabil polifenol-szinteket produkált: az éves átlagok relatív szórása mindössze 7\%,8\% illetve 10\% volt. Az összes többi esetben 28-56\% tartományba esett az évek közötti változékonyság mértéke. Ezek a nagy számok az évjárathatás rendkívül erőteljes befolyására utalnak.

A cianidin koncentráció a várakozásoknak megfelelően minden fajtánál - kezeléstől függetlenül - emelkedett az érés során. A legmagasabb értékeket minden esetben a BMS, a legalacsonyabbat pedig minden esetben a 'BBS' mutatta, a további sorrend azonban évjárattól és termesztési technológiától (virágritkítás van vs. nincs) függően erősen változott.

A fák M. laxa gombával szembeni ellenálló-képessége szempontjából kiemelten fontos klorogénsavak (kolrogénsav+neoklorogénsav) együttes koncentrációja a T1-es érési fázisban 2011-ben jelentősen, fajtától függően 20-190\%-kal kisebb volt, mint 2012-ben. Érdekes, hogy 2011-ben e tekintetben elhanyagolható (1-4\%) különbséget mértünk a virágritkított és a kontroll fák között, viszont 2012-ben ugyanez a különbség 10-32\% volt.

Az összes klorogénsav-tartalom alapján a fajták sorrendje minden évben és ritkított vagy nem ritkított változatban ugyanaz volt: 'H222' > 'BBVG' > ('BMS') > 'MP' > 'BBS'. Említésre 
méltó, hogy a 'H222' összes klorogénsav-tartalma 2012-ben jelentősen, 26-430\%-kal felülmúlta a többi fajtáét, föleg a virágritkított fák esetében.

Összefoglalásként elmondható, hogy a T3-as érési fázist tekintve, táplálkozás-egészségügyi szempontból, magasabb összes polifenol-tartalmuknál fogva a 'BBVG', a 'BMS' és 'H222' fajták tünnek a legjobbnak, és ezek közül a 'BMS' lehet az, amely legkevésbé érzékeny az évjárathatásra. A 'BMS' tünik legkedvezőbbnek a cianidin-koncentráció szempontjából is. A T1-es terminusban mutatott magas összes klorogénsav-tartalma miatt kiemelendő még a 'H222' fajta.

A virágritkításra a legfontosabb egyedi polifenolok koncentrációja, illetve a TKPF érték szempontjából a 'BBS' és 'BBVG' fajták általában pozitívan reagálnak, a 'BMS' általában negatívan, a többi fajta válaszaiban nem találtunk egyértelmü összefüggést, azonban ismét hangsúlyozzuk, hogy az évjárat hatása nagyon erőteljesen befolyásolja ezeket a tendenciákat.

\section{4. Összegzés}

Eredményeink, következtetéseink és javaslataink szintéziseként, esszenciájaként készítettünk egyegy értékelési szempontsort/összefoglaló táblázatot az alany és a virágritkítás hatására vonatkozóan, melyek segítségével a termesztők - a felhasználási cél ismeretében - kiválaszthatják a kívánt gyümölcsminőség elérése szempontjából optimális technológiát (virágritkítás) (15. táblázat), valamint alany-nemes kombinációt (16. táblázat).

15. táblázat: Értékelési szempontsor a virágritkítás hatásáról 5 különböző cseresznyefajta gyümölcseinek mennyiségi és minőségi paramétereire vonatkozóan

\begin{tabular}{|c|c|c|c|}
\hline Szempontok & Nemes & $\begin{array}{l}\text { Virágritk. } \\
\text { pozitív } \\
\text { hatású }\end{array}$ & $\begin{array}{l}\text { Virágritk. } \\
\text { közömbös }\end{array}$ \\
\hline \multirow{5}{*}{$\begin{array}{c}\text { nagyobb } \\
\text { gyümölcsméret }\end{array}$} & BBS & $\mathrm{X}$ & \\
\hline & BBVG & $\mathrm{X}$ & \\
\hline & BMS & $\mathrm{X}$ & \\
\hline & H222 & $\mathrm{X}$ & \\
\hline & MP & $X$ & \\
\hline \multirow{5}{*}{$\begin{array}{c}\text { nagyobb } \\
\text { gyümölcstömeg }\end{array}$} & BBS & X & \\
\hline & BBVG & $\mathrm{X}$ & \\
\hline & BMS & X & \\
\hline & H222 & $\mathrm{X}$ & \\
\hline & MP & X & \\
\hline \multirow{5}{*}{$\begin{array}{l}\text { nagyobb } \\
\text { gyümölcs- } \\
\text { keménység }\end{array}$} & BBS & $\mathrm{X}$ & \\
\hline & BBVG & X & \\
\hline & BMS & X & \\
\hline & $\mathrm{H} 222$ & $X$ & \\
\hline & MP & X & \\
\hline \multirow{5}{*}{$\begin{array}{l}\text { világosabb, } \\
\text { élénkpirosabb } \\
\text { gyümölcsök }\end{array}$} & BBS & & $\mathrm{X}$ \\
\hline & BBVG & & $\mathrm{X}$ \\
\hline & BMS & $\mathrm{X}$ & \\
\hline & $\mathrm{H} 222$ & & $\mathrm{X}$ \\
\hline & MP & $\mathrm{X}$ & \\
\hline
\end{tabular}

\begin{tabular}{|c|c|c|c|c|}
\hline Szempontok & Nemes & $\begin{array}{l}\text { Virágritk. } \\
\text { pozitív } \\
\text { hatású }\end{array}$ & $\begin{array}{l}\text { Virágritk. } \\
\text { közömbös }\end{array}$ & $\begin{array}{l}\text { Virágritk. } \\
\text { negatív } \\
\text { hatású }\end{array}$ \\
\hline $\begin{array}{c}\text { harmonikus, } \\
\text { jó íz } \\
\text { (TSS-TA } \\
\text { viszony) }\end{array}$ & \begin{tabular}{|c|} 
BBS \\
BBVG \\
BMS \\
H222 \\
MP \\
\end{tabular} & X & $\begin{array}{l}X \\
X\end{array}$ & $X$ \\
\hline $\begin{array}{c}\text { magasabb } \\
\text { összes } \\
\text { kromatográfiás } \\
\text { cukortartalom }\end{array}$ & \begin{tabular}{|c|} 
BBS \\
BBVG \\
BMS \\
H222 \\
MP \\
\end{tabular} & $\mathrm{X}$ & $\mathrm{X}$ & $\begin{array}{l}\mathrm{X} \\
\mathrm{X}\end{array}$ \\
\hline $\begin{array}{c}\text { magasabb } \\
\text { összes } \\
\text { kromatográfiás } \\
\text { savtartalom }\end{array}$ & \begin{tabular}{|c|} 
BBS \\
BBVG \\
BMS \\
H222 \\
MP \\
\end{tabular} & $\mathrm{X}$ & $\begin{array}{l}\mathrm{X} \\
\mathrm{X}\end{array}$ & $\begin{array}{l}\mathrm{X} \\
\mathrm{X}\end{array}$ \\
\hline $\begin{array}{c}\text { magasabb } \\
\text { összes } \\
\text { kromatográfiás } \\
\text { polifenol- } \\
\text { tartalom } \\
\end{array}$ & \begin{tabular}{|c|} 
BBS \\
BBVG \\
BMS \\
H222 \\
MP \\
\end{tabular} & $\begin{array}{l}\mathrm{X} \\
\mathrm{X}\end{array}$ & $\begin{array}{l}X \\
X\end{array}$ & $X$ \\
\hline
\end{tabular}




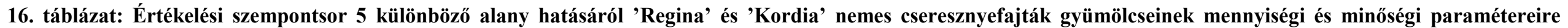
vonatkozóan

\begin{tabular}{|c|c|c|c|}
\hline Szempontok - 'Kordia' & $\begin{array}{l}\text { Alany } \\
\text { pozitív } \\
\text { hatású }\end{array}$ & $\begin{array}{l}\text { Alany } \\
\text { átlagos } \\
\text { hatású }\end{array}$ & $\begin{array}{c}\text { Alany } \\
\text { negatív } \\
\text { hatású }\end{array}$ \\
\hline nagy gyümölcsméret & GiSelA 6 & $\begin{array}{c}\text { GiSelA } 5 \\
\text { PHL-C } \\
\text { Weiroot } 158\end{array}$ & $\mathrm{PiKu} 1$ \\
\hline nagy gyümölcstömeg & GiSelA 6 & $\begin{array}{c}\text { GiSelA 5 } \\
\text { PHL-C } \\
\text { Weiroot } 158\end{array}$ & $\mathrm{PiKu} 1$ \\
\hline magas hasznos gyümölcs arány & PHL-C & $\begin{array}{c}\text { GiSelA } 6 \\
\text { PiKu } 1 \\
\text { Weiroot } 158 \\
\end{array}$ & GiSelA 5 \\
\hline $\begin{array}{c}\text { nagy } \\
\text { kocsány-szakítószilárdság }\end{array}$ & $\begin{array}{c}\text { PHL-C } \\
\text { Weiroot } 158\end{array}$ & $\begin{array}{l}\text { GiSelA } 5 \\
\text { GiSelA } 6\end{array}$ & $\mathrm{PiKu} 1$ \\
\hline sötét színü gyümölcsök & PHL-C & $\begin{array}{c}\text { GiSelA } 5 \\
\text { PiKu } 1 \\
\text { Weiroot } 158\end{array}$ & GiSelA 6 \\
\hline nagy gyümölcskeménység & $\begin{array}{l}\text { GiSelA } 5 \\
\text { GiSelA } 6 \\
\text { PHL-C }\end{array}$ & $\mathrm{PiKu} 1$ & Weiroot 158 \\
\hline $\begin{array}{l}\text { harmonikus, jó íz } \\
\text { (TSS-TA viszony) }\end{array}$ & GiSelA 5 & $\begin{array}{c}\text { PHL-C } \\
\text { PiKu 1 } \\
\text { Weiroot } 158\end{array}$ & GiSelA 6 \\
\hline $\begin{array}{c}\text { magas összes kromatográfiás } \\
\text { cukortartalom }\end{array}$ & $\mathrm{PiKu} 1$ & $\begin{array}{l}\text { GiSelA } 5 \\
\text { GiSelA } 6 \\
\text { PHL-C }\end{array}$ & Weiroot 158 \\
\hline $\begin{array}{c}\text { magas összes kromatográfiás } \\
\text { savtartalom }\end{array}$ & GiSelA 6 & GiSelA 5 & $\begin{array}{c}\text { PHL-C } \\
\text { PiKu } 1 \\
\text { Weiroot } 158\end{array}$ \\
\hline $\begin{array}{c}\text { magas klorogénsav- és } \\
\text { neoklorogénsav-koncentráció } \\
\text { T1-es stádiumban } \\
\end{array}$ & GiSelA 6 & GiSelA 5 & $\begin{array}{c}\text { PHL-C } \\
\text { PiKu } 1 \\
\text { Weiroot } 158 \\
\end{array}$ \\
\hline $\begin{array}{c}\text { magas cianidin-komponens } \\
\text { kocentráció }\end{array}$ & Weiroot 158 & $\begin{array}{l}\text { GiSelA } 5 \\
\text { PHL-C }\end{array}$ & $\begin{array}{l}\text { GiSelA } 6 \\
\text { PiKu } 1\end{array}$ \\
\hline $\begin{array}{c}\text { magas összes kromatográfiás } \\
\text { polifenol-tartalom }\end{array}$ & $\begin{array}{c}\text { GiSelA } 5 \\
\text { Weiroot } 158\end{array}$ & PHL-C & $\begin{array}{l}\text { GiSelA } 6 \\
\text { PiKu } 1\end{array}$ \\
\hline
\end{tabular}

\begin{tabular}{|c|c|c|c|}
\hline Szempontok - 'Regina' & $\begin{array}{l}\text { Alany } \\
\text { pozitív } \\
\text { hatású }\end{array}$ & $\begin{array}{l}\text { Alany } \\
\text { átlagos } \\
\text { hatású }\end{array}$ & $\begin{array}{l}\text { Alany } \\
\text { negatív } \\
\text { hatású }\end{array}$ \\
\hline nagy gyümölcsméret & $\begin{array}{c}\text { GiSelA } 6 \\
\text { PHL-C } \\
\text { Weiroot } 158 \\
\end{array}$ & GiSelA 5 & $\mathrm{PiKu} 1$ \\
\hline nagy gyümölcstömeg & $\begin{array}{c}\text { PHL-C } \\
\text { Weiroot } 158\end{array}$ & GiSelA 6 & $\begin{array}{l}\text { GiSelA } 5 \\
\text { PiKu } 1\end{array}$ \\
\hline magas hasznos gyümölcs arány & $\begin{array}{l}\text { PHL-C } \\
\text { GiSelA } 6\end{array}$ & Weiroot 158 & $\begin{array}{l}\text { GiSelA } 5 \\
\text { PiKu } 1\end{array}$ \\
\hline $\begin{array}{c}\text { nagy } \\
\text { kocsány-szakítószilárdság }\end{array}$ & Weiroot 158 & $\begin{array}{c}\text { GiSelA } 5 \\
\text { GiSelA } 6 \\
\text { PiKu } 1 \\
\end{array}$ & PHL-C \\
\hline sötét színü gyümölcsök & $\mathrm{PiKu} 1$ & $\begin{array}{c}\text { PHL-C } \\
\text { Weiroot } 158\end{array}$ & $\begin{array}{l}\text { GiSelA } 5 \\
\text { GiSelA } 6\end{array}$ \\
\hline nagy gyümölcskeménység & $\begin{array}{l}\text { GiSelA } 5 \\
\text { GiSelA } 6\end{array}$ & $\begin{array}{c}\text { PiKu } 1 \\
\text { Weiroot } 158\end{array}$ & PHL-C \\
\hline $\begin{array}{l}\text { harmonikus, jó íz } \\
\text { (TSS-TA viszony) }\end{array}$ & Weiroot 158 & $\begin{array}{l}\text { GiSelA } 6 \\
\text { PHL-C } \\
\text { PiKu } 1\end{array}$ & GiSelA 5 \\
\hline $\begin{array}{c}\text { magas összes kromatográfiás } \\
\text { cukortartalom }\end{array}$ & $\mathrm{PiKu} 1$ & $\begin{array}{c}\text { GiSelA } 6 \\
\text { PHL-C } \\
\text { Weiroot } 158\end{array}$ & GiSelA 5 \\
\hline $\begin{array}{c}\text { magas összes kromatográfiás } \\
\text { savtartalom }\end{array}$ & PiKu 1 & GiSelA 6 & $\begin{array}{c}\text { GiSelA } 5 \\
\text { PHL-C } \\
\text { Weiroot } 158 \\
\end{array}$ \\
\hline $\begin{array}{c}\text { magas klorogénsav- és } \\
\text { neoklorogénsav-koncentráció } \\
\text { T1-es stádiumban } \\
\end{array}$ & GiSelA 6 & $\begin{array}{l}\text { GiSelA } 5 \\
\text { PHL-C }\end{array}$ & $\begin{array}{c}\text { PiKu } 1 \\
\text { Weiroot } 158\end{array}$ \\
\hline $\begin{array}{c}\text { magas cianidin-komponens } \\
\text { kocentráció }\end{array}$ & $\begin{array}{l}\text { PHL-C } \\
\text { PiKu } 1\end{array}$ & Weiroot 158 & $\begin{array}{l}\text { GiSelA } 5 \\
\text { GiSelA } 6\end{array}$ \\
\hline $\begin{array}{c}\text { magas összes kromatográfiás } \\
\text { polifenol-tartalom }\end{array}$ & $\begin{array}{l}\text { PiKu } 1 \\
\text { PHL-C }\end{array}$ & GiSelA 5 & $\begin{array}{c}\text { GiSelA } 6 \\
\text { Weiroot } 158\end{array}$ \\
\hline
\end{tabular}




\section{7. ÚJ TUDOMÁNYOS EREDMÉNYEK}

A PhD munkám során elért új tudományos eredmények a következők:

1. 'GiSelA 5' alanyra oltott 'Merton Premier' és 'Hybrid 222' cseresznyefajták elsőként történő átfogó elemzése, értékelése a gyümölcs piaci értékét meghatározó fizikai paraméterek és beltartalmi értékek alapján.

Az elsőként mért, elemzett és értékelt paraméterek:

- gyümölcsméret, gyümölcstérfogat, gyümölcs- és csontártömeg, hasznos gyümölcs arány, gyümölcskeménység, kocsány-szakítószilárdság, gyümölcsök héjszíne

- összes vízoldható szárazanyag-tartalom, összes titrálható savtartalom

- egyedi cukor- (fruktóz-, glükóz-, szorbitol-), sav- (almasav-, borostyánkősav-, citromsav) és polifenol-frakció (cianidin-3-O-rutinozid, kvercetin, kvercetin-3-rutinozid, klorogénsav, neoklorogénsav, katechin és 3-p-kumaroil-kínasav)

2. Öt korai érésű cseresznyefajta elsőként történő átfogó összehasonlítása és értékelése a virágritkítás gyümölcsminőségre gyakorolt hatása szempontjából, továbbá e hatás igazolása a vizsgálatba vont öt nemes fajta esetében.

A virágritkítás hatásának igazolása:

- gyümölcsméret, gyümölcstömeg és gyümölcskeménység tekintetében a pozitív hatás igazolása mind az öt fajta esetében

- gyümölcsök világosabb és élénkpirosabb héjszínének igazolása 'BMS' és 'MP' fajták esetében

- gyümölcsök ízminősége (TSS-TA viszony) szempontjából pozitív hatás igazolása 'BBVG', negatív hatás igazolása 'BMS' fajta esetében

- egyedi cukorkomponensek koncentrációjának tekintetében pozitív hatás igazolása 'BBVG' és 'H222' fajtáknál

- egyedi savkomponensek tekintetében negatív hatás igazolása 'BBS' és 'BMS' fajtáknál, pozitív hatás igazolása 'BBVG' fajtánál

- összes kromatográfiás polifenol-tartalom szempontjából pozitív hatás igazolása 'BBS' és 'BBVG' fajták esetében, negatív hatás igazolása 'BMS' fajtánál

3. Két késői érésű nemes cseresznyefajta és öt alany összes kombinációinak elsőként történő átfogó összehasonlítása és értékelése az alany gyümölcsminőségre gyakorolt hatása szempontjából, továbbá e hatás igazolása a vizsgálatba vont alany-nemes kombinációk esetében. 
Az alanyhatás igazolása:

- gyümölcsméret és gyümölcstömeg esetében pozitív hatás igazolása 'Kordia' fajtánál 'GiSelA 6', 'Regina' fajtánál 'PHLC' és 'Weiroot 158' alanyokon, negatív hatás igazolása mindkét fajtánál 'PiKu 1' alanyon

- gyümölcskeménység tekintetében pozitív hatás igazolása mindkét fajtánál 'GiSelA 5' és 'GiSelA 6' alanyokon, negatív hatás igazolása 'Kordia' fajtánál 'Weiroot 158', 'Regina' fajtánál 'PHLC' alanyon

- gyümölcsök világosabb és élénkpirosabb héjszínének igazolása ,Kordia’ fajtánál 'GiSelA 6', 'Regina' fajtánál , GiSelA 5' és ,GiSelA 6' alanyokon, míg sötétebb héjszínének igazolása 'Kordia' fajtánál 'PHLC', 'Regina' fajtánál 'PiKu 1' alanyon

- gyümölcsök ízminősége (TSS-TA viszony) szempontjából pozitív hatás igazolása 'Kordia' fajtánál 'GiSelA 5', 'Regina' fajtánál 'Weiroot 158' alanyon, negatív hatás igazolása ,Kordia' fajtánál 'GiSelA 6', 'Regina' fajtánál ‘GiSelA 5' alanyon

- egyedi cukorkomponensek koncentrációjának tekintetében pozitív hatás igazolása mindkét fajtánál 'PiKu 1' alanyon, negatív hatás igazolása 'Kordia' fajtánál 'Weiroot 158', 'Regina' fajtánál 'GiSelA 5' alanyon

- egyedi savkomponensek koncentrációjának tekintetében pozitív hatás igazolása 'Kordia' fajta esetében 'GiSelA 6', 'Regina' fajtánál 'PiKu 1' alanyon

- összes kromatográfiás polifenol-tartalom, valamint egyedi polifenol-komponensek koncentrációjának szempontjából pozitív hatás igazolása 'Kordia' fajtánál a 'GiSelA 5', 'GiSelA 6' és 'Weiroot 158' alanyoknál, 'Regina' fajtánál a 'PiKu 1' és 'PHLC' alanyoknál

4. Tizenöt vizsgálatba vont cseresznye alany-nemes kombináció gyümölcseinek egészségvédő értékét jelző egyedi polifenol-frakcióinak elsőként történő átfogó vizsgálata és összehasonlító elemzése.

A vizsgált és elemzett egyedi polifenol-frakciók:

- cianidin-3-O-rutinozid, kvercetin, kvercetin-3-rutinozid, klorogénsav, neoklorogénsav, katechin és 3-p-kumaroil-kínasav

5. Az évjárathatás kimutatása a vizsgált alanyok és kezelés (virágritkítás) cseresznye gyümölcsök minőségére gyakorolt hatásában.

Az évjárathatás igazolása a gyümölcsminőségre:

- 'GiSelA 5', 'GiSelA 6', 'PHLC', 'PiKu 1', 'Weiroot 158' alanyok hatására 'Regina' és 'Kordia' nemes fajták esetében az alábbi paraméterekre: gyümölcsméret, gyümölcstömeg, kocsány-szakítószilárdság, gyümölcshéjszín, gyümölcskeménység, összes oldható szárazanyag-tartalom, összes titrálható savtartalom, egyedi cukor-, sav- és polifenolkomponensek koncentrációja 
- virágritkítás hatására 'GiSelA 5' alanyon álló 'Bigarreau Burlat Schreiber', 'Bigarreau Burlat VG', 'Bigarreau Moreau Schreiber', 'Hybrid 222', 'Merton Premier' fajták esetében az alábbi paraméterekre: gyümölcsméret, gyümölcstömeg, kocsány-szakítószilárdság, gyümölcshéjszín, gyümölcskeménység, összes oldható szárazanyag-tartalom, összes titrálható savtartalom, egyedi cukor-, sav- és polifenol-komponensek koncentrációja

6. Elsőként elvégzett olyan cseresznye gyümölcsminőségi vizsgálatok, amelyek eredményei - a mintavétel helyének a magyarországihoz hasonló talaj- és klimatikus viszonyai miatt - a hazai cseresznyetermesztő körzetekben is jól adaptálhatóak.

A jól adaptálható eredmények:

- 15 alany-nemes kombináció gyümölcsminőségének vizsgálatára vonatkozó eredmények

- 10 alany-nemes kombináció alanyhatást igazoló eredményei

- virágritkítás hatását igazoló eredmények 5 nemes fajta 'Bigarreau Burlat Schreiber', 'Bigarreau Burlat VG', 'Bigarreau Moreau Schreiber', 'Hybrid 222', 'Merton Premier' esetén 'GiSelA 5' alanyra oltva

7. Elsőként történő igazolása a cukor-, sav- és polifenol-komponensek egymáshoz viszonyított aránya változatlanságának a vizsgálatba vont 15 cseresznye alany-nemes oltványkombináció gyümölcseinél alanyok, évjáratok és virágritkítás hatására.

8. Új, kétdimenziós módszer kidolgozása és alkalmazása (TSS-TA viszony) a cseresznye gyümölcsök ízértékének jobb szemléltetésére és összehasonlító értékelésére a széleskörüen használt TSS/TA arány helyett, mely gyakorlati segítséggel szolgál a termelőnek és a felhasználónak az elérni kívánt gyümölcsminőség meghatározásához és ellenőrzéséhez.

9. Két értékelési szempontsor létrehozása a vizsgált cseresznye nemesek és alanyok körére, melyek gyakorlati segítséget nyújtanak a kívánt gyümölcsminőség elérése szempontjából optimális alany-nemes kombináció kiválasztásában, valamint technológia (virágritkítás) alkalmazhatóságában. 


\section{8. ÖSSZEFOGLALÁS}

A cseresznye (Prunus avium (L.) L.) korai érése, tetszetős külső megjelenése és kedvező beltartalmi értékeinek köszönhetően az egyik legkedveltebb koranyári gyümölcs. Kultúrájának története során számos cseresznyefajta került nemesítésre és termesztésbe vonásra. A ma fellelhető fajták eltérő fizikai paraméterekkel (gyümölcsméret, héjszín, keménység stb.), beltartalmi összetevőkkel (cukortartalom, savtartalom, vitaminok, ásványi anyagok), valamint egészségvédő értékkel (pl. polifenol-, ill. antocianidin-komponensek) rendelkeznek. Ma már azonban egyre több vizsgálat bizonyítja, hogy ezek a tulajdonságok nem csak a nemes fajtától függnek, hanem az oltvány alany-komponensétől is, bár a hatás még nem teljesen tisztázott. Mindemellett hatással lehet a gyümölcs minőségre a virágritkítás alkalmazása is, de ez a terület is további kutatást igényel. Ismert az is, hogy az említett paraméterek az érés elörehaladtával változnak, de a változás mértéke és iránya nem mindig ismert, vagy ellentmondásos.

Korunkban egyre nagyobb figyelmet kap a helyes táplálkozás, és annak egészségvédő, betegségmegelőző hatása. Ehhez nélkülözhetetlen a kedvező beltartalmi értékekkel rendelkező friss gyümölcsök és zöldségek, illetve az azokból elöállított - szintén magas beltartalmi értékü produktumok fogyasztása. Éppen ezért a cseresznyetermesztők is érdekeltek abban, hogy minél jobb beltartalommal és egészségvédő hatással rendelkező gyümölcsöt produkáló cseresznyeoltványokat használjanak. Kutatásainkkal többek között arra keressük a választ, hogy mely alany-nemes kombinációk lehetnek a legmegfelelőbbek erre a célra, valamint, hogy milyen pozitív hatásai lehetnek a virágritkításnak az említett tulajdonságokra.

Kutatásaink két részből tevődtek össze. Egyik részében 4 éven keresztül (2010-2013) vizsgáltuk - integrált gazdálkodású cseresznyeültetvényben - 5 különböző alany (GiSelA 5', 'GiSelA 6', 'PHL-C', 'PiKu 1' és 'Weiroot 158') hatását 2 féle cseresznye nemes ('Kordia' és 'Regina') gyümölcseinek fizikai, beltartalmi és egészségvédő értékeire. Másik részében 3 éven keresztül (2010-2012) vizsgáltuk ugyanezen értékekre gyakorolt hatását a virágritkításnak - bio cseresznyeültetvényben - 5 különböző nemes ('Bigarreau Burlat Schreiber', 'Bigarreau Burlat VG', 'Bigarreau Moreau Schreiber', 'Hybrid 222' és 'Merton Premier' fajták; alany: 'GiSelA 5') bevonásával.

Vizsgálataink során mindkét ültetvény gyümölcseit az érés három stádiumában szedtük meg: színeződés kezdetén, színeződés második felében és teljes érettségben. A vizsgált fizikai paraméterek a következők voltak: 3 féle gyümölcsátmérö (szélesség, vastagság, magasság), gyümölcstérfogat (számított mennyiség), gyümölcs- és csontártömeg, hasznos gyümölcs arány (számított mennyiség), gyümölcskeménység, gyümölcsök héjszíne, kocsány-szakítószilárdság. A vizsgált fizikokémiai paraméterek az alábbiak voltak: összes vízoldható szárazanyag-tartalom (TSS) és titrálható savtartalom (TA). Munkánk során HPLC (High-Performance Liquid Chromatography) technikával vizsgáltuk a gyümölcsök egyedi cukorkomponenseinek (glükóz, fruktóz, szorbitol), savkomponenseinek (almasav, borostyánkősav, citromsav) és polifenol- 
komponenseinek (cianidin-3-O-rutinozid, kvercetin, kvercetin-3-rutinozid, klorogénsav, neoklorogénsav, katechin és 3-p-kumaroil-kínasav) koncentrációját.

A vizsgálati program részeként elsőként végeztük el a vizsgálatba vont 2 nemes és 5 alany összesen tízféle kombinációjának nagy részletességü, átfogó, összehasonlító elemzését a gyümölcsminőségre vonatkozóan. Az elemzés eredményeképpen fontos összefüggésekre bukkantunk. A vizsgálatba vont alany és nemes fajták vonatkozásában igazoltuk, hogy az alany fajtája szignifikáns mértékben képes módosítani a nemes gyümölcsének fizikai és kémiai paramétereit, illetve beltartalmi értékeit. Megállapítottuk, hogy az alanyhatás kivétel nélkül az összes vizsgált paraméterben megjelenik. Időnként a hatás csak statisztikailag szignifikáns, gyakorlati szempontból jelentéktelennek tünik, de nem szabad elfeledkezni arról, hogy üzemi méretekben a kis különbségek is jelentős többletet vagy veszteséget okozhatnak. Előfordulhat az is, hogy az alany hatása - az időjárás hatásaival kölcsönhatásban - csak egyes években jelentkezik, ezért nem feltétlenül ismerhető fel, ha a vizsgálati időszak csak egy évet ölel fel. Ebböl következően munkánk érdeme az is, hogy az alanyhatást négy éven át - eltérő időjárású években is - vizsgáltuk.

Komplex, összehasonlító tanulmányozásnak vetettük alá öt nemes cseresznyefajta gyümölcsének mennyiségi és minőségi jellemzőit, és megvizsgáltuk azok függését a virágritkítás alkalmazásától. A kutatás részeként elsőként publikáltuk a 'GiSelA 5' alanyra oltott 'Merton Premier' és ‘Hybrid 222’ nemesek viselkedését, gyümölcsminőségi paramétereit.

A vizsgálatok során igazoltuk, hogy a virágritkítás szignifikáns hatással lehet a gyümölcsök külső-belső jegyeire. Kimutattuk, hogy ez a hatás különbözőképpen módosítja a gyümölcs alapvetően a nemesre jellemző - értékeit: bizonyos paramétereket kedvező, másokat kedvezőtlen irányba tol el. A hatás mértéke függ a nemes fajtától és az évjárattól is.

Kutatásunk részeként elsőként végeztük el tizenöt vizsgálatba vont cseresznye alany-nemes kombináció gyümölcseinek egészségvédő értékét jelző egyedi polifenol-frakcióinak vizsgálatát és összehasonlító elemzését magyarországi termesztési viszonyokra jól adaptálható módon.

Az adatok értékelése során a gyümölcsök ízértékének összehasonlítására a szakirodalomban széleskörüen használt TSS/TA arányszámot nem találtuk megfelelően informatívnak, ezért elsőként - kidolgoztunk egy alternatívát, amely egy kétdimenziós állapottérben ábrázolja a gyümölcs TA és TSS értékeit. Ez a módszer sokkal szemléletesebb, és gyakorlati segítséget is nyújthat a termelőnek és a felhasználónak az elérni kívánt gyümölcsminőség meghatározásához és ellenőrzéséhez.

A kiértékelt, feldolgozott adatok birtokában kidolgoztunk egy értékelési rendszert, amely segítségével - a vizsgált nemesek és alanyok keretén belül - kiválasztható az adott célra legmegfelelőbb alany-nemes kombináció valamint technológia (virágritkítás). 
Elsőként igazoltuk a vizsgálatba vont 15 cseresznye alany-nemes oltványkombináció gyümölcseinél, hogy a cukor-, sav- és polifenol-komponensek egymáshoz viszonyított aránya változatlan marad alanyok, évjáratok és virágritkítás hatására is.

A virágritkítással kapcsolatban megállapítható, hogy azt intenzív ültetvényi méretekben nem érdemes elvégezni. A beavatkozás az ipari illetve nagykereskedelmi szempontból legfontosabb paraméterekben csak kisebb változásokat indukál. Ezen változások nem mindegyike pozitív, jó eséllyel kioltják egymás hatását. Abban az esetben is, ha mindegyik hatás pozitív lenne, akkor sem ellensúlyoznák a - vegyszeres vagy kézi - virágritkítás költségeit, és a beavatkozás miatt kieső terméshozam veszteségét. A virágritkítás létjogosultsága véleményünk szerint a házikerti termesztésre korlátozódik, ahol a termelés gazdaságossága rovására nagyobb lehetőség van egyes kedvező tulajdonságokat kidomborítani.

Kutatásaink értékét növeli, hogy a vizsgálatok helyszínéül szolgáló bécsi cseresznyeültetvény klíma- és talajviszonyai nagymértékben hasonlóak a magyarországi körülményekhez, így eredményeink jól adaptálhatók hazai alkalmazásra.

A téma továbbvitelére számos elképzelésünk van. Az alanyhatás-vizsgálat megismétlése által további új és hasznos adatok birtokába kerülhetünk az évjárathatással kapcsolatban. Érdemes lenne további faktorok (pl. időjárás, talajminőség), illetve új gyümölcsminőségi paraméterek (pl. melatonin- és szerotonin-tartalom) bevonása a programba. Ki lehetne terjeszteni a vizsgált cseresznyefajták és alanyok körét. Fejleszthetnénk a TSS-TA diagramot azáltal, hogy irodalmi adatok és a felhasználói igények alapján kijelöljük rajta a kedvező, közömbös és kedvezőtlen ízminőségnek megfelelő tartományokat. Némi informatikai támogatással tökéletesíthető a kidolgozott értékelési szempontrendszer úgy, hogy adatbázisa bővíthető legyen új alany-nemes kombinációk mérési adataival, továbbá, hogy az egyes gyümölcsminőségi paraméterek felhasználó által szabadon súlyozhatók legyenek, és a belső algoritmus a beállított súlyok figyelembevételével válassza ki az optimális alany-nemes kombinációt. Ezeknek a vizsgálatoknak a továbbfolytatásával, illetve új vizsgálati irányok bevonásával még tovább bővíthető a cseresznyetermesztők és felhasználók számára gyakorlatban is hasznosítható ismeretek köre. 


\section{SUMMARY}

Sweet cherry (Prunus avium (L.) L.) - because of its early ripening, attractive appearance and advantageous inner content values - is one of the most favored fruits of early summer. During the history of its culture, several sweet cherry varieties were drawn into breeding and cultivation. The sweet cherry varieties of today have different physical characteristics (e.g. fruit size, color, firmness, etc.) and inner content values (e.g. sugar- and acid-content, vitamins, minerals), as well as different health-protecting potencies (e.g. polyphenol and anthocyanidine components). However, more and more studies support that these characteristics do not depend only on the scion, but also on the rootstock component of the graft, although the nature of this effect has not yet been clarified. On top of that, quality parameters of the sweet cherry fruit might be affected by flower thinning, too, but this field requires further research. It is also known that the above mentioned parameters do change with the progress of ripening, but the extent and direction of the change are not always known, or they are controversial.

Nowadays proper nutrition, and its health protective, illness-preventive effect, get more and more attention. The consumption of fresh fruits and vegetables, as well as of their products, all with beneficial inner content values, is an essential part of it. For this reason sweet cherry producers have an interest in using grafts that produce fruits with the highest possible inner content value and health protective effect. In out reasearch, among others, we sought to find out which of the scion-rootstock combinations is the most fitting for this purpose, also, what positive influence flower thinning may have on the aforementioned characteristics.

Our research consisted of two parts. In the one part, for 4 years (2010-2013), we have studied the effect of 5 different rootstocks (GiSelA 5', 'GiSelA 6', 'PHL-C', 'PiKu 1' and 'Weiroot 158') to the physical, intrinsic and health-protecting properties of the fruits of 2 cherry scion varieties ('Kordia' and 'Regina'), grown in integrated cultivation system. In the other part, for 3 years (2010-2012) we have studied the effect of flower thinning to the same parameters, involving 5 different scions ('Bigarreau Burlat Schreiber', 'Bigarreau Burlat VG', 'Bigarreau Moreau Schreiber', 'Hybrid 222' and 'Merton Premier'; rootstock: 'GiSelA 5'), in bio plantation.

In the course of our study, fruits of both plantations were sampled at three phases of ripening: at the beginning of coloration, in the second half of the coloration process, and at fully ripened state. Studied physical parameters were the following: 3 types of fruit diameter (width, depth, heigth), fruit volume (calculated value), fruit- and stone mass, useful fruit ratio (calculated value), firmness, color, detachment force of fruit stalk. Studied physico-chemical parameters were: total water-soluble solids (TSS) and titratable acids (TA). We also used HPLC (High Performace Liquid Chromatography) technique to measure the concentration of some individual sugar (glucose, fructose and sorbitol), acid (maleic acid, succinic acid and citric acid), and polyphenol (cyanidin3-O-rutinoside, quercetin, quercetin-3-rutinoside, chlorogenic acid, neochlorogenic acid, catechin, and 3-p-coumaroylquinic acid) components. 
As part of the experiment program, we were first to conduct a highly detailed, comprehensive, comparative analysis of altogether 10 combinations of 2 scion and 5 rootstock varieties with regards to the quality of their fruits. As result of the analysis we have found important correlations. In relation of the involved scion and rootstock varieties we confirmed that the kind of rootstock can significantly influence the physical and chemical parameters, as well as the inner content values, of the fruits of the scion. We have demonstrated that the rootstock-effect appears, without exception, in all studied parameters. Sometimes the effect may seem to be significant only in a statistical sense, and not from any practical point of view, but it must not be disregarded that on industrial scale even small differences can generate significant profits or losses. It can even happen that the rootstock-effect presents itself only in certain years, in interaction with the effects of weather, and for this reason it might not necessarily be recognized if the duration of the study is only one year. Consequently, it is a credit to our work that we studied the rootstock effect in four years, weather wise different years, too.

Complex and comparative study was performed involving the qualitative and quantitative characteristics of fruits of 5 sweet cherry scion varieties, and the dependence of these parameters from flower thinning was also studied. As part of our work we were first to publish the behavior and fruit quality parameters of 'Merton Premier' and 'Hybrid 222' scions grafted on 'GiSelA 5' rootstock.

In the course of the tests we have shown that flower thinning can have a significant effect on the internal and external characteristics of fruits. We have demonstrated that this effect influences the fruit quality parameters - which are basically characteristic of the scion - in different ways: some of them are shifted to favorable, others to unfavorable direction. The extent of the effect depends on the scion variety, as well as the weather.

As part of our research, we were first to perform the analysis and comparative study of the individual polyphenol compounds, which latter are indicative of health protecting power, of the fruits of 15 scion-rootstock combinations, in a way that is easily adaptable to Hungarian cultivation conditions.

During the data analysis we found that the TSS/TA ratio, which is widely used in the literature, was not sufficiently informative, and for this reason we have, first in the literature, worked out an alternative, that uses a two dimensional parameter space to chart TA and TSS values of the fruit. This method is much more expressive, and can provide practical assistance to both growers and consumers to determine and monitor the desired fruit quality

In possession of the processed, analyzed data, we have worked out an evaluation system that can help, within range of the studied scion and rootstock varieties, to select the scion-rootstock combination or technology (i.e. usage or lack of flower thinning) that best fits any given purpose. 
We were first to demonstrate, with regards to the involved 15 scion-rootstock combinations, that the concentration ratio of individual sugar compounds - as well as acids and polyphenols remain constant, independently of rootstock, year effect and flower thinning.

In relation of flower thinning it can be concluded that it is not worth doing on intensively cultivated plantation scale. The treatment only induces smaller changes in the paramters that are most important from industrial and wholesale point of view. Some of these changes are not even positive, and there is a good chance that they will nullify each other. Even if all changes were positive, they probably could not balance the costs of the - chemical or manual - flower thinning, and the loss of yield caused by the treatment. In our opinion, flower thinning is only justifiable in croft-scale fruit growing, where there is a better possibility to enhance some beneficial charateristics at the expense of economic operation.

The value of our research is augmented by the fact that the sweet cherry plantation in Vienna, serving as the location of our tests, has such climatic and soil parameters that are very much similar to Hungarian conditions, thus our results can well be adapted for domestic usage.

We have several ideas to advance the theme. By repetition of the rootstock effect test new and useful data could be obtained with regards to year effect. It would be worthwile to involve other factors (e.g. weather, soil quality), as well as new fruit quality parameters (e.g. melatoninand serotonin-content) into the program. The circle of studied scions and rootstocks could be widened. The TSS-TA chart could be improved by designating ranges of favorable, indifferent and unfavorable flavour quality on the chart, based on literature data and consumer acceptance. With some informatics support, the evaluation system could be improved so that its database could be expanded by test results of new scion rootstock combinations. Moreover, if the fruit quality paramteres could be individually weighted by the user, the underlying algorithm could calculate the optimal scion-rootstock combination taking into account the user-preferred weights. Continuing this research, as well as extending the testing to further directions, could widen the circle of a practically useable knowledge at the disposal of sweet cherry growers and consumers. 


\section{MELLÉKLETEK}

\subsection{M1. IRODALOMJEGYZÉK}

1. Abad-Garcia B., Berrueta L. A., Garmón-Lobato S., Gallo B., Vicente F. (2009): A general analytical strategy for the characterization of phenolic compounds in fruit juices by high-performance liquid chromatography with diode array detection coupled to electrospray ionization and triple quadrupole mass spectrometry. Journal of Chromatography A., 1216 (28):5398-5415. DOI: doi:10.1016/j.chroma.2009.05.039

2. AĞLAR E. és YILDIZ K. (2014): Influence of rootstocks (Gisela 5, Gisela 6, MaxMa, SL 64) on performance of '0900 Ziraat' sweet cherry. Journal of Basic \& Applied Sciences, 10:60-66., ISSN: 1927-5129, DOI: http://dx.doi.org/10.6000/1927-5129.2014.10.09

3. Agulheiro-Santos A. C., Palma V., Machado G., Rato A. E., Cabrita M. J. (2012): Quality evaluation of 'Sunburst' cherries harvested at different ripeness stages. In XXVIII International Horticultural Congress on Science and Horticulture, International Symposium, Acta Hort. (ISHS), 934:1127-1131.

4. Albanes D., Heinonen O. P., Huttunen J. K., Taylor Ph. R., Virtamo J., Edwards B. K., HaApakoski J., RautAlahti M., Hartman A. M., PALMGRen J., GREENwald P., (1995): Effects of a-tocopherol and n-carotene supplements on cancer incidence in the Alpha-Tocopherol Beta-Carotene Cancer Prevention Study. Am J. Clin. Nutr., 62:1427S-1430S.

5. Alothman M., BHat R., Karim A. A. (2009): Antioxidant capacity and phenolic content of selected tropical fruits from Malaysia, extracted with different solvents. Food Chemistry, 115 (3):785-788. doi:10.1016/j.foodchem.2008.12.005

6. Andersen R. L., Robinson T., Lang G. A. (1999): Managing the Gisela Cherry Rootstocks. New York Fruit Quarterly, 7 (4):19-22.

7. Andjelković M., Camp J. V., Meulenaer B. D., Depaemelaere G., Socaciu C., Verloo M., Verhe R. (2006): Iron-chelation properties of phenolic acids bearing catechol and galloyl groups. Food Chemistry, 98 (1):23-31., doi:10.1016/j.foodchem.2005.05.044

8. Angiosperm Phylogeny Group (2009): An update of the Angiosperm Phylogeny Group classification for the orders and families of flowering plants: APG III. Botanical Journal of the Linnean Society, 161 (2):105-121.

9. ANTAL D. S., GÂRBAN G., GÂRBAN Z. (2003): The Anthocyans: Biologically Active Substances of Food and Pharmaceutic Interest. The Annals of the University Dunarea de Jos of Galati, Fascicle VI - Food Technology, ISSN 1221-4574, 106-115.

10. Anton D., Matt D., Pedastsaar P., Bender I., Kazimierczak R., Roasto M., PÜssa T. (2014): Three-year comparative study of polyphenol contents and antioxidant capacities in fruits of tomato (Lycopersicon esculentum Mill.) cultivars grown under organic and conventional conditions. J. Agric. Food Chem., 62 (22):5173-5180. DOI: $10.1021 / \mathrm{jf500792k}$

11. Apostol J. (2003): Cseresznye- és meggynemesítés, a fontosabb fajták leírása. In: HROTKÓ K. (szerk): Cseresznye és meggy. Mezőgazda Kiadó, Budapest. p. 37-74. ISBN 963935865 7, ISSN 1214-1042.

12. ARENA M. E. (2008): Fruit growth and composition of two Ribes rubrum varieties growing in Tierra del Fuego, Argentina. Journal of Food, Agriculture and Environment, 6 (1):114-118.

13. ASĂNIČ̃ A., TUdOR V., TEODORESCU R. (2013): Distinctive behaviour of some sweet cherry cultivars related to $\begin{array}{llllll}\text { rootstock type. AgroLife Scientific Journal, } 2 & \text { (1):79-82. URL: }\end{array}$ http://agrolifejournal.usamv.ro/pdf/vol.II/Art11.pdf

14. AYALA M. és ANDRADE M. P. (2009): Effects of fruiting spur thinning on fruit quality and vegetative growth of sweet cherry (Prunus avium). Cien. Inv. Agr. 36 (3):443-450. DOI: http://dx.doi.org/10.4067/s071816202009000300011 
15. BÄDER G. (2006): Sortenbeschreibungen Steinobst. Staatliche Lehr- und Versuchsanstalt für Wein und Obstbau, Weinsberg, 15-33. p.

16. BFW (2015): Digitale Bodenkarte. Bundesforschungs- und Ausbildungszentrum für Wald, Naturgefahren und Landschaft. http://bfw.ac.at/rz/bfwcms.web?dok=7066 (2015.09.27)

17. BicUdo M. O. P., RiBANi R. H., BETA T. (2014): Anthocyanins, phenolic acids and antioxidant properties of juçara fruits (Euterpe edulis M.) along the on-tree ripening process. Plant Foods for Human Nutrition, 69 (2):142-147. DOI: $10.1007 / \mathrm{s} 11130-014-0406-0$

18. BLANKE M. (2009): Kirschblüten wirbeln durch die Luft [Cherry flowers whirling in the air]. Obstbau, 5:264265.

19. BLAŽKOVÁ J., HLUŠIČKOVÁ I., BLǍ̌E J. (2002): Fruit weight, firmness and soluble solids content during ripening of Karešova cv. sweet cherry. Hort. Sci. (Prague), 29:92-98.

20. Blázovics A., Rapavi E., Hagymási K., BalÁzs A., Then M., Szentmihályi K., BÁNyai É., HÉThelyi É., LUGASI A. (2004): Is Medical control of herbal tea consumption necessary? XXVI. International Horticulturae Congress: The Future for Medicinal and Aromatic Plants, Acta Horticulturae, 629:153-160.

21. Blázovics A., Szentmihályi K., Lugasi A., BalÁzs A., Hagymási K., Bányai É., Then M., Rapavi E., HÉTHELY É. (2003): In vitro Analysis of the Properties of Beiqishen Tea. Basic nutritional investigation. Nutrition, 19:869-875. DOI: doi:10.1016/S0899-9007(03)00157-6

22. Boeing H., Bechthold A., Bub A., Ellinger S., Haller D., Kroke A., LeschiK-Bonnet E., Müller M. J., Oberritter H., Schulze M., Stehle P., Watzl B. (2012): Critical review: vegetables and fruit in the prevention of chronicdiseases. Eur J Nutr, 51:637-663, DOI: 10.1007/s00394-012-0380-y

23. BOKU (ANONYM) (2015): Versuchszentrum Jedlersdorf, Obstbau und Gartenbau. https://www.dnw.boku.ac.at/gb/organisation/versuchszentrum-jedlersdorf/ (2015.09.27)

24. BonNefont-Rousselota D. (2010): Melatonin: Action as antioxidant and potential applications in human disease and aging. Toxicology, 278:55-67. DOI: 10.1016/j.tox.2010.04.008

25. Bors W., Heller W., Michel C., SARAN M. (1990): Flavonoids as antioxidants: Determination of radicalscavenging efficiencies. Methods Enzymol, 186:343-355.

26. BOYACI S. és CAGLAR S. (2013): The effect of fruit bud (May Bouquet) thinning on the fruit quality of 'Lapins' sweet cherry on Gisela ${ }^{\circledR} 5$ rootstock. TABAD, Tarım Bilimleri Arastırma Dergisi, 6(2):76-80. ISSN 1308-3945.

27. BRAVO L. (1998): Polyphenols: Chemistry, dietary sources, metabolism, and nutritional significance. Nutr. Rev., 56:317-333.

28. Campoy J. A., Le Dantec L., Barreneche T., Dirlewanger E., Quero-García J. (2014). New Insights into Fruit Firmness and Weight Control in Sweet Cherry. Plant Molecular Biology Reporter, 1-14., DOI: 10.1007/s11105-014-0773-6

29. CAnli F. A., PeKtas M., ErCisli S. (2015): Benzyladenine and gibberellin applications improve fruit weight and delay maturity of sweet cherry. Erwerbs-Obstbau, 1-5.

30. Cantín C. M., Pinochet J., Gogorcena Y., Moreno M. A. (2010): Growth, yield and fruit quality of 'Van' and 'Stark Hardy Giant' sweet cherry cultivars as influenced by grafting on different rootstocks. Scientia Horticulturae, 123 (3):329-335. DOI: 10.1016/j.scienta.2009.09.016

31. CAPRIO J.M. és QUAMME H. A. (2006): Influence of weather on apricot, peach and sweet cherry production in the Okanagan Valley of British Columbia. Can. J. Plant Sci., 86:259-267. DOI: 10.4141/P05-032

32. Cassidy A., O’Reilly E. J., Kay C., Sampson L., Franz M., Forman J. P., Curhan G., Rimm E. B. (2011): Habitual intake of flavonoid subclasses and incident hypertension in adults. Am J Clin Nutr, 93:338-347. DOI: http://dx.doi.org/10.3945/ajen.110.006783 (2015.09.27)

33. Chang Y. Q., Zheng H. Y., QU H. G., MA J. R., MA Y., XI X. W. (2006): Study on Antifatigue Effect of Anthoxanthin of Salix. Food Sci, 27 (8):251-253. 
34. Chaovanalikit A. és Wrolstad R. E. (2004): Total Anthocyanins and Total Phenolics of Fresh and Processed Cherries and Their Antioxidant Properties, Journal of Food Science, 69 (1):67-72., DOI: 10.1111/j.13652621.2004.tb17858.x

35. ChMielewski F. M., MÜller A., BRUns E. (2004): Climate changes and trends in phenology of fruit trees and field crops in Germany, 1961-2000. Agricultural and Forest Meteorology, 121 (1):69-78. doi:10.1016/S01681923(03)00161-8

36. Chun O. K., Kim D., SMith N., SchrÖDER D., HAN J. T., LEE CH. Y. (2005): Daily consumption of phenolics and total antioxidant capacity from fruit and vegetablesin the American diet. J.Sci. Food Agri, 85:1715-1724, DOI: 10.1002 jsfa.2176

37. Cittadini E. D., Balul Y. J., Romano G. S., Pugh A. B. (2013): Effect of intensity and time of thinning on yield and fruit quality of cherry cultivation. RIA, Revista de Investigaciones Agropecuarias, 39 (1):51-59. ISSN0325-8718, URL: http://ria.inta.gov.ar/wp-content/uploads/2013/04/RIA39-1abril20133.pdf

38. Contessa C., Mellano M. G., Beccaro G. L., Giusiano A., Botta R. (2013): Total antioxidant capacity and total phenolic and anthocyanin contents in fruit species grown in Northwest Italy. Scientia Horticulturae, 160:351-357. doi:10.1016/j.scienta.2013.06.019

39. Crisosto C. H., Crisosto G. M., Metheney P. (2003): Consumer acceptance of 'Brooks' and 'Bing' cherries is mainly dependent on fruit SSC and visual skin color. Postharvest Biology and Technology, 28 (1):159-167., doi:10.1016/S0925-5214(02)00173-4.

40. Cuadra P., Harborne J. B., Waterman P. G. (1997): Increases in surface flavonols and photosynthetic pigments in Gnaphalium luteo-album in response to UV-B radiation. Phytochemistry, 45:1377-1383. DOI: http://dx.doi.org/10.1016/s0031-9422(97)00183-0

41. D’Agostino R. B., Belanger A., D’Agostino R. B. JR. (1990): A suggestion for using powerful and informative tests of normality. The American Statistician, 44 (4):316-321. JSTOR 2684359., DOI: 10.1080/00031305.1990.10475751

42. DAVARYNEJAD G. H., NYÉKi J., SZABÓ T., SZABÓ Z. (2008): Influences of hand thinning of bud and blossom on crop load, fruit characteristics and fruit growth dynamic of Újfehértói fürtös sour cherry cultivar. AmericanEurasian J. Agric. \& Environ. Sci, 4 (2):138-141.

43. Demircan V., Ekinci K., KeEner H. M., AKbolat D., EkinCi C. (2006): Energy and economic analysis of sweet cherry production in Turkey: a case study from Isparta province. Energy Conversion and Management, 47 (13):1761-1769.

44. Dever M. C., MacDonald R. A., ClifF M. A., LANE W. D. (1996): Sensory evaluation of sweet cherry cultivars. HortScience, 31 (1):150-153.

45. D’evoli L., Moscatello S., Lucarini M., Aguzzi A., Gabrielli P., Proietti S., Lombardi-Boccia G. (2015): Nutritional traits and antioxidant capacity of kiwifruit (Actinidia deliciosa Planch., cv. Hayward) grown in Italy. Journal of Food Composition and Analysis, 37:25-29.

46. Diplock A. T., Aggett P. J., Ashwell M., Bornet F., Fern E. B., Roberfroid M. B. (1999): Scientific concepts of functional foods in Europe: Concensus document. British Journal of Nutrition, 81:1-27., DOI: 10.1079/BJN19990003

47. DOLENC K. és ŠTAMPAR F. (1998): Determining the quality of different cherry cultivars using the HPLC method. Acta Hort. (ISHS), 468:705-712. http://www.actahort.org/books/468/468_89.htm

48. DuthiE G. G., DuthiE S. J., KYLE J. A. M. (2000): Plant polyphenols in cancer and heart disease: implications as nutritional antioxidants. Nutr. Res. Rev., 13:79-106. doi: 10.1079/095442200108729016.

49. Drkenda P., Spahić A., Begić-AKagić A., GaŠi F., Vranac A., Hudina M., Blanke M. (2014): Pomological Characteristics of Some Autochthonous Genotypes of Cornelian Cherry (Cornus mas L.) in Bosnia and Herzegovina. Erwerbs-Obstbau, 56 (2):59-66. DOI: 10.1007/s10341-014-0203-9 
50. Eberhard W., Schnell S., Werner T. (2006): Tests von erfolgreichen Kleinen - der SüßkirschenVersuchsbetrieb in Wendershausen. Ökologische Agrarwissenschaften, Universität Kassel, Deutschland.

51. EINHORN T. C., WANG Y., TURNER J. (2013): Sweet cherry fruit firmness and postharvest quality of latematuring cultivars are improved with low-rate, single applications of gibberellic acid. HortScience, 48 (8):10101017.

52. Elfalleh W., Tlili N., Nasri N., Yahia Y., Hannachi H., Chaira N., Ferchichi A. (2011): Antioxidant capacities of phenolic compounds and tocopherols from Tunisian pomegranate (Punica granatum) fruits. Journal of Food Science, 76 (5):707-713.

53. Esquivel P., Stintzing F. C., CARLE R. (2012): Comparison of morphological and chemical fruit traits from different pitaya genotypes (Hylocereus sp.) grown in Costa Rica. Journal of Applied Botany and Food Quality, 81 (1):7-14.

54. $\quad$ Esti M., Cinquanta L., Sinesio F., Moneta E., Di Matteo M. (2002): Physicochemical and sensory fruit characteristics of two sweet cherry cultivars after cool storage. Food Chemistry, 76 (4):399-405. doi:10.1016/S0308-8146(01)00231-X

55. EUFORGEN (2009): Distribution map of wild cherry (Prunus avium), http://www.euforgen.org/fileadmin/templates/euforgen.org/upload/Documents/Maps/JPG/Prunus_avium.jpg

56. FAOSTAT (2015): Cherry Production Quantity in 2012. FAO Statistics Division 2015, http://faostat.fao.org/site/567/DesktopDefault.aspx?PageID=567\#ancor (2015.09.27)

57. Ferreres F., Gomes D., Valentáo P., Gonçalves R., Pio R., Alves E., Seabra R. M., Andrade P. B. (2009): Improved loquat (Eriobotrya japonica Lindl.) cultivars: variation of phenolics and antioxidative potential. Food Chemistry, 114 (3):1019-1027. DOI: http://dx.doi.org/10.1016/j.foodchem.2008.10.065

58. Ferretti G., Bacchetti T., Belleggia A., Neri D. (2010): Cherry Antioxidants: From Farm to Table. Molecules, 15:6993-7005; DOI:10.3390/molecules15106993

59. FICZEK G. (2012): Hazai alma- és meggyfajták humán egészségvédő és felhasználhatósági értékei gyümölcsanalízis alapján (Doktori értekezés, Budapesti Corvinus Egyetem)

60. Filzmoser P., Maronna R., Werner M. (2008): Outlier identification in high dimensions, Computational Statistics and Data Analysis, 52 (3):1694-1711., doi:10.1016/j.csda.2007.05.018

61. FleschHUt J., KTAtZer F., REChKEMMER G., KULling S.E. (2006): Stability and biotransformation of various dietary anthocyanins in vitro. European J. of Nutrition, 45(1):7-18. DOI: http://dx.doi.org/10.1007/s00394-0050557-8

62. FORD E. S., \& MOKDAD A. H. (2001): Fruit and vegetable consumption and diabetes mellitus incidence among US adults. Preventive medicine, 32(1):33-39.

63. GAdŽE J., PElaić I., RAdUNIĆ M., ČMELIK Z. (2010): Pomological characteristics and fruit colour of sweet cherry cultivar Lapins grafted on different vegetative rootstocks. Pomologia Croatica, 16 (1-2):37-42.

64. Garcia-Montiel F., Serrano M., Martinez-Romero D., Alburquerque N. (2010): Factors influencing fruit set and quality in different sweet cherry cultivars. Spanish Journal of Agricultural Research, 8 (4):1118-1128. DOI: $10.5424 /$ sjar/2010084-1238

65. Garrido M., Espino J., GonzÁlez-Gómez D., Lozano M., Cubero J., Toribio-Delgado F. A., MaynarMariño J. I., Terrón M. P., Muñoz J. L., PAriente J. A., BArriga C., PAredes S. D., RodríGueZ. A. B. (2009): A nutraceutical product based on Jerte Valley cherries improves sleep and augments the antioxidant status in humans. European Society for Clinical Nutrition and Metabolism, 4 (6):321-326. DOI: doi:10.1016/j.eclnm.2009.09.003

66. GArrido M., Terrón M. P., Rodríguez A. B. (2013): Chrononutrition against Oxidative Stress in Aging, Oxidative Medicine and Cellular Longevity, Article ID 729804, 9 pages, DOI: 10.1155/2013/729804 
67. Geybels M. S.,Verhage B. A. J., Arts I. C. W., van Schooten F. J.,Goldbohm R. A., VAn Den Brandt P. A. (2013): Dietary Flavonoid Intake, Black Tea Consumption, and Risk of Overall and Advanced Stage Prostate Cancer. Am J Epidemiol, 177 (12):1388-1398; DOI: 10.1093/aje/kws419

68. GIRARD B. és KopP T. G., (1998): Physicochemical Characteristics of Selected Sweet Cherry Cultivars. J. Agric. Food Chem., 46:471-476. DOI: http://dx.doi.org/10.1021/jf970646j

69. Gonçalves B., Moutinho-Pereira J., Santos A., Silva A. P., Bacelar E., Correia C., Rosa E. (2005): Scion-rootstock interaction affects the physiology and fruit quality of sweet cherry. Tree Physiology. 26:93-104. DOI: $10.1093 /$ treephys/26.1.93

70. GoMBKÖTÖ G. és SAJGÓ M. (1985): Biokémia. Budapest: Mezőgazdasági Kiadó, 166-175. p.

71. Gorinstein S., Poovarodom S., LeOntowicz H., LeOntowicz M., NAMIESNiK J., Vearasilp S., Tashma Z. (2011): Antioxidant properties and bioactive constituents of some rare exotic Thai fruits and comparison with conventional fruits: in vitro and in vivo studies. Food Research International, 44 (7):2222-2232.

72. Gratacós E., CORTÉS A., KulCZEWSKi B. M. (2008): Rootstock effects on two sweet cherry cultivars in central chile. Acta Horticulturae 795:227-238. URL: http://www.actahort.org/books/795/795_31.htm

73. GRUPPE W. (1985): An overview of the cherry rootstock breeding program at Giessen. Acta Hort. 169:189-198. http://www.ishs.org/ishs-article/169_27

74. GYEVIKI M., Bujdosó G., HROTKÓ K. (2008): Results of cherry rootstock evaluations in Hungary. International Journal of Horticultural Science, 14 (4)11-14.

75. Halliwell B., GutTeridge J. M. C. (1984): Oxigen toxicity, oxigen radicals, transition metals and disease. Biochem. J., 219:1-14.

76. HARborne J. B. (1986): Nature, distribution and function of plant flavonoids. Progress in Clinical Biological Research, 21:15-24.

77. Harborne J. B., Williams C. A. (2000): Advances in flavonoid research since 1992. Phytochemistry, 55:481504. DOI: http://dx.doi.org/10.1016/s0031-9422(00)00235-1

78. Hardcastle A. C., Aucott L., Reid D. M., Macdonald H. M. (2011): Associations Between Dietary Flavonoid Intakes and Bone Health in a Scottish Population, Journal of Bone and Mineral Research, 26 (5):941-947; DOI: $10.1002 / \mathrm{jbmr} .285$

79. Havsteen B. H. (2002): The biochemistry and medical significance of the flavonoids. Pharmacology and Therapeutics, 96:67-202. DOI: doi:10.1016/S0163-7258(02)00298-X

80. HERRMANN K. (1976): Flavonols and flavones in food plants: A review. J. Food Technol, 11:433-448.

81. Hertog M. G., Kromhout D., Aravanis C., Blackburn H., Buzina R., Fidanza F., GiampaOli S., Jansen A., Menotti A., NedeljKovic S. (1995): Flavonoid intake and long-term risk of coronary heart disease and cancer in Seven Countries Study. Archives in Internal Medicine, 155:381-386.

82. HiMELRICK D. (2002): Analyzing health benefits in berries. American Fruit Grower, 3:20-22.

83. HRotKó K. (2003): Cseresznye és meggy. Mezőgazda Kiadó, Budapest. ISBN 963935865 7, ISSN 1214-1042.

84. HU Y. (2007): Sensori influences on consumers' willingness to pay: The apple and cherry markets. PhD Dissertation, Washington State University, School of Economic Sciences.

85. HuAng M. T. és Ferraro T. (1992): Phenolic compounds in food and cancer prevention. In Phenolic compounds in food and their effects on health II. Szerk.: Huang, M. T., Ho, C., Lee. C. Y. New York, ACS Symposium Series, 507:8-34.

86. HuAng R. T., LU J. F., InBaraJ B. S., CHEN B. H. (2015): Determination of phenolic acids and flavonoids in Rhinacanthus nasutus (L.) kurz by high-performance-liquid-chromatography withphotodiode-array detection and tandemmass spectrometry. Journal of Functional Foods, 12:498-508., DOI: 10.1016/j.jff.2014.12.002

87. Huang D., Ou B., Prior R. L. (2005): The Chemistry behind Antioxidant Capacity Assays. J. Agric. Food Chem., 53:1841-1856. DOI: http://dx.doi.org/10.1021/jf030723c 
88. The International Plant Names IndeX (2015). Published on the Internet http://www.ipni.org [accessed 01 Febr 2015]

89. Jacob R. A., Spinozzi G. M., Simon V. A., Kelley D. S., Prior R. L., Hess-Pierce B., Kader A. A. (2003): Consumption of Cherries Lowers Plasma Urate in Healthy Women. J. Nutr., 133:1826-1829, http://www.ncbi.nlm.nih.gov/pubmed/12771324

90. JÄGER A. K., és SAABY L. (2011): Flavonoids and the CNS. Molecules, 16:1471-1485., DOI:10.3390/molecules16021471

91. JAKOBEK L., ŠERUGA M., VoĆA S., ŠINDRAK Z., DOBRIČEVIĆ N. (2009): Flavonol and phenolic acid composition of sweet cherries (cv. Lapins) produced on six different vegetative rootstocks. Scientia Horticulturae, 123:2328., DOI: $10.1016 /$ j.scienta.2009.07.012

92. JAYAPRAKASAM B., VAREED S. K., OlSON L. K., NAIR M. G. (2005): Insulin secretion by bioactive anthocyanins and anthocyanidins present in fruits. Journal of Agricultural Food Chemistry, 53:28-31., DOI: $10.1021 / \mathrm{jf0} 09018+$

93. Jay M., Lichou J., Millan M., Mathieu V., Gout C., Blatche J. P. (2009): Effleureuse Electro'Florw un outil d'assistance a' l'e'claircissage [The flower remover Electro'Florw: a tool for assisting in thinning]. Arboric Fruit., 634:28-30.

94. Jiménez S., Garín A., Albás E. S., Betrán J. A., Gogorcena Y., Moreno M. A. (2004): Effect of several rootstocks on fruit quality of 'Sunburst' sweet cherry. Acta Horticulturae 658:353-358., URL: http://www.actahort.org/books/658/658_51.htm

95. KADER A. A. (1999): Fruit maturity, ripening, and quality relationships. In International Symposium Effect of Pre-\& Postharvest factors in Fruit Storage, Acta Hort. (ISHS), 485:203-208.

96. KALYONCU I. H., ERSOY N., Yilmaz M. (2009): Some physico-chemical properties and mineral contents of sweet cherry (Prunus avium L.) type grown in Konya. African Journal of Biotechnology, 8 (12):2744-2749.

97. KANDASWAMI C. és MidDleton E. JR. (1994): Free radical scavenging and antioxidant activity of plant flavonoids. Adv. Exp. Med. Biol., 366:351-376.

98. KAPPEL F., Fisher-Fleming B., HogUe E. (1996): Fruit characteristics and sensory attributes of an ideal sweet cherry. HortScience, 31 (3):443-446.

99. Kawsar S. M. A., HuQ E., NAHAR N., OzeKI Y. (2008): Identification and quantification of phenolic acids in Macrotyloma uniflorum by reversed phase HPLC. Am. J. Plant Physiol., 3:165-172, doi:10.3923/ajpp.2008.165.172

100. KelebeK H. és Selli S. (2011): Evaluation of chemical constituents and antioxidant activity of sweet cherry (Prunus avium L.) cultivars. International Journal of Food Science and Technology, 46:2530-2537; DOI: 10.1111/j.1365-2621.2011.02777.x

101. Kelley D. S., Rasooly R., Jacob R. A., Kader A. A., Mackey B. E. (2006): Consumption of Bing Sweet Cherries Lowers Circulating Concentrations of Inflammation Markers in Healthy Men and Women. J. Nutr., 136:981-986.

102. KEMP B. (2010): The effect of the timing of leaf removal on berry ripening, flavour and aroma compounds in Pinot Noir wine. Doctoral dissertation, Lincoln University

103. Keppel H., Pieber K., Weiss J., Hiebler A., Mazelle W. (1998): Obstbau. Graz, Leopold Stocker Verlag, 116. p.

104. Kevers C., Pincemail J., Defraigne J. O., Dommes J. (2014): Antioxidant capacity of small dark fruits. Influence of cultivars and harvest time. Journal of Berry Research, 4:97-105., http://hdl.handle.net/2268/159940

105. KhaZAei J., Chegini G. R., BaKhshiani M. (2008): A Novel Alternative Method for Modeling the Effects of Air Temperature and Slice Thickness on Quality and Drying Kinetics of Tomato Slices: Superposition Technique. Drying Technology, 26 (6):759 - 775., DOI: 10.1080/07373930802046427 
106. KIM D. O., JEONG S. W., LEE C. Y. (2003): Antioxidant capacity of phenolic phytochemicals from various cultivars of plums. Food Chemistry, 81 (3):321-326. doi:10.1016/S0308-8146(02)00423-5

107. KIM K. H., TSAO R., YANG R., CUI S. W. (2006): Phenolic acid profiles and antioxidant activities of wheat bran extracts and the effect of hydrolysis conditions. Food Chemistry, 95 (3):466-473. doi:10.1016/j.foodchem.2005.01.032

108. KloutVOR J. (1991): Rust a plodnost tresní na slabé rostoucích podnozích. Zahradnictví, 18 (XXI) (2): 93-100.

109. KNEKT P., JÄRVINEN R., REUNANEN A. és MAATELA J. (1996): Flavonoid intake and coronary mortality in Finland: a cohort study. Br. Med. J., 312:478- 481.

110. KonCZAK I. és ZHANG W. (2004): Anthocyanins-more than nature's colours. J. of Biomedicine and Biotechnology, 5:239-240. DOI: http://dx.doi.org/10.1155/s1110724304407013

111. Kong J. M., Chia L. S.,GoH N. K.,CHIA T. F.,Brouillard R. (2003): Analysis and biological activities of anthocyanins. Phytochemistry, 64:923-933. DOI: doi:10.1016/S0031-9422(03)00438-2

112. Kuppusamy U. R., Khoo H. E., Das N. P. (1990): Structure-activity studies of flavonoids as inhibitors of hyaluronidase. Biochem. Pharm., 40:397-401.

113. KuRLuS R. (2004): Growth, yield and Fruit Quality in Eight Sweet Cherry Cultivars Grafted on 'Tabel Edabriz' Rootstock. Journal of Fruit and Ornamental Plant Research, 12:35-39. DOI: http://dx.doi.org/10.1016/j.scienta.2009.09.016

114. KÜHNAU J. (1976): The flavonoids: a class of semi-essential food components: their role in human nutrition. World Review of Nutrition, 24: 117-120.

115. LAMPE J. W. (1999): Health effects of vegetables and fruit: assessing mechanisms of action in human experimental studies, Am J Clin Nutr; 70:475S-90S

116. LanAuskas J., Uselis N., KVIKLys D., KVIKLIENĖ N., BuSKIENĖ L. (2012): Rootstock effect on the performance of sweet cherry cv. Lapins. Hort. Sci. (Prague), 39:55-60.

117. Lenahan O. M., Whiting M. D., ElfVing D. C. (2006): Gibberellic acid inhibits floral bud induction and improves Bing' sweet cherry fruit quality. HortScience, 41 (3):654-659.

118. LeONG L. P. és SHui G. (2002): An investigation of antioxidant capacity of fruits in Singapore markets. Food chemistry, 76 (1): 69-75. doi:10.1016/S0308-8146(01)00251-5

119. LeOpold L. F., LeOpold N., Diehl H. A., Socaciu C. (2012): Prediction of total antioxidant capacity of fruit juices using FTIR Spectroscopy and PLS Regression. Food Analytical Methods, 5 (3):405-407. DOI: $10.1007 / \mathrm{s} 12161-011-9251-\mathrm{z}$

120. LETH T. és JUSTESEN U. (1998): Analysis of flavonoids in fruits, vegetables and beverages by HPLC-UV method and LC-MS and estimation of the total daily flavonoid intake in Denmark. In: Polyphenols in food. (Eds.: Amado, R., Andersson, H., Bardócz, S., Serra, F.) EU, pp. 39-40.

121. Lichev V., Govedarov G., TABakov S., Yordanov A. (2004): Evaluation of sweet cherry cultivars recently introduced into Bulgaria compared with two Bulgarian cultivars. Journal of Fruit and Ornamental Plant Research, 12 Spec. ed. 2.

122. LIM T. K. (2012): Prunus avium. In Edible Medicinal And Non-Medicinal Plants, Springer Netherlands, pp. 451462.

123. Li Y., Zhou J. Z., Wang G., Huang Z. S., Wang Y., Shan C. J. (2008): Study on extraction of anthoxanthin from ginkgo biloba leaf by ultrasonic and microwave [J]. Food Science and Technology, 6:67.

124. LONG L. E., NúÑEZ-ElisEA R., CAHN H. (2005): Evaluation of sweet cherry cultivars and advanced selections adapted to the Pacific Northwest USA. In V. International Cherry Symposium, Acta Hort. (ISHS), 795:255-260.

125. LugASI A. (2000): Az élelmiszereredetű flavonoidok potenciális egészségvédő hatása. Orvosi Hetilap, 141(32): 1751-1760. 
126. LugAsi A. és HóvÁRi J. (2002): Flavonoid aglycons in food of plant origin II. Fresh and dried fruits. Acta Alimentaria, 31:63-71., DOI: 10.1556/AAlim.31.2002.1.7

127. Mahmood T., Anwar F., Abbas M., Boyce M. C., SaAri N. (2012a): Compositional Variation in Sugars and Organic Acids at Different Maturity Stages in Selected Small Fruits from Pakistan, Int. J. Mol. Sci., 13:13801392; DOI:10.3390/ijms13021380

128. Mahmood T., Anwar F., IQbal T., Bhatti I. A., Ashraf M. (2012b). Mineral composition of strawberry, mulberry and cherrx fruits at different ripening stages as analyzed by inductively coupled plasma-optical emission spectroscopy. Journal of Plant Nutrition, 35 (1):111-122. DOI: 10.1080/01904167.2012.631671

129. MAROSI K. (2008): Élet-mód - A cseresznye. Élet és Tudomány

130. Martínez R., Torres P., Meneses M. A., Figueroa J. G., Pérez-Álvarez J. A., Viuda-Martos M. (2012): Chemical, technological and in vitro antioxidant properties of mango, guava, pineapple and passion fruit dietary fibre concentrate. Food chemistry, 135 (3):1520-1526. doi:10.1016/j.foodchem.2012.05.057

131. Mazza G. és Miniati E. (1993): Anthocyanins in Fruits, Vegetables and Grains. CRC Press, Boca Raton. 85-87. p.

132. MARTYN G. P. (2011): Nutritional compositions. U.S. Patent Application 13/812,241.

133. McCullough M. L, Peterson J. J, Patel R, Jacques P. F, Shah R, Dwyer J, T, (2012): Flavonoid intake and cardiovascular disease mortality in a prospectivecohort of US adults. Am J Clin Nutr; 95:454-64. DOI: http://dx.doi.org/10.3945/ajen.111.016634

134. McNulty J., Nair J. J., Bollareddy E., Keskar K, Thorat A., Crankshaw D. J., Holloway A. C., Khan G., Wright G. D., EJIM L. (2009): Isolation of flavonoids from the heartwood and resin of Prunus avium and some preliminary biological investigations. Phytochemistry, 70:2040-2046., DOI: 10.1016/j.phytochem.2009.08.018

135. Melton M. (2006): The antioxidant myth: a medical fairy tale. New Scientist Magazine, 2563:40-43.

136. Meltsch B., Spornberger A., Steffek R., JeziK K., Kappert R., Barth U., Altenburger J., Blümel S., Koudela M. (2006): Testing of Strawberry Cultivars for Organic Production Based on Different Methods. Acta Horticulturae, 708:595-598.

137. Menzel A., Sparks T. H., Estrella N., Koch E., Aasa A., Ahas R., ... \& Zust A.N.A. (2006): European phenological response to climate change matches the warming pattern. Global Change Biology, 12 (10):19691976.

138. Mozetič B., SiMČIČ M., TReBŠE P. (2006): Anthocyanins and hydroxycinnamic acids of Lambert Compact cherries (Prunus avium L.) after cold storage and 1-methylcyclopropene treatment. Food chemistry, 97 (2):302309. doi:10.1016/j.foodchem.2005.04.018

139. Mozetič B., TrebŠE P., SimČIČ M., HriBAR J. (2004): Changes of anthocyanins and hydroxycinnamic acids affecting the skin colour during maturation of sweet cherries (Prunus avium L.). LWT-Food Science and Technology, 37 (1):123-128. doi:10.1016/S0023-6438(03)00143-9

140. MÖLLER O. (2006): Sortenbeschreibungen Steinobst. Staatliche Lehr- und Versuchsanstalt für Wein- und Obstbau, Weinsberg

141. Mratinić E., Popovski B., MilošEvić T., Popovska M. (2011): Postharvest chemical, sensorial and physicalmechanical properties of wild apricot (Prunus armeniaca L.). Notulae Scientia Biologicae, 3 (4):105-112.

142. MTI (2014): Árbevétel-növekedést tervez az idén a Sió-Eckes. http://www.marketinginfo.hu/hirek/article.php?id=33811.

143. Mulabagal V., Lang G. A., DewitT D. L., Dalavoy S. S., Nair M. G. (2009): Anthocyanin content, lipid peroxidation and cyclooxygenase enzyme inhibitory activities of sweet and sour cherries. Journal of Agricultural Food Chemistry, 57:1239-1246., .DOI: 10.1021/jf8032039 
144. NACZK M. és SHAHIDI F. (2004): Extraction and analysis of phenolics in food. Journal of Chromatography A., 1054 (1-2):95-111., DOI: http://dx.doi.org/10.1016/s0021-9673(04)01409-8

145. NAMes V. (2012). Prunus avium. Fruits. Edible Medicinal And Non-Medicinal Plants, 4 (4):451.

146. NeIlsen G. H., NeIlsen D., Herbert L., Losso I., RABIE B. (2009): Factors affecting within orchard variability of nutrition, yield and quality of sweet cherry (Prunus avium L.). In The Proceedings of the International Plant Nutrition Colloquium XVI.

147. NiKLAS K. J. (2002): Wind, size, and tree safety. Journal of Arboriculture, 28 (2):84-93.

148. OECD, Guidance on objective tests to determine quality of fruits and vegetables and dry and dried produce, URL: http://www.oecd.org/tad/code/36295985.pdf

149. Ogah O., Watkins C. S., UBi B. E., Oraguzie N. C. (2014): Phenolic compounds in rosaceae fruit and nut crops. Journal of Agricultural and Food Chemistry, 62 (39):9369-9386. DOI: 10.1021/jf501574q

150. Oliveira M. C., ESPERANÇA P., FERREIRA M. A. (2001): Characterisation of anthocyanidins by electrospray ionisation and collision-induced dissociation tandem mass spectrometry. Rapid Communications im mass Spectrometry, 15:1525-1532.DOI: 10.1002/rcm.400

151. OsboRnE J. L. (2008): Chemical peach blossom thinning to reduce cropload and improve crop value. Doctoral dissertation, Cornell University.

152. Ostojic S. és Telfser J. (2011): Ökologischer Anbau von Süßkirschen im pannonischen Klimagebiet. Masterarbeit, Universität für Bodenkultur, Wien

153. Pacifico S., Di Maro A., Petriccione M., Galasso S., Piccolella S., Di Giuseppe A. M., Monaco P. (2014): Chemical composition, nutritional value and antioxidant properties of autochthonous Prunus avium cultivars from Campania Region. Food Research International, 64:188-199. doi:10.1016/j.foodres.2014.06.020

154. PARK J. H., LEE M., PARK E. (2014): Antioxidant activity of orange flesh and peel extracted with various solvents. Preventive Nutrition and Food Science, 19 (4):291-298. 10.3746/pnf.2014.19.4.291

155. Pellegrini N., Serafini M., Colombi B., Del Rio D., Salvatore S., Bianchi M., Brighenti F. (2003): Total antioxidant capacity of plant foods, beverages and oils consumed in Italy assessed by three different in vitro assays. The Journal of Nutrition, 133 (9):2812-2819.

156. PERRY R. L. (1987): Cherry rootstocks. In Rom. R. C. - Carlson R. F.: Rootstocks for Fruit crops. John Wiley \& Sons, New York. 217-264.

157. Pinto M. P., SAntos C. N., HenriQues C., Lima M. G., Quedas M. F. (2011): Lycopene content and antioxidant capacity of Portuguese watermelon fruits. Electronic Journal of Environment, Agricultural and food Chemistry, 10 (4):2090-2097.

158. The Plant LiST (2013): Version 1.1. Published on the Internet; http://www.theplantlist.org/ (2015.09.27)

159. Platt K. L., Edenharder R., Aderhold S., Muckel E., Glatt H. (2010): Fruits and vegetables protect against the genotoxicity of heterocyclic aromatic amines activated by human xenobiotic-metabolizing enzymes expressed in immortal mammalian cells, Mutation Research, 703:90-98., DOI: 10.1016/j.mrgentox.2010.08.007

160. PolL L. (1981): Evaluation of 18 apple varieties for their suitability for juice production. Journal of the Science of Food and Agriculture, 32 (11):1081-1090.

161. Prior R. L., Gu L., Wu X., Jacob R. A., Sotoudeh G., Kader A. A., Cook R. A. (2007): Plasma Antioxidant Capacity Changes Following a Meal as a Measure of the Ability of a Food to Alter In Vivo Antioxidant Status.

Journal of the American College of Nutrition, $26 . \quad$ (2):170-181., http://dx.doi.org/10.1080/07315724.2007.10719599

162. Quideau S. (2006): Why Bother with Polyphenols?, Polyphénols Actualités, 24:10-14., http://www.groupepolyphenols.com/the-society/why-bother-with-polyphenols/

163. REVELL J. (2008): Sensory profile and consumer acceptability of sweet cherries. Thesis submitted to the University of Nottingham for the degree of Masters of Research 
164. Rice-Evans C. A., Miller N. J., Paganga G. (1997): Antioxidant properties of phenolic compounds. Trend sin Plant Science, 2 (4):152-159. doi:10.1016/S1360-1385(97)01018-2

165. Robards K., Antolovich M. (1997): Analytical chemistry of fruit bioflavonoids - A review. Analyst., 122(2):R11-R34. DOI: 10.1039/A606499J

166. Robinson T. L. és Hoying S. A. (2009): Training system and rootstock affect yield, fruit size, fruit quality and crop value of sweet cherry. In VI International Cherry Symposium, Acta Hort. (ISHS), 1020:453-462.

167. RoDLER I. (2005): Új tápanyagtáblázat. Budapest: Medicina Kiadó, 300-302. p.

168. Romano G. S., Cittadini E. D., Pugh, B., Schouten R. (2006): Sweet cherry quality in the horticultural production chain. Stewart Postharvest Review, 2 (6):1-9.

169. Rong T. (2010): Chemistry and Biochemistry of Dietary Polyphenols, Nutrients, 2:1231-1246; DOI:10.3390/nu2121231

170. Roussos P. A., Sefferou V., Denaxa N. K., Tsantili E., Stathis V. (2011): Apricot (Prunus armeniaca L.) fruit quality attributes and phytochemicals under different crop load. Scientia Horticulturae, 129 (3):472-478.

171. Ruiz-RodríGuez M., Ancos B. D., SÁnchez-Moreno C., Fernández Ruíz V., SÁnchez Mata M. C., TARdío J. (2014): Wild blackthorn (Prunus spinosa L.) and hawthorn (Crataegus monogyna Jacq.) fruits as valuable sources of antioxidants. Fruits, 69 (01):61-73. DOI: http://dx.doi.org/10.1051/fruits/2013102

172. SAng D. Y., Zhifang G., CANTINi C., LOescher W. H., Nocker S. (2003): Fruit ripening in sour cherry. Journal of the American Society for Horticultural Science, 128:16-22.

173. San Martino L., Manavella F. A., García D. A., Salato G. (2008): Phenology and fruit quality of nine sweet cherry cultivars in South Patagonia. In V International Cherry Symposium, Acta Hort. (ISHS), 795:841-848.

174. SANSAVINI S. és LUGLI S. (2005): Sweet cherry breeding programs in Europe and Asia. In V International Cherry Symposium, 795:41-58.

175. SCHLEISER K., HARWAT M., BÖHM V., Bitsch R. (2002): Assesment of Antioxidant Activity by Using Different In Vitro Methods. Free Radical Research, 36 (2):177-187. DOI: http://dx.doi.org/10.1080/10715760290006411

176. Schoedl K., DenK A., Hummelbrunner S., Modl P., FornecK A. (2009): No improvement in fruit quality through chemical flower thinning in sweet cherry (Prunus avium L.). J. Sci. Food Agric., 89:1236-1240., doi: 10.1002/jsfa.3581

177. SCHUSTER B. és HERRMANN K. (1985): Hydroxybenzoic and hydroxycinnamic acid derivatives in soft fruits. Phytochemistry, 24 (11):2761-2764. doi:10.1016/S0031-9422(00)80722-0

178. Serradilla M. J., Lozano M., Bernalte M. J., Ayuso M. C., López-Corrales M., GonzÁlez-Gómez D. (2011): Physicochemical and bioactive properties evolution during ripening of 'Ambrunés' sweet cherry cultivar. LWT-Food Science and Technology, 44 (1):199-205., doi:10.1016/j.lwt.2010.05.036

179. Seeram N. P., Momin R. A., NAIR M. G., Bourquin L. D., (2001): Cyclooxygenase inhibitory and antioxidant cyanidin glycosides in cherries and berries, Phytomedicine. 8(5):362-369. http://dx.doi.org/10.1078/0944-711300053

180. Serrano M., Guillén F., Martínez-Romero D., Castillo S., Valero D. (2005): Chemical constituents and antioxidant activity of sweet cherry at different ripening stages. Journal of Agricultural Food Chemistry, 7:27412745., DOI: http://dx.doi.org/10.1021/jf0479160

181. Shahbazi F. és Rahmati S. (2013): Mass modeling of sweet cherry (Prunus avium L.) fruit with some physical characteristic. Food and Nutrition Sciences, 4:1-5., DOI: http://dx.doi.org/10.4236/fns.2013.41001

182. SHAHIDI F. és NACZK M. (2004): "Phenolics in Food and Nutraceuticals." 575. Boca Raton London New York Wasington DC.

183. Silva B. M., Andrande P. B., Valentão P., Ferreres F., Seabra, R. M., Ferreira M. A. (2004): Quince (Cydonia oblonga Miller) fruit (pulp, peel, and seed) and jam: Antioxidant activity. Journal of Agricultural and Food Chemistry. 52: 4405-4712. DOI: 10.1021/jf040057v 
184. Simon G., HRotKó K., MAGYAR L. (2004): Fruit quality of sweet cherry cultivars grafted on four different rootstocks. Acta Horticulturae, 658:365-370., URL: http://www.actahort.org/books/658/658_53.htm

185. SîRBU S., NiCUlaUA M., CHIRIŢĂ O. (2012): Physico-chemical and antioxidant properties of new sweet cherry cultivars from Iaşi, Romania. Agronomy Research, 10 (1-2):341-350.

186. SitAReK M. és BARTosiewicz B. (2012): Influence of Five Clonal Rootstocks on the Growth, Productivity and Fruit Quality of 'Sylvia' and 'Karina' Sweet Cherry Trees. Journal of Fruit and Ornamental Plant Research., 20 (2):5-10, ISSN (Print) 1231-0948, DOI: 10.2478/v10290-012-0010-z

187. SitAREK M. és GRZYB Z. S. (2010): Growth, productivity and fruit quality of 'Kordia'sweet cherry trees on eight clonal rootstocks. Journal of Fruit and Ornamental Plant Research, 18 (2):169-176.

188. SOLTÉSZ M., NYÉKI J., SZABÓ Z. (2004): A klímaváltozás kihívásai a gyümölcstermesztésben. AGRO-21 Füzetek, 34:3-20.

189. Sooriyapathirana S. S., Khan A., Sebolt A. M., Wang D., Bushakra J. M., Lin-Wang, K., Iezzoni A. F. (2010): QTL analysis and candidate gene mapping for skin and flesh color in sweet cherry fruit (Prunus avium L.). Tree Genetics \& Genomes, 6 (6):821-832. DOI: 10.1007/s11295-010-0294-X

190. Souci S. W., FAChMANN W., Kraut H. (2008): Food composition an nutrition tables. Medpharm Scientific Publishers Stuttgart.

191. Souci S. W., FAChMANN W., KraUt H. (2015): Souci-Fachmann-Kraut food composition and nutrition tables medpharm online database. Medpharm GmbH Scientific Publishers, Birkenwaldstr. 44, 70191 Stuttgart, http://www.sfk-online.net/cgi-bin/sfkstart.mysql?language=english (2015.02.01)

192. Souza V. R., Pereira P. A. P., Silva T. L. T., Oliveira L. L. C., Pio R., Queiroz F. (2014): Determination of the bioactive compounds, antioxidant activity and chemical composition of Brazilian blackberry, red raspberry, strawberry, blueberry and sweet cherry fruits. Food chemistry, 156:362-368.

193. SPINARDi A. M., ViSAI C., BERTAZZA G. (2005): Effect of rootstock on fruit quality of two sweet cherry cultivars. Acta Horticulturae, 667:201-206. URL: http://www.actahort.org/books/667/667_29.htm

194. Spornberger A. és MOdL P. (2008): Kirschen für den naturnahen Garten. AV Buch, Österreichischer Agrarverlag, Wien

195. Spornberger A. és Modl P. (2009): Kirschen für den Hausgarten. AV Buch, Österreichischer Agrarverlag Druck- und Verlagsges. m. b. H. Nfg. KG, Wien, ISBN 9783704023308.

196. Stabnikova O., WANG J. Y., Ding H. B. (2005): Biotransformation of vegetable and fruit processing wastes into yeast biomass enriched with selenium. Bioresource Technology, 96 (6):747-751.

197. Stanhope K. L., Schwarz J. M., Keim N. L., Griffen S. C., Bremer A. A., Graham J. L., Havel, P. J. (2009): Consuming fructose-sweetened, not glucose-sweetened, beverages increases visceral adiposity and lipids and decreases insulin sensitivity in overweight/obese humans. The Journal of Clinical Investigation, 119 (5):1322.

198. Stégerné M. M., Horváth D., Barta J., Sipos B. Z. (2003): Compositional studies of hip species during ripening. Lippay János - Ormos Imre - Vas Károly Tudományos Ülésszak, 82-83.

199. Stevens P. F. (2013): Angiosperm Phylogeny Website, version 13. University of Missouri, St Louis, and Missouri Botanical Garden. http://www.mobot.org/MOBOT/research/APweb/

200. Stintzing F. C., SCHIEBER A., CARLE R. (2003): Evaluation of colour properties and chemical quality parameters of cactus juices. European Food Research and Technology, 216 (4):303-311. DOI: 10.1007/s00217-002-06570

201. Stover E., FARgione M., Risio R., YANG X., Robinson T. (2001): Fruit weight, cropload, and return bloom of 'Empire' apple following thinning with 6-benzyladenine and NAA at several phenological stages. HortScience, 36 (6):1077-1081.

202. Strack D. és Wray V. (1993): The anthocyanins. In: Harborne J. B. (szerk.): The flavonoids, advances in research since 1986. London: Chapman and Hall, 1-22. 
203. SuÁrez M., Macià A., Romero M. P., Motilva M. J. (2008): Improved liquid chromatography tandem mass spectrometry method for the determination of phenolic compounds in virgin olive oil. Journal of Chromatography A., 1214 (1-2):90-99. Doi: http://dx.doi.org/10.1016/j.chroma.2008.10.098

204. SURÁNYI D. (2003): A cseresznye és a meggy, valamint a rokon fajok botanikai leírása. In: HROTKÓ K. (szerk): Cseresznye és meggy. Mezőgazda Kiadó, Budapest. p. 27-31. ISBN 963935865 7, ISSN 1214-1042.

205. Szeto Y. T., TOMLinson B., BenZIE I. F. (2002): Total antioxidant and ascorbic acid content of fresh fruits and vegetables: implications for dietary planning and food preservation. British Journal of Nutrition, 87 (1):55-59. DOI: http://dx.doi.org/10.1079/BJN2001483

206. Szot I. és Meland M. (2001): Influence of rootstocks on size distribution and fruit quality of sweet cherry cultivars. International Agrophysics, 15 (3):207-214.

207. TABAChNick B. G. és Fidell L. S. (2013): Using Multivariate Statistics, 6th ed., Boston, Pearson

208. TAPPY L. (2012): Q\&A: 'Toxic' effects of sugar: should we be afraid of fructose?. BMC Biology, 10 (1):42.

209. TAREEN M. J., és TAREEN M. N. (2006): Effect of rootstocks on II. Rainier cherry grown in Balochistan (Pakistan). International Journal of Agriculture and Biology, 8 (1):55-56.

210. THURZÓ S. (2008): Cseresznyefajták terméshozása, gyümölcsminősége és tárolhatósága. Doktori értekezés. Debreceni Egyetem, Interdiszciplináris Agrár- és Természettudomáyok Doktori Iskola

211. Thybo A. K., Edelenbos M., Christensen L. P., Sørensen J. N., Thorup-Kristense K. (2006): Effect of organic growing systems on sensory quality and chemical composition of tomatoes, LWT Food Science and Technology, 39 (8): 835-843., DOI: http://dx.doi.org/10.1016/j.lwt.2005.09.010

212. Tournaire C., Croux S., Maurette M. T., Beck I., Hocquaux M., Braun A. M., Oliveros E. (1993): Antioxidant activity of flavonoids: efficiency of singlet oxygen $\left({ }^{1} \Delta_{\mathrm{g}}\right)$ quenching. J. of Photochemistry and Photobiology, 19:205-215. DOI: http://dx.doi.org/10.1016/1011-1344(93)87086-3

213. TREUTTER D. (2005): Significance of flavonoids in plant resistance and enhancement of their biosynthesis. Plant Biology, 7:581-591. DOI: 10.1055/s-2005-873009

214. TREUTTER D. (2006): Significance of flavonoids in plant resistance: a review. Environmental Chemistry Letters, 4 (3):147-157. DOI 10.1007/s10311-006-0068-8

215. Tripoli E., La Guardia M., Giammanco S., Majo D., Giammanco M. (2007): Citrus flavonoids: Molecular structure, biological activity and nutritional properties: A review. Food Chemistry, 104 (2):466-479. DOI: doi:10.1016/j.foodchem.2006.11.054

216. Tsantili E., Konstantinidis K., Christopoulos M. V., Roussos P. A. (2011): Total phenolics and flavonoids and total antioxidant capacity in pistachio (Pistachia vera L.) nuts in relation to cultivars and storage conditions. Scientia Horticulturae, 129 (4):694-701.: doi:10.1016/j.scienta.2011.05.020

217. Tudela J. A., LuChsinger L., ArtÉS-Hdez F., ArtÉS F. (2005). ‘Ambrunes' sweet cherry quality factors change during ripening. In IV International Cherry Symposium, Acta Hort. (ISHS), 667:529-534.

218. Turner J., SeAvert C., ColonnA A., LONG L. E. (2008): Consumer sensory evaluation of sweet cherry cultivars in Oregon, USA. In V International Cherry Symposium, Acta Hort. (ISHS), 795:781-786.

219. Ulrich D., Komes D., Olbricht K., Hoberg E. (2007): Diversity of aroma patterns in wild and cultivated Fragaria accessions. Genetic Resources and Crop Evolution, 54 (6):1185-1196. DOI: 10.1007/s10722-0069009-4

220. USENIK V., FABČIČ J., ŠTAMPAR F. (2008): Sugars, organic acids, phenolic composition and antioxidant activity of sweet cherry (Prunus avium L.). Food Chemistry, 107 (1):185-192., doi:10.1016/j.foodchem.2007.08.004

221. Usenik V., Fajt N., Mikulic-Petkovsek M., Slatnar A., Stampar F., Veberic R. (2010): Sweet cherry pomological and biochemical characteristics influenced by rootstock. Journal of Agricultural Food Chemistry, 58 (8):4928-4933., DOI: 10.1021/jf903755b 
222. Usenik V., Štampar F., Petkovsek M. M., Kastelec D. (2015): The effect of fruit size and fruit colour on chemical composition in 'Kordia'sweet cherry (Prunus avium L.). Journal of Food Composition and Analysis, 38:121-130. doi:10.1016/j.jfca.2014.10.007

223. USENIK V., ZADRAVEC P., ŠTAMPAR F. (2009): Influence of rain protective tree covering on sweet cherry fruit quality. European Journal of Horticultural Science, 74 (2):49.

224. Veres Zs., RemenyiK J., NyéKi J., Szabó Z., Popovics L., Holb I., FÁri M. G. (2005): A meggy (Prunus cerasus) bioaktív anyagai, különös tekintettel az antioxidáns aktivitására. Agrártudományi Közlemények, 17:8387.

225. VERCAMMEN J. és VANRYKeL T. (2014): Use of Gisela 5 for sweet cherries. In VI International Cherry Symposium, Acta Hort. (ISHS), 1020:395-400.

226. Villarino M., SANDín-EsPaña P., Melgarejo P., De CAL A. (2011): High chlorogenic and neochlorogenic acid levels in immature peaches reduce Monilinia laxa infection by interfering with fungal melanin biosynthesis. Journal of Agricultural and Food Chemistry, 59 (7):3205-3213.

227. VoĆA S., DobriČEVIĆ N., HABUN T., ČMELIK Z., DRUŽIĆ J. (2009): Glucose, fructose and sucrose in the cherry fruit, Pomologia Croatica, 14 (2):93-100

228. VOGEL T. (1994): Empfehlungen für den Kirschenanbau in Franken. Bayerisches Staatsministerium für Erenährung, Landwitschaft und Forsten, Landratsamt Forchheim

229. Von Bennewitz E., SANhueZa S., ElORRIAGA A. (2010): Effect of different crop load management strategies on fruit production and quality of sweet cherries (Prunus avium L.) 'Lapins' in Central Chile. Journal of Fruit and Ornamental Plant Research, 18 (1):51-57.

230. Voss D. H. (1992): Relating colorimeter measurement of plant color to the Royal Horticultural Society Colour. Hort Science, 27:1256-1260.

231. VRHOVSEK U. (1998): Extraction of hydroxycinnamoyltartaric acids from berries of different grape varieties. $J$ Agric Food Chem. 46:203-208., doi:10.1021/jf980461s

232. Vursavuş K., KelebeK H., Selli S. (2006): A study on some chemical and physico-mechanic properties of three sweet cherry varieties (Prunus avium L.) in Turkey. Journal of Food Engineering, 74 (4):568-575.

233. Wang H., Guohua C., Ronald L. P. (1996): Total antioxidant capacity of fruits. Journal of Agricultural and Food Chemistry, 44 (3):701-705.

234. WANG S., CHEN C. T., WANG C. Y. (2009): The influence of light and maturity on fruit quality and flavonoid content of red raspberries. Food Chemistry, 112 (3):676-684. DOI: doi:10.1016/j.foodchem.2008.06.032

235. Wani A. A., Singh P., Gul K., Wani M. H., LAngowski H. C. (2014): Sweet cherry (Prunus avium): Critical factors affecting the composition and shelf life. Food Packaging and Shelf life, 1 (1):86-99.

236. Webster A. D. (1997): Strategies for controlling the size of sweet cherry trees. In III International Cherry Symposium, 468:229-240.

237. Weissinger H., Eggbauer R., Steiner I., Spornberger A., Steffek R., Altenburger J., JeziK K. (2010): Yield and fruit quality parameters of new early-ripening strawberry cultivars in organic growing on a highly Verticillium-infested site. 14th International Conference on Organic Fruit-Growing. Proceedings for the conference, Hohenheim, Germany, Fördergemeinschaft Ökologischer Obstbau eV (FÖKO). Ecofruit, pp. 243249.

238. WINTER F. (2002): Lucas' Anleitung zum Obstbau. Überarbeitet von einem Autorenkolektiv. Herausgeber Hermann Link. Verlag Eugen Ulmer

239. Whiting M. D. és LANG G. A. (2004): 'Bing' sweet cherry on the dwarfing rootstock 'Gisela 5': Thinning affects fruit quality and vegetative growth but not net $\mathrm{CO} 2$ exchange. Journal of the American Society for Horticultural Science, 129 (3):407-415. 
240. Whiting M. D., Ophard D., McFerrson J. R. (2006): Chemical blossom thinners vary in their effect on sweet cherry fruit set, yield, fruit quality and crop value. HortTechnology, 16 (1):66-70.

241. Wills R. B. H., Scriven F. M., Greenfield H. (1983): Nutrient composition of stone fruit (Prunus spp.) cultivars: apricot, cherry, nectarine, peach and plum. Journal of the Science of Food and Agriculture. 34: 13831389. DOI: $10.1002 /$ jsfa.2740341211

242. WIRCH J., KAPPEL F., \& SCHEEWE P. (2009): The effect of cultivars, rootstocks, fruit maturity and gibberellic acid on pedicel retention of sweet cherries (Prunus avium L.). Journal of the American Pomological Society, 63 (3):108-114.

243. WolfRAm B. (1996): Advantages and problems of some selected cherry rootstocks in Dresden-Pillnitz. Acta Hort., 410: 233-237.

244. Wolfram B. (2004): U.S. Patent No. PP14,737. Washington, DC: U.S. Patent and Trademark Office.

245. Wosiacki G., Silva N. C. C., Nogueira A., Denardi F. (2009): The apple and its fructose content cultivar Sansa - A case study. Publicatio UEPG-Ciências Exatas e da Terra, Agrárias e Engenharias, 11 (02):27-39.

246. WU és PRIOR (2005): Systematic identification and characterization of anthocyanins by HPLC-ESI-MS/MS in common foods in the united states: fruits and berries. J. Agric. Food Chem., 53:2589-2599.

247. Xiuzhen H., Tao S., HongXiang L. (2007): Dietary Polyphenols and Their Biological Significance, Int. J. Mol. Sci, 8 (9):950-988; DOI:10.3390/i8090950

248. YAng S., BAI G., Chen L., Shen Q., DiAO X., ZhaO G. (2014): The interaction of phenolic acids with Fe (III) in the presence of citrate as studied by isothermal titration calorimetry. Food chemistry, 157:302-309. doi:10.1016/j.foodchem.2014.02.052

249. Yao L. H., Jiang Y. M., Shi J., Tomas-Barberan F. A., Datta N., Singanusong R., Chen S. S. (2004): Flavonoids in food and their health benefits. Plant Foods for Human Nutrition, 59:113-122. DOI: $10.1007 / \mathrm{s} 11130-004-0049-7$

250. ZAMG (ANONYM) (2015): Klimadaten Österreich 1971-2000, Klimastation Gr. Enzersdorf. http://www.zamg.ac.at/fix/klima/oe71-00/klima2000/klimadaten_oesterreich_1971_frame1.htm (2015.09.27)

251. Zhang L., Chen F., An H., Yang H., Sun X., Guo X., Li L. (2008): Physicochemical properties, firmness, and nanostructures of sodium carbonate-soluble pectin of 2 chinese cherry cultivars at 2 ripening stages. Journal of Food Science, 73 (6):17-22.

252. Zhang Y., Neogi T., Chen C., Chaisson C., Hunter D. J., ChOi H. K. (2012): Cherry consumption and decreased risk of recurrent gout attacks, 64 (12):4004-4011., DOI: 10.1002/art.34677

253. ZiMMERMANN B. F. és GALENSA R. (2007): One for all- all for one: proof of authenticity and tracing of foods with flavonoids - Analysis of proanthocyanidins in barley and malt. European Food Research and Technology, 224 (3):385-393. DOI: 10.1007/s00217-006-0333-x 
10.2. M2. ÁBRÁK

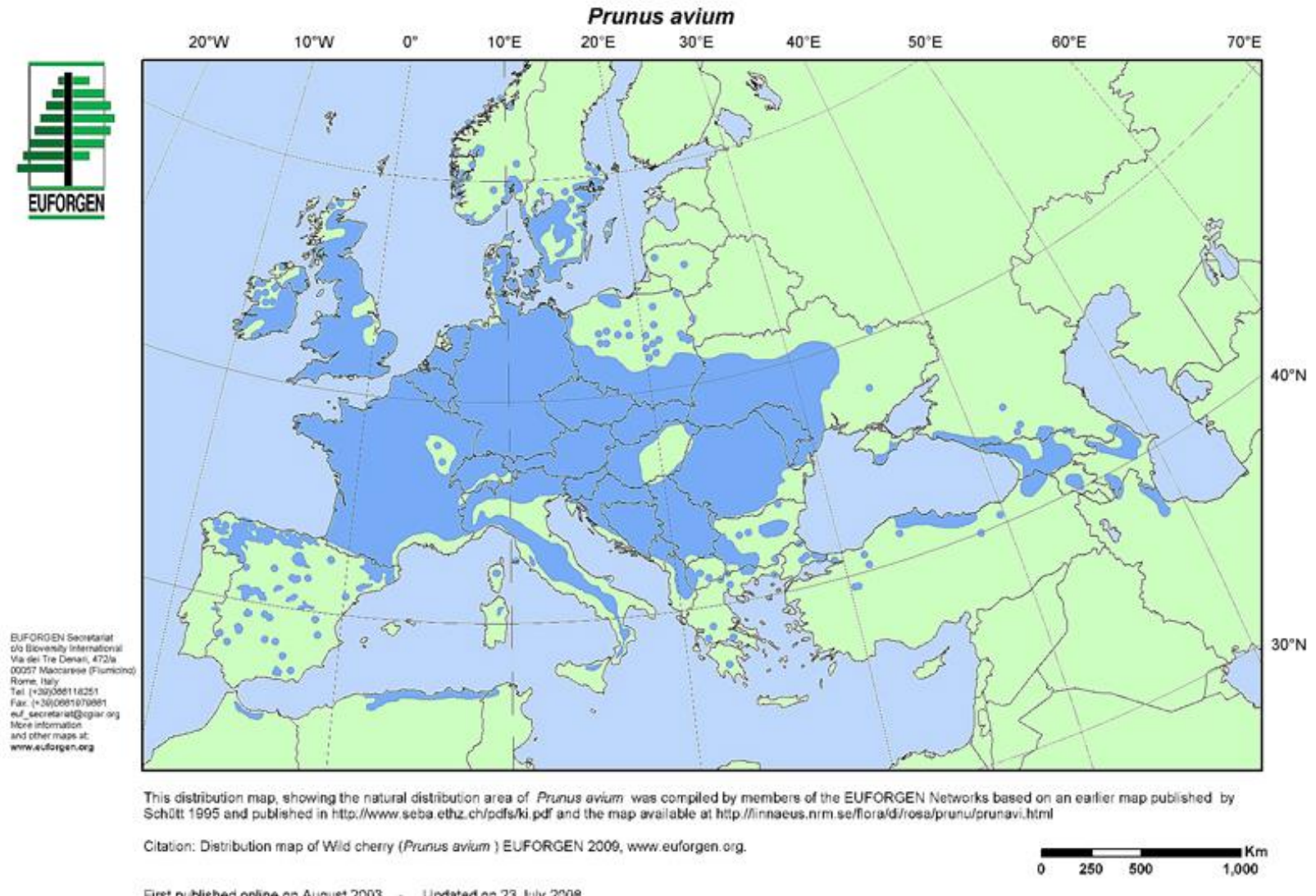

46. ábra: A cseresznye természetes elterjedési területe (forrás: www.euforgen.org) 


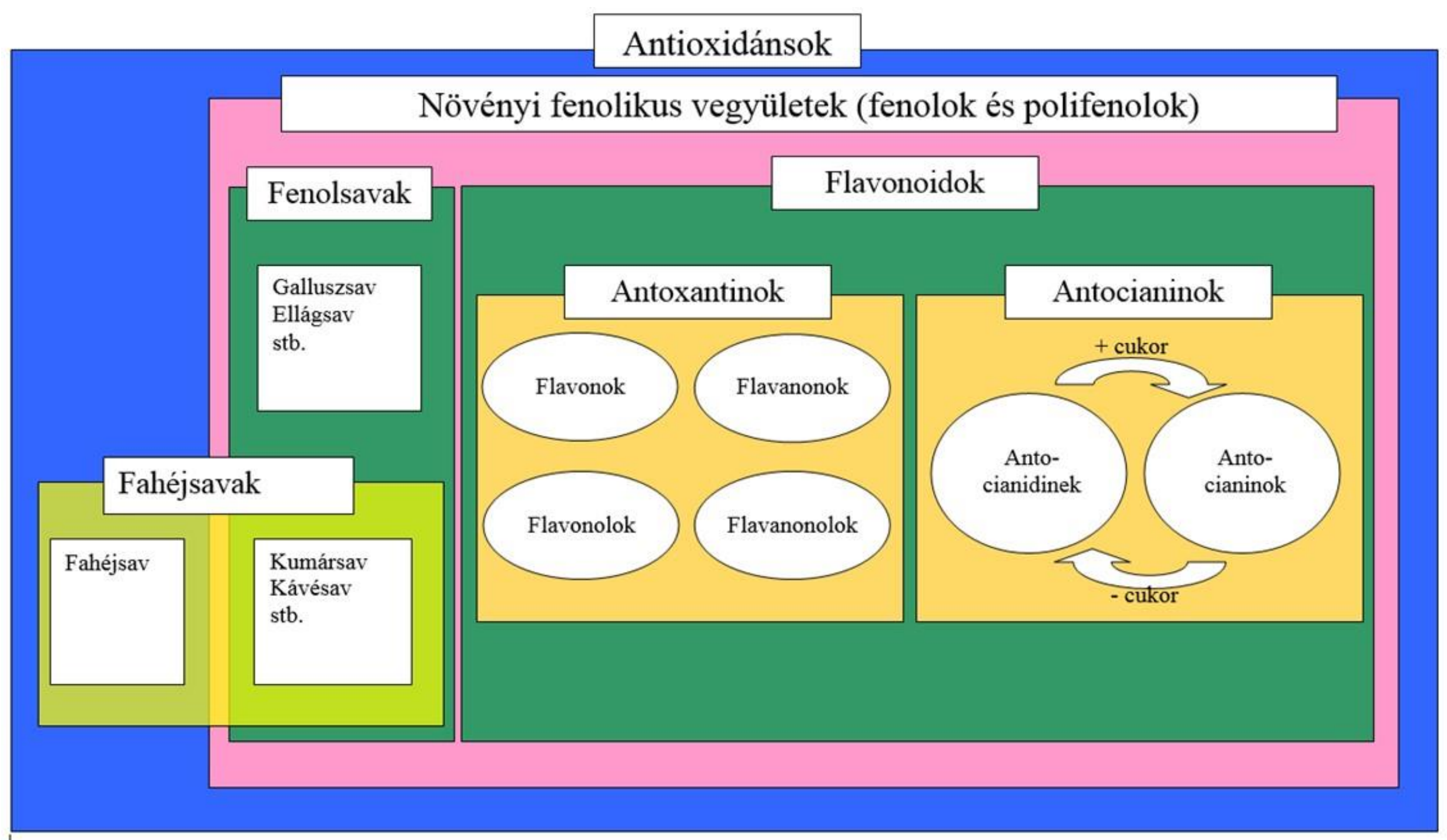

47. ábra: Antioxidánsok csoportosítása 


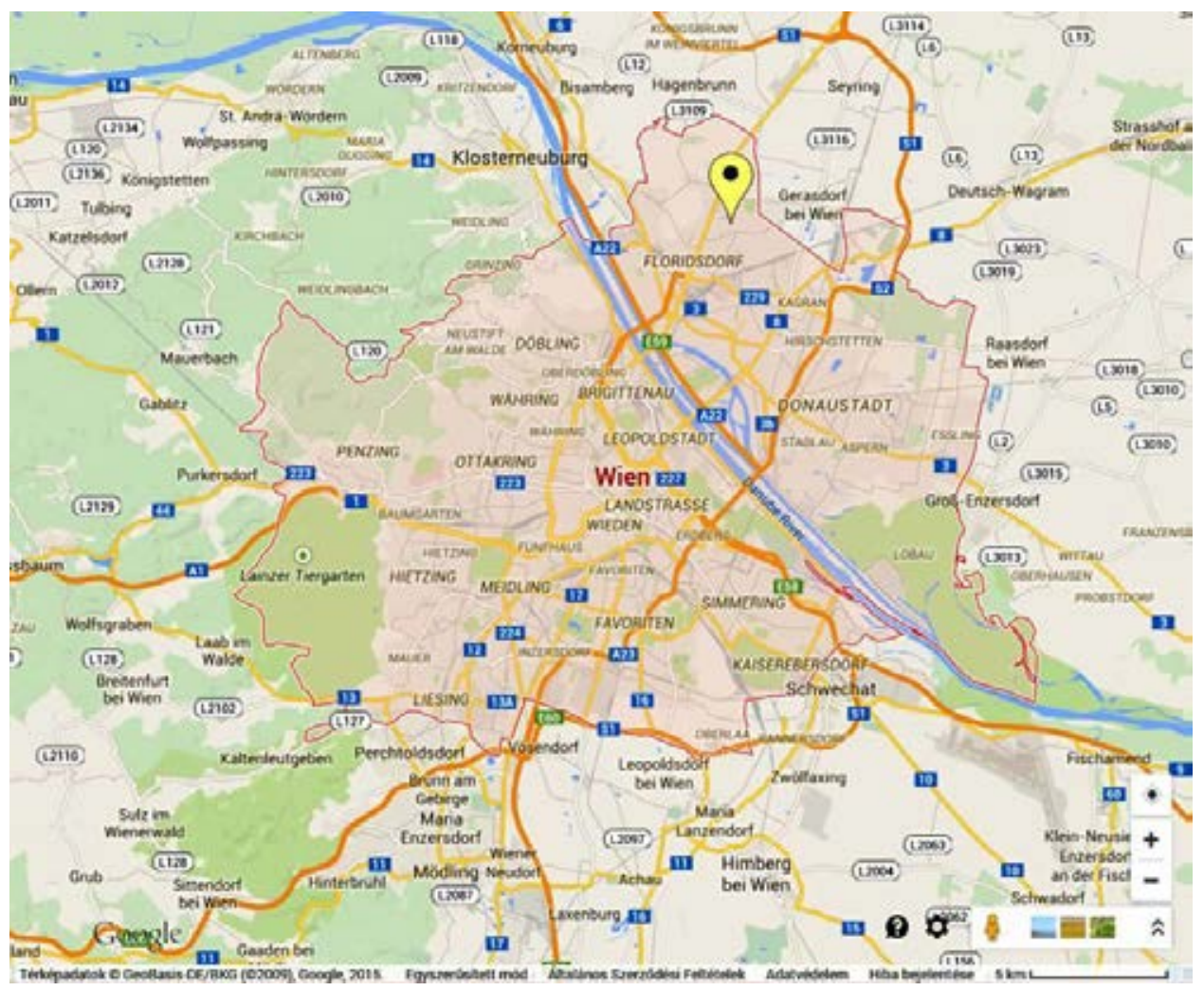

48. ábra: A BOKU kísérleti ültetvényének elhelyezkedése Bécs városán belül (sárga jel)

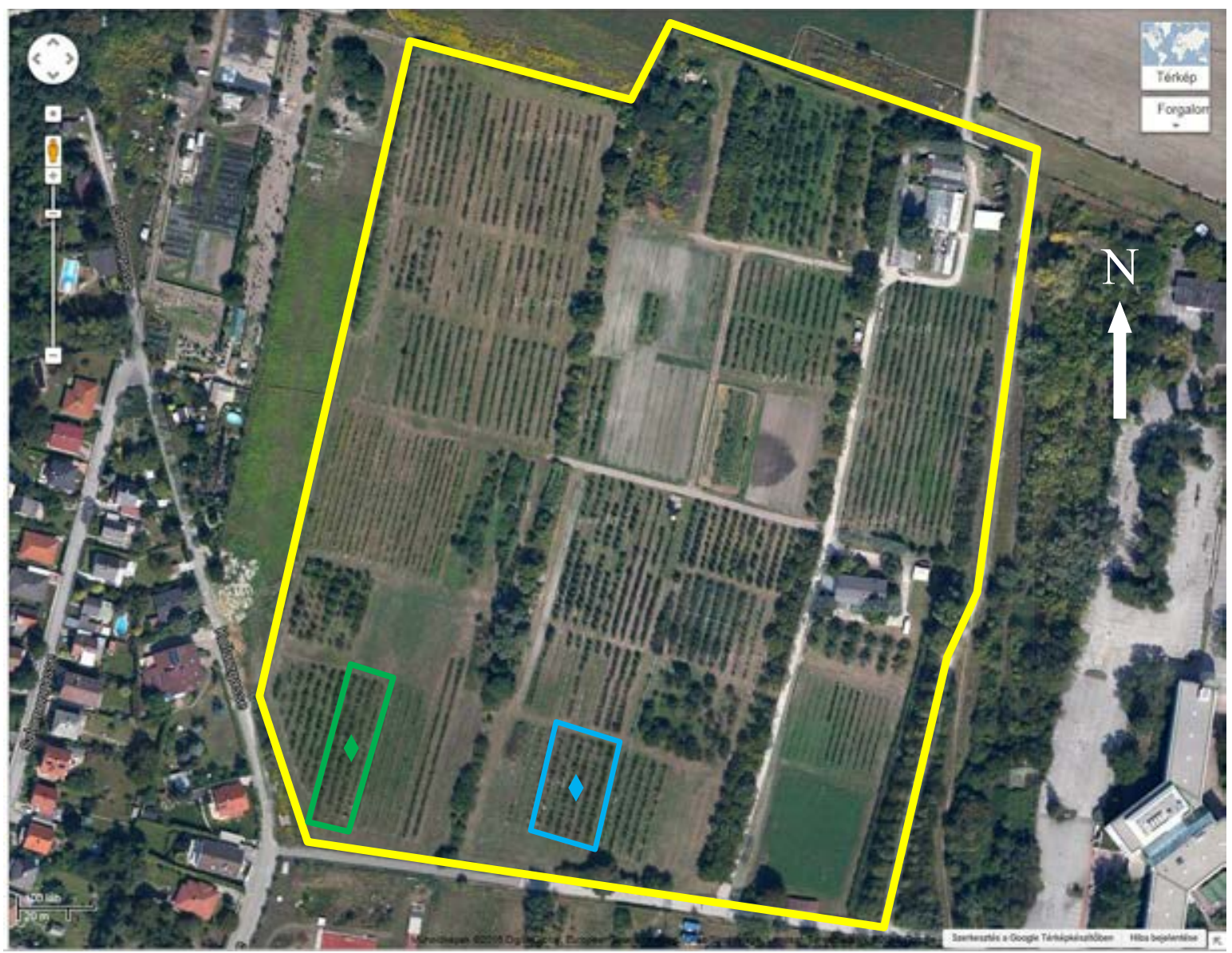

49. ábra: Jedlersdorfi kísérleti üzem (sárga) területének légifotója (forrás: Google Térkép)

48 17'17.4"N 16²5’33.9"E (Q26 ültetvény)

$48^{\circ} 17^{\prime} 16.8^{\prime \prime} \mathrm{N} 16^{\circ} 25^{\prime} 38.1$ "E (Q10 ültetvény) 

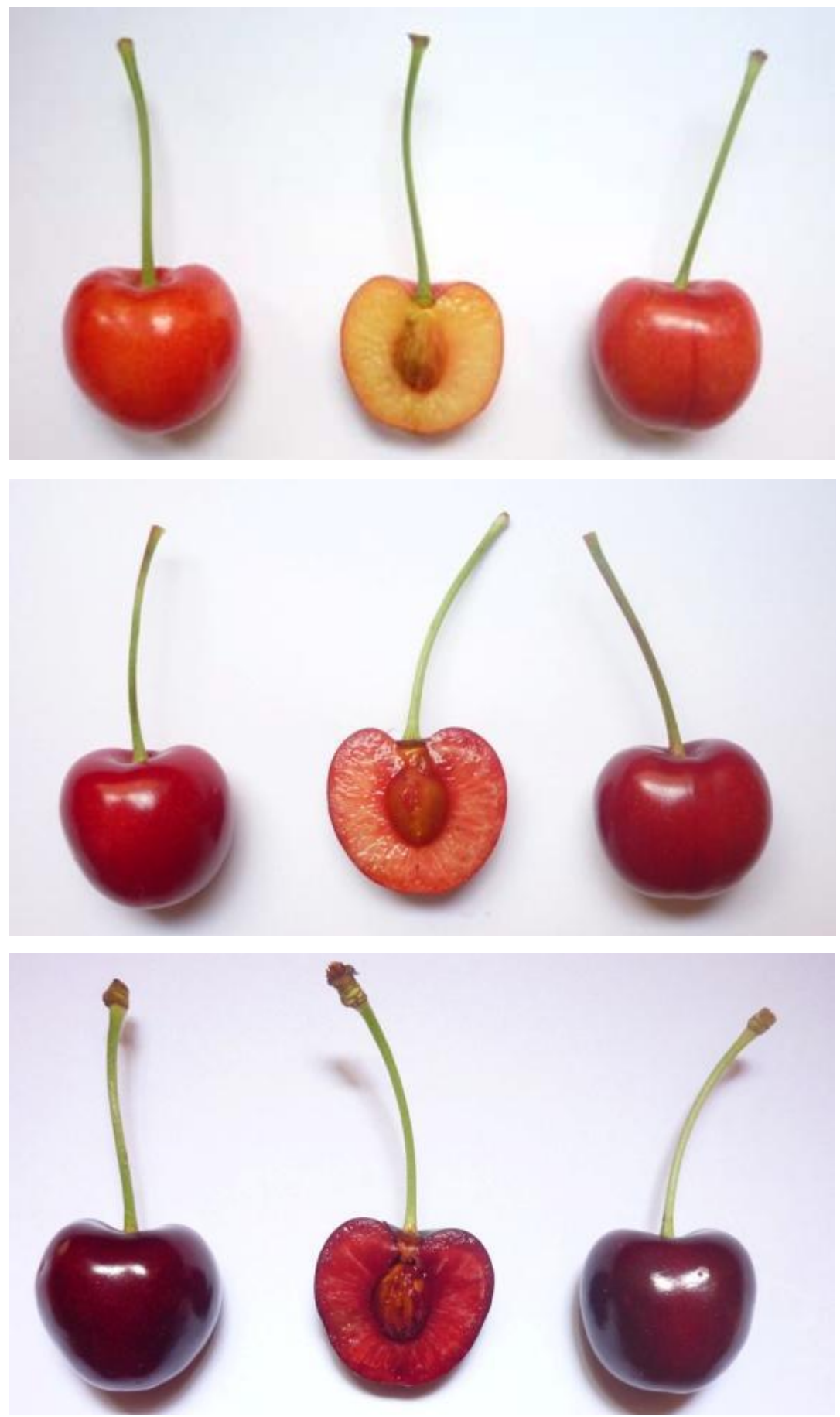

50. ábra: Cseresznye gyümöles színeződés kezdetén (fent), színeződés második felében (középen) és 100 \%-os érettségben (lent) 

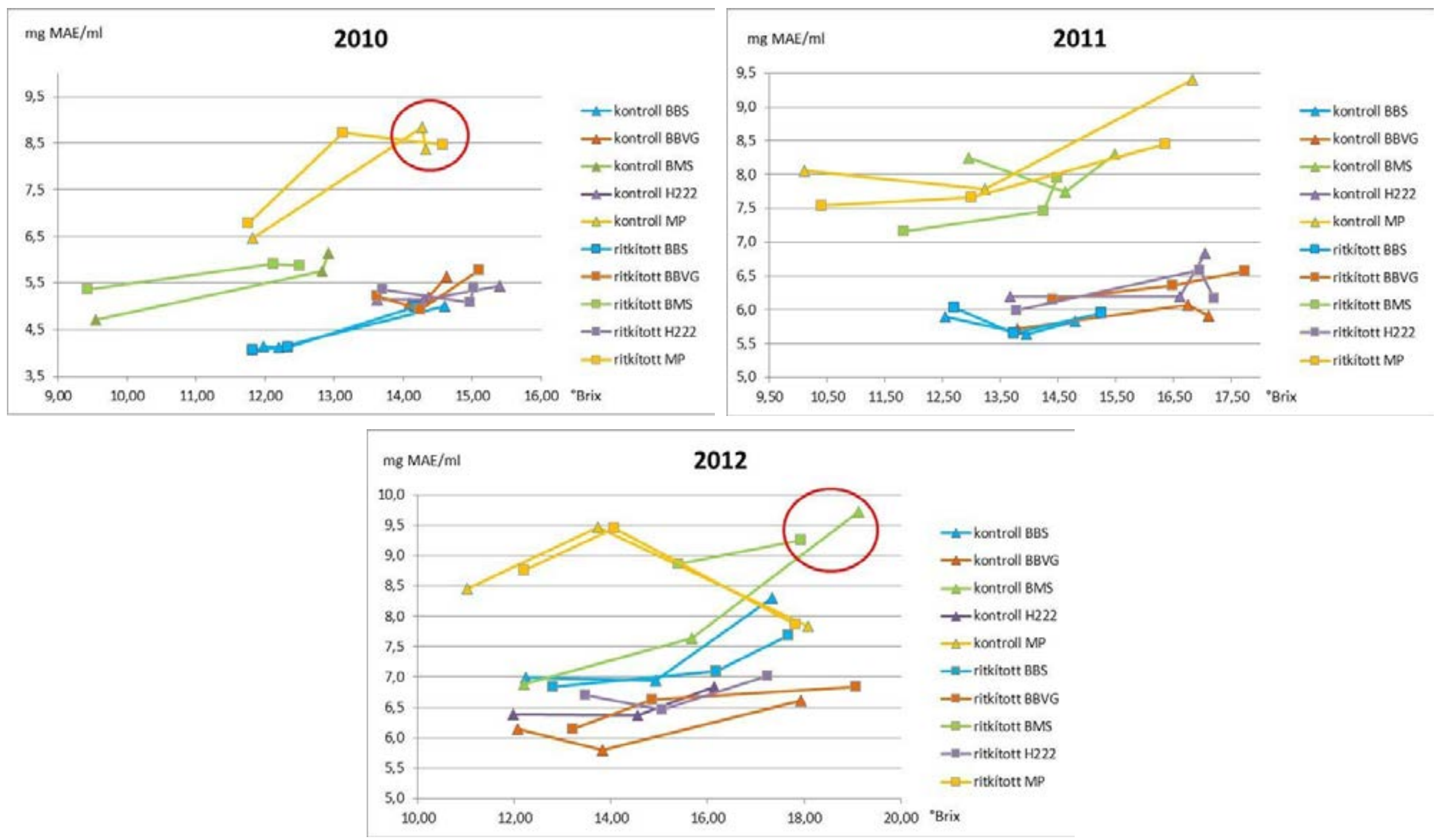

51. ábra: Virágritkított és kontroll cseresznyefajták gyümölcseinek TSS-TA viszonya T1, T2 és T3-as érési stádiumban 2010 és 2012 között 

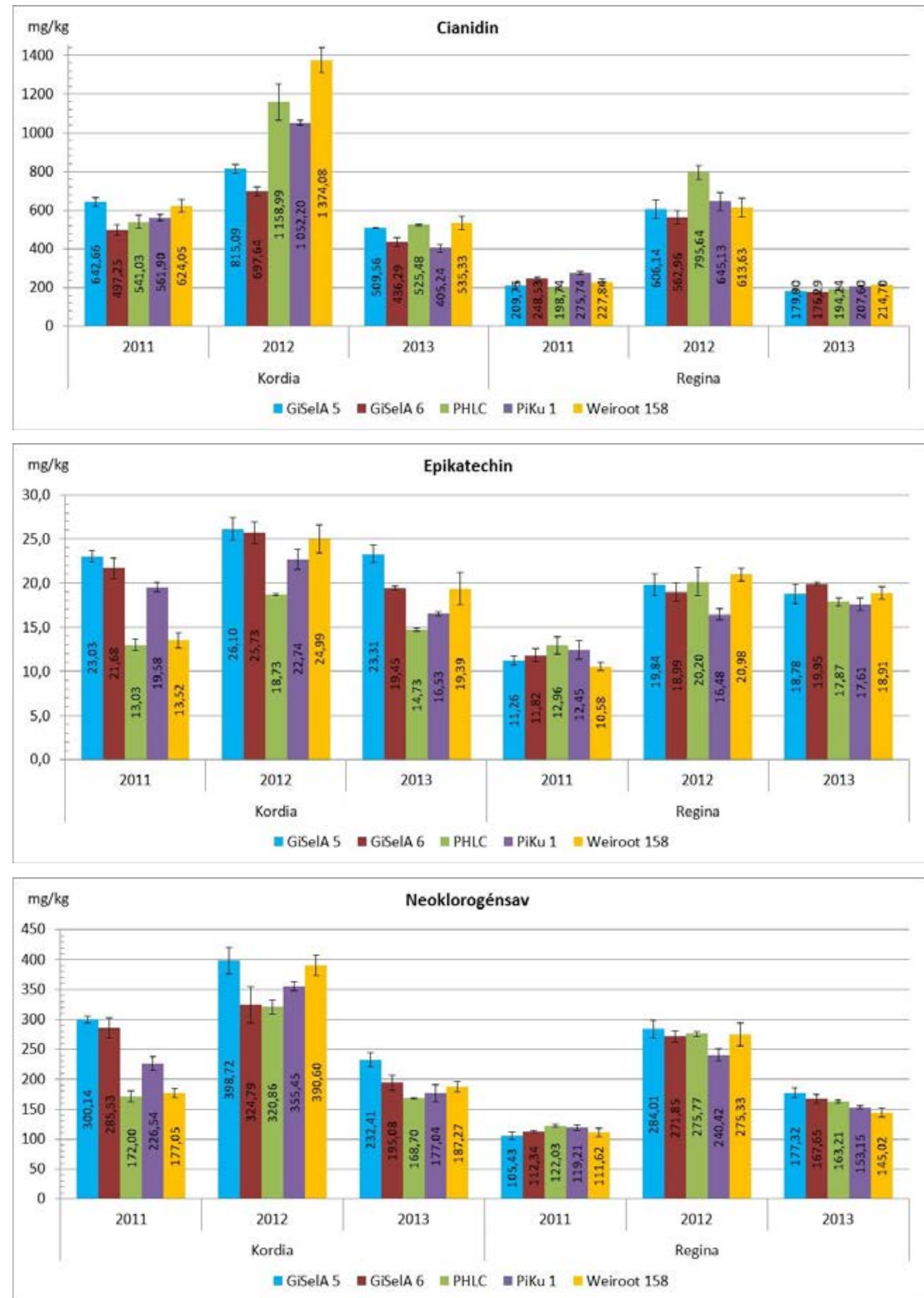

52. ábra (3/ 1.rész): 'Regina' és 'Kordia’ cseresznyefajták gyümölcseiben az egyedi polifenolkomponensek (cianidin, epikatechin, neoklorogénsav, klorogénsav, kínasav, rutin, kvercetin) koncentrációja különböző alanyokon T3-as érési stádiumban 2011 és 2013 között 

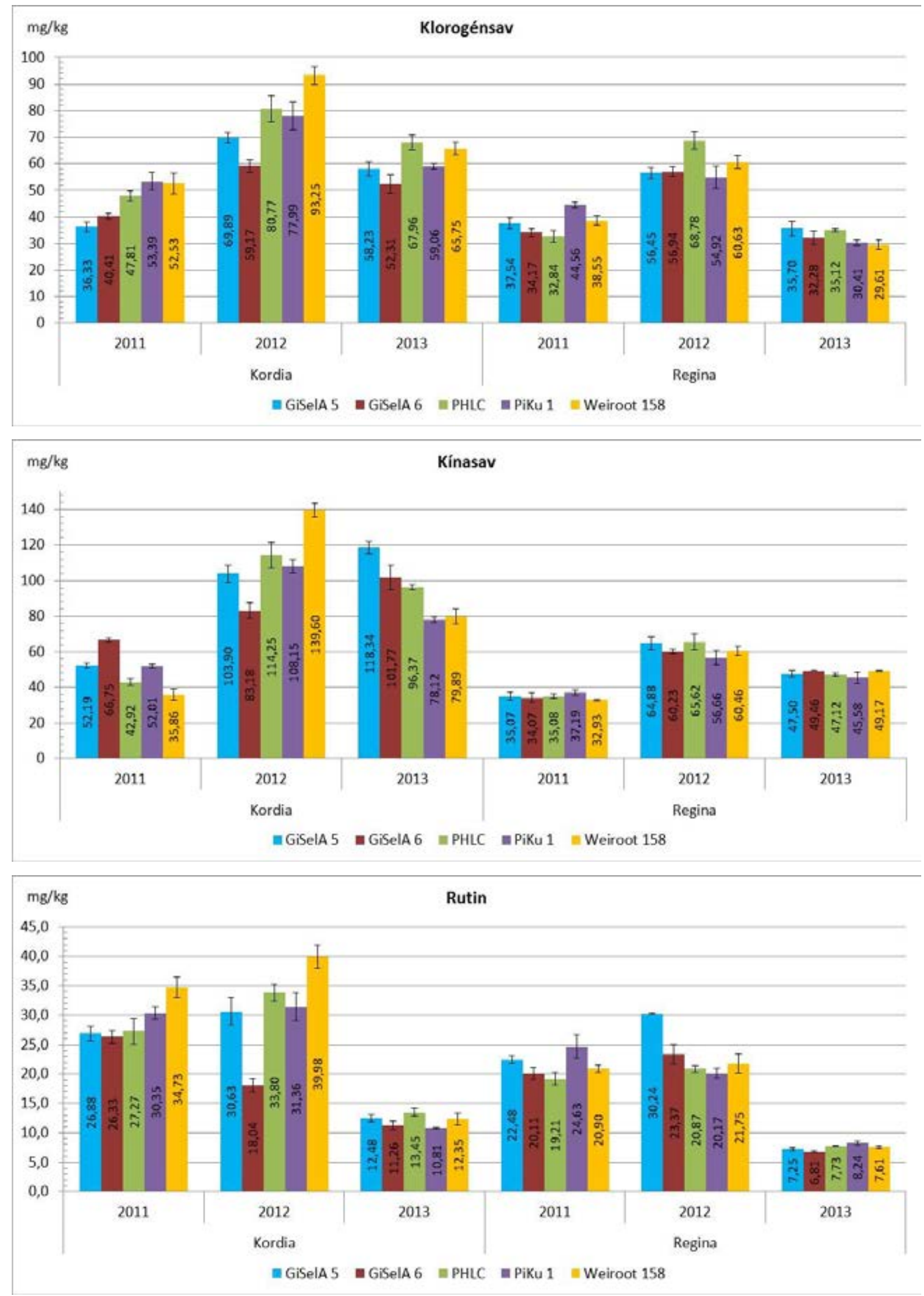

52. ábra (3/ 2.rész): 'Regina' és 'Kordia' cseresznyefajták gyümölcseiben az egyedi polifenolkomponensek (cianidin, epikatechin, neoklorogénsav, klorogénsav, kínasav, rutin, kvercetin) koncentrációja különböző alanyokon T3-as érési stádiumban 2011 és 2013 között 


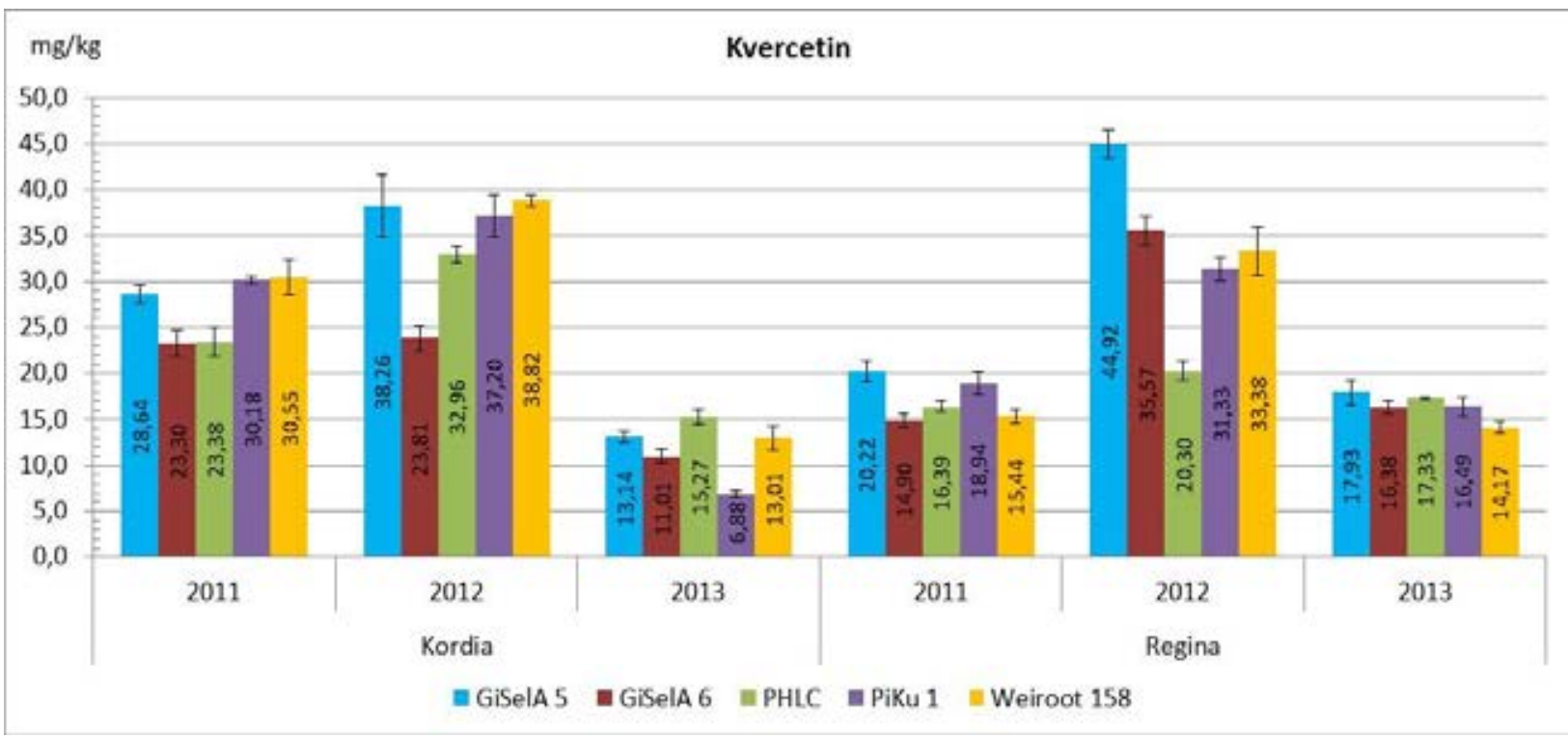

52. ábra (3/ 3.rész): 'Regina' és 'Kordia' cseresznyefajták gyümölcseiben az egyedi polifenolkomponensek (cianidin, epikatechin, neoklorogénsav, klorogénsav, kínasav, rutin, kvercetin) koncentrációja különböző alanyokon T3-as érési stádiumban 2011 és 2013 között 

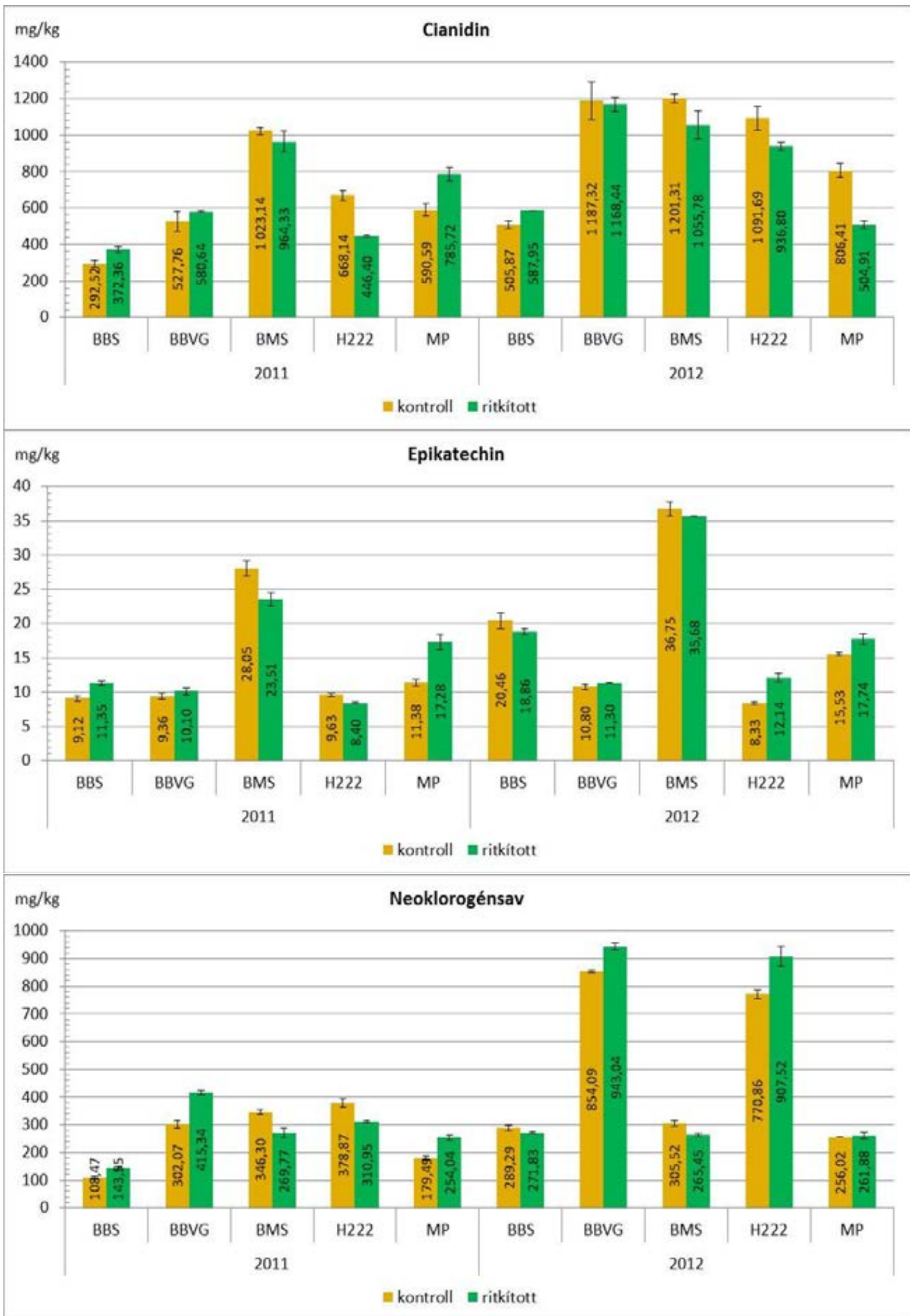

53. ábra (3/ 1.rész): Virágritkított és kontroll cseresznyefajták gyümölcseiben az egyedi polifenolkomponensek (cianidin, epikatechin, neoklorogénsav, klorogénsav, kínasav, rutin, kvercetin) koncentrációja T3-as érési stádiumban 2011 és 2012 között 


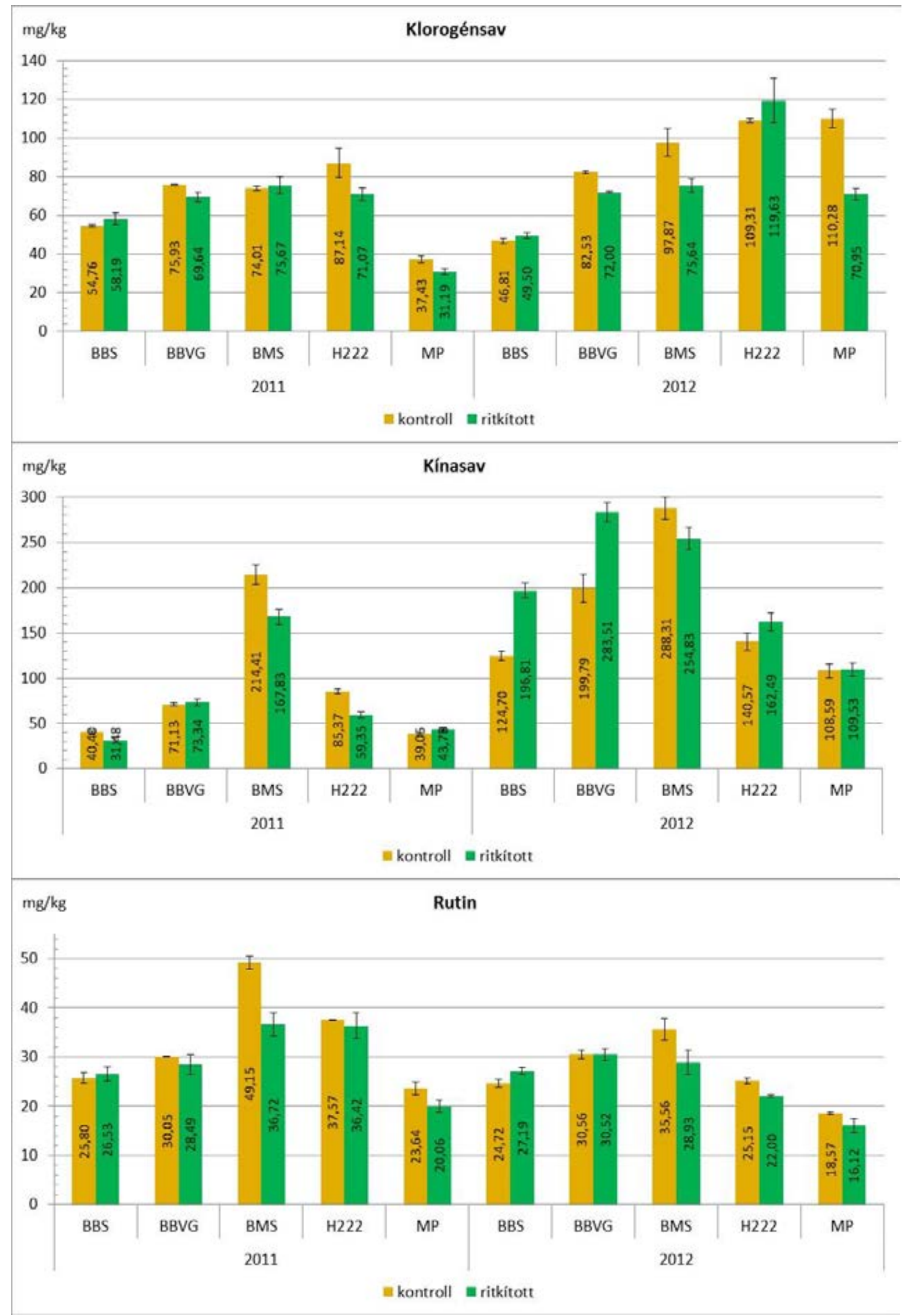

53. ábra (3/ 2.rész): Virágritkított és kontroll cseresznyefajták gyümölcseiben az egyedi polifenolkomponensek (cianidin, epikatechin, neoklorogénsav, klorogénsav, kínasav, rutin, kvercetin) koncentrációja T3-as érési stádiumban 2011 és 2012 között 


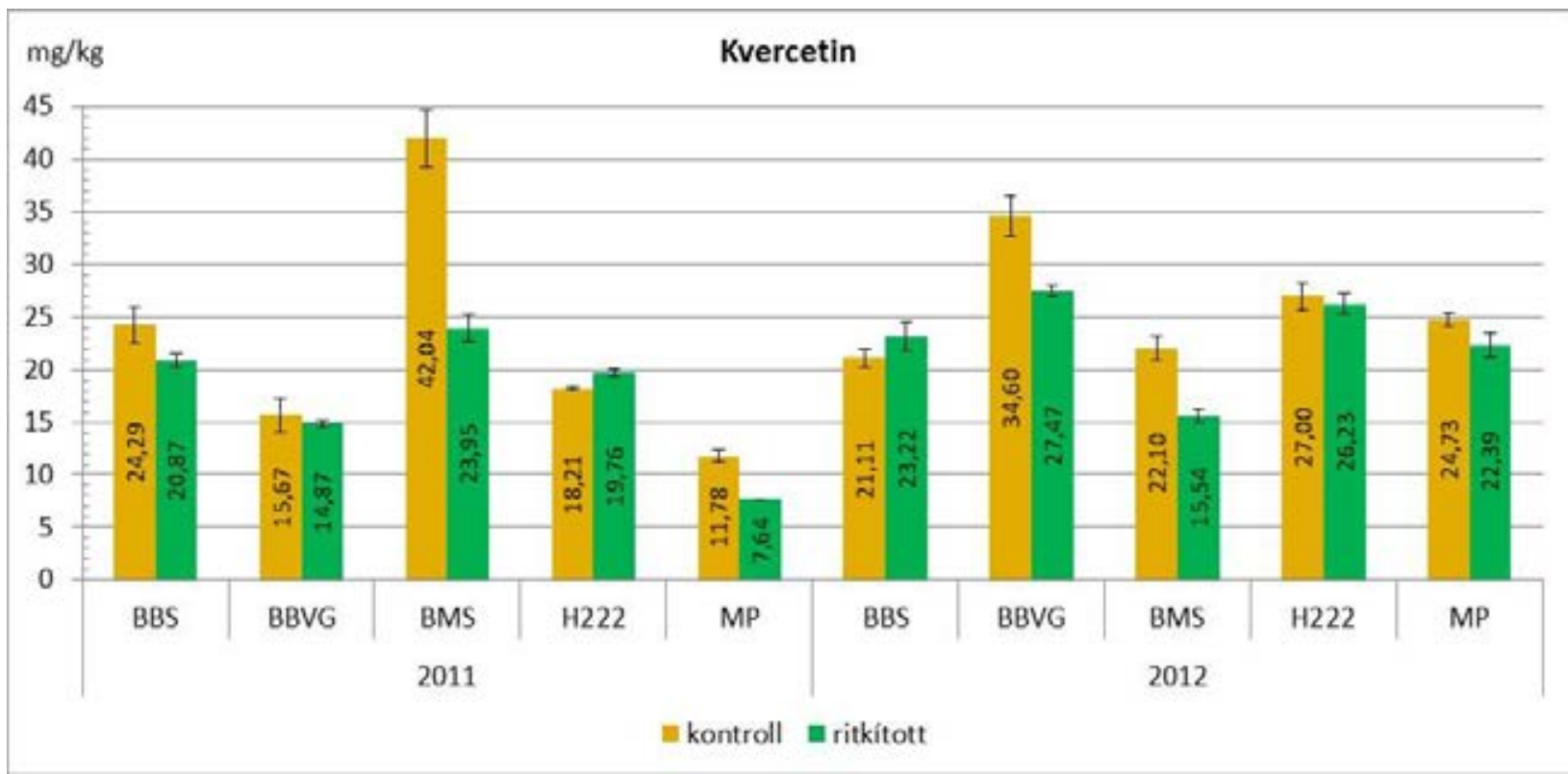

53. ábra (3/ 3.rész): Virágritkított és kontroll cseresznyefajták gyümölcseiben az egyedi polifenolkomponensek (cianidin, epikatechin, neoklorogénsav, klorogénsav, kínasav, rutin, kvercetin) koncentrációja T3-as érési stádiumban 2011 és 2012 között 


\subsection{M3. TÁBLÁZATOK}

17. táblázat: A jedlersdorfi Q10 cseresznyeültetvény alany-nemes kombinációinak sorokon belüli elrendezése

\begin{tabular}{|c|c|c|c|c|c|c|}
\hline & 1. sor & 2. sor & 3. sor & 4. sor & 5. sor & 6. sor \\
\hline 1. fa & $\begin{array}{c}\text { Regina } \\
\text { GiSelA } 5\end{array}$ & $\begin{array}{l}\text { Kordia } \\
\mathrm{PiKu} 1\end{array}$ & $\begin{array}{c}\text { Kordia } \\
\text { Weiroot } 158\end{array}$ & $\begin{array}{c}\text { Regina } \\
\text { GiSelA } 6\end{array}$ & $\begin{array}{c}\text { Regina } \\
\text { Weiroot } 158\end{array}$ & - \\
\hline 2. fa & $\begin{array}{l}\text { Regina } \\
\mathrm{PiKu} 1\end{array}$ & $\begin{array}{c}\text { Kordia } \\
\text { Weiroot } 158\end{array}$ & $\begin{array}{c}\text { Kordia } \\
\text { GiSelA } 6\end{array}$ & $\begin{array}{l}\text { Regina } \\
\text { PHL-C }\end{array}$ & $\begin{array}{l}\text { Regina } \\
\text { PHL-C }\end{array}$ & $\begin{array}{c}\text { Kordia } \\
\text { GiSelA } 6\end{array}$ \\
\hline 3. fa & $\begin{array}{c}\text { Regina } \\
\text { GiSelA } 6\end{array}$ & $\begin{array}{c}\text { Kordia } \\
\text { GiSelA } 5\end{array}$ & $\begin{array}{c}\text { Kordia } \\
\text { GiSelA } 5\end{array}$ & $\begin{array}{c}\text { Regina } \\
\text { Weiroot } 158\end{array}$ & $\begin{array}{c}\text { Regina } \\
\text { GiSelA } 6\end{array}$ & $\begin{array}{l}\text { Kordia } \\
\mathrm{PiKu} 1\end{array}$ \\
\hline 4. $\mathrm{fa}$ & $\begin{array}{l}\text { Regina } \\
\text { PHL-C }\end{array}$ & $\begin{array}{l}\text { Kordia } \\
\text { PHL-C }\end{array}$ & $\begin{array}{l}\text { Kordia } \\
\mathrm{PiKu} 1\end{array}$ & $\begin{array}{l}\text { Regina } \\
\mathrm{PiKu} 1\end{array}$ & $\begin{array}{c}\text { Regina } \\
\text { GiSelA } 5\end{array}$ & $\begin{array}{l}\text { Kordia } \\
\text { PHL-C }\end{array}$ \\
\hline 5. fa & $\begin{array}{c}\text { Regina } \\
\text { Weiroot } 158\end{array}$ & $\begin{array}{c}\text { Kordia } \\
\text { GiSelA } 6\end{array}$ & $\begin{array}{l}\text { Kordia } \\
\text { PHL-C }\end{array}$ & $\begin{array}{c}\text { Regina } \\
\text { GiSelA } 5\end{array}$ & $\begin{array}{l}\text { Regina } \\
\mathrm{PiKu} 1\end{array}$ & $\begin{array}{c}\text { Kordia } \\
\text { GiSelA } 5\end{array}$ \\
\hline 6. fa & pollenadó & pollenadó & pollenadó & pollenadó & pollenadó & pollenadó \\
\hline 7. fa & $\begin{array}{l}\text { Regina } \\
\mathrm{PiKu} 1\end{array}$ & $\begin{array}{c}\text { Kordia } \\
\text { Weiroot } 158\end{array}$ & $\begin{array}{l}\text { Kordia } \\
\mathrm{PiKu} 1\end{array}$ & $\begin{array}{l}\text { Regina } \\
\text { PHL-C }\end{array}$ & - & $\begin{array}{l}\text { Kordia } \\
\mathrm{PiKu} 1\end{array}$ \\
\hline 8. fa & $\begin{array}{c}\text { Regina } \\
\text { Weiroot } 158\end{array}$ & $\begin{array}{c}\text { Kordia } \\
\text { GiSelA } 6\end{array}$ & $\begin{array}{c}\text { Kordia } \\
\text { Weiroot } 158\end{array}$ & $\begin{array}{c}\text { Regina } \\
\text { GiSelA } 5\end{array}$ & $\begin{array}{c}\text { Regina } \\
\text { GiSelA } 5\end{array}$ & $\begin{array}{c}\text { Kordia } \\
\text { Weiroot } 158\end{array}$ \\
\hline 9. fa & $\begin{array}{l}\text { Regina } \\
\text { PHL-C }\end{array}$ & $\begin{array}{c}\text { Kordia } \\
\text { GiSelA } 5\end{array}$ & $\begin{array}{l}\text { Kordia } \\
\text { PHL-C }\end{array}$ & $\begin{array}{c}\text { Regina } \\
\text { GiSelA } 6\end{array}$ & $\begin{array}{l}\text { Regina } \\
\mathrm{PiKu} 1\end{array}$ & $\begin{array}{l}\text { Kordia } \\
\text { PHL-C }\end{array}$ \\
\hline 10. fa & $\begin{array}{c}\text { Regina } \\
\text { GiSelA } 5\end{array}$ & $\begin{array}{l}\text { Kordia } \\
\text { PHL-C }\end{array}$ & $\begin{array}{c}\text { Kordia } \\
\text { GiSelA } 6\end{array}$ & $\begin{array}{l}\text { Regina } \\
\mathrm{PiKu} 1\end{array}$ & $\begin{array}{c}\text { Regina } \\
\text { GiSelA } 6\end{array}$ & $\begin{array}{c}\text { Kordia } \\
\text { GiSelA } 6\end{array}$ \\
\hline 11. fa & $\begin{array}{c}\text { Regina } \\
\text { GiSelA } 6\end{array}$ & $\begin{array}{l}\text { Kordia } \\
\mathrm{PiKu} 1\end{array}$ & $\begin{array}{c}\text { Kordia } \\
\text { GiSelA } 5\end{array}$ & $\begin{array}{c}\text { Regina } \\
\text { Weiroot } 158\end{array}$ & $\begin{array}{l}\text { Regina } \\
\text { PHL-C }\end{array}$ & $\begin{array}{c}\text { Kordia } \\
\text { GiSelA } 5\end{array}$ \\
\hline 12. $\mathrm{fa}$ & $\begin{array}{c}\text { Regina } \\
\text { Weiroot } 158\end{array}$ & $\begin{array}{c}\text { Kordia } \\
\text { GiSelA } 5\end{array}$ & $\begin{array}{c}\text { Kordia } \\
\text { GiSelA } 6\end{array}$ & $\begin{array}{c}\text { Regina } \\
\text { GiSelA } 6\end{array}$ & - & $\begin{array}{c}\text { Kordia } \\
\text { GiSelA } 6\end{array}$ \\
\hline 13. fa & $\begin{array}{l}\text { Regina } \\
\text { PHL-C }\end{array}$ & $\begin{array}{c}\text { Kordia } \\
\text { Weiroot } 158\end{array}$ & $\begin{array}{c}\text { Kordia } \\
\text { Weiroot } 158\end{array}$ & $\begin{array}{c}\text { Regina } \\
\text { Weiroot } 158\end{array}$ & $\begin{array}{l}\text { Regina } \\
\text { PHL-C }\end{array}$ & $\begin{array}{l}\text { Kordia } \\
\text { PHL-C }\end{array}$ \\
\hline 14. fa & $\begin{array}{l}\text { Regina } \\
\mathrm{PiKu} 1\end{array}$ & $\begin{array}{l}\text { Kordia } \\
\mathrm{PiKu} 1\end{array}$ & $\begin{array}{l}\text { Kordia } \\
\mathrm{PiKu} 1\end{array}$ & $\begin{array}{c}\text { Regina } \\
\text { GiSelA } 5\end{array}$ & $\begin{array}{l}\text { Regina } \\
\mathrm{PiKu} 1\end{array}$ & $\begin{array}{c}\text { Kordia } \\
\text { GiSelA } 5\end{array}$ \\
\hline 15. fa & $\begin{array}{c}\text { Regina } \\
\text { GiSelA } 6\end{array}$ & $\begin{array}{l}\text { Kordia } \\
\text { PHL-C }\end{array}$ & $\begin{array}{c}\text { Kordia } \\
\text { GiSelA } 5\end{array}$ & $\begin{array}{l}\text { Regina } \\
\text { PHL-C }\end{array}$ & $\begin{array}{c}\text { Regina } \\
\text { GiSelA } 5\end{array}$ & $\begin{array}{c}\text { Kordia } \\
\text { Weiroot } 158\end{array}$ \\
\hline 16. fa & $\begin{array}{c}\text { Regina } \\
\text { GiSelA } 5\end{array}$ & $\begin{array}{c}\text { Kordia } \\
\text { GiSelA } 6\end{array}$ & $\begin{array}{l}\text { Kordia } \\
\text { PHL-C }\end{array}$ & $\begin{array}{l}\text { Regina } \\
\mathrm{PiKu} 1\end{array}$ & $\begin{array}{c}\text { Regina } \\
\text { GiSelA } 6\end{array}$ & $\begin{array}{l}\text { Kordia } \\
\mathrm{PiKu} 1\end{array}$ \\
\hline
\end{tabular}


18. táblázat: A jedlersdorfi Q26 ültetvény 13 cseresznyefajtájának sorokon belüli elrendezése

\begin{tabular}{|c|c|c|c|c|}
\hline & 1. sor & 2. sor & 3. sor & 4. sor \\
\hline 1. fa & Belise & Summertime & Kritzendorfer & Kritzendorfer \\
\hline 2. fa & Summertime & Belise & Summertime & Belise \\
\hline 3. fa & Merton Prem. & Hybrid 222 & Valeska & Schachl \\
\hline 4. fa & Schachl & Big. Bur. Sch. & Marzer Kirsche & Big. Moreau VG \\
\hline 5. fa & Big. Bur. Sch. & Merton Prem. & Big. Burlat VG & Hybrid 222 \\
\hline 6. fa & Big. Mor. Sch. & Marzer Kirsche & Big. Moreau VG & Big. Burlat VG \\
\hline 7. fa & Big. Burlat VG & Big. Moreau VG & Schachl & Big. Mor. Sch. \\
\hline 8. fa & Marzer Kirsche & Valeska & Big. Bur. Sch. & Merton Prem. \\
\hline 9. fa & Hybrid 222 & Big. Burlat VG & Big. Mor. Sch. & Valeska \\
\hline 10. fa & Valeska & Big. Mor. Sch. & Hybrid 222 & Big. Bur. Sch. \\
\hline 11. fa & Big. Moreau VG & Schachl & Merton Prem. & Marzer Kirsche \\
\hline 12. fa & Big. Burlat VG & Hybrid 222 & Sweetheart & Merchant \\
\hline 13. fa & Big. Bur. Sch. & Marzer Kirsche & Schachl & Big. Bur. Sch. \\
\hline 14. fa & Big. Moreau VG & Sweetheart & Early Lory & Langstielige \\
\hline 15. fa & Big. Mor. Sch. & Big. Moreau VG & Merton Prem. & Marzer Kirsche \\
\hline 16. fa & Marzer Kirsche & Valeska & Merchant & Schachl \\
\hline 17. fa & Merton Prem. & Merchant & Big. Moreau VG & Valeska \\
\hline 18. fa & Valeska & Big. Mor. Sch. & Big. Mor. Sch. & Big. Mor. Sch. \\
\hline 19. fa & Hybrid 222 & Langstielige & Langstielige & Merton Prem. \\
\hline 20. fa & Schachl & Big. Bur. Sch. & Big. Burlat VG & Early Lory \\
\hline 21. fa & Sweetheart & Early Lory & Hybrid 222 & Hybrid 222 \\
\hline 22. fa & Langstielige & Big. Burlat VG & Marzer Kirsche & Big. Mor. VG \\
\hline 23. fa & Early Lory & Schachl & Big. Bur. Sch. & Sweetheart \\
\hline 24. fa & Merchant & Merton Prem. & Valeska & Big. Bur. VG \\
\hline $25 . \mathrm{fa}$ & Kritzendorfer & Kritzendorfer & Frühe K. Ubl & Frühe K. Ubl \\
\hline
\end{tabular}

(vastag betűvel jelölve a vizsgálatba vont fajták) 
19. táblázat: 'Regina' és ‘Kordia' cseresznyefajták gyümölcsméret-paraméterei különböző alanyokon (1.)

\begin{tabular}{|c|c|c|c|c|c|c|c|c|c|}
\hline Év & Nemes & Terminus & Alany & Szélesség (m & & Magasság (n & & Vastagság (m & \\
\hline & & & GiSelA 5 & $19,94 \pm 1,06$ & & $18,50 \pm 1,10$ & $\mathrm{a}$ & $16,50 \pm 1,03$ & \\
\hline & & & GiSelA 6 & $20,19 \pm 0,98$ & $\mathrm{a}$ & $18,69 \pm 1,30$ & & $16,75 \pm 1,18$ & \\
\hline & & T1 & PHL-C & $20,31 \pm 0,79$ & $\mathrm{a}$ & $19,75 \pm 0,68$ & & $17,44 \pm 0,73$ & \\
\hline & & & PiKu 1 & $20,00 \pm 0,63$ & $\mathrm{a}$ & $19,00 \pm 0,89$ & & $16,69 \pm 0,95$ & \\
\hline & & & Weiroot 158 & $19,69 \pm 0,79$ & $\mathrm{a}$ & $19,13 \pm 1,02$ & & $16,63 \pm 0,89$ & $\mathrm{ab}$ \\
\hline & & & GiSelA 5 & $20,88 \pm 1,09$ & $\mathrm{a}$ & $20,38 \pm 1,02$ & $\mathrm{a}$ & $18,19 \pm 1,11$ & \\
\hline & & & GiSelA 6 & $21,38 \pm 0,96$ & $a b$ & $20,94 \pm 0,93$ & & $18,56 \pm 0,89$ & $\mathrm{a}$ \\
\hline 2010 & Kordia & $\mathbf{T 2}$ & PHL-C & $21,69 \pm 1,08$ & & $21,25 \pm 1,29$ & & $18,75 \pm 1,29$ & $\mathrm{a}$ \\
\hline & & & $\mathrm{PiKu} 1$ & $21,75 \pm 0,77$ & $a b$ & $21,19 \pm 1,05$ & & $19,06 \pm 0,93$ & $\mathrm{a}$ \\
\hline & & & Weiroot 158 & $22,19 \pm 1,05$ & $\mathrm{~b}$ & $21,63 \pm 0,81$ & $\mathrm{~b}$ & $18,88 \pm 0,96$ & $\mathrm{a}$ \\
\hline & & & GiSelA 5 & $24,25 \pm 1,34$ & $\mathrm{a}$ & $23,69 \pm 1,25$ & $\mathrm{a}$ & $20,94 \pm 0,77$ & $\mathrm{a}$ \\
\hline & & & GiSelA 6 & $24,56 \pm 1,15$ & $\mathrm{a}$ & $24,06 \pm 1,12$ & $\mathrm{a}$ & $21,06 \pm 1,39$ & $\mathrm{a}$ \\
\hline & & T3 & PHL-C & $25,06 \pm 1,18$ & $\mathrm{a}$ & $24,44 \pm 1,15$ & $\mathrm{a}$ & $21,50 \pm 0,89$ & $\mathrm{a}$ \\
\hline & & & PiKu 1 & $24,94 \pm 1,57$ & $\mathrm{a}$ & $24,50 \pm 1,10$ & $\mathrm{a}$ & $21,44 \pm 1,03$ & $\mathrm{a}$ \\
\hline & & & Weiroot 158 & $25,31 \pm 0,70$ & $\mathrm{a}$ & $24,00 \pm 0,73$ & $\mathrm{a}$ & $21,25 \pm 0,68$ & $\mathrm{a}$ \\
\hline & & & GiSelA 5 & $25,25 \pm 1,18$ & $\mathrm{a}$ & $23,75 \pm 1,06$ & $\mathrm{a}$ & $22,13 \pm 0,81$ & $\mathrm{a}$ \\
\hline & & & GiSelA 6 & $24,56 \pm 1,79$ & $\mathrm{a}$ & $23,31 \pm 1,70$ & $\mathrm{a}$ & $22,13 \pm 1,41$ & $\mathrm{a}$ \\
\hline & & T1 & PHL-C & $25,69 \pm 1,14$ & $\mathrm{a}$ & $24,25 \pm 1,18$ & $\mathrm{a}$ & $22,50 \pm 0,89$ & $\mathrm{a}$ \\
\hline & & & $\mathrm{PiKu} 1$ & $24,88 \pm 1,02$ & $\mathrm{a}$ & $23,94 \pm 0,93$ & $\mathrm{a}$ & $21,81 \pm 0,91$ & $\mathrm{a}$ \\
\hline & & & Weiroot 158 & $25,31 \pm 1,14$ & $\mathrm{a}$ & $23,88 \pm 1,15$ & $\mathrm{a}$ & $22,38 \pm 0,96$ & $\mathrm{a}$ \\
\hline & & & GiSelA 5 & $25,63 \pm 0,89$ & $\mathrm{a}$ & $24,38 \pm 0,89$ & $\mathrm{a}$ & $22,63 \pm 0,72$ & $\mathrm{a}$ \\
\hline & & & GiSelA 6 & $25,50 \pm 0,89$ & $\mathrm{a}$ & $23,88 \pm 1,09$ & $\mathrm{a}$ & $22,50 \pm 1,46$ & $\mathrm{a}$ \\
\hline 2010 & Regina & $\mathbf{T 2}$ & PHL-C & $25,25 \pm 1,39$ & $\mathrm{a}$ & $23,81 \pm 1,47$ & $\mathrm{a}$ & $21,75 \pm 1,24$ & $\mathrm{a}$ \\
\hline & & & PiKu 1 & $25,19 \pm 1,17$ & $\mathrm{a}$ & $23,81 \pm 1,28$ & $\mathrm{a}$ & $22,25 \pm 1,00$ & $\mathrm{a}$ \\
\hline & & & Weiroot 158 & $25,81 \pm 0,98$ & $\mathrm{a}$ & $24,00 \pm 1,32$ & $\mathrm{a}$ & $22,31 \pm 0,95$ & $\mathrm{a}$ \\
\hline & & & GiSelA 5 & $26,56 \pm 1,59$ & $\mathrm{a}$ & $25,31 \pm 1,74$ & $\mathrm{a}$ & $22,94 \pm 1,39$ & $\mathrm{a}$ \\
\hline & & & GiSelA 6 & $26,19 \pm 1,05$ & $\mathrm{a}$ & $24,63 \pm 1,45$ & $\mathrm{a}$ & $22,88 \pm 1,31$ & $\mathrm{a}$ \\
\hline & & T3 & PHL-C & $26,25 \pm 1,48$ & $\mathrm{a}$ & $24,69 \pm 1,08$ & $\mathrm{a}$ & $22,94 \pm 1,12$ & $\mathrm{a}$ \\
\hline & & & PiKu 1 & $25,88 \pm 1,09$ & $\mathrm{a}$ & $25,13 \pm 0,89$ & $\mathrm{a}$ & $22,75 \pm 0,77$ & $\mathrm{a}$ \\
\hline & & & Weiroot 158 & $26,06 \pm 1,12$ & $\mathrm{a}$ & $25,00 \pm 1,26$ & $\mathrm{a}$ & $22,88 \pm 0,81$ & $\mathrm{a}$ \\
\hline & & & GiSelA 5 & $22,26 \pm 1,40$ & $\mathrm{c}$ & $21,63 \pm 1,17$ & $a b$ & $19,39 \pm 0,99$ & $\mathrm{a}$ \\
\hline & & & GiSelA 6 & $21,93 \pm 1,11$ & $\mathrm{bc}$ & $21,87 \pm 1,06$ & b & $19,45 \pm 0,95$ & $\mathrm{a}$ \\
\hline & & T1 & PHL-C & $21,99 \pm 1,07$ & $\mathrm{bc}$ & $21,72 \pm 1,35$ & b & $19,33 \pm 1,54$ & $\mathrm{a}$ \\
\hline & & & PiKu 1 & $21,03 \pm 0,78$ & $\mathrm{a}$ & $20,88 \pm 1,06$ & $\mathrm{a}$ & $18,81 \pm 1,12$ & $\mathrm{a}$ \\
\hline & & & Weiroot 158 & $21,32 \pm 1,54$ & $\mathrm{ab}$ & $21,17 \pm 1,27$ & $a b$ & $18,63 \pm 1,32$ & $\mathrm{a}$ \\
\hline & & & GiSelA 5 & $23,80 \pm 1,14$ & $a b$ & $23,29 \pm 1,01$ & $a b$ & $20,67 \pm 0,97$ & $a b$ \\
\hline & & & GiSelA 6 & $24,41 \pm 1,23$ & $\mathrm{c}$ & $23,75 \pm 0,73$ & bc & $21,40 \pm 0,67$ & $\mathrm{c}$ \\
\hline 2011 & Kordia & $\mathbf{T} 2$ & PHL-C & $24,47 \pm 0,96$ & $\mathrm{bc}$ & $23,97 \pm 0,87$ & $\mathrm{c}$ & $21,01 \pm 0,94$ & $\mathrm{bc}$ \\
\hline & & & PiKu 1 & $23,73 \pm 0,95$ & $\mathrm{a}$ & $22,99 \pm 0,86$ & $\mathrm{a}$ & $20,34 \pm 0,90$ & $\mathrm{a}$ \\
\hline & & & Weiroot 158 & $24,56 \pm 0,90$ & $\mathrm{c}$ & $23,65 \pm 0,69$ & $\mathrm{bc}$ & $20,98 \pm 0,62$ & $\mathrm{bc}$ \\
\hline & & & GiSelA 5 & $26,18 \pm 0,96$ & $\mathrm{~b}$ & $25,34 \pm 1,06$ & bc & $22,45 \pm 0,93$ & $\mathrm{~b}$ \\
\hline & & & GiSelA 6 & $26,50 \pm 0,97$ & $\mathrm{~b}$ & $25,56 \pm 0,76$ & $\mathrm{c}$ & $22,42 \pm 0,85$ & $\mathrm{~b}$ \\
\hline & & T3 & PHL-C & $25,38 \pm 0,97$ & $\mathrm{a}$ & $24,72 \pm 1,11$ & $a b$ & $21,35 \pm 0,86$ & $\mathrm{a}$ \\
\hline & & & PiKu 1 & $24,95 \pm 0,94$ & $\mathrm{a}$ & $24,15 \pm 1,10$ & $\mathrm{a}$ & $21,01 \pm 1,06$ & $\mathrm{a}$ \\
\hline & & & Weiroot 158 & $26,38 \pm 1,12$ & $\mathrm{~b}$ & $24,83 \pm 0,65$ & b & $22,06 \pm 0,89$ & $\mathrm{~b}$ \\
\hline
\end{tabular}

1a különböző betűk a szignifikánsan különböző csoportokat jelölik, MANOVA, p<0,05 (Tukey / Games-Howell) 
19. táblázat: 'Regina' és ‘Kordia' cseresznyefajták gyümölcsméret-paraméterei különböző alanyokon (2.)

\begin{tabular}{|c|c|c|c|c|c|c|c|c|c|}
\hline Év & Nemes & Terminus & Alany & \multicolumn{2}{|c|}{ Szélesség (mm) } & \multicolumn{2}{|c|}{ Magasság (mm) } & \multicolumn{2}{|c|}{ Vastagság (mm) } \\
\hline \multirow{15}{*}{2011} & \multirow{15}{*}{ Regina } & \multirow{5}{*}{ T1 } & GiSelA 5 & $23,94 \pm 0,76$ & & $22,91 \pm 0,64$ & & $21,21 \pm 0,53$ & $\mathrm{~b}$ \\
\hline & & & GiSelA 6 & $24,43 \pm 0,99$ & $\mathrm{~b}$ & $23,21 \pm 0,88$ & $\mathrm{c}$ & $21,54 \pm 0,72$ & bc \\
\hline & & & PHL-C & $22,70 \pm 1,60$ & $\mathrm{a}$ & $22,06 \pm 1,24$ & $\mathrm{a}$ & $20,63 \pm 0,98$ & $\mathrm{a}$ \\
\hline & & & PiKu 1 & $22,91 \pm 1,01$ & $\mathrm{a}$ & $22,31 \pm 0,70$ & & $20,73 \pm 0,66$ & $\mathrm{a}$ \\
\hline & & & Weiroot 158 & $24,35 \pm 1,14$ & $\mathrm{~b}$ & $23,14 \pm 0,69$ & $\mathrm{c}$ & $21,80 \pm 0,71$ & $\mathrm{c}$ \\
\hline & & \multirow{5}{*}{$\mathbf{T} 2$} & GiSelA 5 & $23,61 \pm 0,95$ & $\mathrm{a}$ & $22,51 \pm 0,97$ & $\mathrm{a}$ & $21,57 \pm 0,76$ & $\mathrm{a}$ \\
\hline & & & GiSelA 6 & $23,89 \pm 1,22$ & $\mathrm{a}$ & $22,80 \pm 0,74$ & & $21,70 \pm 0,61$ & $\mathrm{ab}$ \\
\hline & & & PHL-C & $24,76 \pm 1,33$ & $\mathrm{~b}$ & $23,26 \pm 1,07$ & & $22,19 \pm 0,93$ & $\mathrm{bc}$ \\
\hline & & & PiKu 1 & $23,73 \pm 1,15$ & $\mathrm{a}$ & $22,39 \pm 0,84$ & $\mathrm{a}$ & $21,27 \pm 0,76$ & $\mathrm{a}$ \\
\hline & & & Weiroot 158 & $25,20 \pm 1,15$ & $\mathrm{~b}$ & $23,40 \pm 1,13$ & $\mathrm{c}$ & $22,41 \pm 0,93$ & $\mathrm{c}$ \\
\hline & & \multirow{5}{*}{ T3 } & GiSelA 5 & $24,77 \pm 1,15$ & $\mathrm{ab}$ & $23,72 \pm 1,03$ & $a b$ & $22,24 \pm 0,97$ & $a b$ \\
\hline & & & GiSelA 6 & $25,40 \pm 1,21$ & $\mathrm{~b}$ & $23,50 \pm 1,03$ & $\mathrm{a}$ & $22,57 \pm 1,01$ & bc \\
\hline & & & PHL-C & $25,57 \pm 1,58$ & $\mathrm{~b}$ & $24,29 \pm 1,17$ & $\mathrm{~b}$ & $23,18 \pm 1,00$ & $\mathrm{c}$ \\
\hline & & & PiKu 1 & $24,34 \pm 0,97$ & $\mathrm{a}$ & $23,13 \pm 0,82$ & $\mathrm{a}$ & $21,92 \pm 0,76$ & $\mathrm{a}$ \\
\hline & & & Weiroot 158 & $25,49 \pm 0,96$ & $\mathrm{~b}$ & $23,65 \pm 0,79$ & $a b$ & $22,85 \pm 0,85$ & bc \\
\hline \multirow{15}{*}{2012} & \multirow{15}{*}{ Kordia } & \multirow{5}{*}{ T1 } & GiSelA 5 & $21,64 \pm 0,97$ & $\mathrm{~b}$ & $21,54 \pm 0,92$ & $\mathrm{c}$ & $18,26 \pm 0,85$ & $\mathrm{c}$ \\
\hline & & & GiSelA 6 & $21,36 \pm 0,67$ & $\mathrm{~b}$ & $20,89 \pm 0,89$ & $\mathrm{bc}$ & $18,00 \pm 0,53$ & bc \\
\hline & & & PHL-C & $21,06 \pm 0,56$ & $\mathrm{~b}$ & $20,38 \pm 0,83$ & $a b$ & $17,32 \pm 0,50$ & $a b$ \\
\hline & & & $\mathrm{PiKu} 1$ & $20,24 \pm 0,77$ & $\mathrm{a}$ & $20,00 \pm 0,83$ & $\mathrm{a}$ & $17,01 \pm 0,67$ & $\mathrm{a}$ \\
\hline & & & Weiroot 158 & $20,17 \pm 0,85$ & $\mathrm{a}$ & $19,95 \pm 0,96$ & $\mathrm{a}$ & $16,95 \pm 0,85$ & $\mathrm{a}$ \\
\hline & & \multirow{5}{*}{$\mathbf{T} 2$} & GiSelA 5 & $21,79 \pm 0,72$ & $\mathrm{a}$ & $21,57 \pm 0,70$ & $\mathrm{a}$ & $18,65 \pm 0,63$ & $\mathrm{a}$ \\
\hline & & & GiSelA 6 & $22,20 \pm 0,71$ & $\mathrm{a}$ & $21,93 \pm 0,61$ & $\mathrm{a}$ & $18,90 \pm 0,62$ & $\mathrm{a}$ \\
\hline & & & PHL-C & $22,32 \pm 0,61$ & $\mathrm{a}$ & $22,11 \pm 0,51$ & $\mathrm{a}$ & $18,95 \pm 0,58$ & $\mathrm{a}$ \\
\hline & & & PiKu 1 & $22,04 \pm 0,97$ & $\mathrm{a}$ & $21,84 \pm 0,74$ & $\mathrm{a}$ & $18,66 \pm 0,63$ & $\mathrm{a}$ \\
\hline & & & Weiroot 158 & $21,87 \pm 1,01$ & $\mathrm{a}$ & $21,53 \pm 0,92$ & $\mathrm{a}$ & $18,56 \pm 0,83$ & $\mathrm{a}$ \\
\hline & & \multirow{5}{*}{ T3 } & GiSelA 5 & $24,22 \pm 1,42$ & $\mathrm{a}$ & $23,17 \pm 0,92$ & $\mathrm{a}$ & $20,28 \pm 0,88$ & $\mathrm{a}$ \\
\hline & & & GiSelA 6 & $23,74 \pm 0,89$ & $\mathrm{a}$ & $23,05 \pm 0,95$ & $\mathrm{a}$ & $20,44 \pm 0,77$ & $\mathrm{a}$ \\
\hline & & & PHL-C & $23,45 \pm 0,94$ & $\mathrm{a}$ & $23,15 \pm 0,99$ & $\mathrm{a}$ & $20,31 \pm 0,98$ & $\mathrm{a}$ \\
\hline & & & PiKu 1 & $23,82 \pm 0,98$ & $\mathrm{a}$ & $23,46 \pm 0,90$ & $\mathrm{a}$ & $20,56 \pm 0,91$ & $\mathrm{a}$ \\
\hline & & & Weiroot 158 & $23,86 \pm 1,03$ & $\mathrm{a}$ & $23,07 \pm 0,99$ & $\mathrm{a}$ & $20,23 \pm 0,78$ & $\mathrm{a}$ \\
\hline \multirow{15}{*}{2012} & \multirow{15}{*}{ Regina } & \multirow{5}{*}{ T1 } & GiSelA 5 & $20,56 \pm 0,71$ & $\mathrm{a}$ & $20,44 \pm 0,77$ & $\mathrm{a}$ & $18,66 \pm 0,83$ & $\mathrm{a}$ \\
\hline & & & GiSelA 6 & $20,97 \pm 0,62$ & $a b c$ & $20,49 \pm 0,54$ & $\mathrm{a}$ & $18,67 \pm 0,59$ & $\mathrm{a}$ \\
\hline & & & PHL-C & $21,54 \pm 1,08$ & $\mathrm{bc}$ & $21,04 \pm 0,89$ & $\mathrm{a}$ & $19,08 \pm 0,86$ & $\mathrm{a}$ \\
\hline & & & $\mathrm{PiKu} 1$ & $20,72 \pm 0,81$ & $\mathrm{ab}$ & $20,47 \pm 0,58$ & $\mathrm{a}$ & $18,33 \pm 0,70$ & $\mathrm{a}$ \\
\hline & & & Weiroot 158 & $21,61 \pm 1,04$ & $\mathrm{c}$ & $20,75 \pm 0,78$ & $\mathrm{a}$ & $18,72 \pm 0,81$ & $\mathrm{a}$ \\
\hline & & \multirow{5}{*}{$\mathbf{T} 2$} & GiSelA 5 & $21,78 \pm 0,83$ & $\mathrm{a}$ & $21,36 \pm 0,75$ & $\mathrm{a}$ & $19,24 \pm 0,67$ & $\mathrm{a}$ \\
\hline & & & GiSelA 6 & $22,22 \pm 0,80$ & $\mathrm{a}$ & $21,55 \pm 0,51$ & $\mathrm{a}$ & $19,44 \pm 0,72$ & $\mathrm{a}$ \\
\hline & & & PHL-C & $22,49 \pm 0,75$ & $\mathrm{ab}$ & $21,44 \pm 0,61$ & $\mathrm{a}$ & $19,64 \pm 0,71$ & $\mathrm{a}$ \\
\hline & & & PiKu 1 & $21,77 \pm 1,00$ & $\mathrm{a}$ & $21,05 \pm 0,80$ & $\mathrm{a}$ & $18,97 \pm 0,79$ & $\mathrm{a}$ \\
\hline & & & Weiroot 158 & $23,30 \pm 1,03$ & $\mathrm{~b}$ & $22,44 \pm 0,78$ & $\mathrm{~b}$ & $20,42 \pm 0,90$ & $\mathrm{~b}$ \\
\hline & & & GiSelA 5 & $20,42 \pm 0,80$ & $\mathrm{a}$ & $20,21 \pm 0,67$ & $\mathrm{a}$ & $18,22 \pm 1,00$ & $\mathrm{a}$ \\
\hline & & & GiSelA 6 & $20,77 \pm 1,07$ & $\mathrm{a}$ & $19,98 \pm 0,70$ & $\mathrm{a}$ & $18,24 \pm 0,83$ & $\mathrm{a}$ \\
\hline & & T3 & PHL-C & $21,32 \pm 1,31$ & $\mathrm{a}$ & $20,26 \pm 1,49$ & $\mathrm{a}$ & $18,32 \pm 1,33$ & $\mathrm{a}$ \\
\hline & & & PiKu 1 & $20,50 \pm 1,23$ & $\mathrm{a}$ & $20,05 \pm 0,99$ & $\mathrm{a}$ & $17,97 \pm 0,77$ & $\mathrm{a}$ \\
\hline & & & Weiroot 158 & $21,01 \pm 1,29$ & $\mathrm{a}$ & $20,41 \pm 1,25$ & $\mathrm{a}$ & $18,29 \pm 1,13$ & $\mathrm{a}$ \\
\hline
\end{tabular}

1a különböző betűk a szignifikánsan különböző csoportokat jelölik, MANOVA, p<0,05 (Tukey / Games-Howell) 
19. táblázat: 'Regina’ és ‘Kordia’ cseresznyefajták gyümölcsméret-paraméterei különböző alanyokon (3.)

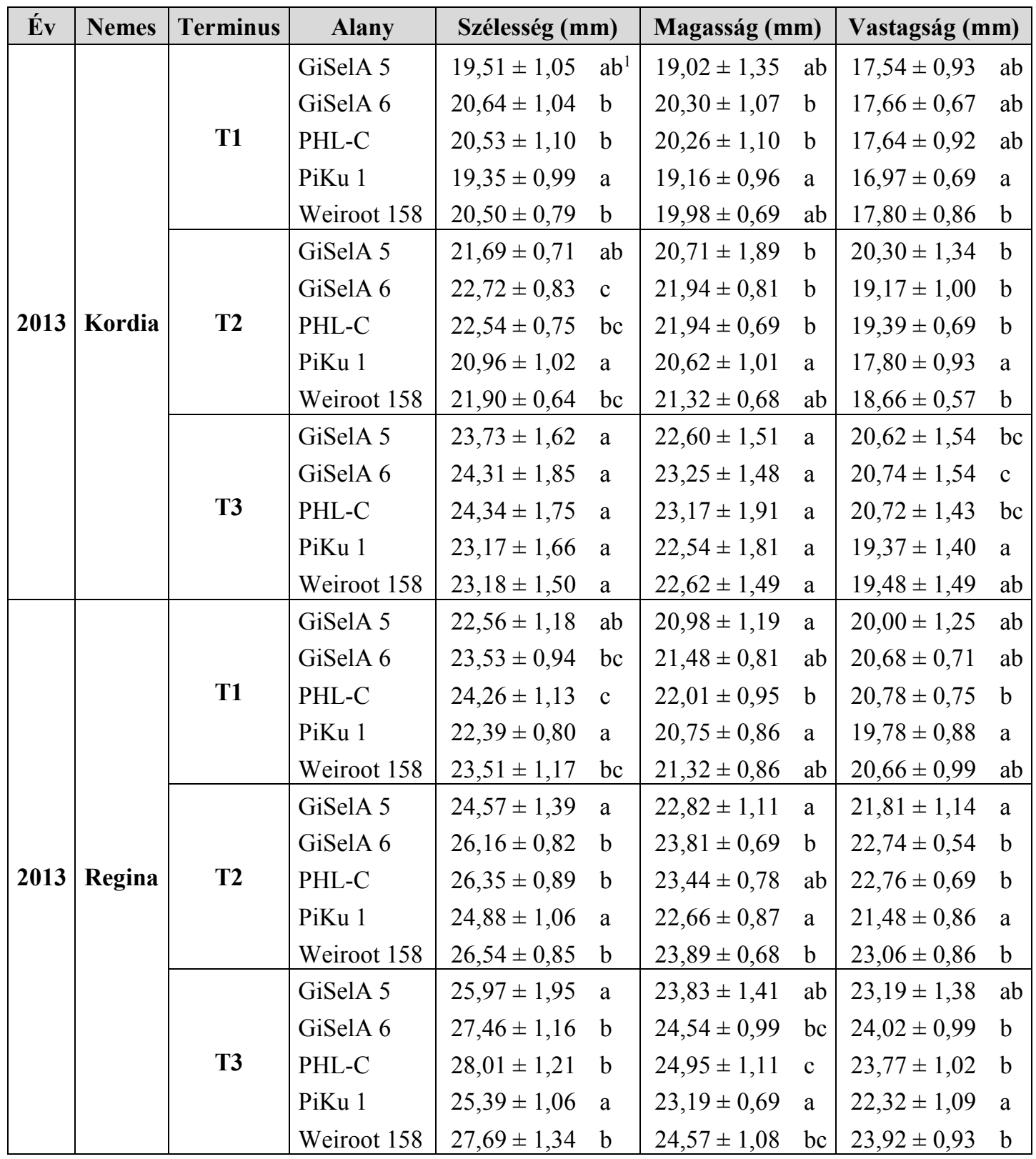

${ }^{1}$ A különböző betük a szignifikánsan különböző csoportokat jelölik. Az elemzést MANOVA módszerrel végeztük $\mathrm{p}<0,05$ szinten, szóráshomogenitás esetén Tukey, enyhe sérülése esetén Games-Howell post hoc tesztet alkalmazva. 
20. táblázat: 'Regina' és ‘Kordia’ gyümölcsök térfogata, kocsány-szakítószilárdsága, keménysége különböző alanyokon (1.)

\begin{tabular}{|c|c|c|c|c|c|c|c|c|c|}
\hline Év & Nemes & Terminus & Alany & Térfogat $(\mathrm{cm}$ & & $\begin{array}{l}\text { Kocsány-szak } \\
\text { szilárdság (N }\end{array}$ & & $\begin{array}{r}\text { Keménysé } \\
\left(\mathrm{kg} / \mathrm{cm}^{2}\right)\end{array}$ & \\
\hline \multirow{3}{*}{2010} & \multirow{3}{*}{ Kordia } & T1 & $\begin{array}{l}\text { GiSelA } 5 \\
\text { GiSelA } 6 \\
\text { PHL-C } \\
\text { PiKu } 1 \\
\text { Weiroot } 158 \\
\end{array}$ & $\begin{array}{l}3,21 \pm 0,53 \\
3,34 \pm 0,57 \\
3,67 \pm 0,35 \\
3,33 \pm 0,39 \\
3,29 \pm 0,46 \\
\end{array}$ & $\begin{array}{l}\mathrm{a}^{1} \\
\mathrm{a} \\
\mathrm{a} \\
\mathrm{a} \\
\mathrm{a}\end{array}$ & $\begin{array}{l}\text { n. a. } \\
\text { n. a. } \\
\text { n. a. } \\
\text { n. a. } \\
\text { n. a. }\end{array}$ & & $\begin{array}{l}4,58 \pm 0,20 \\
5,11 \pm 0,45 \\
5,37 \pm 0,73 \\
5,22 \pm 0,79 \\
4,59 \pm 0,40 \\
\end{array}$ & $\begin{array}{l}\mathrm{a} \\
\mathrm{a} \\
\mathrm{a} \\
\mathrm{a} \\
\mathrm{a}\end{array}$ \\
\hline & & $\mathbf{T} 2$ & $\begin{array}{l}\text { GiSelA } 5 \\
\text { GiSelA } 6 \\
\text { PHL-C } \\
\text { PiKu } 1 \\
\text { Weiroot } 158 \\
\end{array}$ & $\begin{array}{l}4,07 \pm 0,56 \\
4,37 \pm 0,51 \\
4,56 \pm 0,77 \\
4,62 \pm 0,55 \\
4,76 \pm 0,60\end{array}$ & $\begin{array}{l}\mathrm{a} \\
\mathrm{ab} \\
\mathrm{ab} \\
\mathrm{ab} \\
\mathrm{b}\end{array}$ & $\begin{array}{l}\text { n. a. } \\
\text { n. a. } \\
\text { n. a. } \\
\text { n. a. } \\
\text { n. a. }\end{array}$ & & $\begin{array}{l}4,01 \pm 0,56 \\
4,57 \pm 0,52 \\
3,97 \pm 0,53 \\
3,57 \pm 0,18 \\
3,85 \pm 0,44 \\
\end{array}$ & $\begin{array}{l}a b \\
b \\
b \\
a \\
a b\end{array}$ \\
\hline & & T3 & $\begin{array}{l}\text { GiSelA } 5 \\
\text { GiSelA } 6 \\
\text { PHL-C } \\
\text { PiKu } 1 \\
\text { Weiroot } 158 \\
\end{array}$ & $\begin{array}{l}6,33 \pm 0,82 \\
6,56 \pm 0,95 \\
6,92 \pm 0,81 \\
6,90 \pm 0,98 \\
6,77 \pm 0,56 \\
\end{array}$ & $\begin{array}{l}\mathrm{a} \\
\mathrm{a} \\
\mathrm{a} \\
\mathrm{a} \\
\mathrm{a}\end{array}$ & \multicolumn{2}{|l|}{$\begin{array}{l}\text { n. a. } \\
\text { n. a. } \\
\text { n. a. } \\
\text { n. a. } \\
\text { n. a. }\end{array}$} & $\begin{array}{l}3,04 \pm 0,35 \\
3,14 \pm 0,58 \\
3,40 \pm 0,39 \\
3,31 \pm 0,55 \\
3,14 \pm 0,51\end{array}$ & $\begin{array}{l}\mathrm{a} \\
\mathrm{a} \\
\mathrm{a} \\
\mathrm{a} \\
\mathrm{a}\end{array}$ \\
\hline \multirow{3}{*}{2010} & \multirow{3}{*}{ Regina } & T1 & $\begin{array}{l}\text { GiSelA } 5 \\
\text { GiSelA } 6 \\
\text { PHL-C } \\
\text { PiKu } 1 \\
\text { Weiroot } 158 \\
\end{array}$ & $\begin{array}{l}6,98 \pm 0,83 \\
6,72 \pm 1,41 \\
7,36 \pm 0,81 \\
6,82 \pm 0,77 \\
7,11 \pm 0,88 \\
\end{array}$ & $\begin{array}{l}\mathrm{a} \\
\mathrm{a} \\
\mathrm{a} \\
\mathrm{a} \\
\mathrm{a}\end{array}$ & $\begin{array}{l}\text { n. a. } \\
\text { n. a. } \\
\text { n. a. } \\
\text { n. a. } \\
\text { n. a. }\end{array}$ & & $\begin{array}{l}6,15 \pm 0,84 \\
5,05 \pm 0,61 \\
4,94 \pm 0,81 \\
5,04 \pm 0,32 \\
4,69 \pm 0,72 \\
\end{array}$ & $\begin{array}{l}\mathrm{b} \\
\mathrm{a} \\
\mathrm{a} \\
\mathrm{a} \\
\mathrm{a}\end{array}$ \\
\hline & & $\mathbf{T} 2$ & $\begin{array}{l}\text { GiSelA } 5 \\
\text { GiSelA } 6 \\
\text { PHL-C } \\
\text { PiKu } 1 \\
\text { Weiroot } 158 \\
\end{array}$ & $\begin{array}{l}7,41 \pm 0,60 \\
7,20 \pm 0,93 \\
6,90 \pm 1,12 \\
7,02 \pm 0,93 \\
7,27 \pm 0,89\end{array}$ & $\begin{array}{l}\mathrm{a} \\
\mathrm{a} \\
\mathrm{a} \\
\mathrm{a} \\
\mathrm{a}\end{array}$ & $\begin{array}{l}\text { n. a. } \\
\text { n. a. } \\
\text { n. a. } \\
\text { n. a. } \\
\text { n. a. }\end{array}$ & & $\begin{array}{l}4,90 \pm 0,40 \\
4,62 \pm 0,58 \\
4,49 \pm 0,42 \\
4,73 \pm 0,38 \\
4,54 \pm 0,42\end{array}$ & $\begin{array}{l}\mathrm{a} \\
\mathrm{a} \\
\mathrm{a} \\
\mathrm{a} \\
\mathrm{a}\end{array}$ \\
\hline & & T3 & $\begin{array}{l}\text { GiSelA } 5 \\
\text { GiSelA } 6 \\
\text { PHL-C } \\
\text { PiKu } 1 \\
\text { Weiroot } 158 \\
\end{array}$ & $\begin{array}{l}8,15 \pm 1,40 \\
7,77 \pm 1,10 \\
7,83 \pm 1,05 \\
7,76 \pm 0,72 \\
7,83 \pm 0,91 \\
\end{array}$ & $\begin{array}{l}\mathrm{a} \\
\mathrm{a} \\
\mathrm{a} \\
\mathrm{a} \\
\mathrm{a}\end{array}$ & $\begin{array}{l}\text { n. a. } \\
\text { n. a. } \\
\text { n. a. } \\
\text { n. a. } \\
\text { n. a. }\end{array}$ & & $\begin{array}{l}4,05 \pm 0,54 \\
4,07 \pm 0,37 \\
3,49 \pm 0,40 \\
3,73 \pm 0,70 \\
3,31 \pm 0,42\end{array}$ & $\begin{array}{l}\mathrm{bc} \\
\mathrm{c} \\
\mathrm{ab} \\
\mathrm{b} \\
\mathrm{a}\end{array}$ \\
\hline \multirow{3}{*}{2011} & \multirow{3}{*}{ Kordia } & T1 & $\begin{array}{l}\text { GiSelA } 5 \\
\text { GiSelA } 6 \\
\text { PHL-C } \\
\text { PiKu } 1 \\
\text { Weiroot } 158\end{array}$ & $\begin{array}{l}4,92 \pm 0,80 \\
4,91 \pm 0,68 \\
4,88 \pm 0,82 \\
4,34 \pm 0,56 \\
4,45 \pm 0,88\end{array}$ & $\begin{array}{l}\mathrm{b} \\
\mathrm{b} \\
\mathrm{b} \\
\mathrm{a} \\
\mathrm{ab}\end{array}$ & $\begin{array}{l}12,56 \pm 2,27 \\
12,68 \pm 2,07 \\
11,19 \pm 0,48 \\
12,01 \pm 2,72 \\
11,78 \pm 1,01\end{array}$ & $\begin{array}{l}\mathrm{ab} \\
\mathrm{b} \\
\mathrm{a} \\
\mathrm{ab} \\
\mathrm{ab}\end{array}$ & $\begin{array}{l}4,21 \pm 1,00 \\
4,63 \pm 0,81 \\
4,19 \pm 0,60 \\
4,49 \pm 0,71 \\
4,05 \pm 0,26\end{array}$ & $\begin{array}{l}\mathrm{a} \\
\mathrm{a} \\
\mathrm{a} \\
\mathrm{a} \\
\mathrm{a}\end{array}$ \\
\hline & & $\mathbf{T} 2$ & $\begin{array}{l}\text { GiSelA } 5 \\
\text { GiSelA } 6 \\
\text { PHL-C } \\
\text { PiKu } 1 \\
\text { Weiroot } 158 \\
\end{array}$ & $\begin{array}{l}6,02 \pm 0,72 \\
6,51 \pm 0,62 \\
6,47 \pm 0,70 \\
5,83 \pm 0,63 \\
6,39 \pm 0,47\end{array}$ & $\begin{array}{l}\mathrm{ab} \\
\mathrm{c} \\
\mathrm{c} \\
\mathrm{a} \\
\mathrm{bc}\end{array}$ & $\begin{array}{l}12,81 \pm 1,63 \\
13,14 \pm 1,51 \\
12,33 \pm 1,09 \\
10,89 \pm 1,47 \\
13,53 \pm 1,35\end{array}$ & $\begin{array}{l}\mathrm{b} \\
\mathrm{b} \\
\mathrm{b} \\
\mathrm{a} \\
\mathrm{b}\end{array}$ & $\begin{array}{l}3,34 \pm 0,27 \\
3,75 \pm 0,17 \\
3,48 \pm 0,41 \\
3,41 \pm 0,48 \\
3,50 \pm 0,32\end{array}$ & $\begin{array}{l}a \\
b \\
a b \\
a b \\
a b\end{array}$ \\
\hline & & T3 & $\begin{array}{l}\text { GiSelA } 5 \\
\text { GiSelA } 6 \\
\text { PHL-C } \\
\text { PiKu } 1 \\
\text { Weiroot } 158\end{array}$ & $\begin{array}{l}7,83 \pm 0,87 \\
7,97 \pm 0,69 \\
7,04 \pm 0,77 \\
6,66 \pm 0,81 \\
7,58 \pm 0,68\end{array}$ & $\begin{array}{l}\mathrm{b} \\
\mathrm{b} \\
\mathrm{a} \\
\mathrm{a} \\
\mathrm{b}\end{array}$ & $\begin{array}{c}10,37 \pm 1,27 \\
10,38 \pm 1,17 \\
9,75 \pm 1,03 \\
9,16 \pm 1,02 \\
10,09 \pm 1,84\end{array}$ & $\begin{array}{l}\mathrm{a} \\
\mathrm{a} \\
\mathrm{a} \\
\mathrm{a} \\
\mathrm{a}\end{array}$ & $\begin{array}{l}2,84 \pm 0,27 \\
3,05 \pm 0,31 \\
2,95 \pm 0,22 \\
2,74 \pm 0,42 \\
2,58 \pm 0,27\end{array}$ & $\begin{array}{l}\mathrm{b} \\
\mathrm{b} \\
\mathrm{b} \\
\mathrm{ab} \\
\mathrm{a}\end{array}$ \\
\hline
\end{tabular}

${ }^{1}$ a különböző betűk a szignifikánsan különböző csoportokat jelölik, MANOVA, p<0,05 (Tukey / Games-Howell) 
20. táblázat: 'Regina' és ‘Kordia' gyümölcsök térfogata, kocsány szakítószilárdsága, keménysége különböző alanyokon (2.)

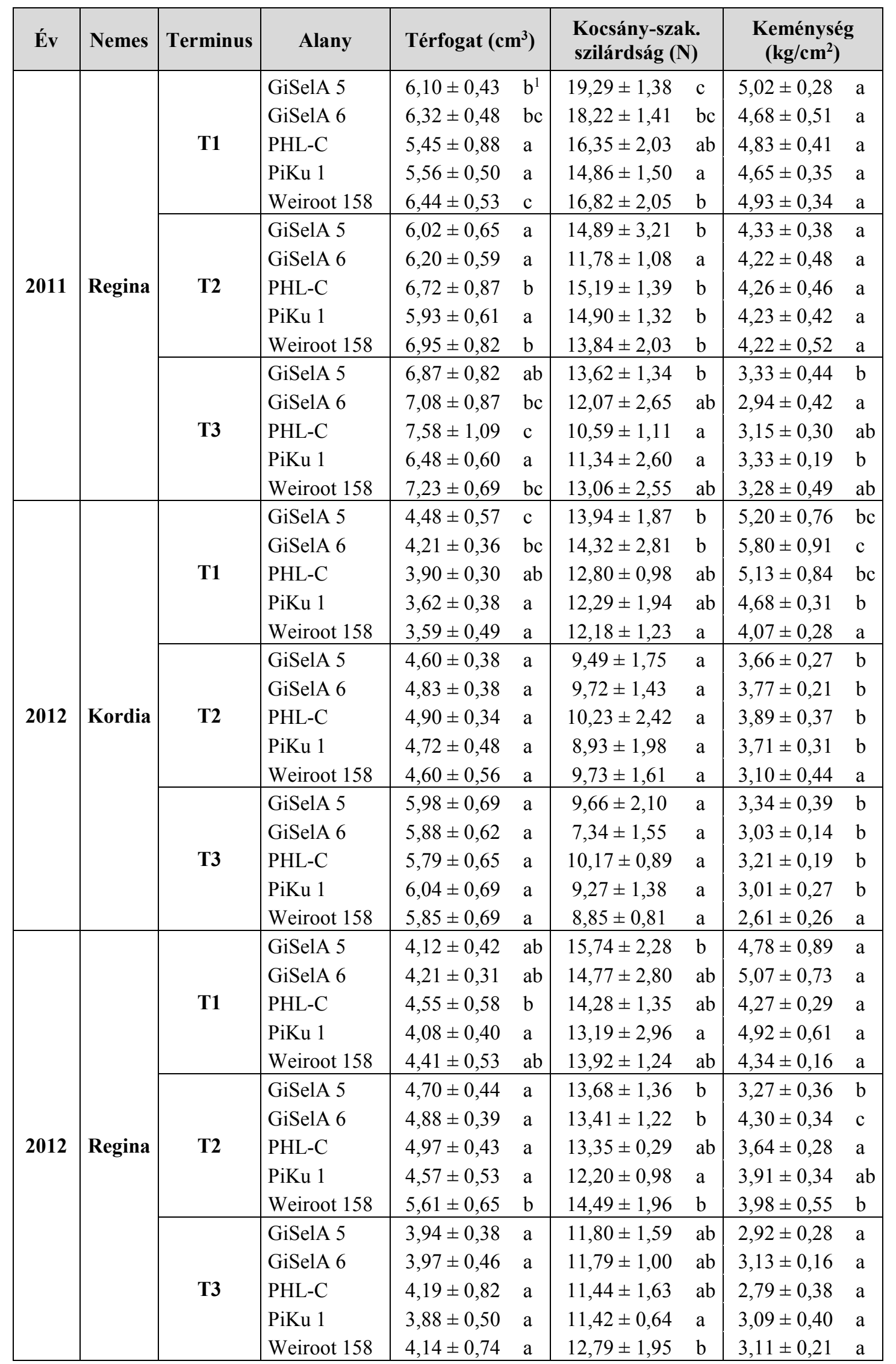

1a különböző betük a szignifikánsan különböző csoportokat jelölik, MANOVA, p<0,05 (Tukey / Games-Howell) 
20. táblázat: 'Regina' és 'Kordia' gyümölcsök térfogata, kocsány szakítószilárdsága, keménysége különböző alanyokon (3.)

\begin{tabular}{|c|c|c|c|c|c|c|c|c|c|}
\hline Év & Nemes & Terminus & Alany & \multicolumn{2}{|c|}{ Térfogat $\left(\mathrm{cm}^{3}\right)$} & \multicolumn{2}{|c|}{$\begin{array}{l}\text { Kocsány-szak. } \\
\text { szilárdság (N) }\end{array}$} & \multicolumn{2}{|c|}{$\begin{array}{c}\text { Keménység } \\
\left(\mathrm{kg} / \mathrm{cm}^{2}\right)\end{array}$} \\
\hline \multirow{15}{*}{2013} & \multirow{15}{*}{ Kordia } & \multirow{5}{*}{ T1 } & GiSelA 5 & $3,43 \pm 0,47$ & & $12,22 \pm 1,38$ & & $5,38 \pm 1,10$ & \\
\hline & & & GiSelA 6 & $3,89 \pm 0,50$ & $\mathrm{c}$ & $12,15 \pm 1,91$ & $\mathrm{a}$ & $4,78 \pm 0,57$ & $\mathrm{~b}$ \\
\hline & & & PHL-C & $3,86 \pm 0,56$ & bc & $11,67 \pm 2,02$ & $\mathrm{a}$ & $4,40 \pm 0,67$ & $a b$ \\
\hline & & & PiKu 1 & $3,31 \pm 0,44$ & $\mathrm{a}$ & $9,95 \pm 0,68$ & $\mathrm{a}$ & $4,73 \pm 0,83$ & $a b$ \\
\hline & & & Weiroot 158 & $3,83 \pm 0,36$ & bc & $11,60 \pm 1,05$ & $\mathrm{a}$ & $4,17 \pm 0,40$ & $\mathrm{a}$ \\
\hline & & \multirow{5}{*}{ T2 } & GiSelA 5 & $4,76 \pm 0,46$ & & $11,40 \pm 1,88$ & $\mathrm{c}$ & $3,71 \pm 0,27$ & $\mathrm{~b}$ \\
\hline & & & GiSelA 6 & $5,02 \pm 0,52$ & $\mathrm{~b}$ & $10,95 \pm 1,14$ & $\mathrm{bc}$ & $3,93 \pm 0,61$ & $\mathrm{~b}$ \\
\hline & & & PHL-C & $5,03 \pm 0,43$ & $\mathrm{~b}$ & $10,01 \pm 1,15$ & $\mathrm{~b}$ & $3,79 \pm 0,41$ & $\mathrm{~b}$ \\
\hline & & & PiKu 1 & $4,05 \pm 0,58$ & $\mathrm{a}$ & $9,19 \pm 1,43$ & $\mathrm{a}$ & $3,79 \pm 0,72$ & $\mathrm{~b}$ \\
\hline & & & Weiroot 158 & $4,57 \pm 0,37$ & $\mathrm{~b}$ & $9,65 \pm 0,92$ & $\mathrm{ab}$ & $3,19 \pm 0,36$ & $\mathrm{a}$ \\
\hline & & \multirow{5}{*}{ T3 } & GiSelA 5 & $5,87 \pm 1,21$ & $\mathrm{a}$ & $9,01 \pm 1,41$ & $\mathrm{ab}$ & $2,53 \pm 0,21$ & $\mathrm{a}$ \\
\hline & & & GiSelA 6 & $6,22 \pm 1,35$ & $\mathrm{a}$ & $9,81 \pm 1,80$ & $a b$ & $2,39 \pm 0,26$ & $\mathrm{a}$ \\
\hline & & & PHL-C & $6,21 \pm 1,40$ & $\mathrm{a}$ & $10,38 \pm 1,74$ & $\mathrm{ab}$ & $2,31 \pm 0,26$ & $\mathrm{a}$ \\
\hline & & & PiKu 1 & $5,37 \pm 1,15$ & $\mathrm{a}$ & $9,02 \pm 1,99$ & $\mathrm{a}$ & $2,29 \pm 0,20$ & $\mathrm{a}$ \\
\hline & & & Weiroot 158 & $5,42 \pm 1,13$ & $\mathrm{a}$ & $10,88 \pm 1,44$ & $\mathrm{~b}$ & $2,28 \pm 0,09$ & $\mathrm{a}$ \\
\hline \multirow{15}{*}{2013} & \multirow{15}{*}{ Regina } & \multirow{5}{*}{ T1 } & GiSelA 5 & $5,00 \pm 0,84$ & $\mathrm{a}$ & $18,50 \pm 4,49$ & & $4,61 \pm 0,79$ & $\mathrm{c}$ \\
\hline & & & GiSelA 6 & $5,49 \pm 0,59$ & $\mathrm{ab}$ & $18,80 \pm 3,19$ & & $5,22 \pm 0,54$ & $\mathrm{bc}$ \\
\hline & & & PHL-C & $5,83 \pm 0,67$ & $\mathrm{~b}$ & $19,21 \pm 3,85$ & & $4,09 \pm 0,38$ & $\mathrm{~b}$ \\
\hline & & & PiKu 1 & $4,83 \pm 0,53$ & $\mathrm{a}$ & $14,34 \pm 3,09$ & $\mathrm{a}$ & $4,22 \pm 0,18$ & $\mathrm{ab}$ \\
\hline & & & Weiroot 158 & $5,45 \pm 0,69$ & $\mathrm{ab}$ & $22,10 \pm 2,20$ & $\mathrm{~b}$ & $4,46 \pm 0,25$ & $\mathrm{a}$ \\
\hline & & \multirow{5}{*}{$\mathbf{T 2}$} & GiSelA 5 & $6,44 \pm 0,94$ & $\mathrm{a}$ & $13,57 \pm 1,40$ & $a b$ & $5,06 \pm 0,70$ & $\mathrm{ab}$ \\
\hline & & & GiSelA 6 & $7,42 \pm 0,48$ & $\mathrm{~b}$ & $17,75 \pm 2,78$ & $\mathrm{~b}$ & $5,09 \pm 0,72$ & $\mathrm{~b}$ \\
\hline & & & PHL-C & $7,37 \pm 0,56$ & $\mathrm{~b}$ & $15,61 \pm 3,44$ & $a b$ & $4,49 \pm 0,45$ & $\mathrm{a}$ \\
\hline & & & PiKu 1 & $6,35 \pm 0,60$ & $\mathrm{a}$ & $12,98 \pm 2,18$ & $\mathrm{a}$ & $4,41 \pm 0,32$ & $\mathrm{a}$ \\
\hline & & & Weiroot 158 & $7,67 \pm 0,67$ & $\mathrm{~b}$ & $16,75 \pm 1,02$ & $\mathrm{ab}$ & $4,13 \pm 0,58$ & $\mathrm{ab}$ \\
\hline & & \multirow{5}{*}{ T3 } & GiSelA 5 & $7,59 \pm 1,41$ & $\mathrm{ab}$ & $15,89 \pm 2,84$ & $\mathrm{a}$ & $3,77 \pm 0,53$ & $\mathrm{~b}$ \\
\hline & & & GiSelA 6 & $8,50 \pm 0,95$ & bc & $13,05 \pm 3,31$ & $\mathrm{a}$ & $4,00 \pm 0,74$ & $\mathrm{~b}$ \\
\hline & & & PHL-C & $8,74 \pm 1,06$ & $\mathrm{c}$ & $14,45 \pm 5,77$ & $\mathrm{a}$ & $3,23 \pm 0,49$ & $\mathrm{ab}$ \\
\hline & & & PiKu 1 & $6,90 \pm 0,76$ & $\mathrm{a}$ & $14,13 \pm 3,97$ & $\mathrm{a}$ & $3,00 \pm 0,34$ & $\mathrm{a}$ \\
\hline & & & Weiroot 158 & $8,56 \pm 1,04$ & bc & $17,76 \pm 2,35$ & $\mathrm{a}$ & $3,44 \pm 0,42$ & $\mathrm{~b}$ \\
\hline
\end{tabular}

${ }^{1}$ A különböző betűk a szignifikánsan különböző csoportokat jelölik. Az elemzést MANOVA módszerrel végeztük p $<0,05$ szinten, szóráshomogenitás esetén Tukey, enyhe sérülése esetén Games-Howell post hoc tesztet alkalmazva. 
21. táblázat: 'Regina' és 'Kordia' cseresznyefajta gyümölcstömege, csontártömege, hasznos gyümölcs aránya különbözö alanyokon (1.)

\begin{tabular}{|c|c|c|c|c|c|c|}
\hline Év & Nemes & Terminus & Alany & $\begin{array}{c}\text { Gyümölcstömeg } \\
\text { (g) }\end{array}$ & $\begin{array}{c}\text { Csontártömeg } \\
\text { (g) }\end{array}$ & $\begin{array}{c}\text { Hasznos gyümölcs } \\
\text { arány (\%) }\end{array}$ \\
\hline \multirow{3}{*}{2010} & \multirow{3}{*}{ Kordia } & T1 & \begin{tabular}{|l} 
GiSelA 5 \\
GiSelA 6 \\
PHL-C \\
PiKu 1 \\
Weiroot 158 \\
\end{tabular} & $\begin{array}{ll}3,78 \pm 0,05 & \mathrm{a}^{1} \\
3,84 \pm 0,07 & \mathrm{a} \\
4,40 \pm 0,07 & \mathrm{~b} \\
3,90 \pm 0,09 & \mathrm{a} \\
3,91 \pm 0,01 & \mathrm{a} \\
\end{array}$ & $\begin{array}{ll}0,41 \pm 0,02 & \text { ab } \\
0,39 \pm 0,00 & \mathrm{a} \\
0,46 \pm 0,02 & \mathrm{~b} \\
0,39 \pm 0,02 & \mathrm{a} \\
0,39 \pm 0,01 & \mathrm{a} \\
\end{array}$ & $\begin{array}{ll}89,2 \pm 0,64 & \mathrm{a} \\
90,0 \pm 0,23 & \mathrm{a} \\
89,6 \pm 0,40 & \mathrm{a} \\
89,9 \pm 0,70 & \mathrm{a} \\
90,1 \pm 0,12 & \mathrm{a} \\
\end{array}$ \\
\hline & & $\mathbf{T} 2$ & $\begin{array}{l}\text { GiSelA } 5 \\
\text { GiSelA } 6 \\
\text { PHL-C } \\
\text { PiKu } 1 \\
\text { Weiroot } 158 \\
\end{array}$ & $\begin{array}{ll}5,11 \pm 0,10 & \mathrm{a} \\
5,59 \pm 0,01 & \mathrm{~b} \\
5,60 \pm 0,00 & \mathrm{~b} \\
5,94 \pm 0,01 & \mathrm{c} \\
5,82 \pm 0,09 & \mathrm{c} \\
\end{array}$ & $\begin{array}{ll}0,40 \pm 0,02 & \mathrm{a} \\
0,42 \pm 0,00 & \mathrm{ab} \\
0,40 \pm 0,01 & \mathrm{a} \\
0,43 \pm 0,01 & \mathrm{~b} \\
0,44 \pm 0,02 & \mathrm{~b}\end{array}$ & $\begin{array}{l}92,3 \pm 0,15 \quad \mathrm{a} \\
92,5 \pm 0,03 \mathrm{ab} \\
92,9 \pm 0,14 \mathrm{~b} \\
92,7 \pm 0,19 \mathrm{ab} \\
92,4 \pm 0,46 \mathrm{ab}\end{array}$ \\
\hline & & T3 & \begin{tabular}{|l} 
GiSelA 5 \\
GiSelA 6 \\
PHL-C \\
PiKu 1 \\
Weiroot 158 \\
\end{tabular} & 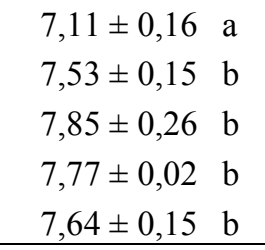 & $\begin{array}{ll}0,37 \pm 0,00 & \mathrm{a} \\
0,40 \pm 0,00 & \mathrm{~b} \\
0,37 \pm 0,00 & \mathrm{a} \\
0,37 \pm 0,00 & \mathrm{a} \\
0,35 \pm 0,01 & \mathrm{a} \\
\end{array}$ & $\begin{array}{ll}94,8 \pm 0,08 & \mathrm{a} \\
94,6 \pm 0,05 & \mathrm{a} \\
95,3 \pm 0,19 & \mathrm{~b} \\
95,2 \pm 0,04 & \mathrm{~b} \\
95,5 \pm 0,05 & \mathrm{~b} \\
\end{array}$ \\
\hline \multirow{3}{*}{2010} & \multirow{3}{*}{ Regina } & T1 & $\begin{array}{l}\text { GiSelA } 5 \\
\text { GiSelA } 6 \\
\text { PHL-C } \\
\text { PiKu } 1 \\
\text { Weiroot } 158 \\
\end{array}$ & $\begin{array}{ll}7,66 \pm 0,07 & \mathrm{a} \\
7,52 \pm 0,26 & \mathrm{a} \\
8,38 \pm 0,16 & \mathrm{~b} \\
7,73 \pm 0,10 & \mathrm{a} \\
8,11 \pm 0,01 & \mathrm{ab}\end{array}$ & $\begin{array}{ll}0,50 \pm 0,01 \quad \mathrm{a} \\
0,51 \pm 0,02 \quad \mathrm{a} \\
0,51 \pm 0,00 \quad \mathrm{~b} \\
0,50 \pm 0,00 \quad \mathrm{a} \\
0,51 \pm 0,00 \quad \mathrm{ab}\end{array}$ & $\begin{array}{ll}93,5 \pm 0,16 & b \\
93,3 \pm 0,03 & a \\
93,9 \pm 0,08 & d \\
93,6 \pm 0,11 & b c \\
93,7 \pm 0,01 & c d\end{array}$ \\
\hline & & $\mathbf{T} 2$ & $\begin{array}{l}\text { GiSelA } 5 \\
\text { GiSelA } 6 \\
\text { PHL-C } \\
\text { PiKu } 1 \\
\text { Weiroot } 158 \\
\end{array}$ & $\begin{array}{l}8,92 \pm 0,04 \quad b \\
8,69 \pm 0,21 \quad b \\
8,37 \pm 0,08 \quad a \\
8,44 \pm 0,01 \quad a \\
8,81 \pm 0,02 \quad b \\
\end{array}$ & $\begin{array}{ll}0,60 \pm 0,01 & \mathrm{a} \\
0,62 \pm 0,01 & \mathrm{a} \\
0,59 \pm 0,02 & \mathrm{a} \\
0,60 \pm 0,00 & \mathrm{a} \\
0,61 \pm 0,02 & \mathrm{a} \\
\end{array}$ & $\begin{array}{ll}93,2 \pm 0,12 & \mathrm{a} \\
92,9 \pm 0,07 & \mathrm{~b} \\
92,9 \pm 0,20 & \mathrm{ab} \\
92,9 \pm 0,06 & \mathrm{ab} \\
93,1 \pm 0,26 & \mathrm{ab} \\
\end{array}$ \\
\hline & & $\mathbf{T 3}$ & \begin{tabular}{|l} 
GiSelA 5 \\
GiSelA 6 \\
PHL-C \\
PiKu 1 \\
Weiroot 158 \\
\end{tabular} & $\begin{array}{ll}9,98 \pm 0,27 & \mathrm{~b} \\
9,59 \pm 0,08 & \mathrm{a} \\
9,53 \pm 0,14 & \mathrm{a} \\
9,59 \pm 0,03 & \mathrm{a} \\
9,68 \pm 0,15 & \mathrm{ab}\end{array}$ & $\begin{array}{ll}0,64 \pm 0,01 & \mathrm{~b} \\
0,60 \pm 0,00 & \mathrm{a} \\
0,63 \pm 0,02 & \mathrm{ab} \\
0,64 \pm 0,02 & \mathrm{~b} \\
0,62 \pm 0,02 & \mathrm{ab}\end{array}$ & $\begin{array}{ll}93,6 \pm 0,08 & \mathrm{ab} \\
93,7 \pm 0,06 & \mathrm{~b} \\
93,4 \pm 0,10 & \mathrm{ab} \\
93,3 \pm 0,17 & \mathrm{a} \\
93,6 \pm 0,35 & \mathrm{ab}\end{array}$ \\
\hline \multirow{3}{*}{2011} & \multirow{3}{*}{ Kordia } & T1 & \begin{tabular}{|l} 
GiSelA 5 \\
GiSelA 6 \\
PHL-C \\
PiKu 1 \\
Weiroot 158 \\
\end{tabular} & 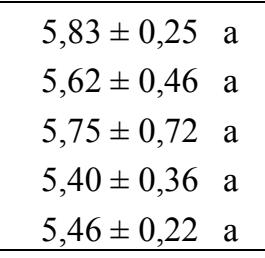 & $\begin{array}{lc}0,43 \pm 0,04 & \mathrm{a} \\
0,43 \pm 0,02 & \mathrm{a} \\
0,41 \pm 0,04 & \mathrm{a} \\
0,45 \pm 0,04 & \mathrm{a} \\
0,40 \pm 0,01 & \mathrm{a} \\
\end{array}$ & $\begin{array}{ll}92,6 \pm 0,94 & \mathrm{ab} \\
92,2 \pm 0,49 & \mathrm{ab} \\
92,9 \pm 0,30 & \mathrm{~b} \\
91,6 \pm 0,31 & \mathrm{a} \\
92,7 \pm 0,04 & \mathrm{~b} \\
\end{array}$ \\
\hline & & $\mathbf{T 2}$ & \begin{tabular}{|l} 
GiSelA 5 \\
GiSelA 6 \\
PHL-C \\
PiKu 1 \\
Weiroot 158 \\
\end{tabular} & $\begin{array}{ll}7,48 \pm 0,29 & \mathrm{ab} \\
8,10 \pm 0,35 & \mathrm{c} \\
7,95 \pm 0,07 & \mathrm{bc} \\
7,24 \pm 0,23 & \mathrm{a} \\
8,04 \pm 0,24 & \mathrm{bc}\end{array}$ & $\begin{array}{ll}0,42 \pm 0,01 & \mathrm{~b} \\
0,43 \pm 0,01 & \mathrm{~b} \\
0,41 \pm 0,03 & \mathrm{ab} \\
0,38 \pm 0,01 & \mathrm{a} \\
0,42 \pm 0,01 & \mathrm{~b} \\
\end{array}$ & $\begin{array}{ll}94,4 \pm 0,25 & \mathrm{a} \\
94,6 \pm 0,35 & \mathrm{a} \\
94,9 \pm 0,37 & \mathrm{a} \\
94,8 \pm 0,11 & \mathrm{a} \\
94,8 \pm 0,22 & \mathrm{a} \\
\end{array}$ \\
\hline & & T3 & \begin{tabular}{|l} 
GiSelA 5 \\
GiSelA 6 \\
PHL-C \\
PiKu 1 \\
Weiroot 158 \\
\end{tabular} & $\begin{array}{ll}9,21 \pm 0,39 & \mathrm{bc} \\
9,35 \pm 0,46 & \mathrm{c} \\
8,33 \pm 0,45 & \mathrm{ab} \\
8,06 \pm 0,54 & \mathrm{a} \\
9,13 \pm 0,05 & \mathrm{bc}\end{array}$ & $\begin{array}{ll}0,43 \pm 0,02 & \mathrm{bc} \\
0,44 \pm 0,02 & \mathrm{c} \\
0,39 \pm 0,02 & \mathrm{ab} \\
0,39 \pm 0,02 & \mathrm{a} \\
0,41 \pm 0,01 & \mathrm{abc}\end{array}$ & $\begin{array}{ll}95,3 \pm 0,24 & \mathrm{a} \\
95,2 \pm 0,14 & \mathrm{a} \\
95,3 \pm 0,11 & \mathrm{a} \\
95,2 \pm 0,23 & \mathrm{a} \\
95,5 \pm 0,08 & \mathrm{a}\end{array}$ \\
\hline
\end{tabular}

${ }^{1}$ a különböző betűk a szignifikánsan különböző csoportokat jelölik, MANOVA, p<0,05 (Tukey / Games-Howell) 
21. táblázat: 'Regina' és 'Kordia' cseresznyefajta gyümölcstömege, csontártömege, hasznos gyümölcs aránya különböző alanyokon (2.)

\begin{tabular}{|c|c|c|c|c|c|c|}
\hline Év & Nemes & Terminus & Alany & $\begin{array}{c}\text { Gyümölcstömeg } \\
\text { (g) }\end{array}$ & $\begin{array}{c}\text { Csontártömeg } \\
\text { (g) }\end{array}$ & $\begin{array}{c}\text { Hasznos gyümölcs } \\
\text { arány }(\%)\end{array}$ \\
\hline \multirow{3}{*}{2011} & \multirow{3}{*}{ Regina } & T1 & \begin{tabular}{|l} 
GiSelA 5 \\
GiSelA 6 \\
PHL-C \\
PiKu 1 \\
Weiroot 158 \\
\end{tabular} & $\begin{array}{ll}6,94 \pm 0,17 & \mathrm{ab}^{1} \\
7,33 \pm 0,30 & \mathrm{~b} \\
6,23 \pm 0,70 & \mathrm{a} \\
6,33 \pm 0,19 & \mathrm{a} \\
7,42 \pm 0,38 & \mathrm{~b} \\
\end{array}$ & $\begin{array}{ll}0,53 \pm 0,01 & \mathrm{a} \\
0,51 \pm 0,03 & \mathrm{a} \\
0,50 \pm 0,02 & \mathrm{a} \\
0,50 \pm 0,01 & \mathrm{a} \\
0,54 \pm 0,02 & \mathrm{a} \\
\end{array}$ & $\begin{array}{ll}92,4 \pm 0,37 & \mathrm{ab} \\
93,0 \pm 0,38 \quad \mathrm{~b} \\
92,0 \pm 0,66 \mathrm{a} \\
92,1 \pm 0,45 \mathrm{ab} \\
92,7 \pm 0,44 \mathrm{ab} \\
\end{array}$ \\
\hline & & $\mathbf{T 2}$ & $\begin{array}{l}\text { GiSelA } 5 \\
\text { GiSelA } 6 \\
\text { PHL-C } \\
\text { PiKu } 1 \\
\text { Weiroot } 158 \\
\end{array}$ & $\begin{array}{ll}7,56 \pm 0,22 & \mathrm{a} \\
7,98 \pm 0,34 & \mathrm{ab} \\
8,58 \pm 0,36 & \mathrm{bc} \\
7,73 \pm 0,61 & \mathrm{a} \\
8,91 \pm 0,15 & \mathrm{c} \\
\end{array}$ & $\begin{array}{l}0,53 \pm 0,04 \quad \mathrm{a} \\
0,51 \pm 0,03 \quad \mathrm{a} \\
0,53 \pm 0,03 \quad \mathrm{a} \\
0,48 \pm 0,04 \quad \mathrm{a} \\
0,54 \pm 0,04 \quad \mathrm{a}\end{array}$ & $\begin{array}{ll}92,9 \pm 0,46 & \mathrm{a} \\
93,6 \pm 0,21 & \mathrm{ab} \\
93,8 \pm 0,39 & \mathrm{~b} \\
93,8 \pm 0,11 & \mathrm{~b} \\
93,9 \pm 0,48 & \mathrm{~b} \\
\end{array}$ \\
\hline & & $\mathbf{T 3}$ & \begin{tabular}{|l} 
GiSelA 5 \\
GiSelA 6 \\
PHL-C \\
PiKu 1 \\
Weiroot 158 \\
\end{tabular} & $\begin{array}{rl}8,89 \pm 0,12 & \mathrm{ab} \\
9,50 \pm 0,14 & \mathrm{bc} \\
10,03 \pm 0,65 & \mathrm{c} \\
8,50 \pm 0,18 & \mathrm{a} \\
9,52 \pm 0,28 & \mathrm{bc}\end{array}$ & $\begin{array}{ll}0,51 \pm 0,01 & \mathrm{a} \\
0,51 \pm 0,02 & \mathrm{a} \\
0,53 \pm 0,02 & \mathrm{a} \\
0,50 \pm 0,02 & \mathrm{a} \\
0,53 \pm 0,02 & \mathrm{a} \\
\end{array}$ & $\begin{array}{ll}94,3 \pm 0,09 & \mathrm{ab} \\
94,6 \pm 0,31 & \mathrm{bc} \\
94,7 \pm 0,21 & \mathrm{c} \\
94,1 \pm 0,15 & \mathrm{a} \\
94,4 \pm 0,11 & \mathrm{abc} \\
\end{array}$ \\
\hline \multirow{3}{*}{2012} & \multirow{3}{*}{ Kordia } & T1 & $\begin{array}{l}\text { GiSelA } 5 \\
\text { GiSelA } 6 \\
\text { PHL-C } \\
\text { PiKu } 1 \\
\text { Weiroot } 158 \\
\end{array}$ & $\begin{array}{ll}5,07 \pm 0,03 & \mathrm{~d} \\
4,78 \pm 0,03 & \mathrm{c} \\
4,35 \pm 0,00 & \mathrm{~b} \\
4,05 \pm 0,02 & \mathrm{a} \\
4,07 \pm 0,03 & \mathrm{a} \\
\end{array}$ & $\begin{array}{ll}0,43 \pm 0,01 & \mathrm{~b} \\
0,41 \pm 0,01 & \mathrm{~b} \\
0,38 \pm 0,00 & \mathrm{a} \\
0,36 \pm 0,02 & \mathrm{a} \\
0,37 \pm 0,00 & \mathrm{a}\end{array}$ & $\begin{array}{ll}91,6 \pm 0,12 & \mathrm{c} \\
91,4 \pm 0,15 & \mathrm{bc} \\
91,3 \pm 0,04 & \mathrm{abc} \\
91,1 \pm 0,37 & \mathrm{ab} \\
90,9 \pm 0,06 & \mathrm{a}\end{array}$ \\
\hline & & $\mathbf{T 2}$ & \begin{tabular}{|l} 
GiSelA 5 \\
GiSelA 6 \\
PHL-C \\
PiKu 1 \\
Weiroot 158 \\
\end{tabular} & $\begin{array}{l}5,53 \pm 0,02 \quad \mathrm{a} \\
5,82 \pm 0,11 \quad \mathrm{~b} \\
5,61 \pm 0,16 \quad \mathrm{ab} \\
5,52 \pm 0,02 \quad \mathrm{a} \\
5,54 \pm 0,13 \quad \mathrm{ab} \\
\end{array}$ & $\begin{array}{ll}0,37 \pm 0,00 & \mathrm{bc} \\
0,38 \pm 0,01 & \mathrm{c} \\
0,36 \pm 0,00 & \mathrm{ab} \\
0,35 \pm 0,01 & \mathrm{a} \\
0,37 \pm 0,01 & \mathrm{bc} \\
\end{array}$ & $\begin{array}{ll}93,3 \pm 0,01 & \mathrm{a} \\
93,5 \pm 0,03 & \mathrm{ab} \\
93,5 \pm 0,20 & \mathrm{~b} \\
93,6 \pm 0,16 & \mathrm{~b} \\
93,3 \pm 0,03 & \mathrm{a} \\
\end{array}$ \\
\hline & & T3 & \begin{tabular}{|l} 
GiSelA 5 \\
GiSelA 6 \\
PHL-C \\
PiKu 1 \\
Weiroot 158 \\
\end{tabular} & $\begin{array}{ll}7,25 \pm 0,08 & \mathrm{a} \\
7,24 \pm 0,18 & \mathrm{a} \\
6,99 \pm 0,05 & \mathrm{a} \\
7,24 \pm 0,21 & \mathrm{a} \\
7,22 \pm 0,06 & \mathrm{a}\end{array}$ & $\begin{array}{ll}0,37 \pm 0,00 & \mathrm{c} \\
0,36 \pm 0,01 & \mathrm{abc} \\
0,35 \pm 0,01 & \mathrm{ab} \\
0,35 \pm 0,01 & \mathrm{a} \\
0,36 \pm 0,00 & \mathrm{bc}\end{array}$ & $\begin{array}{l}94,9 \pm 0,02 \quad \mathrm{a} \\
95,1 \pm 0,06 \quad \mathrm{ab} \\
95,0 \pm 0,10 \quad \mathrm{a} \\
95,2 \pm 0,21 \quad \mathrm{~b} \\
95,0 \pm 0,02 \mathrm{ab}\end{array}$ \\
\hline \multirow{3}{*}{2012} & \multirow{3}{*}{ Regina } & T1 & \begin{tabular}{|l} 
GiSelA 5 \\
GiSelA 6 \\
PHL-C \\
PiKu 1 \\
Weiroot 158 \\
\end{tabular} & $\begin{array}{ll}5,08 \pm 0,07 & \mathrm{ab} \\
5,11 \pm 0,15 & \mathrm{ab} \\
5,54 \pm 0,17 & \mathrm{bc} \\
4,89 \pm 0,03 & \mathrm{a} \\
6,01 \pm 0,47 & \mathrm{c} \\
\end{array}$ & $\begin{array}{ll}0,47 \pm 0,01 & \mathrm{~b} \\
0,46 \pm 0,01 & \mathrm{ab} \\
0,46 \pm 0,01 & \mathrm{~b} \\
0,44 \pm 0,01 & \mathrm{a} \\
0,45 \pm 0,04 & \mathrm{ab} \\
\end{array}$ & $\begin{array}{ll}90,7 \pm 0,10 & \mathrm{a} \\
91,0 \pm 0,04 & \mathrm{~b} \\
91,7 \pm 0,09 & \mathrm{c} \\
91,0 \pm 0,10 & \mathrm{~b} \\
92,5 \pm 0,27 & \mathrm{~d} \\
\end{array}$ \\
\hline & & T2 & \begin{tabular}{|l} 
GiSelA 5 \\
GiSelA 6 \\
PHL-C \\
PiKu 1 \\
Weiroot 158 \\
\end{tabular} & $\begin{array}{ll}5,83 \pm 0,06 & \mathrm{a} \\
6,18 \pm 0,07 & \mathrm{~b} \\
6,15 \pm 0,12 & \mathrm{~b} \\
5,69 \pm 0,01 & \mathrm{a} \\
7,00 \pm 0,19 & \mathrm{c}\end{array}$ & $\begin{array}{ll}0,46 \pm 0,04 & \mathrm{ab} \\
0,47 \pm 0,02 & \mathrm{bc} \\
0,44 \pm 0,00 & \mathrm{ab} \\
0,40 \pm 0,01 & \mathrm{a} \\
0,52 \pm 0,04 & \mathrm{c} \\
\end{array}$ & $\begin{array}{ll}92,2 \pm 0,77 & \mathrm{a} \\
92,3 \pm 0,16 & \mathrm{a} \\
92,9 \pm 0,11 & \mathrm{a} \\
92,9 \pm 0,15 & \mathrm{a} \\
92,6 \pm 0,34 & \mathrm{a} \\
\end{array}$ \\
\hline & & T3 & \begin{tabular}{|l} 
GiSelA 5 \\
GiSelA 6 \\
PHL-C \\
PiKu 1 \\
Weiroot 158 \\
\end{tabular} & $\begin{array}{ll}6,16 \pm 0,23 & \text { ab } \\
6,26 \pm 0,07 & \text { ab } \\
6,65 \pm 0,10 & \mathrm{c} \\
6,11 \pm 0,22 & \mathrm{a} \\
6,50 \pm 0,07 & \mathrm{bc}\end{array}$ & $\begin{array}{ll}0,46 \pm 0,00 & \mathrm{a} \\
0,44 \pm 0,01 & \mathrm{a} \\
0,45 \pm 0,00 & \mathrm{a} \\
0,45 \pm 0,02 & \mathrm{a} \\
0,47 \pm 0,03 & \mathrm{a}\end{array}$ & $\begin{array}{l}92,6 \pm 0,28 \quad \mathrm{a} \\
93,0 \pm 0,03 \quad \mathrm{a} \\
93,2 \pm 0,13 \mathrm{a} \\
92,7 \pm 0,50 \quad \mathrm{a} \\
92,8 \pm 0,42 \quad \mathrm{a}\end{array}$ \\
\hline
\end{tabular}

${ }^{1}$ a különböző betük a szignifikánsan különböző csoportokat jelölik, MANOVA, p $<0,05$ (Tukey / Games-Howell) 
21. táblázat: 'Regina' és 'Kordia' cseresznyefajta gyümölcstömege, csontártömege, hasznos gyümölcs aránya különbözö alanyokon (3.)

\begin{tabular}{|c|c|c|c|c|c|c|}
\hline Év & Nemes & Terminus & Alany & $\begin{array}{c}\text { Gyümölcstömeg } \\
\text { (g) }\end{array}$ & $\begin{array}{c}\text { Csontártömeg } \\
\text { (g) }\end{array}$ & $\begin{array}{c}\text { Hasznos gyümölcs } \\
\text { arány }(\%)\end{array}$ \\
\hline \multirow{15}{*}{2013} & \multirow{15}{*}{ Kordia } & \multirow{5}{*}{ T1 } & GiSelA 5 & $4,14 \pm 0,09 \quad \mathrm{a}^{1}$ & $0,40 \pm 0,00 \quad \mathrm{a}$ & $90,4 \pm 0,15 \quad b$ \\
\hline & & & GiSelA 6 & $4,72 \pm 0,00 \quad b$ & $0,43 \pm 0,01 \quad b$ & $90,9 \pm 0,20 \quad b$ \\
\hline & & & PHL-C & $4,55 \pm 0,30 \quad b$ & $0,40 \pm 0,00 \quad \mathrm{a}$ & $91,1 \pm 0,54 \quad b$ \\
\hline & & & $\mathrm{PiKu} 1$ & $3,92 \pm 0,04 \quad \mathrm{a}$ & $0,43 \pm 0,02 \quad b$ & $89,1 \pm 0,58$ a \\
\hline & & & Weiroot 158 & $4,50 \pm 0,03 \quad \mathrm{~b}$ & $0,42 \pm 0,01 \quad \mathrm{ab}$ & $90,8 \pm 0,20 \quad \mathrm{~b}$ \\
\hline & & \multirow{5}{*}{$\mathbf{T 2}$} & GiSelA 5 & $5,59 \pm 0,03 \quad b$ & $0,42 \pm 0,00 \quad a b$ & $92,5 \pm 0,08$ bc \\
\hline & & & GiSelA 6 & $6,07 \pm 0,12 \quad \mathrm{c}$ & $0,43 \pm 0,00 \quad b$ & $92,9 \pm 0,14 \quad \mathrm{c}$ \\
\hline & & & PHL-C & $6,18 \pm 0,15 \mathrm{c}$ & $0,44 \pm 0,01 \quad b$ & $92,9 \pm 0,35 \mathrm{c}$ \\
\hline & & & $\mathrm{PiKu} 1$ & $4,88 \pm 0,07 \quad \mathrm{a}$ & $0,40 \pm 0,02 \quad \mathrm{a}$ & $91,9 \pm 0,34 \quad \mathrm{a}$ \\
\hline & & & Weiroot 158 & $5,57 \pm 0,00 \quad b$ & $0,43 \pm 0,01 \quad b$ & $92,3 \pm 0,11 \mathrm{ab}$ \\
\hline & & \multirow{5}{*}{ T3 } & GiSelA 5 & $6,56 \pm 0,18 \mathrm{ab}$ & $0,40 \pm 0,01 \quad \mathrm{a}$ & $93,9 \pm 0,33$ a \\
\hline & & & GiSelA 6 & $7,08 \pm 0,48 \quad b$ & $0,39 \pm 0,02 \quad \mathrm{a}$ & $94,4 \pm 0,20 \quad b$ \\
\hline & & & PHL-C & $6,97 \pm 0,39 \quad b$ & $0,39 \pm 0,01 \quad \mathrm{a}$ & $94,4 \pm 0,20 \quad b$ \\
\hline & & & $\mathrm{PiKu} 1$ & $6,15 \pm 0,29 \quad \mathrm{a}$ & $0,37 \pm 0,02 \quad \mathrm{a}$ & $94,0 \pm 0,35 \mathrm{ab}$ \\
\hline & & & Weiroot 158 & $6,12 \pm 0,22 \quad \mathrm{a}$ & $0,38 \pm 0,01 \quad \mathrm{a}$ & $93,7 \pm 0,30 \quad \mathrm{a}$ \\
\hline \multirow{15}{*}{2013} & \multirow{15}{*}{ Regina } & \multirow{5}{*}{ T1 } & GiSelA 5 & $6,20 \pm 0,44 \mathrm{ab}$ & $0,58 \pm 0,04 \quad b$ & $90,7 \pm 0,19$ a \\
\hline & & & GiSelA 6 & $6,78 \pm 0,08 \mathrm{~cd}$ & $0,59 \pm 0,02 \quad b$ & $91,3 \pm 0,18 \quad b$ \\
\hline & & & PHL-C & $7,15 \pm 0,01 \quad \mathrm{~d}$ & $0,56 \pm 0,02 \mathrm{ab}$ & $92,1 \pm 0,26 \mathrm{c}$ \\
\hline & & & $\mathrm{PiKu} 1$ & $5,94 \pm 0,07 \quad \mathrm{a}$ & $0,51 \pm 0,02 \quad \mathrm{a}$ & $91,4 \pm 0,23 \quad b$ \\
\hline & & & Weiroot 158 & $6,64 \pm 0,06 \quad b c$ & $0,58 \pm 0,03 \quad b$ & $91,3 \pm 0,45 \mathrm{~b}$ \\
\hline & & \multirow{5}{*}{$\mathbf{T} 2$} & GiSelA 5 & $7,84 \pm 0,06 \quad \mathrm{a}$ & $0,60 \pm 0,01 \quad \mathrm{c}$ & $92,3 \pm 0,06$ a \\
\hline & & & GiSelA 6 & $9,04 \pm 0,02 \quad b$ & $0,62 \pm 0,00 \quad \mathrm{c}$ & $93,2 \pm 0,03 \quad b$ \\
\hline & & & PHL-C & $9,10 \pm 0,00 \quad b$ & $0,56 \pm 0,02 \quad b$ & $93,8 \pm 0,17 \quad d$ \\
\hline & & & PiKu 1 & $7,87 \pm 0,04 \quad \mathrm{a}$ & $0,52 \pm 0,00 \quad \mathrm{a}$ & $93,4 \pm 0,00 \quad \mathrm{c}$ \\
\hline & & & Weiroot 158 & $9,46 \pm 0,04 \quad \mathrm{c}$ & $0,62 \pm 0,01 \quad \mathrm{c}$ & $93,5 \pm 0,06 \mathrm{c}$ \\
\hline & & \multirow{5}{*}{$\mathbf{T 3}$} & GiSelA 5 & $9,07 \pm 0,01 \quad b$ & $0,60 \pm 0,00 \mathrm{c}$ & $93,4 \pm 0,02$ a \\
\hline & & & GiSelA 6 & $10,16 \pm 0,16 \mathrm{c}$ & $0,57 \pm 0,00 \quad b$ & $94,4 \pm 0,07 \mathrm{c}$ \\
\hline & & & PHL-C & $10,62 \pm 0,23 \mathrm{~d}$ & $0,53 \pm 0,01 \quad \mathrm{a}$ & $95,0 \pm 0,04 \mathrm{~d}$ \\
\hline & & & $\mathrm{PiKu} 1$ & $8,68 \pm 0,11 \quad \mathrm{a}$ & $0,56 \pm 0,01 \quad b$ & $93,5 \pm 0,07 \quad b$ \\
\hline & & & Weiroot 158 & $10,49 \pm 0,11 \mathrm{~cd}$ & $0,60 \pm 0,01 \quad \mathrm{c}$ & $94,3 \pm 0,02 \mathrm{c}$ \\
\hline
\end{tabular}

${ }^{1}$ A különböző betük a szignifikánsan különböző csoportokat jelölik. Az elemzést MANOVA módszerrel végeztük p<0,05 szinten, szóráshomogenitás esetén Tukey, enyhe sérülése esetén Games-Howell post hoc tesztet alkalmazva. 
22. táblázat: 'Regina' és ‘Kordia' cseresznyefajta gyümölcseinek héjszín-paraméterei különböző alanyokon (1.)

\begin{tabular}{|c|c|c|c|c|c|c|c|}
\hline Év & Nemes & Terminus & Alany & $\mathbf{L}^{*}$ & $a^{*}$ & $\mathbf{b}^{*}$ & \\
\hline \multirow{15}{*}{2010} & \multirow{15}{*}{ Kordia } & \multirow{5}{*}{ T1 } & GiSelA 5 & $48,45 \pm 0,89 \mathrm{c}^{1}$ & $34,77 \pm 1,88 \mathrm{ab}$ & $24,23 \pm 1,71$ & $\mathrm{c}$ \\
\hline & & & GiSelA 6 & $48,15 \pm 1,05 b$ & $35,89 \pm 4,35 \mathrm{ab}$ & $23,03 \pm 1,05$ & \\
\hline & & & PHL-C & $45,86 \pm 0,85 a$ & $34,50 \pm 2,70 \quad \mathrm{a}$ & $21,23 \pm 1,03$ & $\mathrm{a}$ \\
\hline & & & PiKu 1 & $46,98 \pm 2,12 \mathrm{ab}$ & $36,46 \pm 1,27 \mathrm{ab}$ & $22,71 \pm 1,36$ & $\mathrm{~b}$ \\
\hline & & & Weiroot 158 & $45,79 \pm 1,47 \mathrm{a}$ & $37,24 \pm 2,24 \quad b$ & $21,21 \pm 1,06$ & $\mathrm{a}$ \\
\hline & & \multirow{5}{*}{$\mathbf{T 2}$} & GiSelA 5 & $37,50 \pm 0,73$ a & $34,54 \pm 2,93$ a & $15,31 \pm 1,12$ & $\mathrm{a}$ \\
\hline & & & GiSelA 6 & $39,55 \pm 1,92 \mathrm{c}$ & $36,51 \pm 1,91 \quad a$ & $17,26 \pm 0,75$ & $\mathrm{c}$ \\
\hline & & & PHL-C & $39,04 \pm 0,89$ & $35,28 \pm 1,25$ a & $16,13 \pm 1,85$ & $a b$ \\
\hline & & & PiKu 1 & $38,27 \pm 0,94 \mathrm{ab}$ & $35,15 \pm 3,00$ a & $16,43 \pm 0,72$ & bc \\
\hline & & & Weiroot 158 & $38,50 \pm 0,73 \mathrm{ab}$ & $34,71 \pm 3,29 \quad \mathrm{a}$ & $15,62 \pm 0,76$ & $\mathrm{ab}$ \\
\hline & & \multirow{5}{*}{ T3 } & GiSelA 5 & $29,26 \pm 0,57 \mathrm{ab}$ & $21,64 \pm 0,89 \quad b$ & $6,11 \pm 0,48$ & $\mathrm{c}$ \\
\hline & & & GiSelA 6 & $29,73 \pm 0,95 b$ & $21,71 \pm 2,24 \quad b$ & $6,45 \pm 0,29$ & \\
\hline & & & PHL-C & $31,22 \pm 0,67 \quad \mathrm{c}$ & $21,66 \pm 1,24 b$ & $6,69 \pm 0,54$ & \\
\hline & & & PiKu 1 & $28,78 \pm 0,58$ a & $19,36 \pm 1,22$ a & $5,08 \pm 0,30$ & $\mathrm{a}$ \\
\hline & & & Weiroot 158 & $29,22 \pm 0,60 \mathrm{ab}$ & $19,64 \pm 0,82$ a & $5,57 \pm 0,22$ & $\mathrm{~b}$ \\
\hline \multirow{15}{*}{2010} & \multirow{15}{*}{ Regina } & \multirow{5}{*}{ T1 } & GiSelA 5 & $49,33 \pm 1,50 \quad a$ & $43,29 \pm 2,20 \quad \mathrm{a}$ & $28,61 \pm 1,42$ & \\
\hline & & & GiSelA 6 & $52,87 \pm 1,33 \mathrm{c}$ & $41,08 \pm 2,94 \quad \mathrm{a}$ & $30,21 \pm 3,64$ & $\mathrm{a}$ \\
\hline & & & PHL-C & $52,36 \pm 1,48$ bc & $42,87 \pm 5,47 \quad a$ & $28,06 \pm 1,78$ & $\mathrm{a}$ \\
\hline & & & PiKu 1 & $51,28 \pm 0,93 \mathrm{~b}$ & $42,93 \pm 2,36$ a & $29,79 \pm 2,91$ & $\mathrm{a}$ \\
\hline & & & Weiroot 158 & $54,83 \pm 1,53 \mathrm{~d}$ & $41,81 \pm 3,88$ a & $30,26 \pm 3,30$ & $\mathrm{a}$ \\
\hline & & \multirow{5}{*}{$\mathbf{T 2}$} & GiSelA 5 & $37,56 \pm 1,67 \mathrm{ab}$ & $38,98 \pm 3,88 \mathrm{ab}$ & $17,86 \pm 0,85$ & \\
\hline & & & GiSelA 6 & $40,36 \pm 0,74 d$ & $41,99 \pm 3,53 b$ & $21,09 \pm 1,69$ & $\mathrm{~d}$ \\
\hline & & & PHL-C & $38,29 \pm 0,97 \quad b c$ & $38,67 \pm 1,68 \mathrm{ab}$ & $16,92 \pm 0,81$ & \\
\hline & & & $\mathrm{PiKu} 1$ & $37,13 \pm 0,87 \quad \mathrm{a}$ & $37,88 \pm 3,58$ a & $16,39 \pm 1,10$ & $\mathrm{a}$ \\
\hline & & & Weiroot 158 & $38,90 \pm 0,73 \mathrm{c}$ & $41,04 \pm 4,28 \quad a b$ & $19,11 \pm 0,81$ & $\mathrm{c}$ \\
\hline & & \multirow{5}{*}{ T3 } & GiSelA 5 & $32,49 \pm 0,77 b$ & $29,41 \pm 1,46 \mathrm{c}$ & $9,23 \pm 0,52$ & $\mathrm{c}$ \\
\hline & & & GiSelA 6 & $31,77 \pm 0,99 \mathrm{ab}$ & $28,84 \pm 2,52 \mathrm{c}$ & $8,97 \pm 0,62$ & $\mathrm{c}$ \\
\hline & & & PHL-C & $32,00 \pm 0,81 b$ & $26,92 \pm 1,44 \quad b$ & $8,13 \pm 0,66$ & \\
\hline & & & PiKu 1 & $30,99 \pm 0,99 \quad \mathrm{a}$ & $24,11 \pm 1,38 \quad \mathrm{a}$ & $6,62 \pm 0,47$ & $\mathrm{a}$ \\
\hline & & & Weiroot 158 & $32,07 \pm 0,85 \quad b$ & $29,77 \pm 1,27 \quad \mathrm{c}$ & $9,35 \pm 0,40$ & $\mathrm{c}$ \\
\hline \multirow{15}{*}{2011} & \multirow{15}{*}{ Kordia } & \multirow{5}{*}{ T1 } & GiSelA 5 & $46,58 \pm 0,98 b$ & $37,63 \pm 2,65$ a & $25,74 \pm 2,36$ & \\
\hline & & & GiSelA 6 & $46,73 \pm 1,05 b$ & $37,93 \pm 2,79 a$ & $24,97 \pm 1,33$ & $\mathrm{a}$ \\
\hline & & & PHL-C & $48,30 \pm 1,20 \mathrm{c}$ & $36,44 \pm 1,51 \quad a$ & $27,02 \pm 2,46$ & $b$ \\
\hline & & & $\mathrm{PiKu} 1$ & $45,32 \pm 1,47 \quad \mathrm{a}$ & $37,75 \pm 3,27 \quad \mathrm{a}$ & $25,60 \pm 1,55$ & $\mathrm{a}$ \\
\hline & & & Weiroot 158 & $46,44 \pm 1,95 \quad b$ & $37,04 \pm 3,37 \quad \mathrm{a}$ & $24,50 \pm 1,04$ & $\mathrm{a}$ \\
\hline & & \multirow{5}{*}{$\mathbf{T 2}$} & GiSelA 5 & $36,43 \pm 1,13 \mathrm{c}$ & $35,29 \pm 3,38 \mathrm{c}$ & $15,81 \pm 1,61$ & $\mathrm{c}$ \\
\hline & & & GiSelA 6 & $34,73 \pm 1,20 \quad b$ & $32,07 \pm 2,19 \quad b$ & $13,20 \pm 1,14$ & $\mathrm{~b}$ \\
\hline & & & PHL-C & $34,86 \pm 1,52 b$ & $31,54 \pm 1,93 \mathrm{ab}$ & $13,19 \pm 0,62$ & $\mathrm{~b}$ \\
\hline & & & $\mathrm{PiKu} 1$ & $34,57 \pm 0,83$ ab & $32,69 \pm 2,93 \mathrm{~b}$ & $12,97 \pm 0,58$ & $\mathrm{~b}$ \\
\hline & & & Weiroot 158 & $33,78 \pm 1,22$ a & $30,17 \pm 1,41 \quad \mathrm{a}$ & $12,03 \pm 0,47$ & $\mathrm{a}$ \\
\hline & & \multirow{5}{*}{ T3 } & GiSelA 5 & $29,65 \pm 1,10 \quad b$ & $18,96 \pm 0,79 \mathrm{bc}$ & $4,79 \pm 0,18$ & \\
\hline & & & GiSelA 6 & $29,47 \pm 1,01 \quad b$ & $18,50 \pm 1,32 \mathrm{ab}$ & $4,92 \pm 0,38$ & $\mathrm{~b}$ \\
\hline & & & PHL-C & $28,67 \pm 0,89$ a & $18,01 \pm 0,78$ a & $4,31 \pm 0,26$ & $\mathrm{a}$ \\
\hline & & & $\mathrm{PiKu} 1$ & $29,56 \pm 1,03 \quad b$ & $20,71 \pm 1,22 \mathrm{~d}$ & $5,41 \pm 0,31$ & $\mathrm{~d}$ \\
\hline & & & Weiroot 158 & $28,24 \pm 1,45$ a & $19,47 \pm 1,17 \quad \mathrm{c}$ & $5,20 \pm 0,29$ & $\mathrm{c}$ \\
\hline
\end{tabular}

1a különböző betűk a szignifikánsan különböző csoportokat jelölik, MANOVA, p<0,05 (Tukey / Games-Howell) 
22. táblázat: 'Regina' és 'Kordia' cseresznyefajta gyümölcseinek héjszín-paraméterei különböző alanyokon (2.)

\begin{tabular}{|c|c|c|c|c|c|c|c|}
\hline Év & Nemes & Terminus & Alany & $\mathbf{L}^{*}$ & $a^{*}$ & $\mathbf{b}^{*}$ & \\
\hline \multirow{15}{*}{2011} & \multirow{15}{*}{ Regina } & \multirow{5}{*}{ T1 } & GiSelA 5 & $48,01 \pm 1,09 \mathrm{a}^{1}$ & $40,38 \pm 3,73$ a & $27,69 \pm 1,28$ & \\
\hline & & & GiSelA 6 & $53,43 \pm 1,82 \mathrm{c}$ & $39,96 \pm 1,70$ a & $30,43 \pm 1,83$ & $\mathrm{~b}$ \\
\hline & & & PHL-C & $48,88 \pm 0,88 \mathrm{ab}$ & $41,67 \pm 2,76 a$ & $27,71 \pm 2,72$ & $\mathrm{a}$ \\
\hline & & & PiKu 1 & $48,03 \pm 0,90 \quad \mathrm{a}$ & $40,86 \pm 2,29 a$ & $27,56 \pm 2,01$ & $\mathrm{a}$ \\
\hline & & & Weiroot 158 & $49,34 \pm 1,62 b$ & $41,25 \pm 3,10 \quad a$ & $28,50 \pm 1,14$ & $\mathrm{a}$ \\
\hline & & \multirow{5}{*}{$\mathbf{T 2}$} & GiSelA 5 & $38,18 \pm 1,69$ bc & $38,02 \pm 3,43 \mathrm{c}$ & $18,03 \pm 1,46$ & d \\
\hline & & & GiSelA 6 & $38,82 \pm 0,75 \mathrm{c}$ & $37,33 \pm 1,55 \mathrm{c}$ & $17,92 \pm 1,30$ & d \\
\hline & & & PHL-C & $37,61 \pm 0,81 \quad b$ & $36,64 \pm 3,51 \quad b c$ & $16,77 \pm 0,80$ & $\mathrm{c}$ \\
\hline & & & $\mathrm{PiKu} 1$ & $35,51 \pm 1,37 \quad a$ & $34,14 \pm 1,39 a$ & $13,88 \pm 0,79$ & $\mathrm{a}$ \\
\hline & & & Weiroot 158 & $36,00 \pm 0,81 \quad \mathrm{a}$ & $35,42 \pm 2,44 \mathrm{ab}$ & $14,77 \pm 0,74$ & $\mathrm{~b}$ \\
\hline & & \multirow{5}{*}{ T3 } & GiSelA 5 & $31,08 \pm 0,73 a$ & $25,65 \pm 1,11 \quad a$ & $8,01 \pm 0,30$ & $\mathrm{a}$ \\
\hline & & & GiSelA 6 & $33,14 \pm 0,68 \mathrm{c}$ & $29,62 \pm 1,29 \mathrm{~d}$ & $10,61 \pm 0,58$ & $\mathrm{c}$ \\
\hline & & & PHL-C & $32,49 \pm 1,06 \quad b$ & $26,75 \pm 1,72 b c$ & $8,46 \pm 0,42$ & $\mathrm{~b}$ \\
\hline & & & $\mathrm{PiKu} 1$ & $32,25 \pm 0,75 \quad b$ & $26,41 \pm 1,12 \mathrm{ab}$ & $8,58 \pm 0,46$ & $\mathrm{~b}$ \\
\hline & & & Weiroot 158 & $32,38 \pm 0,92 \mathrm{~b}$ & $27,33 \pm 1,11 \quad \mathrm{c}$ & $8,66 \pm 0,47$ & $\mathrm{~b}$ \\
\hline \multirow{15}{*}{2012} & \multirow{15}{*}{ Kordia } & \multirow{5}{*}{ T1 } & GiSelA 5 & $53,87 \pm 0,81 \quad b$ & $34,64 \pm 1,43 \quad \mathrm{a}$ & $30,38 \pm 1,62$ & \\
\hline & & & GiSelA 6 & $54,86 \pm 1,12 \mathrm{~b}$ & $34,20 \pm 2,31 \quad a$ & $31,12 \pm 1,24$ & $\mathrm{c}$ \\
\hline & & & PHL-C & $50,09 \pm 1,70$ a & $39,11 \pm 2,49 \quad b$ & $27,44 \pm 1,20$ & $\mathrm{a}$ \\
\hline & & & PiKu 1 & $50,90 \pm 2,48 \quad a$ & $36,80 \pm 3,79 a b$ & $29,02 \pm 2,25$ & $\mathrm{ab}$ \\
\hline & & & Weiroot 158 & $51,50 \pm 1,70$ a & $36,24 \pm 3,34$ a & $27,52 \pm 2,42$ & $\mathrm{a}$ \\
\hline & & \multirow{5}{*}{$\mathbf{T 2}$} & GiSelA 5 & $39,64 \pm 2,07 \quad \mathrm{a}$ & $39,02 \pm 3,46$ a & $20,55 \pm 1,46$ & $\mathrm{a}$ \\
\hline & & & GiSelA 6 & $40,65 \pm 2,07 \mathrm{ab}$ & $40,81 \pm 2,78 a$ & $21,02 \pm 1,01$ & $\mathrm{ab}$ \\
\hline & & & PHL-C & $40,19 \pm 0,77 \quad a$ & $38,71 \pm 3,27$ a & $20,08 \pm 1,02$ & $\mathrm{a}$ \\
\hline & & & PiKu 1 & $42,41 \pm 0,84 \quad c$ & $41,03 \pm 2,57 \quad \mathrm{a}$ & $23,01 \pm 1,01$ & $\mathrm{c}$ \\
\hline & & & Weiroot 158 & $41,96 \pm 1,13 \mathrm{bc}$ & $40,51 \pm 3,28 \quad \mathrm{a}$ & $21,78 \pm 0,82$ & $\mathrm{~b}$ \\
\hline & & \multirow{5}{*}{ T3 } & GiSelA 5 & $29,84 \pm 0,82 \mathrm{ab}$ & $21,77 \pm 0,97$ a & $7,12 \pm 0,35$ & $\mathrm{a}$ \\
\hline & & & GiSelA 6 & $30,48 \pm 0,59$ bc & $26,73 \pm 1,38 \mathrm{c}$ & $9,65 \pm 0,44$ & $\mathrm{c}$ \\
\hline & & & PHL-C & $29,16 \pm 0,59$ a & $23,68 \pm 1,38 \quad b$ & $7,76 \pm 0,32$ & $\mathrm{~b}$ \\
\hline & & & PiKu 1 & $30,63 \pm 0,78 \mathrm{c}$ & $26,74 \pm 1,65 \mathrm{c}$ & $9,41 \pm 0,72$ & $\mathrm{c}$ \\
\hline & & & Weiroot 158 & $30,55 \pm 0,63 \mathrm{c}$ & $26,25 \pm 2,05 \mathrm{c}$ & $9,53 \pm 0,73$ & $\mathrm{c}$ \\
\hline \multirow{15}{*}{2012} & \multirow{15}{*}{ Regina } & \multirow{5}{*}{ T1 } & GiSelA 5 & $52,38 \pm 1,22 \mathrm{a}$ & $40,32 \pm 3,82 a$ & $30,04 \pm 1,52$ & \\
\hline & & & GiSelA 6 & $55,90 \pm 1,10 \mathrm{c}$ & $40,42 \pm 2,88 \quad \mathrm{a}$ & $32,99 \pm 2,30$ & $b$ \\
\hline & & & PHL-C & $53,84 \pm 1,01 \quad b$ & $41,41 \pm 3,08 \quad a$ & $30,44 \pm 1,25$ & $\mathrm{a}$ \\
\hline & & & PiKu 1 & $53,58 \pm 1,77 \mathrm{ab}$ & $40,83 \pm 3,20 \quad \mathrm{a}$ & $30,02 \pm 2,17$ & $\mathrm{a}$ \\
\hline & & & Weiroot 158 & $52,90 \pm 0,95 \mathrm{ab}$ & $41,96 \pm 3,25$ a & $30,03 \pm 2,36$ & $\mathrm{a}$ \\
\hline & & \multirow{5}{*}{$\mathbf{T 2}$} & GiSelA 5 & $39,28 \pm 0,79 \mathrm{c}$ & $38,02 \pm 2,69 b$ & $18,83 \pm 0,88$ & $\mathrm{~d}$ \\
\hline & & & GiSelA 6 & $39,93 \pm 1,12 \mathrm{c}$ & $38,57 \pm 3,28 \quad b$ & $19,19 \pm 0,69$ & $\mathrm{~d}$ \\
\hline & & & PHL-C & $39,57 \pm 0,88 \mathrm{c}$ & $37,18 \pm 1,49$ b & $17,73 \pm 0,72$ & $\mathrm{c}$ \\
\hline & & & $\mathrm{PiKu} 1$ & $37,51 \pm 0,69 b$ & $36,36 \pm 1,41 \mathrm{ab}$ & $16,39 \pm 0,57$ & $\mathrm{~b}$ \\
\hline & & & Weiroot 158 & $34,90 \pm 1,39$ a & $34,34 \pm 1,64$ a & $14,21 \pm 0,53$ & $\mathrm{a}$ \\
\hline & & \multirow{5}{*}{ T3 } & GiSelA 5 & $32,51 \pm 0,98 \quad b$ & $25,90 \pm 2,36 \mathrm{c}$ & $9,16 \pm 1,00$ & \\
\hline & & & GiSelA 6 & $32,11 \pm 0,95 \mathrm{~b}$ & $24,84 \pm 2,07 \quad \mathrm{c}$ & $8,92 \pm 0,53$ & $\mathrm{c}$ \\
\hline & & & PHL-C & $31,95 \pm 0,72 b$ & $21,70 \pm 1,20 \quad b$ & $7,43 \pm 0,57$ & $\mathrm{~b}$ \\
\hline & & & $\mathrm{PiKu} 1$ & $30,64 \pm 0,77$ a & $19,19 \pm 0,92$ a & $6,14 \pm 0,24$ & $\mathrm{a}$ \\
\hline & & & Weiroot 158 & $30,56 \pm 0,65 a$ & $19,16 \pm 0,83$ a & $6,10 \pm 0,38$ & $\mathrm{a}$ \\
\hline
\end{tabular}

1a különböző betűk a szignifikánsan különböző csoportokat jelölik, MANOVA, p<0,05 (Tukey / Games-Howell) 
22. táblázat: 'Regina' és 'Kordia' cseresznyefajta gyümölcseinek héjszín-paraméterei különböző alanyokon (3.)

\begin{tabular}{|c|c|c|c|c|c|c|c|}
\hline Év & Nemes & Terminus & Alany & $\mathbf{L}^{*}$ & $a^{*}$ & $\mathbf{b}^{*}$ & \\
\hline \multirow{15}{*}{2013} & \multirow{15}{*}{ Kordia } & \multirow{5}{*}{ T1 } & GiSelA 5 & $48,69 \pm 1,02 \mathrm{a}^{1}$ & $37,00 \pm 3,32 b$ & $27,98 \pm 4,23$ & \\
\hline & & & GiSelA 6 & $52,75 \pm 1,13 b$ & $32,95 \pm 1,43$ a & $28,66 \pm 2,62$ & \\
\hline & & & PHL-C & $49,71 \pm 1,05$ a & $35,47 \pm 2,85 \mathrm{ab}$ & $26,06 \pm 3,09$ & \\
\hline & & & PiKu 1 & $52,36 \pm 1,67 \quad b$ & $33,92 \pm 1,85$ a & $28,00 \pm 3,20$ & \\
\hline & & & Weiroot 158 & $49,43 \pm 0,87 \quad \mathrm{a}$ & $36,91 \pm 3,24 \quad b$ & $26,23 \pm 2,73 \quad a$ & $\mathrm{a}$ \\
\hline & & \multirow{5}{*}{$\mathbf{T 2}$} & GiSelA 5 & $38,88 \pm 1,19 \mathrm{~d}$ & $36,92 \pm 3,17 b$ & $18,27 \pm 0,65$ & \\
\hline & & & GiSelA 6 & $38,68 \pm 1,17 \mathrm{~d}$ & $36,60 \pm 3,12 b$ & $18,52 \pm 1,11 \mathrm{c}$ & \\
\hline & & & PHL-C & $37,11 \pm 0,65 \mathrm{c}$ & $35,83 \pm 2,87 \quad b$ & $16,61 \pm 0,86 \mathrm{~b}$ & \\
\hline & & & $\mathrm{PiKu} 1$ & $35,76 \pm 0,70 \quad b$ & $34,97 \pm 3,31 \quad b$ & $15,65 \pm 1,12 \mathrm{~b}$ & \\
\hline & & & Weiroot 158 & $34,38 \pm 1,35$ a & $30,34 \pm 1,71 \quad \mathrm{a}$ & $12,43 \pm 1,04 \quad a$ & $\mathrm{a}$ \\
\hline & & \multirow{5}{*}{ T3 } & GiSelA 5 & $30,29 \pm 0,66 b$ & $22,08 \pm 0,97 \quad b$ & $6,27 \pm 0,35$ & $\mathrm{c}$ \\
\hline & & & GiSelA 6 & $29,53 \pm 0,72 \mathrm{a}$ & $24,22 \pm 1,51 \quad \mathrm{c}$ & $7,65 \pm 0,30$ & d \\
\hline & & & PHL-C & $29,92 \pm 0,68 \mathrm{ab}$ & $20,38 \pm 1,52 a$ & $5,40 \pm 0,27$ & $\mathrm{a}$ \\
\hline & & & $\mathrm{PiKu} 1$ & $29,75 \pm 0,73 \mathrm{ab}$ & $21,54 \pm 1,07 \mathrm{ab}$ & $6,06 \pm 0,22 \mathrm{~b}$ & bc \\
\hline & & & Weiroot 158 & $30,39 \pm 0,74 \mathrm{~b}$ & $21,17 \pm 0,87 \mathrm{ab}$ & $5,91 \pm 0,29 \mathrm{~b}$ & $\mathrm{~b}$ \\
\hline \multirow{15}{*}{2013} & \multirow{15}{*}{ Regina } & \multirow{5}{*}{ T1 } & GiSelA 5 & $52,33 \pm 1,47 \quad b c$ & $39,00 \pm 2,03 \quad \mathrm{a}$ & $30,41 \pm 2,59 \mathrm{~b}$ & \\
\hline & & & GiSelA 6 & $51,19 \pm 0,97 \mathrm{ab}$ & $42,56 \pm 5,40 \mathrm{ab}$ & $30,00 \pm 1,41$ & $a b c$ \\
\hline & & & PHL-C & $50,65 \pm 1,15$ a & $41,62 \pm 2,83 \mathrm{ab}$ & $28,02 \pm 1,10$ & $\mathrm{a}$ \\
\hline & & & $\mathrm{PiKu} 1$ & $52,78 \pm 1,53 \mathrm{c}$ & $41,07 \pm 4,63 \mathrm{ab}$ & $30,83 \pm 3,15$ & $\mathrm{c}$ \\
\hline & & & Weiroot 158 & $50,68 \pm 1,10$ a & $43,17 \pm 2,47 \quad b$ & $28,72 \pm 1,60 \quad a$ & $\mathrm{ab}$ \\
\hline & & \multirow{5}{*}{$\mathbf{T 2}$} & GiSelA 5 & $35,46 \pm 0,64 a$ & $39,00 \pm 2,51 \quad \mathrm{a}$ & $19,36 \pm 0,79 \mathrm{~b}$ & \\
\hline & & & GiSelA 6 & $37,22 \pm 0,84 \mathrm{~b}$ & $38,96 \pm 1,41 \quad a$ & $18,23 \pm 0,91$ & \\
\hline & & & PHL-C & $38,23 \pm 0,90 \mathrm{c}$ & $39,85 \pm 3,41 \quad \mathrm{a}$ & $18,60 \pm 0,74$ & $\mathrm{ab}$ \\
\hline & & & $\mathrm{PiKu} 1$ & $38,98 \pm 1,32 \mathrm{c}$ & $40,19 \pm 2,40 \quad a$ & $20,44 \pm 0,84$ & $\mathrm{c}$ \\
\hline & & & Weiroot 158 & $38,46 \pm 0,55 \mathrm{c}$ & $39,81 \pm 2,20 \quad \mathrm{a}$ & $19,22 \pm 0,97 \quad b$ & $\mathrm{~b}$ \\
\hline & & \multirow{5}{*}{ T3 } & GiSelA 5 & $31,27 \pm 0,50 \quad b$ & $25,54 \pm 1,61 b$ & $7,90 \pm 0,40$ & \\
\hline & & & GiSelA 6 & $30,45 \pm 1,27 \mathrm{a}$ & $23,39 \pm 1,28$ a & $6,39 \pm 0,30$ & $\mathrm{a}$ \\
\hline & & & PHL-C & $31,84 \pm 0,66 b$ & $25,40 \pm 1,05 \quad b$ & $7,92 \pm 0,32$ & $\mathrm{c}$ \\
\hline & & & $\mathrm{PiKu} 1$ & $31,10 \pm 1,09 \mathrm{ab}$ & $25,24 \pm 0,74 \quad b$ & $7,24 \pm 0,26 \mathrm{~b}$ & $\mathrm{~b}$ \\
\hline & & & Weiroot 158 & $31,81 \pm 0,70 \quad b$ & $25,63 \pm 1,60 \quad b$ & $8,03 \pm 0,34 \quad c$ & $\mathrm{c}$ \\
\hline
\end{tabular}

${ }^{1}$ A különböző betük a szignifikánsan különböző csoportokat jelölik. Az elemzést MANOVA módszerrel végeztük $\mathrm{p}<0,05$ szinten, szóráshomogenitás esetén Tukey, enyhe sérülése esetén Games-Howell post hoc tesztet alkalmazva. 
23. táblázat: Q10 ültetvény cseresznyefajtáinak gyümölcsméret-paraméterei (1.)

\begin{tabular}{|c|c|c|c|c|c|c|c|c|c|}
\hline Év & Nemes & \multirow{3}{*}{\begin{tabular}{|c|} 
Terminus \\
T1
\end{tabular}} & \multirow{3}{*}{$\begin{array}{c}\text { Virágritkítás } \\
\text { kontroll } \\
\text { ritkított }\end{array}$} & \multicolumn{2}{|c|}{ Szélesség (mm) } & \multicolumn{2}{|c|}{ Magasság (mm) } & \multicolumn{2}{|c|}{ Vastagság (mm) } \\
\hline \multirow{30}{*}{2010} & \multirow{6}{*}{ Big.Bur.Sch. } & & & $25,47 \pm 1,05$ & & $23,75 \pm 1,05$ & $\mathrm{a}$ & $21,63 \pm 0,98$ & $\mathrm{a}$ \\
\hline & & & & $25,72 \pm 1,30$ & $\mathrm{a}$ & $23,69 \pm 0,97$ & $\mathrm{a}$ & $21,69 \pm 1,20$ & $\mathrm{a}$ \\
\hline & & \multirow{2}{*}{$\mathbf{T} 2$} & kontroll & $25,59 \pm 1,41$ & & $23,94 \pm 0,95$ & $\mathrm{a}$ & $21,66 \pm 0,87$ & $\mathrm{a}$ \\
\hline & & & ritkított & $25,56 \pm 1,24$ & $\mathrm{a}$ & $23,88 \pm 1,24$ & $\mathrm{a}$ & $21,19 \pm 1,65$ & $\mathrm{a}$ \\
\hline & & \multirow{2}{*}{ T3 } & kontroll & $25,56 \pm 1,24$ & $\mathrm{a}$ & $24,00 \pm 1,34$ & $\mathrm{a}$ & $21,72 \pm 1,02$ & $\mathrm{a}$ \\
\hline & & & ritkított & $25,19 \pm 1,35$ & $\mathrm{a}$ & $23,94 \pm 1,08$ & $\mathrm{a}$ & $21,38 \pm 1,43$ & $\mathrm{a}$ \\
\hline & \multirow{6}{*}{ Big.Bur.VG } & \multirow{2}{*}{ T1 } & kontroll & $20,63 \pm 1,45$ & $\mathrm{a}$ & $18,75 \pm 0,95$ & $\mathrm{a}$ & $17,50 \pm 1,11$ & $\mathrm{a}$ \\
\hline & & & ritkított & $21,34 \pm 1,07$ & $\mathrm{~b}$ & $18,97 \pm 1,06$ & $\mathrm{a}$ & $18,16 \pm 0,88$ & $\mathrm{~b}$ \\
\hline & & \multirow{2}{*}{$\mathbf{T} 2$} & kontroll & $21,16 \pm 1,19$ & $\mathrm{a}$ & $19,22 \pm 0,94$ & $\mathrm{a}$ & $18,41 \pm 1,19$ & $\mathrm{a}$ \\
\hline & & & ritkított & $21,63 \pm 1,48$ & $\mathrm{a}$ & $19,81 \pm 0,90$ & $\mathrm{~b}$ & $19,09 \pm 0,93$ & $b$ \\
\hline & & \multirow{2}{*}{ T3 } & kontroll & $21,63 \pm 1,29$ & $\mathrm{a}$ & $19,38 \pm 1,62$ & $\mathrm{a}$ & $18,63 \pm 0,87$ & $\mathrm{a}$ \\
\hline & & & ritkított & $21,78 \pm 1,10$ & $\mathrm{a}$ & $19,53 \pm 1,14$ & $\mathrm{a}$ & $18,88 \pm 0,94$ & $\mathrm{a}$ \\
\hline & \multirow{6}{*}{ Big.Mor.Sch. } & \multirow{2}{*}{ T1 } & kontroll & $21,50 \pm 1,48$ & $\mathrm{a}$ & $20,44 \pm 0,98$ & $\mathrm{a}$ & $18,59 \pm 1,04$ & $\mathrm{a}$ \\
\hline & & & ritkított & $22,59 \pm 1,27$ & $\mathrm{~b}$ & $21,06 \pm 1,16$ & $\mathrm{~b}$ & $19,41 \pm 1,70$ & $\mathrm{~b}$ \\
\hline & & \multirow{2}{*}{$\mathbf{T 2}$} & kontroll & $23,81 \pm 1,15$ & $\mathrm{a}$ & $22,31 \pm 1,33$ & $\mathrm{a}$ & $20,28 \pm 1,02$ & $\mathrm{a}$ \\
\hline & & & ritkított & $24,59 \pm 1,21$ & $b$ & $22,78 \pm 0,79$ & $\mathrm{a}$ & $21,16 \pm 0,92$ & $\mathrm{~b}$ \\
\hline & & \multirow{2}{*}{ T3 } & kontroll & $24,34 \pm 1,04$ & $\mathrm{a}$ & $22,94 \pm 0,95$ & $\mathrm{a}$ & $21,03 \pm 1,15$ & $\mathrm{a}$ \\
\hline & & & ritkított & $26,16 \pm 1,39$ & $\mathrm{~b}$ & $24,31 \pm 1,00$ & $\mathrm{~b}$ & $22,19 \pm 2,22$ & $\mathrm{~b}$ \\
\hline & \multirow{6}{*}{ Hybrid 222} & T1 & kontroll & $21,03 \pm 1,12$ & a & $18,91 \pm 1,06$ & $\mathrm{a}$ & $17,94 \pm 0,88$ & $\mathrm{a}$ \\
\hline & & 11 & ritkított & $21,97 \pm 1,09$ & $\mathrm{~b}$ & $19,69 \pm 1,00$ & $\mathrm{~b}$ & $18,66 \pm 0,97$ & $\mathrm{~b}$ \\
\hline & & $\mathbf{T ?}$ & kontroll & $21,19 \pm 1,18$ & $\mathrm{a}$ & $18,94 \pm 1,19$ & $\mathrm{a}$ & $18,19 \pm 1,00$ & $\mathrm{a}$ \\
\hline & & 12 & ritkított & $22,19 \pm 1,15$ & $\mathrm{~b}$ & $19,81 \pm 1,03$ & $\mathrm{~b}$ & $19,16 \pm 1,11$ & $\mathrm{~b}$ \\
\hline & & & kontroll & $21,28 \pm 1,42$ & $\mathrm{a}$ & $19,28 \pm 1,02$ & $\mathrm{a}$ & $18,72 \pm 1,02$ & $\mathrm{a}$ \\
\hline & & 13 & & $21,97 \pm 1,38$ & $\mathrm{a}$ & $19,69 \pm 1,09$ & $\mathrm{a}$ & $19,09 \pm 1,23$ & $\mathrm{a}$ \\
\hline & & & kontroll & $21,59 \pm 1,29$ & $\mathrm{a}$ & $20,09 \pm 1,09$ & $\mathrm{a}$ & $18,72 \pm 0,68$ & $\mathrm{a}$ \\
\hline & & 11 & & $22,06 \pm 1,16$ & $\mathrm{a}$ & $20,22 \pm 1,01$ & $\mathrm{a}$ & $19,03 \pm 0,86$ & $\mathrm{a}$ \\
\hline & Merton & & kontroll & $22,16 \pm 0,77$ & $\mathrm{a}$ & $20,34 \pm 0,83$ & $\mathrm{a}$ & $19,28 \pm 0,63$ & $\mathrm{a}$ \\
\hline & Prem. & T2 & & $22,31 \pm 0,78$ & a & $21,00 \pm 0,80$ & $\mathrm{~b}$ & $19,44 \pm 0,62$ & $\mathrm{a}$ \\
\hline & & & kontroll & $21,63 \pm 1,04$ & $\mathrm{a}$ & $19,69 \pm 0,78$ & $\mathrm{a}$ & $18,56 \pm 0,80$ & $\mathrm{a}$ \\
\hline & & T3 & ritkított & $22,00 \pm 0,92$ & $\mathrm{a}$ & $20,34 \pm 0,65$ & $\mathrm{~b}$ & $19,13 \pm 1,01$ & $\mathrm{~b}$ \\
\hline & & T1 & kontroll & $22,67 \pm 1,64$ & $\mathrm{a}$ & $21,07 \pm 1,50$ & $\mathrm{a}$ & $18,87 \pm 1,27$ & $\mathrm{a}$ \\
\hline & & T1 & ritkított & $22,81 \pm 1,54$ & $\mathrm{a}$ & $20,99 \pm 1,19$ & $\mathrm{a}$ & $18,73 \pm 1,01$ & $\mathrm{a}$ \\
\hline & Bia Rur Sch & $\mathbf{T ?}$ & kontroll & $23,41 \pm 1,57$ & $\mathrm{a}$ & $21,54 \pm 1,13$ & $\mathrm{a}$ & $19,52 \pm 1,35$ & $\mathrm{a}$ \\
\hline & Big.Bur.Sch. & 12 & ritkított & $24,12 \pm 1,45$ & $\mathrm{a}$ & $21,96 \pm 1,14$ & $\mathrm{a}$ & $19,74 \pm 1,07$ & $\mathrm{a}$ \\
\hline & & & kontroll & $23,96 \pm 1,34$ & $\mathrm{a}$ & $22,28 \pm 1,05$ & $\mathrm{a}$ & $20,29 \pm 1,04$ & $\mathrm{a}$ \\
\hline & & T3 & ritkított & $24,66 \pm 1,59$ & $\mathrm{~b}$ & $22,65 \pm 1,37$ & $\mathrm{a}$ & $20,84 \pm 1,24$ & $\mathrm{a}$ \\
\hline & & T1 & kontroll & $21,97 \pm 1,17$ & $\mathrm{a}$ & $19,17 \pm 0,90$ & $\mathrm{a}$ & $18,72 \pm 0,87$ & $\mathrm{a}$ \\
\hline & & 11 & ritkított & $23,11 \pm 0,93$ & $\mathrm{~b}$ & $20,12 \pm 0,75$ & $\mathrm{~b}$ & $19,59 \pm 0,71$ & $\mathrm{~b}$ \\
\hline 2011 & Bic Ru & T? & kontroll & $21,30 \pm 1,21$ & $\mathrm{a}$ & $18,85 \pm 0,95$ & $\mathrm{a}$ & $18,53 \pm 0,87$ & $\mathrm{a}$ \\
\hline 2011 & Big.Bur.VG & 12 & & $21,07 \pm 1,25$ & $\mathrm{a}$ & $18,72 \pm 1,13$ & $\mathrm{a}$ & $18,45 \pm 1,07$ & $\mathrm{a}$ \\
\hline & & TT & kontroll & $24,58 \pm 1,41$ & $\mathrm{a}$ & $21,64 \pm 0,90$ & $\mathrm{a}$ & $21,13 \pm 0,97$ & $\mathrm{a}$ \\
\hline & & 13 & & $24,66 \pm 1,00$ & $\mathrm{a}$ & $21,54 \pm 0,80$ & $\mathrm{a}$ & $21,17 \pm 0,72$ & $\mathrm{a}$ \\
\hline & & & kontroll & $20,89 \pm 1,33$ & $\mathrm{a}$ & $19,33 \pm 1,10$ & $\mathrm{a}$ & $18,10 \pm 1,12$ & $\mathrm{a}$ \\
\hline & & T1 & & $22,17 \pm 1,22$ & $\mathrm{~b}$ & $20,49 \pm 1,11$ & $\mathrm{~b}$ & $19,25 \pm 1,05$ & $\mathrm{~b}$ \\
\hline & & & kontroll & $22,24 \pm 1,28$ & $\mathrm{a}$ & $20,52 \pm 0,96$ & $\mathrm{a}$ & $19,32 \pm 1,10$ & $\mathrm{a}$ \\
\hline & Big.Mor.Sch. & T2 & ritkított & $23,65 \pm 1,26$ & $\mathrm{~b}$ & $21,55 \pm 0,92$ & $\mathrm{~b}$ & $20,55 \pm 1,10$ & $\mathrm{~b}$ \\
\hline & & & kontroll & $22,79 \pm 1,31$ & $\mathrm{a}$ & $21,22 \pm 1,25$ & $\mathrm{a}$ & $20,07 \pm 1,21$ & $\mathrm{a}$ \\
\hline & & T3 & ritkított & $24,19 \pm 1,33$ & $\mathrm{~b}$ & $22,35 \pm 1,02$ & $\mathrm{~b}$ & $21,14 \pm 0,82$ & $\mathrm{~b}$ \\
\hline
\end{tabular}

1a különböző betűk a szignifikánsan különböző csoportokat jelölik, MANOVA, p<0,05 (Tukey / Games-Howell) 
23. táblázat: Q10 ültetvény cseresznyefajtáinak gyümölcsméret-paraméterei (2.)

\begin{tabular}{|c|c|c|c|c|c|c|c|c|c|}
\hline Év & Nemes & Terminus & Virágritkítás & Szélesség (mm & & Magasság (mm & & Vastagság (mn & \\
\hline \multirow{12}{*}{2011} & \multirow{6}{*}{ Hybrid 222} & \multirow{2}{*}{ T1 } & kontroll & $19,78 \pm 1,28$ & & $17,36 \pm 1,03$ & & $17,09 \pm 1,08$ & \\
\hline & & & ritkított & $20,46 \pm 1,05$ & $\mathrm{~b}$ & $17,85 \pm 0,80$ & $\mathrm{~b}$ & $17,57 \pm 0,80$ & $\mathrm{a}$ \\
\hline & & \multirow{2}{*}{$\mathbf{T 2}$} & kontroll & $21,79 \pm 1,43$ & $\mathrm{a}$ & $18,82 \pm 0,97$ & $\mathrm{a}$ & $18,50 \pm 1,05$ & $\mathrm{a}$ \\
\hline & & & ritkított & $22,36 \pm 1,17$ & $\mathrm{a}$ & $19,41 \pm 0,96$ & $\mathrm{~b}$ & $18,93 \pm 0,92$ & $\mathrm{a}$ \\
\hline & & \multirow{2}{*}{ T3 } & kontroll & $24,67 \pm 1,27$ & $\mathrm{a}$ & $21,62 \pm 1,06$ & $\mathrm{a}$ & $21,21 \pm 0,99$ & $\mathrm{a}$ \\
\hline & & & ritkított & $25,02 \pm 1,14$ & $\mathrm{a}$ & $21,90 \pm 0,87$ & $\mathrm{a}$ & $21,26 \pm 1,06$ & $\mathrm{a}$ \\
\hline & \multirow{6}{*}{$\begin{array}{c}\text { Merton } \\
\text { Prem. }\end{array}$} & \multirow{2}{*}{ T1 } & kontroll & $19,51 \pm 0,87$ & $\mathrm{a}$ & $18,45 \pm 1,99$ & $\mathrm{a}$ & $17,36 \pm 0,67$ & $\mathrm{a}$ \\
\hline & & & ritkított & $20,05 \pm 0,92$ & $\mathrm{~b}$ & $18,79 \pm 0,66$ & $\mathrm{~b}$ & $17,68 \pm 0,74$ & $\mathrm{a}$ \\
\hline & & \multirow{2}{*}{$\mathbf{T 2}$} & kontroll & $22,10 \pm 1,44$ & $\mathrm{a}$ & $20,17 \pm 0,59$ & $\mathrm{a}$ & $18,80 \pm 0,64$ & $\mathrm{a}$ \\
\hline & & & ritkított & $22,35 \pm 0,80$ & $\mathrm{~b}$ & $20,52 \pm 0,71$ & $\mathrm{a}$ & $19,03 \pm 0,62$ & $\mathrm{a}$ \\
\hline & & \multirow{2}{*}{ T3 } & kontroll & $23,43 \pm 0,84$ & $\mathrm{a}$ & $21,50 \pm 0,67$ & $\mathrm{a}$ & $19,75 \pm 0,71$ & $\mathrm{a}$ \\
\hline & & & ritkított & $24,15 \pm 0,75$ & $\mathrm{~b}$ & $22,03 \pm 0,69$ & $\mathrm{~b}$ & $20,54 \pm 1,72$ & $\mathrm{~b}$ \\
\hline \multirow{29}{*}{2012} & \multirow{6}{*}{ Big.Bur.Sch. } & \multirow{2}{*}{ T1 } & kontroll & $19,79 \pm 1,21$ & $\mathrm{a}$ & $19,10 \pm 1,09$ & $\mathrm{a}$ & $16,13 \pm 1,15$ & $\mathrm{a}$ \\
\hline & & & ritkított & $20,59 \pm 1,44$ & $\mathrm{~b}$ & $19,66 \pm 1,18$ & $\mathrm{a}$ & $16,62 \pm 1,17$ & $\mathrm{a}$ \\
\hline & & \multirow{2}{*}{$\mathbf{T 2}$} & kontroll & $22,16 \pm 1,11$ & $\mathrm{a}$ & $20,66 \pm 0,98$ & $\mathrm{a}$ & $17,79 \pm 0,88$ & $\mathrm{a}$ \\
\hline & & & ritkított & $23,25 \pm 0,81$ & $\mathrm{~b}$ & $21,15 \pm 0,70$ & $\mathrm{~b}$ & $18,61 \pm 0,72$ & $\mathrm{~b}$ \\
\hline & & \multirow{2}{*}{ T3 } & kontroll & $21,82 \pm 1,97$ & $\mathrm{a}$ & $20,41 \pm 0,95$ & $\mathrm{a}$ & $18,08 \pm 2,32$ & $\mathrm{a}$ \\
\hline & & & ritkított & $22,77 \pm 1,06$ & $\mathrm{~b}$ & $21,03 \pm 0,84$ & $\mathrm{~b}$ & $18,99 \pm 1,87$ & $\mathrm{~b}$ \\
\hline & \multirow{6}{*}{ Big.Bur.VG } & \multirow{2}{*}{$\mathbf{T 1}$} & kontroll & $16,28 \pm 1,26$ & $\mathrm{a}$ & $15,06 \pm 0,73$ & $\mathrm{a}$ & $14,17 \pm 1,00$ & $\mathrm{a}$ \\
\hline & & & ritkított & $17,62 \pm 1,24$ & $\mathrm{~b}$ & $16,51 \pm 0,81$ & $\mathrm{~b}$ & $15,10 \pm 0,94$ & $\mathrm{~b}$ \\
\hline & & \multirow{2}{*}{$\mathbf{T 2}$} & kontroll & $18,23 \pm 1,37$ & $\mathrm{a}$ & $16,24 \pm 1,07$ & $\mathrm{a}$ & $15,43 \pm 1,19$ & $\mathrm{a}$ \\
\hline & & & ritkított & $19,81 \pm 1,33$ & $\mathrm{~b}$ & $17,67 \pm 1,10$ & $\mathrm{~b}$ & $16,55 \pm 0,80$ & $\mathrm{~b}$ \\
\hline & & \multirow{2}{*}{ T3 } & kontroll & $20,69 \pm 1,23$ & $\mathrm{a}$ & $18,57 \pm 0,75$ & $\mathrm{a}$ & $17,59 \pm 0,85$ & $\mathrm{a}$ \\
\hline & & & ritkított & $21,66 \pm 0,94$ & $\mathrm{~b}$ & $19,48 \pm 0,79$ & $\mathrm{~b}$ & $18,30 \pm 0,71$ & $\mathrm{~b}$ \\
\hline & \multirow{5}{*}{ Big.Mor.Sch. } & T1 & $\begin{array}{l}\text { kontroll } \\
\text { ritkított }\end{array}$ & \multicolumn{2}{|l|}{$\begin{array}{l}\text { n. a. } \\
\text { n. a. }\end{array}$} & \multicolumn{2}{|l|}{$\begin{array}{l}\text { n. a. } \\
\text { n. a. }\end{array}$} & \multicolumn{2}{|l|}{$\begin{array}{l}\text { n. a. } \\
\text { n. a. }\end{array}$} \\
\hline & & & kontroll & $21,52 \pm 1,06$ & $\mathrm{a}$ & $19,71 \pm 1,06$ & $\mathrm{a}$ & $18,05 \pm 1,06$ & $\mathrm{a}$ \\
\hline & & T2 & ritkított & $21,98 \pm 1,03$ & $\mathrm{a}$ & $20,03 \pm 0,92$ & $\mathrm{a}$ & $18,37 \pm 0,90$ & $\mathrm{a}$ \\
\hline & & T2 & kontroll & $21,70 \pm 1,12$ & $\mathrm{a}$ & $19,87 \pm 0,72$ & $\mathrm{a}$ & $18,11 \pm 0,79$ & $\mathrm{a}$ \\
\hline & & 13 & ritkított & $22,78 \pm 0,85$ & $\mathrm{~b}$ & $20,69 \pm 0,63$ & $\mathrm{~b}$ & $19,33 \pm 0,88$ & $b$ \\
\hline & & T & kontroll & $15,55 \pm 1,10$ & $\mathrm{a}$ & $14,57 \pm 0,90$ & $\mathrm{a}$ & $13,74 \pm 0,94$ & $\mathrm{a}$ \\
\hline & & 11 & ritkított & $17,08 \pm 0,96$ & $\mathrm{~b}$ & $15,73 \pm 0,77$ & $\mathrm{~b}$ & $14,78 \pm 0,80$ & $b$ \\
\hline & 2 & $T$ & kontroll & $18,61 \pm 0,99$ & $\mathrm{a}$ & $16,84 \pm 0,75$ & $\mathrm{a}$ & $15,83 \pm 0,76$ & $\mathrm{a}$ \\
\hline & Hybrid 222 & 12 & ritkított & $18,83 \pm 0,90$ & $\mathrm{a}$ & $17,10 \pm 0,78$ & $\mathrm{a}$ & $15,73 \pm 0,72$ & $\mathrm{a}$ \\
\hline & & $\mathbf{T 3}$ & kontroll & $20,68 \pm 0,92$ & $\mathrm{a}$ & $18,71 \pm 0,78$ & $\mathrm{a}$ & $17,53 \pm 0,83$ & $\mathrm{a}$ \\
\hline & & 13 & ritkított & $21,16 \pm 1,14$ & $\mathrm{a}$ & $19,26 \pm 1,01$ & $\mathrm{~b}$ & $18,00 \pm 0,90$ & $\mathrm{~b}$ \\
\hline & & & kontroll & $16,57 \pm 1,05$ & $\mathrm{a}$ & $15,91 \pm 0,90$ & $\mathrm{a}$ & $14,86 \pm 0,88$ & $\mathrm{a}$ \\
\hline & & 11 & ritkított & $17,58 \pm 0,84$ & $\mathrm{~b}$ & $17,21 \pm 0,75$ & $\mathrm{~b}$ & $15,61 \pm 0,85$ & b \\
\hline & Merton & T? & kontroll & $18,78 \pm 1,20$ & $\mathrm{a}$ & $17,71 \pm 0,78$ & $\mathrm{a}$ & $16,48 \pm 0,95$ & $\mathrm{a}$ \\
\hline & Prem. & 12 & ritkított & $20,02 \pm 0,90$ & $\mathrm{~b}$ & $18,88 \pm 0,59$ & $\mathrm{~b}$ & $17,04 \pm 0,74$ & $\mathrm{~b}$ \\
\hline & & T3 & kontroll & $21,11 \pm 1,11$ & $\mathrm{a}$ & $19,03 \pm 0,76$ & $\mathrm{a}$ & $17,55 \pm 0,63$ & $\mathrm{a}$ \\
\hline & & 15 & ritkított & $21,20 \pm 0,92$ & $\mathrm{a}$ & $19,25 \pm 0,50$ & $\mathrm{a}$ & $17,37 \pm 0,66$ & $\mathrm{a}$ \\
\hline
\end{tabular}

${ }^{1}$ A különböző betük a szignifikánsan különböző csoportokat jelölik. Az elemzést MANOVA módszerrel végeztük p $<0,05$ szinten, szóráshomogenitás esetén Tukey, enyhe sérülése esetén Games-Howell post hoc tesztet alkalmazva. 
24. táblázat: Q10 ültetvény cseresznyegyümölcseinek térfogata, kocsány-szakítószilárdsága, keménysége (1.)

\begin{tabular}{|c|c|c|c|c|c|c|c|c|c|}
\hline Év & Nemes & Terminus & Virágritkítás & $\begin{array}{l}\text { Térfogat } \\
\left(\mathrm{cm}^{3}\right)\end{array}$ & & $\begin{array}{l}\text { Kocsány-szak } \\
\text { szilárdság }(\mathbf{N})\end{array}$ & & $\begin{array}{c}\text { Keménység } \\
\left(\mathrm{kg} / \mathrm{cm}^{2}\right)\end{array}$ & \\
\hline \multirow{15}{*}{2010} & \multirow{3}{*}{ Big.Bur.Sch. } & $\mathbf{T 1}$ & $\begin{array}{l}\text { kontroll } \\
\text { ritkított }\end{array}$ & $\begin{array}{l}6,87 \pm 0,79 \\
6,95 \pm 0,88\end{array}$ & & $\begin{array}{l}\text { n. a. } \\
\text { n. a. }\end{array}$ & & $\begin{array}{l}2,27 \pm 0,51 \\
2,19 \pm 0,29\end{array}$ & $\begin{array}{l}\mathrm{a} \\
\mathrm{a}\end{array}$ \\
\hline & & $\mathbf{T 2}$ & $\begin{array}{l}\text { kontroll } \\
\text { ritkított }\end{array}$ & $\begin{array}{l}6,97 \pm 0,82 \\
6,80 \pm 0,99\end{array}$ & $\begin{array}{l}\mathrm{a} \\
\mathrm{a}\end{array}$ & $\begin{array}{l}\text { n. a. } \\
\text { n. a. }\end{array}$ & & $\begin{array}{l}2,21 \pm 0,38 \\
2,42 \pm 0,44\end{array}$ & $\begin{array}{l}a \\
b\end{array}$ \\
\hline & & T3 & $\begin{array}{l}\text { kontroll } \\
\text { ritkított }\end{array}$ & $\begin{array}{l}7,00 \pm 0,83 \\
6,78 \pm 0,98\end{array}$ & $\begin{array}{l}\mathrm{a} \\
\mathrm{a}\end{array}$ & $\begin{array}{l}\text { n. a. } \\
\text { n. a. }\end{array}$ & & $\begin{array}{l}1,64 \pm 0,29 \\
1,69 \pm 0,24\end{array}$ & $\begin{array}{l}\mathrm{a} \\
\mathrm{a}\end{array}$ \\
\hline & \multirow{3}{*}{ Big.Bur.VG } & $\mathbf{T 1}$ & $\begin{array}{l}\text { kontroll } \\
\text { ritkított }\end{array}$ & $\begin{array}{l}3,58 \pm 0,62 \\
3,87 \pm 0,55\end{array}$ & $\begin{array}{l}\mathrm{a} \\
\mathrm{b}\end{array}$ & $\begin{array}{l}\text { n. a. } \\
\text { n. a. }\end{array}$ & & $\begin{array}{l}2,86 \pm 0,50 \\
3,28 \pm 0,54\end{array}$ & $\begin{array}{l}a \\
b\end{array}$ \\
\hline & & $\mathbf{T} 2$ & $\begin{array}{l}\text { kontroll } \\
\text { ritkított }\end{array}$ & $\begin{array}{l}3,95 \pm 0,61 \\
4,31 \pm 0,64\end{array}$ & $\begin{array}{l}\mathrm{a} \\
\mathrm{b}\end{array}$ & $\begin{array}{l}\text { n. a. } \\
\text { n. a. }\end{array}$ & & $\begin{array}{l}2,00 \pm 0,35 \\
1,99 \pm 0,40\end{array}$ & $\begin{array}{l}\mathrm{a} \\
\mathrm{a}\end{array}$ \\
\hline & & $\mathbf{T 3}$ & $\begin{array}{l}\text { kontroll } \\
\text { ritkított }\end{array}$ & $\begin{array}{l}4,10 \pm 0,56 \\
4,22 \pm 0,53\end{array}$ & $\begin{array}{l}\mathrm{a} \\
\mathrm{a}\end{array}$ & $\begin{array}{l}\text { n. a. } \\
\text { n. a. }\end{array}$ & & $\begin{array}{l}1,42 \pm 0,29 \\
1,36 \pm 0,23\end{array}$ & $\begin{array}{l}\mathrm{a} \\
\mathrm{a}\end{array}$ \\
\hline & \multirow{3}{*}{ Big.Mor.Sch. } & T1 & $\begin{array}{l}\text { kontroll } \\
\text { ritkított }\end{array}$ & $\begin{array}{l}4,31 \pm 0,67 \\
4,88 \pm 0,86\end{array}$ & $\begin{array}{l}\mathrm{a} \\
\mathrm{b}\end{array}$ & $\begin{array}{l}\text { n. a. } \\
\text { n. a. }\end{array}$ & & $\begin{array}{l}4,56 \pm 0,63 \\
5,10 \pm 0,72\end{array}$ & $\begin{array}{l}a \\
b\end{array}$ \\
\hline & & $\mathbf{T} 2$ & $\begin{array}{l}\text { kontroll } \\
\text { ritkított }\end{array}$ & $\begin{array}{l}5,67 \pm 0,72 \\
6,23 \pm 0,71\end{array}$ & $\begin{array}{l}\mathrm{a} \\
\mathrm{b}\end{array}$ & $\begin{array}{l}\text { n. a. } \\
\text { n. a. }\end{array}$ & & $\begin{array}{l}2,31 \pm 0,36 \\
2,76 \pm 0,50\end{array}$ & $\begin{array}{l}a \\
b\end{array}$ \\
\hline & & $\mathbf{T 3}$ & $\begin{array}{l}\text { kontroll } \\
\text { ritkított }\end{array}$ & $\begin{array}{l}6,17 \pm 0,73 \\
7,43 \pm 1,21\end{array}$ & $\begin{array}{l}\mathrm{a} \\
\mathrm{b}\end{array}$ & $\begin{array}{l}\text { n. a. } \\
\text { n. a. }\end{array}$ & & $\begin{array}{l}2,04 \pm 0,31 \\
2,40 \pm 0,31\end{array}$ & $\begin{array}{l}a \\
b\end{array}$ \\
\hline & \multirow{3}{*}{ Hybrid 222} & $\mathbf{T 1}$ & $\begin{array}{l}\text { kontroll } \\
\text { ritkított }\end{array}$ & $\begin{array}{l}3,76 \pm 0,56 \\
4,25 \pm 0,60\end{array}$ & $\begin{array}{l}\mathrm{a} \\
\mathrm{b}\end{array}$ & $\begin{array}{l}\text { n. a. } \\
\text { n. a. }\end{array}$ & & $\begin{array}{l}2,43 \pm 0,41 \\
2,97 \pm 0,44\end{array}$ & $\begin{array}{l}a \\
b\end{array}$ \\
\hline & & $\mathbf{T 2}$ & $\begin{array}{l}\text { kontroll } \\
\text { ritkított }\end{array}$ & $\begin{array}{l}3,85 \pm 0,59 \\
4,44 \pm 0,65\end{array}$ & $\begin{array}{l}\mathrm{a} \\
\mathrm{b}\end{array}$ & $\begin{array}{l}\text { n. a. } \\
\text { n. a. }\end{array}$ & & $\begin{array}{l}1,96 \pm 0,38 \\
2,00 \pm 0,41\end{array}$ & $\begin{array}{l}\mathrm{a} \\
\mathrm{a}\end{array}$ \\
\hline & & T3 & $\begin{array}{l}\text { kontroll } \\
\text { ritkított }\end{array}$ & $\begin{array}{l}4,05 \pm 0,61 \\
4,36 \pm 0,69\end{array}$ & $\begin{array}{l}\mathrm{a} \\
\mathrm{a}\end{array}$ & $\begin{array}{l}\text { n. a. } \\
\text { n. a. }\end{array}$ & & $\begin{array}{l}1,38 \pm 0,20 \\
1,34 \pm 0,16\end{array}$ & $\begin{array}{l}\mathrm{a} \\
\mathrm{a}\end{array}$ \\
\hline & \multirow{3}{*}{ Merton Prem. } & T1 & $\begin{array}{l}\text { kontroll } \\
\text { ritkított }\end{array}$ & $\begin{array}{l}4,27 \pm 0,57 \\
4,46 \pm 0,56\end{array}$ & $\begin{array}{l}a \\
a\end{array}$ & $\begin{array}{l}\text { n. a. } \\
\text { n. a. }\end{array}$ & & $\begin{array}{l}3,48 \pm 1,98 \\
3,56 \pm 2,23\end{array}$ & $\begin{array}{l}\mathrm{a} \\
\mathrm{a}\end{array}$ \\
\hline & & $\mathbf{T 2}$ & $\begin{array}{l}\text { kontroll } \\
\text { ritkított }\end{array}$ & $\begin{array}{l}4,56 \pm 0,44 \\
4,78 \pm 0,44\end{array}$ & $\begin{array}{l}\mathrm{a} \\
\mathrm{a}\end{array}$ & $\begin{array}{l}\text { n. a. } \\
\text { n. a. }\end{array}$ & & $\begin{array}{l}2,09 \pm 0,35 \\
2,29 \pm 0,38\end{array}$ & $\begin{array}{l}a \\
b\end{array}$ \\
\hline & & T3 & $\begin{array}{l}\text { kontroll } \\
\text { ritkított }\end{array}$ & $\begin{array}{l}4,15 \pm 0,45 \\
4,49 \pm 0,49\end{array}$ & $\begin{array}{l}a \\
b\end{array}$ & $\begin{array}{l}\text { n. a. } \\
\text { n. a. }\end{array}$ & & $\begin{array}{l}1,61 \pm 0,21 \\
1,79 \pm 0,17\end{array}$ & $\begin{array}{l}a \\
b\end{array}$ \\
\hline \multirow{9}{*}{2011} & \multirow{3}{*}{ Big.Bur.Sch. } & $\mathbf{T 1}$ & $\begin{array}{l}\text { kontroll } \\
\text { ritkított }\end{array}$ & $\begin{array}{l}4,77 \pm 0,91 \\
4,73 \pm 0,80\end{array}$ & $\begin{array}{l}\mathrm{a} \\
\mathrm{a}\end{array}$ & $\begin{array}{c}9,8 \pm 2,5 \\
10,0 \pm 2,8\end{array}$ & $\begin{array}{l}\mathrm{a} \\
\mathrm{a}\end{array}$ & $\begin{array}{l}2,18 \pm 0,42 \\
2,24 \pm 0,45\end{array}$ & $\begin{array}{l}\mathrm{a} \\
\mathrm{a}\end{array}$ \\
\hline & & $\mathbf{T} 2$ & $\begin{array}{l}\text { kontroll } \\
\text { ritkított }\end{array}$ & $\begin{array}{l}5,21 \pm 0,95 \\
5,52 \pm 0,87\end{array}$ & $\begin{array}{l}\mathrm{a} \\
\mathrm{a}\end{array}$ & $\begin{array}{l}7,8 \pm 1,6 \\
8,7 \pm 2,2\end{array}$ & $\begin{array}{l}\mathrm{a} \\
\mathrm{a}\end{array}$ & $\begin{array}{l}1,96 \pm 0,20 \\
2,22 \pm 0,32\end{array}$ & $\begin{array}{l}a \\
b\end{array}$ \\
\hline & & $\mathbf{T 3}$ & $\begin{array}{l}\text { kontroll } \\
\text { ritkított }\end{array}$ & $\begin{array}{l}5,71 \pm 0,86 \\
6,14 \pm 0,98\end{array}$ & $\begin{array}{l}\mathrm{a} \\
\mathrm{a}\end{array}$ & $\begin{array}{l}5,9 \pm 1,5 \\
6,0 \pm 1,3\end{array}$ & $\begin{array}{l}\mathrm{a} \\
\mathrm{a}\end{array}$ & $\begin{array}{l}1,36 \pm 0,21 \\
1,45 \pm 0,15\end{array}$ & $\begin{array}{l}a \\
b\end{array}$ \\
\hline & \multirow{3}{*}{ Big.Bur.VG } & $\mathbf{T 1}$ & $\begin{array}{l}\text { kontroll } \\
\text { ritkított }\end{array}$ & $\begin{array}{l}4,15 \pm 0,57 \\
4,78 \pm 0,48\end{array}$ & $\begin{array}{l}a \\
b\end{array}$ & $\begin{array}{l}13,4 \pm 3,8 \\
14,5 \pm 2,9\end{array}$ & $\begin{array}{l}\mathrm{a} \\
\mathrm{a}\end{array}$ & $\begin{array}{l}2,47 \pm 0,50 \\
2,59 \pm 0,46\end{array}$ & $\begin{array}{l}\mathrm{a} \\
\mathrm{a}\end{array}$ \\
\hline & & $\mathbf{T} 2$ & $\begin{array}{l}\text { kontroll } \\
\text { ritkított }\end{array}$ & $\begin{array}{l}3,91 \pm 0,50 \\
3,84 \pm 0,63\end{array}$ & $\begin{array}{l}\mathrm{a} \\
\mathrm{a}\end{array}$ & $\begin{array}{l}7,8 \pm 2,1 \\
9,5 \pm 1,9\end{array}$ & $\begin{array}{l}a \\
b\end{array}$ & $\begin{array}{l}1,75 \pm 0,30 \\
2,10 \pm 0,28\end{array}$ & $\begin{array}{l}a \\
b\end{array}$ \\
\hline & & T3 & $\begin{array}{l}\text { kontroll } \\
\text { ritkított }\end{array}$ & $\begin{array}{l}5,91 \pm 0,81 \\
5,91 \pm 0,61\end{array}$ & $\begin{array}{l}\mathrm{a} \\
\mathrm{a}\end{array}$ & $\begin{array}{l}6,0 \pm 1,8 \\
6,3 \pm 1,6\end{array}$ & $\begin{array}{l}\mathrm{a} \\
\mathrm{a}\end{array}$ & $\begin{array}{l}1,62 \pm 0,25 \\
1,87 \pm 0,21\end{array}$ & $\begin{array}{l}a \\
b\end{array}$ \\
\hline & \multirow{3}{*}{ Big.Mor.Sch. } & $\mathbf{T 1}$ & $\begin{array}{l}\text { kontroll } \\
\text { ritkított }\end{array}$ & $\begin{array}{l}3,86 \pm 0,66 \\
4,53 \pm 0,52\end{array}$ & $\begin{array}{l}\mathrm{a} \\
\mathrm{b}\end{array}$ & $\begin{array}{c}9,5 \pm 2,4 \\
10,5 \pm 2,9\end{array}$ & $\begin{array}{l}\mathrm{a} \\
\mathrm{a}\end{array}$ & $\begin{array}{l}2,91 \pm 0,49 \\
2,90 \pm 0,52\end{array}$ & $\begin{array}{l}\mathrm{a} \\
\mathrm{a}\end{array}$ \\
\hline & & $\mathbf{T 2}$ & $\begin{array}{l}\text { kontroll } \\
\text { ritkított }\end{array}$ & $\begin{array}{l}4,64 \pm 0,66 \\
5,51 \pm 0,70\end{array}$ & $\begin{array}{l}\mathrm{a} \\
\mathrm{b}\end{array}$ & $\begin{array}{l}7,7 \pm 1,7 \\
7,9 \pm 2,0\end{array}$ & $\begin{array}{l}\mathrm{a} \\
\mathrm{a}\end{array}$ & $\begin{array}{l}2,48 \pm 0,35 \\
2,37 \pm 0,27\end{array}$ & $\begin{array}{l}\mathrm{a} \\
\mathrm{a}\end{array}$ \\
\hline & & $\mathbf{T 3}$ & $\begin{array}{l}\text { kontroll } \\
\text { ritkított }\end{array}$ & $\begin{array}{l}5,13 \pm 0,86 \\
6,01 \pm 0,75\end{array}$ & $\begin{array}{l}a \\
b\end{array}$ & $\begin{array}{l}8,0 \pm 2,2 \\
8,2 \pm 1,5\end{array}$ & $\begin{array}{l}\mathrm{a} \\
\mathrm{a}\end{array}$ & $\begin{array}{l}1,81 \pm 0,24 \\
1,75 \pm 0,23\end{array}$ & $\begin{array}{l}\mathrm{a} \\
\mathrm{a}\end{array}$ \\
\hline
\end{tabular}

1a különböző betűk a szignifikánsan különböző csoportokat jelölik, MANOVA, p<0,05 (Tukey / Games-Howell) 
24. táblázat: Q10 ültetvény cseresznyegyümölcseinek térfogata, kocsány-szakítószilárdsága, keménysége (2.)

\begin{tabular}{|c|c|c|c|c|c|c|c|c|c|}
\hline Év & Nemes & Terminus & Virágritkítás & $\begin{array}{l}\text { Térfogat } \\
\left(\mathrm{cm}^{3}\right)\end{array}$ & & $\begin{array}{l}\text { Kocsány-szal } \\
\text { szilárdság ( }\end{array}$ & & $\begin{array}{c}\text { Keménység } \\
\left(\mathrm{kg} / \mathrm{cm}^{2}\right)\end{array}$ & \\
\hline \multirow{12}{*}{2011} & \multirow{6}{*}{ Hybrid 222} & \multirow{2}{*}{$\mathbf{T 1}$} & kontroll & $3,09 \pm 0,51$ & & $13,9 \pm 2,9$ & & $2,78 \pm 0,39$ & \\
\hline & & & ritkított & $3,37 \pm 0,40$ & $\mathrm{~b}$ & $14,0 \pm 3,9$ & $\mathrm{a}$ & $2,87 \pm 0,44$ & $\mathrm{a}$ \\
\hline & & \multirow{2}{*}{$\mathbf{T 2}$} & kontroll & $4,00 \pm 0,62$ & $\mathrm{a}$ & $8,2 \pm 2,4$ & $\mathrm{a}$ & $1,90 \pm 0,28$ & $\mathrm{a}$ \\
\hline & & & ritkított & $4,33 \pm 0,61$ & $\mathrm{~b}$ & $8,9 \pm 2,3$ & $\mathrm{a}$ & $1,94 \pm 0,19$ & $\mathrm{a}$ \\
\hline & & \multirow{2}{*}{ T3 } & kontroll & $5,96 \pm 0,80$ & $\mathrm{a}$ & $6,1 \pm 1,7$ & $\mathrm{a}$ & $1,61 \pm 0,22$ & $\mathrm{a}$ \\
\hline & & & ritkított & $6,13 \pm 0,77$ & $\mathrm{a}$ & $6,1 \pm 1,7$ & $\mathrm{a}$ & $1,68 \pm 0,19$ & $\mathrm{a}$ \\
\hline & \multirow{6}{*}{ Merton Prem. } & \multirow{2}{*}{ T1 } & kontroll & $3,24 \pm 0,38$ & $\mathrm{a}$ & $13,8 \pm 2,3$ & $\mathrm{a}$ & $2,39 \pm 0,53$ & $\mathrm{a}$ \\
\hline & & & ritkított & $3,49 \pm 0,36$ & $\mathrm{a}$ & $12,9 \pm 2,7$ & $\mathrm{a}$ & $2,40 \pm 0,53$ & $\mathrm{a}$ \\
\hline & & \multirow{2}{*}{$\mathbf{T 2}$} & kontroll & $4,38 \pm 0,35$ & $\mathrm{a}$ & $10,8 \pm 1,9$ & $\mathrm{a}$ & $2,19 \pm 0,48$ & $\mathrm{a}$ \\
\hline & & & ritkított & $4,58 \pm 0,39$ & $\mathrm{~b}$ & $11,1 \pm 1,8$ & $\mathrm{a}$ & $2,27 \pm 0,45$ & $\mathrm{a}$ \\
\hline & & \multirow{2}{*}{ T3 } & kontroll & $5,23 \pm 0,47$ & $\mathrm{a}$ & $6,0 \pm 1,6$ & $\mathrm{a}$ & $1,29 \pm 0,15$ & $\mathrm{a}$ \\
\hline & & & ritkított & $5,66 \pm 0,47$ & $\mathrm{~b}$ & $6,4 \pm 1,3$ & $\mathrm{a}$ & $1,35 \pm 0,17$ & a \\
\hline \multirow{29}{*}{2012} & \multirow{6}{*}{ Big.Bur.Sch. } & \multirow{2}{*}{$\mathbf{T 1}$} & kontroll & $3,22 \pm 0,55$ & $\mathrm{a}$ & $8,0 \pm 2,1$ & $\mathrm{a}$ & $3,11 \pm 0,68$ & $\mathrm{a}$ \\
\hline & & & ritkított & $3,56 \pm 0,61$ & $\mathrm{~b}$ & $8,5 \pm 1,9$ & $\mathrm{a}$ & $3,38 \pm 0,39$ & $\mathrm{a}$ \\
\hline & & \multirow{2}{*}{$\mathbf{T 2}$} & kontroll & $4,28 \pm 0,56$ & $\mathrm{a}$ & $11,3 \pm 3,9$ & $\mathrm{a}$ & $2,81 \pm 0,46$ & $\mathrm{a}$ \\
\hline & & & ritkított & $4,80 \pm 0,42$ & $\mathrm{~b}$ & $12,5 \pm 2,5$ & $\mathrm{a}$ & $3,60 \pm 0,63$ & $\mathrm{~b}$ \\
\hline & & \multirow{2}{*}{ T3 } & kontroll & $4,12 \pm 0,51$ & $\mathrm{a}$ & $8,8 \pm 3,4$ & $\mathrm{a}$ & $2,62 \pm 0,50$ & $\mathrm{a}$ \\
\hline & & & ritkított & $4,78 \pm 0,64$ & $\mathrm{~b}$ & $10,7 \pm 3,5$ & $\mathrm{~b}$ & $2,93 \pm 0,58$ & $\mathrm{~b}$ \\
\hline & \multirow{6}{*}{ Big.Bur.VG } & \multirow{2}{*}{$\mathbf{T 1}$} & kontroll & $1,83 \pm 0,32$ & $\mathrm{a}$ & $8,7 \pm 2,6$ & $\mathrm{a}$ & $3,16 \pm 0,49$ & $\mathrm{a}$ \\
\hline & & & ritkított & $2,31 \pm 0,35$ & $\mathrm{~b}$ & $10,1 \pm 2,7$ & $\mathrm{~b}$ & $3,94 \pm 0,62$ & $\mathrm{~b}$ \\
\hline & & \multirow{2}{*}{$\mathbf{T 2}$} & kontroll & $2,42 \pm 0,49$ & $\mathrm{a}$ & $8,8 \pm 2,5$ & $\mathrm{a}$ & $2,48 \pm 0,78$ & $\mathrm{a}$ \\
\hline & & & ritkított & $3,06 \pm 0,51$ & $\mathrm{~b}$ & $10,8 \pm 2,6$ & $\mathrm{~b}$ & $3,37 \pm 0,51$ & $\mathrm{~b}$ \\
\hline & & \multirow{2}{*}{ T3 } & kontroll & $3,56 \pm 0,48$ & $\mathrm{a}$ & $7,4 \pm 2,6$ & $\mathrm{a}$ & $1,76 \pm 0,24$ & $\mathrm{a}$ \\
\hline & & & ritkított & $4,01 \pm 0,37$ & $\mathrm{~b}$ & $6,3 \pm 1,3$ & $\mathrm{a}$ & $1,91 \pm 0,33$ & $\mathrm{~h}$ \\
\hline & \multirow{5}{*}{ Big.Mor.Sch. } & T1 & $\begin{array}{l}\text { kontroll } \\
\text { ritkított }\end{array}$ & $\begin{array}{l}\text { n. a. } \\
\text { n. a. }\end{array}$ & & $\begin{array}{l}\text { n. a. } \\
\text { n. a. }\end{array}$ & & $\begin{array}{l}\text { n. a. } \\
\text { n. a. }\end{array}$ & \\
\hline & & \multirow{2}{*}{$\mathbf{T 2}$} & kontroll & $4,03 \pm 0,58$ & $\mathrm{a}$ & $9,8 \pm 2,2$ & $\mathrm{a}$ & $3,15 \pm 0,40$ & \\
\hline & & & ritkított & $4,25 \pm 0,54$ & $\mathrm{a}$ & $11,3 \pm 2,8$ & $\mathrm{~b}$ & $3,20 \pm 0,28$ & $\mathrm{a}$ \\
\hline & & \multirow{2}{*}{ T3 } & kontroll & $4,11 \pm 0,48$ & $\mathrm{a}$ & $8,7 \pm 2,6$ & $\mathrm{a}$ & $3,19 \pm 0,39$ & $\mathrm{a}$ \\
\hline & & & ritkított & $4,78 \pm 0,47$ & $\mathrm{~b}$ & $10,5 \pm 2,7$ & $\mathrm{~b}$ & $3,31 \pm 0,45$ & $\mathrm{a}$ \\
\hline & \multirow{6}{*}{ Hybrid 222} & & kontroll & $1,64 \pm 0,29$ & $\mathrm{a}$ & $9,6 \pm 2,2$ & $\mathrm{a}$ & $3,58 \pm 0,88$ & $\mathrm{a}$ \\
\hline & & 11 & ritkított & $2,09 \pm 0,27$ & $\mathrm{~b}$ & $8,8 \pm 2,2$ & $\mathrm{a}$ & $3,91 \pm 0,48$ & $\mathrm{a}$ \\
\hline & & $\mathbf{T}$ & kontroll & $2,61 \pm 0,35$ & $\mathrm{a}$ & $9,4 \pm 2,0$ & $\mathrm{a}$ & $2,23 \pm 0,36$ & $\mathrm{a}$ \\
\hline & & 12 & ritkított & $2,66 \pm 0,35$ & $\mathrm{a}$ & $10,3 \pm 3,1$ & $\mathrm{a}$ & $3,08 \pm 0,45$ & $\mathrm{~b}$ \\
\hline & & & kontroll & $3,57 \pm 0,42$ & $\mathrm{a}$ & $7,3 \pm 2,0$ & $\mathrm{a}$ & $1,45 \pm 0,20$ & $\mathrm{a}$ \\
\hline & & 13 & ritkított & $3,86 \pm 0,55$ & $\mathrm{~b}$ & $8,2 \pm 2,1$ & $\mathrm{a}$ & $1,59 \pm 0,18$ & $\mathrm{~b}$ \\
\hline & & T1 & kontroll & $2,07 \pm 0,33$ & $\mathrm{a}$ & $11,3 \pm 2,6$ & $\mathrm{a}$ & $3,92 \pm 1,18$ & $\mathrm{a}$ \\
\hline & & 11 & ritkított & $2,48 \pm 0,29$ & $\mathrm{~b}$ & $11,5 \pm 1,9$ & $\mathrm{a}$ & $3,94 \pm 0,78$ & $\mathrm{a}$ \\
\hline & Mar & T? & kontroll & $2,89 \pm 0,42$ & $\mathrm{a}$ & $9,3 \pm 2,2$ & $\mathrm{a}$ & $3,02 \pm 0,91$ & $\mathrm{a}$ \\
\hline & Merton Prem. & 12 & ritkított & $3,38 \pm 0,36$ & $\mathrm{~b}$ & $9,9 \pm 1,8$ & $\mathrm{a}$ & $3,20 \pm 0,46$ & $\mathrm{a}$ \\
\hline & & $\mathbf{T}$ & kontroll & $3,71 \pm 0,43$ & $\mathrm{a}$ & $5,4 \pm 2,2$ & $\mathrm{a}$ & $1,25 \pm 0,55$ & 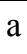 \\
\hline & & 15 & ritkított & $3,72 \pm 0,37$ & $\mathrm{a}$ & $5,2 \pm 1,9$ & $\mathrm{a}$ & $1,74 \pm 0,42$ & $\mathrm{~b}$ \\
\hline
\end{tabular}

${ }^{1}$ A különböző betűk a szignifikánsan különböző csoportokat jelölik. Az elemzést MANOVA módszerrel végeztük $\mathrm{p}<0,05$ szinten, szóráshomogenitás esetén Tukey, enyhe sérülése esetén Games-Howell post hoc tesztet alkalmazva. 
25. táblázat: Q10 ültetvény cseresznyegyümölcseinek gyümölcstömege, csontártömege, hasznos gyümölcs aránya (1.)

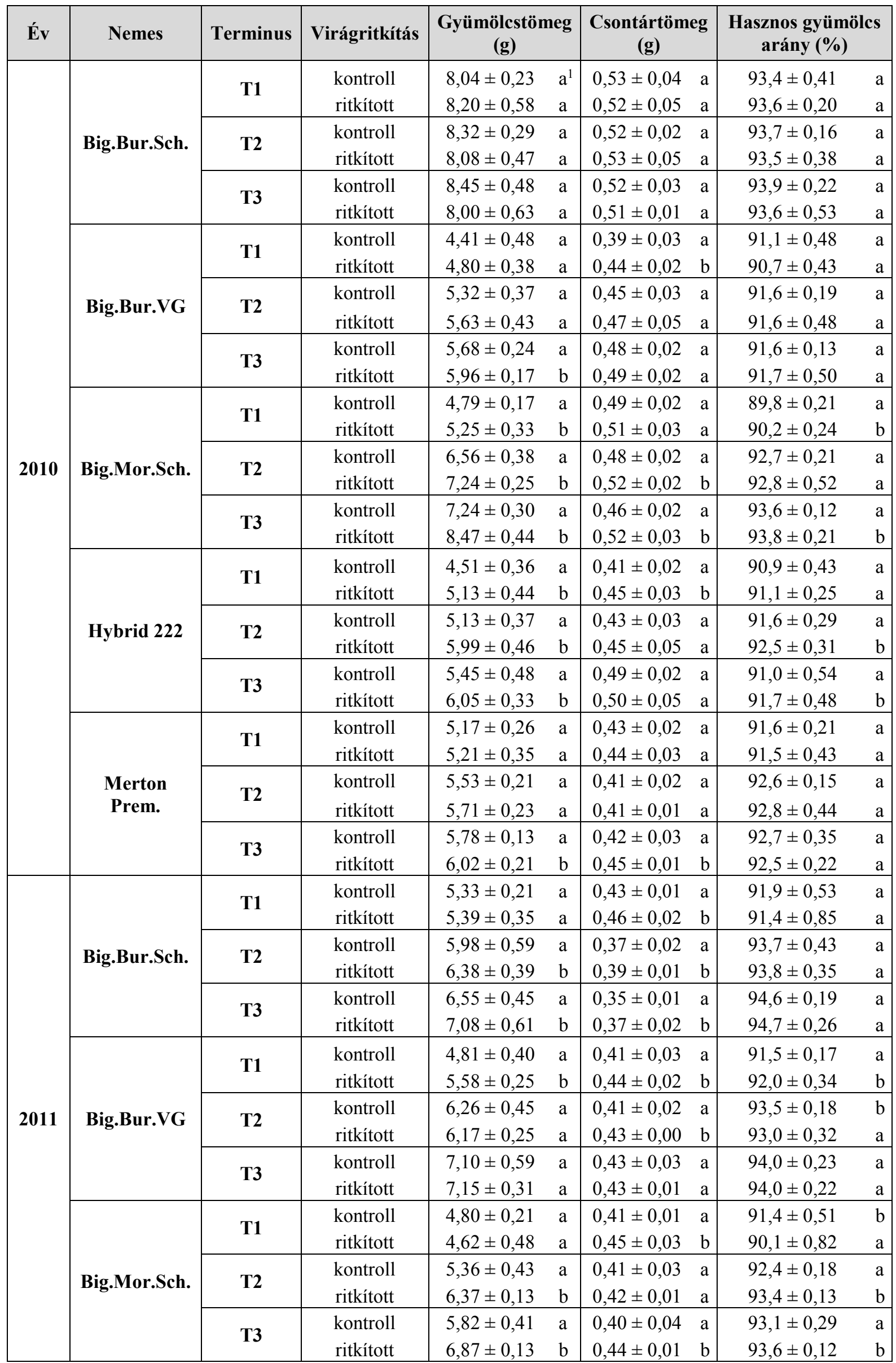

1ª különböző betűk a szignifikánsan különböző csoportokat jelölik, MANOVA, p<0,05 (Tukey / Games-Howell) 
25. táblázat: Q10 ültetvény cseresznyegyümölcseinek gyümölcstömege, csontártömege, hasznos gyümölcs aránya (2.)

\begin{tabular}{|c|c|c|c|c|c|c|c|c|}
\hline Év & Nemes & Terminus & Virágritkítás & $\begin{array}{c}\text { Gyümölcstöm } \\
\text { (g) }\end{array}$ & & $\begin{array}{c}\text { Csontártömeg } \\
\text { (g) }\end{array}$ & $\begin{array}{c}\text { Hasznos gyümölc } \\
\text { arány }(\%)\end{array}$ & \\
\hline \multirow{11}{*}{2011} & \multirow{5}{*}{ Hybrid 222} & T1 & kontroll & $\begin{array}{l}4,71 \pm 0,32 \\
5,28+036\end{array}$ & & $\begin{array}{l}0,43 \pm 0,02 \quad \mathrm{a} \\
0,42 \pm 0,02\end{array}$ & $\begin{array}{l}90,9 \pm 0,51 \\
920 \pm 026\end{array}$ & \\
\hline & & \multirow{2}{*}{$\mathbf{T 2}$} & kontroll & $6,22 \pm 0,58$ & $\mathrm{a}$ & $0,42 \pm 0,02 \quad \mathrm{a}$ & $93,2 \pm 0,33$ & $\mathrm{a}$ \\
\hline & & & ritkított & $6,60 \pm 0,39$ & $\mathrm{a}$ & $0,44 \pm 0,02 \quad b$ & $93,3 \pm 0,16$ & $\mathrm{a}$ \\
\hline & & \multirow{2}{*}{ T3 } & kontroll & $7,15 \pm 0,68$ & $\mathrm{a}$ & $0,44 \pm 0,04 \quad a$ & $93,8 \pm 0,23$ & $\mathrm{a}$ \\
\hline & & & ritkított & $7,37 \pm 0,62$ & $\mathrm{a}$ & $0,43 \pm 0,02 \quad a$ & $94,1 \pm 0,33$ & $\mathrm{a}$ \\
\hline & \multirow{6}{*}{$\begin{array}{l}\text { Merton } \\
\text { Prem. }\end{array}$} & \multirow{2}{*}{ T1 } & kontroll & $4,32 \pm 0,19$ & $\mathrm{a}$ & $0,39 \pm 0,02 \quad a$ & $91,0 \pm 0,21$ & $\mathrm{a}$ \\
\hline & & & ritkított & $4,67 \pm 0,20$ & $\mathrm{~b}$ & $0,41 \pm 0,02 \quad \mathrm{a}$ & $91,2 \pm 0,24$ & $\mathrm{~b}$ \\
\hline & & \multirow{2}{*}{$\mathbf{T 2}$} & kontroll & $5,11 \pm 0,25$ & $\mathrm{a}$ & $0,39 \pm 0,03 \quad a$ & $92,3 \pm 0,49$ & $\mathrm{a}$ \\
\hline & & & ritkított & $5,39 \pm 0,13$ & $\mathrm{~b}$ & $0,38 \pm 0,01 \quad a$ & $92,9 \pm 0,20$ & $\mathrm{~b}$ \\
\hline & & \multirow{2}{*}{$\mathbf{T 3}$} & kontroll & $6,17 \pm 0,25$ & $\mathrm{a}$ & $0,38 \pm 0,04 \quad a$ & $93,8 \pm 0,46$ & $\mathrm{a}$ \\
\hline & & & ritkított & $6,67 \pm 0,22$ & $\mathrm{~b}$ & $0,41 \pm 0,02 \quad \mathrm{a}$ & $93,9 \pm 0,22$ & $\mathrm{a}$ \\
\hline \multirow{29}{*}{2012} & \multirow{6}{*}{ Big.Bur.Sch. } & \multirow{2}{*}{ T1 } & kontroll & $4,49 \pm 0,18$ & $\mathrm{a}$ & $0,56 \pm 0,04 \quad a$ & $87,4 \pm 1,26$ & $\mathrm{a}$ \\
\hline & & & ritkított & $4,78 \pm 0,26$ & $\mathrm{~b}$ & $0,60 \pm 0,04 \quad \mathrm{a}$ & $87,5 \pm 0,89$ & $\mathrm{a}$ \\
\hline & & \multirow{2}{*}{$\mathbf{T} 2$} & kontroll & $5,78 \pm 0,33$ & $\mathrm{a}$ & $0,54 \pm 0,06 \quad \mathrm{a}$ & $90,6 \pm 0,80$ & $\mathrm{a}$ \\
\hline & & & ritkított & $6,41 \pm 0,14$ & $\mathrm{~b}$ & $0,54 \pm 0,03 \quad \mathrm{a}$ & $91,6 \pm 0,41$ & $\mathrm{~b}$ \\
\hline & & \multirow{2}{*}{ T3 } & kontroll & $5,71 \pm 0,12$ & $\mathrm{a}$ & $0,47 \pm 0,03 \quad \mathrm{a}$ & $91,7 \pm 0,35$ & $\mathrm{a}$ \\
\hline & & & ritkított & $6,44 \pm 0,17$ & $\mathrm{~b}$ & $0,55 \pm 0,04 \quad b$ & $91,5 \pm 0,44$ & $\mathrm{a}$ \\
\hline & \multirow{6}{*}{ Big.Bur.VG } & \multirow{2}{*}{ T1 } & kontroll & $2,84 \pm 0,23$ & $\mathrm{a}$ & $0,34 \pm 0,02 \quad a$ & $88,0 \pm 0,32$ & $\mathrm{a}$ \\
\hline & & & ritkított & $3,52 \pm 0,30$ & $\mathrm{~b}$ & $0,36 \pm 0,01 \quad b$ & $89,6 \pm 0,96$ & $\mathrm{~b}$ \\
\hline & & \multirow{2}{*}{$\mathbf{T} 2$} & kontroll & $3,37 \pm 0,30$ & $\mathrm{a}$ & $0,34 \pm 0,03 \quad a$ & $90,0 \pm 0,41$ & $\mathrm{a}$ \\
\hline & & & ritkított & $4,12 \pm 0,23$ & $\mathrm{~b}$ & $0,35 \pm 0,02 \quad a$ & $91,5 \pm 0,65$ & $\mathrm{~b}$ \\
\hline & & \multirow{2}{*}{$\mathbf{T 3}$} & kontroll & $4,76 \pm 0,24$ & $\mathrm{a}$ & $0,32 \pm 0,02 \quad \mathrm{a}$ & $93,3 \pm 0,23$ & $\mathrm{a}$ \\
\hline & & & ritkított & $5,41 \pm 0,21$ & $\mathrm{~b}$ & $0,34 \pm 0,02 \quad \mathrm{a}$ & $93,8 \pm 0,18$ & $\mathrm{~b}$ \\
\hline & \multirow{5}{*}{ Big.Mor.Sch. } & T1 & $\begin{array}{l}\text { kontroll } \\
\text { ritkított }\end{array}$ & $\begin{array}{l}\text { n. a. } \\
\text { n. a. }\end{array}$ & & $\begin{array}{l}\text { n. a. } \\
\text { n. a. }\end{array}$ & $\begin{array}{l}\text { n. a. } \\
\text { n. a. }\end{array}$ & \\
\hline & & \multirow{2}{*}{$\mathbf{T} 2$} & kontroll & $5,27 \pm 0,49$ & $\mathrm{a}$ & $0,52 \pm 0,04 \quad \mathrm{a}$ & $90,0 \pm 0,92$ & \\
\hline & & & ritkított & $5,45 \pm 0,17$ & $\mathrm{a}$ & $0,53 \pm 0,04 \quad \mathrm{a}$ & $90,3 \pm 0,42$ & $\mathrm{a}$ \\
\hline & & \multirow{2}{*}{ T3 } & kontroll & $5,60 \pm 0,39$ & $\mathrm{a}$ & $0,43 \pm 0,04 \quad \mathrm{a}$ & $92,2 \pm 0,47$ & $\mathrm{a}$ \\
\hline & & & ritkított & $6,29 \pm 0,05$ & $\mathrm{~b}$ & $0,48 \pm 0,03 \quad b$ & $92,3 \pm 0,56$ & $\mathrm{a}$ \\
\hline & \multirow{6}{*}{ Hybrid 222} & \multirow{2}{*}{ T1 } & kontroll & $2,59 \pm 0,20$ & $\mathrm{a}$ & $0,33 \pm 0,02 \quad a$ & $87,4 \pm 0,46$ & $\mathrm{a}$ \\
\hline & & & ritkított & $3,17 \pm 0,08$ & $\mathrm{~b}$ & $0,35 \pm 0,02 \quad b$ & $89,0 \pm 0,73$ & $\mathrm{~b}$ \\
\hline & & T? & kontroll & $3,38 \pm 0,24$ & $\mathrm{a}$ & $0,33 \pm 0,02 \quad a$ & $90,3 \pm 0,67$ & $\mathrm{a}$ \\
\hline & & 12 & ritkított & $3,41 \pm 0,18$ & $\mathrm{a}$ & $0,32 \pm 0,02 \quad a$ & $90,5 \pm 0,24$ & $\mathrm{a}$ \\
\hline & & T3 & kontroll & $4,75 \pm 0,14$ & $\mathrm{a}$ & $0,31 \pm 0,01 \quad \mathrm{a}$ & $93,5 \pm 0,31$ & $\mathrm{a}$ \\
\hline & & 13 & ritkított & $5,19 \pm 0,15$ & $\mathrm{~b}$ & $0,31 \pm 0,01 \quad \mathrm{a}$ & $94,0 \pm 0,07$ & $\mathrm{~b}$ \\
\hline & & T1 & kontroll & $3,11 \pm 0,26$ & $\mathrm{a}$ & $0,42 \pm 0,04 \quad a$ & $86,3 \pm 0,70$ & $\mathrm{a}$ \\
\hline & & 11 & ritkított & $3,52 \pm 0,08$ & $\mathrm{~b}$ & $0,44 \pm 0,04 \quad a$ & $87,4 \pm 0,93$ & $\mathrm{~b}$ \\
\hline & Merton & T2 & kontroll & $3,84 \pm 0,30$ & $\mathrm{a}$ & $0,39 \pm 0,01 \quad a$ & $89,7 \pm 0,84$ & $\mathrm{a}$ \\
\hline & Prem. & 12 & ritkított & $4,37 \pm 0,21$ & $\mathrm{~b}$ & $0,43 \pm 0,01 \quad b$ & $90,2 \pm 0,44$ & $\mathrm{a}$ \\
\hline & & T3 & kontroll & $5,13 \pm 0,31$ & $\mathrm{a}$ & $0,36 \pm 0,00 \quad a$ & $93,0 \pm 0,46$ & $\mathrm{a}$ \\
\hline & & & ritkított & $5,19 \pm 0,14$ & $\mathrm{a}$ & $0,37 \pm 0,02 \quad b$ & $92,8 \pm 0,15$ & $\mathrm{a}$ \\
\hline
\end{tabular}

${ }^{1}$ A különböző betűk a szignifikánsan különböző csoportokat jelölik. Az elemzést MANOVA módszerrel végeztük p $<0,05$ szinten, szóráshomogenitás esetén Tukey, enyhe sérülése esetén Games-Howell post hoc tesztet alkalmazva. 
26. táblázat: Q10 ültetvény cseresznyegyümölcseinek héjszín-paraméterei (1.)

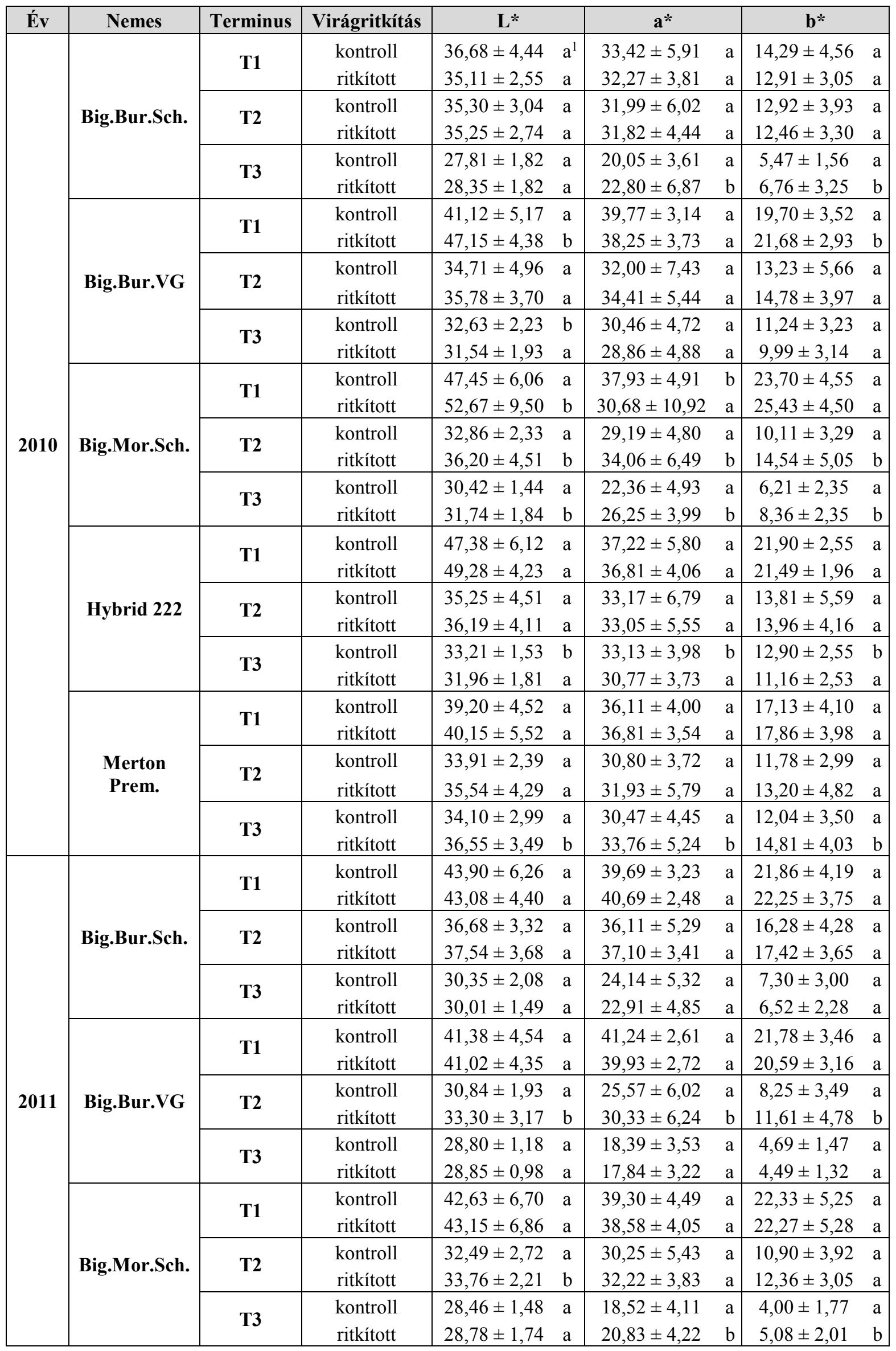

1a különböző betűk a szignifikánsan különböző csoportokat jelölik, MANOVA, p<0,05 (Tukey / Games-Howell) 
26. táblázat: Q10 ültetvény cseresznyegyümölcseinek héjszín-paraméterei (2.)

\begin{tabular}{|c|c|c|c|c|c|c|c|c|c|}
\hline Év & Nemes & Terminus & Virágritkítás & $\mathbf{L *}$ & & $a^{*}$ & & $\mathbf{b}^{*}$ & \\
\hline \multirow{11}{*}{2011} & \multirow{5}{*}{ Hybrid 222} & $\mathbf{T 1}$ & kontroll & $\begin{array}{l}41,62 \pm 4,96 \\
39,94 \pm 4,61\end{array}$ & & $\begin{array}{l}40,04 \pm 2,67 \\
38,44 \pm 3,73\end{array}$ & a & $\begin{array}{l}21,04 \pm 3,16 \\
1947 \pm 409\end{array}$ & $\mathrm{a}$ \\
\hline & & \multirow{2}{*}{$\mathbf{T 2}$} & & $31.11 \pm 2,45$ & $\mathrm{a}$ & $26,45 \pm 5.22$ & $\mathrm{a}$ & $8.67 \pm 3.39$ & $\mathrm{a}$ \\
\hline & & & ritkított & $30,06 \pm 1,87$ & $\mathrm{a}$ & $24,59 \pm 4,61$ & $\mathrm{a}$ & $7,49 \pm 2,63$ & $\mathrm{a}$ \\
\hline & & \multirow{2}{*}{ T3 } & kontroll & $29,18 \pm 1,13$ & $\mathrm{~b}$ & $19,83 \pm 3,85$ & $\mathrm{~b}$ & $5,27 \pm 1,67$ & $\mathrm{~b}$ \\
\hline & & & ritkított & $28,47 \pm 1,30$ & $\mathrm{a}$ & $17,39 \pm 4,02$ & $\mathrm{a}$ & $4,20 \pm 1,65$ & $\mathrm{a}$ \\
\hline & \multirow{6}{*}{$\begin{array}{c}\text { Merton } \\
\text { Prem. }\end{array}$} & \multirow{2}{*}{$\mathbf{T 1}$} & kontroll & $45,27 \pm 3,55$ & $\mathrm{a}$ & $41,48 \pm 1,90$ & $\mathrm{a}$ & $25,43 \pm 2,17$ & $\mathrm{a}$ \\
\hline & & & ritkított & $45,05 \pm 3,25$ & $\mathrm{a}$ & $41,11 \pm 1,39$ & $\mathrm{a}$ & $24,74 \pm 2,33$ & $\mathrm{a}$ \\
\hline & & \multirow{2}{*}{$\mathbf{T} 2$} & kontroll & $36,64 \pm 2,73$ & $\mathrm{a}$ & $37,30 \pm 3,21$ & $\mathrm{a}$ & $17,10 \pm 3,43$ & $\mathrm{a}$ \\
\hline & & & ritkított & $38,16 \pm 3,00$ & $\mathrm{~b}$ & $37,44 \pm 2,90$ & $\mathrm{a}$ & $17,68 \pm 3,31$ & $\mathrm{a}$ \\
\hline & & \multirow{2}{*}{ T3 } & kontroll & $29,67 \pm 1,59$ & $\mathrm{a}$ & $21,60 \pm 4,77$ & $\mathrm{a}$ & $5,93 \pm 2,41$ & $\mathrm{a}$ \\
\hline & & & ritkított & $30,22 \pm 1,33$ & $\mathrm{a}$ & $24,10 \pm 4,13$ & $\mathrm{~b}$ & $7,13 \pm 2,11$ & $\mathrm{~b}$ \\
\hline \multirow{29}{*}{2012} & \multirow{6}{*}{ Big.Bur.Sch. } & \multirow{2}{*}{$\mathbf{T 1}$} & kontroll & $50,38 \pm 4,02$ & $\mathrm{a}$ & $41,71 \pm 3,15$ & $\mathrm{a}$ & $26,29 \pm 2,21$ & $\mathrm{a}$ \\
\hline & & & ritkított & $48,09 \pm 6,21$ & $\mathrm{a}$ & $41,68 \pm 3,95$ & $\mathrm{a}$ & $25,45 \pm 4,28$ & $\mathrm{a}$ \\
\hline & & \multirow{2}{*}{$\mathbf{T 2}$} & kontroll & $38,63 \pm 4,42$ & $\mathrm{~b}$ & $36,44 \pm 5,01$ & $\mathrm{~b}$ & $17,61 \pm 4,38$ & $\mathrm{~b}$ \\
\hline & & & ritkított & $36,27 \pm 4,00$ & $\mathrm{a}$ & $31,07 \pm 7,18$ & $\mathrm{a}$ & $14,33 \pm 5,06$ & $\mathrm{a}$ \\
\hline & & \multirow{2}{*}{ T3 } & kontroll & $34,40 \pm 3,72$ & $\mathrm{a}$ & $29,45 \pm 7,92$ & $\mathrm{~b}$ & $12,54 \pm 5,08$ & $\mathrm{~b}$ \\
\hline & & & ritkított & $33,15 \pm 2,34$ & $\mathrm{a}$ & $25,00 \pm 6,18$ & $\mathrm{a}$ & $10,07 \pm 3,41$ & $\mathrm{a}$ \\
\hline & \multirow{6}{*}{ Big.Bur.VG } & \multirow{2}{*}{ T1 } & kontroll & $51,75 \pm 4,40$ & $\mathrm{a}$ & $42,72 \pm 3,42$ & $\mathrm{~b}$ & $29,50 \pm 2,66$ & $\mathrm{a}$ \\
\hline & & & ritkított & $53,16 \pm 6,50$ & $\mathrm{a}$ & $39,68 \pm 5,86$ & $\mathrm{a}$ & $28,94 \pm 3,52$ & $\mathrm{a}$ \\
\hline & & \multirow{2}{*}{$\mathbf{T} 2$} & kontroll & $37,34 \pm 3,84$ & $\mathrm{a}$ & $36,76 \pm 7,75$ & $\mathrm{a}$ & $18,16 \pm 4,76$ & $\mathrm{a}$ \\
\hline & & & ritkított & $39,99 \pm 5,03$ & $\mathrm{~b}$ & $40,06 \pm 4,50$ & $\mathrm{~b}$ & $20,15 \pm 4,81$ & $\mathrm{a}$ \\
\hline & & \multirow{2}{*}{ T3 } & kontroll & $30,14 \pm 2,15$ & $\mathrm{a}$ & $18,84 \pm 6,95$ & $\mathrm{a}$ & $6,65 \pm 2,83$ & $\mathrm{~b}$ \\
\hline & & & ritkított & $29,80 \pm 1,21$ & $\mathrm{a}$ & $16,36 \pm 3,79$ & $\mathrm{a}$ & $5,50 \pm 1,34$ & $\mathrm{a}$ \\
\hline & \multirow{5}{*}{ Big.Mor.Sch. } & T1 & $\begin{array}{l}\text { kontroll } \\
\text { ritkított }\end{array}$ & $\begin{array}{l}\text { n. a. } \\
\text { n. a. }\end{array}$ & & $\begin{array}{l}\text { n. a. } \\
\text { n. a. }\end{array}$ & & $\begin{array}{l}\text { n. a. } \\
\text { n. a. }\end{array}$ & \\
\hline & & \multirow{2}{*}{ T2 } & kontroll & $34,85 \pm 3,05$ & $\mathrm{a}$ & $31,55 \pm 6,63$ & $\mathrm{a}$ & $13,49 \pm 4,73$ & $\mathrm{a}$ \\
\hline & & & ritkított & $35,39 \pm 4,14$ & $\mathrm{a}$ & $33,09 \pm 6,41$ & $\mathrm{a}$ & $14,52 \pm 5,32$ & $\mathrm{a}$ \\
\hline & & \multirow{2}{*}{ T3 } & kontroll & $30,10 \pm 1,86$ & $\mathrm{a}$ & $18,58 \pm 5,65$ & $\mathrm{a}$ & $6,21 \pm 2,08$ & $\mathrm{a}$ \\
\hline & & & ritkított & $32,84 \pm 2,80$ & $\mathrm{~b}$ & $23,71 \pm 7,77$ & $\mathrm{~b}$ & $9,06 \pm 4,23$ & $\mathrm{~b}$ \\
\hline & \multirow{6}{*}{ Hybrid 222} & \multirow{2}{*}{ T1 } & kontroll & $56,00 \pm 5,22$ & $\mathrm{~b}$ & $38,76 \pm 6,26$ & $\mathrm{a}$ & $32,22 \pm 2,05$ & $\mathrm{~b}$ \\
\hline & & & ritkított & $53,37 \pm 4,33$ & $\mathrm{a}$ & $40,32 \pm 4,64$ & $\mathrm{a}$ & $29,88 \pm 2,98$ & $\mathrm{a}$ \\
\hline & & T2 & kontroll & $37,97 \pm 4,01$ & $\mathrm{a}$ & $38,17 \pm 6,28$ & $\mathrm{a}$ & $18,26 \pm 5,30$ & $\mathrm{a}$ \\
\hline & & 12 & ritkított & $38,71 \pm 4,04$ & $\mathrm{a}$ & $40,12 \pm 4,72$ & $\mathrm{a}$ & $19,59 \pm 4,57$ & $\mathrm{a}$ \\
\hline & & T & kontroll & $31,53 \pm 1,72$ & $\mathrm{a}$ & $22,20 \pm 6,75$ & $\mathrm{a}$ & $8,00 \pm 2,79$ & $\mathrm{a}$ \\
\hline & & 15 & ritkított & $31,47 \pm 1,45$ & $\mathrm{a}$ & $23,70 \pm 4,14$ & $\mathrm{a}$ & $8,24 \pm 1,87$ & $\mathrm{a}$ \\
\hline & & $\mathbf{T}$ & kontroll & $55,94 \pm 4,01$ & $\mathrm{a}$ & $38,25 \pm 4,08$ & $\mathrm{a}$ & $33,09 \pm 2,47$ & $\mathrm{a}$ \\
\hline & & 11 & ritkított & $54,76 \pm 4,54$ & $\mathrm{a}$ & $39,97 \pm 4,19$ & $\mathrm{a}$ & $31,02 \pm 1,89$ & $\mathrm{~b}$ \\
\hline & Merton & $\mathbf{T}$ & kontroll & $39,14 \pm 4,48$ & $\mathrm{a}$ & $37,66 \pm 5,37$ & $\mathrm{a}$ & $19,28 \pm 5,33$ & $\mathrm{a}$ \\
\hline & Prem. & 12 & ritkított & $41,52 \pm 2,80$ & $\mathrm{~b}$ & $41,46 \pm 3,18$ & $\mathrm{~b}$ & $21,98 \pm 3,18$ & $\mathrm{~b}$ \\
\hline & & T3 & kontroll & $30,41 \pm 1,60$ & $\mathrm{a}$ & $18,73 \pm 4,95$ & $\mathrm{a}$ & $6,94 \pm 1,77$ & $\mathrm{a}$ \\
\hline & & & ritkított & $31,82 \pm 1,46$ & $\mathrm{~b}$ & $22,38 \pm 5,69$ & $\mathrm{~b}$ & $8,38 \pm 2,26$ & $\mathrm{~b}$ \\
\hline
\end{tabular}

${ }^{1}$ A különböző betük a szignifikánsan különböző csoportokat jelölik. Az elemzést MANOVA módszerrel végeztük p $<0,05$ szinten, szóráshomogenitás esetén Tukey, enyhe sérülése esetén Games-Howell post hoc tesztet alkalmazva. 
27. táblázat: 'Regina' és 'Kordia' cseresznyefajta gyümölcseinek TSS, TA és TSS/TA értékei különböző alanyokon (1.)

\begin{tabular}{|c|c|c|c|c|c|c|c|c|c|}
\hline Év & Nemes & Terminus & Alany & $\begin{array}{c}\text { TSS } \\
\text { ('Brix) }\end{array}$ & & $\begin{array}{c}\text { TA } \\
\text { (mg MAE/m }\end{array}$ & & TSS/TA & \\
\hline \multirow{15}{*}{2010} & \multirow{15}{*}{ Kordia } & \multirow{5}{*}{ T1 } & GiSelA 5 & $9,85 \pm 0,14$ & $a^{1}$ & $7,66 \pm 0,06$ & & $1,29 \pm 0,01$ & $\mathrm{a}$ \\
\hline & & & GiSelA 6 & $11,40 \pm 0,08$ & $\mathrm{~b}$ & $7,97 \pm 0,26$ & & $1,43 \pm 0,06$ & $\mathrm{ab}$ \\
\hline & & & PHL-C & $11,30 \pm 0,17$ & $\mathrm{~b}$ & $6,62 \pm 0,69$ & $\mathrm{a}$ & $1,72 \pm 0,15$ & $\mathrm{c}$ \\
\hline & & & PiKu 1 & $11,15 \pm 0,30$ & $\mathrm{~b}$ & $7,42 \pm 0,21$ & $\mathrm{~b}$ & $1,50 \pm 0,00$ & $\mathrm{~b}$ \\
\hline & & & Weiroot 158 & $11,10 \pm 0,28$ & $\mathrm{~b}$ & $8,42 \pm 0,14$ & $\mathrm{c}$ & $1,32 \pm 0,01$ & $\mathrm{a}$ \\
\hline & & \multirow{5}{*}{$\mathbf{T} 2$} & GiSelA 5 & $12,75 \pm 0,37$ & $\mathrm{a}$ & $7,85 \pm 0,53$ & $a b$ & $1,63 \pm 0,16$ & $a b$ \\
\hline & & & GiSelA 6 & $13,60 \pm 0,10$ & $\mathrm{a}$ & $7,40 \pm 0,16$ & $\mathrm{a}$ & $1,84 \pm 0,05$ & $\mathrm{c}$ \\
\hline & & & PHL-C & $14,50 \pm 0,33$ & $\mathrm{~b}$ & $7,63 \pm 0,03$ & $\mathrm{a}$ & $1,90 \pm 0,05$ & $\mathrm{c}$ \\
\hline & & & PiKu 1 & $13,30 \pm 0,49$ & $\mathrm{a}$ & $7,28 \pm 0,10$ & $\mathrm{a}$ & $1,83 \pm 0,09$ & $\mathrm{bc}$ \\
\hline & & & Weiroot 158 & $13,60 \pm 0,08$ & $\mathrm{a}$ & $8,47 \pm 0,42$ & $\mathrm{~b}$ & $1,61 \pm 0,07$ & $\mathrm{a}$ \\
\hline & & \multirow{5}{*}{ T3 } & GiSelA 5 & $12,60 \pm 0,08$ & $\mathrm{a}$ & $5,67 \pm 0,11$ & $\mathrm{ab}$ & $2,22 \pm 0,06$ & $a b$ \\
\hline & & & GiSelA 6 & $13,20 \pm 0,00$ & $\mathrm{~b}$ & $5,84 \pm 0,02$ & $\mathrm{~b}$ & $2,26 \pm 0,01$ & $\mathrm{~b}$ \\
\hline & & & PHL-C & $13,90 \pm 0,26$ & $\mathrm{c}$ & $5,46 \pm 0,11$ & $\mathrm{a}$ & $2,55 \pm 0,10$ & $\mathrm{c}$ \\
\hline & & & $\mathrm{PiKu} 1$ & $13,95 \pm 0,12$ & $\mathrm{c}$ & $5,68 \pm 0,06$ & $\mathrm{ab}$ & $2,46 \pm 0,05$ & $\mathrm{c}$ \\
\hline & & & Weiroot 158 & $13,20 \pm 0,17$ & $\mathrm{~b}$ & $6,21 \pm 0,23$ & $\mathrm{c}$ & $2,13 \pm 0,05$ & $\mathrm{a}$ \\
\hline \multirow{15}{*}{2010} & \multirow{15}{*}{ Regina } & \multirow{5}{*}{ T1 } & GiSelA 5 & $13,40 \pm 0,25$ & bc & $4,42 \pm 0,31$ & $\mathrm{a}$ & $3,04 \pm 0,15$ & d \\
\hline & & & GiSelA 6 & $13,55 \pm 0,04$ & $\mathrm{c}$ & $5,22 \pm 0,11$ & $\mathrm{~b}$ & $2,60 \pm 0,05$ & $\mathrm{~b}$ \\
\hline & & & PHL-C & $12,50 \pm 0,09$ & $\mathrm{a}$ & $5,27 \pm 0,21$ & $\mathrm{~b}$ & $2,38 \pm 0,08$ & $\mathrm{a}$ \\
\hline & & & PiKu 1 & $13,15 \pm 0,04$ & $\mathrm{~b}$ & $4,65 \pm 0,00$ & $\mathrm{a}$ & $2,83 \pm 0,01$ & $\mathrm{c}$ \\
\hline & & & Weiroot 158 & $13,20 \pm 0,18$ & $\mathrm{~b}$ & $5,15 \pm 0,02$ & $\mathrm{~b}$ & $2,56 \pm 0,03$ & $\mathrm{~b}$ \\
\hline & & \multirow{5}{*}{$\mathbf{T 2}$} & GiSelA 5 & $15,25 \pm 0,04$ & $\mathrm{~cd}$ & $5,01 \pm 0,08$ & $\mathrm{a}$ & $3,05 \pm 0,04$ & $\mathrm{~d}$ \\
\hline & & & GiSelA 6 & $14,80 \pm 0,00$ & $\mathrm{~b}$ & $6,00 \pm 0,38$ & $\mathrm{c}$ & $2,48 \pm 0,16$ & $a b$ \\
\hline & & & PHL-C & $14,25 \pm 0,23$ & $\mathrm{a}$ & $5,77 \pm 0,11$ & $\mathrm{bc}$ & $2,47 \pm 0,01$ & $\mathrm{a}$ \\
\hline & & & PiKu 1 & $15,45 \pm 0,05$ & d & $5,52 \pm 0,07$ & $\mathrm{~b}$ & $2,80 \pm 0,04$ & $\mathrm{c}$ \\
\hline & & & Weiroot 158 & $14,95 \pm 0,23$ & $\mathrm{bc}$ & $5,67 \pm 0,14$ & $\mathrm{bc}$ & $2,64 \pm 0,03$ & $\mathrm{bc}$ \\
\hline & & \multirow{5}{*}{ T3 } & GiSelA 5 & $17,45 \pm 0,53$ & $\mathrm{~b}$ & $5,46 \pm 0,10$ & $\mathrm{a}$ & $3,20 \pm 0,04$ & $\mathrm{c}$ \\
\hline & & & GiSelA 6 & $17,60 \pm 0,08$ & $\mathrm{~b}$ & $6,33 \pm 0,06$ & $\mathrm{~b}$ & $2,78 \pm 0,04$ & $a b$ \\
\hline & & & PHL-C & $16,30 \pm 0,44$ & $\mathrm{a}$ & $6,16 \pm 0,50$ & $\mathrm{~b}$ & $2,66 \pm 0,14$ & $\mathrm{a}$ \\
\hline & & & PiKu 1 & $18,20 \pm 0,27$ & $\mathrm{c}$ & $6,42 \pm 0,13$ & $\mathrm{~b}$ & $2,83 \pm 0,01$ & $b$ \\
\hline & & & Weiroot 158 & $17,45 \pm 0,40$ & $\mathrm{~b}$ & $6,50 \pm 0,19$ & $\mathrm{~b}$ & $2,69 \pm 0,03$ & $a b$ \\
\hline \multirow{15}{*}{2011} & \multirow{15}{*}{ Kordia } & \multirow{5}{*}{ T1 } & GiSelA 5 & $13,73 \pm 0,49$ & $\mathrm{bc}$ & $9,84 \pm 0,61$ & $a b$ & $1,40 \pm 0,08$ & $\mathrm{~b}$ \\
\hline & & & GiSelA 6 & $12,25 \pm 0,87$ & $\mathrm{a}$ & $10,83 \pm 0,09$ & $\mathrm{c}$ & $1,13 \pm 0,07$ & $\mathrm{a}$ \\
\hline & & & PHL-C & $13,18 \pm 0,19$ & $a b$ & $9,66 \pm 0,48$ & $a b$ & $1,37 \pm 0,08$ & $\mathrm{~b}$ \\
\hline & & & $\mathrm{PiKu} 1$ & $14,45 \pm 0,10$ & $\mathrm{c}$ & $9,12 \pm 0,60$ & $\mathrm{a}$ & $1,59 \pm 0,10$ & $\mathrm{c}$ \\
\hline & & & Weiroot 158 & $13,68 \pm 0,51$ & $\mathrm{bc}$ & $10,35 \pm 0,21$ & $\mathrm{bc}$ & $1,32 \pm 0,06$ & $\mathrm{~b}$ \\
\hline & & \multirow{5}{*}{$\mathbf{T 2}$} & GiSelA 5 & $15,03 \pm 0,67$ & $\mathrm{a}$ & $8,97 \pm 0,15$ & $\mathrm{~b}$ & $1,67 \pm 0,06$ & $\mathrm{a}$ \\
\hline & & & GiSelA 6 & $14,85 \pm 0,48$ & $\mathrm{a}$ & $8,24 \pm 0,32$ & $\mathrm{a}$ & $1,81 \pm 0,13$ & $a b$ \\
\hline & & & PHL-C & $15,73 \pm 0,19$ & $a b$ & $8,35 \pm 0,12$ & $\mathrm{a}$ & $1,88 \pm 0,03$ & bc \\
\hline & & & PiKu 1 & $16,60 \pm 0,36$ & $\mathrm{~b}$ & $8,17 \pm 0,06$ & $\mathrm{a}$ & $2,03 \pm 0,05$ & $\mathrm{c}$ \\
\hline & & & Weiroot 158 & $16,40 \pm 0,34$ & $\mathrm{~b}$ & $8,80 \pm 0,13$ & $\mathrm{~b}$ & $1,86 \pm 0,03$ & $\mathrm{~b}$ \\
\hline & & \multirow{5}{*}{ T3 } & GiSelA 5 & $17,05 \pm 0,34$ & $\mathrm{~b}$ & $8,13 \pm 0,11$ & $\mathrm{a}$ & $2,10 \pm 0,05$ & $\mathrm{c}$ \\
\hline & & & GiSelA 6 & $15,43 \pm 0,17$ & $\mathrm{a}$ & $8,21 \pm 0,18$ & $\mathrm{a}$ & $1,88 \pm 0,03$ & $\mathrm{a}$ \\
\hline & & & PHL-C & $16,63 \pm 0,39$ & $\mathrm{~b}$ & $8,53 \pm 0,23$ & $\mathrm{a}$ & $1,95 \pm 0,03$ & $a b$ \\
\hline & & & PiKu 1 & $17,23 \pm 0,69$ & $\mathrm{~b}$ & $8,24 \pm 0,44$ & $\mathrm{a}$ & $2,09 \pm 0,09$ & $\mathrm{c}$ \\
\hline & & & Weiroot 158 & $17,03 \pm 0,40$ & $\mathrm{~b}$ & $8,55 \pm 0,22$ & $\mathrm{a}$ & $1,99 \pm 0,03$ & $\mathrm{bc}$ \\
\hline
\end{tabular}

1a különböző betűk a szignifikánsan különböző csoportokat jelölik, MANOVA, p<0,05 (Tukey / Games-Howell) 
27. táblázat: 'Regina' és 'Kordia’ cseresznyefajta gyümölcseinek TSS, TA és TSS/TA értékei (2.)

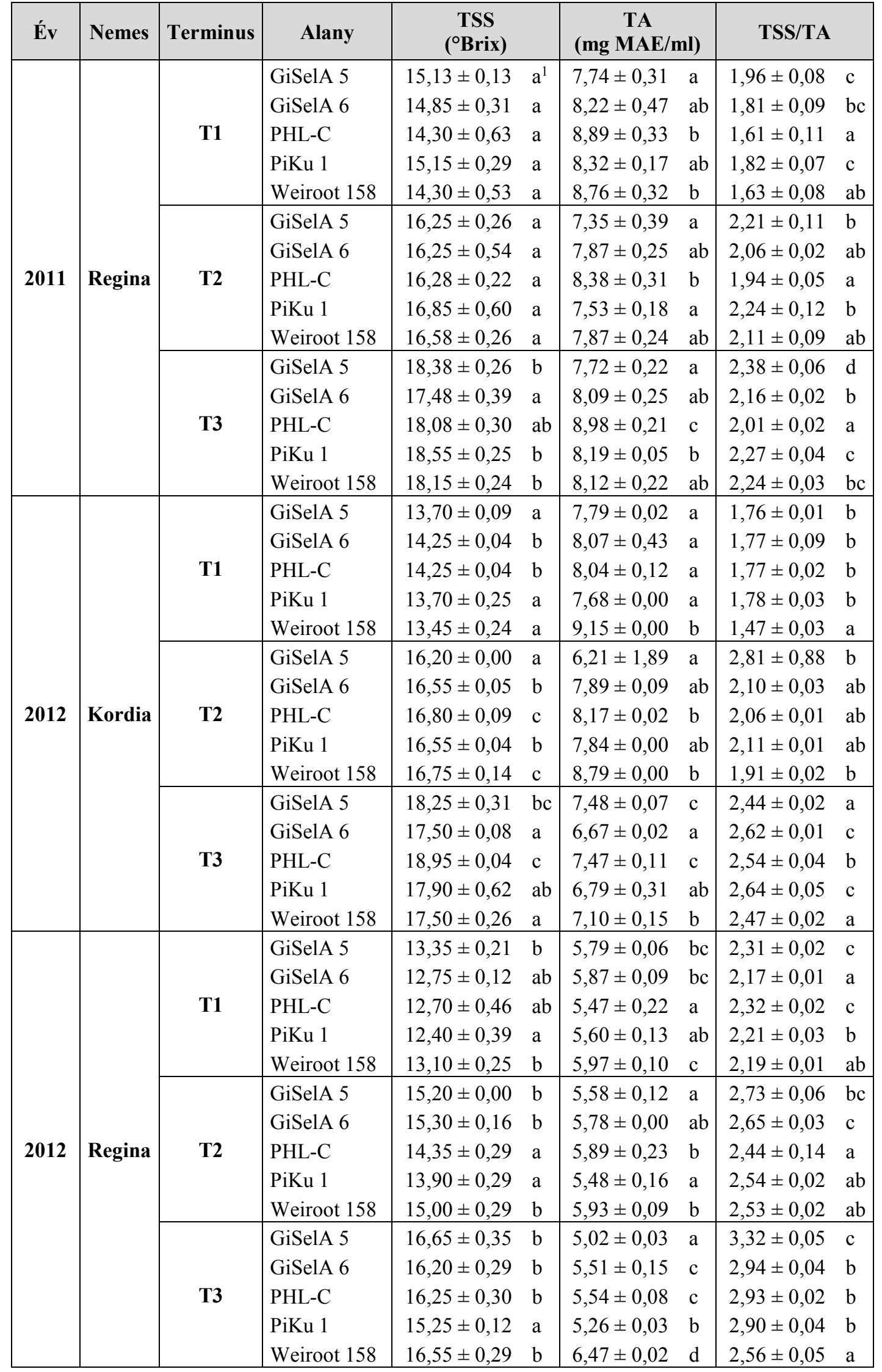

${ }^{1}$ a különböző betük a szignifikánsan különböző csoportokat jelölik, MANOVA, p<0,05 (Tukey / Games-Howell) 
27. táblázat: 'Regina' és 'Kordia' cseresznyefajta gyümölcseinek TSS, TA és TSS/TA értékei (3.)

\begin{tabular}{|c|c|c|c|c|c|c|c|c|c|}
\hline Év & Nemes & Terminus & Alany & $\begin{array}{c}\text { TSS } \\
\left({ }^{\circ} \text { Brix) }\right.\end{array}$ & & $\begin{array}{c}\text { TA } \\
(\mathrm{mg} \mathrm{MAE} / \mathrm{l}\end{array}$ & & TSS/TA & \\
\hline \multirow{15}{*}{2013} & \multirow{15}{*}{ Kordia } & \multirow{5}{*}{ T1 } & GiSelA 5 & $10,30 \pm 0,00$ & $a^{1}$ & $11,53 \pm 0,19$ & $\mathrm{c}$ & $0,89 \pm 0,01$ & $\mathrm{a}$ \\
\hline & & & GiSelA 6 & $11,30 \pm 0,00$ & $\mathrm{c}$ & $10,18 \pm 0,04$ & $\mathrm{~b}$ & $1,11 \pm 0,00$ & $\mathrm{~b}$ \\
\hline & & & PHL-C & $10,40 \pm 0,16$ & $a b$ & $9,59 \pm 0,35$ & $\mathrm{a}$ & $1,09 \pm 0,03$ & $\mathrm{~b}$ \\
\hline & & & PiKu 1 & $10,75 \pm 0,32$ & $\mathrm{~b}$ & $9,95 \pm 0,06$ & $a b$ & $1,08 \pm 0,03$ & $\mathrm{~b}$ \\
\hline & & & Weiroot 158 & $10,20 \pm 0,09$ & $\mathrm{a}$ & $11,10 \pm 0,42$ & $\mathrm{c}$ & $0,92 \pm 0,03$ & $\mathrm{a}$ \\
\hline & & \multirow{5}{*}{$\mathbf{T} 2$} & GiSelA 5 & $12,55 \pm 0,23$ & $\mathrm{a}$ & $9,93 \pm 0,43$ & $\mathrm{~b}$ & $1,26 \pm 0,03$ & $\mathrm{a}$ \\
\hline & & & GiSelA 6 & $13,00 \pm 0,10$ & $\mathrm{~b}$ & $9,49 \pm 0,12$ & $\mathrm{~b}$ & $1,37 \pm 0,01$ & $\mathrm{~b}$ \\
\hline & & & PHL-C & $13,20 \pm 0,19$ & $\mathrm{~b}$ & $8,63 \pm 0,29$ & $\mathrm{a}$ & $1,53 \pm 0,03$ & $\mathrm{c}$ \\
\hline & & & $\mathrm{PiKu} 1$ & $13,20 \pm 0,28$ & $\mathrm{~b}$ & $8,74 \pm 0,08$ & $\mathrm{a}$ & $1,51 \pm 0,02$ & $\mathrm{c}$ \\
\hline & & & Weiroot 158 & $12,55 \pm 0,05$ & $\mathrm{a}$ & $9,91 \pm 0,05$ & $\mathrm{~b}$ & $1,27 \pm 0,00$ & $\mathrm{a}$ \\
\hline & & \multirow{5}{*}{ T3 } & GiSelA 5 & $15,17 \pm 0,86$ & $a b$ & $8,97 \pm 1,64$ & $\mathrm{a}$ & $1,76 \pm 0,46$ & $\mathrm{a}$ \\
\hline & & & GiSelA 6 & $15,50 \pm 0,63$ & $a b$ & $9,26 \pm 1,46$ & $\mathrm{a}$ & $1,72 \pm 0,35$ & $\mathrm{a}$ \\
\hline & & & PHL-C & $14,73 \pm 0,31$ & $\mathrm{ab}$ & $8,35 \pm 1,64$ & $\mathrm{a}$ & $1,84 \pm 0,45$ & $\mathrm{a}$ \\
\hline & & & PiKu 1 & $15,80 \pm 0,59$ & $\mathrm{~b}$ & $9,10 \pm 2,03$ & $\mathrm{a}$ & $1,80 \pm 0,37$ & $\mathrm{a}$ \\
\hline & & & Weiroot 158 & $14,43 \pm 0,67$ & $\mathrm{a}$ & $8,17 \pm 1,29$ & $\mathrm{a}$ & $1,82 \pm 0,40$ & $\mathrm{a}$ \\
\hline \multirow{15}{*}{2013} & \multirow{15}{*}{ Regina } & \multirow{5}{*}{ T1 } & GiSelA 5 & $14,20 \pm 0,10$ & $\mathrm{c}$ & $9,56 \pm 0,23$ & $\mathrm{a}$ & $1,49 \pm 0,03$ & $\mathrm{c}$ \\
\hline & & & GiSelA 6 & $14,05 \pm 0,05$ & $\mathrm{c}$ & $10,31 \pm 0,04$ & $\mathrm{~b}$ & $1,36 \pm 0,00$ & $\mathrm{~d}$ \\
\hline & & & PHL-C & $13,85 \pm 0,29$ & $\mathrm{bc}$ & $11,52 \pm 0,36$ & $\mathrm{c}$ & $1,20 \pm 0,01$ & $\mathrm{a}$ \\
\hline & & & PiKu 1 & $13,40 \pm 0,00$ & $\mathrm{a}$ & $10,36 \pm 0,42$ & $\mathrm{~b}$ & $1,29 \pm 0,05$ & $\mathrm{~b}$ \\
\hline & & & Weiroot 158 & $13,60 \pm 0,28$ & $\mathrm{ab}$ & $10,97 \pm 0,47$ & $\mathrm{bc}$ & $1,24 \pm 0,03$ & $\mathrm{ab}$ \\
\hline & & \multirow{5}{*}{$\mathbf{T 2}$} & GiSelA 5 & $15,40 \pm 0,08$ & $\mathrm{~b}$ & $7,85 \pm 0,05$ & $a b c$ & $1,96 \pm 0,02$ & $\mathrm{bc}$ \\
\hline & & & GiSelA 6 & $15,35 \pm 0,12$ & $\mathrm{~b}$ & $7,68 \pm 0,07$ & $\mathrm{ab}$ & $2,00 \pm 0,00$ & $\mathrm{c}$ \\
\hline & & & PHL-C & $15,10 \pm 0,00$ & $a b$ & $8,03 \pm 0,22$ & $\mathrm{bc}$ & $1,88 \pm 0,05$ & $\mathrm{a}$ \\
\hline & & & $\mathrm{PiKu} 1$ & $14,50 \pm 0,56$ & $\mathrm{a}$ & $7,61 \pm 0,18$ & $\mathrm{a}$ & $1,90 \pm 0,03$ & $\mathrm{ab}$ \\
\hline & & & Weiroot 158 & $15,10 \pm 0,39$ & $\mathrm{ab}$ & $8,16 \pm 0,29$ & $\mathrm{c}$ & $1,85 \pm 0,03$ & $\mathrm{a}$ \\
\hline & & \multirow{5}{*}{ T3 } & GiSelA 5 & $16,50 \pm 0,18$ & $\mathrm{a}$ & $6,65 \pm 0,05$ & $\mathrm{a}$ & $2,48 \pm 0,01$ & $\mathrm{c}$ \\
\hline & & & GiSelA 6 & $16,55 \pm 0,53$ & $\mathrm{a}$ & $7,13 \pm 0,14$ & $\mathrm{~b}$ & $2,32 \pm 0,04$ & $\mathrm{~b}$ \\
\hline & & & PHL-C & $16,40 \pm 0,20$ & $\mathrm{a}$ & $7,26 \pm 0,21$ & $\mathrm{~b}$ & $2,26 \pm 0,04$ & $\mathrm{a}$ \\
\hline & & & PiKu 1 & $16,20 \pm 0,45$ & $\mathrm{a}$ & $6,46 \pm 0,19$ & $\mathrm{a}$ & $2,51 \pm 0,01$ & $\mathrm{c}$ \\
\hline & & & Weiroot 158 & $16,35 \pm 0,24$ & $\mathrm{a}$ & $7,20 \pm 0,07$ & $\mathrm{~b}$ & $2,27 \pm 0,02$ & $\mathrm{ab}$ \\
\hline
\end{tabular}

${ }^{1}$ A különböző betük a szignifikánsan különböző csoportokat jelölik. Az elemzést MANOVA módszerrel végeztük p $<0,05$ szinten, szóráshomogenitás esetén Tukey, enyhe sérülése esetén Games-Howell post hoc tesztet alkalmazva. 
28. táblázat: Q26 ültetvény cseresznyegyümölcseinek TSS, TA és TSS/TA értékei (1.)

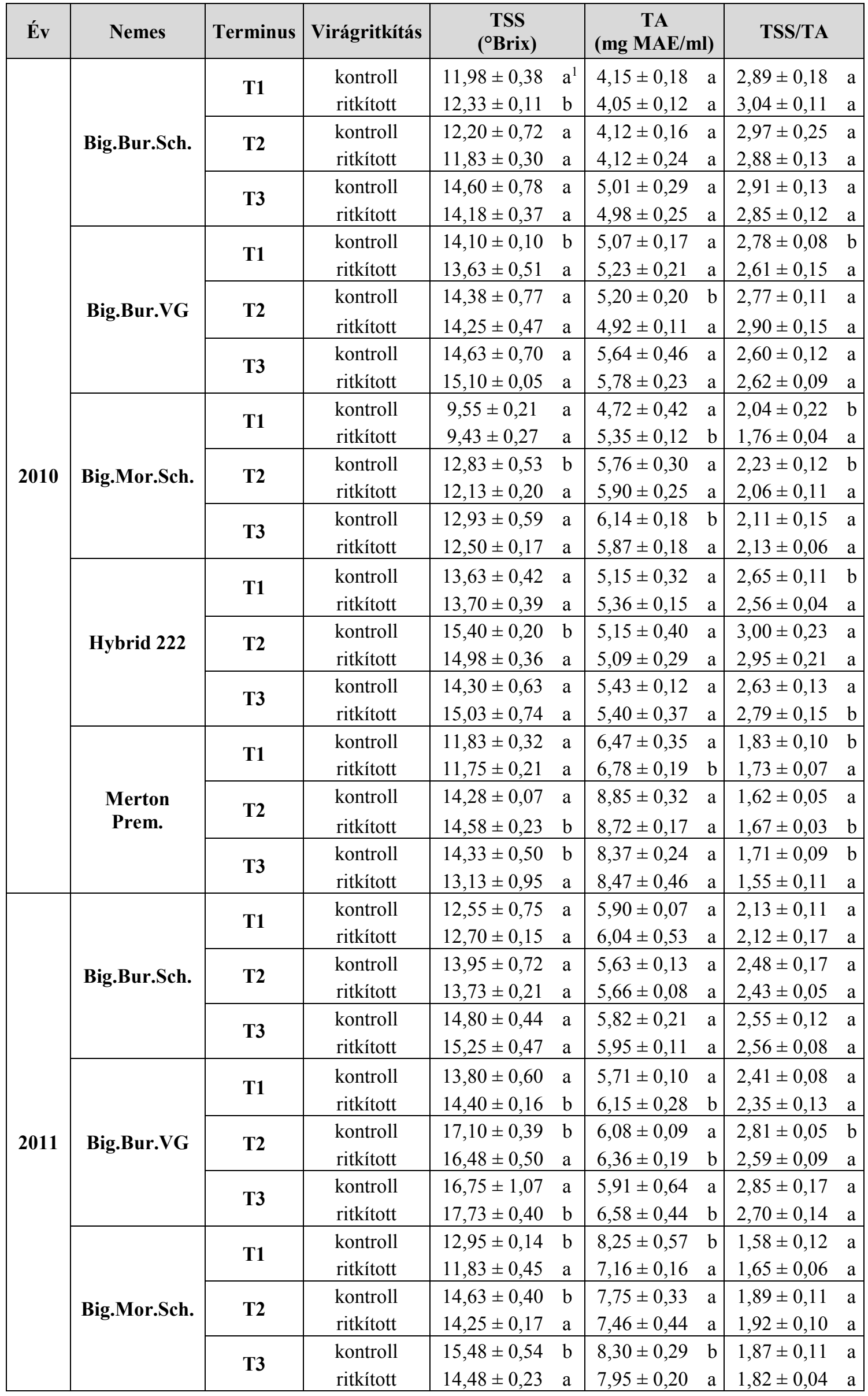

1a különböző betük a szignifikánsan különböző csoportokat jelölik, MANOVA, p<0,05 (Tukey / Games-Howell) 
28. táblázat: Q26 ültetvény cseresznyegyümölcseinek TSS, TA és TSS/TA értékei (2.)

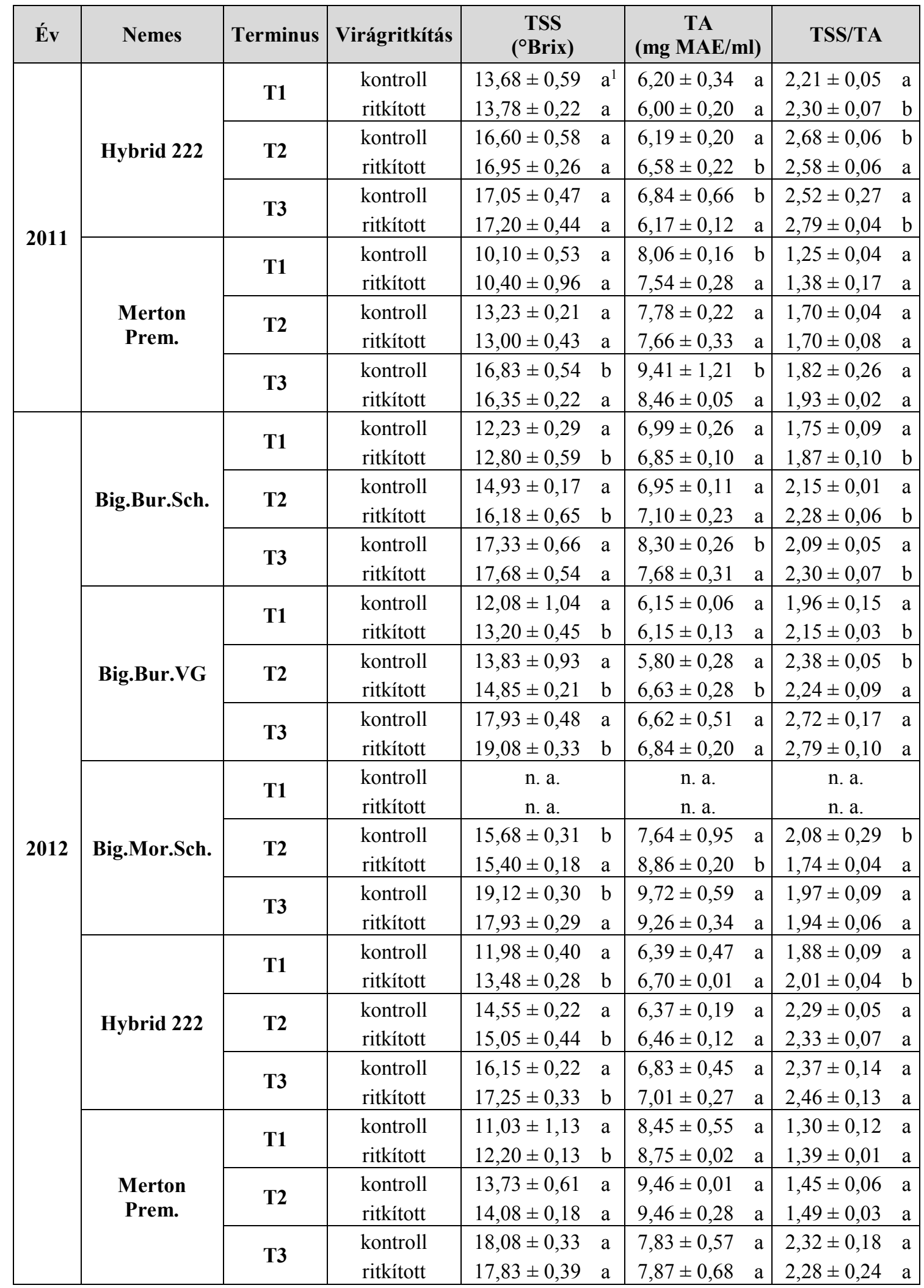

${ }^{1}$ A különböző betük a szignifikánsan különböző csoportokat jelölik. Az elemzést MANOVA módszerrel végeztük $\mathrm{p}<0,05$ szinten, szóráshomogenitás esetén Tukey, enyhe sérülése esetén Games-Howell post hoc tesztet alkalmazva. 
29. táblázat: 'Regina' és 'Kordia' cseresznyefajta gyümölcseinek fruktóz, glükóz, szorbitol koncentrációja, valamint összes kromatográfiás cukortartalma (TKC) (1.)

\begin{tabular}{|c|c|c|c|c|c|c|c|c|c|c|c|}
\hline Év & Nemes & Term. & Alany & $\begin{array}{l}\text { Fruktóz } \\
\text { (mg/ml) }\end{array}$ & & $\begin{array}{l}\text { Glükóz } \\
\text { (mg/ml) }\end{array}$ & & $\begin{array}{c}\text { Szorbitol } \\
(\mathrm{mg} / \mathrm{ml})\end{array}$ & & $\begin{array}{c}\text { TKC } \\
(\mathrm{mg} / \mathrm{ml})\end{array}$ & \\
\hline \multirow{15}{*}{2010} & \multirow{15}{*}{ Kordia } & \multirow{5}{*}{$\mathbf{T 1}$} & GiSelA 5 & $32,02 \pm 0,46$ & $a^{1}$ & $47,05 \pm 0,47$ & $\mathrm{a}$ & $10,75 \pm 0,15$ & $a b$ & $89,82 \pm 0,93$ & $\mathrm{a}$ \\
\hline & & & GiSelA 6 & $32,94 \pm 5,56$ & $\mathrm{ab}$ & $46,71 \pm 4,54$ & $\mathrm{a}$ & $10,28 \pm 1,24$ & $\mathrm{a}$ & $89,93 \pm 10,86$ & $\mathrm{a}$ \\
\hline & & & PHL-C & $37,92 \pm 0,44$ & $\mathrm{~b}$ & $52,72 \pm 1,71$ & $\mathrm{a}$ & $12,39 \pm 0,17$ & $\mathrm{c}$ & $103,04 \pm 2,09$ & $\mathrm{~b}$ \\
\hline & & & PiKu 1 & $36,03 \pm 1,65$ & $\mathrm{ab}$ & $50,70 \pm 3,72$ & $\mathrm{a}$ & $12,18 \pm 0,74$ & bc & $98,91 \pm 5,78$ & $a b$ \\
\hline & & & Weiroot 158 & $34,51 \pm 1,08$ & $\mathrm{ab}$ & $51,09 \pm 2,39$ & $\mathrm{a}$ & $11,17 \pm 0,28$ & $\mathrm{abc}$ & $96,77 \pm 3,53$ & $\mathrm{ab}$ \\
\hline & & \multirow{5}{*}{$\mathbf{T} 2$} & GiSelA 5 & $44,73 \pm 0,58$ & $\mathrm{a}$ & $60,57 \pm 0,84$ & $\mathrm{a}$ & $15,64 \pm 0,25$ & $\mathrm{a}$ & $120,94 \pm 1,59$ & $\mathrm{a}$ \\
\hline & & & GiSelA 6 & $49,79 \pm 1,84$ & $\mathrm{~b}$ & $66,57 \pm 2,10$ & $\mathrm{c}$ & $17,48 \pm 0,51$ & $\mathrm{~b}$ & $133,84 \pm 3,54$ & $\mathrm{c}$ \\
\hline & & & PHL-C & $53,14 \pm 0,76$ & $\mathrm{c}$ & $70,22 \pm 0,68$ & $\mathrm{~d}$ & $20,39 \pm 1,37$ & $\mathrm{c}$ & $143,76 \pm 2,73$ & $\mathrm{~d}$ \\
\hline & & & PiKu 1 & $47,49 \pm 1,19$ & $\mathrm{~b}$ & $62,49 \pm 1,75$ & $\mathrm{ab}$ & $17,33 \pm 0,85$ & $a b$ & $127,30 \pm 3,70$ & $\mathrm{~b}$ \\
\hline & & & Weiroot 158 & $47,43 \pm 0,58$ & $\mathrm{~b}$ & $65,37 \pm 1,02$ & $\mathrm{bc}$ & $17,07 \pm 0,46$ & $\mathrm{ab}$ & $129,87 \pm 1,75$ & $\mathrm{bc}$ \\
\hline & & \multirow{5}{*}{$\mathbf{T 3}$} & GiSelA 5 & $47,97 \pm 1,22$ & $\mathrm{a}$ & $61,37 \pm 1,41$ & $\mathrm{a}$ & $15,91 \pm 0,48$ & $\mathrm{a}$ & $125,24 \pm 3,07$ & $\mathrm{a}$ \\
\hline & & & GiSelA 6 & $49,36 \pm 1,98$ & $\mathrm{a}$ & $63,27 \pm 1,44$ & $\mathrm{ab}$ & $16,45 \pm 0,71$ & $\mathrm{a}$ & $129,08 \pm 3,75$ & $\mathrm{a}$ \\
\hline & & & PHL-C & $47,29 \pm 4,76$ & $\mathrm{a}$ & $60,24 \pm 6,78$ & $\mathrm{a}$ & $16,86 \pm 1,53$ & $\mathrm{a}$ & $124,38 \pm 12,96$ & $\mathrm{a}$ \\
\hline & & & PiKu 1 & $56,10 \pm 2,61$ & $\mathrm{~b}$ & $70,39 \pm 3,04$ & $\mathrm{~b}$ & $19,80 \pm 0,85$ & $\mathrm{~b}$ & $146,28 \pm 6,42$ & $\mathrm{~b}$ \\
\hline & & & Weiroot 158 & $48,25 \pm 0,69$ & $\mathrm{a}$ & $62,40 \pm 0,82$ & $\mathrm{a}$ & $16,54 \pm 0,43$ & $\mathrm{a}$ & $127,18 \pm 1,82$ & $\mathrm{a}$ \\
\hline \multirow{15}{*}{2010} & \multirow{15}{*}{ Regina } & \multirow{5}{*}{ T1 } & GiSelA 5 & $49,83 \pm 0,08$ & $\mathrm{~b}$ & $64,33 \pm 0,35$ & $\mathrm{~b}$ & $13,00 \pm 0,16$ & $\mathrm{bc}$ & $127,16 \pm 0,54$ & $\mathrm{~b}$ \\
\hline & & & GiSelA 6 & $49,38 \pm 0,17$ & $\mathrm{~b}$ & $65,02 \pm 0,75$ & $\mathrm{~b}$ & $13,63 \pm 0,51$ & $\mathrm{~d}$ & $128,03 \pm 1,37$ & $\mathrm{~b}$ \\
\hline & & & PHL-C & $46,60 \pm 0,61$ & $\mathrm{a}$ & $61,63 \pm 0,49$ & $\mathrm{a}$ & $11,86 \pm 0,17$ & $\mathrm{a}$ & $120,09 \pm 1,02$ & $\mathrm{a}$ \\
\hline & & & PiKu 1 & $50,20 \pm 0,54$ & $\mathrm{~b}$ & $65,04 \pm 0,71$ & $\mathrm{~b}$ & $14,60 \pm 0,19$ & $\mathrm{c}$ & $129,84 \pm 1,13$ & $\mathrm{~b}$ \\
\hline & & & Weiroot 158 & $49,61 \pm 1,04$ & $\mathrm{~b}$ & $64,63 \pm 1,90$ & $\mathrm{~b}$ & $12,70 \pm 0,34$ & $\mathrm{~b}$ & $126,94 \pm 3,25$ & $\mathrm{~b}$ \\
\hline & & \multirow{5}{*}{$\mathbf{T} 2$} & GiSelA 5 & $58,84 \pm 0,68$ & $\mathrm{~b}$ & $74,45 \pm 0,38$ & $\mathrm{a}$ & $17,60 \pm 0,10$ & $\mathrm{bc}$ & $150,89 \pm 1,09$ & $\mathrm{~b}$ \\
\hline & & & GiSelA 6 & $65,12 \pm 5,19$ & $\mathrm{c}$ & $82,68 \pm 7,10$ & $\mathrm{~b}$ & $18,75 \pm 2,15$ & $\mathrm{c}$ & $166,54 \pm 13,50$ & $\mathrm{c}$ \\
\hline & & & PHL-C & $52,19 \pm 0,63$ & a & $67,84 \pm 1,37$ & $\mathrm{a}$ & $14,15 \pm 0,11$ & $\mathrm{a}$ & $134,18 \pm 2,04$ & $\mathrm{a}$ \\
\hline & & & PiKu 1 & $58,10 \pm 0,78$ & $\mathrm{~b}$ & $73,14 \pm 1,18$ & $\mathrm{a}$ & $17,97 \pm 0,75$ & bc & $149,21 \pm 2,57$ & $\mathrm{~b}$ \\
\hline & & & Weiroot 158 & $57,05 \pm 0,59$ & $\mathrm{ab}$ & $72,51 \pm 0,57$ & $\mathrm{a}$ & $16,51 \pm 0,13$ & $\mathrm{~b}$ & $146,07 \pm 1,29$ & $a b$ \\
\hline & & \multirow{5}{*}{$\mathbf{T 3}$} & GiSelA 5 & $65,51 \pm 3,60$ & $\mathrm{a}$ & $81,70 \pm 4,77$ & $\mathrm{a}$ & $23,01 \pm 1,54$ & $\mathrm{bc}$ & $170,22 \pm 9,83$ & $\mathrm{a}$ \\
\hline & & & GiSelA 6 & $65,29 \pm 0,45$ & $\mathrm{a}$ & $82,34 \pm 1,21$ & $\mathrm{a}$ & $21,97 \pm 0,12$ & $\mathrm{~b}$ & $169,61 \pm 1,65$ & $\mathrm{a}$ \\
\hline & & & PHL-C & $62,91 \pm 1,62$ & a & $79,27 \pm 1,40$ & $\mathrm{a}$ & $19,41 \pm 0,24$ & $\mathrm{a}$ & $161,59 \pm 3,24$ & $\mathrm{a}$ \\
\hline & & & PiKu 1 & $66,21 \pm 2,47$ & a & $82,90 \pm 2,15$ & $\mathrm{a}$ & $23,83 \pm 0,72$ & $\mathrm{c}$ & $172,95 \pm 5,31$ & $\mathrm{a}$ \\
\hline & & & Weiroot 158 & $64,77 \pm 0,13$ & $\mathrm{a}$ & $81,59 \pm 0,49$ & $\mathrm{a}$ & $22,03 \pm 0,10$ & $\mathrm{~b}$ & $168,39 \pm 0,71$ & $\mathrm{a}$ \\
\hline \multirow{15}{*}{2011} & \multirow{15}{*}{ Kordia } & \multirow{5}{*}{$\mathbf{T 1}$} & GiSelA 5 & $39,93 \pm 2,46$ & $\mathrm{a}$ & $53,68 \pm 3,34$ & $\mathrm{a}$ & $14,31 \pm 0,92$ & $a b$ & $107,93 \pm 6,63$ & $\mathrm{a}$ \\
\hline & & & GiSelA 6 & $39,59 \pm 2,11$ & $\mathrm{a}$ & $57,80 \pm 3,13$ & $\mathrm{a}$ & $13,61 \pm 0,94$ & $\mathrm{a}$ & $111,00 \pm 6,06$ & $\mathrm{a}$ \\
\hline & & & PHL-C & $45,01 \pm 2,39$ & $\mathrm{ab}$ & $60,78 \pm 2,91$ & $a b$ & $15,55 \pm 1,18$ & $a b$ & $121,34 \pm 6,38$ & $a b$ \\
\hline & & & PiKu 1 & $45,02 \pm 3,38$ & $a b$ & $61,09 \pm 5,56$ & $a b$ & $16,16 \pm 1,06$ & $\mathrm{bc}$ & $122,27 \pm 9,98$ & $a b$ \\
\hline & & & Weiroot 158 & $51,22 \pm 4,81$ & $\mathrm{~b}$ & $68,49 \pm 6,78$ & $\mathrm{~b}$ & $18,52 \pm 1,57$ & $\mathrm{c}$ & $138,23 \pm 13,15$ & $\mathrm{~b}$ \\
\hline & & \multirow{5}{*}{$\mathbf{T} 2$} & GiSelA 5 & $53,42 \pm 4,21$ & $\mathrm{a}$ & $68,03 \pm 3,70$ & $\mathrm{a}$ & $19,20 \pm 1,33$ & $\mathrm{a}$ & $140,65 \pm 7,43$ & $\mathrm{a}$ \\
\hline & & & GiSelA 6 & $58,93 \pm 1,60$ & $\mathrm{ab}$ & $75,20 \pm 2,01$ & $\mathrm{ab}$ & $19,86 \pm 1,01$ & $\mathrm{a}$ & $154,00 \pm 4,26$ & $\mathrm{ab}$ \\
\hline & & & PHL-C & $65,30 \pm 4,78$ & $\mathrm{~b}$ & $81,63 \pm 5,86$ & $\mathrm{~b}$ & $24,20 \pm 2,32$ & $\mathrm{~b}$ & $171,14 \pm 12,86$ & $\mathrm{~b}$ \\
\hline & & & PiKu 1 & $57,54 \pm 4,72$ & $\mathrm{ab}$ & $71,73 \pm 2,65$ & $\mathrm{a}$ & $23,83 \pm 2,10$ & $\mathrm{~b}$ & $153,09 \pm 9,20$ & $\mathrm{ab}$ \\
\hline & & & Weiroot 158 & $64,37 \pm 2,29$ & $\mathrm{~b}$ & $80,61 \pm 2,77$ & $\mathrm{~b}$ & $26,21 \pm 1,35$ & $\mathrm{~b}$ & $171,18 \pm 6,38$ & $\mathrm{~b}$ \\
\hline & & \multirow{5}{*}{$\mathbf{T 3}$} & GiSelA 5 & $71,51 \pm 4,25$ & $a b$ & $88,58 \pm 5,92$ & $a b$ & $30,82 \pm 2,57$ & $\mathrm{~b}$ & $190,91 \pm 12,06$ & $a b$ \\
\hline & & & GiSelA 6 & $64,01 \pm 4,18$ & $\mathrm{a}$ & $80,98 \pm 5,28$ & $\mathrm{a}$ & $24,06 \pm 2,06$ & $\mathrm{a}$ & $169,04 \pm 9,95$ & $\mathrm{a}$ \\
\hline & & & PHL-C & $65,90 \pm 6,03$ & $\mathrm{a}$ & $81,45 \pm 7,46$ & $\mathrm{a}$ & $29,05 \pm 2,43$ & $\mathrm{~b}$ & $176,39 \pm 15,40$ & $\mathrm{a}$ \\
\hline & & & PiKu 1 & $78,36 \pm 3,97$ & $\mathrm{~b}$ & $97,02 \pm 4,46$ & $\mathrm{~b}$ & $29,38 \pm 1,61$ & $\mathrm{~b}$ & $204,76 \pm 9,80$ & $\mathrm{~b}$ \\
\hline & & & Weiroot 158 & $65,19 \pm 4,82$ & $\mathrm{a}$ & $80,97 \pm 5,21$ & $\mathrm{a}$ & $29,48 \pm 2,19$ & $\mathrm{~b}$ & $175,64 \pm 11,36$ & $\mathrm{a}$ \\
\hline
\end{tabular}

1 a különböző betük a szignifikánsan különböző csoportokat jelölik, MANOVA, p<0,05 (Tukey / Games-Howell) 
29. táblázat: 'Regina' és 'Kordia' cseresznyefajta gyümölcseinek fruktóz, glükóz, szorbitol koncentrációja, valamint összes kromatográfiás cukortartalma (TKC) (2.)

\begin{tabular}{|c|c|c|c|c|c|c|c|c|c|c|c|}
\hline Év & Nemes & Term. & Alany & $\begin{array}{l}\text { Fruktóz } \\
\text { (mg/ml) }\end{array}$ & & $\begin{array}{l}\text { Glükóz } \\
\text { (mg/ml) }\end{array}$ & & $\begin{array}{c}\text { Szorbitol } \\
(\mathrm{mg} / \mathrm{ml})\end{array}$ & & $\begin{array}{c}\text { TKC } \\
(\mathrm{mg} / \mathrm{ml})\end{array}$ & \\
\hline \multirow{15}{*}{2011} & \multirow{15}{*}{ Regina } & \multirow{5}{*}{$\mathbf{T 1}$} & GiSelA 5 & $59,88 \pm 3,98$ & $a^{1}$ & $76,58 \pm 4,87$ & $\mathrm{a}$ & $21,95 \pm 1,30$ & $\mathrm{a}$ & $158,41 \pm 10,15$ & $\mathrm{a}$ \\
\hline & & & GiSelA 6 & $61,21 \pm 2,69$ & $\mathrm{a}$ & $76,53 \pm 3,26$ & $\mathrm{a}$ & $23,95 \pm 1,34$ & $a b$ & $161,69 \pm 7,25$ & $\mathrm{a}$ \\
\hline & & & PHL-C & $68,86 \pm 4,82$ & $\mathrm{~b}$ & $88,10 \pm 5,98$ & $\mathrm{~b}$ & $26,40 \pm 1,85$ & $\mathrm{~b}$ & $183,36 \pm 12,65$ & $\mathrm{~b}$ \\
\hline & & & PiKu 1 & $57,85 \pm 1,91$ & $\mathrm{a}$ & $73,83 \pm 1,94$ & $\mathrm{a}$ & $22,49 \pm 0,91$ & $\mathrm{a}$ & $154,16 \pm 4,67$ & $\mathrm{a}$ \\
\hline & & & Weiroot 158 & $63,93 \pm 1,40$ & $\mathrm{ab}$ & $81,72 \pm 1,82$ & $\mathrm{ab}$ & $23,01 \pm 0,63$ & $\mathrm{a}$ & $168,66 \pm 3,54$ & $a b$ \\
\hline & & \multirow{5}{*}{$\mathbf{T} 2$} & GiSelA 5 & $59,29 \pm 9,11$ & $\mathrm{a}$ & $77,33 \pm 11,76$ & $\mathrm{a}$ & $19,50 \pm 2,53$ & $\mathrm{a}$ & $156,11 \pm 23,37$ & $\mathrm{a}$ \\
\hline & & & GiSelA 6 & $59,01 \pm 1,88$ & $\mathrm{a}$ & $74,87 \pm 2,49$ & $\mathrm{a}$ & $21,11 \pm 0,80$ & $a b$ & $154,99 \pm 4,72$ & $\mathrm{a}$ \\
\hline & & & PHL-C & $73,99 \pm 3,95$ & $\mathrm{~b}$ & $92,56 \pm 6,02$ & $\mathrm{~b}$ & $24,37 \pm 1,43$ & $\mathrm{~b}$ & $190,92 \pm 10,81$ & $\mathrm{~b}$ \\
\hline & & & PiKu 1 & $56,92 \pm 1,65$ & $\mathrm{a}$ & $75,33 \pm 1,97$ & $\mathrm{a}$ & $19,32 \pm 0,90$ & $\mathrm{a}$ & $151,57 \pm 4,32$ & $\mathrm{a}$ \\
\hline & & & Weiroot 158 & $54,57 \pm 4,82$ & $\mathrm{a}$ & $70,67 \pm 6,56$ & $\mathrm{a}$ & $17,63 \pm 1,97$ & $\mathrm{a}$ & $142,88 \pm 13,29$ & $\mathrm{a}$ \\
\hline & & \multirow{5}{*}{ T3 } & \begin{tabular}{|l|} 
GiSelA 5 \\
\end{tabular} & $79,76 \pm 3,65$ & $\mathrm{~b}$ & $102,91 \pm 4,02$ & $\mathrm{~b}$ & $26,22 \pm 1,08$ & $\mathrm{~b}$ & $208,89 \pm 8,73$ & $\mathrm{~b}$ \\
\hline & & & GiSelA 6 & $74,79 \pm 3,21$ & $\mathrm{ab}$ & $95,92 \pm 2,39$ & $\mathrm{ab}$ & $26,50 \pm 1,12$ & $\mathrm{~b}$ & $197,21 \pm 6,51$ & $\mathrm{ab}$ \\
\hline & & & PHL-C & $74,61 \pm 6,40$ & $\mathrm{ab}$ & $99,63 \pm 6,36$ & $\mathrm{ab}$ & $25,41 \pm 3,77$ & $\mathrm{~b}$ & $199,65 \pm 16,12$ & $\mathrm{ab}$ \\
\hline & & & PiKu 1 & $80,42 \pm 3,76$ & $\mathrm{~b}$ & $103,29 \pm 4,44$ & $\mathrm{~b}$ & $28,66 \pm 1,54$ & $\mathrm{~b}$ & $212,38 \pm 9,70$ & $\mathrm{~b}$ \\
\hline & & & Weiroot 158 & $68,69 \pm 2,43$ & $\mathrm{a}$ & $91,77 \pm 3,15$ & $\mathrm{a}$ & $21,11 \pm 0,42$ & $\mathrm{a}$ & $181,57 \pm 5,89$ & $\mathrm{a}$ \\
\hline \multirow{15}{*}{2012} & \multirow{15}{*}{ Kordia } & \multirow{5}{*}{ T1 } & GiSelA 5 & $44,59 \pm 1,93$ & $\mathrm{a}$ & $56,62 \pm 3,39$ & $\mathrm{a}$ & $16,90 \pm 0,88$ & $\mathrm{a}$ & $118,11 \pm 6,03$ & $\mathrm{a}$ \\
\hline & & & GiSelA 6 & $44,23 \pm 4,53$ & $\mathrm{a}$ & $57,54 \pm 7,36$ & $\mathrm{a}$ & $14,90 \pm 1,21$ & $\mathrm{a}$ & $116,67 \pm 12,78$ & $\mathrm{a}$ \\
\hline & & & PHL-C & $53,05 \pm 0,68$ & $\mathrm{~b}$ & $68,45 \pm 1,34$ & $\mathrm{bc}$ & $20,61 \pm 0,23$ & $\mathrm{~b}$ & $142,11 \pm 2,07$ & $\mathrm{~b}$ \\
\hline & & & PiKu 1 & $58,75 \pm 4,11$ & $\mathrm{~b}$ & $71,21 \pm 7,26$ & $\mathrm{c}$ & $27,93 \pm 2,92$ & $\mathrm{c}$ & $157,89 \pm 14,10$ & $\mathrm{~b}$ \\
\hline & & & Weiroot 158 & $44,76 \pm 1,10$ & $\mathrm{a}$ & $57,89 \pm 1,12$ & $a b$ & $16,21 \pm 0,27$ & $\mathrm{a}$ & $118,87 \pm 2,40$ & $\mathrm{a}$ \\
\hline & & \multirow{5}{*}{$\mathbf{T} 2$} & GiSelA 5 & $56,79 \pm 3,11$ & $\mathrm{a}$ & $69,57 \pm 2,60$ & $\mathrm{a}$ & $25,23 \pm 0,93$ & $\mathrm{a}$ & $151,59 \pm 6,45$ & $\mathrm{a}$ \\
\hline & & & GiSelA 6 & $68,24 \pm 3,92$ & $\mathrm{c}$ & $83,26 \pm 4,53$ & $\mathrm{~b}$ & $28,81 \pm 1,88$ & $\mathrm{~b}$ & $180,31 \pm 10,21$ & $\mathrm{~b}$ \\
\hline & & & PHL-C & $66,81 \pm 6,85$ & bc & $83,04 \pm 10,26$ & $\mathrm{~b}$ & $28,94 \pm 2,94$ & $\mathrm{~b}$ & $178,78 \pm 19,63$ & $\mathrm{~b}$ \\
\hline & & & PiKu 1 & $59,45 \pm 0,61$ & $a b$ & $72,64 \pm 0,46$ & $\mathrm{ab}$ & $26,33 \pm 0,31$ & $\mathrm{ab}$ & $158,41 \pm 1,37$ & $\mathrm{ab}$ \\
\hline & & & Weiroot 158 & $57,02 \pm 0,31$ & $\mathrm{a}$ & $69,93 \pm 0,70$ & $\mathrm{a}$ & $25,18 \pm 0,16$ & $\mathrm{a}$ & $152,13 \pm 1,11$ & $\mathrm{a}$ \\
\hline & & \multirow{5}{*}{ T3 } & GiSelA 5 & $63,62 \pm 1,37$ & $\mathrm{~b}$ & $77,20 \pm 2,42$ & $\mathrm{~b}$ & $30,52 \pm 0,76$ & $\mathrm{bc}$ & $171,33 \pm 4,51$ & $\mathrm{~b}$ \\
\hline & & & GiSelA 6 & $63,13 \pm 1,51$ & $\mathrm{~b}$ & $76,77 \pm 1,72$ & $\mathrm{~b}$ & $27,83 \pm 0,80$ & $\mathrm{ab}$ & $167,74 \pm 3,97$ & $\mathrm{~b}$ \\
\hline & & & PHL-C & $73,72 \pm 4,03$ & $\mathrm{c}$ & $89,81 \pm 3,90$ & $\mathrm{c}$ & $33,69 \pm 2,98$ & $\mathrm{c}$ & $197,22 \pm 10,54$ & $\mathrm{c}$ \\
\hline & & & PiKu 1 & $65,77 \pm 0,55$ & $\mathrm{~b}$ & $82,97 \pm 0,54$ & $\mathrm{~b}$ & $27,22 \pm 0,33$ & $\mathrm{ab}$ & $175,97 \pm 1,36$ & $\mathrm{~b}$ \\
\hline & & & Weiroot 158 & $57,10 \pm 3,91$ & $\mathrm{a}$ & $68,95 \pm 4,49$ & $\mathrm{a}$ & $24,22 \pm 2,05$ & $\mathrm{a}$ & $150,26 \pm 10,43$ & $\mathrm{a}$ \\
\hline \multirow{15}{*}{2012} & \multirow{15}{*}{ Regina } & \multirow{5}{*}{$\mathbf{T 1}$} & GiSelA 5 & $40,91 \pm 0,30$ & $\mathrm{c}$ & $55,12 \pm 0,23$ & $\mathrm{c}$ & $13,63 \pm 0,07$ & $\mathrm{~d}$ & $109,66 \pm 0,59$ & $\mathrm{~d}$ \\
\hline & & & GiSelA 6 & $40,85 \pm 0,63$ & $\mathrm{c}$ & $53,17 \pm 0,32$ & $\mathrm{c}$ & $12,57 \pm 0,16$ & $\mathrm{c}$ & $106,59 \pm 1,02$ & $\mathrm{c}$ \\
\hline & & & PHL-C & $41,69 \pm 0,14$ & $\mathrm{c}$ & $54,75 \pm 0,27$ & $\mathrm{c}$ & $12,82 \pm 0,02$ & $\mathrm{c}$ & $109,26 \pm 0,37$ & $\mathrm{~cd}$ \\
\hline & & & PiKu 1 & $36,79 \pm 0,53$ & $\mathrm{a}$ & $50,32 \pm 0,40$ & $\mathrm{a}$ & $11,66 \pm 0,11$ & $\mathrm{a}$ & $98,77 \pm 1,02$ & $\mathrm{a}$ \\
\hline & & & Weiroot 158 & $39,43 \pm 0,74$ & $\mathrm{~b}$ & $52,01 \pm 1,39$ & $\mathrm{~b}$ & $12,05 \pm 0,31$ & $\mathrm{~b}$ & $103,49 \pm 2,36$ & $\mathrm{~b}$ \\
\hline & & \multirow{5}{*}{$\mathbf{T} 2$} & GiSelA 5 & $52,77 \pm 2,33$ & $\mathrm{~b}$ & $67,07 \pm 2,43$ & $\mathrm{c}$ & $19,27 \pm 0,87$ & $\mathrm{c}$ & $139,11 \pm 5,61$ & $\mathrm{c}$ \\
\hline & & & GiSelA 6 & $45,90 \pm 1,74$ & $\mathrm{a}$ & $57,19 \pm 1,16$ & $\mathrm{a}$ & $15,25 \pm 0,59$ & $\mathrm{a}$ & $118,34 \pm 3,21$ & a \\
\hline & & & PHL-C & $43,77 \pm 0,44$ & $\mathrm{a}$ & $54,93 \pm 1,12$ & $\mathrm{a}$ & $14,69 \pm 0,20$ & $\mathrm{a}$ & $113,38 \pm 1,67$ & a \\
\hline & & & PiKu 1 & $49,90 \pm 1,62$ & $\mathrm{~b}$ & $63,13 \pm 0,99$ & $\mathrm{~b}$ & $17,67 \pm 0,38$ & $\mathrm{~b}$ & $130,69 \pm 2,93$ & $\mathrm{~b}$ \\
\hline & & & Weiroot 158 & $43,88 \pm 1,37$ & $\mathrm{a}$ & $55,73 \pm 1,24$ & $\mathrm{a}$ & $14,69 \pm 0,30$ & $\mathrm{a}$ & $114,30 \pm 2,86$ & $\mathrm{a}$ \\
\hline & & \multirow{5}{*}{ T3 } & GiSelA 5 & $53,72 \pm 1,94$ & $\mathrm{~b}$ & $67,16 \pm 2,57$ & $a b$ & $21,91 \pm 0,81$ & $\mathrm{bc}$ & $142,79 \pm 5,30$ & $\mathrm{~b}$ \\
\hline & & & GiSelA 6 & $52,69 \pm 0,86$ & $a b$ & $66,00 \pm 0,99$ & $a b$ & $19,84 \pm 0,24$ & $a b$ & $138,52 \pm 2,08$ & $a b$ \\
\hline & & & PHL-C & $47,24 \pm 5,59$ & $\mathrm{a}$ & $59,82 \pm 8,36$ & $\mathrm{a}$ & $18,15 \pm 2,12$ & $\mathrm{a}$ & $125,20 \pm 15,99$ & $\mathrm{a}$ \\
\hline & & & PiKu 1 & $58,01 \pm 1,16$ & $\mathrm{~b}$ & $72,75 \pm 0,70$ & $\mathrm{~b}$ & $22,83 \pm 0,32$ & $\mathrm{c}$ & $153,59 \pm 2,11$ & $\mathrm{~b}$ \\
\hline & & & Weiroot 158 & $58,53 \pm 0,54$ & $\mathrm{~b}$ & $73,12 \pm 0,43$ & $\mathrm{~b}$ & $21,19 \pm 0,19$ & $\mathrm{bc}$ & $152,84 \pm 1,16$ & $\mathrm{~b}$ \\
\hline
\end{tabular}

1 a különböző betük a szignifikánsan különböző csoportokat jelölik, MANOVA, p<0,05 (Tukey / Games-Howell) 
29. táblázat: 'Regina' és 'Kordia' cseresznyefajta gyümölcseinek fruktóz, glükóz, szorbitol koncentrációja, valamint összes kromatográfiás cukortartalma (TKC) (3.)

\begin{tabular}{|c|c|c|c|c|c|c|c|c|c|c|c|}
\hline Év & Nemes & Term. & Alany & $\begin{array}{l}\text { Fruktóz } \\
\text { (mg/ml) }\end{array}$ & & $\begin{array}{l}\text { Glükóz } \\
\text { (mg/ml) }\end{array}$ & & $\begin{array}{c}\text { Szorbitol } \\
\text { (mg/ml) }\end{array}$ & & $\begin{array}{c}\text { TKC } \\
(\mathrm{mg} / \mathrm{ml})\end{array}$ & \\
\hline \multirow{15}{*}{2013} & \multirow{15}{*}{ Kordia } & \multirow{5}{*}{ T1 } & GiSelA 5 & $33,45 \pm 1,94$ & $a b^{1}$ & $58,27 \pm 4,76$ & $\mathrm{a}$ & $12,48 \pm 1,51$ & $\mathrm{~b}$ & $104,20 \pm 5,98$ & $\mathrm{ab}$ \\
\hline & & & GiSelA 6 & $48,64 \pm 3,69$ & $\mathrm{c}$ & $74,49 \pm 6,75$ & $\mathrm{~b}$ & $14,63 \pm 1,34$ & $\mathrm{c}$ & $137,76 \pm 11,58$ & $\mathrm{c}$ \\
\hline & & & PHL-C & $34,91 \pm 1,20$ & $\mathrm{ab}$ & $55,60 \pm 1,30$ & $\mathrm{a}$ & $11,80 \pm 0,27$ & $a b$ & $102,31 \pm 2,71$ & $\mathrm{ab}$ \\
\hline & & & PiKu 1 & $36,97 \pm 1,80$ & $\mathrm{~b}$ & $59,89 \pm 2,43$ & $\mathrm{a}$ & $12,24 \pm 0,74$ & $a b$ & $109,10 \pm 4,91$ & $\mathrm{~b}$ \\
\hline & & & Weiroot 158 & $31,69 \pm 0,25$ & $\mathrm{a}$ & $52,98 \pm 0,92$ & $\mathrm{a}$ & $10,29 \pm 0,15$ & $\mathrm{a}$ & $94,95 \pm 1,26$ & $\mathrm{a}$ \\
\hline & & \multirow{5}{*}{$\mathbf{T} 2$} & GiSelA 5 & $39,84 \pm 2,77$ & $\mathrm{a}$ & $59,05 \pm 4,28$ & $\mathrm{a}$ & $13,04 \pm 0,89$ & $\mathrm{a}$ & $111,92 \pm 7,88$ & $\mathrm{a}$ \\
\hline & & & GiSelA 6 & $53,33 \pm 5,05$ & $\mathrm{~b}$ & $70,78 \pm 4,25$ & $\mathrm{~b}$ & $15,48 \pm 1,99$ & $a b$ & $139,59 \pm 11,22$ & $\mathrm{~b}$ \\
\hline & & & PHL-C & $51,26 \pm 1,64$ & $\mathrm{~b}$ & $69,79 \pm 3,35$ & $\mathrm{~b}$ & $16,02 \pm 0,72$ & $b$ & $137,07 \pm 5,45$ & $\mathrm{~b}$ \\
\hline & & & $\mathrm{PiKu} 1$ & $53,02 \pm 4,24$ & $\mathrm{~b}$ & $74,49 \pm 7,17$ & $\mathrm{~b}$ & $15,73 \pm 1,62$ & $a b$ & $143,24 \pm 12,95$ & $\mathrm{~b}$ \\
\hline & & & Weiroot 158 & $48,46 \pm 1,49$ & $\mathrm{~b}$ & $69,78 \pm 2,90$ & $\mathrm{~b}$ & $14,26 \pm 0,75$ & $\mathrm{ab}$ & $132,50 \pm 4,96$ & $\mathrm{~b}$ \\
\hline & & \multirow{5}{*}{ T3 } & GiSelA 5 & $53,12 \pm 2,68$ & $a b$ & $74,09 \pm 2,87$ & $\mathrm{~b}$ & $22,25 \pm 1,26$ & bc & $149,46 \pm 6,08$ & $\mathrm{~b}$ \\
\hline & & & GiSelA 6 & $57,83 \pm 3,25$ & $\mathrm{bc}$ & $75,63 \pm 4,27$ & $\mathrm{~b}$ & $22,07 \pm 1,49$ & bc & $155,53 \pm 8,57$ & $\mathrm{~b}$ \\
\hline & & & PHL-C & $51,93 \pm 4,14$ & $\mathrm{ab}$ & $68,99 \pm 3,40$ & $\mathrm{ab}$ & $21,04 \pm 0,96$ & $a b$ & $141,96 \pm 8,33$ & $a b$ \\
\hline & & & PiKu 1 & $64,61 \pm 3,93$ & $\mathrm{c}$ & $86,13 \pm 6,42$ & $\mathrm{c}$ & $25,87 \pm 3,76$ & $\mathrm{c}$ & $176,61 \pm 10,69$ & $\mathrm{c}$ \\
\hline & & & Weiroot 158 & $47,31 \pm 2,93$ & $\mathrm{a}$ & $64,13 \pm 1,08$ & $\mathrm{a}$ & $17,26 \pm 0,52$ & $\mathrm{a}$ & $128,70 \pm 4,28$ & $\mathrm{a}$ \\
\hline \multirow{15}{*}{2013} & \multirow{15}{*}{ Regina } & \multirow{5}{*}{$\mathbf{T 1}$} & GiSelA 5 & $41,60 \pm 2,17$ & $\mathrm{ab}$ & $66,87 \pm 1,35$ & $\mathrm{~b}$ & $17,01 \pm 0,76$ & $\mathrm{~b}$ & $125,48 \pm 4,10$ & $\mathrm{~b}$ \\
\hline & & & GiSelA 6 & $38,40 \pm 2,25$ & $\mathrm{a}$ & $61,80 \pm 3,23$ & $\mathrm{a}$ & $14,46 \pm 1,31$ & $\mathrm{a}$ & $114,66 \pm 6,58$ & $\mathrm{a}$ \\
\hline & & & PHL-C & $46,68 \pm 3,05$ & $\mathrm{c}$ & $73,61 \pm 1,70$ & $\mathrm{c}$ & $16,23 \pm 1,32$ & $a b$ & $136,53 \pm 5,59$ & $\mathrm{c}$ \\
\hline & & & $\mathrm{PiKu} 1$ & $43,13 \pm 1,96$ & $\mathrm{bc}$ & $69,26 \pm 1,57$ & $\mathrm{bc}$ & $16,23 \pm 0,59$ & $\mathrm{ab}$ & $128,63 \pm 4,03$ & bc \\
\hline & & & Weiroot 158 & $40,94 \pm 0,71$ & $\mathrm{ab}$ & $57,53 \pm 1,53$ & $\mathrm{a}$ & $15,23 \pm 0,07$ & $\mathrm{ab}$ & $113,71 \pm 2,28$ & $\mathrm{a}$ \\
\hline & & \multirow{5}{*}{$\mathbf{T} 2$} & GiSelA 5 & $43,63 \pm 0,81$ & $\mathrm{bc}$ & $61,39 \pm 1,21$ & $\mathrm{~b}$ & $17,94 \pm 0,67$ & $\mathrm{~b}$ & $122,95 \pm 2,53$ & $\mathrm{bc}$ \\
\hline & & & GiSelA 6 & $41,83 \pm 2,64$ & $\mathrm{~b}$ & $58,10 \pm 3,67$ & $\mathrm{~b}$ & $15,86 \pm 2,28$ & & $115,80 \pm 8,16$ & $\mathrm{~b}$ \\
\hline & & & PHL-C & $37,00 \pm 2,42$ & $\mathrm{a}$ & $51,00 \pm 2,78$ & $\mathrm{a}$ & $13,41 \pm 1,14$ & $\mathrm{a}$ & $101,41 \pm 6,30$ & $\mathrm{a}$ \\
\hline & & & $\mathrm{PiKu} 1$ & $46,00 \pm 0,82$ & $\mathrm{c}$ & $64,29 \pm 4,11$ & $\mathrm{~b}$ & $18,08 \pm 0,03$ & $\mathrm{~b}$ & $128,37 \pm 4,84$ & $\mathrm{c}$ \\
\hline & & & Weiroot 158 & $42,83 \pm 0,78$ & bc & $64,08 \pm 0,90$ & $\mathrm{~b}$ & $16,55 \pm 0,06$ & $\mathrm{~b}$ & $123,46 \pm 1,69$ & bc \\
\hline & & \multirow{5}{*}{ T3 } & GiSelA 5 & $41,73 \pm 1,42$ & $\mathrm{a}$ & $62,54 \pm 4,70$ & $\mathrm{a}$ & $17,20 \pm 1,18$ & & $121,48 \pm 7,11$ & $\mathrm{a}$ \\
\hline & & & GiSelA 6 & $46,92 \pm 2,30$ & $\mathrm{~b}$ & $68,26 \pm 3,49$ & $\mathrm{ab}$ & $17,99 \pm 1,59$ & $a b$ & $133,17 \pm 7,31$ & $\mathrm{ab}$ \\
\hline & & & PHL-C & $53,42 \pm 0,72$ & $\mathrm{c}$ & $77,30 \pm 4,16$ & $b$ & $19,37 \pm 0,92$ & $a b$ & $150,09 \pm 5,80$ & $\mathrm{c}$ \\
\hline & & & $\mathrm{PiKu} 1$ & $52,61 \pm 3,54$ & $\mathrm{c}$ & $76,25 \pm 5,54$ & $b$ & $20,96 \pm 3,15$ & $b$ & $149,83 \pm 11,53$ & $\mathrm{c}$ \\
\hline & & & Weiroot 158 & $45,52 \pm 1,17$ & $\mathrm{ab}$ & $75,34 \pm 1,92$ & $\mathrm{~b}$ & $17,18 \pm 0,44$ & a & $138,05 \pm 3,40$ & bc \\
\hline
\end{tabular}

${ }^{1}$ A különböző betük a szignifikánsan különböző csoportokat jelölik. Az elemzést MANOVA módszerrel végeztük $\mathrm{p}<0,05$ szinten, szóráshomogenitás esetén Tukey, enyhe sérülése esetén Games-Howell post hoc tesztet alkalmazva. 
30. táblázat: 'Regina' és 'Kordia' cseresznyefajta gyümölcseinek almasav, borostyánkősav és citromsav koncentrációja, valamint összes kromatográfiás savtartalma (TKS) (1.)

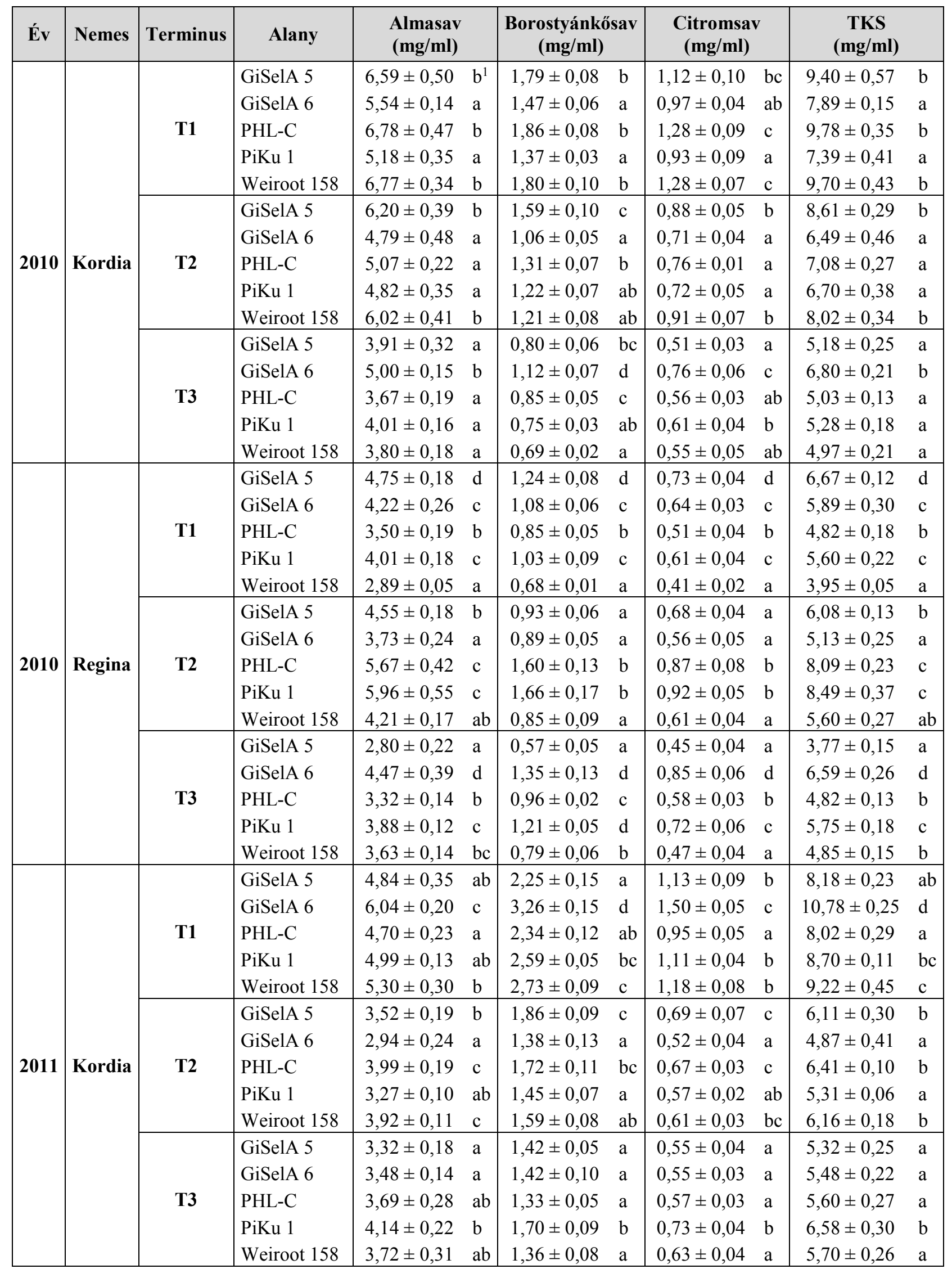

1 a különböző betük a szignifikánsan különböző csoportokat jelölik, MANOVA, p<0,05 (Tukey / Games-Howell) 
30. táblázat: 'Regina' és 'Kordia' cseresznyefajta gyümölcseinek almasav, borostyánkősav és citromsav koncentrációja, valamint összes kromatográfiás savtartalma (TKS) (2.)

\begin{tabular}{|c|c|c|c|c|c|c|c|c|c|c|c|}
\hline Év & Nemes & Terminus & Alany & \multicolumn{2}{|l|}{$\begin{array}{l}\text { Almasav } \\
(\mathrm{mg} / \mathrm{ml})\end{array}$} & \multicolumn{2}{|c|}{$\begin{array}{c}\text { Borostyánkősav } \\
(\mathrm{mg} / \mathrm{ml})\end{array}$} & \multicolumn{2}{|l|}{$\begin{array}{l}\text { Citromsav } \\
(\mathrm{mg} / \mathrm{ml})\end{array}$} & \multicolumn{2}{|l|}{$\begin{array}{c}\text { TKS } \\
(\mathrm{mg} / \mathrm{ml})\end{array}$} \\
\hline \multirow{15}{*}{2011} & \multirow{15}{*}{ Regina } & \multirow{5}{*}{ T1 } & GiSelA 5 & $8,37 \pm 0,28$ & & $4,23 \pm 0,27$ & $\mathrm{a}$ & $1,93 \pm 0,10$ & & $14,51 \pm 0,43$ & $a b$ \\
\hline & & & GiSelA 6 & $7,97 \pm 0,47$ & $a b$ & $3,88 \pm 0,17$ & $\mathrm{a}$ & $1,62 \pm 0,04$ & & $13,50 \pm 0,65$ & $\mathrm{a}$ \\
\hline & & & PHL-C & $9,07 \pm 0,84$ & $\mathrm{~b}$ & $4,77 \pm 0,32$ & $\mathrm{~b}$ & $1,94 \pm 0,16$ & $\mathrm{~b}$ & $15,84 \pm 1,31$ & $b$ \\
\hline & & & PiKu 1 & $8,13 \pm 0,45$ & & $4,24 \pm 0,23$ & $\mathrm{ab}$ & $1,60 \pm 0,10$ & $\mathrm{a}$ & $14,06 \pm 0,65$ & $\mathrm{a}$ \\
\hline & & & Weiroot 158 & $7,64 \pm 0,28$ & $\mathrm{a}$ & $4,05 \pm 0,24$ & $\mathrm{a}$ & $1,51 \pm 0,09$ & $\mathrm{a}$ & $13,29 \pm 0,61$ & $\mathrm{a}$ \\
\hline & & \multirow{5}{*}{$\mathbf{T} 2$} & GiSelA 5 & $5,34 \pm 0,07$ & $\mathrm{~b}$ & $2,60 \pm 0,05$ & $\mathrm{~b}$ & $0,99 \pm 0,03$ & & $8,98 \pm 0,06$ & $\mathrm{~b}$ \\
\hline & & & GiSelA 6 & $5,66 \pm 0,31$ & $\mathrm{~b}$ & $2,51 \pm 0,17$ & $\mathrm{~b}$ & $1,04 \pm 0,03$ & $\mathrm{~b}$ & $9,24 \pm 0,50$ & $\mathrm{~b}$ \\
\hline & & & PHL-C & $5,61 \pm 0,29$ & $\mathrm{~b}$ & $2,41 \pm 0,12$ & $\mathrm{~b}$ & $1,07 \pm 0,08$ & $\mathrm{~b}$ & $9,09 \pm 0,23$ & $\mathrm{~b}$ \\
\hline & & & PiKu 1 & $5,02 \pm 0,42$ & $a b$ & $2,13 \pm 0,08$ & $\mathrm{a}$ & $0,94 \pm 0,09$ & $a b$ & $8,09 \pm 0,52$ & $\mathrm{a}$ \\
\hline & & & Weiroot 158 & $4,68 \pm 0,28$ & $\mathrm{a}$ & $1,99 \pm 0,08$ & $\mathrm{a}$ & $0,87 \pm 0,06$ & $\mathrm{a}$ & $7,54 \pm 0,26$ & $\mathrm{a}$ \\
\hline & & \multirow{5}{*}{ T3 } & GiSelA 5 & $3,92 \pm 0,30$ & $\mathrm{a}$ & $1,53 \pm 0,05$ & $\mathrm{a}$ & $0,81 \pm 0,04$ & $\mathrm{a}$ & $6,22 \pm 0,28$ & $\mathrm{a}$ \\
\hline & & & GiSelA 6 & $4,50 \pm 0,44$ & $\mathrm{a}$ & $1,84 \pm 0,05$ & $\mathrm{~b}$ & $1,01 \pm 0,03$ & $\mathrm{a}$ & $7,29 \pm 0,45$ & $\mathrm{~b}$ \\
\hline & & & PHL-C & $4,26 \pm 0,26$ & $\mathrm{a}$ & $1,87 \pm 0,13$ & $\mathrm{~b}$ & $0,94 \pm 0,05$ & $\mathrm{a}$ & $7,04 \pm 0,17$ & $\mathrm{~b}$ \\
\hline & & & PiKu 1 & $4,34 \pm 0,06$ & $\mathrm{a}$ & $2,10 \pm 0,08$ & $\mathrm{c}$ & $0,99 \pm 0,03$ & $\mathrm{a}$ & $7,42 \pm 0,16$ & $\mathrm{~b}$ \\
\hline & & & Weiroot 158 & $4,35 \pm 0,43$ & $\mathrm{a}$ & $2,03 \pm 0,12$ & $\mathrm{bc}$ & $0,93 \pm 0,05$ & $\mathrm{a}$ & $7,30 \pm 0,52$ & $\mathrm{~b}$ \\
\hline \multirow{15}{*}{2012} & \multirow{15}{*}{ Kordia } & \multirow{5}{*}{$\mathbf{T 1}$} & GiSelA 5 & $7,60 \pm 0,15$ & $\mathrm{c}$ & $2,36 \pm 0,08$ & $\mathrm{c}$ & $1,47 \pm 0,07$ & $\mathrm{c}$ & $11,31 \pm 0,29$ & $\mathrm{c}$ \\
\hline & & & GiSelA 6 & $6,22 \pm 0,39$ & $\mathrm{ab}$ & $1,90 \pm 0,12$ & $\mathrm{~b}$ & $1,25 \pm 0,08$ & $\mathrm{~b}$ & $9,25 \pm 0,26$ & $\mathrm{~b}$ \\
\hline & & & PHL-C & $5,90 \pm 0,34$ & $\mathrm{a}$ & $1,69 \pm 0,09$ & $\mathrm{a}$ & $1,06 \pm 0,06$ & $\mathrm{a}$ & $8,55 \pm 0,48$ & $\mathrm{a}$ \\
\hline & & & PiKu 1 & $9,65 \pm 0,16$ & d & $3,00 \pm 0,07$ & $\mathrm{~d}$ & $1,82 \pm 0,02$ & $\mathrm{~d}$ & $14,32 \pm 0,25$ & $\mathrm{~d}$ \\
\hline & & & Weiroot 158 & $6,69 \pm 0,09$ & $\mathrm{~b}$ & $1,95 \pm 0,02$ & $\mathrm{~b}$ & $1,26 \pm 0,02$ & $\mathrm{~b}$ & $9,78 \pm 0,13$ & $\mathrm{~b}$ \\
\hline & & \multirow{5}{*}{$\mathbf{T} 2$} & GiSelA 5 & $7,33 \pm 0,45$ & $\mathrm{~b}$ & $2,12 \pm 0,19$ & $\mathrm{~b}$ & $1,47 \pm 0,14$ & $\mathrm{~b}$ & $10,76 \pm 0,30$ & $\mathrm{~b}$ \\
\hline & & & GiSelA 6 & $6,69 \pm 0,47$ & $a b$ & $1,84 \pm 0,08$ & $\mathrm{a}$ & $1,27 \pm 0,05$ & $\mathrm{a}$ & $9,67 \pm 0,59$ & $\mathrm{a}$ \\
\hline & & & PHL-C & $6,14 \pm 0,39$ & $\mathrm{a}$ & $1,74 \pm 0,09$ & $\mathrm{a}$ & $1,21 \pm 0,08$ & $\mathrm{a}$ & $8,96 \pm 0,55$ & $\mathrm{a}$ \\
\hline & & & PiKu 1 & $6,22 \pm 0,01$ & a & $1,76 \pm 0,02$ & $\mathrm{a}$ & $1,21 \pm 0,01$ & $\mathrm{a}$ & $9,05 \pm 0,01$ & $\mathrm{a}$ \\
\hline & & & Weiroot 158 & $6,12 \pm 0,10$ & $\mathrm{a}$ & $1,68 \pm 0,03$ & $\mathrm{a}$ & $1,17 \pm 0,04$ & $\mathrm{a}$ & $8,83 \pm 0,16$ & $\mathrm{a}$ \\
\hline & & \multirow{5}{*}{ T3 } & GiSelA 5 & $6,71 \pm 0,47$ & $\mathrm{c}$ & $1,87 \pm 0,12$ & $\mathrm{c}$ & $1,22 \pm 0,10$ & $\mathrm{c}$ & $9,68 \pm 0,68$ & $\mathrm{c}$ \\
\hline & & & GiSelA 6 & $5,30 \pm 0,06$ & $a b$ & $1,78 \pm 0,03$ & $\mathrm{c}$ & $0,96 \pm 0,00$ & $\mathrm{ab}$ & $7,98 \pm 0,09$ & $\mathrm{~b}$ \\
\hline & & & PHL-C & $5,74 \pm 0,31$ & $\mathrm{~b}$ & $1,52 \pm 0,10$ & $\mathrm{~b}$ & $1,07 \pm 0,06$ & $\mathrm{~b}$ & $8,21 \pm 0,46$ & $\mathrm{~b}$ \\
\hline & & & PiKu 1 & $4,85 \pm 0,31$ & $\mathrm{a}$ & $1,02 \pm 0,05$ & $\mathrm{a}$ & $0,91 \pm 0,06$ & $\mathrm{a}$ & $6,64 \pm 0,37$ & $\mathrm{a}$ \\
\hline & & & Weiroot 158 & $5,10 \pm 0,17$ & $a b$ & $1,72 \pm 0,04$ & $\mathrm{c}$ & $0,98 \pm 0,02$ & $\mathrm{ab}$ & $7,73 \pm 0,23$ & $\mathrm{~b}$ \\
\hline \multirow{15}{*}{2012} & \multirow{15}{*}{ Regina } & \multirow{5}{*}{$\mathbf{T 1}$} & GiSelA 5 & $4,79 \pm 0,08$ & $\mathrm{c}$ & $1,59 \pm 0,02$ & $\mathrm{c}$ & $0,81 \pm 0,00$ & $\mathrm{c}$ & $7,15 \pm 0,09$ & $\mathrm{c}$ \\
\hline & & & GiSelA 6 & $4,32 \pm 0,25$ & $\mathrm{a}$ & $1,41 \pm 0,09$ & $a b$ & $0,74 \pm 0,04$ & $\mathrm{a}$ & $6,44 \pm 0,39$ & $\mathrm{a}$ \\
\hline & & & PHL-C & $4,51 \pm 0,00$ & $\mathrm{ab}$ & $1,39 \pm 0,02$ & $\mathrm{ab}$ & $0,74 \pm 0,03$ & $\mathrm{a}$ & $6,60 \pm 0,05$ & $\mathrm{a}$ \\
\hline & & & PiKu 1 & $4,60 \pm 0,05$ & $\mathrm{bc}$ & $1,46 \pm 0,01$ & $\mathrm{~b}$ & $0,76 \pm 0,02$ & $\mathrm{a}$ & $6,79 \pm 0,02$ & $a b$ \\
\hline & & & Weiroot 158 & $4,41 \pm 0,01$ & $a b$ & $1,35 \pm 0,01$ & $\mathrm{a}$ & $0,77 \pm 0,01$ & $\mathrm{ab}$ & $6,48 \pm 0,02$ & $\mathrm{a}$ \\
\hline & & \multirow{5}{*}{$\mathbf{T} 2$} & GiSelA 5 & $4,70 \pm 0,18$ & $\mathrm{c}$ & $1,42 \pm 0,05$ & $\mathrm{~d}$ & $0,78 \pm 0,02$ & $\mathrm{~d}$ & $6,85 \pm 0,25$ & c \\
\hline & & & GiSelA 6 & $4,27 \pm 0,02$ & $\mathrm{~b}$ & $1,23 \pm 0,00$ & $\mathrm{~b}$ & $0,71 \pm 0,01$ & $\mathrm{~b}$ & $6,16 \pm 0,02$ & $\mathrm{~b}$ \\
\hline & & & PHL-C & $4,17 \pm 0,03$ & $\mathrm{~b}$ & $1,22 \pm 0,01$ & $\mathrm{~b}$ & $0,72 \pm 0,01$ & $\mathrm{bc}$ & $6,05 \pm 0,04$ & $\mathrm{~b}$ \\
\hline & & & PiKu 1 & $4,31 \pm 0,00$ & $\mathrm{~b}$ & $1,30 \pm 0,00$ & $\mathrm{c}$ & $0,73 \pm 0,00$ & $\mathrm{c}$ & $6,30 \pm 0,00$ & $b$ \\
\hline & & & Weiroot 158 & $3,93 \pm 0,05$ & $\mathrm{a}$ & $1,14 \pm 0,03$ & $\mathrm{a}$ & $0,66 \pm 0,00$ & $\mathrm{a}$ & $5,68 \pm 0,08$ & $\mathrm{a}$ \\
\hline & & \multirow{5}{*}{$\mathbf{T 3}$} & GiSelA 5 & $4,33 \pm 0,13$ & $\mathrm{a}$ & $1,65 \pm 0,03$ & $\mathrm{a}$ & $0,83 \pm 0,01$ & $\mathrm{a}$ & $6,78 \pm 0,18$ & $\mathrm{a}$ \\
\hline & & & GiSelA 6 & $4,60 \pm 0,04$ & $\mathrm{~b}$ & $1,64 \pm 0,03$ & $\mathrm{a}$ & $0,85 \pm 0,02$ & $\mathrm{a}$ & $7,05 \pm 0,09$ & $a b$ \\
\hline & & & PHL-C & $4,59 \pm 0,00$ & $\mathrm{~b}$ & $1,72 \pm 0,00$ & $\mathrm{~b}$ & $0,96 \pm 0,00$ & $\mathrm{~b}$ & $7,21 \pm 0,00$ & $\mathrm{bc}$ \\
\hline & & & PiKu 1 & $4,59 \pm 0,03$ & $\mathrm{~b}$ & $1,73 \pm 0,01$ & $\mathrm{~b}$ & $0,94 \pm 0,02$ & $\mathrm{~b}$ & $7,21 \pm 0,03$ & $\mathrm{~b}$ \\
\hline & & & Weiroot 158 & $4,88 \pm 0,13$ & $\mathrm{c}$ & $1,71 \pm 0,03$ & $\mathrm{~b}$ & $0,94 \pm 0,02$ & $\mathrm{~b}$ & $7,48 \pm 0,19$ & c \\
\hline
\end{tabular}

1 a különböző betük a szignifikánsan különböző csoportokat jelölik, MANOVA, p<0,05 (Tukey / Games-Howell) 
30. táblázat: 'Regina' és 'Kordia' cseresznyefajta gyümölcseinek almasav, borostyánkősav és citromsav koncentrációja, valamint összes kromatográfiás savtartalma (TKS) (3.)

\begin{tabular}{|c|c|c|c|c|c|c|c|c|c|c|c|}
\hline Év & Nemes & Terminus & Alany & \multicolumn{2}{|l|}{$\begin{array}{c}\text { Almasav } \\
(\mathrm{mg} / \mathrm{ml})\end{array}$} & \multicolumn{2}{|c|}{$\begin{array}{c}\text { Borostyánkősav } \\
(\mathrm{mg} / \mathrm{ml})\end{array}$} & \multicolumn{2}{|c|}{$\begin{array}{c}\text { Citromsav } \\
(\mathrm{mg} / \mathrm{ml})\end{array}$} & \multicolumn{2}{|l|}{$\begin{array}{c}\text { TKS } \\
(\mathrm{mg} / \mathrm{ml})\end{array}$} \\
\hline \multirow{15}{*}{2013} & \multirow{15}{*}{ Kordia } & \multirow{5}{*}{ T1 } & GiSelA 5 & $8,77 \pm 0,48$ & & $2,94 \pm 0,18$ & & $1,75 \pm 0,13$ & & $13,32 \pm 0,75$ & $\mathrm{bc}$ \\
\hline & & & GiSelA 6 & $8,32 \pm 0,44$ & $\mathrm{a}$ & $2,63 \pm 0,13$ & & $1,60 \pm 0,10$ & & $12,42 \pm 0,66$ & $a b$ \\
\hline & & & PHL-C & $9,92 \pm 0,70$ & $\mathrm{~b}$ & $3,03 \pm 0,18$ & $\mathrm{~d}$ & $1,77 \pm 0,11$ & $\mathrm{~b}$ & $14,58 \pm 0,98$ & $\mathrm{c}$ \\
\hline & & & PiKu 1 & $7,83 \pm 0,50$ & $\mathrm{a}$ & $2,22 \pm 0,09$ & $\mathrm{a}$ & $1,54 \pm 0,10$ & & $11,42 \pm 0,54$ & $\mathrm{a}$ \\
\hline & & & Weiroot 158 & $7,95 \pm 0,43$ & $\mathrm{a}$ & $2,55 \pm 0,14$ & $\mathrm{~b}$ & $1,46 \pm 0,12$ & $\mathrm{a}$ & $11,86 \pm 0,68$ & $\mathrm{ab}$ \\
\hline & & \multirow{5}{*}{$\mathbf{T 2}$} & GiSelA 5 & $6,67 \pm 0,28$ & $\mathrm{ab}$ & $2,13 \pm 0,04$ & $\mathrm{~b}$ & $1,16 \pm 0,04$ & & $9,90 \pm 0,33$ & $\mathrm{bc}$ \\
\hline & & & GiSelA 6 & $7,38 \pm 0,32$ & $\mathrm{bc}$ & $2,15 \pm 0,07$ & $\mathrm{~b}$ & $1,24 \pm 0,07$ & $\mathrm{c}$ & $10,69 \pm 0,30$ & $\mathrm{~cd}$ \\
\hline & & & PHL-C & $6,21 \pm 0,10$ & $\mathrm{a}$ & $1,74 \pm 0,13$ & $\mathrm{a}$ & $0,97 \pm 0,05$ & $\mathrm{a}$ & $8,86 \pm 0,14$ & $\mathrm{a}$ \\
\hline & & & PiKu 1 & $6,39 \pm 0,49$ & $\mathrm{a}$ & $1,77 \pm 0,11$ & $\mathrm{a}$ & $1,04 \pm 0,09$ & $\mathrm{ab}$ & $9,12 \pm 0,49$ & $a b$ \\
\hline & & & Weiroot 158 & $7,58 \pm 0,31$ & $\mathrm{c}$ & $2,21 \pm 0,12$ & $\mathrm{~b}$ & $1,25 \pm 0,05$ & $\mathrm{c}$ & $10,96 \pm 0,47$ & $\mathrm{c}$ \\
\hline & & \multirow{5}{*}{$\mathbf{T 3}$} & GiSelA 5 & $6,23 \pm 0,37$ & $\mathrm{~b}$ & $2,05 \pm 0,08$ & $\mathrm{~b}$ & $1,02 \pm 0,09$ & $\mathrm{bc}$ & $9,27 \pm 0,41$ & $\mathrm{~b}$ \\
\hline & & & GiSelA 6 & $6,94 \pm 0,11$ & $\mathrm{c}$ & $2,27 \pm 0,08$ & $\mathrm{c}$ & $1,12 \pm 0,09$ & $\mathrm{c}$ & $10,30 \pm 0,04$ & $\mathrm{c}$ \\
\hline & & & PHL-C & $5,67 \pm 0,25$ & $\mathrm{a}$ & $1,75 \pm 0,11$ & $\mathrm{a}$ & $0,81 \pm 0,03$ & $\mathrm{a}$ & $8,22 \pm 0,23$ & $\mathrm{a}$ \\
\hline & & & PiKu 1 & $5,48 \pm 0,15$ & $\mathrm{a}$ & $1,63 \pm 0,08$ & $\mathrm{a}$ & $0,89 \pm 0,05$ & $\mathrm{ab}$ & $7,95 \pm 0,14$ & $\mathrm{a}$ \\
\hline & & & Weiroot 158 & $5,38 \pm 0,25$ & $\mathrm{a}$ & $1,77 \pm 0,09$ & $\mathrm{a}$ & $0,82 \pm 0,07$ & $\mathrm{a}$ & $7,97 \pm 0,23$ & $\mathrm{a}$ \\
\hline \multirow{15}{*}{2013} & \multirow{15}{*}{ Regina } & \multirow{5}{*}{ T1 } & GiSelA 5 & $5,82 \pm 0,02$ & $\mathrm{ab}$ & $2,14 \pm 0,07$ & $\mathrm{bc}$ & $1,24 \pm 0,01$ & & $9,12 \pm 0,06$ & $\mathrm{~b}$ \\
\hline & & & GiSelA 6 & $5,25 \pm 0,25$ & $\mathrm{a}$ & $1,68 \pm 0,08$ & $\mathrm{a}$ & $1,07 \pm 0,04$ & $\mathrm{a}$ & $7,90 \pm 0,17$ & $\mathrm{a}$ \\
\hline & & & PHL-C & $6,06 \pm 0,50$ & $\mathrm{~b}$ & $1,97 \pm 0,17$ & $\mathrm{~b}$ & $1,12 \pm 0,06$ & & $9,08 \pm 0,67$ & $\mathrm{~b}$ \\
\hline & & & PiKu 1 & $6,19 \pm 0,06$ & $\mathrm{~b}$ & $2,27 \pm 0,01$ & $\mathrm{c}$ & $1,33 \pm 0,03$ & $\mathrm{c}$ & $9,69 \pm 0,07$ & $\mathrm{~b}$ \\
\hline & & & Weiroot 158 & $6,52 \pm 0,47$ & $\mathrm{~b}$ & $2,16 \pm 0,17$ & $\mathrm{bc}$ & $1,27 \pm 0,10$ & $\mathrm{c}$ & $9,86 \pm 0,73$ & $\mathrm{~b}$ \\
\hline & & \multirow{5}{*}{$\mathbf{T} 2$} & GiSelA 5 & $4,69 \pm 0,28$ & $\mathrm{a}$ & $1,48 \pm 0,12$ & $\mathrm{~b}$ & $0,86 \pm 0,05$ & & $6,96 \pm 0,45$ & $\mathrm{a}$ \\
\hline & & & GiSelA 6 & $4,71 \pm 0,16$ & $\mathrm{a}$ & $1,37 \pm 0,15$ & $\mathrm{ab}$ & $0,78 \pm 0,02$ & $\mathrm{ab}$ & $6,81 \pm 0,20$ & $\mathrm{a}$ \\
\hline & & & PHL-C & $5,46 \pm 0,36$ & $b$ & $1,82 \pm 0,07$ & $\mathrm{c}$ & $0,89 \pm 0,04$ & $\mathrm{c}$ & $8,14 \pm 0,33$ & $\mathrm{~b}$ \\
\hline & & & PiKu 1 & $5,92 \pm 0,28$ & $\mathrm{~b}$ & $1,98 \pm 0,10$ & $\mathrm{c}$ & $1,06 \pm 0,06$ & $\mathrm{~d}$ & $8,91 \pm 0,27$ & $\mathrm{c}$ \\
\hline & & & Weiroot 158 & $4,49 \pm 0,08$ & $\mathrm{a}$ & $1,26 \pm 0,01$ & $\mathrm{a}$ & $0,73 \pm 0,02$ & $\mathrm{a}$ & $6,43 \pm 0,09$ & $\mathrm{a}$ \\
\hline & & \multirow{5}{*}{ T3 } & GiSelA 5 & $3,78 \pm 0,06$ & $\mathrm{bc}$ & $1,07 \pm 0,01$ & $\mathrm{~b}$ & $0,61 \pm 0,00$ & $\mathrm{~b}$ & $5,41 \pm 0,07$ & $\mathrm{~b}$ \\
\hline & & & GiSelA 6 & $3,57 \pm 0,16$ & $\mathrm{ab}$ & $0,90 \pm 0,04$ & $\mathrm{a}$ & $0,55 \pm 0,01$ & $\mathrm{a}$ & $4,97 \pm 0,19$ & $\mathrm{a}$ \\
\hline & & & PHL-C & $3,30 \pm 0,25$ & $\mathrm{a}$ & $1,08 \pm 0,06$ & $\mathrm{~b}$ & $0,54 \pm 0,02$ & $\mathrm{a}$ & $4,90 \pm 0,27$ & $\mathrm{a}$ \\
\hline & & & PiKu 1 & $3,96 \pm 0,10$ & $\mathrm{c}$ & $1,43 \pm 0,04$ & $\mathrm{c}$ & $0,68 \pm 0,01$ & $\mathrm{c}$ & $6,05 \pm 0,15$ & $\mathrm{c}$ \\
\hline & & & Weiroot 158 & $3,62 \pm 0,05$ & $b$ & $0,96 \pm 0,06$ & $\mathrm{a}$ & $0,57 \pm 0,02$ & $\mathrm{a}$ & $5,11 \pm 0,12$ & $a b$ \\
\hline
\end{tabular}

${ }^{1}$ A különböző betük a szignifikánsan különböző csoportokat jelölik. Az elemzést MANOVA módszerrel végeztük $\mathrm{p}<0,05$ szinten, szóráshomogenitás esetén Tukey, enyhe sérülése esetén Games-Howell post hoc tesztet alkalmazva. 
31. táblázat: 'Regina' és 'Kordia' cseresznyefajták gyümölcseiben az egyedi polifenol-komponensek koncentrációi, valamint a totál kromatográfiás polifenol-tartalom (1.)

\begin{tabular}{|c|c|c|c|c|c|c|c|c|c|c|c|c|c|c|c|c|c|c|c|}
\hline Év & Nemes & Term. & Alany & \multicolumn{2}{|l|}{$\begin{array}{l}\text { Cianidin } \\
\text { (mg/kg) }\end{array}$} & \multicolumn{2}{|c|}{$\begin{array}{l}\text { Epikatechin } \\
\text { (mg/kg) }\end{array}$} & \multicolumn{2}{|c|}{$\begin{array}{l}\text { Neoklorogénsav } \\
(\mathrm{mg} / \mathrm{kg})\end{array}$} & \multicolumn{2}{|c|}{$\begin{array}{l}\text { Klorogénsav } \\
(\mathrm{mg} / \mathrm{kg})\end{array}$} & \multicolumn{2}{|l|}{$\begin{array}{l}\text { Kínasav } \\
\text { (mg/kg) }\end{array}$} & \multicolumn{2}{|l|}{$\begin{array}{l}\text { Rutin } \\
\text { (mg/kg) }\end{array}$} & \multicolumn{2}{|l|}{$\begin{array}{l}\text { Kvercetin } \\
(\mathrm{mg} / \mathrm{kg})\end{array}$} & \multicolumn{2}{|l|}{$\begin{array}{c}\text { TKPF } \\
(\mathrm{mg} / \mathrm{kg})\end{array}$} \\
\hline \multirow{15}{*}{2011} & \multirow{15}{*}{ Kordia } & \multirow{5}{*}{ T1 } & iS 5 & $112,08 \pm 6,78$ & a & $25,25 \pm 2,11$ & $\mathrm{a}$ & $383,59 \pm 9,15$ & & $33,93 \pm 1,40$ & & $57,47 \pm 3,02$ & & $26,08 \pm 1,10$ & & $17,44 \pm 0,91$ & & $655,8 \pm 13,4$ & $\mathrm{~b}$ \\
\hline & & & & $125,04 \pm 5,72$ & $\mathrm{~b}$ & $42,14 \pm 2,34$ & $\mathrm{~d}$ & $474,23 \pm 24,65$ & $\mathrm{~d}$ & $52,93 \pm 2,15$ & e & $86,79 \pm 4,56$ & $\mathrm{~d}$ & $32,04 \pm 1,43$ & & $24,50 \pm 1,67$ & & $837,6 \pm 31,1$ & $\mathrm{~d}$ \\
\hline & & & PHL-C & $103,47 \pm 4,85$ & $\mathrm{a}$ & $23,01 \pm 0,57$ & $\mathrm{a}$ & $265,36 \pm 7,11$ & & $28,11 \pm 0,59$ & & $50,68 \pm 3,77$ & $\mathrm{a}$ & $24,33 \pm 1,05$ & & $16,60 \pm 0,74$ & & $511,5 \pm 10,7$ & $\mathrm{a}$ \\
\hline & & & $\mathrm{PiKu}$ & $134,04 \pm 3,64$ & $\mathrm{bc}$ & $34,52 \pm 1,52$ & $\mathrm{c}$ & $375,62 \pm 21,59$ & $\mathrm{c}$ & $44,21 \pm 2,25$ & $\mathrm{~d}$ & $70,30 \pm 2,06$ & $\mathrm{c}$ & $27,89 \pm 1,29$ & $\mathrm{~b}$ & $16,74 \pm 0,49$ & & $703,3 \pm 24,9$ & $\mathrm{c}$ \\
\hline & & & & $144,68 \pm 2,18$ & c & $30,51 \pm 0,54$ & $\mathrm{~b}$ & $335,46 \pm 12,42$ & $\mathrm{~b}$ & $38,77 \pm 1,00$ & c & $63,43 \pm 4,04$ & $\mathrm{bc}$ & $32,83 \pm 1,86$ & $\mathrm{c}$ & $23,49 \pm 2,35$ & $\mathrm{~b}$ & $669,1 \pm 14,9$ & $\mathrm{bc}$ \\
\hline & & \multirow{5}{*}{$\mathbf{T} 2$} & & $206,03 \pm 8,24$ & $\mathrm{a}$ & $26,35 \pm 0,67$ & $\mathrm{c}$ & $310,95 \pm 6,44$ & & $35,15 \pm 1,01$ & $\mathrm{~b}$ & & $\mathrm{c}$ & $25,36 \pm 1,69$ & $\mathrm{~b}$ & $17,62 \pm 1,01$ & & $681,4 \pm 18,1$ & $\mathrm{c}$ \\
\hline & & & GiS 6 & $189,36 \pm 12,98$ & $\mathrm{a}$ & $31,38 \pm 1,80$ & $\mathrm{~d}$ & $365,14 \pm 10,87$ & & $35,10 \pm 3,45$ & $\mathrm{~b}$ & $63,83 \pm 3,78$ & $\mathrm{c}$ & $18,33 \pm 1,16$ & $\mathrm{a}$ & $17,07 \pm 0,83$ & & $720,2 \pm 18,4$ & $\mathrm{c}$ \\
\hline & & & PHL-C & $190,95 \pm 5,40$ & $\mathrm{a}$ & $16,53 \pm 0,72$ & $\mathrm{a}$ & $203,06 \pm 16,00$ & $\mathrm{a}$ & $26,23 \pm 0,71$ & $\mathrm{a}$ & $41,65 \pm 1,93$ & $\mathrm{a}$ & $19,26 \pm 1,22$ & $\mathrm{a}$ & $16,17 \pm 0,72$ & & $513,8 \pm 19,4$ & $\mathrm{a}$ \\
\hline & & & & $260,09 \pm 1$ & $\mathrm{~b}$ & $15,15 \pm 0,81$ & $\mathrm{a}$ & $242,39 \pm 12,69$ & $\mathrm{~b}$ & $28,34 \pm 1,23$ & $\mathrm{a}$ & & $a b$ & $27,77 \pm 2,02$ & $\mathrm{~b}$ & $23,61 \pm 1,00$ & & $642,0 \pm 15,5$ & $\mathrm{~b}$ \\
\hline & & & & $313,34 \pm 1$ & c & $19,44 \pm 1,25$ & $\mathrm{~b}$ & $232,34 \pm 14,01$ & $\mathrm{~b}$ & $29,81 \pm 1,72$ & $\mathrm{a}$ & $48,01 \pm 3,07$ & $\mathrm{~b}$ & $25,55 \pm 0,88$ & $\mathrm{~b}$ & $19,42 \pm 0,76$ & $\mathrm{~b}$ & $687,9 \pm 17,4$ & c \\
\hline & & \multirow{5}{*}{ T3 } & 5 & $642,66 \pm 22,97$ & $\mathrm{c}$ & $23,03 \pm 0,62$ & $\mathrm{c}$ & $300,14 \pm 5,14$ & $\mathrm{c}$ & $36,33 \pm 1,81$ & $\mathrm{a}$ & $52,19 \pm 1,18$ & $\mathrm{c}$ & $26,88 \pm 1,25$ & $\mathrm{a}$ & $28,64 \pm 0,97$ & $\mathrm{~b}$ & $1109,8 \pm 16,9$ & $\mathrm{c}$ \\
\hline & & & & $497,25 \pm 2$ & $\mathrm{a}$ & & $\mathrm{c}$ & $285,53 \pm 16,42$ & & & $\mathrm{a}$ & & $\mathrm{d}$ & & $\mathrm{a}$ & & & & $\mathrm{b}$ \\
\hline & & & L-C & $541,03 \pm 31,96$ & $\mathrm{ab}$ & $13,03 \pm 0,66$ & $\mathrm{a}$ & $172,00 \pm 8,90$ & & $47,81 \pm 1,94$ & $\mathrm{~b}$ & $42,92 \pm 1,83$ & $\mathrm{~b}$ & $27,27 \pm 2,19$ & $\mathrm{ab}$ & $23,38 \pm 1,60$ & & $867,4 \pm 33,1$ & $\mathrm{a}$ \\
\hline & & & $\mathrm{Ku}$ & $561,90 \pm 16,39$ & $\mathrm{~b}$ & $19,58 \pm 0,51$ & $\mathrm{~b}$ & $226,54 \pm 11,53$ & $\mathrm{~b}$ & $53,39 \pm 3,42$ & $\mathrm{~b}$ & $52,01 \pm 1,19$ & $\mathrm{c}$ & $30,35 \pm 1,08$ & $\mathrm{~b}$ & $30,18 \pm 0,35$ & $\mathrm{~b}$ & $973,9 \pm 24,0$ & $\mathrm{~b}$ \\
\hline & & & & $624,05 \pm 3$ & $\mathrm{c}$ & $13,52 \pm 0,88$ & $\mathrm{a}$ & $177,05 \pm 7,20$ & $\mathrm{a}$ & $52,53 \pm 3,97$ & $\mathrm{~b}$ & & $\mathrm{a}$ & $34,73 \pm 1,78$ & $\mathrm{c}$ & $30,55 \pm 1,88$ & $\mathrm{~b}$ & $968,3 \pm$ & $\mathrm{b}$ \\
\hline \multirow{15}{*}{2011} & \multirow{15}{*}{ Regina } & \multirow{5}{*}{ T1 } & GiS 5 & $107,11 \pm 5,71$ & $\mathrm{bc}$ & $23,97 \pm 1,68$ & $\mathrm{~b}$ & $278,65 \pm 19,24$ & & $28,46 \pm 0,68$ & $\mathrm{a}$ & $61,00 \pm 7,46$ & $\mathrm{ab}$ & $20,85 \pm 1,99$ & $\mathrm{a}$ & $21,18 \pm 1,27$ & & $541,2 \pm$ & $\mathrm{a}$ \\
\hline & & & 6 & $107,44 \pm$ & $\mathrm{bc}$ & $22,57 \pm 1,58$ & $\mathrm{ab}$ & $244,64 \pm 19,73$ & $\mathrm{a}$ & $28,57 \pm 0,95$ & $\mathrm{a}$ & $52,81 \pm 2,25$ & $\mathrm{a}$ & $24,29 \pm 0,34$ & $\mathrm{bc}$ & $19,09 \pm 0,21$ & $\mathrm{ab}$ & $499,4 \pm 24,6$ & $\mathrm{a}$ \\
\hline & & & PHL-C & $110,22 \pm 2,95$ & $\mathrm{c}$ & $27,83 \pm 0,58$ & $\mathrm{c}$ & $319,02 \pm 21,57$ & $\mathrm{~b}$ & $40,18 \pm 1,90$ & $\mathrm{~b}$ & $70,35 \pm 5,68$ & $\mathrm{~b}$ & $27,44 \pm 1,42$ & $\mathrm{c}$ & $24,70 \pm 1,55$ & & $619,7 \pm 16,2$ & $\mathrm{~b}$ \\
\hline & & & & $98,57 \pm 7,18$ & $\mathrm{~b}$ & $20,84 \pm 1,15$ & $\mathrm{a}$ & $252,53 \pm 12,99$ & $\mathrm{a}$ & $28,24 \pm 2,14$ & $\mathrm{a}$ & $52,79 \pm 3,95$ & $\mathrm{a}$ & $24,16 \pm 1,84$ & $\mathrm{~b}$ & $20,88 \pm 0,55$ & & $498,0 \pm 23,2$ & $\mathrm{a}$ \\
\hline & & & & 85,48 & $\mathrm{a}$ & $24,29 \pm 1,23$ & $\mathrm{~b}$ & $271,64 \pm 7,17$ & $\mathrm{a}$ & $28,57 \pm 1,69$ & $\mathrm{a}$ & $54,36 \pm 3,26$ & $\mathrm{a}$ & $21,36 \pm 1,05$ & $a b$ & $17,17 \pm 0,86$ & $\mathrm{a}$ & $502,8 \pm 16,1$ & $\mathrm{a}$ \\
\hline & & \multirow{5}{*}{$\mathbf{T} 2$} & & & $\mathrm{~b}$ & & $\mathrm{a}$ & $156,24 \pm 7,79$ & $\mathrm{~b}$ & $18,86 \pm 0,94$ & $\mathrm{~b}$ & & $a b$ & $19,88 \pm 0,61$ & $\mathrm{~b}$ & 15,74 & $\mathrm{c}$ & 3,4 & $\mathrm{a}$ \\
\hline & & & & $124,00 \pm 2,74$ & $\mathrm{a}$ & $10,76 \pm 0,78$ & $\mathrm{a}$ & $147,15 \pm 9,13$ & & $16,69 \pm 1,04$ & $\mathrm{ab}$ & $27,79 \pm 1,89$ & $\mathrm{a}$ & $17,92 \pm 1,28$ & $\mathrm{ab}$ & $13,31 \pm 0,97$ & & $357,6 \pm 17,6$ & $\mathrm{a}$ \\
\hline & & & PHL-C & $140,44 \pm 6,41$ & $\mathrm{~b}$ & $10,82 \pm 0,97$ & $\mathrm{a}$ & $161,74 \pm 9,33$ & $\mathrm{~b}$ & $26,32 \pm 1,46$ & $\mathrm{~d}$ & $93,02 \pm 4,83$ & $\mathrm{c}$ & $20,07 \pm 0,43$ & $\mathrm{~b}$ & $15,85 \pm 0,98$ & c & $468,2 \pm 20,9$ & $\mathrm{~b}$ \\
\hline & & & & $150,80 \pm 8,51$ & $\mathrm{~b}$ & $13,21 \pm 0,66$ & $\mathrm{~b}$ & $133,01 \pm 4,67$ & & $22,25 \pm 1,43$ & $\mathrm{c}$ & & $\mathrm{b}$ & $19,20 \pm 1,45$ & $a b$ & $15,35 \pm 1,26$ & & $390,1 \pm 11,0$ & $\mathrm{a}$ \\
\hline & & & & $136,49 \pm 8,46$ & $\mathrm{ab}$ & $10,04 \pm 0,56$ & $\mathrm{a}$ & $145,30 \pm 10,36$ & $\mathrm{ab}$ & $16,10 \pm 0,95$ & $\mathrm{a}$ & $27,70 \pm 2,06$ & $\mathrm{a}$ & $17,07 \pm 1,20$ & $\mathrm{a}$ & $13,08 \pm 0,61$ & $\mathrm{a}$ & $365,7 \pm 23,4$ & $\mathrm{a}$ \\
\hline & & \multirow{5}{*}{ T3 } & GiS 5 & $209,75 \pm 14,14$ & $\mathrm{ab}$ & $11,26 \pm 0,47$ & $a b$ & $105,43 \pm 6,15$ & $\mathrm{a}$ & $37,54 \pm 2,02$ & $\mathrm{bc}$ & $35,07 \pm 2,39$ & $a b$ & $22,48 \pm 0,71$ & $\mathrm{bc}$ & $20,22 \pm 1,14$ & $\mathrm{~b}$ & $441,7 \pm 6,3$ & $\mathrm{a}$ \\
\hline & & & & $248,53 \pm 7,63$ & $\mathrm{c}$ & $11,82 \pm 0,72$ & $\mathrm{abc}$ & $112,34 \pm 2,44$ & $a b$ & $34,17 \pm 1,57$ & $a b$ & $34,07 \pm 2,69$ & $a b$ & $20,11 \pm 1,05$ & $a b$ & $14,90 \pm 0,74$ & $\mathrm{a}$ & $475,9 \pm 9,3$ & $\mathrm{~b}$ \\
\hline & & & PHL-C & $198,74 \pm 6,20$ & $\mathrm{a}$ & $12,96 \pm 0,99$ & $\mathrm{c}$ & $122,03 \pm 2,76$ & $\mathrm{~b}$ & $32,84 \pm 2,21$ & $\mathrm{a}$ & $35,08 \pm 1,55$ & $a b$ & $19,21 \pm 1,13$ & $\mathrm{a}$ & $16,39 \pm 0,62$ & & $437,2 \pm 7,8$ & $\mathrm{a}$ \\
\hline & & & $\mathrm{iKu}$ & $275,74 \pm 6,98$ & $\mathrm{~d}$ & $12,45 \pm 1,04$ & $\mathrm{bc}$ & $119,21 \pm 4,97$ & $\mathrm{~b}$ & $44,56 \pm 0,97$ & $\mathrm{~d}$ & $37,19 \pm 1,66$ & $\mathrm{~b}$ & $24,63 \pm 2,06$ & $\mathrm{c}$ & $18,94 \pm 1,18$ & $\mathrm{~b}$ & $532,7 \pm 11,3$ & $\mathrm{c}$ \\
\hline & & & Wei & $227,84 \pm 17,43$ & $\mathrm{bc}$ & $10,58 \pm 0,41$ & $\mathrm{a}$ & $111,62 \pm 7,20$ & $\mathrm{ab}$ & $38,55 \pm 1,85$ & $\mathrm{c}$ & $32,93 \pm 0,37$ & $\mathrm{a}$ & $20,90 \pm 0,62$ & $\mathrm{ab}$ & $15,44 \pm 0,75$ & $\mathbf{a}$ & $457,8 \pm 18,1$ & $a b$ \\
\hline
\end{tabular}

1a különböző betűk a szignifikánsan különböző csoportokat jelölik, MANOVA, p<0,05 (Tukey / Games-Howell) 
31. táblázat: 'Regina' és 'Kordia’ cseresznyefajták gyümöleseiben az egyedi polifenol-komponensek koncentrációi, valamint a totál kromatográfiás polifenol-tartalom (2.)

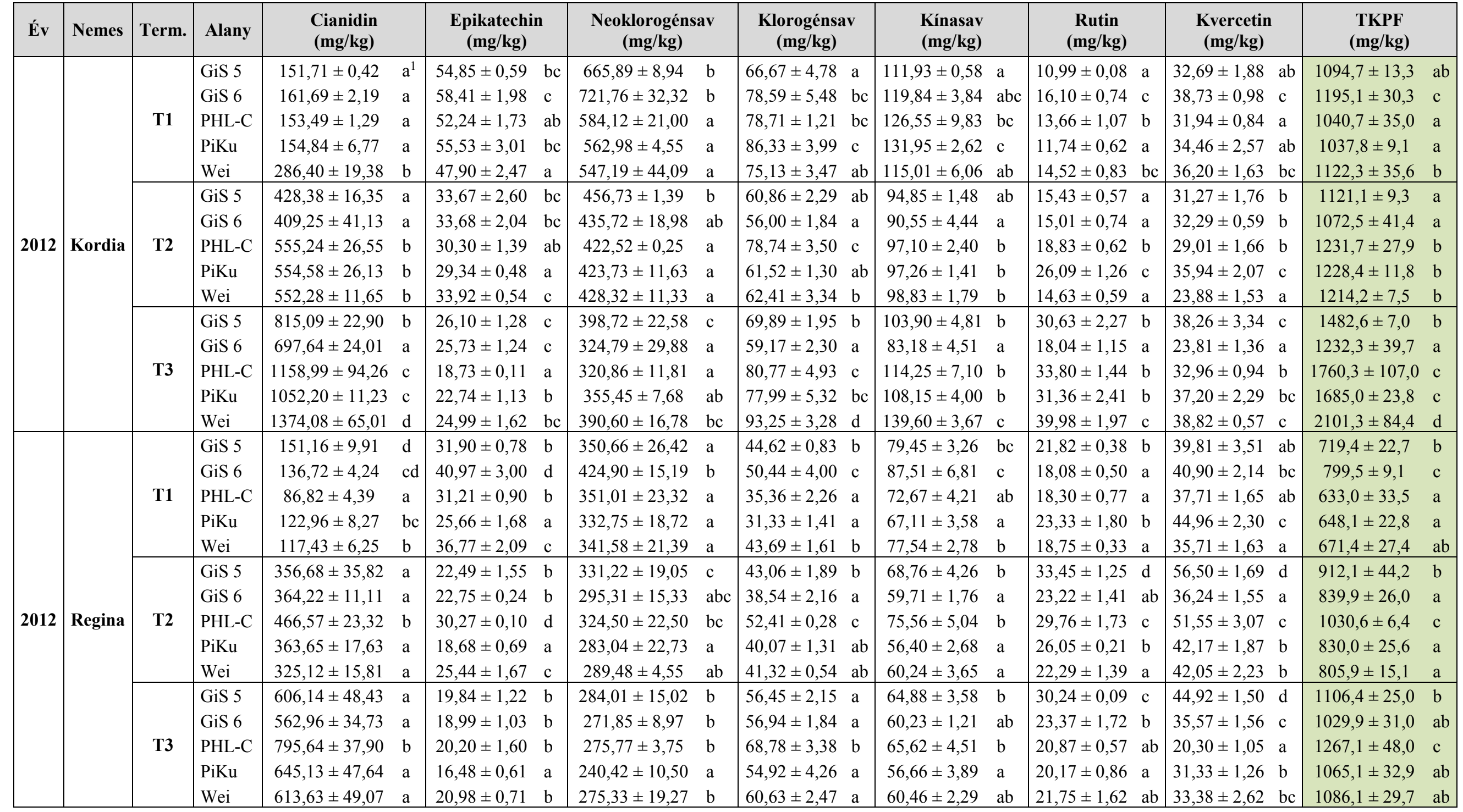

1a különböző betűk a szignifikánsan különböző csoportokat jelölik, MANOVA, p<0,05 (Tukey / Games-Howell) 
31. táblázat: 'Regina' és 'Kordia' cseresznyefajták gyümölcseiben az egyedi polifenol-komponensek koncentrációi, valamint az összes kromatográfiás polifenol-tartalom (3.)

\begin{tabular}{|c|c|c|c|c|c|c|c|c|c|c|c|c|c|c|c|c|c|c|c|}
\hline Év & nes & erm. & Alany & $\begin{array}{c}\text { Cianidin } \\
(\mathrm{mg} / \mathrm{kg})\end{array}$ & & $\begin{array}{l}\text { Epikatechin } \\
\text { (mg/kg) }\end{array}$ & & $\begin{array}{c}\text { Neoklorogénsa } \\
(\mathrm{mg} / \mathrm{kg})\end{array}$ & & $\begin{array}{c}\text { Klorogénsa } \\
(\mathrm{mg} / \mathrm{kg})\end{array}$ & & $\begin{array}{l}\text { Kínasav } \\
\text { (mg/kg) }\end{array}$ & & $\begin{array}{l}\text { Rutin } \\
\text { (mg/kg) }\end{array}$ & & $\begin{array}{c}\text { Kvercetin } \\
\text { (mg/kg) }\end{array}$ & & $\begin{array}{c}\text { TKPF } \\
\text { (mg/kg) }\end{array}$ & \\
\hline \multirow{15}{*}{2013} & \multirow{15}{*}{ Kordia } & \multirow{5}{*}{ T1 } & GiS 5 & $133,11 \pm 6,03$ & $b^{1}$ & $76,43 \pm 0,11$ & & $615,03 \pm 3,03$ & & $94,46 \pm 3,07$ & & $387,94 \pm 7,99$ & & $23,90 \pm 1,62$ & $\mathrm{c}$ & $37,03 \pm 1,98$ & & $1367,8 \pm 19,1$ & $\mathrm{e}$ \\
\hline & & & S 6 & $124,78 \pm 7,05$ & $\mathrm{~b}$ & $62,42 \pm 4,37$ & $\mathrm{c}$ & $487,74 \pm 4,55$ & d & $47,14 \pm 4,21$ & $\mathrm{a}$ & $339,21 \pm 19,50$ & $\mathrm{c}$ & $17,39 \pm 0,84$ & $\mathrm{~b}$ & $31,05 \pm 2,16$ & $\mathrm{~b}$ & $1109,7 \pm 39,8$ & $\mathrm{~d}$ \\
\hline & & & PHL-C & $101,65 \pm 6,52$ & $\mathrm{a}$ & $52,63 \pm 2,71$ & & $417,61 \pm 12,72$ & & $59,12 \pm 4,13$ & $\mathrm{~b}$ & $305,99 \pm 24,19$ & $\mathrm{bc}$ & $0,00 \pm 0,00$ & $\mathrm{a}$ & $30,26 \pm 1,24$ & & $967,2 \pm 32,7$ & $\mathrm{c}$ \\
\hline & & & $\mathrm{PiKu}$ & $91,66 \pm 4,10$ & $\mathrm{a}$ & $42,35 \pm 0,58$ & $\mathrm{a}$ & $328,89 \pm 10,97$ & $\mathrm{a}$ & $46,74 \pm 2,89$ & $\mathrm{a}$ & $260,26 \pm 11,01$ & $\mathrm{a}$ & $0,00 \pm 0,00$ & $\mathrm{a}$ & $26,24 \pm 2,36$ & & $796,1 \pm 19,2$ & $\mathrm{a}$ \\
\hline & & & Wei & $104,11 \pm 7,80$ & $\mathrm{a}$ & $50,41 \pm 1,08$ & $\mathrm{~b}$ & $363,24 \pm 8,83$ & $\mathrm{~b}$ & $54,55 \pm 3,69$ & $\mathrm{ab}$ & $294,21 \pm 7,12$ & $\mathrm{~b}$ & $0,00 \pm 0,00$ & $\mathrm{a}$ & $28,07 \pm 1,11$ & $\mathrm{ab}$ & $894,5 \pm 29,6$ & $\mathrm{~b}$ \\
\hline & & \multirow{5}{*}{$\mathbf{T} 2$} & GiS 5 & $171,67 \pm 6,15$ & $\mathrm{c}$ & $33,91 \pm 1,74$ & $\mathrm{~d}$ & $284,99 \pm 19,79$ & $\mathrm{c}$ & $44,78 \pm 2,07$ & $\mathrm{c}$ & $150,75 \pm 7,68$ & $\mathrm{c}$ & $8,55 \pm 0,57$ & $\mathrm{bc}$ & $19,53 \pm 0,88$ & & $714,1 \pm 34,4$ & $\mathrm{c}$ \\
\hline & & & GiS 6 & $173,00 \pm 9,48$ & $\mathrm{c}$ & $23,31 \pm 0,99$ & $a b$ & $256,21 \pm 24,36$ & $\mathrm{bc}$ & $38,18 \pm 2,85$ & $\mathrm{~b}$ & $231,23 \pm 14,73$ & d & $7,82 \pm 0,40$ & $a b$ & $18,53 \pm 0,60$ & & $748,2 \pm 31,8$ & $\mathrm{c}$ \\
\hline & & & PHL-C & $128,57 \pm 7,28$ & $\mathrm{a}$ & $21,04 \pm 0,96$ & $\mathrm{a}$ & $196,36 \pm 9,00$ & $\mathrm{a}$ & $25,44 \pm 1,72$ & $\mathrm{a}$ & $104,88 \pm 5,79$ & $\mathrm{a}$ & $7,28 \pm 0,44$ & $\mathrm{a}$ & $15,65 \pm 0,80$ & $\mathrm{a}$ & $499,2 \pm 20,9$ & $\mathrm{a}$ \\
\hline & & & $\mathrm{PiKu}$ & $120,98 \pm 9,92$ & a & $25,78 \pm 1,85$ & $\mathrm{bc}$ & $225,69 \pm 20,19$ & $\mathrm{ab}$ & $35,77 \pm 2,64$ & $\mathrm{~b}$ & $118,02 \pm 10,35$ & $\mathrm{ab}$ & $9,23 \pm 0,39$ & $\mathrm{c}$ & $19,71 \pm 0,87$ & $\mathrm{~b}$ & $555,1 \pm 36,2$ & $a b$ \\
\hline & & & Wei & $150,27 \pm 9,02$ & $\mathrm{~b}$ & $27,40 \pm 1,53$ & $\mathrm{c}$ & $226,77 \pm 10,69$ & $a b$ & $37,32 \pm 0,53$ & $\mathrm{~b}$ & $128,31 \pm 7,34$ & $\mathrm{~b}$ & $9,28 \pm 0,53$ & $\mathrm{c}$ & $18,95 \pm 0,50$ & $\mathrm{~b}$ & $598,3 \pm 5,6$ & $\mathrm{~b}$ \\
\hline & & \multirow{5}{*}{ T3 } & GiS 5 & $509,56 \pm 1,89$ & $\mathrm{~b}$ & $23,31 \pm 0,99$ & $\mathrm{c}$ & $232,41 \pm 11,84$ & c & $58,23 \pm 2,56$ & $\mathrm{~b}$ & $118,34 \pm 3,43$ & $\mathrm{c}$ & $12,48 \pm 0,63$ & $\mathrm{bc}$ & $13,14 \pm 0,61$ & $\mathrm{c}$ & $967,4 \pm 21,9$ & $\mathrm{e}$ \\
\hline & & & & $436,29 \pm 22,07$ & $\mathrm{a}$ & $19,45 \pm 0,19$ & $\mathrm{~b}$ & $195,08 \pm 12,70$ & $\mathrm{~b}$ & $52,31 \pm 3,48$ & $\mathrm{a}$ & $101,77 \pm 6,84$ & $\mathrm{~b}$ & $11,26 \pm 0,74$ & $a b$ & $11,01 \pm 0,69$ & $\mathrm{~b}$ & $827,1 \pm 27,0$ & $\mathrm{~b}$ \\
\hline & & & PHL-C & $525,48 \pm 5,09$ & $\mathrm{~b}$ & $14,73 \pm 0,19$ & $\mathrm{a}$ & $168,70 \pm 1,37$ & $\mathrm{a}$ & $67,96 \pm 2,88$ & $\mathrm{c}$ & $96,37 \pm 1,30$ & $\mathrm{~b}$ & $13,45 \pm 0,68$ & $\mathrm{c}$ & $15,27 \pm 0,82$ & $\mathrm{~d}$ & $901,9 \pm 5,9$ & $\mathrm{c}$ \\
\hline & & & $\mathrm{PiKu}$ & $405,24 \pm 20,83$ & $\mathrm{a}$ & $16,53 \pm 0,23$ & $\mathrm{a}$ & $177,04 \pm 13,63$ & $\mathrm{ab}$ & $59,06 \pm 1,13$ & $\mathrm{~b}$ & $78,12 \pm 1,50$ & $\mathrm{a}$ & $10,81 \pm 0,11$ & $\mathrm{a}$ & $6,88 \pm 0,35$ & $\mathrm{a}$ & $753,6 \pm 24,5$ & a \\
\hline & & & Wei & $535,33 \pm$ & $\mathrm{b}$ & $19,39 \pm 1,80$ & $\mathrm{~b}$ & $187,27 \pm 8,71$ & $\mathrm{ab}$ & $65,75 \pm 2,39$ & $\mathrm{c}$ & $79,89 \pm 4,33$ & $\mathrm{a}$ & $12,35 \pm 0,99$ & $\mathrm{bc}$ & $13,01 \pm 1,37$ & $\mathrm{c}$ & $912,9 \pm$ & $\mathrm{cd}$ \\
\hline \multirow{15}{*}{2013} & \multirow{15}{*}{ Regina } & \multirow{5}{*}{ T1 } & GiS 5 & $94,46 \pm 6,24$ & $\mathrm{~b}$ & $25,91 \pm 1,15$ & $\mathrm{a}$ & $222,55 \pm 13,70$ & $\mathrm{a}$ & $42,02 \pm 1,75$ & $\mathrm{~b}$ & $69,04 \pm 5,21$ & $\mathrm{~b}$ & $9,46 \pm 0,39$ & $\mathrm{~b}$ & $20,60 \pm 0,65$ & & $484,0 \pm 27,4$ & $\mathrm{~b}$ \\
\hline & & & GiS 6 & $130,22 \pm 2,98$ & $\mathrm{~d}$ & $34,37 \pm 0,24$ & $\mathrm{c}$ & $258,10 \pm 0,04$ & $\mathrm{~b}$ & $43,57 \pm 2,35$ & $\mathrm{~b}$ & $71,85 \pm 0,28$ & $\mathrm{~b}$ & $0,00 \pm 0,00$ & $\mathrm{a}$ & $18,02 \pm 0,28$ & $\mathrm{~b}$ & $556,1 \pm 0,8$ & $\mathrm{c}$ \\
\hline & & & PHL-C & $101,25 \pm 2,24$ & $\mathrm{bc}$ & $28,18 \pm 0,74$ & $a b$ & $205,07 \pm 5,19$ & $\mathrm{a}$ & $32,27 \pm 1,07$ & $\mathrm{a}$ & $60,71 \pm 0,10$ & $\mathrm{a}$ & $0,00 \pm 0,00$ & $\mathrm{a}$ & $17,47 \pm 0,20$ & $a b$ & 444,9 & $\mathrm{a}$ \\
\hline & & & $\mathrm{PiKu}$ & $106,37 \pm 5,71$ & $\mathrm{c}$ & $30,23 \pm 1,41$ & $\mathrm{~b}$ & $248,45 \pm 7,39$ & b & $42,04 \pm 1,13$ & $\mathrm{~b}$ & $72,37 \pm 4,35$ & $\mathrm{~b}$ & $9,77 \pm 0,74$ & $\mathrm{~b}$ & $20,03 \pm 1,25$ & $\mathrm{c}$ & $529,2 \pm 5,8$ & $\mathrm{c}$ \\
\hline & & & Wei & $78,84 \pm 3,00$ & $\mathrm{a}$ & $28,50 \pm 2,06$ & $\mathrm{ab}$ & $218,98 \pm 14,94$ & $\mathrm{a}$ & $34,52 \pm 2,29$ & $\mathrm{a}$ & $71,61 \pm 4,44$ & $\mathrm{~b}$ & $0,00 \pm 0,00$ & $\mathrm{a}$ & $16,50 \pm 0,35$ & $\mathrm{a}$ & $448,9 \pm 11,2$ & $\mathrm{a}$ \\
\hline & & \multirow{5}{*}{$\mathbf{T 2}$} & GiS 5 & $110,96 \pm$ & $\mathrm{a}$ & $25,19 \pm 1,14$ & $\mathrm{c}$ & $207,28 \pm 12,61$ & $\mathrm{~b}$ & $31,38 \pm 1,31$ & $\mathrm{~b}$ & $55,40 \pm 3,97$ & $\mathrm{a}$ & $8,51 \pm 0,29$ & $\mathrm{c}$ & $15,86 \pm 0,73$ & $\mathrm{a}$ & $454,5 \pm 22,6$ & $\mathrm{a}$ \\
\hline & & & GiS 6 & $156,48 \pm 15,25$ & $\mathrm{c}$ & $23,74 \pm 0,23$ & $\mathrm{bc}$ & $178,36 \pm 1,84$ & $\mathrm{a}$ & $23,43 \pm 0,90$ & $\mathrm{a}$ & $60,14 \pm 2,79$ & $\mathrm{a}$ & $5,29 \pm 0,29$ & $\mathrm{~b}$ & $15,17 \pm 0,98$ & & $462,6 \pm 16,3$ & a \\
\hline & & & PHL-C & $129,62 \pm 4,60$ & $\mathrm{~b}$ & $22,14 \pm 1,38$ & $\mathrm{ab}$ & $174,71 \pm 7,95$ & $\mathrm{a}$ & $29,50 \pm 1,86$ & $\mathrm{~b}$ & $55,48 \pm 3,23$ & $\mathrm{a}$ & $5,28 \pm 0,28$ & $\mathrm{~b}$ & $18,63 \pm 0,87$ & $\mathrm{~b}$ & $435,3 \pm 14,4$ & $\mathrm{a}$ \\
\hline & & & $\mathrm{PiKu}$ & $126,80 \pm 5,92$ & $a b$ & $20,51 \pm 1,37$ & $\mathrm{a}$ & $183,99 \pm 11,86$ & $a b$ & $28,37 \pm 1,19$ & $\mathrm{~b}$ & $53,32 \pm 4,01$ & $\mathrm{a}$ & $4,91 \pm 0,33$ & $a b$ & $15,54 \pm 0,82$ & & $433,4 \pm 18,4$ & $\mathrm{a}$ \\
\hline & & & Wei & $134,25 \pm 0,41$ & $\mathrm{~b}$ & $22,49 \pm 1,19$ & $\mathrm{ab}$ & $200,19 \pm 6,87$ & $\mathrm{bc}$ & $34,57 \pm 1,80$ & $\mathrm{c}$ & $57,20 \pm 3,84$ & $\mathrm{a}$ & $4,59 \pm 0,22$ & $\mathrm{a}$ & $15,98 \pm 0,74$ & $\mathrm{a}$ & $469,2 \pm 12,0$ & $\mathrm{a}$ \\
\hline & & \multirow{5}{*}{ T3 } & GiS 5 & $179,90 \pm 7,12$ & $\mathrm{a}$ & $18,78 \pm 1,07$ & & $177,32 \pm 8,11$ & $\mathrm{~d}$ & $35,70 \pm 2,73$ & $\mathrm{~b}$ & $47,50 \pm 1,77$ & $\mathrm{ab}$ & $7,25 \pm 0,26$ & $\mathrm{ab}$ & $17,93 \pm 1,35$ & & $484,3 \pm 16,7$ & $\mathrm{a}$ \\
\hline & & & GiS 6 & $176,29 \pm 7,65$ & $\mathrm{a}$ & $19,95 \pm 0,16$ & $\mathrm{~b}$ & $167,65 \pm 7,09$ & $\mathrm{~cd}$ & $32,28 \pm 2,55$ & $a b$ & $49,46 \pm 0,10$ & $\mathrm{~b}$ & $6,81 \pm 0,15$ & $\mathrm{a}$ & $16,38 \pm 0,67$ & b & $468,8 \pm 18,0$ & $\mathrm{a}$ \\
\hline & & & PHL-C & $194,24 \pm 7,18$ & $\mathrm{~b}$ & $17,87 \pm 0,46$ & $\mathrm{a}$ & $163,21 \pm 2,94$ & $\mathrm{bc}$ & $35,12 \pm 0,59$ & $\mathrm{~b}$ & $47,12 \pm 0,79$ & $\mathrm{ab}$ & $7,73 \pm 0,02$ & $\mathrm{c}$ & $17,33 \pm 0,14$ & $\mathrm{~b}$ & $482,6 \pm 2,5$ & $\mathrm{a}$ \\
\hline & & & $\mathrm{PiKu}$ & $207,60 \pm 4,68$ & $\mathrm{bc}$ & $17,61 \pm 0,70$ & $\mathrm{a}$ & $153,15 \pm 2,62$ & $\mathrm{ab}$ & $30,41 \pm 1,15$ & $\mathrm{a}$ & $45,58 \pm 3,17$ & $\mathrm{a}$ & $8,24 \pm 0,32$ & d & $16,49 \pm 1,06$ & $\mathrm{~b}$ & $479,0 \pm 4,3$ & $\mathrm{a}$ \\
\hline & & & Wei & $214,70 \pm 2,27$ & $\mathrm{c}$ & $18,91 \pm 0,68$ & $\mathrm{ab}$ & $145,02 \pm 7,71$ & $\mathrm{a}$ & $29,61 \pm 1,67$ & $\mathrm{a}$ & $49,17 \pm 0,37$ & $\mathrm{ab}$ & $7,61 \pm 0,20$ & $\mathrm{bc}$ & $14,17 \pm 0,53$ & $\mathrm{a}$ & $479,1 \pm 8,3$ & $\mathrm{a}$ \\
\hline
\end{tabular}

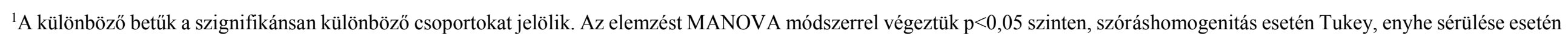
Games-Howell post hoc tesztet alkalmazva 
32. táblázat: Q26 ültetvény cseresznyegyümölcseinek fruktóz, glükóz, szorbitol koncentrációja, valamint összes kromatográfiás cukortartalma (TKC) (1.)

\begin{tabular}{|c|c|c|c|c|c|c|c|c|c|c|c|}
\hline Év & Nemes & Terminus & $\begin{array}{l}\text { Virág- } \\
\text { ritkítás }\end{array}$ & $\begin{array}{l}\text { Fruktóz } \\
\text { (mg/ml) }\end{array}$ & & $\begin{array}{c}\text { Glükóz } \\
\text { (mg/ml) }\end{array}$ & & $\begin{array}{l}\text { Szorbitol } \\
(\mathrm{mg} / \mathrm{ml})\end{array}$ & & $\begin{array}{c}\text { TKC } \\
(\mathrm{mg} / \mathrm{ml})\end{array}$ & \\
\hline \multirow{30}{*}{2010} & \multirow{6}{*}{ BBS } & \multirow{2}{*}{ T1 } & kontroll & $46,00 \pm 0,05$ & & $58,01 \pm 0,03$ & & $8,28 \pm 0,00$ & & $112,29 \pm 0,09$ & \\
\hline & & & ritkított & $44,36 \pm 0,11$ & $\mathrm{a}$ & $56,77 \pm 0,14$ & $\mathrm{a}$ & $8,10 \pm 0,02$ & a & $109,23 \pm 0,27$ & $\mathrm{a}$ \\
\hline & & \multirow{2}{*}{$\mathbf{T 2}$} & kontroll & $56,43 \pm 0,20$ & $\mathrm{a}$ & $71,10 \pm 0,19$ & $\mathrm{a}$ & $11,44 \pm 0,10$ & $\mathrm{a}$ & $138,97 \pm 0,48$ & $\mathrm{a}$ \\
\hline & & & ritkított & $55,94 \pm 0,78$ & $\mathrm{a}$ & $71,66 \pm 2,60$ & $\mathrm{a}$ & $11,54 \pm 0,36$ & $\ldots$ & $139,14 \pm 3,73$ & $\mathrm{a}$ \\
\hline & & \multirow{2}{*}{ T3 } & kontroll & $63,60 \pm 0,51$ & $\mathrm{~b}$ & $81,27 \pm 0,81$ & $\mathrm{~b}$ & $15,07 \pm 0,25$ & b & $159,94 \pm 1,49$ & $\mathrm{~b}$ \\
\hline & & & ritkított & $60,04 \pm 0,13$ & $\mathrm{a}$ & $76,04 \pm 0,18$ & $\mathrm{a}$ & $14,40 \pm 0,05$ & $a$ & $150,48 \pm 0,35$ & $\mathrm{a}$ \\
\hline & \multirow{6}{*}{ BBVG } & \multirow{2}{*}{ T1 } & kontroll & $55,65 \pm 0,00$ & $\mathrm{a}$ & $67,16 \pm 0,05$ & $\mathrm{a}$ & $7,70 \pm 0,00$ & $\mathrm{a}$ & $130,51 \pm 0,04$ & $\mathrm{a}$ \\
\hline & & & ritkított & $57,38 \pm 0,19$ & $\mathrm{~b}$ & $68,37 \pm 0,11$ & $\mathrm{~b}$ & $8,13 \pm 0,02$ & b & $133,88 \pm 0,32$ & $\mathrm{~b}$ \\
\hline & & \multirow{2}{*}{$\mathbf{T} 2$} & kontroll & $57,26 \pm 0,20$ & $\mathrm{a}$ & $67,14 \pm 0,13$ & $\mathrm{a}$ & $11,76 \pm 0,03$ & $\mathrm{a}$ & $136,16 \pm 0,35$ & $\mathrm{a}$ \\
\hline & & & ritkított & $59,99 \pm 0,40$ & $\mathrm{~b}$ & $70,16 \pm 0,29$ & $\mathrm{~b}$ & $11,82 \pm 0,15$ & $\mathrm{a}$ & $141,97 \pm 0,84$ & $\mathrm{~b}$ \\
\hline & & \multirow{2}{*}{ T3 } & kontroll & $58,65 \pm 0,44$ & $\mathrm{a}$ & $70,75 \pm 0,67$ & $\mathrm{a}$ & $13,29 \pm 0,06$ & $\mathrm{a}$ & $142,69 \pm 1,16$ & $\mathrm{a}$ \\
\hline & & & ritkított & $62,75 \pm 1,30$ & $\mathrm{~b}$ & $74,60 \pm 1,41$ & $\mathrm{~b}$ & $14,60 \pm 0,24$ & b & $151,95 \pm 2,95$ & $\mathrm{~b}$ \\
\hline & \multirow{6}{*}{ BMS } & \multirow{2}{*}{ T1 } & kontroll & $38,74 \pm 0,04$ & $\mathrm{a}$ & $43,96 \pm 0,05$ & $\mathrm{a}$ & $4,27 \pm 0,01$ & b & $86,97 \pm 0,10$ & $\mathrm{a}$ \\
\hline & & & ritkított & $38,45 \pm 0,26$ & $\mathrm{a}$ & $43,79 \pm 0,40$ & $\mathrm{a}$ & $4,21 \pm 0,02$ & a & $86,46 \pm 0,67$ & $\mathrm{a}$ \\
\hline & & \multirow{2}{*}{ T2 } & kontroll & $49,99 \pm 0,16$ & $\mathrm{a}$ & $55,41 \pm 0,20$ & $\mathrm{a}$ & $6,49 \pm 0,01$ & $\mathrm{a}$ & $111,89 \pm 0,38$ & $\mathrm{a}$ \\
\hline & & & ritkított & $53,47 \pm 0,69$ & $\mathrm{~b}$ & $59,13 \pm 0,48$ & $\mathrm{~b}$ & $7,64 \pm 0,11$ & b & $120,23 \pm 1,20$ & $\mathrm{~b}$ \\
\hline & & T3 & kontroll & $50,45 \pm 0,22$ & $\mathrm{a}$ & $55,53 \pm 0,28$ & $\mathrm{a}$ & $7,13 \pm 0,07$ & $\mathrm{a}$ & $113,10 \pm 0,56$ & $\mathrm{a}$ \\
\hline & & 10 & & $53,25 \pm 0,26$ & $\mathrm{~b}$ & $58,60 \pm 0,32$ & $\mathrm{~b}$ & $8,14 \pm 0,06$ & b & $119,99 \pm 0,64$ & $\mathrm{~b}$ \\
\hline & & T1 & kontroll & $40,37 \pm 0,03$ & $\mathrm{a}$ & $49,07 \pm 0,05$ & $\mathrm{a}$ & $5,19 \pm 0,00$ & $\mathrm{a}$ & $94,63 \pm 0,05$ & $\mathrm{a}$ \\
\hline & & ex & ritkított & $49,61 \pm 0,65$ & $\mathrm{~b}$ & $59,93 \pm 0,74$ & $\mathrm{~b}$ & $6,32 \pm 0,17$ & b & $115,86 \pm 1,55$ & b \\
\hline & & T2 & kontroll & $55,05 \pm 0,06$ & $\mathrm{a}$ & $67,21 \pm 0,10$ & $\mathrm{a}$ & $13,16 \pm 0,01$ & b & $135,42 \pm 0,17$ & $\mathrm{a}$ \\
\hline & & 12 & ritkított & $64,77 \pm 0,06$ & $\mathrm{~b}$ & $75,74 \pm 0,09$ & $\mathrm{~b}$ & $11,56 \pm 0,01$ & $\mathrm{a}$ & $152,07 \pm 0,16$ & $\mathrm{~b}$ \\
\hline & & & kontroll & $65,47 \pm 0,63$ & $\mathrm{a}$ & $76,95 \pm 0,66$ & $\mathrm{a}$ & $12,37 \pm 0,34$ & $\mathrm{a}$ & $154,80 \pm 1,62$ & $\mathrm{a}$ \\
\hline & & 13 & ritkított & $87,99 \pm 0,48$ & $\mathrm{~b}$ & $102,28 \pm 0,60$ & $\mathrm{~b}$ & $23,60 \pm 0,12$ & b & $213,87 \pm 1,18$ & $\mathrm{~b}$ \\
\hline & \multirow{6}{*}{ MP } & \multirow{2}{*}{ T1 } & kontroll & $45,86 \pm 0,08$ & $\mathrm{~b}$ & $52,15 \pm 0,05$ & $\mathrm{~b}$ & $5,60 \pm 0,03$ & b & $103,61 \pm 0,14$ & $\mathrm{~b}$ \\
\hline & & & ritkított & $42,22 \pm 0,07$ & $\mathrm{a}$ & $47,92 \pm 0,03$ & $\mathrm{a}$ & $5,31 \pm 0,02$ & a & $95,45 \pm 0,11$ & $\mathrm{a}$ \\
\hline & & \multirow{2}{*}{$\mathbf{T} 2$} & kontroll & $49,91 \pm 0,04$ & $\mathrm{~b}$ & $57,50 \pm 0,02$ & $\mathrm{~b}$ & $5,62 \pm 0,01$ & b & $113,02 \pm 0,05$ & $\mathrm{~b}$ \\
\hline & & & & $45,71 \pm 0,10$ & $\mathrm{a}$ & $52,26 \pm 0,07$ & $\mathrm{a}$ & $5,16 \pm 0,01$ & a & $103,13 \pm 0,18$ & $\mathrm{a}$ \\
\hline & & \multirow{2}{*}{ T3 } & kontroll & $60,58 \pm 0,38$ & $\mathrm{~b}$ & $68,68 \pm 0,44$ & $\mathrm{~b}$ & $8,29 \pm 0,04$ & b & $137,55 \pm 0,85$ & $\mathrm{~b}$ \\
\hline & & & & $57,17 \pm 0,22$ & $\mathrm{a}$ & $64,97 \pm 0,33$ & $\mathrm{a}$ & $8,18 \pm 0,01$ & a & $130,32 \pm 0,57$ & $\mathrm{a}$ \\
\hline \multirow{18}{*}{2011} & \multirow{12}{*}{ BBVG } & \multirow{2}{*}{ T1 } & kontroll & $41,82 \pm 0,99$ & $\mathrm{~b}$ & $56,90 \pm 0,90$ & $\mathrm{~b}$ & $10,10 \pm 0,17$ & b & $108,81 \pm 2,05$ & $\mathrm{~b}$ \\
\hline & & & ritkított & $36,78 \pm 0,33$ & $\mathrm{a}$ & $47,39 \pm 0,25$ & $\mathrm{a}$ & $8,50 \pm 0,22$ & a & $92,67 \pm 0,78$ & $\mathrm{a}$ \\
\hline & & T2 & kontroll & $58,39 \pm 0,38$ & $\mathrm{a}$ & $68,42 \pm 0,55$ & $\mathrm{a}$ & $12,37 \pm 0,47$ & b & $139,18 \pm 1,32$ & \\
\hline & & 12 & tott & $57,43 \pm 0,70$ & $\mathrm{a}$ & $69,63 \pm 1,08$ & $\mathrm{a}$ & $9,61 \pm 0,40$ & a & $136,67 \pm 2,16$ & $\mathrm{a}$ \\
\hline & & T3 & kontroll & $63,44 \pm 1,89$ & $\mathrm{a}$ & $71,41 \pm 2,10$ & $\mathrm{a}$ & $11,57 \pm 0,37$ & $\mathrm{a}$ & $146,41 \pm 4,34$ & $\mathrm{a}$ \\
\hline & & 10 & & $63,48 \pm 0,93$ & $\mathrm{a}$ & $73,81 \pm 1,34$ & $\mathrm{a}$ & $12,20 \pm 0,31$ & $\mathrm{~b}$ & $149,49 \pm 2,55$ & $\mathrm{a}$ \\
\hline & & T1 & kontroll & $53,06 \pm 1,67$ & $\mathrm{a}$ & $64,92 \pm 2,13$ & $\mathrm{a}$ & $8,91 \pm 0,11$ & a & $126,89 \pm 3,91$ & $\mathrm{a}$ \\
\hline & & & & $54,37 \pm 1,08$ & $\mathrm{a}$ & $64,61 \pm 3,00$ & $\mathrm{a}$ & $9,59 \pm 0,16$ & b & $128,57 \pm 4,06$ & $\mathrm{a}$ \\
\hline & & $\mathrm{T} 2$ & kontroll & $62,12 \pm 1,12$ & $\mathrm{a}$ & $73,85 \pm 0,92$ & $\mathrm{a}$ & $10,91 \pm 0,20$ & $\mathrm{a}$ & $146,88 \pm 1,95$ & $\mathrm{a}$ \\
\hline & & 12 & ritkított & $63,34 \pm 2,78$ & $\mathrm{a}$ & $74,03 \pm 2,29$ & $\mathrm{a}$ & $12,47 \pm 0,48$ & b & $149,83 \pm 5,41$ & $\mathrm{a}$ \\
\hline & & T3 & kontroll & $67,45 \pm 2,43$ & $\mathrm{a}$ & $78,15 \pm 3,41$ & $\mathrm{a}$ & $15,31 \pm 0,60$ & b & $160,91 \pm 6,40$ & \\
\hline & & $1 J$ & ritkított & $78,35 \pm 0,39$ & b & $92,87 \pm 0,22$ & $\mathrm{~b}$ & $13,79 \pm 0,55$ & $\mathrm{a}$ & $185,00 \pm 0,66$ & $\mathrm{~b}$ \\
\hline & & T1 & kontroll & $41,92 \pm 0,92$ & $\mathrm{a}$ & $54,08 \pm 2,23$ & $\mathrm{a}$ & $9,19 \pm 0,23$ & $\mathrm{a}$ & $105,18 \pm 3,36$ & \\
\hline & & & ritkított & $41,83 \pm 0,80$ & $\mathrm{a}$ & $58,19 \pm 1,29$ & $\mathrm{~b}$ & $9,37 \pm 0,12$ & $\mathrm{a}$ & $109,39 \pm 2,17$ & $\mathrm{a}$ \\
\hline & BMS & T2 & kontroll & $54,89 \pm 1,67$ & a & $66,90 \pm 1,13$ & $\mathrm{~b}$ & $14,76 \pm 0,32$ & b & $136,55 \pm 3,00$ & \\
\hline & Dins & 12 & ritkított & $54,14 \pm 0,58$ & $\mathrm{a}$ & $61,76 \pm 0,56$ & $\mathrm{a}$ & $10,25 \pm 0,06$ & $\mathrm{a}$ & $126,16 \pm 1,19$ & $\mathrm{a}$ \\
\hline & & T3 & kontroll & $63,91 \pm 0,51$ & $\mathrm{a}$ & $74,68 \pm 0,75$ & $\mathrm{a}$ & $14,74 \pm 0,55$ & b & $153,32 \pm 1,80$ & \\
\hline & & & ritkított & $63,28 \pm 2,41$ & $\mathrm{a}$ & $76,70 \pm 2,12$ & $\mathrm{a}$ & $10,03 \pm 0,25$ & $\mathrm{a}$ & $150,01 \pm 4,71$ & 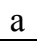 \\
\hline
\end{tabular}

1a különböző betük a szignifikánsan különböző csoportokat jelölik, MANOVA, p<0,05 (Tukey / Games-Howell) 
32. táblázat: Q10 ültetvény cseresznyegyümölcseinek fruktóz, glükóz, szorbitol koncentrációja, valamint összes kromatográfiás cukortartalma (TKC) (2.)

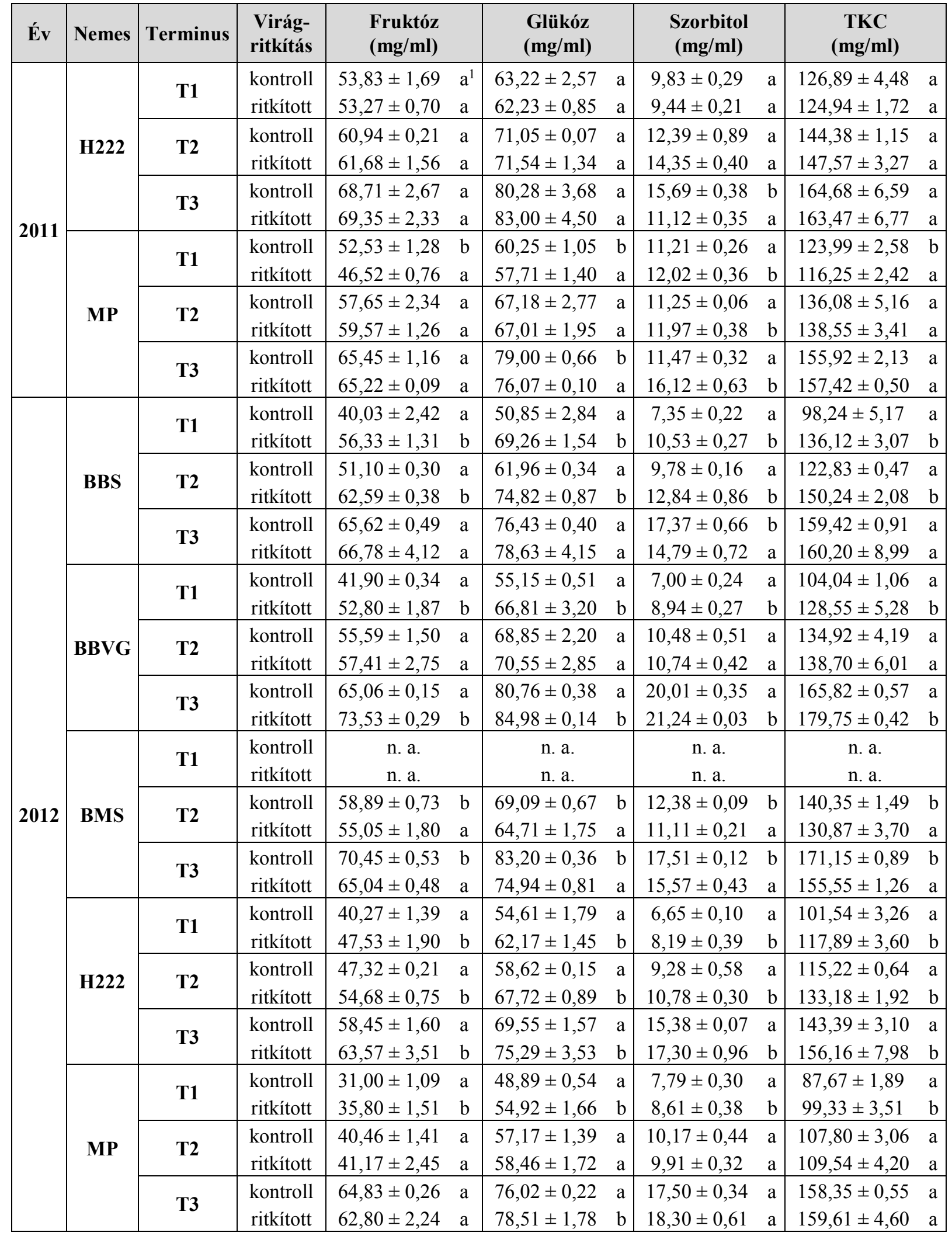

${ }^{1}$ A különböző betük a szignifikánsan különböző csoportokat jelölik. Az elemzést MANOVA módszerrel végeztük p $<0,05$ szinten, szóráshomogenitás esetén Tukey, enyhe sérülése esetén Games-Howell post hoc tesztet alkalmazva. 
33. táblázat: Q10 ültetvény cseresznyegyümölcseinek almasav, borostyánkősav és citromsav koncentrációja, valamint összes kromatográfiás savtartalma (TKS) (1.)

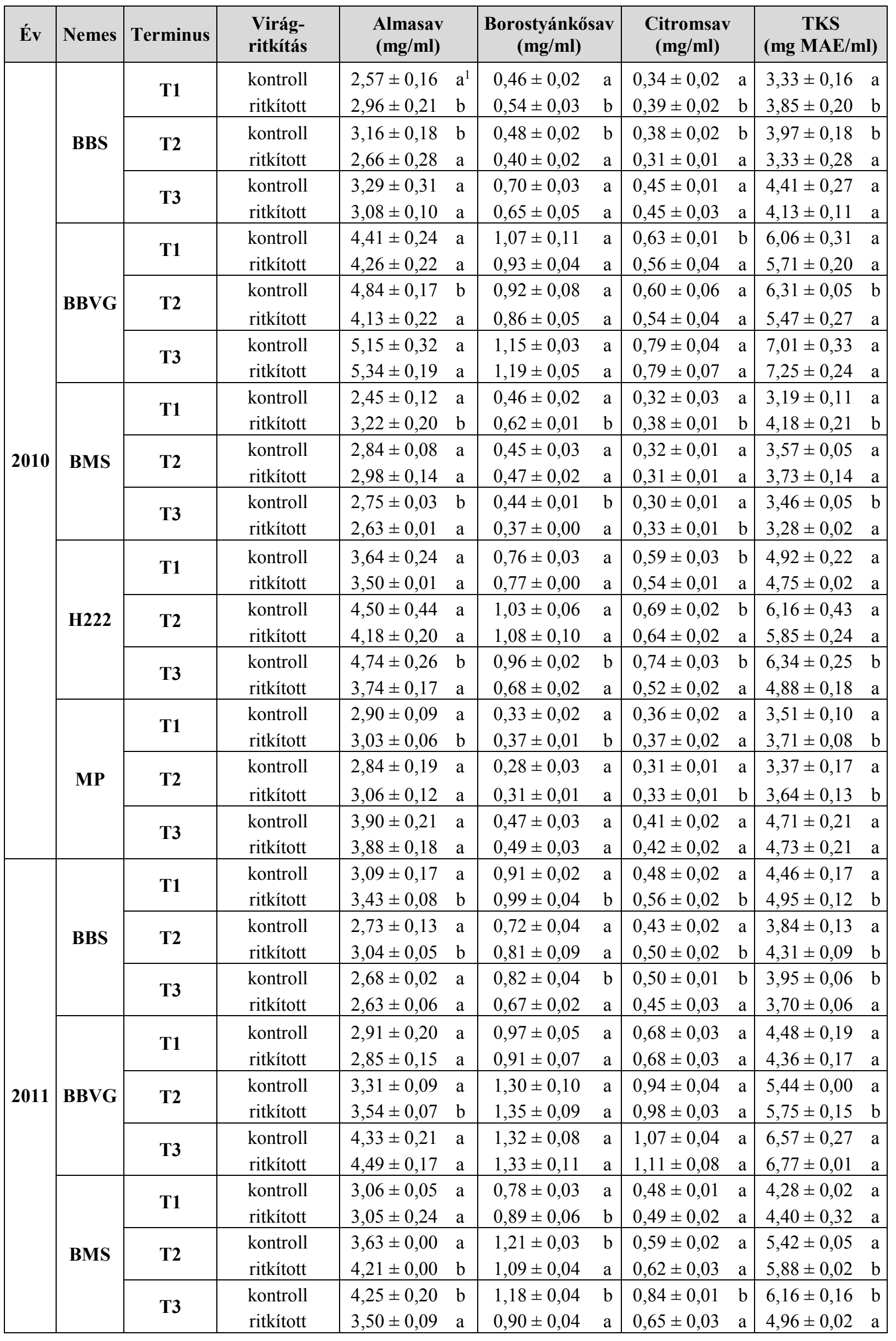

1 a különböző betük a szignifikánsan különböző csoportokat jelölik, MANOVA, p<0,05 (Tukey / Games-Howell) 
33. táblázat: Q10 ültetvény cseresznyegyümölcseinek almasav, borostyánkősav és citromsav koncentrációja, valamint összes kromatográfiás savtartalma (TKS) (2.)

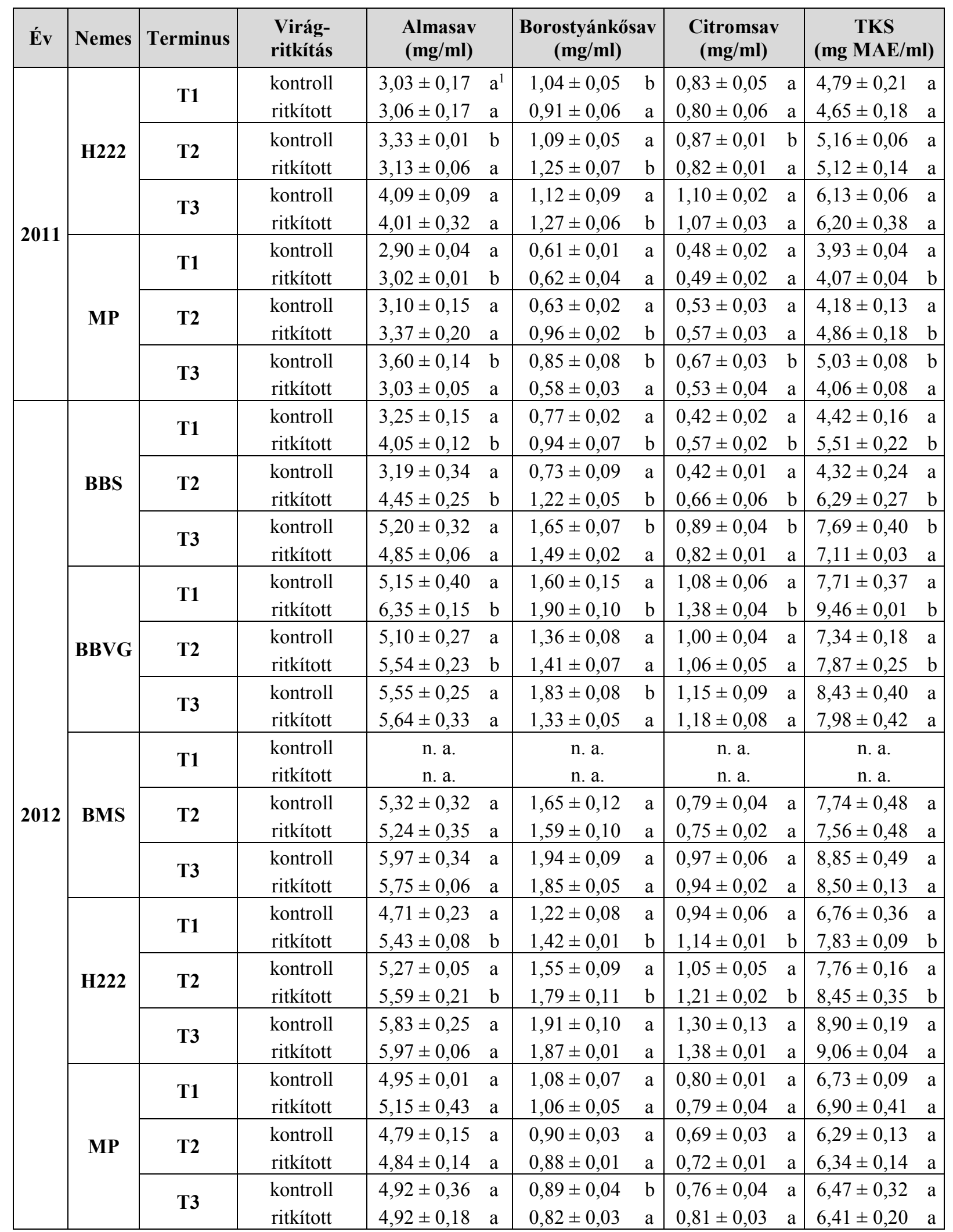

${ }^{1}$ A különböző betük a szignifikánsan különböző csoportokat jelölik. Az elemzést MANOVA módszerrel végeztük p $<0,05$ szinten, szóráshomogenitás esetén Tukey, enyhe sérülése esetén Games-Howell post hoc tesztet alkalmazva. 
34. táblázat: Q26 ültetvény cseresznyegyümölcseiben az egyedi polifenol-komponensek koncentrációi, valamint a totál kromatográfiás polifenol-tartalom (1.)

\begin{tabular}{|c|c|c|c|c|c|c|c|c|c|c|c|c|c|c|c|c|c|}
\hline Év & Nemes & Term. & Virágritk. & $\begin{array}{l}\text { Cianidin } \\
(\mathrm{mg} / \mathrm{kg})\end{array}$ & & $\begin{array}{c}\text { Epikatechin } \\
(\mathrm{mg} / \mathrm{kg})\end{array}$ & & $\begin{array}{c}\text { Neoklorogénsav } \\
(\mathrm{mg} / \mathrm{kg})\end{array}$ & $\begin{array}{c}\text { Klorogénsav } \\
(\mathrm{mg} / \mathrm{kg})\end{array}$ & $\begin{array}{l}\text { Kínasav } \\
(\mathrm{mg} / \mathrm{kg})\end{array}$ & & $\begin{array}{l}\text { Rutin } \\
(\mathrm{mg} / \mathrm{kg})\end{array}$ & & $\begin{array}{l}\text { Kvercetin } \\
(\mathrm{mg} / \mathrm{kg})\end{array}$ & & $\begin{array}{c}\text { TKPF } \\
(\mathrm{mg} / \mathrm{kg})\end{array}$ & \\
\hline \multirow{30}{*}{2011} & \multirow{6}{*}{ BBS } & \multirow{2}{*}{ T1 } & & $111,6 \pm 11,0$ & & $9,66 \pm 0,66$ & & $260,6 \pm 11,4 \quad \mathrm{a}$ & $17,00 \pm 0,95 \quad \mathrm{a}$ & $26,05 \pm 1,29$ & $\mathrm{a}$ & $14,80 \pm 0,57$ & $\mathrm{a}$ & $10,67 \pm 0,66$ & & $450,4 \pm 11,6$ & $\mathrm{a}$ \\
\hline & & & ritkított & $119,2 \pm 6,6$ & $\mathrm{a}$ & $6,94 \pm 0,33$ & $\mathrm{a}$ & $267,5 \pm 22,9 \quad \mathrm{a}$ & $21,46 \pm 1,59 \quad b$ & $26,66 \pm 0,83$ & $\mathrm{a}$ & $24,61 \pm 1,73$ & $\mathrm{~b}$ & $19,38 \pm 0,77$ & $v_{1}$ & $485,8 \pm 29,2$ & $\mathrm{a}$ \\
\hline & & \multirow{2}{*}{$\mathbf{T} 2$} & & $173,4 \pm 9,9$ & $\mathrm{a}$ & $9,09 \pm 0,58$ & $\mathrm{~b}$ & $187,6 \pm 8,0 \quad b$ & $27,49 \pm 1,10 \quad \mathrm{a}$ & $27,20 \pm 1,21$ & $\mathrm{~b}$ & $24,73 \pm 1,31$ & $\mathrm{a}$ & $16,75 \pm 0,59$ & $\mathrm{~b}$ & $466,3 \pm 13,9$ & $\mathrm{a}$ \\
\hline & & & ritkított & $240,0 \pm 7,0$ & $\mathrm{~b}$ & $7,21 \pm 0,37$ & $\mathrm{a}$ & $126,1 \pm 0,1$ & $31,23 \pm 0,83 \quad b$ & $23,94 \pm 1,29$ & $\mathrm{a}$ & $23,77 \pm 2,41$ & $\mathrm{a}$ & $15,24 \pm 0,53$ & $a^{a}$ & $467,5 \pm 7,0$ & $\mathrm{a}$ \\
\hline & & \multirow{2}{*}{ T3 } & & $292,5 \pm 19,6$ & $\mathrm{a}$ & $9,12 \pm 0,41$ & $\mathrm{a}$ & $108,4 \pm 5,6 \quad$ a & $54,76 \pm 0,38 \quad \mathrm{a}$ & $40,40 \pm 1,89$ & $\mathrm{~b}$ & $25,80 \pm 1,11$ & $\mathrm{a}$ & $24,29 \pm 1,72$ & b & $555,3 \pm 24,5$ & $\mathrm{a}$ \\
\hline & & & & $372,3 \pm 17,5$ & $\mathrm{~b}$ & $11,35 \pm 0,31$ & $\mathrm{~b}$ & $143,5 \pm 5,5 \quad b$ & $58,19 \pm 3,07 \quad \mathrm{a}$ & $31,48 \pm 2,47$ & $\mathrm{a}$ & $26,53 \pm 1,46$ & $\mathrm{a}$ & $20,87 \pm 0,67$ & $\mathrm{a}$ & $664,3 \pm 23,7$ & $\mathrm{~b}$ \\
\hline & \multirow{6}{*}{ BBVG } & \multirow{2}{*}{ T1 } & & & $\mathrm{b}$ & & $\mathrm{b}$ & $559,9 \pm 27,0 \quad$ a & $35,88 \pm 1,10 \quad b$ & $40,86 \pm 3,73$ & $\mathrm{~b}$ & $37,38 \pm 2,28$ & $\mathrm{~b}$ & $24,22 \pm 0,92$ & $\mathrm{~b}$ & $870,2 \pm 33,5$ & $\mathrm{a}$ \\
\hline & & & ott & $128,8 \pm 3,2$ & $\mathrm{a}$ & $7,14 \pm 0,55$ & $\mathrm{a}$ & $568,3 \pm 41,4 \quad \mathrm{a}$ & $32,47 \pm 2,04 \quad \mathrm{a}$ & $35,55 \pm 1,79$ & $\mathrm{a}$ & $26,97 \pm 1,85$ & $\mathrm{a}$ & $17,23 \pm 0,65$ & $\mathrm{a}$ & $816,5 \pm 39,6$ & $\mathrm{a}$ \\
\hline & & \multirow{2}{*}{$\mathbf{T} 2$} & & $500,9 \pm 8,4$ & $\mathrm{~b}$ & $11,54 \pm 0,63$ & $\mathrm{a}$ & $446,2 \pm 17,1 \quad \mathrm{a}$ & $80,68 \pm 2,82 \quad b$ & $127,54 \pm 7,21$ & $\mathrm{~b}$ & $33,90 \pm 1,97$ & $\mathrm{~b}$ & $19,75 \pm 0,88$ & $\mathrm{a}$ & $1220,6 \pm 11,6$ & $\mathrm{~b}$ \\
\hline & & & ritkított & $442,3 \pm 32,8$ & $\mathrm{a}$ & $11,69 \pm 0,08$ & $\mathrm{a}$ & $498,5 \pm 6,8 \quad b$ & $72,39 \pm 1,22 \quad \mathrm{a}$ & $62,27 \pm 4,28$ & $\mathrm{a}$ & $30,69 \pm 0,88$ & $\mathrm{a}$ & $21,77 \pm 1,48$ & $a$ & $1139,6 \pm 26,2$ & $\mathrm{a}$ \\
\hline & & \multirow{2}{*}{ T3 } & kontroll & $527,7 \pm 54,4$ & $\mathrm{a}$ & $9,36 \pm 0,43$ & 0 & $302,0 \pm 13,6 \quad \mathrm{a}$ & $75,93 \pm 0,08 \quad b$ & $71,13 \pm 1,85$ & $\mathrm{a}$ & $30,05 \pm 0,04$ & $\mathrm{a}$ & $15,67 \pm 1,53$ & $\mathrm{a}$ & $1031,9 \pm 47,0$ & $\mathrm{a}$ \\
\hline & & & ritkított & $580,6 \pm 5,2$ & $\mathrm{a}$ & $10,10 \pm 0,48$ & $\mathrm{a}$ & $415,3 \pm 8,4 \quad b$ & $69,64 \pm 2,33 \quad \mathrm{a}$ & $73,34 \pm 3,83$ & $\mathrm{a}$ & $28,49 \pm 2,04$ & $\mathrm{a}$ & $14,87 \pm 0,30$ & $\mathrm{a}$ & $1192,4 \pm 12,9$ & $\mathrm{~b}$ \\
\hline & \multirow{6}{*}{ BMS } & \multirow{2}{*}{ T1 } & kontroll & $264,8 \pm 13,9$ & $\mathrm{~b}$ & $15,03 \pm 0,50$ & $\mathrm{a}$ & $509,8 \pm 12,0 \quad \mathrm{a}$ & $35,50 \pm 1,70 \quad b$ & $35,36 \pm 2,26$ & $\mathrm{a}$ & $31,63 \pm 1,40$ & $\mathrm{~b}$ & $24,63 \pm 0,32$ & b & $916,8 \pm 25,2$ & $\mathrm{~b}$ \\
\hline & & & & & $\mathrm{a}$ & & $\mathrm{b}$ & $500,8 \pm 6,1 \quad \mathrm{a}$ & $27,08 \pm 1,76 \quad \mathrm{a}$ & $40,60 \pm 0,73$ & $\mathrm{~b}$ & & $\mathrm{a}$ & & $\mathrm{a}$ & & $\mathrm{a}$ \\
\hline & & \multirow{2}{*}{$\mathbf{T 2}$} & kontroll & $452,0 \pm 17,1$ & $\mathrm{~b}$ & $15,88 \pm 0,52$ & & $391,5 \pm 23,6 \quad$ a & $35,87 \pm 2,77 \quad \mathrm{a}$ & $36,07 \pm 0,38$ & $\mathrm{a}$ & $34,09 \pm 3,27$ & $\mathrm{~b}$ & $29,13 \pm 2,17$ & $b$ & $994,6 \pm 32,5$ & $\mathrm{~b}$ \\
\hline & & & & $252,8 \pm 15,9$ & $\mathrm{a}$ & $14,73 \pm 0,71$ & $\mathrm{a}$ & $409,3 \pm 0,8$ & $32,24 \pm 2,10 \quad \mathrm{a}$ & $35,14 \pm 2,75$ & $\mathrm{a}$ & $27,47 \pm 1,16$ & $\mathrm{a}$ & $22,85 \pm 1,18$ & $a^{a}$ & $794,5 \pm 18,9$ & $\mathrm{a}$ \\
\hline & & \multirow{2}{*}{ T3 } & ko1 & $1023,1 \pm 17,6$ & $\mathrm{a}$ & $28,05 \pm 1,16$ & $\mathrm{~b}$ & $346,3 \pm 8,0$ & $74,01 \pm 1,18 \quad \mathrm{a}$ & $214,41 \pm 11,10$ & $\mathrm{~b}$ & $49,15 \pm 1,32$ & $\mathrm{~b}$ & $42,04 \pm 2,68$ & b & $1777,1 \pm 19,0$ & $\mathrm{~b}$ \\
\hline & & & itott & $964,3 \pm$ & $\mathrm{a}$ & $23,51 \pm 0,95$ & $\mathrm{a}$ & $269,7 \pm 16,6 \quad \mathrm{a}$ & $75,67 \pm 4,28 \quad \mathrm{a}$ & $167,83 \pm 8,63$ & $\mathrm{a}$ & $36,72 \pm 2,33$ & $\mathrm{a}$ & $23,95 \pm 1,30$ & a & $1561,7 \pm 72,6$ & $\mathrm{a}$ \\
\hline & \multirow{6}{*}{ H222 } & \multirow{2}{*}{ T1 } & oll & $163,7 \pm 9,1$ & $\mathrm{a}$ & $10,01 \pm 0,36$ & 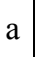 & $618,3 \pm 10,7 \quad b$ & $32,73 \pm 1,37 \quad \mathrm{a}$ & $41,90 \pm 2,09$ & $\mathrm{a}$ & $27,78 \pm 0,75$ & $\mathrm{a}$ & $17,56 \pm 1,07$ & & $912,0 \pm 17,9$ & $\mathrm{a}$ \\
\hline & & & & $168,9 \pm 2,6$ & $\mathrm{a}$ & $10,90 \pm 0,62$ & $\mathrm{a}$ & $591,2 \pm 20,9 \quad \mathrm{a}$ & $33,69 \pm 0,36 \quad \mathrm{a}$ & $42,58 \pm 0,50$ & $\mathrm{a}$ & $29,97 \pm 0,60$ & $\mathrm{~b}$ & $18,21 \pm 0,69$ & $\mathrm{a}$ & $895,5 \pm 22,7$ & $\mathrm{a}$ \\
\hline & & \multirow{2}{*}{$\mathbf{T 2}$} & kontroll & $301,3 \pm 15,0$ & $\mathrm{a}$ & $10,93 \pm 0,16$ & & $425,8 \pm 25,1 \quad \mathrm{a}$ & $74,06 \pm 4,50 \quad \mathrm{a}$ & $42,03 \pm 0,45$ & $\mathrm{a}$ & $34,13 \pm 2,20$ & $\mathrm{a}$ & $21,08 \pm 0,99$ & $\mathrm{a}$ & $909,3 \pm 41,6$ & $\mathrm{a}$ \\
\hline & & & & & $\mathrm{b}$ & $13,38 \pm 0,94$ & $\mathrm{~b}$ & $428,4 \pm 25,8 \quad \mathrm{a}$ & $83,40 \pm 3,56 \quad b$ & $49,87 \pm 4,24$ & $\mathrm{~b}$ & $37,09 \pm 3,29$ & $\mathrm{a}$ & $24,38 \pm 1,50$ & b & $1049,1 \pm 33,1$ & $\mathrm{~b}$ \\
\hline & & \multirow{2}{*}{ T3 } & kontroll & $668,1 \pm 29,7$ & $\mathrm{~b}$ & $9,63 \pm 0,25$ & $\mathrm{~b}$ & $378,8 \pm 16,7 \quad b$ & $87,14 \pm 7,52 \quad b$ & $85,37 \pm 2,77$ & $\mathrm{~b}$ & $37,57 \pm 0,10$ & $\mathrm{a}$ & $18,21 \pm 0,17$ & $\mathrm{a}$ & $1284,9 \pm 36,7$ & $\mathrm{~b}$ \\
\hline & & & ritkított & $446,4 \pm 3,4$ & $\mathrm{a}$ & $8,40 \pm 0,11$ & $\mathrm{a}$ & $310,9 \pm 4,2$ & $71,07 \pm 3,39 \quad \mathrm{a}$ & $59,35 \pm 3,24$ & $\mathrm{a}$ & $36,42 \pm 2,61$ & $\mathrm{a}$ & $19,76 \pm 0,38$ & b & $952,3 \pm 7,2$ & $\mathrm{a}$ \\
\hline & \multirow{6}{*}{ MP } & \multirow{2}{*}{ T1 } & kontroll & $62,6 \pm 2,9$ & $\mathrm{~b}$ & $11,89 \pm 0,06$ & $\mathrm{~b}$ & $394,4 \pm 21,4 \quad a$ & $30,02 \pm 2,58 \quad b$ & $34,27 \pm 2,59$ & $\mathrm{a}$ & $22,63 \pm 0,73$ & $\mathrm{a}$ & $14,22 \pm 0,72$ & $\mathrm{a}$ & $570,1 \pm 20,7$ & $\mathrm{a}$ \\
\hline & & & & $39,4 \pm 0,9$ & $\mathrm{a}$ & $7,31 \pm 0,64$ & $\mathrm{a}$ & $395,3 \pm 25,4 \quad \mathrm{a}$ & $25,77 \pm 0,43 \quad \mathrm{a}$ & $30,90 \pm 1,79$ & $\mathrm{a}$ & $21,58 \pm 0,81$ & $\mathrm{a}$ & $16,14 \pm 0,55$ & b & $536,5 \pm 24,2$ & $\mathrm{a}$ \\
\hline & & \multirow{2}{*}{$\mathbf{T 2}$} & kontroll & $399,4 \pm 8,5$ & $\mathrm{~b}$ & $12,78 \pm 0,85$ & & $301,1 \pm 16,5 \quad \mathrm{a}$ & $32,02 \pm 2,96 \quad \mathrm{a}$ & $40,60 \pm 2,48$ & $\mathrm{a}$ & $22,78 \pm 1,20$ & $\mathrm{~b}$ & $17,73 \pm 1,04$ & b & $826,4 \pm 14,4$ & $\mathrm{~b}$ \\
\hline & & & & & $\mathrm{a}$ & & $\mathrm{b}$ & $361,7 \pm 21,2 \quad b$ & $29,32 \pm 0,02 \quad \mathrm{a}$ & $44,51 \pm 2,25$ & $\mathrm{a}$ & $18,13 \pm 0,86$ & $\mathrm{a}$ & $15,45 \pm 0,65$ & a & $742,4 \pm 43,5$ & $\mathrm{a}$ \\
\hline & & \multirow{2}{*}{ T3 } & kontroll & $590,5 \pm 34,7$ & $\mathrm{a}$ & $11,38 \pm 0,47$ & & $179,4 \pm 7,0 \quad \mathrm{a}$ & $37,43 \pm 1,60 \quad b$ & $39,05 \pm 0,64$ & $\mathrm{a}$ & $23,64 \pm 1,38$ & $\mathrm{~b}$ & $11,78 \pm 0,63$ & b & $893,3 \pm 32,3$ & $\mathrm{a}$ \\
\hline & & & ritkított & $785,7 \pm 35,7$ & $\mathrm{~b}$ & $17,28 \pm 1,07$ & $\mathrm{~b}$ & $254,0 \pm 10, \quad b$ & $31,19 \pm 1,52 \quad \mathrm{a}$ & $43,78 \pm 2,30$ & $\mathrm{~b}$ & $20,06 \pm 1,15$ & $\mathrm{a}$ & $7,64 \pm 0,02$ & $\mathrm{a}$ & $1159,7 \pm 29,7$ & $b$ \\
\hline
\end{tabular}

1 a különböző betük a szignifikánsan különböző csoportokat jelölik, MANOVA, p<0,05 (Tukey / Games-Howell) 
34. táblázat: Q26 ültetvény cseresznyegyümölcseiben az egyedi polifenol-komponensek koncentrációi, valamint az összes kromatográfiás polifenol-tartalom (2.)

\begin{tabular}{|c|c|c|c|c|c|c|c|c|c|c|c|c|c|c|c|c|c|c|c|}
\hline Év & emes & erm. & Virágritk. & $\begin{array}{c}\text { Cianidin } \\
(\mathrm{mg} / \mathrm{kg})\end{array}$ & & $\begin{array}{l}\text { Epikatechin } \\
\text { (mg/kg) }\end{array}$ & & $\begin{array}{c}\text { Neoklorogénsa } \\
(\mathbf{m g} / \mathbf{k g})\end{array}$ & & $\begin{array}{c}\text { Klorogénsav } \\
(\mathrm{mg} / \mathrm{kg})\end{array}$ & & $\begin{array}{l}\text { Kínasav } \\
\text { (mg/kg) }\end{array}$ & & $\begin{array}{c}\text { Rutin } \\
\text { (mg/kg) }\end{array}$ & & $\begin{array}{l}\text { Kvercetin } \\
\text { (mg/kg) }\end{array}$ & & $\begin{array}{c}\text { TKPF } \\
(\mathrm{mg} / \mathrm{kg})\end{array}$ & \\
\hline \multirow{27}{*}{2012} & \multirow{4}{*}{ BBS } & T1 & $\begin{array}{l}\text { kontroll } \\
\text { ritkított }\end{array}$ & $\begin{array}{l}296,3 \pm 6,6 \\
307,9 \pm 8,1\end{array}$ & $\begin{array}{l}a^{1} \\
a\end{array}$ & $\begin{array}{l}25,63 \pm 1,55 \\
23,25 \pm 0,56\end{array}$ & $\mathrm{a}$ & $\begin{array}{c}452,6 \pm 16,4 \\
298,9 \pm 2,3\end{array}$ & $\begin{array}{l}\mathrm{b} \\
\mathrm{a}\end{array}$ & $\begin{array}{l}42,72 \pm 2,46 \\
39,42 \pm 1,49\end{array}$ & $\mathrm{a}$ & $\begin{array}{l}81,12 \pm 6,67 \\
76,64 \pm 0,43\end{array}$ & & $\begin{array}{l}22,61 \pm 1,22 \\
23,98 \pm 0,84\end{array}$ & & $\begin{array}{l}24,12 \pm 0,32 \\
25,22 \pm 1,55\end{array}$ & $\mathrm{a}$ & $\begin{array}{c}945,1 \pm 18,4 \\
795,4 \pm 5,6\end{array}$ & $\mathrm{a}$ \\
\hline & & \multirow[t]{2}{*}{$\mathbf{T} 2$} & kontroll & $415,7 \pm 4,2$ & $\mathrm{~b}$ & $18,93 \pm 0,68$ & $\mathrm{a}$ & $341,0 \pm 21,9$ & $\mathrm{~b}$ & $40,61 \pm 0,37$ & $\mathrm{a}$ & $90,71 \pm 1,38$ & $\mathrm{a}$ & $19,56 \pm 1,37$ & $\mathrm{a}$ & $16,18 \pm 0,33$ & a & $942,8 \pm 19,9$ & $\mathrm{~b}$ \\
\hline & & & & & $\mathrm{a}$ & & b & & $\mathrm{a}$ & $1 \pm 1,68$ & $\underline{a}$ & $91,98 \pm 0,56$ & $\mathrm{a}$ & $19,47 \pm 0,80$ & - & $15,50 \pm 1,18$ & $\underline{a}$ & $863,5 \pm 14,9$ & $\mathrm{a}$ \\
\hline & & T3 & $\begin{array}{l}\text { kontroll } \\
\text { ritkított }\end{array}$ & $\begin{array}{r}505,8 \\
5879\end{array}$ & $\begin{array}{l}a \\
b\end{array}$ & $\begin{array}{l}20,46 \pm 1,16 \\
18,86 \pm 0,43\end{array}$ & b & $\begin{array}{l}289 \\
271\end{array}$ & $\begin{array}{l}\mathrm{b} \\
\mathrm{a}\end{array}$ & $\begin{array}{l}46,81 \pm 1,44 \\
49,50 \pm 1,53\end{array}$ & b & $\begin{array}{l}124,70 \pm 5,18 \\
196,81 \pm 8,35\end{array}$ & $\begin{array}{l}a \\
b\end{array}$ & $\begin{array}{l}24,72 \pm 0,78 \\
27.19 \pm 0,63\end{array}$ & $\begin{array}{l}a \\
b\end{array}$ & $\begin{array}{l}21,11 \pm 0,81 \\
23,22 \pm 1,34\end{array}$ & $\mathrm{a}$ & $\begin{array}{l}1032,9 \pm 34,9 \\
1175,3 \pm 13,2\end{array}$ & $\begin{array}{l}\mathrm{a} \\
\mathrm{b}\end{array}$ \\
\hline & \multirow{6}{*}{ BBVG } & \multirow{2}{*}{ T1 } & & $127,7 \pm 6,5$ & $\mathrm{a}$ & $16,75 \pm 0,29$ & $\mathrm{a}$ & $1114,3 \pm 35,1$ & $\mathrm{a}$ & $32,79 \pm 1,07$ & $\mathrm{a}$ & $88,84 \pm 1,49$ & $\mathrm{a}$ & $16,91 \pm 0,11$ & $\mathrm{~b}$ & $32,26 \pm 0,43$ & $\mathrm{~b}$ & $1429,6 \pm 42,9$ & $\mathrm{a}$ \\
\hline & & & & 177,9 & $\mathrm{~b}$ & $17,45 \pm 0,37$ & $\mathrm{~b}$ & $1242,3 \pm 10,0$ & $\mathrm{~b}$ & $49,83 \pm 2,67$ & b & $93,88 \pm 1,36$ & $\mathrm{~b}$ & $12,91 \pm 0,35$ & $\mathrm{a}$ & $31,37 \pm 0,47$ & $\mathrm{a}$ & $1625,7 \pm 14,6$ & $\mathrm{~b}$ \\
\hline & & \multirow{2}{*}{ T2 } & & 234,4 & $\mathrm{~b}$ & & $\mathrm{a}$ & & $\mathrm{a}$ & & $\mathrm{a}$ & $86,98 \pm 0,74$ & $\mathrm{a}$ & $22,65 \pm 1,01$ & $\mathrm{~b}$ & $28,20 \pm 1,23$ & $\mathrm{a}$ & $1421,6 \pm 21,3$ & $\mathrm{a}$ \\
\hline & & & & 200 & $\mathrm{a}$ &, 33 & $b$ & 110 & $\mathrm{~b}$ & 54, & $\underline{b}$ & $\pm 0,06$ & $\mathrm{~b}$ & $11,15 \pm 0,56$ & $\mathrm{a}$ & $30,49 \pm 0,96$ & b & $1517,4 \pm 10,2$ & $\mathrm{~b}$ \\
\hline & & \multirow{2}{*}{ T3 } & & $1187,3 \pm 102,1$ & $\mathrm{a}$ & $10,80 \pm 0,38$ & $\mathrm{a}$ & $854,0 \pm 3,7$ & $\mathrm{a}$ & $82,53 \pm 0,74$ & $\mathrm{~b}$ & $199,79 \pm 15,64$ & $\mathrm{a}$ & $30,56 \pm 0,88$ & $\mathrm{a}$ & $34,60 \pm 1,93$ & & $2399,6 \pm 109,7$ & $\mathrm{a}$ \\
\hline & & & & $=38,4$ & $\mathrm{a}$ & $11,30 \pm 0,08$ & $\mathrm{~b}$ & $943,0 \pm 12,5$ & $\mathrm{~b}$ & $72,00 \pm 0,44$ & $\mathrm{a}$ & $283,51 \pm 10,74$ & $\mathrm{~b}$ & $30,52 \pm 1,20$ & $\mathrm{a}$ & $27,47 \pm 0,51$ & $\mathrm{a}$ & $2536,2 \pm 51,9$ & $\mathrm{a}$ \\
\hline & \multirow{5}{*}{ BMS } & T1 & $\begin{array}{l}\text { kontroll } \\
\text { ritkított }\end{array}$ & \multicolumn{2}{|l|}{$\begin{array}{l}\text { n. a. } \\
\text { n. a. }\end{array}$} & & \multicolumn{2}{|l|}{$\begin{array}{l}\text { n. a. } \\
\text { n. a. }\end{array}$} & \multicolumn{2}{|l|}{$\begin{array}{l}\text { n. a. } \\
\text { n. a. }\end{array}$} & \multicolumn{2}{|l|}{$\begin{array}{l}\text { n. a. } \\
\text { n. a. }\end{array}$} & \multicolumn{2}{|l|}{$\begin{array}{l}\text { n. a. } \\
\text { n. a. }\end{array}$} & \multicolumn{2}{|l|}{$\begin{array}{l}\text { n. a. } \\
\text { n. a. }\end{array}$} & \multicolumn{2}{|l|}{$\begin{array}{l}\text { n. a. } \\
\text { n. a. }\end{array}$} \\
\hline & & \multirow{2}{*}{ T2 } & & $700,9 \pm 47,3$ & $\mathrm{a}$ & $29,38 \pm 1,00$ & $\mathrm{a}$ & $374,2 \pm 9,7$ & $\mathrm{~b}$ & $51,97 \pm 0,13$ & $\mathrm{a}$ & $134,81 \pm 4,83$ & $\mathrm{a}$ & $29,41 \pm 1,09$ & $\mathrm{~b}$ & $24,55 \pm 0,96$ & & $1345,3 \pm 47,1$ & $\mathrm{a}$ \\
\hline & & & & 9,9 & $\mathrm{a}$ & 0,66 & $\mathrm{a}$ & & $\mathrm{a}$ & & $\mathrm{a}$ & $158,02 \pm 4,08$ & $\mathrm{~b}$ & $25,45 \pm 0,26$ & $\mathrm{a}$ & $23,47 \pm 1,47$ & & $1324,5=$ & $\mathrm{a}$ \\
\hline & & \multirow{2}{*}{ T3 } & & 1201 & $\mathrm{~b}$ & $36,75 \pm 0,99$ & $\mathrm{a}$ & $305,5 \pm 10,4$ & $\mathrm{~b}$ & $97,87 \pm 7,12$ & b & $288,31 \pm 12,32$ & $\mathrm{~b}$ & $35,56 \pm 2,17$ & $b$ & $22,10 \pm 1,16$ & & $1987,4 \pm 44,8$ & $\mathrm{~b}$ \\
\hline & & & & 1055 & $\mathrm{a}$ & $35,68 \pm 0,01$ & $\mathrm{a}$ & $265,4 \pm 4,9$ & $\mathrm{a}$ & $75,64 \pm 3,52$ & $\mathrm{a}$ & $254,83 \pm 12,43$ & $\mathrm{a}$ & $28,93 \pm 2,47$ & $\mathrm{a}$ & $15,54 \pm 0,65$ & $\mathrm{a}$ & $1731,8 \pm 90,4$ & $\mathrm{a}$ \\
\hline & \multirow{6}{*}{ H222 } & \multirow{2}{*}{ T1 } & roll & $143,8 \pm 2,1$ & $\mathrm{a}$ & $20,87 \pm 0,32$ & $\mathrm{a}$ & $1389,6 \pm 9,8$ & $\mathrm{a}$ & $56,40 \pm 0,63$ & $\mathrm{a}$ & $105,06 \pm 0,86$ & $\mathrm{a}$ & $19,23 \pm 0,50$ & & $39,81 \pm 0,02$ & $\mathrm{a}$ & $1774,8 \pm 9,4$ & $\mathrm{a}$ \\
\hline & & & & & $\mathrm{b}$ & $24,23 \pm 0,99$ & b & $1735,8 \pm 54,0$ & $\mathrm{~b}$ & $60,26 \pm 2,48$ & $\mathrm{~b}$ & $116,16 \pm 3,92$ & $\mathrm{~b}$ & $23,43 \pm 1,11$ & $\mathrm{~b}$ & $42,04 \pm 1,65$ & b & $2158,2 \pm 57,0$ & $\mathrm{~b}$ \\
\hline & & \multirow{2}{*}{$\mathbf{T 2}$} & kontroll & $427,2 \pm 27,3$ & $\mathrm{~b}$ & $12,01 \pm 1,07$ & $\mathrm{a}$ & $844,3 \pm 63,5$ & $\mathrm{a}$ & $57,75 \pm 5,96$ & $\mathrm{a}$ & $78,97 \pm 2,66$ & $\mathrm{a}$ & $22,77 \pm 1,47$ & $\mathrm{a}$ & $27,95 \pm 1,09$ & $\mathrm{a}$ & $1471,1 \pm 55,6$ & $\mathrm{a}$ \\
\hline & & & & & $\mathrm{a}$ & & b & & $\mathrm{b}$ & & $\mathrm{a}$ & $93,95 \pm 3,91$ & $\mathrm{~b}$ & $24,65 \pm 0,22$ & $\mathrm{~b}$ & $26,93 \pm 0,85$ & $\mathrm{a}$ & $1530,1 \pm 51,5$ & $\mathrm{a}$ \\
\hline & & \multirow{2}{*}{ T3 } & roll & $1091,6 \pm 64,8$ & $\mathrm{~b}$ & $8,33 \pm 0,20$ & & $770,8 \pm 16,1$ & $\mathrm{a}$ & $109,31 \pm 1,02$ & $\mathrm{a}$ & $140,57 \pm 9,48$ & $\mathrm{a}$ & $25,15 \pm 0,64$ & $b$ & $27,00 \pm 1,32$ & $\mathrm{a}$ & $2172,9 \pm 81,3$ & $\mathrm{a}$ \\
\hline & & & & $936,8 \pm 21,4$ & $\mathrm{a}$ & $12,14 \pm 0,59$ & b & $907,5 \pm 35,0$ & $\mathrm{~b}$ & $119,63 \pm 11,47$ & $\mathrm{a}$ & $162,49 \pm 9,89$ & $\mathrm{~b}$ & $22,00 \pm 0,27$ & $\mathrm{a}$ & $26,23 \pm 1,02$ & a & $2186,8 \pm 70,0$ & $\mathrm{a}$ \\
\hline & & T1 & kontroll & $174,7 \pm 5,5$ & $\mathrm{a}$ & $35,89 \pm 1,06$ & & $404,7 \pm 19,9$ & $\mathrm{a}$ & $110,92 \pm 6,24$ & $\mathrm{~b}$ & $117,02 \pm 4,89$ & $\mathrm{a}$ & $14,65 \pm 0,78$ & & $38,75 \pm 2,70$ & & $896,7 \pm 22,9$ & \\
\hline & & & & & $\mathrm{b}$ & $43,58 \pm 0,72$ & b & $504,1 \pm 20,7$ & $\mathrm{~b}$ & $61,69 \pm 4,86$ & $\mathrm{a}$ & $134,67 \pm 4,67$ & $\mathrm{~b}$ & $13,17 \pm 0,66$ & $\mathrm{a}$ & $38,16 \pm 1,23$ & $\mathrm{a}$ & $1019,7 \pm 19,9$ & $\mathrm{~h}$ \\
\hline & MP & T2 & kontroll & $296,3 \pm 30,9$ & $\mathrm{a}$ & $25,99 \pm 0,94$ & $\mathrm{a}$ & $375,7 \pm 29,9$ & $\mathrm{a}$ & $65,09 \pm 2,06$ & $\mathrm{~b}$ & $84,73 \pm 5,51$ & $\mathrm{a}$ & $17,30 \pm 1,04$ & $\mathrm{~b}$ & $28,08 \pm 1,29$ & b & $893,2 \pm 12,0$ & $\mathrm{a}$ \\
\hline & & & & & $\mathrm{b}$ & & & $338,4 \pm 19,8$ & $\mathrm{a}$ & $57,88 \pm 1,99$ & 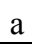 & $80,31 \pm 2,90$ & $\mathrm{a}$ & $12,76 \pm 0,62$ & $\mathrm{a}$ & $25,68 \pm 1,01$ & $\mathrm{a}$ & $916,7 \pm 21,7$ & $\underline{\mathrm{a}}$ \\
\hline & & T3 & kontroll & $806,4 \pm 40,3$ & $\mathrm{~b}$ & $15,53 \pm 0,27$ & a & $256,0 \pm 0,6$ & $\mathrm{a}$ & $110,28 \pm 4,84$ & $\mathrm{~b}$ & $108,59 \pm 7,57$ & $\mathrm{a}$ & $18,57 \pm 0,29$ & & $24,73 \pm 0,63$ & & $1340,1 \pm 34,5$ & b \\
\hline & & & & $504,9 \pm 21,6$ & $\mathrm{a}$ & $17,74 \pm 0,70$ & b & $261,8 \pm 10,3$ & $\mathrm{a}$ & $70,95 \pm 2,99$ & $\mathrm{a}$ & $109,53 \pm 7,19$ & $\mathrm{a}$ & $16,12 \pm 1,41$ & a & $22,39 \pm 1,11$ & $\mathrm{a}$ & $1003,5 \pm 24,2$ & $\mathrm{a}$ \\
\hline
\end{tabular}

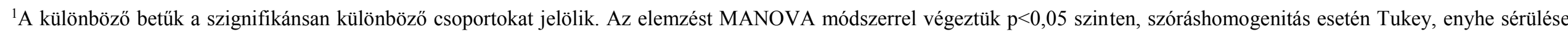
esetén Games-Howell post hoc tesztet alkalmazva 


\subsection{M4. ÁBRAJEGYZÉK}

1. ábra: A cseresznyében legnagyobb mennyiségben található szénhidrátok szerkezeti képlete....7

2. ábra: A cseresznyében legnagyobb mennyiségben található karbonsavak szerkezeti képlete....8

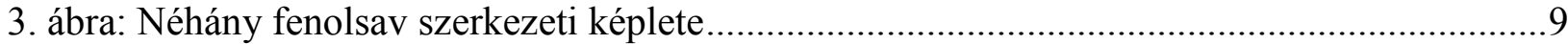

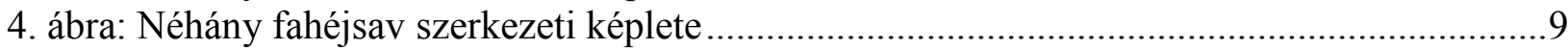

5. ábra: A) flaván alapváz; B) flavilium kation alapváz, C) flavon alapváz .............................10

6. ábra: Antocianidinek és antocianinek kapcsolata a peonidin konkrét példáján bemutatva.......11

7. ábra: Néhány gyakoribb antoxantin szerkezeti képlete ..................................................... 11

8. ábra: A csapadék és a globálsugárzás adatai havi lebontásban 2010 januárja és 2013

decembere között a kísérleti ültetvény területén ................................................................26

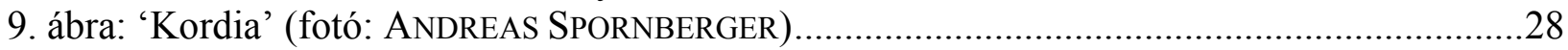

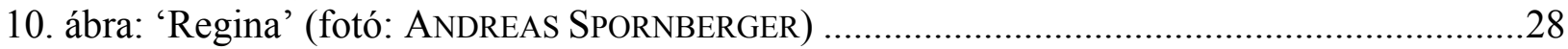

11. ábra: 'Bigarreau Burlat' (fotó: SLAVEN OSTOJIC és JOSEF TELFSER)......................................29

12. ábra: 'Bigarreau Moreau’ (fotó: SLAVEN OSTOJIC és JOSEF TELFSER) ....................................30

13. ábra: 'Hybrid 222' (fotó: SLAVEN OSTOJIC és JOSEF TELFSER) ...............................................30

14. ábra: 'Merton Premier' (fotó: SLAVEN OSTOJIC és JOSEF TELFSER) .........................................31

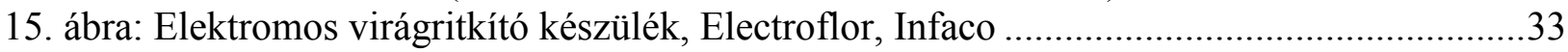

16. ábra: Cseresznyefa virágai virágritkítás előtt (balra) és után (jobbra).................................33

17. ábra: A cseresznye szélessége (sz), magassága (m), vastagsága (v) ....................................34

18. ábra: Cseresznye gyümölcsök tömeg-térfogat diagramja (Regina' és 'Kordia') ....................35

19. ábra: AFG $500 \mathrm{~N}$ típusú húzó-nyomó erőmérő készülék (balra) és a kocsány

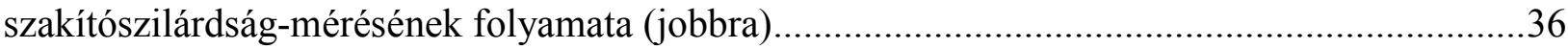

20. ábra: Konica Minolta CR-400 típusú színmérő müszer (balra) és elméleti háttere (jobbra)...36

21. ábra: AFG 500N típusú húzó-nyomó erőmérö készülék (balra) gyümölcskeménység

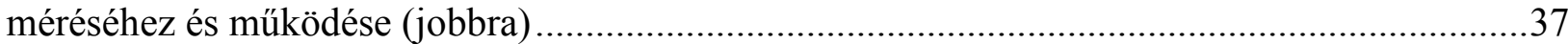

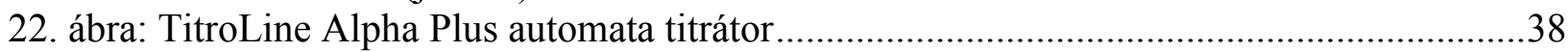

23. ábra: 'Regina' és ‘Kordia' cseresznyefajták átlagos gyümölcstérfogata különböző alanyokon

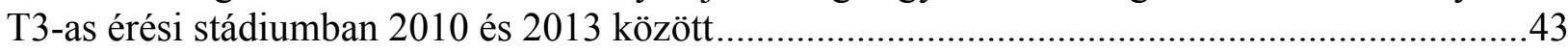

24. ábra: 'Regina' és 'Kordia' cseresznyefajták átlagos gyümölcstömege különböző alanyokon

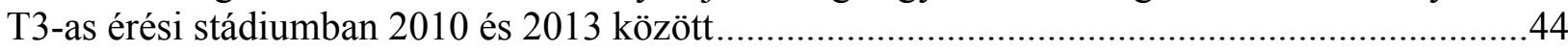

25. ábra: 'Regina' és 'Kordia' cseresznyefajták gyümölcseinek átlagos csontártömege különböző

alanyokon T3-as érési stádiumban 2010 és 2013 között ......................................................45

26. ábra: 'Regina' és 'Kordia' cseresznyefajták hasznos gyümölcs aránya különböző alanyokon

T3-as érési stádiumban 2010 és 2013 között........................................................................46

27. ábra: 'Regina' és 'Kordia' cseresznyefajták gyümölcseinek kocsány-szakítószilárdsága

különböző alanyokon T3-as érési stádiumban 2011 és 2013 között ...........................................47

28. ábra: 'Regina' és 'Kordia' cseresznyefajták gyümölcseinek L*, a* és b* értékei különböző

alanyokon T3-as érési stádiumban 2010 és 2013 között

29. ábra: 'Regina' és 'Kordia' cseresznyefajták gyümölcskeménysége különböző alanyokon T3-

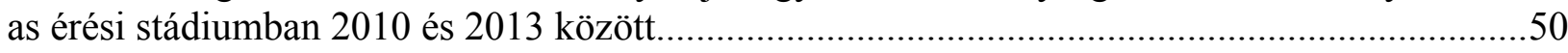

30. ábra: Virágritkított és kontroll cseresznyefajták átlagos gyümölcstérfogata T3-as érési

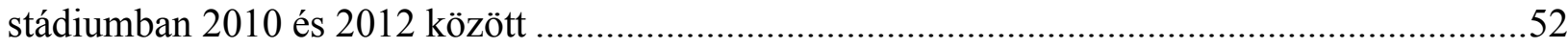

31. ábra: Virágritkított és kontroll cseresznyefajták átlagos gyümölcstömege T3-as érési

stádiumban 2010 és 2012 között

32. ábra: Virágritkított és kontroll cseresznyefajták gyümölcseinek csontártömege T3-as érési

stádiumban 2010 és 2012 között .

33. ábra: Virágritkított és kontroll cseresznyefajták hasznos gyümölcs aránya T3-as érési

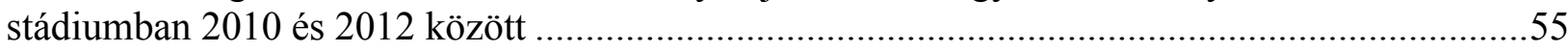

34. ábra: Virágritkított és kontroll cseresznyefajták gyümölcseinek kocsány-szakítószilárdsága

T3-as érési stádiumban 2011 és 2012 között..... 
35. ábra: Virágritkított és kontroll cseresznyefajták gyümölcseinek színparaméterei T3-as érési stádiumban 2010 és 2012 között

36. ábra: Virágritkított és kontroll cseresznyefajták gyümölcskeménysége T3-as érési stádiumban 2010 és 2012 között

37. ábra: 'Regina' és 'Kordia' cseresznyefajták gyümölcseinek TSS értéke különböző alanyokon

T3-as érési stádiumban 2010 és 2013 között

38. ábra: 'Regina' és 'Kordia' cseresznyefajták gyümölcseinek összes titrálható savtartalma (TA)

különböző alanyokon T3-as érési stádiumban 2010 és 2013 között ....

39. ábra: 'Regina' és 'Kordia' cseresznyefajták gyümölcseinek TSS-TA viszonya különböző

alanyokon T1, T2 és T3-as érési stádiumban 2010 és 2013 között.

40. ábra: Virágritkított és kontroll cseresznyefajták gyümölcseinek összes vízoldható

szárazanyag-tartalma (TSS) T3-as érési stádiumban 2010 és 2012 között

41. ábra: Virágritkított és kontroll cseresznyefajták gyümölcseinek összes titrálható savtartalma

(TA) T3-as érési stádiumban 2010 és 2012 között.....

42. ábra: 'Regina' és 'Kordia' cseresznyefajták gyümölcseiben az egyedi cukorkomponensek (fruktóz, glükóz, szorbitol) koncentrációja különböző alanyokon T3-as érési stádiumban 2010 és 2013 között

43. ábra: 'Regina' és 'Kordia' cseresznyefajták gyümölcseiben az egyedi savkomponensek

(almasav, borostyánkősav, citromsav) koncentrációja különböző alanyokon T3-as érési

stádiumban 2010 és 2013 között

44. ábra: Virágritkított és kontroll cseresznyefajták gyümölcseiben az egyedi cukorkomponensek

(fruktóz, glükóz, szorbitol) koncentrációja T3-as érési stádiumban 2010 és 2012 között .....

45. ábra: Virágritkított és kontroll cseresznyefajták gyümölcseiben az egyedi savkomponensek (almasav, borostyánkősav, citromsav) koncentrációja T3-as érési stádiumban 2010 és 2012

között

46. ábra: A cseresznye természetes elterjedési területe (forrás: www.euforgen.org)............... M15

47. ábra: Antioxidánsok csoportosítása ................................................................................

48. ábra: A BOKU kísérleti ültetvényének elhelyezkedése Bécs városán belül (sárga jel) ...... M17

49. ábra: Jedlersdorfi kísérleti üzem (sárga) területének légifotója (forrás: Google Térkép) ... M17

50. ábra: Cseresznye gyümölcs színeződés kezdetén (fent), színeződés második felében

(középen) és $100 \%$-os érettségben (lent).....

51. ábra: Virágritkított és kontroll cseresznyefajták gyümölcseinek TSS-TA viszonya T1, T2 és

T3-as érési stádiumban 2010 és 2012 között.

52. ábra (3/ 3.rész): 'Regina' és 'Kordia' cseresznyefajták gyümölcseiben az egyedi

polifenolkomponensek (cianidin, epikatechin, neoklorogénsav, klorogénsav, kínasav, rutin, kvercetin) koncentrációja különböző alanyokon T3-as érési stádiumban 2011 és 2013 közöttM22 53. ábra (3/ 3.rész): Virágritkított és kontroll cseresznyefajták gyümölcseiben az egyedi polifenol-komponensek (cianidin, epikatechin, neoklorogénsav, klorogénsav, kínasav, rutin, kvercetin) koncentrációja T3-as érési stádiumban 2011 és 2012 között 


\subsection{M5. TÁBLÁZATJEGYZÉK}

1. táblázat: A cseresznye cukor-sav arányának összefüggése az ízértékkel (REVELL 2008) ............4

2. táblázat: A cseresznye fö összetevői (SouCI et al. 2008) ….......................................................4

3. táblázat: A cseresznyében fellelhető vitaminok (SoucI et al. 2008) ...........................................5

4. táblázat: A cseresznyében előforduló ásványi anyagok és nyomelemek (SoUCI et al. 2008 és

2015)

5. táblázat: A cseresznyében megtalálható aminosavak (SoUCI et al. 2008 és 2015) .....................5

6. táblázat: A legfontosabb szénhidrátok koncentrációja az érett cseresznyében ..........................6

7. táblázat: A legfontosabb savak koncentrációja az érett cseresznyében......................................7

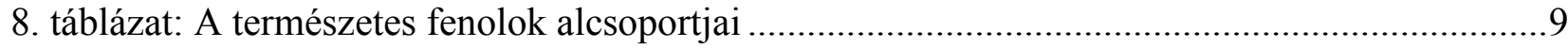

9. táblázat: A cseresznye jellemző fenolikus komponensei ....................................................13

10. táblázat: Évenkénti időjárási paraméterek a jedlersdorfi kísérleti ültetvény területén (2010-

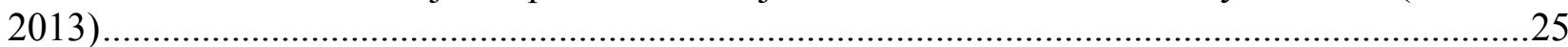

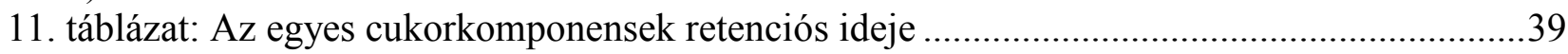

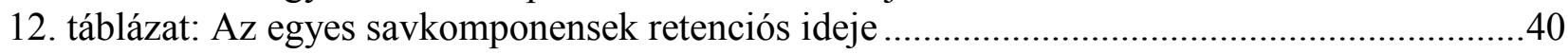

13. táblázat: Az eluens összetételének változása többlépcsős lineáris gradiens mentén.................41

14. táblázat: Polifenol-komponensek retenciós ideje $280 \mathrm{~nm}$-en $(* 530 \mathrm{~nm}$-en) ...........................41

15. táblázat: Értékelési szempontsor a virágritkítás hatásáról 5 különböző cseresznyefajta

gyümölcseinek mennyiségi és minőségi paramétereire vonatkozóan ....

16. táblázat: Értékelési szempontsor 5 különböző alany hatásáról 'Regina' és 'Kordia' nemes cseresznyefajták gyümölcseinek mennyiségi és minőségi paramétereire vonatkozóan................111 17. táblázat: A jedlersdorfi Q10 cseresznyeültetvény alany-nemes kombinációinak sorokon belüli elrendezése .....

18. táblázat: A jedlersdorfi Q26 ültetvény 13 cseresznyefajtájának sorokon belüli elrendezése M27 19. táblázat: 'Regina' és 'Kordia' cseresznyefajták gyümölcsméret-paraméterei különböző alanyokon (1.)......

20. táblázat: 'Regina' és 'Kordia' gyümölcsök térfogata, kocsány-szakítószilárdsága, keménysége különböző alanyokon (1.)...

21. táblázat: 'Regina' és 'Kordia' cseresznyefajta gyümölcstömege, csontártömege, hasznos gyümölcs aránya különböző alanyokon (1.).

22. táblázat: 'Regina' és 'Kordia' cseresznyefajta gyümölcseinek héjszín-paraméterei különböző alanyokon (1.).

23. táblázat: Q10 ültetvény cseresznyefajtáinak gyümölcsméret-paraméterei (1.).

24. táblázat: Q10 ültetvény cseresznyegyümölcseinek térfogata, kocsány-szakítószilárdsága, keménysége (1.)

25. táblázat: Q10 ültetvény cseresznyegyümölcseinek gyümölcstömege, csontártömege, hasznos

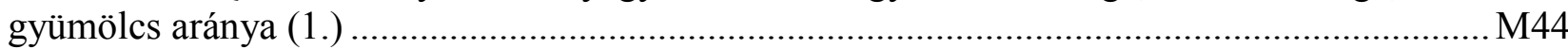

26. táblázat: Q10 ültetvény cseresznyegyümölcseinek héjszín-paraméterei (1.) ...................... M46

27. táblázat: 'Regina' és 'Kordia' cseresznyefajta gyümölcseinek TSS, TA és TSS/TA értékei különböző alanyokon (1.)...

28. táblázat: Q26 ültetvény cseresznyegyümölcseinek TSS, TA és TSS/TA értékei (1.)........... M51 29. táblázat: 'Regina' és 'Kordia' cseresznyefajta gyümölcseinek fruktóz, glükóz, szorbitol koncentrációja, valamint összes kromatográfiás cukortartalma (TKC) (1.)............................. M53 30. táblázat: 'Regina' és 'Kordia' cseresznyefajta gyümölcseinek almasav, borostyánkősav és citromsav koncentrációja, valamint összes kromatográfiás savtartalma (TKS) (1.) .................. M56 31. táblázat: 'Regina' és 'Kordia' cseresznyefajták gyümölcseiben az egyedi polifenolkomponensek koncentrációi, valamint a totál kromatográfiás polifenol-tartalom (1.) ............... M59 32. táblázat: Q26 ültetvény cseresznyegyümölcseinek fruktóz, glükóz, szorbitol koncentrációja,

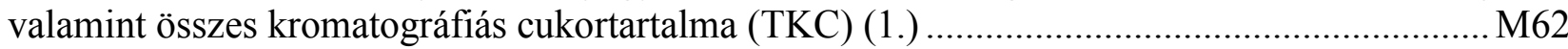
33. táblázat: Q10 ültetvény cseresznyegyümölcseinek almasav, borostyánkősav és citromsav koncentrációja, valamint összes kromatográfiás savtartalma (TKS) (1.) ................................. M64 34. táblázat: Q26 ültetvény cseresznyegyümölcseiben az egyedi polifenol-komponensek koncentrációi, valamint a totál kromatográfiás polifenol-tartalom (1.) 


\section{KÖSZÖNETNYILVÁNÍTÁS}

Mindenekelőtt szeretnék köszönetet mondani témavezetőmnek, Dr. Végvári Györgynek, hogy szakmai tudásával és felkészültségével, szemléletformáló meglátásaival, gondolatébresztő tanácsaival segítette fejlődésemet és $\mathrm{PhD}$-dolgozatom elkészülését.

Külön köszönet illeti Dr. Andreas Sporbergert is, aki Bécsben tartózkodásom alatt nyújtott szakmai támogatást és segítséget, akivel közösen több publikációnk is megjelent, és aki nagyban hozzájárult dolgozatom elkészültéhez.

Köszönet illeti Dr. Tóth Magdolna tanszékvezető aszonyt, aki mindvégig odaadóan figyelemmel kísérte és támogatta minden törekvésemet és fáradozásomat a Gyümölcstermő Növények Tanszéken.

Hálával tartozom továbbá Újváry Margitnak, Claudia Hubernek, Theresa Ringwaldnak és Dragana Buvacnak a laboratóriumi mérésekben nyújtott asszisztenciáért.

Köszönöm a Gyümölcstermő Növények Tanszék minden dolgozójának segítőkészségét, különösképpen Hajnal Veronikának, aki gyakran segítő kezet nyújtott nekem feladataimban.

Köszönöm a Talajtan és Vízgazdálkodás Tanszék minden munkatársának segítő viszonyulását, különösképpen Vidéki Edinának, Begyik Andrásnak, Galgóczi Zsoltnak, Dr. Kotroczó Zsoltnak és Juhos Katalinnak, akik többször is segítségemre siettek munkám során.

Köszönet illeti a Növénytani Tanszékről Dr. Barabás Sándort, aki folyamatos támogatása mellett szakmai felkészültségével, éleslátásával és precizitásával is hozzájárult a dolgozat elkészüléséhez.

Hálásan köszönöm Dr. Ladányi Mártának a statisztikai elemzésekben nyújtott önzetlen, odaadó segítségét.

Vizsgálataim elvégzését, a vizsgálatokhoz szükséges infrastruktúra biztosításával és pénzügyi finanszírozással támogatta a TÁMOP 4.2.1./B-09/01/KMR/2010-0005 számú pályázat, a TÁMOP-4.2.2/B-10/1-2010-0023 számú pályázat, az Osztrák-Magyar Akció Alapítvány, valamint a CEEPUS ösztöndíj program.

Végül, de nem utolsó sorban, köszönettel tartozom férjemnek, családomnak szeretetükért, törödésükért, folyamatos biztatásukért, türelmükért és támogatásukért. 